\author{
UNIVERSIDADE DE BRASÍLIA \\ INSTITUTO DE CIÊNCIAS SOCIAIS \\ DEPARTAMENTO DE SOCIOLOGIA
}

\title{
A desigualdade vista do topo: a concentração de renda entre os ricos no Brasil, 1926-2013
}

Autor: Pedro Herculano Guimarães Ferreira de Souza

Brasília, setembro de 2016 


\author{
UNIVERSIDADE DE BRASÍLIA \\ INSTITUTO DE CIÊNCIAS SOCIAIS \\ DEPARTAMENTO DE SOCIOLOGIA
}

\title{
A desigualdade vista do topo: a concentração de renda entre os ricos no Brasil, 1926-2013
}

\author{
Autor: Pedro Herculano Guimarães Ferreira de Souza
}

Tese apresentada ao Departamento de Sociologia da Universidade de Brasília/UnB como parte dos requisitos para a obtenção do título de Doutor.

Brasília, setembro de 2016 


\author{
UNIVERSIDADE DE BRASÍLIA \\ INSTITUTO DE CIÊNCIAS SOCIAIS \\ DEPARTAMENTO DE SOCIOLOGIA
}

\title{
Tese de Doutorado
}

\section{A desigualdade vista do topo: a concentração de renda entre os ricos no Brasil, 1926-2013}

Autor: Pedro Herculano Guimarães Ferreira de Souza

Orientador: Marcelo Medeiros Coelho de Souza (UnB e Ipea)

Banca: Prof ${ }^{a}$. Doutora Ana Cristina Murta Collares (UnB)

Prof. Doutor Carlos Antonio Costa Ribeiro (IESP/Uerj)

Prof. Doutor Carlos Henrique Leite Corseuil (Ipea)

Prof. Doutor Leonardo Monteiro Monasterio (UCB e Ipea)

Prof. Doutor Fernando Gaiger Silveira (Ipea - suplente) 
Para Ligia, Carmela e Matilda 


\section{Agradecimentos}

Um dos privilégios inesperados desta pesquisa de tantos anos foi me deparar com a generosidade de tantos amigos e colegas. Seria impossível mencionar aqui todos que contribuíram para que esta tese viesse ao mundo, e o perigo da pieguice seria imenso. Ainda assim, algumas dívidas são grandes demais e merecem, no mínimo, ser reconhecidas.

Esta pesquisa só foi possível graças ao amparo institucional que recebi nos últimos anos. Agradeço aos professores e funcionários do Programa de Pós-Graduação em Sociologia da Universidade de Brasília pelo acolhimento; ao Instituto de Pesquisa Econômica Aplicada (Ipea) por me conceder a licença que possibilitou a escrita desta tese; e à Coordenação de Aperfeiçoamento de Pessoal de Ensino Superior (Capes) pela bolsa que permitiu minha estadia como aluno visitante na Universidade da Califórnia - Berkeley.

Agradeço à Universidade da Califórnia - Berkeley pela receptividade e pela experiência inesquecível. Esta tese beneficiou-se imensamente dos comentários e sugestões do professor Emmanuel Saez, que gentilmente aceitou ser meu orientador ao longo do doutorado sanduíche e me encorajou durante a pesquisa.

Agradeço ao meu orientador, professor Marcelo Medeiros, cujo empenho, amizade, obstinação e brilhantismo superaram as expectativas mais otimistas e megalomaníacas que eu poderia ter. Espero um dia poder retribuir ao menos em parte sua dedicação.

Agradeço também aos membros da banca examinadora - Ana Cristina Murta Collares, Carlos Antonio Costa Ribeiro, Carlos Henrique Leite Corseuil e Leonardo Monteiro Monasterio - pela disposição, pela leitura atenta e sobretudo pelos excelentes comentários, críticas e sugestões.

Muitas pessoas colaboraram diretamente para a elaboração e o aperfeiçoamento desta tese, motivadas apenas por um impressionante espírito cooperativo.

Cristóvam Barcelos da Nóbrega tirou minhas dúvidas e esclareceu filigranas da tortuosa história do imposto de renda no Brasil. Sua pesquisa sobre o imposto poupou dezenas de horas de trabalho e, em última instância, viabilizou esta tese.

Eustáquio Reis, José Alcides Figueiredo Santos, Marta Arretche e Rodolfo Hoffmann tiveram paciência e ânimo fantásticos para ler e comentar minuciosamente alguns dos capítulos da Parte II, oferecendo críticas, sugestões e contribuições inestimáveis.

Ana Paula Soares Carvalho, Frederico Rodrigues Abraham, Gabriel Banaggia, Leonardo Monteiro Monasterio e Isabel Martinez leram capítulos e/ou discutiram comigo algumas das principais ideias desta tese. Flavio Carvalhaes, Rafael Henrique Moraes Pereira e Rogério Barbosa, em suas diferentes cidades e instituições, compartilharam comigo as 
agruras e angústias de fazer doutorado e ainda deram um jeito de arrumar tempo para ler diligentemente vários dos capítulos desta tese. Espero ter feito jus à inspiração e às sugestões valiosas que vocês me deram, dos pequenos detalhes às maiores ideias.

Clichê ou não, minha família foi fundamental nesse percurso. Só posso agradecer sinceramente ao meus pais, Antonio e Margareth, por todo o estímulo e o apoio que recebi em toda a minha vida, inclusive quando inventei essa história de sociologia. Imagino que não deve ter sido fácil.

Ligia Gonçalves Diniz. Ou só Ligia, minha companheira, amiga, interlocutora, revisora, apoiadora e muito mais: esta tese é só uma entre as inúmeras coisas da minha vida que seriam impossíveis sem você. Não há como quantificar sua presença estética, intelectual e afetiva neste trabalho. Muito obrigado por me ajudar a redescobrir a sociologia e a não ter medo de tirar os pés do chão.

Por fim, agradeço à Carmela e à Matilda por nada saberem e nada fazerem além de tornar a minha vida muito melhor. 
O desenvolvimento gradual da igualdade das condições é um fato providencial. Possui suas principais características: é universal, é duradouro, escapa cada dia ao poder humano; todos os acontecimentos, bem com o todos os homens, contribuem para ele. [...] Alguém acredita que, depois de ter destruído o feudalismo e vencido os reis, a democracia recuará diante dos burgueses e dos ricos? Irá ela se deter agora, que se tornou tão forte e seus adversários tão fracos?

Alexis de Tocqueville, A Democracia na América (1835) 


\section{Resumo}

Esta tese usa tabulações do imposto de renda para construir novas séries históricas para a concentração de renda no topo no Brasil. Entre 1926 e 2013, as frações recebidas pelos mais ricos combinaram estabilidade e mudança em um padrão distinto do observado nos países ricos no mesmo período. Ao contrário do previsto por teorias da industrialização e modernização, não houve nenhuma tendência secular clara. A fatia do centésimo mais rico da população adulta, em particular, oscilou frequentemente entre $20 \%$ e $25 \%$, inclusive nos anos recentes.

A concentração no topo teve idas e vindas que, mesmo temporárias, foram significativas, coincidindo com os grandes ciclos políticos do país. A fração apropriada para o 1\% mais rico aumentou durante o Estado Novo e a $2^{a}$ Guerra e caiu no imediato pós-guerra e, mais ainda, na segunda metade da década de 1950, tendência revertida depois do golpe militar de 1964, com uma volta ao patamar de duas décadas antes. Os anos 1970 foram marcados por instabilidade, mas a desigualdade cresceu novamente na década seguinte. Em seguida, houve alguma desconcentração até o fim da década de 1990 ou, talvez, meados dos anos 2000, e estabilidade desde então.

Além disso, a análise empírica explora a repartição da renda entre os ricos, a comparação do Brasil com outros países e o contraste dos dados tributários com as PNADs e os Censos. Nesse último caso, as séries produzidas são usadas também para corrigir os coeficientes de Gini, levando em conta a subestimação dos rendimentos dos mais ricos nas pesquisas domiciliares.

A discussão é estruturada por três perguntas de cunho histórico-comparativo, e os resultados são interpretados do ponto de vista institucional. As origens, implicações e justificativas para isso são apresentadas nos capítulos teóricos que precedem a análise empírica. Esses capítulos oferecem uma reconstrução da história das ideias sobre estratificação social no último século e colocam em destaque a longa e heterogênea tradição de estudos sobre os ricos. Seu argumento central é que o interesse acadêmico e político pela questão distributiva aflora quando ela é concebida em termos dicotômicos, com foco sobre os mais ricos.

Palavras-chave: desigualdade de renda; estratificação social; políticas públicas; altos rendimentos; ricos; imposto de renda. 


\section{Abstract}

This dissertation uses income tax tabulations to estimate top income shares over the long-run for Brazil. Between 1926 and 2013, the concentration of income at the top of the distribution combined stability and change, diverging from the European and American patterns in the $20^{\text {th }}$ century. Contrary to benign industrialization and modernization theories, there was no overarching, long-term trend. Most of the time the income share of the top $1 \%$ of the adult population fluctuated within a $20 \%-25 \%$ range, even in recent years.

Still, top income shares had temporary yet significant ups and downs which largely coincided with the country's most important political cycles. The top $1 \%$ income share increased during the Estado Novo and World War II, then declined in the early post-war years and even more so in the second half of the 1950s. The 1964 coup d'état reversed that trend and income inequality rose back to post-war levels after a few years of military rule. The 1970s were marked by instability, but top income shares surged again in the 1980s. The share of the $1 \%$ then decreased somewhat in the 1990s and perhaps the mid-2000s. There were no real changes since then.

In addition, this dissertation analyzes the concentration of income among the rich, provides international comparisons of top income shares, and contrasts the income tax series with estimates from household surveys. The income tax series are also used to compute "corrected" Gini coefficients which take into account the underestimation of top incomes in household surveys.

The major research questions are comparative and historically oriented, and I argue in favor of an institutional interpretation of the results. The motivation for and implications of this approach are presented in the more theoretical chapters that precede the empirical analysis. In these chapters, I engage with the history of ideas about inequality and social stratification and highlight the long and heterogeneous tradition of studies about the rich and the wealthy. My main argument is that the academic and political concern with distributional issues flourishes when inequality is conceived in binary or dichotomous terms.

Keywords: income inequality; social stratification; public policy; top incomes; rich; income tax. 


\section{Résumé}

Cette thèse utilise des tableux statistiques de l'impôt de revenu pour construire des nouvelles séries historiques pour la concentration de revenu dans la couche plus fortunée au Brésil. Entre 1926 et 2013, les fractions reçues par les plus riches combine stabilité et changement dans un modèle distinct de celui observé aux pays riches à la même période. Au contraire du pronostic des théories de l'industrialisation et de la modernisation, aucune tendance séculaire était produite. En particulier, la tranche du centième plus riche de la population adulte a oscillé fréquemment entre $20 \%$ et $25 \%$, les dernières années y compris.

Cette concentration au sommet a eu des oscillations qui étaient significatives, même temporairement, en coïncidant avec les grands cycles politiques du pays. La fraction détenue par le $1 \%$ le plus riche augmente pendant l'État nouveau brésilien et la 2e Guerre mondiale et tombe immédiatement dans l'après-guerre, et plus encore à la deuxième moitié de la décennie de 1950, tendance refoulée après le coup militaire de 1964, avec un retour au même niveau de deux décennies avant. Les années 1970 sont marquées par l'instabilité, et l'inégalité a repoussé la décennie suivante. Ensuite, une déconcentration du revenu a eu lieu jusqu'à la fin de la décennie de 1990, peut-être jusqu'aux milieux des années 2000 et après cela, une période de stabilité se passe.

En outre, l'analyse empirique explorera la répartition du revenu entre les riches, la comparaison du Brésil avec d'autres pays et le contraste des données tributaires avec les PNADs (Pesquisa Nacional por Amostra de Domicílios) et les Recensements. Dans ce dernier cas, les séries produites seront aussi utilisées pour corriger les coefficients de Gini en tenant compte la sous-estimation des revenus des plus riches dans les enquêtes sur les ménages.

La discussion sera structurée par trois questions à caractère historique et comparative et les résultats seront interprétés du point de vue institutionnel. Les origines, implications et justifications pour cela seront présentées aux chapitres théoriques qui précèdent l'analyse empirique. Ces chapitres offriront une reconstruction de l'histoire des idées sur la stratification sociale pendant le dernier siècle et détachera la longue et hétérogène tradition des études sur les couches riches. L'argument central est que l'intérêt académique et politique par le sujet de la distribution de revenu émerge quand il est conçu dans des termes dichotomiques, mettant en relief les plus riches.

Mots-clés : inégalité de revenu; stratification sociale; politique publique; hauts revenus ; impôt sur le revenu. 


\section{Resumen}

Esta tesis utiliza tabulaciones del impuesto sobre la renta para construir nuevas series históricas para la alta concentración de renta en Brasil. Entre 1926 y 2013, las fracciones recibidas por los más ricos combinaron estabilidad y cambios en un estándar distinto de lo observado en los países ricos en el mismo periodo. Al contrario de lo previsto por teorías de la industrialización y de la modernización, no hubo ninguna tendencia secular clara. La tajada del centésimo más rico de la población adulta osciló, en particular, frecuentemente entre $20 \%$ y $25 \%$, incluso en los años recientes.

La concentración en la cima tuvo muchas idas y vueltas que, aunque temporarias, fueron significativas, coincidiendo con los grandes ciclos políticos del país. La fracción apropiada para el $1 \%$ más rico aumentó durante el Estado Nuevo y la Segunda Guerra Mundial y cayó inmediatamente en la posguerra y, todavía más, en la segunda mitad de la década de 1950, tendencia revertida después del Golpe Militar de 1964, volviendo al mismo nivel de dos décadas anteriores. El año de 1970 estuvo marcado por instabilidad, pero la desigualdad creció nuevamente en la década siguiente. A continuación, hubo alguna desconcentración hasta el final de la década de 1990 o, tal vez, mediados de los años 2000, y, desde entonces, estabilidad.

Además, el análisis empírico explora la repartición de renta entre los ricos, la comparación de Brasil con otros países, y el contraste de datos tributarios con las PNADs y los Censos. En este último caso, las series producidas son utilizadas también para corregir los coeficientes de Gini, considerando la subestimación de los ingresos de los más ricos en las investigaciones domiciliares.

La discusión está estructurada por tres preguntas de carácter histórico-comparativo y los resultados son interpretados desde el punto de vista institucional. Las orígenes, implicaciones y justificativas para esto serán presentadas en los capítulos teóricos que preceden el análisis empírico. Estos capítulos ofrecen una reconstrucción de la historia de las ideas sobre la estratificación social en el último siglo y destacan la larga y heterogenia tradición de estudios sobre los ricos. Su argumento central es que el interés académico por la cuestión distributiva surge cuando está concebida en términos dicotómicos, con enfoque sobre los más ricos.

Palabras-clave: desigualdad de renta; estratificación social; politicas públicas; altos ingresos; ricos; impuesto sobre la renta. 


\section{Lista de ilustrações}

Figura 1 - Variação real anual do PIB per capita em países industrializados selecionados - 1875/2010 . . . . . . . . . . . . . . . . 37

Figura 2 - Frequência relativa de termos relacionados a classes ou estratos sociais no corpus em inglês do Google Books, 1875-2000 . . . . . . . . . . . . . 38

Figura 3 - Frequência relativa de expressões com três termos (threegrams) relacionados à desigualdade no corpus em inglês do Google Books, 1875-2000

Figura 4 - Frequência relativa de artigos sobre desigualdade ou estratificação em periódicos selecionados de economia, 1970-2014 (\%) . . . . . . . . . . 111

Figura 5 - Frequência relativa de artigos sobre desigualdade ou estratificação em periódicos selecionados de sociologia, 1970-2014 (\%) . . . . . . . . . 111

Figura 6 - Frequência relativa de termos associados a classe lato sensu e à questão distributiva nos títulos dos artigos sobre desigualdade nos periódicos selecionados de sociologia, 1970-2014 (\%) . . . . . . . . . . . 119

Figura 7 - Fração da renda total recebida pelo 1\% mais rico em países desenvolvidos selecionados, 1910-2015 (\%) . . . . . . . . . . . . 131

Figura 8 - Coeficientes de Gini para a renda domiciliar per capita, renda individual total, renda total do trabalho e renda horária do trabalho principal Brasil, 1976-2013 . . . . . . . . . . . . . . . . . . . 140

Figura 9 - Médias mensais para a renda domiciliar per capita, renda individual total e renda total do trabalho - Brasil, 1976-2013 ( $\$$ \$ 2013) . . . . . 140

Figura 10 - Carga tributária total e federal e arrecadação do imposto de renda em relação ao PIB - Brasil, 1920-2013 (\%) . . . . . . . . . . . . . . . 162

Figura 11 - Participação do imposto de renda na carga tributária bruta e na arrecadação federal - Brasil, 1920-2013 (\%) . . . . . . . . . . . . . . . . 162

Figura 12 - Carga tributária bruta no Brasil e em grupos de países selecionados em relação ao PIB, 1965-2013 (\%) . . . . . . . . . . . . . . . . . . 164

Figura 13 - Arrecadação do imposto de renda no Brasil e em grupos de países selecionados em relação ao PIB, 1965-2013 (\%) . . . . . . . . . . . . 164

Figura 14 - Frequência relativa de declarantes e contribuintes do IRPF na população de 20 anos ou mais - Brasil, 1927-2013 (\%) . . . . . . . . . . 165

Figura 15 - Número de alíquotas de tributação do IRPF no Brasil e nos Estados Unidos, 1920-2013 . . . . . . . . . . . . . . . . 166

Figura 16 - Alíquotas marginais máximas do IRPF no Brasil e nos Estados Unidos, 1920-2013 . . . . . . . . . . . . . . . . . . 167

Figura 17 - Razão entre as linhas de corte para as alíquotas marginais máximas do IRPF e a renda média - Brasil, 1923-2013 . . . . . . . . . . . . 169 
Figura 18 - Participação dos rendimentos não tributáveis nos rendimentos totais declarados ao IRPF e inflação anual - Brasil, 1974-1988 . . . . . . . . 171

Figura 19 - Participação dos rendimentos isentos e dos tributados exclusivamente na fonte nos rendimentos totais declarados ao IRPF - Brasil, 1996-2013177

Figura 20 - Participação das deduções no rendimento bruto tributável total (\%) Brasil, 1998-2013 . . . . . . . . . . . . . . . . 179

Figura 21 - Probabilidades acumuladas de distribuições de Pareto com diferentes coeficientes de forma . . . . . . . . . . . . . . . . . . . . 199

Figura 22 - Probabilidades acumuladas de distribuição de Pareto e da Normal . . . 199

Figura 23 - População total e controle para população adulta (milhões) - Brasil,

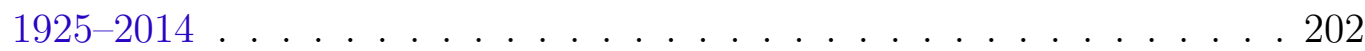

Figura 24 - Controle preferido para renda total e dois controles alternativos em relação ao PIB (\%) - Brasil, 1925-2013 . . . . . . . . . . . . . . . . 206

Figura 25 - Fração do $1 \%$ mais rico e coeficiente de Gini corrigido pelos dados tributários - Brasil, 1926-2013 . . . . . . . . . . . . 216

Figura 26 - PIB per capita e renda disponível per capita ( $\$$ \$ 2014) - Brasil, 1925-2014217 Figura 27 - Variação anual real do PIB per capita (\%) - Brasil, 1925-2014 . . . . . 218 Figura 28 - Inflação anual de acordo com o deflator do PIB (\%) - Brasil, 1925-2014 218 Figura 29 - Contribuição da indústria de transformação para o valor agregado e taxa de abertura da economia (\%) - Brasil, 1947-2013 . . . . . . . . . 219

Figura 30 - Fração da renda recebida pelos 0,01\%, 0,1\% e 1\% mais ricos - Brasil, $1926-2013(\%) \ldots \ldots \ldots \ldots \ldots \ldots$

Figura 31 - Fração da renda recebida pelos 1\%, 5\%, 10\% e 15\% mais ricos - Brasil, 1926-2013 (\%)

Figura 32 - Fração da renda recebida pelos 0,01\%, 0,1\% 1\%, 5\% e 10\%\% mais ricos nos dados observados para rendimentos brutos tributáveis e rendimentos totais - Brasil, 1926-2013 (\%) . . . . . . . . . . . . . . . 222

Figura 33 - Fração da renda total recebida por subgrupos dentro do $1 \%$ mais rico Brasil, 1926-2013 (\%) . . . . . . . . . . . . . . . . 228

Figura 34 - Fração da renda total recebida por subgrupos dentro dos $10 \%$ mais ricos - Brasil, 1969-2013 (\%) . . . . . . . . . . . . . . . . . 228

Figura 35 - Distribuição da renda dentro do 1\% mais rico - Brasil, 1926-2013 (\%) . 230 Figura 36 - Distribuição da renda dentro dos 10\% mais ricos - Brasil, 1969-2013 (\%)230 Figura 37 - Renda anual média dos estratos mais ricos - Brasil, 1926-2013 (R\$2014)232 Figura 38 - Renda anual mínima para pertencer aos estratos mais ricos - Brasil,

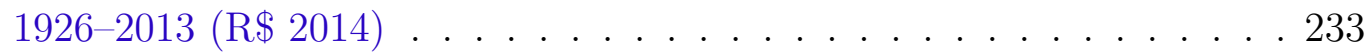

Figura 39 - Fração recebida pelo 0,1\% mais rico nos dados tributários, PNADs e Censos Demográficos - Brasil, 1960-2013 (\%) . . . . . . . . . . . . . 235

Figura 40 - Fração recebida pelo 1\% mais rico nos dados tributários, PNADs e Censos Demográficos - Brasil, 1960-2013 (\%) . . . . . . . . . . 235 
Figura 41 - Fração recebida pelo $10 \%$ mais rico nos dados tributários, PNADs e Censos Demográficos - Brasil, 1960-2013 (\%) . . . . . . . . . . . . 236

Figura 42 - Coeficiente de Gini observado nas PNADs e corrigido de acordo com dados tributários - Brasil, 1976-2013 (\%) . . . . . . . . . . . . . 240

Figura 43 - Coeficiente de Gini observado nos Censos Demográficos e corrigido de acordo com dados tributários - Brasil, 1960, 1970, 1991, 2000 e 2010 (\%)241

Figura 44 - Fração recebida pelo 1\% mais rico no Brasil e em países desenvolvidos selecionados, 1920-2013 . . . . . . . . . . . . . . . . 244

Figura 45 - Fração recebida pelo 1\% mais rico no Brasil e em países em desenvolvimento selecionados, 1920-2013 . . . . . . . . . . . . . . . 246

Figura 46 - Relação entre a fração recebida pelo 1\% mais rico e renda per capita em 29 países, 2010 . . . . . . . . . . . . . . . . . . . 251

Figura 47 - Relação entre desigualdade e renda per capita - Brasil, 1926-2010 (\%) 252

Figura 48 - Relação entre a fração recebida pelo 1\% mais rico e renda per capita no Brasil e em países desenvolvidos selecionados, 1920-2010 . . . . . . . . 254

Figura 49 - Relação entre a fração recebida pelo 1\% mais rico e renda per capita no Brasil e em países em desenvolvimento selecionados, 1920-2010 . . . . 255

Figura 50 - Relação entre a variação da fração recebida pelo $1 \%$ mais rico e o crescimento do PIB per capita no Brasil e em países desenvolvidos selecionados, 1920-2010 . . . . . . . . . . . . . . . 257

Figura 51 - Fração recebida pelo 1\% mais rico considerando apenas os rendimentos brutos tributáveis para a série preferida e séries observadas ordenadas por diferentes conceitos de renda - Brasil, 1926-2013 (\%) . . . . . . . . 260

Figura 52 - Fração recebida pelo 1\% mais rico considerando os rendimentos totais para a série preferida e séries observadas ordenadas por diferentes conceitos de renda - Brasil, 1974-2013 (\%) . . . . . . . . . . . . . 260

Figura 53 - Fração recebida pelo $1 \%$ mais rico considerando apenas os rendimentos brutos tributáveis, com diferentes denominadores de população total Brasil, 1926-2013 (\%) . . . . . . . . . . . . . . . 262

Figura 54 - Fração recebida pelo $1 \%$ mais rico considerando rendimentos totais, com diferentes denominadores de população total - Brasil, 1974-2013 (\%)262

Figura 55 - Fração recebida pelo $1 \%$ mais rico considerando apenas os rendimentos brutos tributáveis, com diferentes denominadores de renda total - Brasil,

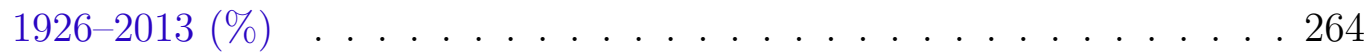

Figura 56 - Fração recebida pelo $1 \%$ mais rico considerando os rendimentos totais, com diferentes denominadores de renda total - Brasil, 1974-2013 (\%) 264

Figura 57 - Participação dos componentes dos rendimentos brutos tributáveis do 1\% mais rico na renda total brasileira - Brasil, 1947-1960 (\%) . . . . . 285

Figura 58 - Fração recebida pelo $1 \%$ mais rico e salário mínimo real ( $\mathrm{R} \$$ fevereiro/2016) - Brasil, 1925-2015 (\%) . . . . . . . . . . . . . 288 
Figura 59 - Participação dos componentes dos rendimentos brutos tributáveis do $1 \%$ mais rico na renda total brasileira - Brasil, 1964-1978 (\%) . . . . . 291

Figura 60 - Alíquota efetiva do IRPF para os estratos mais ricos como fração dos rendimentos brutos tributáveis - Brasil, 1945-1978 (\%) . . . . . . . . . 295

Figura 61 - Participação na renda total dos componentes dos rendimentos totais do $1 \%$ mais rico - Brasil, 1974-1987 (\%) . . . . . . . . . . . . . 301

Figura 62 - Participação na renda total dos componentes dos rendimentos totais do $1 \%$ mais rico - Brasil, 2006-2013 (\%) . . . . . . . . . . . . 308

Figura 63 - Composição dos rendimentos totais do 1\% mais rico - Brasil, 2006-2013

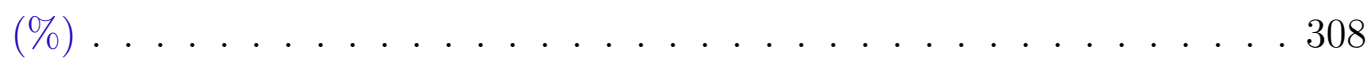

Figura 64 - Retornos salariais à educação para níveis educacionais selecionados Brasil, 1976-2013 (\%) . . . . . . . . . . . . . . . 310

Figura 65 - Alíquota efetiva do IRPF para os estratos mais ricos como fração dos rendimentos totais - Brasil, 2007-2013 (\%) . . . . . . . . . . . . 319 


\section{Lista de tabelas}

Tabela 1 - Abatimentos mais frequentes no IRPF - Brasil, 1923-1988 . . . . . . . 174

Tabela 2 - Composição dos rendimentos não tributáveis como percentual do rendimento total $(\%)$ - Brasil, 2007-2013 . . . . . . . . . . 178

Tabela 3 - Principais categorias das tabulações disponíveis do IRPF para o anobase $2013 \ldots \ldots$. . . . . . . . . . . . . . . . . 181

Tabela 4 - Fontes publicamente disponíveis com tabulações do IRPF para o Brasil, $1927-2013$. . . . . . . . . . . . . . . . . . . . 182

Tabela 5 - Fração média recebida pelo 1\% mais rico nos quinquênios 1930-1935, 1970-1975 e 2010-2015 . . . . . . . . . . . . . . . . . . . . . . . 249

Tabela 6 - Ocupações com maior renda total média nas declarações de IRPF -

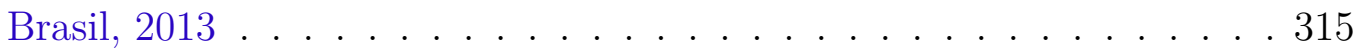




\section{Lista de abreviaturas e siglas}

IR Imposto de Renda

IRPF Imposto de Renda - Pessoa Física

IRPJ Imposto de Renda - Pessoa Jurídica

IBGE Instituto Brasileiro de Geografia e Estatística

Ipea Instituto de Pesquisa Econômica Aplicada

PIB Produto Interno Bruto

PNAD Pesquisa Nacional por Amostra de Domicílios

POF Pesquisa de Orçamentos Familiares

SCN Sistema de Contas Nacionais

SRF Secretaria da Receita Federal

WWID World Wealth and Income Database 


\section{Sumário}

INTRODUÇÃo $\ldots \ldots \ldots \ldots \ldots \ldots \ldots$

I POR QUE OS RICOS?

CAPITALISTAS, ELITES, RICOS: DISCURSOS SOBRE DESIGUALDADE E POLARIZAÇÃO, 1880/1945 . . . . . . . . . . 31

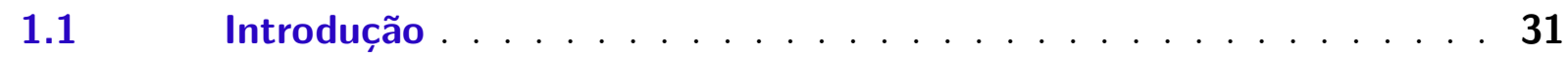

1.2 Do darwinismo social ao socialismo . . . . . . . . . . . . 35

1.3 A ascensão das concepções dicotômicas da estratificação . . . . . 40

$1.4 \quad$ Os ricos e os estudos sobre desigualdade no entreguerras . . . . . 48

$1.5 \quad$ O funcionalismo americano e a legitimidade da hierarquia . . . . . 55

$1.6 \quad$ Considerações finais . . . . . . . . . . . . . . . 59

2 A DOMESTICAÇÃO DA DESIGUALDADE E A ERA DO OTIMISMO, $1945 / 1975 \ldots \ldots \ldots \ldots \ldots 6 \ldots$

$2.1 \quad$ Introdução . . . . . . . . . . . . . . . 61

2.2 A queda da desigualdade e o nascimento dos "trinta gloriosos" . . 63

$2.3 \quad$ A era das narrativas benignas sobre o Ocidente . . . . . . . 67

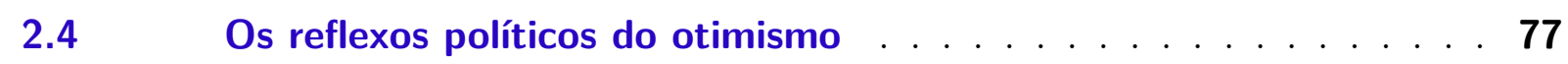

2.5 Declínio e queda das narrativas benignas . . . . . . . . 81

$2.6 \quad$ Kuznets nos trópicos? . . . . . . . . . . . . . . . . . . . 93

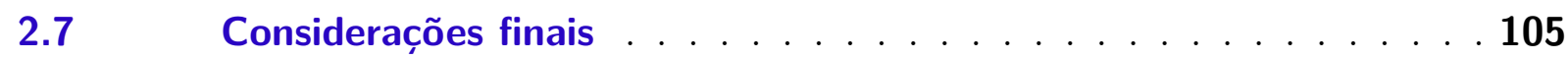

3 O OCASO E O RETORNO DA DESIGUALDADE, 1975/2015 . . 107

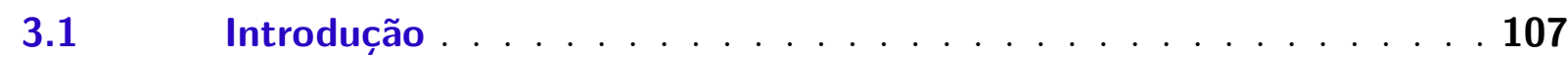

$3.2 \quad 0$ breve ocaso da desigualdade . . . . . . . . . . . 109

3.3 Teorias de classes: de aspirações elevadas à luta para sobreviver . . 117

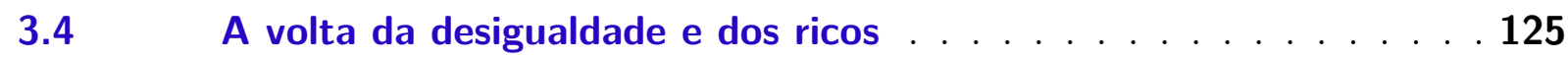

$3.5 \quad$ As idas e vindas da desigualdade brasileira . . . . . . . . . 135

$3.6 \quad$ Considerações finais . . . . . . . . . . . . . . . . 148 
DADOS TRIBUTÁRIOS: MODOS DE USAR . . . . . . . . . . . . 152

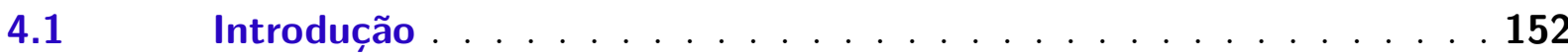

4.2 Por que usar dados do imposto de renda? . . . . . . . . . . . . . . . 154

4.2.1 As limitações das pesquisas domiciliares . . . . . . . . . . . . . . . . . . 154

4.2.2 Vantagens e desvantagens dos dados do imposto de renda . . . . . . . . 156

$4.3 \quad$ Breve história do imposto de renda no Brasil . . . . . . . . . . 159

4.4 A apuração dos rendimentos no IRPF, 1922-2013 . . . . . . . . 169

4.4.1 Modelo geral até o ano-base $1988 \ldots \ldots$. . . . . . . . . . . . 169

4.4.2 Modelo geral entre os anos-base 1989 e 2013 . . . . . . . . . . . . 176

$4.5 \quad$ Fontes disponíveis com tabulações do IRPF . . . . . . . . . . . . 180

4.6 Definição do conceito de renda . . . . . . . . . . . . . . . 187

$4.7 \quad$ Ajustes e imputações iniciais às tabulações . . . . . . . . . . . . . . 190

4.7.1 Ajuste da cobertura geográfica em 1927-1943 e 1966 . . . . . . . . . . . . 190

4.7.2 Imputação dos declarantes por faixa de renda em 1963 e 1964 . . . . . . . 191

4.7.3 Imputação dos rendimentos brutos tributáveis em 1927-1963 . . . . . . . . 192

4.7.4 Imputação do consumo de capital fixo . . . . . . . . . . . . . . 194

$4.8 \quad$ A estimação da desigualdade . . . . . . . . . . . . . . 195

4.8.1 Medidas de desigualdade . . . . . . . . . . . . . . . . . . 195

4.8.2 A interpolação de Pareto . . . . . . . . . . . . . . . 196

4.8.3 Controle para a população total . . . . . . . . . . . . . . . 200

4.8.4 Controle para a renda total . . . . . . . . . . . . . . . . . . . . 202

4.9 Ajustes finais e construção das séries preferidas . . . . . . . . . 206

4.9.1 Desagregando os resultados de 1926-1927 . . . . . . . . . . . . . 206

4.9.2 Escolha dos melhores dados para cada ano . . . . . . . . . . . . . 207

4.9.3 Interpolação e imputação de componentes da renda . . . . . . . . . . . . . 208

4.10 Considerações finais . . . . . . . . . . . . . . . . . 209

5 OS RICOS E A DESIGUALDADE NO BRASIL AO LONGO DE NOVE DÉCADAS ...................... . . 211

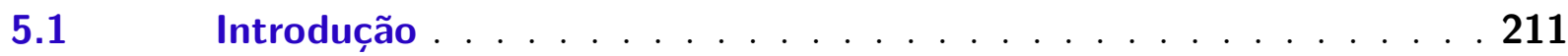

5.2 Prévia dos resultados e breve contexto histórico . . . . . . . . . 215

5.3 A concentração da renda entre os mais ricos no Brasil . . . . . . . 220

5.3.1 A fração da renda recebida pelos ricos . . . . . . . . . . . . . . . . 220

5.3.2 A repartição da renda entre os ricos . . . . . . . . . . . . . . . 227

5.4 Dados tributários vs. pesquisas domiciliares: da concentração no topo ao coeficiente de Gini . . . . . . . . . . . . . . . . . . . . . . . . 234

5.4.1 A fração dos mais ricos nos dados tributários, PNADs e Censos . . . . . . . 234

5.4.2 Corrigindo o coeficiente de Gini . . . . . . . . . . . . . . . 237 
5.5 A concentração no topo no Brasil e no mundo . . . . . . . . . 243

5.5.1 A fatia do $1 \%$ mais rico em comparação internacional . . . . . . . . . . 243

5.5.2 Em busca da curva de Kuznets . . . . . . . . . . . . . . . . . 250

5.6 Quão robustos são os resultados? . . . . . . . . . . . . . . 258

5.7 Considerações finais . . . . . . . . . . . . . . . . . . 265

6 UMA HISTÓRIA POLÍTICA DA DESIGUALDADE NO BRASIL . . 270

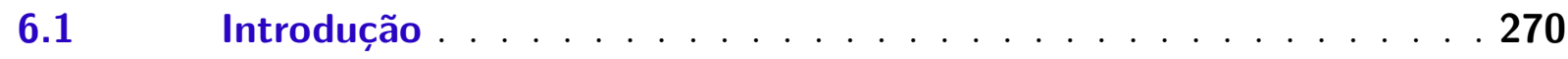

6.2 Do colapso da República Velha ao Estado Novo (1926-1945) . . . 272

$6.3 \quad$ A era de ouro do desenvolvimentismo $(1945-1964) \ldots \ldots$. . . . 280

6.4 Ditadura, repressão e desigualdade $(1964-1979) \ldots 289$

6.5 Inflação e redemocratização (1979-1988) . . . . . . . . . . 300

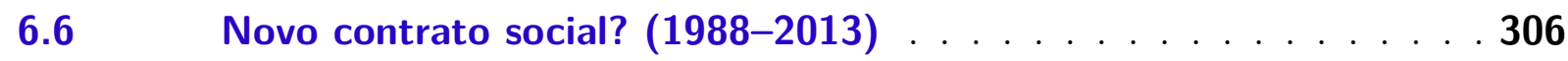

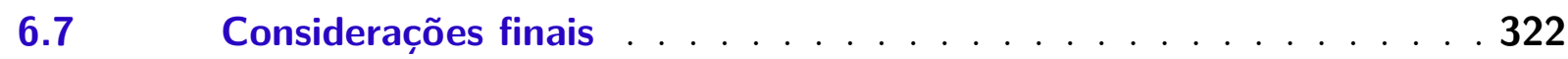

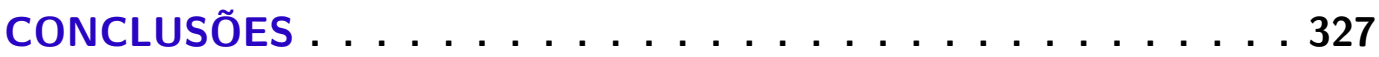

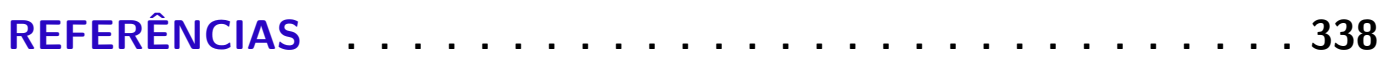




\section{Introdução}

A desigualdade é diferente vista do topo. Quando os ricos estão no centro das atenções, os diagnósticos, hipóteses e interpretações não são os mesmos que emergem ao se analisarem outros estratos, como os mais pobres ou a dita classe média, ou indicadores sintéticos da distribuição de renda como um todo, como o coeficiente de Gini. Analogamente, variados graus de concentração no topo trazem consigo implicações políticas, econômicas e morais diversas. Uma sociedade com uma pequena elite abastada e uma massa empobrecida tende a ser radicalmente diferente de uma sociedade em que a hierarquia de renda ou riqueza é relativamente achatada, ainda que ambas tenham a mesma renda per capita.

Os ricos não são um grupo claramente delimitado. Ainda assim, o volume de recursos econômicos e políticos acumulados por eles costuma ser grande o suficiente para colocar os ricos em uma posição privilegiada para influir na vida social. Na prática, a concentração de renda ou riqueza entre os mais ricos é em geral tão intensa que sua dinâmica afeta inclusive indicadores de desigualdade pouco sensíveis a ela, como o Gini. Com possível exceção dos países mais igualitários, a própria compreensão da distribuição de renda como um todo exige consideração especial para o topo.

Apesar disso, os ricos ainda não são um objeto de estudo frequente, pelo menos não tanto quanto deveriam. A própria falta de uma terminologia consensual trai seu papel secundário: ao contrário do que ocorre com os pobres, o uso do termo "ricos" ainda causa estranheza, a ponto de boa parte da literatura - inclusive esta tese - optar frequentemente por expressões anódinas como "os mais ricos", os "afluentes" ou, em inglês, os top incomes. Talvez até pela posição social dos acadêmicos, acaba-se reproduzindo a ambiguidade de um estrato social que, seja lá como for definido, é alvo de fascínio ao mesmo tempo que se reveste de pudor. Todos querem ser ricos, mas ricos são sempre os outros.

As tendências recentes, no entanto, apontam para um enfoque cada vez maior nos mais ricos, revigorando uma tradição minoritária e antiga, que, embora muito heterogênea, compartilha um olhar sobre a estratificação social a partir do que ocorre no topo. Esta tese ambiciona contribuir para essa tradição, que deveria ter mais protagonismo no Brasil. Somos um país com um alto grau de desigualdade, cuja característica mais marcante e visível é precisamente a concentração de renda e riqueza em um pequena fração da população. Não à toa, a discussão sobre desigualdade quase sempre encontrou por aqui receptividade muito maior do que em outros países. Mesmo assim, o foco recai com muito mais frequência sobre os mais pobres e o que lhes "falta". Não obstante uma pequena e valiosa produção nacional, os mais ricos e o que lhes "sobra" ainda são assunto relativamente pouco explorado. 
O objetivo central desta tese é analisar empiricamente a concentração de renda no topo nas últimas nove décadas no Brasil. Com base em tabulações publicamente disponíveis do Imposto de Renda de Pessoas Físicas (IRPF), apresento estimativas para a desigualdade de renda de 1926 a 2013, o que representa a mais longa e completa série histórica para o Brasil até o momento. Essas estimativas permitem recontar a história do Brasil desde a década de 1920 do ponto de vista da concentração no topo, algo impossível de ser realizado com outras fontes de dados mais conhecidas, como as pesquisas domiciliares amostrais.

Para contornar controvérsias nem sempre fecundas, as querelas sobre a definição conceitual do que é "ser rico" foram deliberadamente evitadas. Essa opção não implica qualquer julgamento de valor acerca da literatura sobre o assunto, que é crescente e muitas vezes fascinante. Assim como no caso da pobreza, por ser uma definição tão normativa quanto técnica significa que não existe, e é altamente improvável que um dia venha a existir, qualquer consenso sobre o tema. Por isso, tanto a definição da pobreza quanto a da riqueza costumam se orientar por escolhas predominantemente pragmáticas. Este trabalho não é diferente: em linha com boa parte das pesquisas recentes, optei por uma definição operacional que preza pela simplicidade, centrada em frações predeterminadas da distribuição de renda, variando do $0,01 \%$ aos $15 \%$ no topo. O centésimo mais rico da população adulta - isto é, o $1 \%$ no topo da distribuição de renda - recebe destaque adicional, assim como ocorre na literatura recente. Trata-se de um estrato numeroso e rico o suficiente para ter alta visibilidade e grande capacidade de afetar tanto o nível quanto a dinâmica da desigualdade mesmo quando se considera a distribuição como um todo.

Teorias e hipóteses sobre a desigualdade nunca estão muito longe de discursos morais e políticos e tendem a carregar marcas de nascença impressas pelos seus contextos socioeconômico e intelectual. Esse aspecto não pode ser ignorado em uma tese ancorada em uma perspectiva histórica. No plano mais abstrato, uma característica frequente da boa sociologia é recuperar as condições de possibilidade da própria análise e os desdobramentos que tornaram possível em determinado momento recortar a realidade de certa forma e colocar em questão certos objetos de estudo. Por exemplo, por muito tempo a sociologia se definiu, ao menos em parte, pela prioridade acordada à análise da estrutura de classes, em detrimento da distribuição de renda. Tratar dos ricos qua ricos rompe com esse comprometimento, algo cada vez mais comum. A recapitulação dos debates intelectuais elucida por que isso vem ocorrendo e, de quebra, a relação da abordagem desta tese com o campo de estudos sobre estratificação. O argumento, por sinal, não se restringe à sociologia: a recuperação do foco nos mais ricos partiu sobretudo de economistas, na esteira de um renovado interesse sobre as questões distributivas. Apurar as origens, motivações e desdobramentos dessas mudanças é parte integral da construção do objeto desta tese.

Mais concretamente, o olhar histórico sobre a evolução dos discursos sobre desigualdade e seu contexto é o que justifica as hipóteses e perguntas que norteiam a análise empírica. As ciências sociais são pródigas em redescobrir a pólvora; a constante reinvenção 
do dualismo "colônia de exploração" vs. "colônia de povoamento" é um bom exemplo (MONASTERIO; EHRL, 2015). Em outros casos, somente um exame mais detalhado de controvérsias e unanimidades passadas desvela como o óbvio nem sempre foi óbvio e, muitas vezes, não permaneceu óbvio por muito tempo. Como discuto mais adiante, a célebre hipótese do "U invertido" de Simon Kuznets - que postula que a desigualdade tende a aumentar nos primeiros estágios do desenvolvimento, para posteriormente refluir é indissociável do seu ambiente sociopolítico, marcando uma guinada otimista na interpretação da desigualdade que deslocou os ricos para segundo plano. Contra muitas das evidências disponíveis, mudanças bruscas foram reinterpretadas como processos graduais de domesticação da desigualdade em um momento em que o medo anterior da desordem paulatinamente deu lugar à satisfação com o apaziguamento social.

Por tudo isso, esta tese está organizada em duas partes que podem ser lidas em separado mas que se iluminam mutuamente. A Parte I cumpre um papel introdutório, apresentando uma história das ideias sobre estratificação que põe em relevo a longa, variada e descontínua tradição de estudos sobre os ricos. Seu objetivo principal é mostrar a efervescência, decadência e, por fim, a recuperação recente desse modo específico de abordar a desigualdade. Para organizar a exposição, recorro à tipologia de David Cannadine (1999), que, em seu estudo das representações históricas da desigualdade na Grã-Bretanha, concluiu que os inúmeros discursos podem ser resumidos em três modelos básicos: o modelo hierárquico, que concebe a sociedade como uma sequência graduada de relações de superioridade e inferioridade; o triádico, que postula a existência de três grandes grupos, correspondentes, grosso modo, às classes baixas, médias e altas; e o dicotômico ou binário, que vê a sociedade polarizada em dois grupos em conflito latente ou explícito.

O argumento que unifica os capítulos da Parte I especula que o interesse intelectual pela desigualdade está estreitamente correlacionado à prevalência do modelo dicotômico, que, por sua vez, remete inexoravelmente à problematização do topo da distribuição de renda ou riqueza. A matéria-prima fundamental é a análise qualitativa da literatura acadêmica, em especial a produção anglo-saxã, desde o fim do século XIX, complementada, onde possível, por evidências quantitativas de caráter bibliométrico e pela recapitulação de eventos políticos e econômicos, sobretudo dos países desenvolvidos.

Em termos do objetivo último desta tese, a contribuição da Parte I para a análise empírica é múltipla. Primeiro, como dito, trata-se de um exercício fundamental de construção do objeto que relaciona esta tese à extensa produção teórica e empírica precedente. Segundo, a Parte I introduz e discute as principais explicações sugeridas pela literatura ao longo do tempo e, com isso, apresenta as hipóteses e perguntas que estruturam a análise empírica. Terceiro, trata-se de justificar e legitimar o estudo dos ricos, em particular em um país como o Brasil. A reconstituição histórica, em consonância com o espírito de toda a tese, oferece uma via alternativa aos esforços sempre presentes em trabalhos sobre desigualdade de provar a relevância do próprio tema. Não é incomum que teses dessa natureza 
comecem pela discussão de teorias da justiça que, espera-se, sejam capazes de afastar as persistentes suspeitas que cercam as questões distributivas; outros preferem legitimar-se recorrendo a evidências empíricas de efeitos nefastos da desigualdade excessiva. Aqui, a opção é por uma terceira alternativa: a recapitulação serve, entre outras coisas, para deixar claro como a exigência do "fardo da prova" é historicamente contingente e que o lado do debate que teve que arcar com a legitimação de sua posição variou ao longo do tempo. Em determinados momentos, foram desvios em relação a um ideal igualitário que tiveram que ser reiteradamente justificados; em outros, como no período mais recente, foi a crítica à desigualdade efetivamente existente que precisou afirmar-se como razoável. Isso abre espaço para que certas questões sejam encaradas por outro ponto de vista: corroborando o que já escreveu Christopher Jencks (2002), os argumentos mais igualitaristas são no mínimo tão fortes quanto os "pró desigualdade", e não há por que considerar que os termos atuais do debate são autoevidentes.

A Parte I possui três capítulos. O capítulo 1 lida com as controvérsias entre as últimas décadas do século XIX e o fim da $2^{a}$ Guerra Mundial, momento em que a preocupação com a desigualdade adquiriu proeminência intelectual e política talvez inédita, movida pelo espectro da polarização social. Em seus diversos sabores, a concepção binária da estratificação, explicitada em oposições como capitalistas/trabalhadores e elites/massas, ganhou enorme visibilidade em um período marcado pelo avanço da industrialização, profunda instabilidade econômica, crescente agitação social e socialista e medo da anomia. No campo intelectual, tudo isso refletiu-se na chamada "descoberta do social", em que os seguidos questionamentos e crises da ordem vigente ajudaram a colocar a desigualdade e as fraturas socioeconômicas em uma posição de destaque. Pelo menos no nível da retórica, desvios com relação ao igualitarismo tiveram que ser cada vez mais justificados, e o fardo da prova recaiu com mais frequência sobre os discursos legitimadores do status quo.

Os discursos dicotômicos sobre desigualdade não eram homogêneos. Pelo contrário, a disputa para estabelecer o eixo fundamental de antagonismo foi ferrenha e extravasou em muito os círculos socialistas. Afinal, as implicações de uma dicotomia insuperável entre capitalistas e trabalhadores são muito distintas das que resultam da oposição entre monopolistas e consumidores em geral, e assim por diante. Em comum, do ponto de vista distributivo, havia a atenção direcionada aos ricos, ou ao menos parte deles, e, exceto entre os mais conservadores, a crença difusa em uma relação causal entre a polarização social e a instabilidade política e econômica. Reformistas e revolucionários de várias estirpes acreditavam ser possível conciliar prosperidade, estabilidade e igualdade. A distinção entre igualdade de oportunidades e de resultados era pouco destacada, não por desconhecimento, e sim pela ideia de que a redução da primeira levaria à queda da segunda.

Diagnósticos e prescrições surpreendentemente contemporâneos podem ser identificados já nessa época. Crítica a monopólios e à concentração de capital, demandas por regulação estatal e maior uso da tributação progressiva para remediar os contrastes sociais 
mais extremos estavam na ordem do dia dos debates acadêmicos e políticos. Empiricamente, as tabulações do imposto de renda e afins constituíam a principal fonte de informações.

Depois da $2^{a}$ Guerra, o mundo mudou rapidamente. O capítulo 2 recupera as reverberações dos "trinta anos gloriosos" sobre o clima intelectual. As sementes plantadas anteriormente pelo funcionalismo e outras correntes encontraram então condições propícias para prosperarem. Objetivamente, os Estados Unidos e boa parte da Europa, entre outros países, saíram da guerra muito menos desiguais do que antes, com grandes reduções na concentração de renda e riqueza no topo, e logo entraram em uma fase de crescimento acelerado, distensão das lutas ideológicas e expansão dos Estados de Bem-Estar Social. Em comparação com as turbulências anteriores, essas mudanças estimularam o aparecimento de um novo repertório teórico composto por "narrativas benignas", como chamou David Grusky (2011), que em nada lembravam os pendores apocalípticos de antes.

Apesar das evidências de que as mudanças foram súbitas e acidentais, em boa parte dessas narrativas a prosperidade e a relativa igualdade apareciam como desdobramento natural das sociedades industriais modernas. As grandes fraturas sociais haviam ficado para trás - ou se tornaram típicas dos países em desenvolvimento - em uma ordem social razoavelmente pacificada. Os ricos e a polarização saíram de cena, e concepções explicitamente hierárquicas ou triádicas da sociedade ganharam cada vez mais espaço. O fardo da prova continuou recaindo sobre a justificação da desigualdade, algo muito mais fácil de ser feito com sucesso em um mundo em que hierarquias de status ou gradações suaves do sistema ocupacional foram promovidas a loci principais da estratificação social.

Talcott Parsons e Simon Kuznets, dois gigantes em suas áreas, foram talvez os maiores expoentes dessas narrativas benignas de meados do século passado. As teorias da modernização, por sua vez, transfiguraram a pacificação da ordem social em ponto de chegada para o resto do mundo ainda em vias de superação do "atraso". Como seria de se esperar, no entanto, sua incorporação nesses países muitas vezes encontrou percalços. No Brasil, a transposição dessas ideias não foi tão simples, principalmente após o golpe de 1964. A controvérsia acerca do aumento da desigualdade nos anos 1960 opôs fortemente defensores da ditadura, que adaptaram à sua maneira as narrativas benignas para o caso nacional, e seus críticos, que apontaram repetidas vezes para a permanência de conflitos de interesses e para as consequências distributivas das ações do Estado.

Seja como for, é difícil negar que, com o tempo, a questão distributiva, agora formulada em termos mais benevolentes, perdeu espaço no novo clima intelectual. $\mathrm{O}$ descompasso entre o otimismo e os fatos ficou grande demais. Dos conflitos raciais nos Estados Unidos ao choque do petróleo, passando por maio de 1968, o novo cenário tratou de solapar as narrativas benignas totalizantes, que progressivamente deram lugar a explicações e justificativas mais abertamente instrumentais. O trade-off entre eficiência e equidade tornou-se incontornável. Se o radicalismo da "nova esquerda" aflorou e rapidamente 
minguou, o novo diagnóstico à direita de incompatibilidade entre objetivos sociais antes vistos como interdependentes - como liberdade, crescimento e moderação da desigualdade - foi muito mais bem-sucedido.

O capítulo 3 conta a história desse período mais recente e heterogêneo, começando pelo que Andrei Shleifer (2009) chamou de "Era de Milton Friedman". A renovada crença no livre mercado ofereceu respostas em um momento em que as soluções antigas claramente deixaram de funcionar. Da candidatura derrotada de Barry Goldwater à presidência americana em 1964 à vitória de Ronald Reagan em 1980, o cenário mudara drasticamente. Como observou Ralf Dahrendorf (1990), o colapso histórico do socialismo foi ainda mais súbito que o do liberalismo no início do século XX.

Nessa conjuntura, o interesse pelo estudo da desigualdade murchou. As novas teorias dominantes não eram tão benignas como outrora, porém a questão distributiva tornou-se secundária e, não raro, vista com certo fatalismo. Empiricamente, a aparente estabilidade da distribuição de renda nos Estados Unidos e na Europa chancelavam o status menor do tema. Enquanto isso, as teorias de classes fracassaram repetidamente em formular uma alternativa com base em antagonismos estruturais que atendesse às aspirações mais elevadas imputadas ao conceito; a única saída foi a progressiva redução das expectativas e ambições em meio a um malaise contínuo. Na prática, o enfoque hierárquico ou triádico foi mantido, os ricos permaneceram fora de cena, o mercado de trabalho consagrou-se ainda mais como o eixo privilegiado da estratificação social, e explicações com base no capital humano tornaram-se pervasivas. Em uma época em que mercados competitivos foram, mais do que um ponto de partida, um pressuposto fundamental de muitas análises, os estudos sobre desigualdades tiveram que arcar com um fardo da prova de sua relevância muito maior do que outrora. Em muitos casos, a suspeita deu lugar à explícita hostilidade quanto à problematização da questão distributiva.

Esse estado de coisas não perdurou. Mesmo sem revoluções intelectuais comparáveis, as últimas duas décadas afastaram-se da ortodoxia dos anos 1980, com o ressurgimento de um grande interesse pela desigualdade. As mudanças empíricas na distribuição de renda nos Estados Unidos e alhures constituíram um forte estímulo inicial, e o acúmulo de evidências apontou para a centralidade da concentração no topo, fenômeno que passou batido para as análises sociológicas ancoradas em classes. Foram os trabalhos de Thomas Piketty e seus colaboradores que potencializaram esses desdobramentos, recolocando a discussão sobre desigualdade - e os ricos - no centro do palco depois de muitos anos.

As concepções dicotômicas da estratificação social foram, por assim dizer, redescobertas. Dessa vez, o foco finalmente recaiu nos ricos propriamente ditos, definidos do ponto de vista distributivo, e não mais das relações de produção. O "1\%" é uma categoria puramente nominal, sem a menor pretensão de expressar uma "classe para si" ou mesmo uma "classe em si", e ainda assim com impacto cultural capaz de organizar todo um debate, 
cabendo até aos críticos posicionarem-se em relação à nova polarização social percebida, seja para negá-la, seja para reafirmá-la em outro eixo.

A redescoberta dos ricos não é uma simples volta ao passado. Para ficar só no plano estritamente intelectual, ainda somos herdeiros das narrativas benignas e das controvérsias posteriores, e não houve rupturas no arcabouço intelectual dominante das últimas décadas. O trade-off entre eficiência e equidade, por exemplo, foi amolecido por novas evidências empíricas e novos modelos teóricos, mas permanece um ponto de partida importante. Igualmente, o fardo da prova foi atenuado, mas não eliminado. Por outro lado, a reaparição dos ricos e da desigualdade na agenda de pesquisas de diversas disciplinas realizou-se em conjunto com a disseminação de modelos menos restritivos e certo ecletismo teórico. Mesmo a sociologia alargou seu escopo para privilegiar também a distribuição de renda.

A Parte II desta tese dialoga diretamente com essas tendências recentes, aproveitando o esgotamento do chamado "crescimento pró pobre" brasileiro dos últimos anos para aproximar-se da produção contemporânea internacional sobre desigualdade. A análise empírica desenvolvida nos capítulos finais desta tese vai ao encontro de quatro aspectos particularmente importantes no debate atual. O primeiro é a ênfase nos ricos. Os outros três, também discutidos na Parte I, são o uso de dados do imposto de renda como fonte primária, a perspectiva de longo prazo da análise e a crescente sensibilidade aos determinantes institucionais da desigualdade.

A interrelação entre esses quatro aspectos estrutura toda a análise empírica e constitui sua principal contribuição ao estudo da estratificação social no Brasil. Afinal, a ressurgência dos estudos sobre os ricos trouxe de volta uma prática que entrara em decadência com a popularização das pesquisas domiciliares amostrais: o uso de tabulações do imposto de renda para estudar empiricamente a concentração de renda no topo da distribuição. Desde Vilfredo Pareto até meados do século XX, os dados tributários foram talvez a principal fonte para a análise da desigualdade; no pós-guerra, junto com a prevalência de concepções hierárquicas e/ou triádicas e das narrativas benignas, eles deram lugar aos surveys, o que, por sinal, ilustra como muitas vezes determinadas formas de interpretar o mundo e os instrumentos que viabilizam a interpretação evoluem pari passu.

Ao mesmo tempo, a recuperação dos dados tributários como fonte fundamental de informações estimulou a adoção de perspectivas de mais longo prazo, para muito além dos horizontes restritos impostos pelas pesquisas amostrais. A confluência com outros campos é notória, em particular com o também florescente interesse em história econômica, inclusive sobre a trajetória da América Latina. Mais ainda, nos dois casos - tanto nos ressurgentes estudos sobre os ricos baseados em dados tributários quanto nas hipóteses para o relativo atraso da América Latina e sua alta desigualdade -, as explicações baseadas em processos históricos e políticos e nas "regras do jogo" tornaram-se centrais. De Daron Acemoglu a Thomas Piketty, a abordagem institucional da estratificação social, em todas as suas 
vertentes, fortaleceu-se e desalojou - ou pelo menos passou a complementar - as abordagens ancoradas quase exclusivamente em forças de mercado e mudanças tecnológicas.

Para reavaliar a história do Brasil desde a década de 1920 sob essa ótica, a Parte II está organizada também em três capítulos. O capítulo 4 discute detalhadamente os aspectos metodológicos vinculados ao uso de informações tributárias, começando pelas vantagens e desvantagens associadas a essa fonte de dados. Uma característica um tanto desafortunada da literatura recente é a tendência a deixar tais questões em segundo plano, muitas vezes relegando toda a discussão a apêndices e anexos excessivamente sucintos. É compreensível que isso seja feito para poupar espaço, e não haveria problema caso se tratasse de fontes amplamente conhecidas e utilizadas. Em breve, talvez essa condição seja atendida; no momento, ainda não é.

Portanto, para dar tanta transparência quanto possível e facilitar a replicação dos resultados, as decisões metodológicas ganham um capítulo próprio nesta tese, tão exaustivo quanto possível. Analisar tabulações publicadas de modo intermitente e não padronizado ao longo de nove décadas não é uma tarefa trivial, havendo um preço a pagar por suas vantagens. Por isso, o capítulo 4 traz uma breve recapitulação da história do IRPF no Brasil, explica em termos gerais a forma de apuração dos rendimentos ao longo do tempo, enumera as fontes publicamente disponíveis para as estimativas e documenta todos os procedimentos necessários para o tratamento dos dados e estimação da concentração de renda no topo. As imperfeições, limitações e incertezas associadas ao uso das tabulações do IRPF para estudar a desigualdade recebem consideração reforçada.

O capítulo 5 inicia a análise empírica propriamente dita, apresentando uma visão geral dos resultados obtidos. A evolução histórica da concentração da renda entre os mais ricos no Brasil de 1926 a 2013 é o seu carro-chefe, com destaque para a fração recebida pelo centésimo mais rico da população adulta. Além desse contraste entre os ricos e o resto da população, os dados tributários permitem a análise da repartição de renda entre os ricos, que serve para deixar claro como, mesmo para o topo da distribuição, nem todas as mudanças na concentração de renda são iguais. Em seguida, o capítulo parte para a comparação com os resultados derivados dos Censos e das PNADs, duas das principais pesquisas domiciliares brasileiras, ampliando temporariamente o recorte do objeto para cotejar os coeficientes de Gini originalmente calculados nessas pesquisas com versões "corrigidas" de acordo com os resultados dos dados tributários. Esse exercício permite que se avalie em que medida a subestimação da renda dos mais ricos nas PNADs e afins afeta o nível e a dinâmica do Gini, o indicador sintético de desigualdade mais usado no mundo. Posteriormente, o foco volta ao topo da distribuição de renda, desta vez para que a experiência brasileira seja comparada à do resto do mundo ao longo do último século. Por fim, o capítulo se encerra com a análise de robustez dos resultados a algumas das principais decisões e definições adotadas. 
Três perguntas principais funcionam como fio condutor para o capítulo 5: a) a concentração de renda no topo no Brasil segue alguma tendência nítida de longo prazo?; b) como a alternância entre ditadura e democracia moldou nossa desigualdade?; c) quando o Brasil se tornou muito desigual em comparação com o resto do mundo?

As origens, justificativas e relevância dessas perguntas são apresentadas na Parte I, que discute como elas se situam entre as lacunas da produção nacional e as heranças dos debates clássicos e tendências contemporâneas aqui e lá fora. Por ora, cabe apenas apresentálas brevemente. A primeira pergunta vincula-se aos efeitos das mudanças estruturais do último século, com ênfase na busca pelo "U invertido" de Kuznets, que permanece proeminente na literatura, apesar de já não gozar de tanta credibilidade quanto no passado. A crença geral em efeitos redistributivos da urbanização e da industrialização permeou muitos debates desde o pós-guerra até hoje, de modo que a visão de longo prazo oferecida pelos dados tributários é uma boa oportunidade para reavaliá-la.

Em contraste, a segunda pergunta põe em jogo os determinantes institucionais da desigualdade, ainda que em termos gerais dados pela simples natureza do regime político. Mais concretamente, ela dialoga com a sensação otimista e difusa - e muito razoável de que a redemocratização e a Constituição Federal de 1988 foram divisores de águas, estabelecendo as bases para um novo perfil distributivo do Estado, menos elitista e mais permeável às demandas sociais das camadas mais pobres da população.

A última pergunta traz à tona a perspectiva histórica e as controvérsias recentes sobre o "excepcionalismo" latino-americano, isto é, o fato de que a região é a mais desigual do mundo. A sabedoria convencional atribui à forma de colonização espanhola e portuguesa as origens da elevada concentração de renda, contrastando os latifúndios movidos por trabalho escravo às pequenas e médias propriedades características do norte dos Estados Unidos no período colonial. Mais recentemente, ao lado de reformulações desse diagnóstico, alguns pesquisadores, notadamente Jeffrey Williamson (2015), lançaram interpretações revisionistas que propõem que, em comparação com a Europa, a América Latina só se tornou muito mais desigual no século XX. Mais uma vez, a disponibilidade de dados tributários de longo prazo oferece uma ocasião para avaliar essa hipótese.

O capítulo 6, o último desta tese, complementa a visão geral desenvolvida no capítulo anterior com uma análise histórica da trajetória brasileira desde o entreguerras. O argumento central é que a correlação da dinâmica da concentração de renda no topo com nossos grandes ciclos políticos é compatível com a história política e econômica do Brasil no período e, mais ainda, não é mera coincidência. O capítulo procura dar substância à interpretação esboçada no capítulo anterior acerca da determinação institucional da desigualdade e o caráter inercial da concentração de renda no topo, que, seja no Brasil ou no exterior, tende a só mudar significativamente em arroubos causados por crises e rupturas, que abrem espaço para o redesenho de um amplo leque de instituições. 
A ideia básica é que determinado padrão de desigualdade resulta sobretudo do efeito combinado e cumulativo de uma série de políticas e programas, de pequenas e grandes decisões, e que, em condições democráticas normais, tanto a ameaça de desorganização social quanto o próprio perde-e-ganha político dificultam muito a redistribuição duradoura e significativa dos mais ricos para o resto da população. Reformas radicais tendem a permanecer imprevisíveis e excessivamente arriscadas, enquanto reformas graduais, cumulativas e persistentes dificilmente obtêm sucesso no longo prazo, dada a ausência de um único mecanismo que seja capaz de explicar determinada distribuição de renda e do poder de veto e barganha característico de grupos com recursos econômicos abundantes.

Por sua própria natureza, este último capítulo é o mais especulativo de todo o trabalho, exigindo certas qualificações que, em diferentes graus, também se aplicam aos capítulos precedentes. Dado o enquadramento, o escopo e o recorte temporal desta tese, a combinação de evidências qualitativas e quantitativas é inevitável, de modo que a narrativa histórica baseada na série estimada para a concentração de renda no Brasil ocupa o primeiro plano, em detrimento de quaisquer testes estatísticos rigorosos de afirmações pontuais, que, vale dizer, seriam impossíveis, tanto pela falta de informações quanto pela abrangência das duas partes desta tese. De um modo ou de outro, pelo menos nesse quesito esta tese está em boa companhia, filiando-se a toda a literatura recente sobre top incomes, capitaneada por Piketty e associados, e a muitos dos debates recentes sobre a história da desigualdade na América Latina, que também adotam abordagens mais panorâmicas do que econométricas.

Em conjunto, os seis capítulos desta tese almejam contribuir para a extensa literatura sobre desigualdade por meio de uma abordagem histórica atenta tanto aos discursos quanto à evolução empírica da concentração de renda no topo. Se os argumentos apresentados estiverem corretos, os ricos devem permanecer no radar das ciências sociais por um bom tempo e, junto com eles, o interesse pela desigualdade, especialmente no Brasil. Quase dois séculos depois, o assombro expresso por Alexis de Tocqueville nas linhas que servem de epígrafe a este trabalho está longe de ter se tornado realidade. 
Parte I

Por que os ricos? 


\title{
1 Capitalistas, elites, ricos: discursos sobre desigualdade e polarização, 1880/1945
}

\begin{abstract}
So long as all the increased wealth which modern progress brings goes but to build up great fortunes, to increase luxury and make sharper the contrast between the House of Have and the House of Want, progress is not real and cannot be permanent.
\end{abstract}

Henry George, Progress \& Poverty (1879)

\subsection{Introdução}

Em 2014, a repercussão em torno d'O Capital no Século XXI, de Thomas Piketty, transformou o estudo dos ricos em fenômeno pop. Piketty virou o "economista rock star" (KACHKA, 2014) e rapidamente as dezenas de resenhas e reportagens sobre o livro passaram a conviver com matérias sobre seu sucesso comercial: o livro foi o mais vendido em toda a história da Harvard University Press (TRACY, 2014; VANDERMEY, 2014). A badalação manifestou-se de modo mais debochado na capa da primeira Businessweek de junho de 2014, que imitou uma revista adolescente com Piketty como o galã do momento. Já sua expressão mais prestigiosa deu-se alguns meses depois, no início de 2015, quando o presidente americano Barack Obama tratou explicitamente da riqueza acumulada pelo $1 \%$ mais rico e da desigualdade em seu discurso anual no Congresso sobre o estado da nação. ${ }^{1}$

O sucesso de Piketty foi merecido. Seu Capital é a culminação de uma agenda de pesquisa de quase duas décadas, com colaboradores de alto nível e um trabalho histórico de primeira linha, que mudou os termos do debate acadêmico sobre desigualdade. O curioso é que o fenômeno não é inédito. Discursos críticos acerca da concentração de renda e riqueza entre os mais ricos certamente não são novidade, como atesta a frase de Henry George na epígrafe deste capítulo. Só que os precedentes vão além, e o próprio George é um ótimo exemplo. Como o Capital de Piketty, seu Progress $\&$ Poverty é um calhamaço de mais de 500 páginas cujo objetivo era explicar as causas por trás das grandes fortunas

\footnotetext{
1 A reprodução da capa da Businessweek parodiando o sucesso de Piketty está disponível em <https: //web.archive.org/web/20150730061159/http://www.bloomberg.com/bw/articles/2014-05-29/ pikettys-capital-economists-inequality-ideas-are-all-the-rage $>$. A transcrição do discurso de Obama pode ser encontrada em < https://web.archive.org/web/20150730065757/https://www.whitehouse.gov/ the-press-office/2015/01/20/remarks-president-state-union-address-january-20-2015>. Para garantir a validade dos sites mencionados nesta tese, sempre que possível reporto os endereços arquivados pelo Wayback Machine, do Internet Archive. Os links encaminham para as páginas originais enquanto elas permanecerem ativas. Se as páginas saírem do ar, eles redirecionam o browser para a cópia salva nos servidores do Internet Archive no momento em que foram gerados. Mais informações em <https://archive.org/web/>. Acessos em 30 jul. 2015.
} 
e propor reformas para remediá-las. Como o Capital de Piketty, seu Progress 6 Poverty está longe de ser um libelo socialista, comunista ou o que for, apesar de desafiar as teorias dominantes em sua época sobre o assunto. Como o Capital de Piketty, seu Progress 6 Poverty foi um grande bestseller, que trouxe imensa notoriedade ao seu autor: com uma generosa dose de exagero, sua neta Agnes George De Mille (1979) escreveu mais tarde que George, outrora um desconhecido, transformara-se no terceiro homem mais famoso dos Estados Unidos, depois de Thomas Edison e Mark Twain.

Em outras palavras, a descoberta dos ricos com Piketty foi na verdade uma redescoberta; o objetivo deste e dos próximos capítulo é justamente recuperar essa história. Afinal, a contextualização das discussões sobre a desigualdade ajuda muito a entender a reemergência do "problema dos ricos" e as hipóteses explicativas vigentes.

A tese central desta Parte I é que a sensibilidade acadêmica à desigualdade teve idas e vindas desde o final do século XIX, com o maior interesse pela questão distributiva ocorrendo quando ela foi frequentemente concebida em termos binários ou polarizados, em especial com a oposição entre os ricos e o resto da população. Foi assim com Henry George e tem sido assim com Piketty. Neste capítulo, a análise se dedica aos anos entre a publicação de Progress $\& 5$ Poverty e a $2^{a}$ Guerra Mundial, marcados pela problematização crescente da desigualdade e pela ascensão do modelo dicotômico de estratificação.

Como comentado na Introdução, recuperar o debate histórico coloca em perspectiva uma questão tão recorrente quanto desconcertante para quem estuda a desigualdade: por que, aliás, se importar com isso? Milhares de páginas já foram escritas para tentar responder essa pergunta. Sem dúvida, parte do problema está na fronteira porosa entre estudar a desigualdade e querer reduzi-la. No primeiro caso, não parece ser muito controverso que se trata de um assunto relevante para as ciências sociais: para além dos impactos da estratificação social sobre as chances de vida dos indivíduos, não é preciso ser sociólogo e muito menos socialista para admitir que a renda ou riqueza de terceiros afeta o bem-estar das pessoas, e que a percepção de injustiça na sua distribuição provoca sentimentos fortes, como argumentou Milanovic (2007). Já a segunda questão é bem mais espinhosa e, em última instância, não tem resposta definitiva, apesar de todas as tentativas para resolvêla seja pelo lado da filosofia política, seja por argumentos acerca das consequências da desigualdade. Do ponto de vista moral, para cada Rawls, há um Nozick; do ponto de vista consequencialista, o caráter normalmente precário das evidências empíricas em ciências sociais e as reações viscerais provocadas pelo assunto fazem com que consensos duradouros sobre níveis desejáveis de desigualdade sejam pouco prováveis.

A recapitulação histórica ajuda a desnaturalizar os termos da controvérsia. Durante muito tempo, a exigência de justificação recaiu com frequência não sobre o ímpeto igualitarista, e sim sobre a defesa do status quo. Grosso modo, só nas últimas décadas do século passado é que a situação se inverteu. Embora obviamente não resolva a questão 
nem apague os melhores argumentos anti-igualitaristas, recordar essa história pode arejar as discussões recentes e explicitar pressupostos. Em sua revisão dos estudos sobre as consequências da desigualdade, Christopher Jencks (2002) destacou um ponto parecido: se é verdade que os argumentos igualitaristas estão longe de ser incontestáveis, é bom lembrar que o caso "pró desigualdade" sofre do mesmo embaraço.

A referência principal para esse exercício é a tipologia adotada por David Cannadine (1999) em seu esforço para recontar a história do conceito de "classe" como a história das percepções acerca da sociedade. Ao analisar as representações populares e sobretudo políticas da Grã-Bretanha desde o século XVIII, Cannadine concluiu que os britânicos sempre recorreram a três modelos básicos de estratificação social, sendo que a palavra "classe" foi usada indiscriminadamente para se referir a todos eles, de modo que os próprios indivíduos não tinham dificuldade em deslizar de um modelo para outro conforme sua conveniência. Em sua narrativa, o modelo histórico mais popular foi o hierárquico, i.e., a descrição da sociedade como um continuum, uma gradação de finas camadas interligadas por relações verticais, do ponto mais baixo até o cume da hierarquia social. O segundo modelo é o triádico, a concepção da sociedade como composta por três grandes grupos sociais, normalmente classificados como as classes baixas, médias e altas. Por fim, ele apontou a existência de um modelo dicotômico e/ou polarizado, em que a sociedade é vista como dividida entre dois grupos antagônicos em conflito real ou potencial.

Cannadine tratou os três modelos como simplificações grosseiras da realidade. Contudo, sua querela com a interpretação marxista da história britânica acabou impelindoo a criticar com muito mais avidez o modelo binário do que os demais. Ao mesmo tempo, em diversas passagens ele defende o modelo hierárquico como o menos problemático. $\mathrm{Na}$ mesma linha, embora mostre interesse e comente os ciclos de ascensão e queda na popularidade de cada modelo ao longo do tempo, ele optou por reiterar com mais ênfase a estabilidade da coexistência ininterrupta dos três.

O argumento desenvolvido aqui modifica um pouco essa abordagem de Cannadine. O foco está precisamente na intensidade do interesse intelectual pela desigualdade e na ascensão e queda do poder de persuasão do modelo dicotômico. O recorte é mais acadêmico, pois não se trata de determinar qual visão da sociedade era mais comum no público em geral. Os discursos e representações construídas por políticos são citados de forma ilustrativa, e não definitiva, para mostrar a ressonância das controvérsias intelectuais em outras esferas. Tampouco afirmo aqui que um ou outro modelo foi universalmente adotado por intelectuais e acadêmicos em qualquer momento. Assim como Cannadine, não ambiciono explicar em detalhes por que as concepções da estratificação variaram ao longo do tempo nem determinar se o motor da mudança foi interno ou externo à esfera intelectual. Algumas especulações sobre isso são feitas ao longo do texto - seria impossível escrever sobre o assunto sem entrar nessa seara - sem a pretensão de dar uma resposta compreensiva ou definitiva, o que seria de resto inviável. 
Antes de passar para a análise, cabem algumas ressalvas de ordem prática. Primeiro, como não poderia deixar de ser, o recorte temporal foi escolhido apenas para facilitar a exposição e viabilizar o trabalho. Segundo, trato principalmente de autores e publicações britânicas e americanas, com a ocasional presença de outras nacionalidades e regiões. Para o bem ou para o mal, há muito a influência das discussões nesses países ultrapassa as suas fronteiras. Estados Unidos e Grã-Bretanha são líderes em termos políticos, econômicos e acadêmicos, e sua capacidade de pautar ou fornecer os parâmetros de referência para as discussões alheias não deve ser menosprezada. Terceiro, a análise não explora a fundo a ampla literatura marxista e socialista. Em boa parte, a relativa negligência é proposital e fortalece o argumento defendido neste capítulo: seria fácil mobilizar exclusivamente autores socialistas para defender a prevalência de concepções polarizadas da desigualdade. O ponto é que mesmo autores de outras vertentes operaram com concepções semelhantes. Quarto, em nenhum momento a recapitulação tem a presunção nem de desmascarar nem de glorificar quaisquer autores ou correntes teóricas. As diversas interpretações são reproduzidas e/ou criticadas conforme a lógica do argumento central do capítulo.

A quinta e última ressalva merece um tratamento à parte. Ao longo do texto, refiro-me à "desigualdade" e à "estratificação" de forma intercambiável, e com sentido abrangente, com o intuito de dar conta das tentativas de interpretação das disparidades socioeconômicas. Essa decisão é útil e conveniente para meus fins, apesar do desconforto que pode causar em alguns leitores, em especial para os marxistas, para quem a centralidade do conflito de classes não pode ser reduzida nem à "desigualdade" nem à "estratificação", dados os significados historicamente associados a esses termos. Há muito, por exemplo, Stavenhagen (1974) opunha a análise de classes ao estudo da estratificação social: para ele, esta última seria um fenômeno da superestrutura que cumpriria uma função ideológica de diluir o conflito objetivo de classes em uma hierarquia de prestígio, ocultando o processo dinâmico configurado pelas relações de produção.

O capítulo está organizado da seguinte forma: a seção 1.2 delineia as mudanças no clima intelectual no período anterior à $1^{a}$ Guerra Mundial e os elementos mais salientes do contexto socioeconômico do período; a seção 1.3 aprofunda a análise, examinando a literatura em mais detalhe e destacando a prevalência de concepções polarizadas da estratificação e a problematização dos ricos; a seção 1.4 avança para os anos entre a $1^{a}$ e a $2^{a}$ Guerras Mundiais, que testemunharam tanto a continuidade do processo como algumas novidades, como a proliferação de estudos empíricos sobre desigualdade; a seção 1.5 discute a emergência das teorias funcionalistas nos anos anteriores à $2^{a}$ Guerra como uma das sementes que permitiram a ascensão de concepções não polarizadas da sociedade no pós-guerra; e a seção 1.6 resume os principais pontos do capítulo. 


\subsection{Do darwinismo social ao socialismo}

Talcott Parsons, talvez o sociólogo mais influente do século XX, começou sua primeira grande obra repetindo a pergunta do historiador americano Crane Brinton: quem ainda lia Herbert Spencer em plena década de 1930? Spencer, um dos mais proeminentes intelectuais europeus do século XIX, estava física e intelectualmente morto. Para Parsons (1949c), a evolução da teoria social destronara o evolucionismo. O darwinismo social, a crença absoluta na autorregulação de uma ordem contratual pura e, de modo geral, as teorias positivistas da ação estavam desmoralizadas. Em contrapartida, teorias de cunho anti-individualista, coletivista ou socialista, entre outras, estavam em ascensão.

Na visão de Parsons, essa era uma revolução intelectual virtualmente sem precedentes na interpretação das sociedades humanas. Não por acaso, seu livro explora como tal revolução foi acompanhada pela transformação da estrutura dos sistemas teóricos. Sua tese é que questões imanentes à teoria social induziram a emergência de "teorias voluntaristas da ação". Independentemente do mérito de sua síntese teórica, Parsons não estava errado sobre Spencer, em boa medida apagado da história da sociologia, que elegeu seus (quase) contemporâneos Karl Marx, Émile Durkheim e Max Weber como pais fundadores.

Um aspecto central dessa "revolução" foi a mudança radical na percepção dominante quanto às desigualdades socioeconômicas, pelo menos no mundo já industrializado. $\mathrm{O}$ final do século XIX foi a era de ouro do que Collins e Makowsky (1993) chamaram, com propriedade, de "descoberta do social", estimulando a reinterpretação de dramas individuais como coletivos. Com a ordem social intensamente questionada, a preocupação com a desigualdade adquiriu legitimidade intelectual e política talvez inéditas. Reformistas, revolucionários e conservadores de todas os matizes digladiaram-se o tempo todo.

Basta notar o contraste entre Spencer e seus discípulos, de um lado, e Marx, Durkheim e Weber, de outro. No fim do século XIX, a sensibilidade vitoriana dos primeiros já estava à flor da pele. Em 1883, ano da morte de Marx, o sociólogo americano William Graham Sumner, um então influente discípulo de Spencer, publicou What social classes owe each other (1974) com o objetivo de refutar o "sentimentalismo" que culpava os ricos pelos problemas sociais. Em uma sociedade de homens livres e independentes, baseada em uma ordem contratual, distinções de classe resultam do sucesso dos homens em aproveitar suas oportunidades. Logo, não haveria possibilidade de realizar a igualdade sem ferir o princípio maior da liberdade. Grandes capitães da indústria, escreveu ele, são tão raros e preciosos quanto grandes generais, e o acúmulo de grandes fortunas é condição necessária para o avanço social. No ano seguinte, o próprio Spencer (1981) ecoou essas ideias em tom ainda mais pessimista, antevendo a derrocada da liberdade face à escravidão. Para ele, a ampliação do voto para as massas, a crença errônea de que o sofrimento social poderia e deveria ser erradicado e a falta de resistência dos liberais só poderiam desembocar na expansão desastrosa da interferência do Estado na vida social e, por fim, no socialismo. 
Apesar de todas as suas diferenças, os pais fundadores eleitos pela sociologia do século XX estavam a um mundo de distância de Spencer, e o momentum estava com eles. A década de 1880 testemunhou a publicação póstuma do segundo volume d'O Capital em alemão e a tradução para o inglês do primeiro volume. Em 1893, Durkheim publicou A Divisão Social do Trabalho, que insistia na primazia da sociedade, no caráter falacioso da oposição entre regras e liberdade e na necessidade de regulação social para moderar as desigualdades e assegurar a solidariedade orgânica diante da ameaça da anomia (DURKHEIM, 1984). Nas décadas seguintes, Weber - o menos socialista dos três, por assim dizer - escreveu extensamente sobre dominação, estratificação e legitimidade a partir de um ponto de vista muito mais próximo de Marx do que de Spencer, a despeito das divergências intelectuais e políticas entre eles (e.g., WEBER, 1978).

Assim, não obstante o acerto factual de Spencer quanto à expansão do Estado, em meados do século XX a incompatibilidade entre liberdade e igualdade já não era mais autoevidente. Com efeito, essa expansão ainda continuou por décadas: nos países ricos, a carga tributária saltou de cerca de 10\% em 1910 para 20-25\% em 1940 e 30-50\% em 1980, estabilizando-se desde então (PIKETTY, 2014a, p. 475).

Nada disso implica que todos tenham se tornado igualitaristas ou que argumentos como os de Spencer, em particular a ideia de um caminho escorregadio rumo à servidão, tenham desaparecido por completo. Em 1944, por exemplo, Friedrich von Hayek (2006) obteve grande repercussão com A estrada para a servidão, que evocava muitos desses medos. O lugar da fala, no entanto, mudara completamente: se Spencer era um dos luminares intelectuais do século XIX, personificando a voz do establishment, Hayek ainda era um intelectual em ascensão nesse momento, tendo escrito sua diatribe contra o planejamento governamental como uma reação ao establishment.

Em resumo, entre a época de Spencer e a $2^{a}$ Guerra Mundial, ao menos no plano retórico, os desvios com relação a um ideal igualitário tiveram que ser cada vez mais justificados. O liberalismo clássico estava em baixa, assim como o evolucionismo que legitimava a hierarquia social. Mesmo nos Estados Unidos, a era de ouro de narrativas do tipo "dos trapos à riqueza" (rags to riches), simbolizada pelos livros infanto-juvenis de Horatio Alger, encontrava o seu fim. Como escreveu o historiador inglês R.H. Tawney no prefácio à reedição de 1938 de seu manifesto Equality:

Às vezes ainda se sugere que aquilo que o professor Pigou, em seu último trabalho, chama de "desigualdades gritantes de riqueza e oportunidade que deformam nossa civilização no presente" são benéficas, irreversíveis, ou ambos. [...] Se houve um tempo em que absurdos desse tipo podiam ser defendidos a partir das conclusões da ciência econômica, esse tempo já passou. O fardo da prova recai hoje não sobre os críticos das desigualdades econômicas e sociais examinadas nas páginas seguintes, mas sobre seus defensores. (TAWNEY, 1964, p. 27) ${ }^{2}$

2 Ao longo de toda esta tese, todas as citações de obras que constam nas referências bibliográficas em 
Figura 1. Variação real anual do PIB per capita em países industrializados selecionados $1875 / 2010$

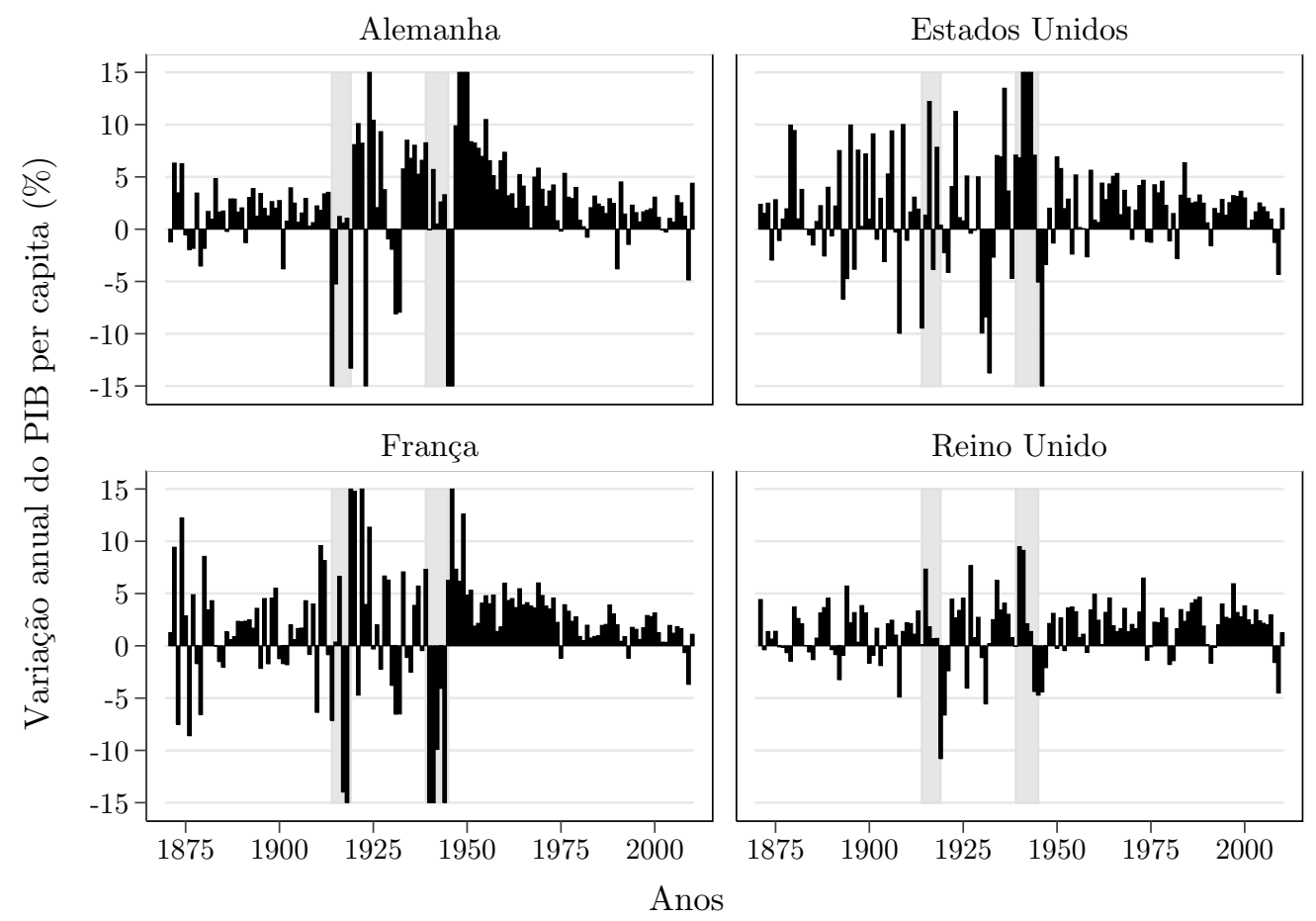

Fonte: elaboração do autor a partir da Maddison Project Database (THE MADDISON PROJECT, 2013).

N.B.: valores truncados em $\pm 15 \%$ para facilitar a visualização. As áreas sombreadas representam as duas guerras mundiais.

É tentador explicar essa mudança a partir das muitas agruras econômicas de uma época pródiga em grandes crises, que testemunhou duas grandes depressões (a Longa Depressão de 1873-79 e a Grande Depressão dos anos 1930) e duas guerras mundiais, além de uma miríade de recessões, pânicos e revoluções nacionais, incluindo, obviamente, a Revolução Russa de 1917. No entanto, a história não é tão simples. Como Cannadine (1999) bem argumenta, a relação entre percepções sociais e a realidade objetiva nunca é tão transparente. Às turbulências objetivas é preciso somar o impacto da emergência de uma nova categoria social, com enorme visibilidade: a "classe trabalhadora".

Comecemos pela imensa volatilidade econômica, com alternância frenética de crises e surtos de crescimento. A Figura 1 mostra as taxas anuais de crescimento do PIB per capita entre 1875 e 2010 nos principais países industrializados do começo do século XX. A maior volatilidade no período anterior à $2^{a}$ Guerra salta aos olhos, apenas com possível exceção do Reino Unido. Em boa parte dos países mais ricos, houve mais anos tanto com crescimento negativo quanto com crescimento elevado (i.e., acima de 5\%) do PIB per capita entre 1870 e 1940 do que entre 1940 e 2010. Nos maiores países da América do Sul, também houve menor volatilidade no período mais recente pelo menos no Brasil, no Chile e, em alguma medida, na Argentina, embora nem tanto na Colômbia.

outros idiomas foram traduzidas por mim para o português, a não ser que se indique o contrário. 
Figura 2. Frequência relativa de termos relacionados a classes ou estratos sociais no corpus em inglês do Google Books, 1875-2000

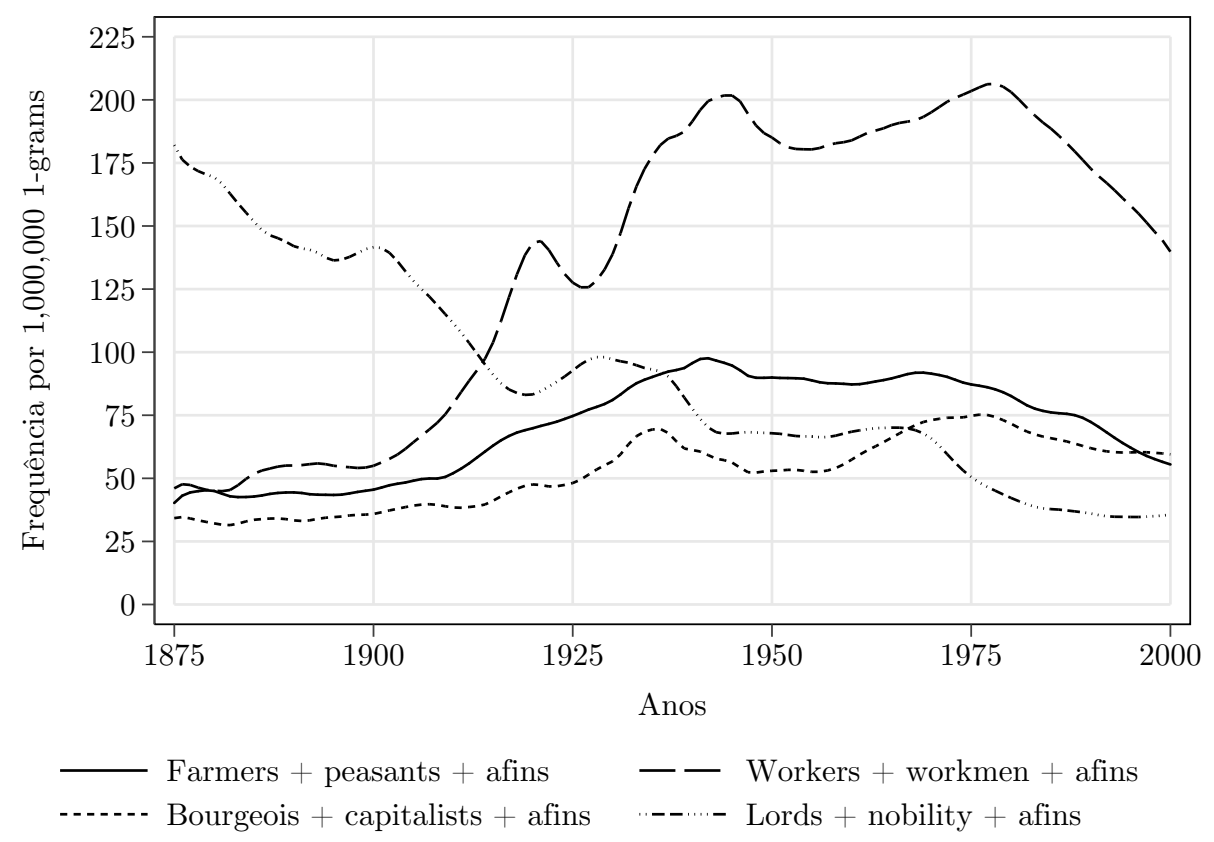

Fonte: elaboração do autor a partir do Google Ngram.

N.B.: dados suavizados por regressão local com banda de 10 dez anos. Cada categoria abrange os cinco termos mais populares sobre o tópico. Mais informações com o autor.

O que potencializou os efeitos dessa fase de crescimento com alta volatilidade foi o prosseguimento da industrialização ter gerado uma classe trabalhadora definida justamente por ser indispensável à nova ordem e ao mesmo tempo estar desprotegida frente às instabilidades. De Marx a Robert Castel (2003), incontáveis páginas já foram escritas sobre esse processo. Ainda assim, é útil tentar quantificar, ainda que de forma um tanto grosseira, a ascensão do "trabalhador" em termos de visibilidade social. A Figura 2 mostra a frequência relativa de termos associados a quatro grandes estratos sociais camponeses, trabalhadores, burgueses e nobres - em livros de ficção e não ficção do corpus em inglês do Google Books, extraídos via Google Ngram Viewer. ${ }^{3}$

Poucos gráficos expressam tão bem como as mudanças objetivas do período repecurtiram sobre discursos e percepções. Com todas suas limitações, a Figura 2 ilustra como a categoria social dos "trabalhadores" não só ganhou enorme visibilidade em relação ao início do período, como também em relação aos outros estratos sociais. ${ }^{4}$ Entre 1875 e 1950, o uso de termos relacionados aos trabalhadores aumentou quatro vezes, de cerca de 50 para 200 a cada milhão de palavras, mantendo-se estável desde então, com alguma tendência de

3 O Google NGram Viewer é uma ferramenta de buscas que registra as frequências absoluta e relativa de blocos de texto (n-grams) nas obras digitalizadas do Google Books. Para mais informações, ver Michel et al. (2011) ou o site do projeto: <https://books.google.com/ngrams>. Acesso em 30 jun 2015.

$4 \mathrm{O}$ aumento discreto de termos ligados à burguesia decorre em parte o fato de que os resultados dizem respeito apenas a palavras ou unigrams, deixando de fora termos compostos, como middle class. Expressões com diferentes números de termos não são diretamente comparáveis. 
queda no fim do século XX. Já os termos vinculados à nobreza tiveram trajetória oposta. Os termos para burgueses e camponeses apresentam crescimento modesto, seguido por estabilidade. Como referência, Michel et al. (2011) consideram uma palavra ou unigram comum se sua frequência relativa é superior a um em um milhão.

Tamanha visibilidade é pouco dissociável da agitação sindical e da disseminação de ideias socialistas. Uma das faces da "descoberta da sociedade" foi o questionamento crescente da ordem social. Consolidou-se a ideia de que a desigualdade era alta e até excessiva, o que refletiu mais uma mudança de visão do que propriamente transformações objetivas na distribuição de recursos econômicos, até mesmo em função da escassez de dados à disposição dos contemporâneos. Muitas escaramuças intelectuais e políticas da época deslocaram-se para como atacar a questão e promover o progresso social.

O período entre o fim do século XIX e o início do século XX foi a era de ouro de teorias de cunho socialista baseadas na luta de classes. Grosso modo, a questão distributiva era encarada como epifenômeno do antagonismo fundamental inscrito nas relações de produção. Marx e sua Crítica ao Programa de Gotha (1996) representam bem essa abordagem. Mais ainda, os socialistas nutriam a crença de que as virtudes andariam juntas, sendo possível resolver simultaneamente os problemas da desigualdade e da instabilidade econômica, isto é, da irracionalidade intrínseca ao capitalismo.

De Eugene Debbs a Leon Trostky, a lista de socialistas renomados do período é extensa, e, por isso, cito aqui apenas dois exemplos representativos. O primeiro mostra como mesmo os não revolucionários passaram a crer, em certo momento, na inevitabilidade do colapso do capitalismo. Em 1923, Sidney e Beatrice Webb - co-fundadores da London School of Economics e personagens centrais do socialismo fabiano e do Partido Trabalhista inglês - publicaram The Decay of Capitalist Civilisation, uma ampla condenação das sociedades capitalistas, que estariam se dissolvendo diante dos olhos de todos. No livro, eles discutiram os "quatros males do capitalismo", cuja raiz comum estaria na propriedade privada dos meios de produção: a pobreza das massas, a desigualdade de renda, as disparidades no grau de liberdade individual e a irracionalidade do sistema (WEBB; WEBB, 1923).

O segundo exemplo é tardio, porém notável por ser tão inusitado para o mundo do século XXI. Em 1949, Albert Einstein - já radicado nos Estados Unidos, ganhador do prêmio Nobel em física e reconhecido internacionalmente - escreveu um pequeno ensaio para a edição inaugural da revista socialista Monthly Review explicando por que acreditava no socialismo como único remédio para a crise de seu tempo. Para Einstein, a essência da crise estava na relação do indivíduo com a sociedade: o homem é um ser social, que depende da sociedade - i.e., de suas relações diretas e indiretas com seus contemporâneos e antecessores - para se desenvolver. Contudo, o homem do século XX só sentia essa dependência como ameaça ou restrição a seus direitos naturais, e não como um vínculo orgânico positivo. A fonte de tal distorção seria a anarquia econômica da 
sociedade capitalista, com sua ênfase irracional no lucro e na competição e sua tendência a concentrar a propriedade dos meios de produção em poucas mãos. O resultado seria um sistema instável, com grandes massas de desempregados e um oligarquia econômica com enorme influência sobre a política e os meios de comunicação (EINSTEIN, 1949).

\subsection{A ascensão das concepções dicotômicas da estratificação}

A retórica socialista teve grande influência em colocar a estratificação social na ordem do dia. Como os exemplos anteriores mostram, o antagonismo entre classes não excluía a preocupação com a distribuição de renda e riqueza, embora essas dimensões aparecessem normalmente de forma subordinada, como consequência das relações de produção. No entanto, o socialismo jamais foi a visão única ou dominante, mesmo entre reformadores sociais. O trabalho de Cannadine (1999) insiste sobre isso, desmistificando a ideia de que existia uma "consciência de classe", no sentido marxista, em larga escala.

A análise da literatura não socialista anterior à $1^{a}$ Guerra expõe a frequência crescente em que a estratificação foi concebida em termos binários, isto é, como dicotomia ou antagonismo entre grandes grupos sociais, tal como na tipologia de Cannadine (1999). Entre os socialistas, a prevalência desse modelo é óbvia, principalmente a partir da definição marxista de classes, apesar de muitos autores deslizarem com frequência para outras dimensões, como a renda. Os Webbs, por exemplo, escrevem que "o objetivo primário do socialista é chamar a atenção para o tipo peculiar de tirania exercido mesmo nas democracias mais avançadas por uma classe relativamente pequena de homens ricos sobre a massa de homens pobres" (WEBB; WEBB, 1923, p. 5).

O mais significativo, contudo, é sua prevalência também entre autores não socialistas e mesmo antissocialistas. Em parte por influência do socialismo, a visão polarizada da estratificação social tornou-se muito frequente e por vezes até dominante. Intelectuais e políticos do período repetidas vezes recorreram a oposições do tipo capitalistas/trabalhadores, ricos/pobres, elites/massas, privilegiados/explorados, dominantes/dominados e afins, em que os polos eram definidos de forma mais ou menos vaga, conforme a conveniência do autor. A preocupação comum por trás dessa miríade de termos era o excesso de poder e recursos nas mãos dos mais ricos. Nesse contexto, a diferenciação entre desigualdade de oportunidades e desigualdade de resultados nem sempre era muito clara, e muitos intelectuais apostavam que ambas andariam juntas.

Cannadine (1999, cap. 4) reconheceu a ascensão do modelo dicotômico na sociedade britânica no fim do século XIX, notando que sua emergência em meio a um período de agitação social replicava em parte a politização dos discursos vista na época do Great Reform Act de 1832, que alterou o sistema eleitoral e expandiu os direitos políticos. Porém, Cannadine preferiu insistir sobre a hegemonia da visão hierárquica e o caráter simplista, 
teoricamente ambíguo e factualmente errôneo das representações binárias. Não importa aqui discutir se tais representações eram ilusões ou não, nem se a maioria da população as rejeitava. O relevante é que, na Inglaterra, nos Estados Unidos e alhures, o clima intelectual mudou, com a contestação crescente da desigualdade econômica, o uso mais disseminado de concepções binárias da estratificação e a aceitação do imperativo de reforma social entre acadêmicos e políticos. Essas três características alimentaram-se mutuamente. Sumner e Spencer sentiram a novidade no ar e deploraram o possível triunfo dos socialistas. O fato decisivo, entretanto, é que o novo espírito do tempo ultrapassou em muito o círculo de militantes socialistas e demais revolucionários.

Um bom ponto de partida para mostrar essa ascensão na literatura não socialista é um autor já discutido, Henry George, cujo livro de estreia, Progress 8 Poverty, fez sucesso em 1879, ainda durante o reinado de Spencer, por assim dizer. Seu longo tratado tentou dar sentido ao que George via como o maior paradoxo do seu tempo: a convivência de uma enorme opulência com a pobreza abjeta nas sociedades mais avançadas. George proclamava que o progresso material era incapaz de resolver o problema da pobreza:

[O] enorme aumento da capacidade produtiva que marcou o nosso século [...] não possui nenhuma tendência para extirpar a pobreza [...]. Ele simplesmente aumenta o golfo entre o homem rico e Lázaro, e torna o conflito pela existência mais intenso. [...] É como se uma imensa cunha estivesse sendo forçada não abaixo, mas através da sociedade. Aqueles acima do ponto de separação são elevados, mas aqueles que estão abaixo são esmagados. (GEORGE, 1935, p. 8-9) ${ }^{5}$

George era um reformista social e nem de longe um socialista. A tese central do livro era que tamanha polarização decorria do antagonismo de interesses entre capital e trabalho, de um lado, e os proprietários de terras urbanas e rurais, de outro. O remédio proposto era um imposto único sobre o valor da terra, capaz de redirecionar os rents privados para serviços públicos. No mesmo tom que permeava muitas obras socialistas, George acreditava que a solução para o conflito distributivo significaria também a superação da instabilidade macroeconômica. Justiça e prosperidade andariam juntas, estando bloqueadas apenas por um arranjo institucional defeituoso.

Dez anos depois, um personagem insuspeito pronunciou-se sobre o assunto. Em 1889, o filantropo e magnata do aço Andrew Carnegie, então um dos homens mais ricos do mundo, publicou o texto que veio a ser conhecido como seu "evangelho da riqueza". A problematização da desigualdade, a visão polarizada da estratificação e o desejo de reforma social aparecem já nas primeiras linhas, quando Carnegie declara que o problema de sua época é "a administração adequada da riqueza, de modo que laços de fraternidade continuem unindo ricos e pobres em uma relação harmoniosa" (CARNEGIE, 1889, p. 653).

5 A expressão "o homem rico e Lázaro" é uma referência à parábola de mesmo nome narrada no Evangelho de Lucas. 
Carnegie escreveu como um homem entre dois mundos: ao mesmo tempo que personificava o robber baron americano do século XIX, ele era muito lúcido quanto às turbulências sociais do seu tempo. Para ele, a civilização dependia da sacralidade da propriedade privada e o individualismo era o único caminho compatível com o progresso, que beneficia a todos. O preço era alto - "grande desigualdade de ambiente", "concentração dos negócios industriais nas mãos de poucos" -, mas a obediência à "lei da competição" era essencial ao "futuro da raça" (CARNEGIE, 1889, p. 655).

Ainda assim, era preciso fazer algo a respeito das desigualdades. O objetivo implícito era restaurar a legitimidade de uma visão hierárquica da estratificação social. Refutando anarquistas e socialistas, Carnegie pregava que a solução dependia dos proprietários de grandes fortunas, que deveriam assumir responsabilidade moral por elas: a riqueza "excessiva" deveria ser redirecionada para o bem comum, para atividades filantrópicas capazes ajudar àqueles que desejavam melhorar de vida. Dados os riscos morais associados à assistência pura e simples, o melhor modo de dispor da riqueza seria investindo-a na própria comunidade, financiando bens comuns e instituições públicas.

As décadas seguintes de fato testemunharam substancial expansão dos serviços e bens públicos nos países desenvolvidos, não pela via filantrópica, e sim pela transformação do papel do Estado, desaguando no que Castel (2003) chamou de "sociedade salarial". Para os nossos propósitos, o mais importante desse processo é a emergência de uma sensibilidade aguda à desigualdade, interpretada com frequência em termos de polarização social e oposições binárias entre grupos sociais, com grande destaque sobre os ricos e milionários, em meio à industrialização e volatilidade econômica.

Essa transformação acelerou-se nos anos seguintes, ainda que os polos definidores nem sempre fossem os mesmos. No polo da pobreza, Charles Booth (1889) publicou o primeiro volume do seu pioneiro Life and labour of the people in London. Booth não era um entusiasta da visão polarizada e seu trabalho, eminentemente descritivo, estratificava a população em oito classes. Todavia, seu impacto deu-se pelo uso pioneiro de uma linha de pobreza e pela conclusão de que quase um terço dos londrinos eram pobres.

No polo social oposto, a virada do século XX foi o auge das teorias clássicas das elites, com Vilfredo Pareto, Gaetano Mosca, Robert Michels e, em uma chave um tanto distinta, Thorsten Veblen. Grosso modo, Mosca, Pareto e Michels eram conservadores que escreviam contra o suposto triunfo nefasto da retórica socialista. Mantendo o modelo binário de estratificação, eles insistiam que a verdadeira oposição universal se dava entre classes governantes e governadas, e que qualquer revolução igualitarista seria no máximo uma vitória pírrica, pois estava fadada apenas a produzir uma nova elite ainda mais despótica que governaria as massas.

Pareto, mais estridente, apontava o dedo para as elites do seu tempo, que teriam se tornado "humanitárias" e "fracas" (e.g., PARETO, 2000). Já Mosca (1939) citava as 
crises econômicas e a concentração da riqueza entre os mais ricos como mecanismos de enfraquecimento da coesão social, resultando em um quadro de empobrecimento da classe média e de polarização social fértil para o movimento socialista. Sua aversão à democracia social fez com que ele considerasse o sufrágio universal como um grande erro, ainda que fosse impossível voltar atrás. A manutenção da liberdade exigiria um arranjo social que rompesse parcialmente com a lógica binária, com uma espécie de democracia de pequenos e médios proprietários, isto é, uma grande classe média independente composta por gentlemen com tempo livre para servir à nação. Michels (1949), o mais sociológico dos três, enunciou sua "lei de ferro da oligarquia" a partir da análise do Partido Social Democrata alemão: não há democracia sem organização, e tampouco há organização sem oligarquia, pois a profissionalização e burocratização até das organizações mais ostensivamente igualitárias retira progressivamente o poder de decisão das massas, concentrando-o em sua cúpula.

O americano Veblen era bem diferente dos italianos Pareto e Mosca e do alemão Michels. Sua mordaz teoria da classe ociosa tornou-se um sucesso editorial em 1899 por criticar o consumo conspícuo e as demonstrações de status das elites americanas. A oposição dicotômica que aparece como o grande problema social se dá entre a classe ociosa - vale dizer, a rica classe proprietária não industrial - e as classes produtivas. O parasitismo da classe ociosa asfixiava a inovação e bloqueava as mudanças capazes de adequar as instituições da sociedade às necessidades da época, estando fundado sobre uma distribuição de riqueza muito desigual:

[O] estabelecimento de uma classe ociosa faz com que as classes mais baixas tornem-se conservadoras, pois retira delas o tanto quanto possível dos seus meios de subsistência, reduzindo seu consumo e, consequentemente, sua energia disponível, a ponto de torná-las incapazes do esforço exigido para aprender e adotar novos hábitos de pensamento. A acumulação de riqueza no topo da escala pecuniária implica privação na outra ponta dessa escala. (VEBLEN, 2007, p. 135)

Autores já esquecidos também escreveram sobre a desigualdade tomando o enquadramento dicotômico como referência e mirando nos ricos. Em muitos casos, os três elementos destacados - preocupação crescente com a estratificação, concepção binária da sociedade e desejo de reforma social - aparecem de forma cristalina, seja como problemas em si mesmos ou como constatação factual. Em outros, a intenção era combater a visão polarizada, que, de qualquer modo, continuava como referência discursiva. Esse quadro é perceptível já no início do século XX, mesmo antes da $1^{a}$ Guerra. Uma boa fonte é o American Journal of Sociology $(A J S)$, o primeiro periódico acadêmico de sociologia dos Estados Unidos e ainda hoje um dos principais na área em todo o mundo.

Para exemplos do primeiro grupo, podemos começar com o artigo de Emil Munsterberg (1904) sobre a emergência de uma nova concepção da pobreza, vista como algo solucionável a partir da diminuição das desigualdades, na esteira da enorme polarização 
social gerada pela Revolução Industrial. Dois anos mais tarde, Ira Howerth (1906) comentou a existência de "centenas de livros, panfletos e artigos" sobre a "questão social". Se em outros séculos a principal questão social fora a conquista das liberdades religiosa e política, a de sua época era econômica:

Lemos hoje que um homem controla esta, aquela ou uma outra indústria, ou que poucos homens são os donos de metade das ferrovias do país. Isso implica que o poder concentrou-se nas mãos daqueles que são proprietários dos meios de produção, e em alguns casos esse poder é maior do que o exercido antigamente por reis e imperadores. Seria um milagre se esse poder não fosse abusado [...]. Há por toda parte um movimento social na direção de assegurar controle popular da indústria. (HOWERTH, 1906, p. 258-259)

Em 1908, o primeiro presidente da American Sociological Association, Lester Ward, escreveu sobre a desejabilidade da eliminação das classes sociais, que constituíam entraves ao progresso, pois refletiam desigualdades artificiais. A hierarquia de classe era polarizada: para Ward, mesmo nos países mais avançados cerca de $80 \%$ da população ainda pertenceria às classes baixas, sem condições de desenvolver seus dons e habilidades, ao contrário das classes altas. O rompimento da polarização permitiria um aumento sem precedentes do que hoje chamaríamos de produtividade. O texto de Ward prima pela relativa indiferenciação entre as ideias de desigualdade de resultados e de oportunidades, ou, melhor dizendo, da crença implícita de que ambas seriam inseparáveis. O argumento poderia ser formulado apenas em termos de desigualdade de oportunidades, só que Ward acreditava que isso implicaria a abolição de classes sociais tout court, já que, para ele, as desigualdades naturais raramente tornam um homem superior ou inferior a outro, apenas diferente, produzindo estratificação horizontal, não vertical (WARD, 1908).

Em 1915, foi a vez de Scott Nearing (1915) escrever para o AJS criticando a ideia de que a remuneração dos fatores produtivos segue sua produtividade marginal e apontando para o poder de monopólio sobre a propriedade como fonte dos rendimentos de capitalistas e proprietários rurais. Para Nearing, a classificação dos fatores em terra, capital e trabalho era enganosa, e o fundamental era a oposição entre os rendimentos pagos aos donos da propriedade e aqueles pagos a quem investe sua energia na produção. Na edição seguinte, Victor Yarros (1915) redefiniu o problema mantendo a oposição binária, retrucando que sua raiz estava nos monopólios, em especial na apropriação de enormes ativos nacionais por pequenos grupos, e não nos rendimentos do capital per se.

Um último exemplo, na mesma edição do $A J S$, vem de Anne Marion MacLean (1915), socióloga da primeira geração da Escola de Chicago. Sem um pingo de ironia, MacLean debruçou-se sobre o "drama dos ricos em uma democracia". Surpreendentemente, o texto é mais um lamento do que uma tentativa de negar a polarização ou de justificar a sociedade de seu tempo. Pelo contrário, MacLean opina que o correto seria alterar as regras do jogo, e não culpar pessoalmente aqueles que obtêm sucesso dentro delas: 
O preconceito contra o milionário é evidente por todos os lados [...]. Há algum tempo, os escritos mais populares são protestos injuriosos contra as condições atuais, em especial as condições duras resultantes da indústria moderna. [...] [O] empregador foi declarado o culpado. Como o empregador normalmente é mais rico do que aqueles que reclamam, o aumento de sua riqueza é uma afronta, até o ponto em que o homem rico é tido como responsável pela maior parte dos desajustes sociais [...] [É] um homem a ser ridicularizado; ou seja, precisamente o homem que foi bem-sucedido em atingir o que praticamente todos os outros homens desejam adquirir tornou-se ao mesmo tempo alguém a ser desprezado. Essa é uma situação única. (MACLEAN, 1915, p. 339 e 341)

Os textos que combatiam a visão dicotômica também são reveladores do espírito do tempo. Muitos reconheciam explícita ou implicitamente essa visão como dominante e, quase sempre, dedicavam-se a refutar Marx e seus discípulos. Alguns negavam de todo que esse fosse o caso. Com frequência, reconhecia-se a existência de uma crise e a sensação de polarização para então elencar sugestões de reformas capazes de restaurar a sociedade ao seu estado adequado. Com efeito, parte do esforço desses autores era formular um modelo de estratificação alternativo. Adaptando a tipologia de Cannadine (1999), essas formulações alternativas oscilavam entre um modelo triádico que destacava o papel da classe média e um modelo hierárquico em que as diferenciações de renda e afins ocorreriam em meio a uma unidade coletiva, e pluribus unum, seja pelo pertencimento a uma mesma comunidade, seja pela institucionalização da igualdade de oportunidades. ${ }^{6}$ Na maior parte dos casos, as reformas sociais eram defendidas justamente como meio para concretizar esses modelos ideias de estratificação e romper de vez com a polarização.

Continuando apenas entre com os artigos do AJS, temos Victor Yarros (1904) argumentando que os representantes do capital e do trabalho pregavam os mesmos preceitos individualistas, e que a "questão social" dizia respeito a certos resultados do sistema produtivo, não ao sistema em si. "Justiça econômica" significava, para ele, a institucionalização de um regime de igualdade de oportunidades com o maior grau possível de liberdade individual compatível com segurança social, estabilidade e harmonia. Já John R. Commons (1908) se perguntou se o conflito de classes na América estava crescendo e postulou que o conflito entre trabalhadores assalariados e proprietários era inevitável, mas era preciso lembrar que tais grupos constituíam apenas uma pequena fração da força de trabalho. O resultado dependeria da capacidade dos grupos antagônicos de formar alianças com as outras categorias, o que poderia desembocar em instituições mediadoras capazes de assegurar procedimentos justos de resolução de conflitos. Ideias semelhantes foram desenvolvidas, com feição conservadora nítida, por Gustav von Schmoller (1915) em seu ensaio sobre o conflito de classes, embora o texto tenha suas peculiaridades: ao

$\overline{6}$ Cannadine prioriza o papel da deferência e dos títulos honoríficos na sustentação das visões hierárquicas da sociedade. Não há dúvida que esse é ou foi o caso em muitos países europeus. Porém, o que ele chama de "sociedade sem classes" à moda americana constitui um tipo de visão hierárquica: todos se consideram iguais e, portanto, não há deferência nos mesmos moldes, mas a diferenciação por renda, riqueza ou prestígio cumpre papel análogo. 
mesmo tempo que ataca o socialismo e reafirma a existência de uma estrutura de classes não polarizadas em sociedades modernas, o autor repetidamente opõe pobres e ricos, em geral a partir da ideia de que as instituições devem limitar o abismo econômico entre eles em nome da paz social.

Outros cientistas sociais também olharam para a desigualdade e para os ricos. George P. Watkins (1907), por exemplo, defendeu tese de doutorado em economia em Cornell sobre o crescimento das grandes fortunas. Watkins justificou seu trabalho citando o interesse crescente em questões distributivas e empenhou-se em entender o que separaria os ricos dos demais. Para ele, ao contrário de tempos passados, as causas do surgimento de grandes fortunas eram econômicas, e não políticas, remontando a três transformações simultâneas: o surgimento de indústrias de grande escala, a multiplicação de possibilidades de ganhos de capital e a financeirização da economia. Sem deixar de reconhecer as iniciativas filantrópicas e a desejabilidade de alguma desigualdade, Watkins mostrou-se preocupado com a concentração excessiva no topo, considerando que o problema mais urgente dos Estados Unidos era controlar o poder desenfreado dos ricos e suas corporações, que ameaçava a igualdade de oportunidades.

Assim como na sociologia, claro, também havia vozes dissonantes que criticavam o que percebiam como o foco inadequado em conflitos de classe e oposições binárias. John Martin (1909) atacou o Partido Socialista americano com base em argumentos semelhantes aos defendidos antes por Commons. Para Martin, o partido abraçava com ardor a doutrina do antagonismo entre classes, só que a sociedade americana não era estratificada de modo binário, e sim em uma pluralidade de classes divididas por interesses econômicos, temperamento, educação e características de gênero e raça. A reconstrução social só poderia se dar pela via reformista, porque os conflitos inegáveis entre capital e trabalho envolviam apenas frações de classes.

Um último exemplo da nova sensibilidade à desigualdade no período anterior à $1^{a}$ Guerra diz respeito a ninguém menos do que John Bates Clark, o célebre economista neoclássico americano. Clark (1914) começou seu Social Justice without Socialism de forma auspiciosa, afirmando que, de certa forma, todos haviam de fato se tornado socialistas, pois inserir a democracia na vida industrial seria o princípio básico para qualquer corpo político que desejasse sucesso. As diferenças estariam nos métodos. Clark pregou a necessidade de uma via media entre o laissez faire e o inchaço do Estado: o fundamental seriam reformas que recuperassem a competição e estabelecessem instituições capazes de mediar os conflitos distributivos. Além de fazer apelos mais ou menos genéricos à "classe média", ele se viu obrigado a redefinir a oposição central dos discursos sobre estratificação: a luta de classes realmente necessária se daria entre o "trabalho honesto" aliado ao "capital honesto" contra o "capital desonesto" (CLARK, 1914, p. 14-15).

O questionamento da estrutura social e a preocupação com a desigualdade não 
ficaram restritos ao mundo acadêmico. Longe disso, a polarização política nutriu-se da percepção de polarização social e serviu para amplificá-la. A controvérsia causada pelo People's Budget, proposto pelo então Chanceler do Tesouro, Lloyd George, no Reino Unido em 1909, captura bem o espírito do momento. Para financiar seu plano de combate à pobreza, George propôs a elevação do tributo sobre heranças, a introdução de alíquotas progressivas no imposto de renda e a criação de um tributo sobre propriedades imobiliárias similar a um imposto sobre ganhos de capital (LINDERT, 1987; SABINE, 2006). A reação na Câmara dos Lordes foi violenta e o orçamento foi inicialmente reprovado, deflagrando uma crise constitucional que só se resolveu com 1911, quando, após seguidas vitórias eleitorais dos liberais, aprovou-se o ato que subordinou os Lordes à Câmara dos Comuns, retirando seu poder absoluto de veto.

Lloyd George e o seu Partido Liberal sempre direcionaram seus apelos mais ao que poderia ser chamado de "baixa classe média" do que aos trabalhadores manuais. No transcorrer da crise, a retórica de George radicalizou-se e ele abraçou a polarização, opondo explicitamente os ricos proprietários rurais ao povo, como no famoso discurso de Limehouse, bairro industrial de Londres (reproduzido em PARCQ, 1912, vol. IV, p. 678-685). Como escreveu Lindert, quando a crise se resolveu, os lordes perderam no Parlamento "mais por serem ricos do que por serem proprietários rurais" (LINDERT, 1987, p. 25).

Algo semelhante ocorreu também nos Estados Unidos, onde esse período ficou conhecido como a "era progressiva". A retórica da oposição binária entre o povo e os robber barons foi mobilizada por políticos e ativistas. Durante sua presidência, entre 1901 e 1909, Theodore Roosevelt ficou conhecido como trust buster, embora seu sucessor, William Taft, tenha sido mais duro no enfrentamento de monopólios, culminando com o desmembramento da petroleira Standard Oil em 1911 (KOLASKY, 2011). Com a escalada de conflitos industriais, em 1912, Taft autorizou a criação de um Comitê para Relações Industriais como resposta à comoção causada pelo atentado à sede do Los Angeles Times, que matara 20 pessoas em 1910. O relatório principal da "Comissão Walsh", publicado em 1915, foi tão radical que a maioria dos membros da comissão recusou-se a assiná-lo, e coincidiu com a consolidação da aliança duradoura entre sindicatos, reformistas e o Partido Democrata. O relatório advogava a "democracia industrial" e citava a desigualdade de renda e da riqueza, em especial sua concentração entre os mais ricos, entre as principais causas de descontentamento dos trabalhadores: 
A convicção de que a riqueza da nação e a renda produzida pela labuta dos trabalhadores é distribuída sem nenhuma relação com qualquer padrão de justiça é tão difundida quanto profunda. [...] O que os milhões ganham por seu trabalho, por suas habilidades, pelos riscos de vida e mutilação? [...] Acumulada aos milhões, na outra ponta da escala social, estão fortunas de tamanho jamais sonhado, cujos próprios donos não conhecem a medida [...]. [A]s grandes fortunas daqueles que lucraram com a enorme expansão da indústria americana foram transmitidas, ou estão em vias de serem, por meio de heranças para o controle de herdeiros ou trustees que agem como seus 'vice-regentes'. Eles são frequentemente chamados pelos jornais de 'monarcas da indústria', e de fato ocupam na nossa República uma posição análoga à dos lordes feudais. (U.S. COMMISSION ON INDUSTRIAL RELATIONS, 1915, p. 23-27 e 30)

\subsection{Os ricos e os estudos sobre desigualdade no entreguerras}

O cataclismo provocado pela $1^{a}$ Guerra não provocou mudanças abruptas no zeitgeist. Nos Estados Unidos, mesmo durante a guerra o debate sobre a desigualdade permaneceu ativo em livros e periódicos. Por exemplo, o então influente economista Jacob Hollander (1914) diagnosticou que o grande ressentimento popular era contra a maneira antissocial como as grandes fortunas da época eram geradas, e não contra grandes fortunas em si mesmas. O tom era semelhante ao do padre e intelectual católico John Ryan (1919) em seu livro sobre justiça distributiva, lançado originalmente em 1916. Ryan também era um reformista não socialista que acreditava que a redistribuição da riqueza era a maior necessidade do seu tempo, e os ricos eram o foco do seu livro. Muitas das reformas propostas por ele são quase idênticas às principais sugestões de intelectuais e políticos do século XXI, como o combate a monopólios, a tributação progressiva da renda e das heranças, um salário mínimo legal com valor adequado e o fortalecimento dos sindicatos. Já nos anos finais da guerra, Arland Weeks (1917) insistiu na dicotomia entre pobres e ricos ao escrever artigo satírico sobre o ponto de vista conservador sobre a pobreza:

\footnotetext{
Deixemos que os despossuídos fiquem contentes com suas condições que eles imitem os ricos, que estão reconciliados com as suas. [...] Os críticos maldosos do estado atual de coisas não dão o valor apropriado à especialização crescente na qual os extremamente ricos se engajam. Não é fácil encontrar novas maneiras de gastar dinheiro. [...] Ao restringir a riqueza dos mais pobres, os muito ricos assumem o risco de degeneração moral associado ao luxo e à complacência. [...] [O]s pobres invejosos não percebem essa sublime ousadia moral e esse espírito de sacríficio. (WEEKS, 1917, p. 780, 782, 783)
}

Nos pós-guerra, foi a vez de Irving Fisher (1919) se pronunciar sobre o assunto, dedicando sua conferência anual como presidente da American Economic Association ao "novo impulso para servir ao público" sentido por economistas. Fisher não tinha dúvidas de que esse impulso deveria ser abraçado e se perguntava qual a melhor maneira de fazê-lo. Para ele, os Estados Unidos tinham uma oportunidade especial: propagar uma ciência 
econômica humanitária e democrática, não contaminada por interesses particulares. A profissão deveria ser imparcial para poder arbitrar a luta de classes, rejeitando tanto o ponto de vista dos patrões - segundo ele, adotado quase automaticamente por economistas de outros tempos - quanto a perspectiva exclusiva dos trabalhadores.

Com isso, Fisher abordou então seu tema central, o imperativo do estudo científico das "causas e curas para a distribuição atual de capital e renda entre indivíduos" (FISHER, 1919, p. 11). Para ele, havia um conflito distributivo que só se resolveria se as reformas adequadas fossem feitas. O conflito refletia, mais uma vez, a concepção polarizada da estratificação, com uma concentração excessiva de renda e riqueza no topo: os dois fatores citados como responsáveis pela distribuição "não democrática" dos recursos econômicos foram as heranças e o "sistema de lucros". As reformas sugeridas por ele envolviam um mix de tributação progressiva, regulação e envolvimento ativo do Estado na economia.

Fisher não foi uma voz isolada. Muitas outras figuras de maior ou menor destaque ecoaram esses argumentos: como diriam os anglófonos, o importante era não jogar fora o bebê junto com a água do banho. Ao mesmo tempo que se defendia a superioridade da ordem competitiva sobre o socialismo, reconhecia-se a polarização e advogavam-se reformas. Outros autores eram mais conservadores do que reformistas, mas, mesmo entre estes, é possível identificar o espírito do tempo. Para começar, sua posição era definida por oposição ao socialismo e ao antagonismo inevitável entre grupos sociais. Com isso, em muitos deles há o reconhecimento explícito da percepção social de polarização e, em alguns casos, até mesmo de sua realidade objetiva.

Alguns exemplos podem ser citados. Para Abbott Usher (1921), não fazia sentido desejar que a distribuição de riqueza fosse justa e as consequências não antecipadas provocariam o fracasso de qualquer redistribuição em larga escala. Ele negava qualquer relação entre o conforto dos ricos e a privação dos pobres e notava que muitos ricos devotavam grande parte de suas fortunas para fins sociais. Ainda assim, Usher concedia a existência de uma proporção indevida de altas rendas e de um número muito pequeno de indivíduos com rendimentos intermediários. Charles Platt (1925) rejeitou que a desigualdade entre ricos e pobres estivesse piorando, não o fato de que ela estava sob os holofotes. Ricos e pobres sempre existiram, escreveu ele; o que era novo era a consciência de classe dos pobres. E esse era o problema: em termos quase thatcherianos, Platt afirmava que "a consciência de classe nos cega, ela é uma crosta egoísta que nos separa dos nossos semelhantes e impede o entendimento" (PLATT, 1925, p. 561). Era preciso restaurar a hierarquia harmoniosa de outrora combatendo a ignorância mútua de ricos e pobres: contra Sumner e Spencer, ele ressaltava que os pobres desconheciam as responsabilidades dos ricos e que os ricos desconheciam a falta de oportunidades vivida pelos pobres. Em chave mais analítica, Pitirim Sorokin (1926), um dos pioneiros do estudo da mobilidade social na sociologia e notório anticomunista, tentou explicar a Revolução Russa e, de modo geral, a expansão do estado no mundo ocidental com uma teoria ancorada na polarização entre pobres e 
ricos. O empobrecimento relativo ou absoluto dos pobres com relação aos ricos facilitaria a expansão da interferência governamental nas relações econômicas e vice-versa, isto é, a diminuição dos contrastes econômicos facilitaria a liberalização. O comunismo, portanto, seria o sintoma de uma doença social, não sua cura.

A vida política do entreguerras também continuou polarizada. Embora note que a concepção dominante na Grã-Bretanha ainda era hierárquica, Cannadine (1999) reconheceu a influência do discurso dicotômico sobre atores políticos centrais do período. A ascensão rápida do Partido Trabalhista, que chegou ao poder pela primeira vez por alguns meses em 1924, garantiu que a desigualdade continuasse na ordem do dia e sinalizou a progressiva institucionalização da mediação dos conflitos sociais. O processo foi permeado por grandes irrupções, como a greve geral de 1926. Intensa mobilização sindical também foi observada em outros países: com exceção de um breve período nos anos 1920, as taxas de sindicalização nos países desenvolvidos cresceram quase continuamente até o período imediatamente após a $2^{a}$ Guerra. ${ }^{7}$ Do outro lado do Atlântico, basta lembrar os conflitos de Franklin D. Roosevelt e do New Deal com a Suprema Corte em meados dos anos 1930, que chegaram muito perto de provocar uma crise constitucional inédita nos Estados Unidos (LEUCHTENBURG, 2005). Sem dúvida, o exemplo mais trágico da retórica polarizada acerca da estrutura social vem do nazismo, que se opôs ferozmente à ideia da luta de classes e reformulou o antagonismo social fundamental em termos raciais.

Guardadas as devidas proporções, o Brasil não passou imune a tamanha agitação social. Sob inspiração inicial anarquista e trabalhista, o movimento operário ganhou visibilidade inédita com as grandes greves dos anos 1917-1920, colocando a "questão social" na pauta política, com a proliferação de demandas por regulação. Não obstante guinadas como a de Ruy Barbosa, que se tornou moderadamente reformista em sua última candidatura presidencial, e a aprovação de leis esparsas e de abrangência limitada, a resposta estatal foi nesse primeiro momento sobretudo repressiva (DIAS, 1962; FAUSTO, 1977; SIMÃO, 1981). Com a ruptura institucional provocada pela Revolução de 1930, a "questão social" ganhou novo estatuto no discurso político dominante, ainda que, como sempre, seja preciso fazer as devidas ressalvas quanto aos atores por trás da "revolução", as ambiguidades ideológicas de Vargas e outros tantos aspectos do novo regime (ver capítulo 6). A retórica polarizada afetou percepções e discursos em nosso país, como no caso de Oliveira Vianna (1951), um dos principais intelectuais do regime varguista. Para ele, o problema social, expresso pelo conflito entre patrões e trabalhadores, seria uma característica universal dos países modernos; por aqui, as disputas violentas entre classes estava em estado latente graças à suposta índole pacífica e ordeira do povo brasileiro. $\mathrm{O}$ trunfo de Vargas, para Vianna, fora atacar a questão sem promover um nefasto nivelamento

7 Neumann, Pedersen e Westergard-Nielsen (1991, p. 252) apresentam dados para nove países - Alemanha, Austrália, Bélgica, Canadá, Dinamarca, Estados Unidos, Finlândia, Reino Unido e Suécia - em 1910 e 1950 e em todos há um aumento expressivo das taxas de sindicalização, com a média não ponderada subindo de $12 \%$ para $43 \%$. 
geral, como no comunismo, e sim pela criação de instituições que reconheciam a dignidade do trabalhador. Contra o liberalismo que transformava todos em mercadorias, o novo regime aproximava classes e remediava o suposto déficit de coesão social no Brasil, superando antagonismos e promovendo a solidariedade social pela via profissional.

O período entre guerras não foi só uma repetição do que ocorrera antes. Uma novidade foi a proliferação de estudos empíricos sobre o tema. Decerto, os trabalhos pioneiros sobre o assunto datam já das últimas décadas do século XIX, mas quase todos os textos mencionados até aqui eram puramente teóricos. Booth (1889) e Watkins (1907) são algumas das exceções. Pareto também formulou sua célebre lei acerca da imutabilidade da distribuição de renda no topo a partir de dados empíricos, inclusive voltando atrás diante de novas evidências (SHIRRAS, 1935). Nos Estados Unidos, Holmes (1893) já produzira uma estimativa pioneira para a desigualdade de riqueza. Apesar de seu tom moderado - e por vezes racista -, ele se espantou com o grau de concentração no topo revelado pelos seus resultados. Em função disso, as oposições binárias reaparecem a todo momento em seu texto, seja em termos de ricos/pobres ou de credores/devedores.

Sem desconsiderar essas iniciativas, não é controverso considerar que só a partir da $1^{a}$ Guerra a investigação empírica tornou-se mais comum, com atenção crescente para a desigualdade de renda, em resposta ao maior interesse geral pelo assunto. A Figura 3 ilustra isso, mais uma vez com base no Google Ngram: o uso de expressões como distribution of income ou concentration of income cresce muito mais rápido do que o de expressões análogas para a riqueza, o poder ou oportunidades entre 1900 e 1950. Se, antes, a distribuição de riqueza era de longe a mais citada, em meados do século XX as referências à distribuição de renda tornaram-se quase tão frequentes. O declínio recente reflete em parte a disseminação de expressões alternativas mais curtas (e.g., income distribution ou income inequality) e, em parte, o breve eclipse no entusiasmo pelo tema (ver capítulo 3).

Inicialmente, os trabalhos acadêmicos de cunho empírico não destoaram do enquadramento binário, privilegiando o uso de dados tributários para examinar a distância entre os mais ricos e o resto da população. Na Inglaterra, Bowley (1914) foi um dos primeiros, senão o primeiro, a usar tabulações do imposto de renda. Diante de dificuldades metodológicas, seu texto inicial foi pouco conclusivo. Stamp (1916) deu um passo adiante e, depois, Bowley (1920) atacou de novo, combinando várias fontes para analisar a desigualdade britânica. Ele concluiu que não houve mudanças significativas entre 1880 e 1913 e que, portanto, "o aumento do luxo e da abundância de riqueza que muitos acreditam ter observado antes da guerra foram ilusões estimuladas pelos jornais" (BOWLEY, 1920, p. 20). Além de refutar as teses socialistas, a constância das proporções sugeria um ar de inevitabilidade, escreveu ele, sem desenvolver o assunto.

Nos Estados Unidos, a estimativa de desigualdade mais influente foi publicada pela primeira vez em 1915 por Willford King. Suas informações sobre heranças levaram-no à 
Figura 3. Frequência relativa de expressões com três termos (threegrams) relacionados à desigualdade no corpus em inglês do Google Books, 1875-2000

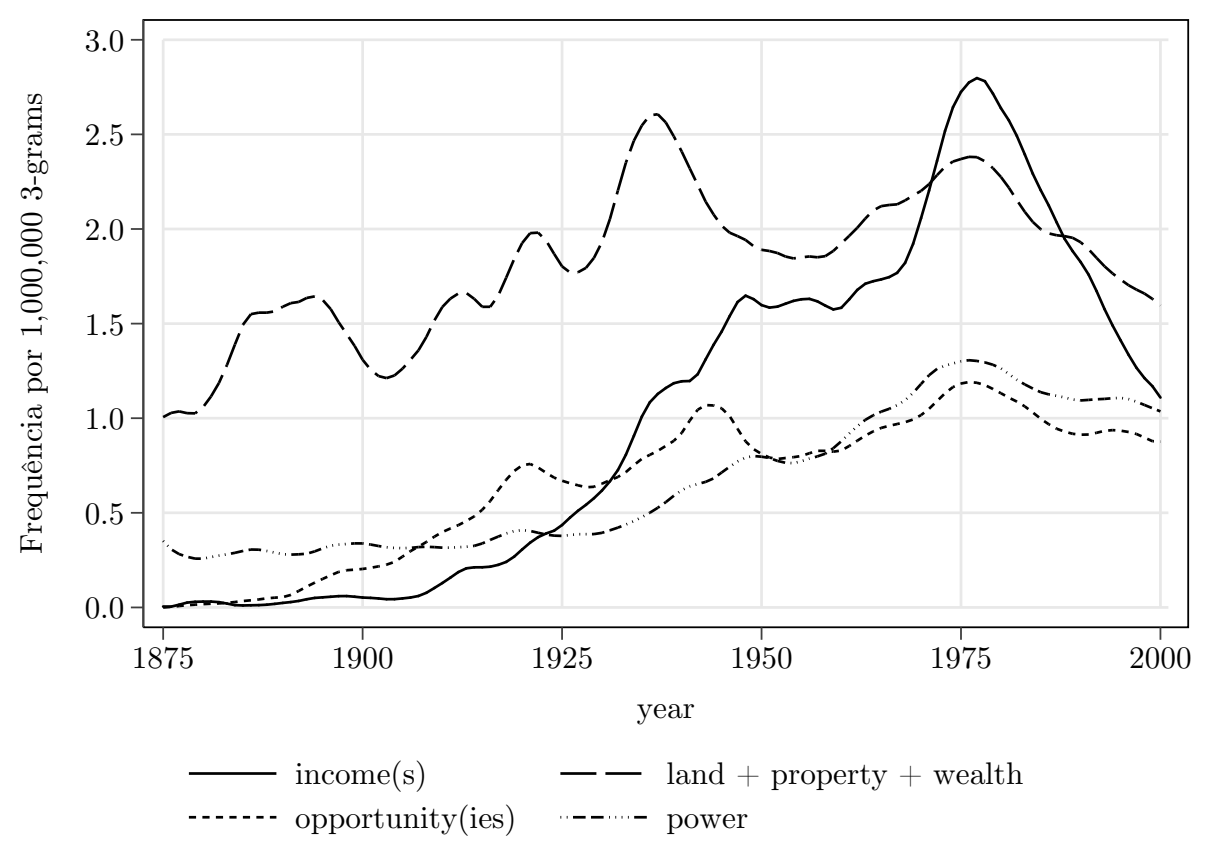

Fonte: elaboração do autor a partir do Google Ngram

N.B.: dados suavizados por regressão local com banda de dez anos. Cada série corresponde à soma dos resultados dos seus termos nas expressões concentration of, distribution of, equality of, inequality(ies) of e redistribution of. Mais informações com o autor.

conclusão de que havia um enorme abismo entre as classes ricas e as pobres, com os $2 \%$ no topo detendo quase $60 \%$ do patrimônio total, sem grandes mudanças desde o fim do século XIX. No caso da distribuição de renda, dados compilados a partir de diversas fontes também indicavam grande polarização entre ricos e pobres, com tendência de aumento ao longo do tempo. Por isso, King tratou quase o tempo todo da desigualdade em termos binários, mostrando-se ora cautelosamente favorável à redistribuição, ora malthusianamente antipático a ela, por medo de uma explosão populacional (KING, 1922). Nessa época, a própria mensuração da desigualdade tornou-se objeto de reflexão, com contribuições fundamentais como a de Dalton (1920).

Desde sempre, os trabalhos empíricos chamaram a atenção. Embora muitos se surpreendessem com o grau de concentração, alguns comentadores tiravam conclusões opostas. Para o admitidamente arquiconservador William H. Mallock (1916), os dados de King contrariavam a noção radical de que os ricos - definidos por ele em termos absolutos, e não como frações da população - se apropriavam da maior parte da renda do país. Na visão de Mallock, os resultados confirmavam que a distribuição da renda não era produto de acidentes locais, e sim de um princípio geral aplicado a todos os países industrializados. Esse princípio operava de acordo com a concepção da estratificação como hierarquia: os salários eram determinados pela produtividade dos trabalhadores, cuja distribuição natural entre os homens se dava em termos de uma gradação de "eficiências". 
Outros comentadores eram mais contidos. Por exemplo, Allyn Young (1917) argumentou que a má qualidade das informações, o caráter dinâmico do mundo e outros fatores mitigavam a gravidade dos contrastes econômicos observados. Em suma, não era necessário fechar os olhos às vicissitudes geradas pela desigualdade para sustentar que as coisas não estavam tão ruins. Como outros, Young concedia a injustiça das condições da época e a concentração da riqueza, mas tentava redefinir o problema em termos de outra concepção da estratificação e projetar um ideal de igualdade de oportunidades. A concentração de riqueza era um efeito colateral do progresso; mais importante seria olhar as tendências da classe média, que seria o núcleo da vida econômica.

Apesar desses esforços, boa parte das investigações empíricas dos anos seguintes permaneceu amarrada a uma visão implicitamente dicotômica da estratificação, sem tratar das desigualdades de resultados e de oportunidades como categorias estanques. Assim, Sorokin (1925) estudou milionários e multimilionários e acreditou ter detectado maior rigidez no topo e diminuição das oportunidades para mobilidade ascendente. Já Josiah Wedgwood (1928) analisou a transmissão de heranças na Inglaterra e concluiu que os maiores patrimônios eram deixados por quem também havia recebido grandes heranças.

Embora esquecido, um dos trabalhos mais instigantes desse período foi o de S.N. Procopovitch (1926), que sugeriu aperfeiçoamentos à análise de dados tributários que antecipavam em boa medida a prática de Piketty e seus associados quase um século depois, como o uso de procedimentos de interpolação para obter frações fixas da população e o de denominadores da renda para obter valores relativos para os rendimentos. ${ }^{8}$ Sua análise da Prússia entre 1879 e 1919 revelou um quadro geral de estabilidade, violado apenas pelos 0,5\% mais ricos, cuja fração da renda aumentara significativamente no período, levando Procopovitch a postular a existência de tendências plutocráticas. Ao investigar outros países, Procopovitch salientou os altos níveis de desigualdade, notando alguma queda na concentração entre os mais ricos pelo menos nos Estados Unidos e na Inglaterra.

O prosseguimento dos trabalhos empíricos desembocou em uma mudança de perspectiva. A partir de pelo menos meados dos anos 1930, o declínio na concentração de renda no topo foi privilegiado, dando origem a narrativas mais benignas sobre o status quo. Rufus Tucker (1938) foi um bom expoente desse momento por sua sofisticação. À parte o uso de medidas de desigualdade um tanto grosseiras para padrões atuais, o esforço em combinar dados do imposto de renda com outras fontes tributárias históricas merece reconhecimento. De acordo com seus resultados, as coisas não iam tão mal assim: a concentração de renda no topo nos Estados Unidos teria sido muito maior na época da Guerra Civil e durante a $1^{a}$ Guerra do que no seu tempo, indicando uma redução secular da desigualdade. A reconcentração ocorrida nos anos 1920 fora apagada pela Grande Depressão e, para início

8 Procopovitch não usa a renda total como denominador e, portanto, não trabalha com frações da renda, mas chega bem perto disso: ele divide os rendimentos pela renda média per capita da população para poder expressá-los em termos do que chama de "unidades orçamentárias" (budget units). 
de conversa, sequer deveria ser tão lamentada: para Tucker, ceteris paribus, a desigualdade teria um caráter pró-cíclico em função do aumento dos lucros, sinalizando a prosperidade que, no fim das contas, era a verdadeira fonte de elevação do padrão de vida da população. Para completar, Tucker destacou o grau de mobilidade entre os mais ricos, um grupo heterogêneo que estaria longe do estereótipo de uma plutocracia hereditária, e o fato de que o Reino Unido apresentava trajetória idêntica. Por tudo isso, sua conclusão passou longe de qualquer radicalismo: bastava calibrar o sistema tributário para moderar os ciclos de negócios e distribuir a renda de forma mais igualitária, com extremo cuidado para não prejudicar atividade econômica.

Inegavelmente, tais resultados eram um sopro de ar fresco para o liberalismo, ainda que, de resto, ele tivesse pouco a ver com o liberalismo clássico do século XIX, dada a penetração da social democracia, ainda longe de atingir seu ápice. No mínimo, não seria mais necessário ficar tão na defensiva, em particular se a comparação fosse com os regimes totalitários à direita. Afinal, como argumentou Sweezy (1939), tanto a desigualdade de renda quanto a de riqueza pioraram bastante nos anos 1930 na Alemanha nazista.

De fato, o caminho não comunista para uma sociedade menos desigual tornou-se mais palpável e atraente nesse período. Como notou Piketty (2014a, p. 135), a "eutanásia do rentista" fora especulada pelo próprio John Maynard Keynes em 1936 como um desfecho possível do colapso em curso. A passagem está no último capítulo da Teoria do Emprego, do Juro e da Moeda, que começa arrolando a desigualdade entre os principais defeitos da época, para em seguida emendar que "[d] esde o fim do século XIX, a tributação direta [...] vem conseguindo realizar, especialmente na Grã-Bretanha, considerável progresso na diminuição das grandes desigualdades de riqueza e de renda" (KEYNES, 1996, p. 341).

Os estudos modernos sobre desigualdade corroboram apenas em parte esses diagnósticos. Estimulados pelas necessidades de guerra, os sistemas tributários realmente tornaram-se mais progressivos. Em países como Alemanha, Estados Unidos, França e Reino Unido, as alíquotas máximas do imposto de renda saíram de menos de 10\% em 1910 e atingiram valores entre 60\% e 90\% em meados do século (PIKETTY; SAEZ, 2013, p. 396). No Brasil, o imposto de renda foi criado em 1922 e seguiu trajetória similar, como discuto no capítulo 4. A concentração no topo de fato caiu bastante nos Estados Unidos e em boa parte da Europa entre as duas grandes guerras. No entanto, o processo não foi nem tão suave nem tão contínuo como muitos dos autores da época supunham. As mudanças foram abruptas e relacionadas a grandes crises, com maior intensidade nos países mais afetados e em especial durante a $2^{a}$ Guerra Mundial. Na Alemanha, Estados Unidos, França e Reino Unido, a fração da renda apropriada pelos $1 \%$ mais rico era $18-20 \%$ por volta de 1910 e apenas 8-12\% no final dos anos 1940. O principal motivo da redução foi a queda na concentração dos rendimentos de capital, afetados por falências, inflação, tributos emergenciais e pela própria destruição física. Com isso, houve uma substancial alteração na composição da renda dos mais ricos, com os gerentes e profissionais substituindo ao 
menos em parte os rentistas (ALVAREDO et al., 2013; ATKINSON; PIKETTY; SAEZ, 2011; PIKETTY; SAEZ, 2003; PIKETTY; SAEZ, 2006).

De um jeito ou de outro, pode-se identificar uma clara mudança na disposição de muitos intelectuais da segunda metade dos anos 1930, que consideravam pouco convincentes as interpretações polarizadas da sociedade e o marxismo. Os resultados empíricos publicados nas revistas acadêmicas revelavam que, na pior das hipóteses, a polarização estava cedendo. Enquanto isso, no plano teórico, ganhava força uma onda intelectual capaz de reformular a desigualdade remanescente em termos menos antagônicos - o funcionalismo.

\subsection{O funcionalismo americano e a legitimidade da hierarquia}

A disseminação de interpretações binárias da estratificação e dos conflitos sociais desde o início provocou reações por vezes violentas. Muitos intelectuais e políticos oscilaram entre manter a dicotomia, alterando apenas os polos em conflito, e querer superá-la pela afirmação de um modelo alternativo, ainda que muitas vezes reconhecessem a necessidade de reformas. Muitas dessas concepções alternativas iam pouco além da declaração de princípios ou apelos genéricos às diferenças naturais entre os homens. O problema, ao menos em parte, era intelectual, devido à falta de arcabouços teóricos que pudessem dar conta satisfatoriamente dos dramas da época ou pelo menos mudar os termos do debate.

A revolução marginalista e, de forma mais ampla, a economia neoclássica tinham potencial para tal. Se diferenças salariais refletem, em última instância, diferenças de produtividade, então não cabe falar em exploração ou antagonismos inconciliáveis. Ocorre que o edifício teórico ancorado no primeiro teorema fundamental da welfare economics ${ }^{9}$ e na teoria do capital humano só foi erguido a partir de uma série de rupturas com a economia clássica em meados do século XX. Como observou Michel Foucault (2008, p. 297-320), somente nos anos 1950 e 1960, com Becker, Schultz e Mincer, é que o projeto intelectual embutido na definição de Lionel Robbins (1932, p. 15) para a ciência econômica - "[a] economia é a ciência que estuda o comportamento humano a partir da relação entre fins e meios escassos e com usos alternativos" - foi levado às suas últimas consequências.

O neoliberalismo - se é que é possível usar essa palavra sem a carga ideológica um tanto ridícula depositada nela - permitiu reformular a economia como a análise da racionalidade interna da ação, reconceituando os próprios salários como a remuneração a um capital específico produzido a partir da mesma lógica maximizadora presente na competição entre empresas. Não importam aqui os méritos ou deméritos dessa abordagem, e sim suas consequências para a estratificação: com a dissolução do antagonismo entre

9 Desenvolvido matematicamente por nomes como Harold Hotelling, Kenneth Arrow, Gérard Debreu e outros, o primeiro teorema da economia do bem-estar postula, sob certas condições, o equilíbrio competitivo de mercado é Pareto-eficiente, isto é, maximiza a eficiência social. 
capital e trabalho e a hierarquização dos indivíduos na escala da renda, as concepções polarizadas da desigualdade poderiam ficar de vez para trás.

Os próximos capítulos tratam dessa reformulação, que, de todo modo, só poderia encontrar um ambiente hostil nas primeiras décadas do século XX. Por um lado, o poder de persuasão dessa perspectiva neoliberal beneficiou-se muito da expansão do assalariamento e dos enormes choques à riqueza privada infligidos pela guerra. Por outro, como se depreende da discussão de Parsons no início deste capítulo, teorias de cunho estritamente racionalista estavam em baixa diante da afirmação do "social".

As teorias das elites ofereciam outra possibilidade para preencher essa lacuna, com sua ênfase em aspectos não racionais do comportamento humano. As dificuldades, entretanto, eram muitas. Todas elas mantinham a visão polarizada, só mudando os polos em conflito. Além disso, a verve de Pareto, Mosca e afins era eminentemente negativa ou defensiva, e demasiado aristocrática para países como os Estados Unidos.

Restava uma alternativa: sem o ranço elitista e muito antes de os neoclássicos tornarem-se hegemônicos, as teorias liberais de cunho funcionalista constituíram vetor para a afirmação de concepções não polarizadas da estratificação. Sua origem é antiga e seu apogeu também ocorreu somente no pós-guerra, sem dúvida, mas é possível perceber sua ascensão já no entreguerras. Em harmonia com o espírito do tempo, seu viés era não individualista, partindo da "sociedade" ou do "sistema social"; contrariamente às interpretações polarizadas, elas priorizavam o problema da ordem, não os conflitos sociais.

Desde o início, o funcionalismo fez-se presente em vários sabores. No que diz respeito à estratificação social, sua ascendência a partir dos anos 1930 ligou-se ao desconforto com a polissemia do conceito de "classe". O conceito sempre foi importante para sociólogos, e não apenas marxistas, pois abria a possibilidade de vincular ação e estrutura, ou seja, entender a evolução política e social a partir de condições estruturais objetivas. O inconveniente, para muitos, é que não havia consenso sobre seu significado preciso, porque o conceito era usado indiscriminadamente para se referir a objetos díspares.

Muitos cientistas sociais tentaram contornar o obstáculo a partir da busca dos traços básicos universais da estratificação social. Joseph Schumpeter (1966) foi um deles. Em 1927, ele publicou a primeira versão do seu famoso ensaio sobre classes sociais, em que define e interpreta a existência de classes como fenômeno universal. Schumpeter argumentou que a família é a verdadeira unidade de interesse da análise de classes, que, por sua vez, seriam mais do que a mera agregação de indivíduos, possuindo algum grau de coesão e consciência de si. Sua tese é antimarxista, acentuando a mobilidade social, o empreendedorismo e a inovação e rejeitando o automatismo do processo de acumulação e polarização da riqueza. O ponto central era que toda classe tem uma função especial, e sua posição nas estruturas de cada país depende do significado social atribuído a cada função e do quão bem cada classe desempenha sua função. Ao fim e ao cabo, todo o fenômeno de 
classes decorreria das diferenças de aptidões dos clãs e famílias para exercer as funções que o ambiente torna socialmente necessárias.

Hans Speier (1936) também bateu nos marxistas, que, segundo ele, erravam ao colocar tanta ênfase no conflito e na exploração, pois a característica universal das relações entre classes seria a hierarquia, reconhecida e legitimada até certo grau pelos indivíduos e grupos envolvidos. Na prática, Speier antecipou, sem usar os mesmos termos, muitos insights popularizados por Bourdieu, como a busca pela distinção e os conflitos simbólicos. A posição de um indivíduo na hierarquia seria a manifestação objetiva dos julgamentos sociais, de modo que a estratificação aparece como um traço cultural. O problema, então, seria encontrar as bases objetivas da diferenciação social. Variáveis como a propriedade, a ocupação ou a renda podiam ser descartadas, já que muitas sociedades eram hierarquizadas sobre eixos distintos. A sugestão de Speier era que diferenciações de classe formam-se com base na contribuição para o que é considerado útil de acordo com a escala de valores vigente em determinado contexto social. Caberia ao estudo da estratificação definir os padrões implícitos de avaliação em vigor e sua significação para a formação de classes.

Nem todos se deram por satisfeitos. George Simpson (1939), por exemplo, atacou Speier e outros por sua abordagem culturalista: para ele, o conceito deveria estar ancorado em bases objetivas, caso contrário os estados subjetivos seriam incompreensíveis. Ainda assim, é inegável que a ideia de classe como hierarquia de status acabou por ter grande influência na sociologia americana, aparecendo como uma forte concepção não polarizada da estratificação antes do fim da $2^{a}$ Guerra.

Kingsley Davis e Wilbert Moore, dois alunos de Parsons em Harvard, foram particularmente importantes para essa redefinição, com artigos muito citados e representativos da abordagem estrutural-funcionalista da estratificação (DAVIS, 1942; DAVIS; MOORE, 1944). Neles, o problema central é teorizar a manutenção da ordem social, com atenção à formação das preferências individuais, assunto caro à sociologia e normalmente deixado de lado por economistas. O esforço, de novo, é para decifrar as características universais dos sistemas de estratificação. Davis e Moore partiram da ideia de que a estrutura social consiste de posições institucionalizadas que asseguram direitos e obrigações a seus incumbentes, gerando uma tensão entre solidariedade e diferenciação. A solidariedade social demandaria que a diferenciação de posições e cargos operasse sobre um pano de fundo de valores e fins compartilhados, e que os indivíduos fossem socializados nessa cultura comum. Ao mesmo tempo, toda sociedade precisaria alocar os indivíduos adequados para cada posição e motivá-los a desempenhar bem suas tarefas, em um contexto em que as posições variam quanto à sua importância funcional para a sociedade e à escassez de pessoal qualificado para exercê-las. Com isso, enquanto o imperativo da solidariedade impõe uma demanda de igualdade, ao menos no nível de valores e fins, o imperativo da alocação e motivação desemboca inevitavelmente em uma distribuição desigual de recompensas associadas às diferentes posições. 
Para eles, a solução estava no desenvolvimento de uma escala hierárquica de prestígio vinculada às diferentes posições. Os diferenciais de prestígio - e os benefícios materiais a eles associados - cumpririam o papel motivacional em consonância com os valores e fins comuns à sociedade, dada sua relação com a importância funcional das posições. Isso garantiria a congruência entre estrutura social e personalidade, uma vez que a hierarquia seria reconhecida por todos como legítima, assegurando a cooperação e reciprocidade entre os estratos sociais.

O funcionalismo mudou os termos do debate: saem a polarização e os ricos; entram a manutenção da ordem, a legitimidade da hierarquia e diferenças de prestígio. As desigualdades materiais não foram negadas, mas perderam sua centralidade e tornaram-se basicamente epifenômenos. Como escreveram Davis e Moore, nenhuma posição traz poder e prestígio porque traz altos rendimentos, e sim o oposto: altos rendimentos advêm de posições prestigiosas e/ou com relativa escassez de pessoal qualificado disponível. Além disso, desigualdade de resultados e de oportunidades puderam voltar a ser diferenciadas analiticamente: a primeira seria inevitável e a segunda, indesejável.

O contraste com as concepções anteriores é nítido, mesmo que Davis e Moore abram espaço para a aproximação por estarem mais interessados em negar a inevitabilidade do conflito de classes do que em afirmar sua impossibilidade. Com efeito, suas ressalvas indicam várias circunstâncias em que o conflito pode acontecer, o que inclui a inevitável referência a Marx como alguém cujo erro foi generalizar em cima de uma entre muitas possibilidades. Em certo sentido, Davis e Moore foram até além do necessário nas concessões aos seus críticos à esquerda. A concessão mais branda foi o reconhecimento do "problema do rentista", decorrente da dificuldade em justificar a posição de herdeiros de grandes fortunas. A mais pesada dizia respeito ao próprio regime de propriedade privada:

\footnotetext{
[A] propriedade em bens de capital inevitavelmente introduz um elemento de compulsão mesmo dentro da relação contratual nominalmente livre. De fato, em alguns aspectos a autoridade do empregador contratual é maior do que a do senhor feudal, na medida em que este último estava limitado pelas reciprocidades tradicionais. Mesmo a economia clássica reconheceu que os competidores iriam avançar de forma desigual, mas ela não levou isso à sua conclusão necessária de que, seja qual for sua forma de aquisição, o controle desigual de bens e serviços enseja assimetria entre as partes em um contrato. (DAVIS; MOORE, 1944, p. 247)
}

Essas ressalvas não apagam o contraste com as concepções polarizadas. Pelo contrário, elas só enfatizam a transição, ao menos - embora não só - na sociologia americana nos anos 1940. Em pouco tempo, o clima intelectual mudou de todo. Narrativas muito mais benignas sobre a desigualdade alcançaram a visibilidade até então reservada à polarização social. Na sociologia, o nome mais influente neste processo foi Talcott Parsons, nosso herói do início do capítulo e mentor intelectual do estrutural funcionalismo, assunto do próximo capítulo. 


\subsection{Considerações finais}

A problematização acadêmica e política da desigualdade aumentou sensivelmente nos Estados Unidos, na Grã-Bretanha e em outros países industrializados nos anos entre o fim do século XIX e a $2^{a}$ Guerra Mundial. Nesse período a desigualdade passou a ser interpretada com muito mais frequência em termos binários ou polarizados, de maneira em geral crítica ao status quo. Os termos da dicotomia variaram muitos entre autores, indo do antagonismo entre capitalistas e proletários até a oposição entre elites dirigentes e massas governadas, com especial destaque para a preocupação com os ricos, em geral definidos a partir da oposição às "pessoas comuns", "trabalhadores" ou "pobres".

A enorme visibilidade dos ricos é perceptível até entre autores e políticos não socialistas, que repetidamente buscaram diagnosticar os males sociais e redefinir qual dicotomia era fundamental e quais desigualdades eram legítimas. O afã reformista era pervasivo, e muitas das propostas batiam nas mesmas teclas do debate atual, insistindo sobre a tributação progressiva da renda e da riqueza, o combate a monopólios e privilégios, a regulação do mercado de trabalho e afins. A distinção entre a desigualdade de resultados e a de oportunidades não era tão clara nos discursos da época. Não se tratava de ignorância ou confusão intelectual, e sim da crença, mais ou menos disseminada, de que a equalização de oportunidades ensejaria menor desigualdade de resultados. Não por acaso, a transmissão de grandes heranças foi tão questionada por autores de diversas filiações ideológicas.

Em meio ao furores da época de "descoberta da sociedade", foram os desvios com relação a um ideal igualitário que precisaram ser justificados e legitimados. Em muitos círculos intelectuais acreditava-se em uma relação causal entre a polarização social e a instabilidade econômica e que todas as agruras poderiam ser resolvidas de uma só tacada. Reformadores ou revolucionários, muitos sustentavam que a racionalização do capitalismo poderia unir prosperidade e igualdade. A ideia de um trade-off inevitável entre equidade e eficiência estava longe do grau de aceitação que adquiriria décadas depois.

Não há dúvida de que esse clima intelectual foi ao mesmo tempo causa e produto de um momento muito específico, marcado por grande cataclismos e agitações sociais, em que muitos acreditavam que a ordem social estava de fato em vias de se esfacelar ou, pelo menos, ser radicalmente transformada. Por isso, os diagnósticos à direita e à esquerda deslizavam continuamente entre tentativas de realizar análises objetivas e projeções ideológicas de um mundo ideal. Em boa medida, a retórica contra a desigualdade alinhava-se aos contornos definidos pela mobilização social e trabalhista da época, mesmo que para isso fosse necessário muitas vezes tornar opaco o outro polo do conflito, possibilitando alianças, por exemplo, entre as classes médias e trabalhadores manuais.

O quadro só começou a apresentar sinais fortes de mudanças nos anos anteriores à $2^{a}$ Guerra Mundial, em particular com a ascensão do funcionalismo americano, também alimentado pela percepção de que o caráter da estratificação social estava se alterando. 
Com décadas de distanciamento, pode-se hoje afirmar que essa era crítica foi também o período de maior redução das desigualdades de renda e riqueza na história moderna de boa parte dos países ricos. Mesmo sem dados e análises tão sofisticados quanto os atuais, os cientistas sociais da época perceberam essas mudanças, principalmente os choques ao patrimônio dos mais ricos. A preocupação crescente com a distribuição de renda em comparação com a de riqueza serve como símbolo desse processo, que, de resto, também ocasionou a diferenciação mais clara entre desigualdade de resultados e de oportunidades.

Por fim, cabe apenas lembrar aos espíritos simpáticos à redução das desigualdades que devemos evitar romancear além da conta as lutas e até as conquistas do período. A despeito de todo o clima intelectual, não se tratou de uma época de avanços contínuos ou suaves. A grande redução das desigualdades de renda e riqueza ocorreu de forma abrupta durante grandes catástrofes. Como destaca a literatura atual sobre o tema, a expansão dos Estados de Bem-Estar Social parece ter sido mais importante para evitar ou ao menos adiar a reconcentração de renda e riqueza. Analogamente, é ilusório tentar extrapolar os termos das discussões acadêmicas para a "opinião pública" como um todo.

Além disso, não se pode esquecer que nem todas as desigualdades eram igualmente relevantes. No plano doméstico, desigualdades muito salientes aos nossos olhos, como as de gênero e raça, não eram nem de longe tão problematizadas, para dizer o mínimo. O exemplo óbvio é a permanência das leis Jim Crow e da segregação racial de jure nos Estados Unidos, em tese o mais liberal dos países industrializados, até meados dos anos 1960. É difícil desprezar a continuidade da segregação como um arcaísmo em meio a uma era progressista quando se lembra que o Solid South foi um bastião democrata durante quase todo o período, apoiando e fortalecendo o New Deal, tendo abandonado o Partido Democrata em massa apenas depois do sucesso do movimento dos direitos civis na década de 1960. No plano internacional, o cenário não era tão diferente. A descolonização, sobretudo da África, só avançou de fato no período após a $2^{a}$ Guerra, muitas vezes com conflitos sangrentos. A desigualdade de renda global - isto é, entre todos os indivíduos do planeta - aparentemente aumentou de forma contínua entre 1820 e 1950 (BOURGUIGNON; MORRISSON, 2002). 


\title{
2 A domesticação da desigualdade e a era do otimismo, 1945/1975
}

\begin{abstract}
While diversities of income, corresponding to varieties of function and capacity, would survive, they would neither be heightened by capricious inequalities of circumstances and opportunity, nor perpetuated from generation to generation by the institution of inheritance. Differences of remuneration between different individuals might remain; contrasts between the civilization of different classes would vanish.
\end{abstract}

R. H. Tawney, Equality (1964[1931])

\subsection{Introdução}

Nos anos 1930, ao escrever as linhas que servem de epígrafe a este capítulo, R.H. Tawney imaginou o que seria um futuro desejável e, logo em seguida, voltou à realidade para criticar os argumentos usados pelos ricos para justificar o status quo. Duas décadas depois, muitos intelectuais de renome voltaram a utilizar termos muito parecidos, dessa vez para descrever o presente. Passaram-se mais vinte anos e tudo ficou para trás. A história deste capítulo é a história dessas mudanças, e do papel desempenhado pela desigualdade na ascensão e queda das narrativas benignas de meados do século passado.

Em linha com os demais capítulos desta Parte I, o objetivo é duplo. Em termos teóricos, trata-se de recuperar as controvérsias históricas sobre a estratificação social, evidenciando as origens por vezes esquecidas dos debates contemporâneos e mostrando como as categorias e esquemas interpretativos de cada momento moldam as abordagens do tema. Grande parte das discussões das ciências sociais do último século se defrontou com a desigualdade, com diferentes hipóteses, teorias e interpretações. Porém, a intensidade da problematização explícita do tema variou, com uma alta correlação entre o maior interesse pelo assunto e sua concepção em termos dicotômicos, binários ou polarizados, palavras usadas aqui de modo intercambiável. Em termos pragmáticos, a recapitulação da bibliografia sobre desigualdade, classes sociais e distribuição de renda e riqueza permite apresentar as principais hipóteses elaboradas para explicar tendências e causas do fenômeno, justificando as perguntas que motivam as análise empírica da Parte II.

Os anos dourados entre 1945 e 1975 são excelente matéria-prima, porque ilustram a passagem de uma preocupação intensa com a polarização social para a celebração de uma ordem graduada pacificada. O capítulo trata de analisar os pressupostos e a estrutura dos principais argumentos, delineando o panorama intelectual sem a pretensão de fazer a 
exegese dos textos. A interação entre mudanças sociais profundas e a comparação com as décadas anteriores deram origem a narrativas benignas não só sobre a desigualdade, mas sobre o próprio Ocidente, elevado propriamente à condição de Primeiro Mundo. Nesse processo, a superação das desigualdades extremas atuou como elemento central, embora nem sempre explícito, e, até pelo menos até meados dos anos 1970, o fardo da prova continuou pesando sobre a justificativa das desigualdades, e não sobre o ideal igualitarista. O declínio e a queda de tais narrativas benignas inverteram isso, sem alterar as visões predominantes hierárquicas ou triádicas da desigualdade, o que acabou por diminuir depois o interesse geral pelo tema.

A ideia de que os "trinta gloriosos" foram marcados por interpretações otimistas não é nova. Piketty (2014a, p. 11), por exemplo, falou do súbito apreço dos economistas por "contos de fadas", enquanto Grusky (2011) cunhou a expressão "narrativas benignas" para descrever parte importante da produção intelectual do período. Salvo engano, o argumento ainda não foi desenvolvido em detalhe, o que faço aqui, como no capítulo anterior, inspirado pela tipologia de Cannadine (1999) de concepções da desigualdade. Mais uma vez, trato o que ele chamaria de discursos sobre a "sociedade sem classes" uma sociedade de classe média em que desigualdades de renda não ensejam relações de deferência - como parte das visões hierárquicas. Se essa distinção fazia sentido para o recorte escolhido por Cannadine, aqui ela é desnecessária.

As demais ressalvas discutidas no Capítulo 1 continuam aplicáveis. De novo, o recorte temporal tem somente fins heurísticos. As referências bibliográficas seguem majoritariamente americanas e britânicas pelos motivos discutidos acima, embora o capítulo abra mais espaço para o Brasil do que o anterior. A bibliografia marxista e socialista permanece pouco explorada, agora por motivos distintos: com exceção de determinadas disciplinas em alguns países, os marxistas não eram dominantes no debate intelectual do pós-guerra, e o próprio campo fraturou-se ao longo do tempo, seja pela cisão entre União Soviética e China, seja pelas diferentes respostas teóricas aos acontecimentos dos anos 1950, que deram origem à "Nova Esquerda". Por sinal, alguns dos mais influentes intelectuais marxistas, como Theodor Adorno, Max Horkheimer e Herbert Marcuse, acabaram chegando a posições próximas ao estrutural-funcionalismo de Talcott Parsons, apenas com o tom invertido. Afinal, a frustração com a não-revolução operária impeliu os luminares da Escola de Frankfurt a uma interpretação pelo avesso de Parsons, postulando uma distopia moderna sustentada por uma integração social e funcional praticamente completa (e.g., VANDENBERGHE, 1998).

Assim como no capítulo anterior, concentro-me em textos escritos durante o período de interesse, evitando, salvo exceções, comentários e revisões bibliográficas mais recentes. O universo de possibilidades, entretanto, era gigantesco. Como ilustração, a base de dados do Web of Science registra quase 94 mil artigos em inglês em periódicos de economia, sociologia e ciência política entre 1945 e 1975, valor cerca de 340\% maior do que o observado entre 
1900 e 1945. ${ }^{1}$ Logo, não restou opção senão seguir na estratégia anterior - selecionando os textos mais relevantes a partir de critérios relativamente informais de reputação dos autores e periódicos, citações por outros autores influentes e afins - com a consciência reforçada de que os trabalhos aqui citados estão longe de esgotar a discussão do período.

O resto deste capítulo está organizado da seguinte forma. A seção 2.2 cobre a transição entre o pessimismo do final dos anos 1940 e o otimismo dos anos 1950, com destaque para a influência dos estudos empíricos nessa virada; a seção 2.3 recapitula a era de ouro das narrativas benignas, tanto na economia quanto na sociologia, no plano doméstico e internacional; a seção 2.4 traz algumas reverberações políticas dessas narrativas em meio à Guerra Fria; a seção 2.6 dedica-se à recepção e adaptação dessas ideias no Brasil, aos seus desdobramentos durante a ditadura militar e à famosa querela acerca do aumento da desigualdade nos anos 1960; e a seção 2.7 resume os principais argumentos.

\subsection{A queda da desigualdade e o nascimento dos "trinta gloriosos"}

Nenhum período da história recente recebeu epítetos tão triunfantes quanto as décadas que se seguiram à $2^{a}$ Guerra Mundial. Expressões como "os trinta gloriosos", "a era de ouro do crescimento" ou "a sociedade afluente" carregam consigo tanto a nostalgia da prosperidade perdida nos anos 1970 quanto a sensação de ruptura com as turbulências que se multiplicaram desde o fim do século XIX. A mística do período que transformou os Estados Unidos e a Europa ocidental em Primeiro Mundo oferece atrativos para diversos públicos, permitindo esquecer ou deixar de lado os episódios mais desagradáveis. Conservadores como Charles Murray (2012) lamentam o desmoronamento das virtudes cívicas, a perda dos valores comunitários e a degradação cultural nos Estados Unidos a partir do final dos anos 1960, enquanto sociais-democratas como Tony Judt (2010) lastimam a perda, dos dois lados do Atlântico, do consenso em torno do projeto igualitarista que permitiu superar as crises anteriores por uma via não autoritária.

Não foi sempre assim. Nos estertores da $2^{a}$ Guerra e no imediato pós-guerra, muitos temiam pelo pior. Roberto Campos (1964, p. 171), que esteve na comissão brasileira na Conferência de Bretton Woods, em 1944, registrou a crença geral de que o fim da guerra traria uma crise deflacionária e a depressão econômica. Karl Polanyi (1947) partiu dos medos e incertezas associados à sociedade industrial mesmo depois do ocaso do liberalismo clássico para especular sobre as condições necessárias para um futuro menos sombrio. Raymond Aron (1950a, 1950b) culpou a fraqueza e a incompetência dos governos de esquerda pela "regressão econômica" da França desde 1945. Em 1952, John Kenneth Galbraith (1993) documentou com humor o descompasso entre a prosperidade americana

1 Infelizmente, o Web of Science, mantido pela Thomson Reuters, tem problemas de abrangência no período em questão, que também é muito curto para produzir resultados relevantes no Google Ngram.

Por isso, optei não incluir evidências quantitativas neste capítulo. 
e a sensação generalizada de insegurança. Se boa parte do empresariado bradava contra a instauração do socialismo e a perda da liberdade, os liberais - no sentido americano do termo - mostravam-se cada vez mais desconfortáveis com a proeminência das grandes corporações. Ambos temiam que uma nova depressão fosse iminente.

Em pouco tempo essas preocupações foram esquecidas por acadêmicos e políticos. Em 1956, W.W. Rostow (1956) já teorizava sobre as condições para o "crescimento auto-sustentado". No ano seguinte, o recém-eleito primeiro ministro conservador britânico Harold Macmillan fez seu famoso discurso em que proclamava que os britânicos nunca tinham vivido tão bem. ${ }^{2}$ Em 1963, o presidente americano democrata John F. Kennedy popularizou a ideia de que "uma maré crescente carrega todos os barcos", em discurso que celebrava a prosperidade do país desde o fim da $2^{a}$ Guerra. ${ }^{3}$ No ano seguinte, Seymour Lipset (1964) citou, com satisfação, o diagnóstico do socialista Oscar Pollack de que a afluência dos trabalhadores esmorecera o afã pela luta de classes.

Em boa medida, o pessimismo foi derrotado pela força bruta dos fatos. No entanto, só se converteu em otimismo a partir do momento em que a nova ordem foi devidamente digerida por novas teorias, que não tardaram a aparecer. Não obstante a permanência do marxismo como força cultural, a produção intelectual dos países desenvolvidos tornou-se mais positiva desde pelo menos meados dos anos 1950. Nas versões mais deslumbradas, a prosperidade europeia e a americana eram quase inevitáveis.

As desigualdades econômicas tinham protagonismo na maior parte dessas narrativas, com um caráter essencialmente benigno, como observou Grusky (2011). Sua redução foi interpretada como um desfecho mais ou menos natural do processo de desenvolvimento e modernização. As visões polarizadas do início do século deram lugar a concepções triádicas ou hierárquicas da estratificação, e a desigualdade remanescente passou a ser justificada em termos bem funcionalistas. Com o tempo, a distinção entre desigualdades de oportunidades e de resultados tornou-se nítida, e esta última perdeu importância. A maioria dos autores assumiu a estabilidade dos níveis moderados de desigualdade nos países avançados como um dado, uma précondição para um sistema meritocrático capaz de conter conflitos sociais e prover os incentivos adequados. Só entre o fim da década de 1960 e o início dos anos 1970 o novo consenso tornou-se problemático.

Comecemos pelos fatos. À parte vozes discordantes como as de Aron, houve uma percepção crescente de nivelamento social nos países ricos. No Reino Unido, difundiu-se a ideia de que a $2^{a}$ Guerra havia obliterado as divisões de classe (CANNADINE, 1999, p. 150 ${ }^{4}$. Em meados da década, Sorokin (1945) diagnosticava, sem muita comemoração,

2 Trechos disponíveis em <https://web.archive.org/web/20150828231417/http://news.bbc.co.uk/ onthisday/hi/dates/stories/july/20/newsid_3728000/3728225.stm>. Acesso em 28 ago. 2015.

3 Em inglês, "a rising tide lifts all boats". Transcrição disponível em < https://web.archive.org/web/ 20150822042052/http://www.presidency.ucsb.edu/ws/index.php?pid=9455>. Acesso em 21 ago. 2015.

4 Cannadine documentou o sentimento de equalização para em seguida questioná-lo. Aqui, a veracidade ou não desses discursos é irrelevante. De todo modo, cabe notar que Cannadine exagerou na ênfase 
enormes mudanças na estratificação social das populações "euro-americanas", destacando a redução das desigualdades decorrente do "empobrecimento em massa" dos ricos e do "desaparecimento" dos grandes proprietários rurais e mesmo dos capitalistas. Mais rigorosamente, Mary Smelker (1948) contrastou a estabilidade da concentração de renda no topo nos dados tributários entre 1929 e 1940 com a equalização durante a guerra.

O trabalho mais influente dessa lavra foi a estimativa de Simon Kuznets (1953) para as frações da renda dos mais ricos nos Estados Unidos entre 1913 e 1948. Ainda que tenha feito qualificações, Kuznets também destacou a quebra na tendência a partir de 1939, comparando, como Smelker, o declínio na concentração no topo nos anos 1940 com a flutuação sem direção no período anterior. A interpretação de Geoffrey Moore (1952) para os mesmos dados mudou apenas o momento da quebra. Para ele, a Grande Depressão fora o divisor de águas, dando início a um período de forte compressão dos rendimentos no topo, reduzindo a fração dos mais ricos a níveis inéditos.

O que de início foi visto como mudança abrupta foi logo reinterpretado como queda secular e gradual. Ao comentar resultados preliminares de Kuznets no relatório anual do National Bureau of Economic Research (NBER), Arthur Burns (1951), futuro diretor do conselho econômico da presidência e do Federal Reserve, foi grandiloquente: ${ }^{5}$

\begin{abstract}
A distribuição da renda nacional é sempre uma preocupação vital para um povo livre e progressista que deseja elevar seu padrão de vida. [...] $[\mathrm{P}]$ oucos americanos e um número ainda menor de europeus estão cientes da transformação na distribuição de nossa renda nacional que ocorreu nos últimos vinte anos - uma transformação transcorrida de modo pacífico e gradual, mas que já pode ser considerada uma das grandes revoluções sociais da história. [...] Infelizmente, a "cortina de ferro" impede a comparação do nosso feito com aqueles das celebradas "democracias populares", mas é permissível questionar se muitas delas podem reivindicar tamanha democratização do processo distributivo em seus próprios países. (BURNS, 1951, p. 3-4)
\end{abstract}

O próprio Kuznets (1955) gravitou para essa visão, fornecendo o substrato teórico fundamental com a sua teoria do "U invertido", enunciada em sua conferência anual como presidente da American Economic Association. Ele propôs que, no longo prazo, o processo de desenvolvimento primeiro provocaria o aumento, seguido por um período de estabilidade e, por fim, de redução da desigualdade, em função das mudanças setoriais, demográficas,

dada aos discursos binários no pós-guerra porque a politicização se deu com base em um consenso maior acerca dos arranjos institucionais existentes.

5 Fundado em 1920, o NBER é maior instituto privado não-lucrativo de pesquisa econômica dos Estados Unidos. Ver: <https://web.archive.org/web/20150817014639/http://www.nber.org/info.html>. O Council of Economic Advisors é uma agência estabelecida em 1946 e vinculada à presidência americana. Arthur Burns foi seu chairman entre 1953 e 1956. Ver: <http://web.archive.org/web/20150817014819/ https://www. whitehouse.gov/administration/eop/cea/about/former-chairs >. O Federal Reserve, criado em 1913, é o banco central americano. Burns serviu como chairman do Board of Governors entre 1970 e 1978. Ver: <http://web.archive.org/web/20150817014855/http://www.federalreservehistory. org/People/DetailView/11>. Acessos em 16 ago. 2015. 
econômicas e sociais intrínsecas à modernização. Kuznets foi bastante cauteloso quanto à validade de suas hipóteses, mas, no fim das contas, sua teoria tornou-se um mantra em muitos círculos intelectuais e políticos. Por exemplo, Jeffrey Williamson (1965) elaborou, anos depois, uma hipótese para a evolução das desigualdades regionais que seguia na prática a trajetória prevista por Kuznets, com maior desigualdade e, posteriormente, convergência dos Produtos Internos Brutos (PIBs) per capita. Como observou Piketty (2014a, p. 13-15), tratava-se de uma arma política importante em meio à Guerra Fria, e Kuznets tinha consciência disso. Uma preocupação palpável do texto de Kuznets era se os países subdesenvolvidos seguiriam o mesmo padrão, com temor explícito quanto às consequências da maior desigualdade nesses países.

Simbolicamente, a conferência de Kuznets pode ser considerada como o abandono definitivo da visão polarizada da estratificação. Ou, melhor dizendo, a exportação do problema para o chamado mundo subdesenvolvido. Se a lógica do desenvolvimento havia, grosso modo, resolvido o conflito distributivo doméstico, a dicotomia entre pobres e ricos era a característica essencial dos países mais pobres:

\begin{abstract}
[Os países subdesenvolvidos] não possuem classes "médias": há um contraste agudo entre a proporção preponderante da população cuja renda média está bem abaixo da média nacional, e um pequeno grupo no topo com um excesso relativo de renda muito grande. Os países desenvolvidos, por outro lado, são caracterizados por um aumento muito mais gradual das frações baixas às altas, com grupos substanciais recebendo mais do que a alta média nacional e os grupos no topo assegurando frações menores. (KUZNETS, 1955, p. 22)
\end{abstract}

Estudos empíricos subsequentes ajudaram a corroborar Kuznets. Robert Lampman (1954, 1959), que antes havia questionado a robustez dos resultados de Kuznets, acabou por concluir que, nos Estados Unidos e na Inglaterra, a tendência na primeira metade do século fora de redução da desigualdade de riqueza. Com base em dados transversais internacionais, Irving Kravis (1960) ratificou a hipótese do "U invertido", enquanto Edward Budd (1970) observou, em pesquisas domiciliares e em dados tributários, a razoável estabilidade da distribuição de renda americana no pós-guerra, registrando apenas pequenas perdas relativas nos extremos da distribuição em favor dos décimos intermediários.

Com isso, a preocupação com o crescimento econômico tornou-se ainda mais central entre economistas, em detrimento das questões distributivas. Anos mais tarde, em um momento de renovada atenção à desigualdade, James Tobin (1970) - ganhador do Nobel em $1981^{6}$ - relatou ter sido questionado por um colega cientista político sobre os motivos pelos quais os economistas não falavam mais da distribuição de renda. Sociólogos tampouco

$\overline{6}$ Leitores mais pedantes podem lembrar que o prêmio concedido pelo Banco Central sueco em homenagem a Alfred Nobel não é estritamente um "prêmio Nobel". Cabe notar, contudo, que a própria Fundação Nobel reconhece o prêmio em economia como uma das categorias em disputa. Ver: <https://web.archive.org/web/20150828234750/http://www.nobelprize.org/nobel_organizations/ org_structure.html>. Acesso em 28 ago. 2015. 
ficaram imunes, e muitas das contendas dos anos 1950 e 1960 giraram em torno de diferenças de status, e apenas secundariamente de classe ou renda.

As consequências intelectuais da prosperidade foram intuitivas. Se o desenvolvimento se encarrega de reduzir as desigualdades e se a interação entre mercados livres e igualdade de oportunidades tem efeitos virtuosos, então o medo da polarização e dos antagonismos sociais só pode dar lugar a uma visão mais benigna e graduada da sociedade. Todos podem ser iguais e diferentes, vale dizer, a hierarquia de rendimentos associada sobretudo ao mercado de trabalho pode coexistir com uma "sociedade de classe média" sem grandes problemas, em um mundo em que o crescimento econômico é normal e esperado. A preocupação principal poderia se deslocar, inclusive, para os exageros do igualitarismo, algo expresso por Joseph Spengler (1953) já na primeira metade dos anos 1950:

\begin{abstract}
Não é provável que a desigualdade de renda possa continuar a ser reduzida de modo significativo. [...] A motivação adequada só pode ser gerada se as recompensas forem baseadas predominantemente na produtividade, que varia enormemente entre indivíduos [...]. [A] mera manipulação de escalas salariais, com o objetivo de equalizar rendimentos, quase certamente vai afetar negativamente a quantidade e a composição do produto. (SPENGLER, 1953, p. 258-259)
\end{abstract}

\title{
2.3 A era das narrativas benignas sobre o Ocidente
}

Kuznets foi só o começo da era das narrativas benignas. Afinal, a preocupação com os limites do igualitarismo remetia mais à questão da legitimidade das desigualdades remanescentes do que à contestação do otimismo, refletindo o fato de que o fardo continuava no lado que defendia a utilidade e/ou necessidade da desigualdade. Piketty (2014a, p. 11) viu no modelo de crescimento de Robert Solow o mesmo tom otimista, por exemplo. A conclusão faz sentido: Solow $(1956,1957)$ primeiro analisou teoricamente as condições para o crescimento equilibrado no longo prazo - i.e.: em que o progresso mantém a desigualdade relativamente estável - a partir de um arcabouço neoclássico; depois, concluiu em sua análise empírica que, na média, as mudanças tecnológicas haviam sido de fato neutras, e que o aumento da produtividade por trabalhador respondia por quase $90 \%$ do crescimento do produto na primeira metade do século.

David Grusky (2011), além da referência obrigatória a Kuznets, acrescentou, entre economistas, os estudos de Gary Becker sobre discriminação, cujo corolário era que o livre funcionamento do mercado seria capaz de erodir as desigualdades de oportunidades provenientes de atitudes racistas dos empregadores. Pelo menos nesse momento, a abordagem associada aos economistas da Universidade de Chicago - que posteriormente apareceria como alternativa às narrativas benignas tradicionais (ver seção 2.5) - contribuiu para a reelaboração da desigualdade em termos não dicotômicos, benignos e funcionais. A teoria do capital humano desenvolvida por Theodore Schultz, Gary Becker e Jacob Mincer, entre 
outros, relacionou persuasivamente a produtividade dos trabalhadores, os investimentos em educação e os diferenciais salariais via uma abordagem centrada em escolhas individuais e incentivos (e.g., MINCER, 1974), ditando os termos do debate: uma vez superada a resistência à ideia de "capital" humano, boa parte das críticas recaiu sobre o peso relativo da educação e de outras habilidades.

Nem mesmo Milton Friedman (2002) foi imune à sedução das narrativas benignas, algo compreensível face à Guerra Fria. Publicado em 1962, seu Capitalism \& Freedom era um libelo libertário que batia insistentemente nos males causados pela intervenção pública em assuntos privados e glorificava a liberdade econômica como fim em si mesma e como suporte indispensável para a liberdade política. Coerente, Friedman via com maus olhos a emergência de um sentimento coletivista em países ocidentais que insistia na igualdade de condições como objetivo social. A eficiência, escreveu, dependia da função alocativa cumprida pelo princípio de remuneração de acordo com o produto, o que, por definição, atribuía à desigualdade um papel instrumental. Para Friedman (2002, cap. 10), a tributação progressiva da renda era injustificada, ferindo a liberdade individual, e a distribuição de renda era mais uma área em que o governo causava mais mal do que bem.

Nada disso impediu que uma interpretação benigna kuznetsiana se infiltrasse em seu argumento. O imperativo de refutar a retórica socialista fez Friedman perdoar os pecados coletivistas dos welfare states ocidentais, mencionando-os para louvar a capacidade do capitalismo em promover a redução da desigualdade, com destaque para a diminuição da polarização entre as classes mais altas e as demais:

Outro fato marcante, contrário à concepção popular, é que o capitalismo
conduz a uma menor desigualdade do que sistemas alternativos de orga-
nização, e que o desenvolvimento do capitalismo diminuiu largamente a
extensão da desigualdade. Comparações no espaço e no tempo confirmam
essa visão. Há certamente menos desigualdade nas sociedades capitalistas
ocidentais como os países escandinavos, França, Reino Unido e Estados
Unidos do que em uma sociedade de status como a Índia ou um país
atrasado com o Egito. [...] [S]e medida pelas diferenças em padrão de
vida entre as classes privilegiadas e as demais, a desigualdade parece
decididamente menor em países capitalistas do que nos comunistas. Entre
os países ocidentais, a desigualdade é menor quanto mais capitalista o
país é: menor no Reino Unido do que na França, menor nos Estados
Unidos do que no Reino Unido. (FRIEDMAN, 2002, p. 169)

O elogio da prosperidade com baixa desigualdade, com referência à atenuação da polarização, causa surpresa em um autor que deveria ser impermeável a tais preocupações. Friedman, um intelectual de alto nível, certamente tinha consciência da estranheza do argumento, para não falar da afirmação falsa acerca da menor desigualdade americana. Não à toa, o resto do capítulo é repleto de nuances e qualificações, e Friedman (2002, p. 195) volta ao tema mais tarde para lembrar que a menor desigualdade é apenas um efeito 
colateral benéfico, não a principal justificação para uma sociedade de mercado, e que era preciso distinguir entre igualdade de resultados e de oportunidades.

A ideia de que o capitalismo, o industrialismo ou qualquer outro "ismo" característico dos países ocidentais ricos causa menor desigualdade difundiu-se, ainda que nem sempre formulada explicitamente. Muitos intelectuais e cientistas sociais tomaram a menor desigualdade do pós-guerra como ponto de partida para explicar os arranjos sociais virtuosos ou, em chave menos triunfalista, a dinâmica social dos anos seguintes, produzindo outro tipo de narrativa benigna que, embora tenha sobreposição com a visão kuznetsiana, não pode ser reduzida a ela. A controvérsia em torno do conceito de "classe" expressa melhor do que qualquer outra essa vertente, que olhou menos para as causas da equalização do que para suas consequências.

Desde sempre, classe foi um conceito atraente por oferecer um vínculo entre a estrutura social e mudanças políticas, e não apenas para marxistas. Como observou Wrong (1964), todos os analistas clássicos trabalhavam com uma ideia realista de classes como grupos mais ou menos bem demarcados e com alguma consciência (real ou potencial) de sua situação comum, fosse ela baseada em interesses econômicos ou qualquer outro critério. No final da década de 1940, muitos autores começaram a se preocupar com o uso indiscriminado do termo e tentaram organizar o debate (e.g., GOLDSCHMIDT, 1950; GORDON, 1949; GROSS, 1949; HATT, 1950; LIPSET; BENDIX, 1951a, 1951b). A controvérsia tinha vários aspectos, do caráter nacional ou local das classes à sua existência objetiva ou subjetiva, mas pode ser resumida pelo alargamento do conceito de classe, que nunca teve definição unívoca, para dar conta de uma nova realidade que parecia irredutível a oposições binárias ou categóricas entre grandes grupos.

Esse sentimento também repercutiu na Europa e na esquerda, como mostra o texto do socialista fabiano inglês G.D.H. Cole (1950) sobre a classe média. Para ele, a luta de classes marxista perdeu plausibilidade em um mundo em que as desigualdades extremas haviam sido moderadas, o Estado passara a prover inúmeros serviços e os grupos intermediários e heterogêneos haviam se multiplicado, com a acentuação de gradações ocupacionais e de rendimentos. Com isso, o termo "classe média" tornava-se cada vez mais meramente descritivo, em vez de definir um grupo social bem demarcado.

A formulação mais influente na Europa foi a de T.H. Marshall (1964b), originalmente apresentada em 1949. O ensaio é famoso pela caracterização em etapas da evolução dos direitos civis, políticos e sociais na Inglaterra. Na mesma linha do capítulo 1, Marshall constatou o interesse crescente pela igualdade como "princípio de justiça social" nas últimas décadas do século XIX, o que desaguou em uma ordem social que, paradoxalmente, ancorava sua estabilidade na tensão entre dois princípios contraditórios, o princípio de mercado e o princípio igualitário de justiça. Ou seja, entre os resultados inevitáveis de uma ordem competitiva e a igualdade humana básica expressa pelo conceito de cidadania. 
A emergência e a estabilidade de tal arranjo só puderam nascer da atenuação das desigualdades extremas e da expansão da produção em massa. "A integração social espalhou-se da esfera do sentimento e do patriotismo para a do gozo material. [...] A diminuição da desigualdade fortaleceu a demanda por sua abolição, pelo menos no tocante ao essencial do bem-estar social", escreveu Marshall (1964b, p. 96). Os novos serviços sociais ambicionavam equalizar mais o status do que os rendimentos dos indivíduos, e puderam acomodar-se aos dois princípios pela via da igualdade de oportunidades:

Primeiro, a compressão, em ambos os extremos, da escala de distribuição
de renda. Segundo, a grande extensão da área de cultura e experiência
comuns. E terceiro, o enriquecimento do status universal de cidadania,
em conjunto com o reconhecimento e estabilização de certas diferenças de
status primariamente pelos sistemas interligados de educação e ocupação.
Os dois primeiros tornaram o terceiro possível. Diferenças de status
podem receber o carimbo de legitimidade em termos de uma cidadania
democrática desde que não cortem fundo demais, mas sim ocorram em
uma população unida em uma única civilização; e desde que não sejam
expressão de privilégios hereditários. Isso significa que desigualdades
podem ser toleradas em uma sociedade fundamentalmente igualitária
desde que não sejam dinâmicas [...]. (MARSHALL, 1964b, p. 116)

Marshall articulou um conjunto de ideias que se tornou muito popular, ainda que, no processo, a tensão e as inconsistências sublinhadas por ele tenham progressivamente perdido importância em prol da noção de equilíbrio. Esse conjunto de ideias sustentava a domesticação da desigualdade e a institucionalização do Estado de Bem-Estar como fiadores de uma ordem pacificada, que dissolvera os grandes antagonismos em hierarquias mais de status do que propriamente de renda ou riqueza. Nessa estrutura social pluralista, o sistema ocupacional desempenhava um papel especial, com uma crescente divisão do trabalho e a proliferação de ocupações burocráticas e profissionais. Desvios em relação à igualdade material continuaram tendo que ser justificados, o que se dava em termos de incentivos e imperativos funcionais de sociedades afluentes. Com a cautela e as ressalvas habituais, o próprio Marshall (1964a) reiterou muitas dessas ideias em seu panorama da literatura sobre estratificação em meados da década de 1950.

Outros nomes de peso fizeram coro. Entre os conservadores, Robert Nisbet (1959) proclamou a obsolescência do conceito de classe social para as sociedades ocidentais modernas, afirmando que ele só era útil para a sociologia histórica ou para o mundo não desenvolvido. Para ele, o conceito dizia respeito a grupos sociais reconhecíveis pela observação. Se no início do século XX muitos entendiam "classe" como uma realidade, a situação teria se tornado insustentável no pós-guerra com a consolidação da social democracia, os avanços educacionais, a compressão e suavização da distribuição de renda e riqueza e o pluralismo econômico e social. Nada disso deveria ser surpreendente. Em uma reelaboração da recorrente tese das "amarras feudais" (HIRSCHMAN, 1982), Nisbet propôs que a saliência anterior do conceito de classe decorrera da fusão de elementos 
modernos e tradicionais que deram origem à solidariedade, funcionalidade e estabilidade da aristocracia rural britânica do século XIX, que, por sua vez, teria servido como o modelo básico de estratificação para os socialistas. As sociedades modernas continuariam desiguais, mas seriam governadas sobretudo por diferenças de status, irredutíveis a uma hierarquia unívoca e contínuas demais para dar origem a grupos sociais.

No campo mais identificado com a esquerda ou com o liberalismo à americana, a variação foi mais de tom do que de diagnóstico. Em American Capitalism, publicado em 1952, John Kenneth Galbraith (1993) quis conciliar a suposta inevitabilidade dos oligopólios e da concentração industrial com a prosperidade generalizada à sua volta. A resposta era simples: se as grandes corporações eram o locus por excelência da inovação industrial, sua própria existência incentivava o surgimento de um "poder compensatório" (countervailing power), cujo exemplo paradigmático seria o grande sindicato industrial. O livro é moderadamente otimista, com críticas mais severas ao liberalismo clássico e a seus colegas economistas do que à sociedade americana. Em seu livro de 1958 sobre a "sociedade afluente", Galbraith (1984) foi ao mesmo tempo mais otimista e mais pessimista, contrastando a afluência privada com a miséria pública nos Estados Unidos. Apesar de cético quanto à redistribuição efetivamente praticada, Galbraith decretou a "trégua" em torno da questão distributiva, mencionando a perda de prestígio associado à propriedade devido ao crescimento do governo e à burocratização. A expansão contínua das profissões e das ocupações prazerosas foi outro postulado das narrativas benignas aceito por Galbraith, que apelou, nesse caso, pela generalização do processo.

Em termos acadêmicos, o ícone máximo do triunfalismo ocidental de meados do século foi Talcott Parsons, cuja obra refletiu e moldou a nova sabedoria convencional. Era o homem certo na época certa: desde os anos 1930, Parsons ambicionou formular uma teoria geral da vida social que desse conta do "problema da ordem", com ênfase nas instituições e na conformação social da motivação dos indivíduos, o que, ironicamente, acabou fazendo com que ele migrasse de teorias voluntaristas da ação (e.g., PARSONS, 1949c) para uma análise radicalmente formalista e explicitamente evolucionista (e.g., PARSONS, 1966). A transição do romantismo voluntarista para o funcionalismo utilitarista ocorreu simultaneamente à passagem da desordem traumática da Grande Depressão para a afluência triunfante do pós-guerra (GOULDNER, 1970).

As primeiras investidas de Parsons foram contra as insuficiências do utilitarismo e das teorias econômicas do comportamento humano, principalmente por abrirem mão de explicar a formação das preferências e pela ênfase unilateral no ímpeto aquisitivo e o autointeresse. Sua teorização inicial insistiu sobre os valores morais compartilhados como elementos de estruturação das ações e de resolução do problema da ordem (PARSONS, 1935a, 1935b, 1940b, 1949a, 1949c). Em um segundo momento, Parsons abraçou a abordagem funcional-estrutural para realizar descrições estruturais capazes de indicar a funcionalidade dos processos para o sistema social. Valores e normas sociais continuaram 
sendo os elementos fundamentais de integração dos fins individuais e do sistema total de ação, pois o sistema social, o sistema cultural e a personalidade se interpenetram e precisam estar funcionalmente integrados. Os atores individuais aparecem como compósitos de "status-papéis", cuja institucionalização garantiria a reciprocidade de expectativas (PARSONS, 1991). Em sua última fase, Parsons acreditou ter identificado, com seu famoso esquema AGIL, as quatro funções universais que todo sistema teria de cumprir para se reproduzir. Com isso, ele recaiu em uma teoria da evolução social que basicamente ignorava os atores e privilegiava a "capacidade adaptativa" das sociedades - i.e.: auto-suficiência em relação ao seu ambiente - como critério central, o que convenientemente colocava os sistemas sociais ocidentais modernos na ponta do processo evolutivo (PARSONS, 1966, 1971). Valores compartilhados continuaram a ter importância vital, afinal, Parsons via a evolução como "processos automáticos de diferenciação social, crescente adaptação ao meio e mutações e seleções culturais que aparecem com a função precípua de permitir uma crescente generalização de valores capazes de integrar aquelas cada vez mais diferenciadas unidades do sistema social" (DOMINGUES, 2004, p. 48).

A centralidade das normas fez com que a estratificação social sempre ocupasse lugar privilegiado nas análises de Parsons, sendo concebida como um ordenamento hierárquico assentado em avaliações morais e de caráter integrativo. Sem entrar nos meandros, qualificações e refinamentos introduzidos ao longo do tempo, a ideia básica era que o sistema de valores dominante nos Estados Unidos era do tipo universalista e orientado ao desempenho; por consequência, o eixo central da estratificação seria a realização individual em um sistema ocupacional organizado em campos funcionalmente especializados. O resultado seria uma hierarquia relativamente imprecisa de prestígio, sem elites ou classes dirigentes ostensivas, com prioridade para a igualdade de oportunidades. Com isso, o conflito de classes marxistas perdia toda aura de inevitabilidade, e só se poderia falar de classes como um conjunto de unidades familiares com status semelhante que porventura se distinguissem em estilos de vida (PARSONS, 1940a, 1949b, 1954).

As semelhanças com a teoria funcionalista de seus ex-alunos Davis e Moore (1944) são óbvias, embora, como observou Wrong (1959), ao menos no início os últimos reconhecessem mais a possibilidade de separação entre os diversos tipos de recompensa e, portanto, se afastassem da noção de um consenso em torno de um único sistema de valores na sociedade. Entretanto, Parsons (1970) não teve problemas para acomodar um maior reconhecimento da pluralidade de eixos de estratificação, ainda que mantendo a primazia do sistema ocupacional. O próprio Wilbert Moore (1963) percorreu caminho parecido ao qualificar sua formulação original, chamando a atenção principalmente para a fragmentação dos contextos de diferenciação social e questionando a existência de uma hierarquia unívoca de status. Moore também reconheceu que, nessas condições, os rendimentos poderiam ser tornar um denominador comum relevante quando julgamentos sociais se fizessem necessários, algo já discutido por Parsons (1940b). 
Por tudo isso, apesar do reconhecimento esporádico de possíveis conflitos, Parsons e o estrutural-funcionalismo primavam pelo otimismo, inclusive quanto à desigualdade de resultados, com o reconhecimento - ora tácito, ora explícito - de que o sistema moderno associa-se a uma distribuição de renda relativamente comprimida, sobretudo no topo:

Outro fato notável [...] é a magnitude da 'compressão' da escala, no
que diz respeito ao aspecto da renda, que ocorreu mais ou menos nessa
última geração. Essa [compressão] resultou de pressões nas duas "pontas".
$[\ldots]$ [E]levada tributação progressiva, tanto de rendimentos quanto de
patrimônio, e mudanças na estrutura da economia 'podaram' o antigo
estrato superior [...]. Um símbolo notável disso é o destino recente da
propriedade da família de J.P. Morgan em Long Island, que teve que
ser leiloada em função do não pagamento de impostos. Podemos nos
perguntar o que Veblen diria se estivesse escrevendo hoje em vez de no
auge da "era dourada". (PARSONS, 1954, p. 431)

Como visto no capítulo 1, o funcionalismo americano foi um dos vetores da mudança na visão da estratificação, substituindo as concepções dicotômicas por hierarquias mais palatáveis já antes da $2^{a}$ Guerra. A substituição do conflito de classes pelos incentivos e processos de alocação dos indivíduos na estrutura ocupacional foi feita por esses autores antes de Kuznets publicar seus resultados e de os economistas da Escola de Chicago atingirem o pico de sua influência. Com efeito, a justificativa neoclássica para a desigualdade é uma espécie de amoralização, no bom sentido, do funcionalismo (ver seção 2.5).

Isso não escapou aos participantes dos debates da época: em meio à controvérsia tardia em torno da teoria funcionalista da estratificação, Wrong (1959) notou que Davis e Moore propunham no fundo apenas um caso especial do mecanismo de mercado, enquanto Simpson (1956) foi além e sugeriu que a sociologia deveria abandonar o conceito normativamente carregado de "necessidade funcional" em prol da análise em termos de oferta e demanda. Para ele, a especificidade sociológica seria mantida com a sensibilidade às recompensas não materiais, instituições e afins; suas conclusões, no entanto, não foram muito além de uma reformulação amoralizada dos argumentos de Davis e Moore.

Aliás, este era o cerne da querela: o que mais incomodava os críticos, como Tumin (1953), Schwartz (1955), Buckley (1958) e Wrong (1959), era a visão panglossiana dos funcionalistas parsonianos acerca da estratificação social de fato existente. Até Robert Merton (1948), grande expoente de um funcionalismo bem diferente, criticou a negligência de Parsons (1948) em relação aos processos de mudança social, aos diferenciais de poder e à forma como determinadas instituições se apoiam nos interesses de grupos específicos. Kingsley Davis $(1953,1959)$ sempre negou essas acusações. Suas respostas seriam mais convincentes se não fossem tão irascíveis e acusatórias, recriminando críticos como Tumin e Buckley por serem movidos por motivações ideológicas inconfessáveis e incapazes de entender a diferença entre proposições teóricas abstratas e generalizações empíricas. Moore (1963) pelo menos foi mais elegante ao evocar os mesmos sentimentos. 
A controvérsia terminou sem nenhum consenso. Para o argumento deste capítulo, isso é irrelevante. Muitas das críticas específicas à teoria de Davis e Moore conviviam com a aceitação de um mesmo diagnóstico geral, mesmo à esquerda. Dennis Wrong (1959, 1961), por exemplo, foi um crítico contumaz de Davis, Moore e Parsons que também concluiu que o conceito realista de classes deveria ser abandonado e que as desigualdades socioeconômicas nas sociedades industriais "pós-burguesas" se expressavam em hierarquias sem barreiras categóricas entre grupos (WRONG, 1964). Mais ainda, salvo exceções, toda a contenda desdobrou-se em meio à aceitação implícita ou explícita de que algum nível de desigualdade material era inevitável em sociedades minimamente complexas. Em meio a décadas de acúmulo da retórica igualitarista, esse ponto não era tão banal quanto pode soar aos nossos ouvidos; naquele momento, o fardo da prova ainda recaía sobre os não igualitaristas. Parsons, que não se tornou um gigante intelectual à toa, enunciou isso com clareza, mostrando perfeita consciência dos objetivos do seu projeto teórico:

\begin{abstract}
[H]ouve um deslocamento do fardo da prova. As desigualdades constitutivas de um sistema de estratificação anteriormente tendiam a ocupar o centro das atenções, com a institucionalização de igualdades sendo interpretada como manifestação da necessidade de conter os excessos da desigualdade. Agora a tendência é enfatizar os aspectos em que unidades societárias, em especial pessoas, são e devem ser tratadas como iguais, e exigir o fardo da prova não apenas quanto à explicação, mas acima de tudo quanto à justificativa dos componentes da desigualdade. O princípio mais geral parece claro, isto é, que os termos da justificativa devem referir-se às necessidades funcionais dos diversos sistemas de ação que são objeto de análise. (PARSONS, 1970, p. 19)
\end{abstract}

A vitalidade do arcabouço parsoniano manifestou-se em uma agenda de pesquisa empírica que estava na vanguarda da época em termos metodológicos e pelo uso de pesquisas domiciliares. Para ficar apenas na sociologia, um dos legados do estrutural-funcionalismo foi a consagração do status ou prestígio ocupacional como variável fundamental de interesse, além do estímulo aos estudos de mobilidade intergeracional com objetivo de testar empiricamente as teses acerca das sociedades modernas.

Toda a tradição de estudos de "realização de status" (status attainment) remete a tais narrativas benignas. Nessa seara, cabe mencionar o inovador The American Occupational Structure, de Peter Blau e Otis Dudley Duncan (1967), cujas conclusões, grosso modo, corroboravam que o sistema de estratificação social americano era governado por critérios universalistas e meritocráticos. A construção e validação de escalas contínuas de prestígio ou índices socioeconômicos análogos, embora não fosse uma novidade, ocupou pesquisadores como Duncan (1961), Hodge, Siegel e Rossi (1964) e muitos outros. Donald Treiman (1977) fez boa revisão dessa extensa bibliografia, listando 85 estudos em mais de 50 países entre o fim da $2^{a}$ Guerra e o início da década de 1970. Seu livro permanece, talvez, a realização máxima dessa vertente por estabelecer uma das principais generalizações empíricas da sociologia sobre estratificação social, a relativa invariância no tempo e no 
espaço do ranking de prestígio das ocupações (HOUT; DIPRETE, 2006). A explicação proposta por Treiman manteve-se em boa medida nos termos do funcionalismo e das teorias liberais da industrialização, mas, em um claro sinal dos tempos, ele atribuiu peso muito maior aos diferenciais de poder e de privilégios do que seus predecessores.

Outra faceta das narrativas benignas do pós-guerra diz respeito à contrapartida externa dos diagnósticos felizes. Como vimos, Kuznets avançara nessa direção com sua teoria do "U invertido" e a caracterização dos países subdesenvolvidos como pobres e desiguais, em contraste com as sociedades mais afluentes. Também nesse caso, as teorias otimistas não pararam por aí. Mais ainda, a importância do estrutural-funcionalismo salta aos olhos quando se leva em conta um influente conjunto de teorias que tinham em Parsons uma das suas inspirações: as teorias da modernização que propunham uma interpretação não marxista para o processo de mudança social (KNOBL, 2003).

Seu núcleo comum era a análise comparativa pela ótica da passagem do "tradicional" ao "moderno", pensados a partir de oposições como particularismo/universalismo, herança/realização e afetividade/racionalismo. O processo reorganizaria a vida social como um todo, de acordo com um script mais ou menos linear (KNOBL, 2003). Em tempos de Guerra Fria, essas teorias uniam o útil ao agradável, competindo com o comunismo pela atenção e lealdade do mundo subdesenvolvido (PIETERSE, 2010, cap. 2). W.W. Rostow era talvez sua face mais confiante e abertamente anticomunista, com sua contagiante teoria da decolagem para o crescimento sustentável (e.g., ROSTOW, 1956).

As consequências das teorias da modernização para as interpretações da desigualdade podem ser resumidas em um movimento duplo. Por um lado, o antagonismo aparentemente insuperável entre capitalismo e socialismo era dissolvido em favor da noção de sociedade industrial, cujos imperativos funcionais determinavam a inevitabilidade de alguma desigualdade de resultados e a promoção da igualdade de oportunidades. Parsons desde o início operou nessa direção, recorrendo ao fenômeno da profissionalização para refutar a concepção estritamente capitalista das sociedades ocidentais modernas (GOULDNER, 1970, p. 151-157). O reconhecimento de que as desigualdades de renda e poder permaneciam no mundo comunista e em outros arranjos coletivistas e que a União Soviética estava ridiculamente distante da utopia prometida tornaram essas ideias ainda mais persuasivas (ARON, 1950b; LANE, 1971; ROSENFELD, 1951; WRONG, 1959). Por outro lado, na linha de Kuznets, os estudos comparativos internacionais ressaltavam como os conflitos distributivos dos estágios iniciais da modernização, já superados nos países ricos, estavam a pleno vapor nos países mais atrasados, cujas estruturas sociais ainda não tinham gerado as condições necessárias para o ciclo virtuoso da industrialização.

Os exemplos são abundantes. Parsons (1949c) desde cedo minimizou as diferenças entre sociedades industriais capitalistas e não capitalistas. Nos seus escritos tardios, ele entregou-se à teoria da modernização com todas as forças: as sociedades modernas seriam 
universalistas, meritocráticas e especializadas, desmanchando os conflitos ideológicos de outrora e a oposição entre socialismo e livre mercado com a institucionalização do Estado de Bem-Estar e da tributação progressiva. A revolução educacional e o triunfo da ciência garantiriam a elevação constante dos padrões de vida, a expansão das camadas profissionais e a melhoria das condições gerais de trabalho. Os Estados Unidos seriam a imagem do futuro, para a Europa e quiçá até para a União Soviética, por sua superioridade em termos de institucionalização de liberdades (PARSONS, 1971).

Seymour Lipset (1964) seguiu pelo mesmo caminho, considerando a americanização da Europa como resultado da industrialização. A la Kuznets, ele reiterou a associação entre maior produtividade econômica e a distribuição mais igualitária de acesso a bens de consumo e à educação, com redução das tensões sociais que, de resto, seriam resquícios de distinções pré-modernas de religião e status. A ideologia cada vez mais aceita da "sociedade aberta" operava sobre um consenso mais profundo em torno do que chamou de "socialismo conservador". Anos antes, o mesmo Lipset (1959) havia analisado os "pré-requisitos sociais da democracia", privilegiando a interdependência das instituições modernas: o desenvolvimento econômico estaria causalmente associado à estabilidade das democracias. Nos países avançados, o consenso em torno do Estado de Bem-Estar e a institucionalização das negociações coletivas tinham moderado o furor revolucionário. Lipset tratou o aumento da renda nacional de um país e a redução da desigualdade basicamente como processos indissociáveis. Enquanto os países mais ricos seriam estratificados em um continuum, os mais pobres eram inevitavelmente polarizados:

A maior riqueza [nacional] está causalmente relacionada ao desenvolvi-
mento da democracia não apenas pela mudança nas condições sociais
dos trabalhadores, mas também pelos seus efeitos sobre o papel político
da classe média, pois altera o formato da estrutura de estratificação de
uma pirâmide alongada, com uma grande base de classe baixa, para um
losango com uma classe média crescente. [...] Quanto mais pobre um
país, e quanto mais baixo o padrão de vida das classes baixas, maior a
pressão sobre os estratos superiores para tratá-las como seres aquém dos
limites da humanidade, vulgares, inferiores, uma casta baixa. [...] [O]s
estratos superiores tendem a encarar a concessão de direitos políticos
para os estratos inferiores, em especial o direito de compartilhar o poder,
como essencialmente absurda e imoral. (LIPSET, 1959, p. $83-84$ )

Sociólogos e cientistas políticos não foram os únicos a se contagiar. Na economia, Kerr et al. (1964) ofereceram uma das explanações institucionalistas mais famosas dentre as teorias liberais da industrialização. Sem desmerecer a análise, é possível fazer um bingo com os leitmotifs da época. Quase todos estão lá: a marcha comum rumo à industrialização (com a qualificação de que eles reconhecem a possibilidade de estratégias e caminhos alternativos); capitalismo e comunismo como expressões da mesma lógica industrial, com superioridade para as democracias ocidentais; o amadurecimento da industrialização ensejando o declínio dos conflitos trabalhistas; o esmorecimento das paixões ideológicas; a 
vinculação entre sociedade industrial e meritocracia; a educação como motor do progresso e da estratificação social; a substituição de desigualdades dicotômicas para uma gradação ocupacional em que a maioria é ao mesmo tempo supervisora e supervisionada; a ascensão das grandes corporações; a consolidação do papel do Estado na organização da vida social. Suas conclusões condensam esses temas em poucas páginas, com realce para a obsolescência da polarização social e a moderação da desigualdade:

A passagem do tempo é em si mesma uma força. [...] O grupo de elite cresce em tamanho e se torna menos identificável, fundindo-se sucessivamente a cada uma das camadas inferiores na nova hierarquia.[...] A sociedade industrial precisa ser administrada; e os administradores tornam-se cada vez mais benevolentes e qualificados. [...] [O] conflito de ideologias entre sociedades é amortecido e desvanece. O consenso emerge sempre que a industrialização é bem sucedida. [... ] A educação almeja reduzir a escassez de pessoal qualificados, e isso depois de um tempo reduz os diferenciais salariais que eles recebem. [... ] Isso conduz a uma nova igualdade, que não tem nada a ver com ideologia; de fato, ela pode se concretizar mais rápida e completamente em uma sociedade de classe média do que em uma sociedade guiada por intelectuais revolucionários que proclamam a igualdade como objetivo primário. [...] O Estado, em todo lugar, torna-se um instrumento importante na sociedade. (KERR et al., 1964, p. 227, 288 e 290)

Um último exemplo expõe a aura construída em torno da industrialização até o início da década de 1970: em revisão da literatura, Donald Treiman (1970) enumerou e avaliou as hipóteses disponíveis acerca dos impactos da industrialização - considerada a tendência mais essencial das sociedades nacionais na época - sobre a estratificação. Como de hábito, Treiman foi rigoroso, com ressalvas quanto à precariedade dos dados e à escassez de evidências. Quase todas as proposições - inclusive as caracterizadas como empiricamente bem fundamentadas - eram muito positivas ou benignas, atribuindo à industrialização o declínio da desigualdade de renda, o aumento da escolaridade e da renda, a diminuição da influência direta dos pais sobre o status e escolaridade dos filhos, e assim por diante.

Não cabe aqui documentar em detalhe os percalços das teorias das modernização; Wolgang Knobl (2003) fez um bom resumo, narrando os problemas internos e seguidas reformulações que culminaram com seu eventual declínio no final da década de 1960 e opondo-se à interpretação de que elas foram derrotadas por uma nova sensibilidade ao marxismo.

\subsection{Os reflexos políticos do otimismo}

Políticos no poder têm grande apreço por narrativas otimistas. Logo, não é surpreendente que a sabedoria convencional benevolente tenha sido explorada a esmo. A efusividade de Harold Macmillan, na Inglaterra, e de John F. Kennedy, nos Estados Unidos, 
já foi mencionada. Eles não foram os únicos, nem mesmo nos países ocidentais ricos com tradição trabalhista mais forte. Apesar de Cannadine (1999) destacar a prevalência da retórica polarizada, a política britânica fornece um bom exemplo da ascensão de narrativas benignas, e o próprio autor reconhece isso em mais de uma passagem de seu livro.

O fenômeno é mais evidente na recapitulação de um cético como W.G. Runciman (1972, p. 92 e seguintes), que descreveu como o fim da $2^{a}$ Guerra foi acompanhado por demandas intensas por justiça social. De fato, diz ele, o Partido Trabalhista, que ocupou o poder entre 1945 e 1951 com Clement Attlee, levou a cabo a nacionalização de diversas indústrias e a criação do Sistema Nacional de Saúde. Muitos conflitos afloraram com o ressentimento da classe média e a crença generalizada - e, para Runciman, falsa - de que uma grande redistribuição de riqueza estava em curso. No entanto, já em 1950 o programa de nacionalizações e regulações fora moderado, e o Partido Trabalhista fez campanha alegando que a distribuição equitativa dos recursos já havia sido assegurada. Quando os conservadores voltaram ao poder com Churchill, em 1951, a questão distributiva não estava mais na pauta, prevalecendo a percepção errônea de que não havia mais nem ricos nem pobres na Inglaterra (RUNCIMAN, 1972, p. 93-94).

A distensão política e o crescimento econômico foram celebrados pelo então primeiro ministro Tory Harold Macmillan em mais de uma ocasião, e não só no seu supracitado discurso de 1957. Em 1959, como reportado por Cannadine (1999, p. 153), Macmillan comemorou seu novo triunfo eleitoral proclamando que seu partido havia vencido a luta de classes. De Churchill a Alec Douglas-Home, os conservadores elegeram quatro primeirosministros em seguida, ocupando o poder por 13 anos ininterruptos, apesar de o crescimento médio do Reino Unido ter sido o mais baixo entre os principais países da Europa ocidental entre 1955 e 1975 (TEMIN, 2002, p. 5). Os trabalhistas só voltaram em 1974, com Harold Wilson, quando o otimismo havia dado lugar à crise, e a retórica polarizada voltou com força total, embora a historiografia tradicional considere que o consenso do pós-guerra tenha colapsado apenas mais tarde, com Margaret Thatcher (e.g., KAVANAGH, 1992).

Algo semelhante ocorreu no sistema político já patologicamente otimista americano. Os anos 1950 começaram com a paranoia macartista evocando alguns dos conflitos conflagrados pelo New Deal, mas nos anos seguintes o clima tornou-se mais leve, com o "degelo" da Guerra Fria e a des-Stalinização promovidos pelo líder soviético Nikita Khruschev, que, em 1956, denunciou o "culto à personalidade" e parte das atrocidades perpetradas por Josef Stalin, morto em $1953 .^{7}$

O próprio discurso de despedida da presidência de Dwight Eisenhower, em 1961,

7 A transcrição do "discurso secreto" de Khruschev no congresso do Partido Comunista em 1956 está disponível em <https://web.archive.org/web/20150830010151/http://www.theguardian.com/ theguardian/2007/apr/26/greatspeeches2>. Em 2006, John Rettie, correspondente da Reuters responsável pela divulgação do discurso no ocidente, contou à $\mathrm{BBC}$ os bastidores do processo; ver < https://web.archive.org/web/20150830010331/http://news.bbc.co.uk/2/hi/programmes/from_ our_own_correspondent/4723942.stm >.Acessos em 29 ago. 2015. 
sempre lembrado pela ameaçadora referência ao "complexo industrial-militar", foi menos lúgubre do que seria de se imaginar. Ao mesmo tempo que enumerou riscos para o futuro, Eisenhower reconheceu que a situação era inevitável no contexto da Guerra Fria e reafirmou a posição dos Estados Unidos como o país mais forte, influente e produtivo de todos, portador da missão de promover a paz e a liberdade no planeta. ${ }^{8}$

A versão americana do "consenso do pós-guerra" ficou evidente na massacrante vitória do democrata Lyndon Johnson sobre o arquiconservador republicano Barry Goldwater em 1964. Johnson obteve quase $91 \%$ dos 538 votos no colégio eleitoral, o maior percentual até então, e mais de $61 \%$ dos votos populares, recorde ainda inigualado. Goldwater, que votara contra a lei dos direitos civis por discordar da interferência federal em assuntos estaduais, venceu em apenas seis dos cinquenta estados: os cinco do Deep South (Alabama, Carolina do Sul, Georgia, Louisiana e Mississippi) e o Arizona, seu estado natal. ${ }^{9}$

Além da aprovação do Civil Rights Act, os seis anos do governo Johnson ficaram marcados por duas guerras, com raízes no governo Kennedy: no plano exterior, houve a escalada da Guerra do Vietnã e, no plano doméstico, a "Guerra à Pobreza", nome informal dado a um conjunto de políticas e programas para erradicar a pobreza absoluta nos Estados Unidos. Dois aspectos da Guerra à Pobreza merecem ser mencionados. Primeiro, como as taxas de pobreza segundo a linha oficial estavam em torno de $20 \%$ em meados dos anos 1960, a própria empreitada reflete bem o clima esperançoso reinante na época. Basta lembrar o apoio "incondicional" declarado por Johnson em seu discurso de State of the Union em 1964. ${ }^{10}$ Analogamente, a impressão crescente, a partir do fim da década de 1970, de que a empreitada fora um fracasso reflete as mudanças no clima intelectual. Se, de início, as maiores críticas vieram do campo conservador (e.g., KRISTOL, 1971), a estabilidade da pobreza nos anos 1970 e sua piora na recessão do início dos anos 1980 levaram muitos democratas e simpatizantes a um diagnóstico parecido (e.g., BELL; WRAY, 2004; para uma avaliação mais favorável, ver JORGENSON, 1998).

Um segundo aspecto da Guerra à Pobreza é que, não obstante a metáfora bélica e potencialmente polarizante, sua retórica era essencialmente harmoniosa. Mais uma vez, o discurso de anúncio do programa fornece um bom exemplo: Lyndon Johnson repetidamente defendeu que o programa partiria de uma abordagem cooperativa e destacou que as iniciativas não beneficiariam apenas os mais pobres, mas sim todos os americanos, fosse via oferta de serviços e bens públicos, fosse via redução de impostos. Em nenhum momento o então presidente empregou a palavra "redistribuição" ou articulou uma visão binária da

\footnotetext{
8 A transcrição do discurso está disponível em < https://web.archive.org/web/20150822041308/http: //eisenhower.archives.gov/research/online_documents/farewell_address/1961_01_17_Press_

Release.pdf $>$. Acesso em 21 ago. 2015.

9 Resultados disponíveis em <http://www.archives.gov/federal-register/electoral-college/historical. html>. Acesso em 21 ago. 2015.

10 Transcrição disponível em <https://web.archive.org/web/20150823015523/http://www.presidency. ucsb.edu/ws/?pid=26787>. Acesso em 2 ago. 2015.
} 
sociedade. A estratégia envolvia políticas keynesianas para estimular a demanda agregada e investimentos em educação e em programas de treinamento e capacitação, o que foi atacado na época pelos simpatizantes mais radicais do Partido Democrata, como Hyman Minsky, como uma concessão ao programa neoclássico (BELL; WRAY, 2004).

Seja como for, o importante aqui é salientar os reflexos dos discursos otimistas e das narrativas benignas na vida política. Exageros à parte, o já mencionado artigo de Lipset (1964) sobre as mudanças estruturais e políticas na Europa do pós-guerra ilustra como o fenômeno não se restringiu à Inglaterra e aos Estados Unidos.

Não é surpreendente que políticos abracem interpretações róseas do mundo para legitimar seu legado e permanecer no poder. O intrigante é a capacidade de persuasão dos apelos citados nos parágrafos anteriores. Uma peculiaridade dos "trinta gloriosos" é que, quanto mais de perto se examina, mais curto o período se torna, pelo menos no que diz respeito a turbulências políticas, quase sempre relacionadas a conflitos externos. Mesmo no auge da era de ouro, entre 1945 e 1965, as tensões não arrefeceram. O mundo ocidental foi chacoalhado por duas crises em Berlim (o bloqueio soviético em 1948 e a construção do muro em 1961), duas grandes revoluções comunistas (China, em 1949, e Cuba, em 1953-1959), ${ }^{11}$ a Guerra da Coreia (1950-1953), a Revolução Egípcia (1952) e a invasão ocidental fracassada contra Nasser na crise de Suez (1956), a guerra de independência da Argélia contra a França (1954-1962), a tentativa fracassada de invasão americana (o ataque à Baía dos Porcos, em 1961) e a crise dos mísseis em Cuba (1962), o início da prolongada Guerra do Vietnã (1955-1975), além de muitas outras rebeliões, guerras e conflitos ligados à Guerra Fria e/ou à luta anti-colonial. Nos Estados Unidos, Kennedy foi assassinado em 1963, o Movimento pela Liberdade de Expressão (Free Speech Movement) sacudiu os campi universitários entre 1964 e 1965, e o Movimento dos Direitos Civis (Civil Rights Movement) colocou em primeiro plano antigas fraturas sociais entre 1955 e 1968. Na União Soviética, a queda de Khruschev em 1964 e a ascensão de Leonid Brezhnev puseram fim às reformas liberalizantes. Na Europa, o Império Britânico desmoronou, a França sofreu uma ruptura institucional com fim da $4^{a}$ República em 1958, e as potências, incluindo a não europeias, perderam suas colônias. No limite, o mundo quase acabou.

Não cabe aqui examinar esse aparente mistério a fundo. Pode-se especular, contudo, que as narrativas benignas sobre a desigualdade e a modernização tiveram poder porque satisfizeram simultaneamente critérios objetivos e ideológicos. No primeiro caso, em comparação com as décadas anteriores, as turbulências só poderiam parecer pequenas, e a afluência e a harmonia sociais mui razoavelmente ofereciam grande fascínio. Como notou Galbraith (1984), havia motivos para que as teorias econômicas da virada do século XX fossem tão sombrias; em comparação, o sucesso do pós-guerra era arrebatador. No

11 Rigorosamente falando, o regime de Fidel Castro foi desde o início nacionalista e socializante, só se alinhando explicitamente ao comunismo e à União Soviética mais tarde. Note-se, inclusive, que as revoluções chinesa e cubana foram não foram as únicas revoluções socialistas ou comunistas do período. 
segundo caso, a polarização canalizada pela Guerra Fria gerou inevitáveis incentivos para que essa grande transformação fosse interpretada em termos de uma lógica própria do capitalismo e do industrialismo, e não como mero acidente histórico, particularmente a partir do momento em que os pecados soviéticos começaram a vir à tona. A Guerra Fria ofereceu um segundo caminho para exportação dos antagonismos, de modo que, no plano doméstico, as interpretações graduadas ou triádicas - nem sempre muito distinguíveis entre si - acabaram dominantes, permitindo que os aspectos mais desagradáveis da realidade fossem convenientemente esquecidos ou relegados a um segundo plano.

Já no fim dos anos 1960, o descompasso sempre existente entre fatos e interpretações começou a se tornar grande demais, em parte pelo afloramento de antigas tensões, em parte por problemas decorrentes do funcionamento do compromisso social-democrático e em parte pelo sucesso das interpretações mais otimistas e seus efeitos sobre as expectativas das gerações mais novas. Com isso as críticas - e as crises - pipocaram em muitos lados e em poucos anos as narrativas benignas viraram coisa do passado.

\subsection{Declínio e queda das narrativas benignas}

A história intelectual tem períodos marcados por ideias dominantes, mas dificilmente produz consensos. Por mais que a sabedoria convencional analisada nas seções anteriores tenha sido influente, ela jamais foi unanimidade. O próprio Parsons, por exemplo, recebeu críticas pesadas desde pelo menos os anos 1950, fosse quanto ao caráter utópico e escolástico do estrutural-funcionalismo (DAHRENDORF, 1958), fosse por basear sua visão "superintegrada" da sociedade em uma concepção "supersocializada" do homem (WRONG, 1961). Para entender o declínio mais ou menos abrupto das narrativas benignas no fim dos anos 1960 e na primeira metade dos anos 1970, é bom recuperar o tratamento dado à desigualdade nas primeiras ondas críticas.

As contestações mais claras partiram do desconforto com a era de ouro do otimismo e com o peso dado à noção de equilíbrio social. Algumas foram defensivas, tentando rebater pontos caros à sabedoria convencional. Goldthorpe et al. (1967), por exemplo, testaram a tese do aburguesamento do operariado, concluindo que ela não se sustentava empiricamente. De modo revelador, eles não negaram a afluência dos trabalhadores nem sua remuneração compatível com padrões de classe média; só afirmaram que nada disso teria provocado mudanças substantivas nos valores, experiência de trabalho, estilos de vida, sociabilidade e escolhas eleitorais que sugerissem o fim das barreiras de classe.

Outros foram mais propositivos, tentando recuperar diretamente a visão binária ou dicotômica da desigualdade, ainda que sob vieses distintos, o que deu origem a um conjunto de trabalhos heterogêneos que jamais se articularam em um sistema lógico fechado. Com isso, as bases para a polarização e suas consequências variavam de acordo 
com autor. Ralf Dahrendorf (1959) quis construir, como Marx, uma teoria do conflito para entender como estruturas sociais produzem os elementos de sua própria superação a partir do antagonismo entre grupos sociais. Marx deveria ser descartado porque Dahrendorf aceitava muitos dos pontos das teorias dominantes. As sociedades da época seriam "póscapitalistas": os direitos de cidadania, a mobilidade social, a "decomposição do capital" pela separação entre controle e propriedade e a "decomposição do trabalho" devido à diferenciação ocupacional e à expansão das hierarquias administrativas teriam erodido de facto a unidade das classes marxistas. O que Dahrendorf não aceitava era que isso significasse o fim das bases estruturais dos conflitos. Relações de autoridade essencialmente dicotômicas seriam geradoras de um conflito latente sobre sua própria legitimidade, o que, dadas certas condições, poderia se expressar na forma de grupos organizados. Haveria, portanto, um antagonismo insuperável entre quem manda e quem obedece.

O problema, notado por Giddens (1975, cap. 4), é que esse modelo produz, no limite, uma infinidade de classes, pois é aplicável a qualquer associação coordenada imperativamente, e, assim, o foco de Dahrendorf nos conflitos na indústria e no governo era arbitrário. Mais ainda, Dahrendorf apreciava as peculiaridades do pós-guerra. Seus escritos estão entre os mais interessantes de sua geração por oferecerem interpretações nuançadas e não teleológicas da sabedoria convencional sem romper com ela de todo. Seu diagnóstico da estrutura de classes europeia nos pós-guerra (DAHRENDORF, 1964) tinha muito em comum com o de Seymour Lipset (1964), sem cair nas armadilhas das teorias da modernização. Dahrendorf reconheceu a queda da "velha ordem" polarizada, os avanços social e econômico, a falta de solidariedade e homogeneidade das classes dirigentes, a maior burocratização e a profissionalização, a proeminência das hierarquias de status, o pluralismo das bases de estratificação e o arrefecimento dos conflitos ideológicos. No entanto, ele também examinou o outro lado da moeda, recuperando o espírito da jaula de ferro weberiana para criticar a asfixia burocrática:

\footnotetext{
Quando o senso de solidariedade cede lugar à competição individual, há pouca esperança para grupos políticos radicais. [...] Ao mesmo tempo, o governo representativo torna-se singularmente ineficaz nesse mundo pacífico. Na ausência de forças progressistas, os poderes constituídos, e acima de tudo a força inerte da burocracia, mantêm as coisas como elas são, sem jamais mudá-las. [...] [U]ma espécie pouco inspiradora de conservadorismo burocrático domina a cena. O que tiver começado continua, continua e continua. (DAHRENDORF, 1964, p. 264)
}

Charles Wright Mills (1959) reintroduziu a polarização social na análise das sociedades modernas com seu livro sobre a "elite do poder", originalmente publicado em 1956. Mills narra uma nova dicotomia gerada pelo arranjo social americano, com uma elite corporativa, política e militar relativamente integrada e consciente de si opondo-se às massas, em flagrante contradição com as ideologias pluralistas dominantes. Menos do que uma constante histórica, a polarização seria produto de uma época, com a aproximação 
das elites por interesses comuns e por relações pessoais e afinidades psicológicas. Contra a ideia de uma "revolução dos gerentes" e do desaparecimento dos ricos, Mills enfatizou a perpetuação da riqueza e as afinidades entre grandes proprietários e executivos. Na prática, a consciência de classe estava viva e atuante apenas na elite do poder:

\begin{abstract}
As pessoas dos círculos mais altos podem ser concebidas como membros de um estrato social superior, [...] uma entidade social e psicológica mais ou menos compacta; elas se tornaram membros autoconscientes de uma classe social. [...] O topo do sistema americano de poder é muito mais unificado e muito mais poderoso, e os que estão embaixo são muito mais fragmentados e, na realidade, impotentes do que normalmente supõem aqueles que se distraem com as unidades intermediárias do poder que não expressam nem o que ocorre na parte debaixo nem determinam as decisões no topo. (MILLS, 1959, p. 11 e 29)
\end{abstract}

Ao contrário de Dahrendorf, portanto, Mills rompeu de vez com a sabedoria convencional benigna; apesar disso, seu impacto acadêmico foi limitado, até por sua morte precoce, em 1962, aos 45 anos. O subtexto conspiratório e o sabor jornalístico de certas passagens tampouco ajudaram. Parsons (1957) e Daniel Bell (1958) bateram repetidamente no que viam como militância, estridência, generalizações indevidas, imprecisão conceitual e unilateralismo. Robert Dahl (1958) criticou o caráter quase metafísico das teorias das elites dirigentes, propondo testes para avaliar empiricamente suas hipóteses fundamentais. Mesmo sem antecipar o julgamento, seu ceticismo era palpável. Afinal, ele era um dos grandes expoentes do pluralismo em voga na ciência política americana.

Um último exemplo que merece ser citado é o singular The rise of meritocracy, de Michael Young (1961), originalmente publicado em 1958. O livro, que cunhou o termo "meritocracia", é um relato ficcional sobre um futuro distópico, uma recapitulação histórica, atribuída a um sociólogo do futuro, que tenta explicar as origens dos tumultos sociais da Inglaterra em 2033. Como nos bons ensaios satíricos, o narrador canta as virtudes do status quo e, apesar de identificar as causas da crise, permanece alegremente iludido quanto às suas consequências. Na história do livro, o Reino Unido teria testemunhado, a partir de meados do século XX, o triunfo real das narrativas benignas das seções anteriores, em particular a primazia do aumento da produtividade e da igualdade de oportunidades. A nova ordem meritocrática substituíra o conflito de classes pela hierarquia de habilidades, proporcionando a prosperidade nacional graças à valorização da educação, que se libertara da ênfase sentimental no nivelamento de desigualdades para priorizar a formação de elites intelectuais. O imperativo da eficiência enquanto fim em si mesmo pôde triunfar com o desenvolvimento de técnicas cada vez mais sofisticadas de avaliação de inteligência, separando desde muito cedo a futura elite intelectual - "os 5\% que sabem o que significa 5\%" (YOUNG, 1961, p. 103) - das massas não qualificadas, que, diante do avanço da tecnologia e da mecanização, acabaram retornando à condição de empregados domésticos. 
No fim das contas, emerge uma nova polarização social entre a elite e as massas, com novas fontes de tensão. Dadas as incertezas e neuroses de uma ordem puramente meritocrática e o avanço da homogamia entre os "inteligentes", os conservadores passam a defender a volta do princípio de hereditariedade, minimizando a perda de eficiência em nome da redução do estresse psicológico. Enquanto isso, de modo mais ameaçador, grupos dissidentes das elites aliam-se às classes baixas para denunciar o próprio princípio da eficiência e do mérito, defendendo subversivamente "a oportunidade igual para todas as pessoas, independentemente de sua 'inteligência', desenvolverem as virtudes e talentos para os quais são aptas, todas as suas capacidades para apreciar a beleza e a profundidade da experiência humana" (YOUNG, 1961, p. 170). O tranquilo narrador não via grandes perigos em tais tremores, julgando que "maio de 2034 vai ser na melhor das hipóteses igual a 1948" (YOUNG, 1961, p. 188); o livro, contudo, é interrompido abruptamente, com uma nota de rodapé dos editores explicando que o autor do ensaio fora assassinado em um dos protestos. Na época, Michael Young era filiado ao Partido Trabalhista inglês, alvo de muitas das suas críticas. Seu livro obteve repercussão, ao menos na Inglaterra, e o termo "meritocracia" rapidamente entrou em circulação, mas com conotação oposta à do ensaio. A tentativa de remar contra as narrativas benignas cristalizadas fracassou.

Na contramão de Dahrendorf, Mills e Young, a repolarização que mais ressoou no ambiente intelectual veio da crítica liberal à retórica socialista. Os já mencionados artigos de Raymond Aron (1950a, 1950b) são um bom modelo, dedicando-se à desmistificação da "sociedade sem classes" soviética com o argumento de que, diferente do imaginado, os países comunistas constituiriam as verdadeiras sociedades polarizadas, fraturadas entre elites unificadas e onipotentes e massas desprotegidas e desorganizadas, com consequências catastróficas para a liberdade. Já as sociedades burguesas seriam caracterizadas pelo pluralismo, diferenciação social e elites fragmentadas, em um sistema de pesos e contrapesos favorável à liberdade. A melhor maneira de evitar o perigo seria pela eliminação dos resíduos feudais na Europa, remediando as injustiças pré-existentes ao capitalismo burguês, e pela promoção da industrialização e do crescimento.

Essa crítica liberal da burocratização foi repetida muitas vezes, ainda que em versões menos enfáticas. Milton Friedman (2002) foi por aí para defender a liberdade econômica como condição necessária, não suficiente, para a liberdade política. Como observado, Friedman tinha uma relação ambígua com a sabedoria convencional otimista, dependendo do contexto. Apesar disso, ele foi, em conjunto com George Stigler e outros, um dos grandes artífices da derrocada posterior das narrativas benignas, consolidando as raízes intelectuais, organizacionais e políticas da ascensão da Escola de Chicago.

Friedman e seus associados trabalharam duro desde os anos 1950 para reabilitar a teoria das firmas como maximizadoras de lucros, contrapondo-se a institucionalistas como Galbraith, que partiam da predominância das grandes corporações e preços administrados. Ao mesmo tempo, o monetarismo de Friedman era uma óbvia alternativa à política 
fiscal tradicional (LAIDLER, 2010). Em termos organizacionais, Friedman, Stigler e afins alteraram a dinâmica interna do Departamento de Economia de Chicago, rompendo o isolamento dos subcampos da disciplina pela aplicação de uma abordagem comum (EMMETT, 2010). Fora dos muros da universidade, eles e outros professores de Chicago, como Aaron Director e Frank Knight, foram em 1947 co-fundadores, junto com Friedrich von Hayek, Ludwig von Mises, Karl Popper e outros, da célebre Mont Pelerin Society, organização internacional cujo objetivo era "manter acesa a chama" do liberalismo clássico e que permanece atuante até hoje (BUTLER, 2014). Por fim, a proximidade de Friedman com a política profissional é bem conhecida, inclusive com episódios lamentáveis, como sua associação (por vezes exagerada) com a ditadura de Pinochet no Chile e suas tentativas um tanto constrangedoras de justificá-la (e.g., SCHLIESSER, 2010). ${ }^{12}$ Como escreveram Van Horn e Mirowski (2010, p. 196), o projeto intelectual de Friedman partiu da "admissão, contrária ao liberalismo clássico, que seu programa político triunfará somente se reconciliarse com o fato de que as condições para seu sucesso precisam ser construídas, não emergindo 'naturalmente' na ausência de esforços coordenados".

O contraste entre os esforços metódicos dos herdeiros do liberalismo clássico e a heterogeneidade dos progressistas ajuda a entender o desfecho dos tumultuados anos entre o fim da década de 1960 e o início dos anos 1970, quando as turbulências, até então relativamente bem absorvidas pelas narrativas benignas, adquiriram proporções grandes demais. Nos Estados Unidos, os conflitos raciais se intensificaram a partir de 1964, com a proliferação de marchas pacíficas e protestos violentos. Muitas grandes cidades foram convulsionadas pelo que se chamou, eufemisticamente, de "distúrbios civis". Entre 1967 e 1969, houve quase 600 protestos com violência, com mais de 160 mortos e 53 mil prisões, acelerando o declínio econômico dos centros urbanos (COLLINS; MARGO, 2007).

Nos Estados Unidos e na Europa, a agitação estudantil colaborou para abalar a ordem. As batalhas campais de maio de 1968 em Paris estão entre os momentos mais icônicos da época, reunindo estudantes e sindicalistas em torno de pautas difusas, com grande destaque para slogans libertários e anticapitalistas. De modo mais pacífico e caricato, a súbita visibilidade da contracultura mostrou-se intratável para o estruturalfuncionalismo. Para completar, a escalada da Guerra do Vietnã arranhou mais ainda a aura de legitimidade e estabilidade americana.

Todos esses eventos tinham em comum um caráter contestatório visceral. O fato de que algumas das descrições soam hoje apenas pitorescas diz mais sobre os desdobramentos

$\overline{12}$ O histórico de intelectuais de esquerda é tão ou mais desabonador. Tony Judt (1992) documentou em detalhe a constrangedora fascinação de parte da intelligentsia francesa com a União Soviética. A desilusão com o comunismo soviético não arrefeceu o encantamento de alguns por regimes totalitários, haja visto a posterior adesão de Jean Paul Sartre ao maoísmo e o entusiasmo de Michel Foucault pela Revolução Iraniana de 1978. Um contra-argumento, não inteiramente convincente, é que nem todos à esquerda abraçaram o autoritarismo em nome de uma utopia, como, por exemplo, Albert Camus, e que, de todo modo, nenhum dos radicais prestou consultoria diretamente a regimes repressivos, como no caso da Escola de Chicago e Pinochet. 
posteriores do que sobre as incertezas do período. A ameaça da desordem e/ou de uma súbita virada drástica à esquerda foi, para muitos, bastante real. Robert Nisbet (1969) lamentou que o "crepúsculo da autoridade" em uma época de "mudança revolucionária", dada a aversão dos homens pelo caos, só poderia desaguar no exercício da coerção aberta. O niilismo da "Nova Esquerda", abastecido pelo tédio de uma geração de estudantes de classe média, seria o grande culpado. Nisbet pregava que apenas um novo contrato social poderia refazer o tecido da sociedade. Irving Kristol (1970), outro nome de peso do neoconservadorismo emergente, chegou a conclusões semelhantes. Já Alvin Gouldner (1970), muito mais simpático ao novo radicalismo, foi igualmente apocalíptico, referindo-se, no prefácio de seu livro, à "matriz social caindo aos pedaços", aos "centros urbanos paralisados" e à teorização feita ao "som de armas".

Para além da sua intensidade, os protestos expressaram uma combinação em proporções inéditas do que Luc Boltanski (2002) chamou de "crítica social" e "crítica estética" do capitalismo. ${ }^{13}$ A primeira teria como alvos a desigualdade, a exploração e a pobreza, enquanto a crítica estética direcionava-se à disciplina e opressão fabris, a uniformização da sociedade de massas e à asfixia burocrática. Se, até então, a crítica social havia sido dominante entre a esquerda, os eventos de 1968 assinalavam um protagonismo inédito para a crítica estética (BOLTANSKI, 2002; ver também LOWY, 1987).

Parte da literatura acadêmica seguiu a mesma trajetória contestatória. Ao contrário da utopia meritocrática de Michael Young, a crítica social reapareceu graças à decepção empírica com os discursos triunfantes e à reelaboração teórica do igualitarismo. O terreno foi preparado com a publicação do Relatório Coleman, em 1966, comissionado para avaliar o grau de igualdade de oportunidades educacionais nos Estados Unidos. Sua repercussão foi enorme em função das conclusões - resumidas em Coleman (1966) - acerca do peso da origem familiar sobre o desempenho escolar. Anos depois, Samuel Bowles (1972) reiterou a dúvida sobre o efeito equalizador da educação sobre a renda e argumentou que trabalhos anteriores haviam subestimado a influência da origem familiar tanto sobre a educação quanto sobre os rendimentos, concluindo que o sistema educacional era um dos principais veículos de transmissão intergeracional de status.

Mais influente ainda foi a reanálise de Christopher Jencks (1972) dos dados de Coleman. Além de reiterar a força da origem familiar sobre a escolaridade alcançada pelos indivíduos, Jencks deu o passo radical de questionar os efeitos da escolaridade sobre a renda: como nenhuma das variáveis tradicionais - educação, origem familiar, habilidade cognitiva e outras - explicava muito da dispersão de renda, ele interpretou a desigualdade como algo mais associado a competências muito específicas e sobretudo ao acaso ou à sorte. Em uma hipótese instigante, Jencks (1972, p. 209-210) propôs que só grandes catástrofes

13 Boltanski usa o termo "crítica artística", traduzido aqui por "crítica estética" para destacar a conexão com distinções semelhantes feitas anteriormente por outros autores, como Michael Lowy (1987), que também viu nos anos 1960 ápice da "crítica romântica" à civilização moderna. 
alteram significativamente a distribuição de renda. O livro é recheado de afirmações que batiam de frente com a sabedoria convencional, fosse por insistir que é quase impossível equalizar oportunidades sem reduzir o nível absoluto de desigualdade, fosse por postular que reformas no sistema educacional dificilmente teriam grandes repercussões para fora dos muros das escolas, fosse por concluir que apenas alterações diretas nas regras do jogo poderiam reduzir sensivelmente a desigualdade de renda.

Do ponto de vista filosófico, o nome maior do renovado ímpeto igualitarista foi John Rawls, que desde os anos 1960 burilou sua "teoria da justiça", culminando com a sua publicação em livro em 1971 (RAWLS, 1999). O título anódino ocultava uma ambição colossal: diante da ausência de valores compartilhados que ajudassem a resolver os conflitos sociais modernos, Rawls atribuiu-se a missão de elaborar princípios de validade geral que permitissem uma distribuição de direitos e deveres aceitável por indivíduos morais e racionais. Retomando a tradição contratualista em termos da "posição original", Rawls elaborou dois princípios de justiça, ordenados de forma lexicográfica: primeiro, cada pessoa deveria ter direito às mais extensivas liberdades básicas compatíveis com uma liberdade similar para os outros; segundo, as desigualdades econômicas e sociais deveriam ser reguladas de forma a) servirem para o maior benefício dos menos privilegiados e b) estarem ligadas a cargos e posições abertos a todos sob condições de igualdade de oportunidades justas - o famoso "princípio da diferença" (RAWLS, 1999, p. 53 e seguintes). Não é preciso consultar a literatura posterior sobre Rawls para aquilatar o sabor fortemente igualitarista da sua teoria, que não só exigia a justificação das desigualdades de renda e riqueza como também impunha critérios bastante restritos para elas.

Por sua própria natureza, a crítica estética repercutiu de modo mais difuso no meio acadêmico. Sem dúvida, a Escola de Frankfurt e, em especial, Herbert Marcuse inspiraram a Nova Esquerda anti-stalinista que emergiu depois do "discurso secreto" de Khrushchev e da rebelião húngara de 1956, ainda que Marcuse, o "guru improvável" (GIDDENS, 1997), fosse ambivalente quanto a isso. Wright Mills também é normalmente arrolado entre as influências intelectuais dessa corrente, combinando a crítica e a estética.

Entre os trabalhos conscientemente escritos como resposta entusiástica a essas ideias, o exemplo paradigmático para os nossos fins é Alvin Gouldner e seu The Coming Crisis of Western Sociology (1970). Gouldner compartilhava a causa dos protestos estudantis, mas repudiava a negligência dos estudantes em assuntos teóricos. O livro procurava suprir essa lacuna com uma crítica exaustiva do autor símbolo do status quo, Talcott Parsons. O ímpeto era principalmente estético; Gouldner escreveu sobre a importância da nova "estrutura de sentimentos" da nova geração (GOULDNER, 1970, p. 7-9), a "revolta psicodélica contra o utilitarismo", a rejeição dos padrões dominantes de "sucesso" e a insuficiência do Estado de Bem-Estar na administração da crise (GOULDNER, 1970, cap. 3). As críticas a Parsons foram externas e internas à sua teoria. Gouldner (1970, p. 157) viu em Parsons a passagem do voluntarismo normativo a um utilitarismo de sabor social 
como o triunfo de uma experiência de classe que, tendo deixado para trás a desordem da Grande Depressão, "não possui estímulos para olhar para o passado e tem poucos desejos de que o futuro seja radicalmente diferente". Ele investiu nas contradições, omissões e vieses de Parsons, produzindo algumas passagens memoráveis:

A visão fundamental de Parsons requer a afirmação sistemática e repetida da importância de se olhar para o mundo social em relação ao seu código moral. E Parsons faz isso incessantemente. Apesar disso, as diferenças que ele observa entre a realidade e a moralidade nunca o perturbam e certamente nunca o deixam indignado; elas são, para ele, sempre discrepâncias temporárias, aberrações secundárias, desvios marginais sem consequências para o grande esquema das coisas. Parsons é uma criatura rara: o moralista contente. (GOULDNER, 1970, p. 289-290)

O novo radicalismo ajudou a arruinar de vez as narrativas benignas sem ocupar o espaço deixado por elas. Anedoticamente, vale lembrar que Richard Nixon foi eleito presidente em 1968 e reeleito por larga margem em 1972; Ronald Reagan inaugurou sua carreira política como governador da Califórnia em 1966 prometendo "acabar com a bagunça" na Universidade da Califórnia em Berkeley; Hayek ganhou o Nobel em economia em 1974, Friedman foi laureado em 1976, Schultz em 1979, e Stigler em 1982. Em suma, a visão rósea da desigualdade foi substituída por um libertarianismo de mercado que, como discutido no capítulo 3, relegou a desigualdade ao segundo plano por um bom tempo.

Explicar os meandros de tamanha inflexão intelectual é uma tarefa ingrata. Certamente as bases organizacionais e a confluência com interesses políticos e econômicos, entre outros fatores, desempenharam papel relevante. Cabe aqui destacar apenas alguns aspectos relevantes. Primeiro, é significativo que a onda igualitarista tenha se dado muito mais como crítica ou desmistificação de Kuznets, Parsons e afins do que em termos propositivos ou analíticos. A Nova Esquerda nasceu justamente pela ruptura com o marxismo ortodoxo e pela desilusão com a União Soviética, representando um sopro voluntarista e libertário em uma época de estruturalismos. A contrapartida disso foi mitigar parte do ímpeto prescritivo da esquerda tradicional. A célebre definição de classe "não como uma 'estrutura', nem mesmo uma 'categoria', mas como algo que de fato acontece [...] em relações humanas", do historiador inglês E.P. Thompson (1966, p. 9), é um bom modelo.

Por conseguinte, em segundo lugar, é forçoso notar o fracasso dessas críticas em formular uma interpretação da desigualdade em termos inequivocamente dicotômicos. Se há mérito no argumento de fundo dos capítulos desta primeira parte - i.e.: a intensidade do interesse pela desigualdade está associada à sua formulação em termos binários -, então isso provavelmente contribuiu para a perda de entusiasmo pelo assunto. Com efeito, as críticas à esquerda ofereceram visões polarizadas com maior frequência do que a produção intelectual dominante; contudo, sua centralidade não chegou nem perto do que ocorrera na primeira metade do século (ver capítulo 1). Em uma época em que a crítica estética ganhou ares tão libertários, talvez fosse realmente difícil articular uma interpretação do mundo em termos 
de grandes grupos sociais. Empiricamente, as mudanças do pós-guerra contribuíram para erodir a credibilidade das antigas teorias. Ademais, os instrumentos utilizados tampouco eram condizentes com a problematização específica dos ricos, burgueses ou afins, na medida em que dados tributários caíram em desuso com a ascensão das pesquisas domiciliares. Curiosamente, entre os autores citados, o que talvez mais tenha enfatizado o caráter antagônico da desigualdade foi Alvin Gouldner (1970, capítulo 8), ao criticar a teoria da estratificação parsoniana, chamando a atenção para a importância dos muito ricos e para a centralidade da propriedade privada. Dada a generalização da "sociedade salarial" (CASTEL, 2003) e a lembrança ainda recente da maior proeminência dos ricos no período anterior à $2^{a}$ Guerra, esse apelo não teve maior repercussão.

Em terceiro lugar, não se pode menosprezar que, ao contrário dos radicais e do centrismo keynesiano, o emergente "neoliberalismo" foi capaz de dar respostas concretas para alguns dos principais problemas da época, e, mais, essas respostas eram logicamente consistentes e palatáveis para boa parte dos atores e instituições mais influentes. O caso paradigmático aqui foi a visibilidade adquirida pelo monetarismo de Milton Friedman em consequência do choque do petróleo de 1973, do fracasso dos controles de preços instituído por Nixon e da estagflação do resto da década. Tamanha notoriedade ajudou a alavancar mudanças profundas nos campos acadêmico e político, com um novo quadro interpretativo em que as virtudes do mercado eram opostas às muitas falhas do governo. O processo, claro, já vinha de longe e não se restringia a uma reação conservadora ao radicalismo vide a acidez do debate entre dois democratas, Solow (1967) e Galbraith (1967), ainda no final dos anos 1960 -, mas atingiu seu ápice em meados da década de 1970.

Em conjunto com a resistência do eleitor e do intelectual medianos ao ímpeto revolucionário dos radicais, a confluência desses fatores ilumina o desmoronamento das narrativas benignas e a derrota subsequente da crítica social ao longo da década de 1970. Não é que a ênfase no mercado fosse desprovida de apelos normativos; pelo contrário, muitos textos deslizam continuamente entre afirmações pretensamente descritivas e abertamente normativas. A equivalência entre preocupação com a desigualdade e inveja, por exemplo, aparece constantemente nos escritos dos mais conservadores. Adicionalmente, Friedman e afins adotaram uma retórica de valorização da liberdade e de respeito às escolhas do "homem comum" que era compatível com boa parte das demandas exigidas pela crítica estética do status quo. Soberania do consumidor e democracia andavam juntas em discursos de cunho antielitista que, assim, fechavam a porta para qualquer iniciativa redistributiva por parte do Estado, apelando tanto à eficiência quanto à liberdade (BOLTANSKI, 2002). No mundo do trabalho, a reconceitualização do salário como retorno ao capital humano e a elevação do trabalhador a um "empresário de si mesmo" (FOUCAULT, 2008, p. 311) representava uma valorização do indivíduo analiticamente útil, antitética à interpretação do mundo em termos de grandes grupos sociais e capaz de reservar um lugar mais satisfatório à ação humana do que o estruturalismo marxista ortodoxo. 
Logo, a diferença em relação à sabedoria convencional não estava na ausência de prescrições normativas. Negava-se, em particular, a suposta harmonia natural e previsibilidade de objetivos sociais que, durante os anos dourados, foram interpretados como mutuamente interdependentes: liberdade, igualdade de oportunidades com moderação da desigualdade de resultados, crescimento econômico. Agora, afirmavam-se muitos desses objetivos como incompatíveis e, acima de tudo, deixavam-se de lado proposições morais totalizantes. Se em Parsons a integração era perfeita, com a congruência entre mercados, instituições sociais e valores subjetivos, agora a formação dos valores saía de cena e a separação aguda entre as esferas pública e privada não deixava dúvidas de que objetivos coletivos só poderiam ir de encontro às liberdades individuais. Se o fim do século XIX operou a "descoberta da sociedade", o início dos anos 1970 tratou de reduzi-la à agregação de indivíduos. Enquanto a sociologia afastou-se da noção de equilíbrio social, a economia pôde aferrar-se a equilíbrios de mercado como perspectiva unificadora de suas análises. Condenar ou elogiar tal desdobramento é irrelevante aqui; trata-se de observar quão distante o clima intelectual estava da situação anterior, em meio a uma crise indomável pelo instrumental keynesiano ortodoxo e a demandas legítimas por autonomia individual.

Esses sentimentos, aliados à crítica de bandeiras da esquerda, estão em muitos textos dos principais intelectuais da época. Para James Buchanan (1968), futuro ganhador do Nobel em economia, mesmo a preocupação de Friedman com a pobreza e sua proposta de um imposto de renda negativo estavam erradas: economistas, em nome da coerência metodológica, deveriam levar a sério as preferências e escolhas dos indivíduos, respeitando a falta de interesse em qualquer redistribuição de renda. Gordon Tullock (1971), seu coautor de longa data, não foi tão radical em sua aplicação da teoria econômica às heranças, mas concluiu inequivocamente que elas deveriam ser defendidas só em termos de eficiência. Para George Stigler (1970), a redistribuição de renda promovida pelo poder público era mera expressão dos interesses particulares de coalizões de eleitores - em especial da classe média -, que aproveitavam os poderes coercitivos do Estado para melhorar sua posição, equivalendo a uma espécie de discriminação. Já a diatribe irada de Harry Johnson (1973) era em essência uma reformulação amoralizada da teoria da estratificação funcionalista: para ele, o igualitarismo refletia um "antropomorfismo infantil" que ignorava o papel social das desigualdades na motivação e alocação dos indivíduos e sua contribuição para a organização da sociedade e para o progresso. Repetindo Milton Friedman (2002, cap. 10), Johnson assegurou que boa parte da desigualdade de renda observada decorria apenas de diferenças entre preferências individuais, aversão ao risco e etapas do ciclo de vida. Abba Lerner (1972), por sua vez, foi explícito ao associar soberania do consumidor, eficiência e democracia a uma visão amoralizada da vida social: 
Enquanto crítico social, posso tentar alterar alguns desejos [de terceiros] para outros que eu aprove, mas, enquanto economista, devo me preocupar com os mecanismos que permitam às pessoas conseguir o que elas desejam [...]. Considero essa visão muito próxima à ideia de democracia ou liberdade - a ideia de normalmente permitir que cada membro da sociedade decida o que é melhor para si, ao invés de atribuir a um terceiro um papel paternal. Ela também é muito próxima da ideia de eficiência - eficiência no uso de recursos para a maior satisfação possível para as necessidades e desejos das pessoas. (LERNER, 1972, p. 258)

Entre não economistas, Irving Kristol foi o mais fervoroso crítico do igualitarismo. Com a veemência de sempre, ele reafirmou o desinteresse do grande público pela desigualdade em si mesma e denunciou a defesa da igualdade como uma fachada que ocultava a intenção das classes profissionais e burocráticas de usurpar o poder e status pertencentes à comunidade empresarial (KRISTOL, 1972). Dois anos depois, ele voltou ao tema, criticando Jencks e outros e apregoando que a crença na existência de uma oligarquia americana era uma fantasia paranoica. Pelo contrário, Kristol defendeu que não havia ricos em número suficiente para que os impostos progressivos pudessem ser realmente distributivos, apontou que os limites da redistribuição haviam sido atingidos e bradou contra as patologias sociais causadas pelo Estado de Bem-Estar, um dos seus alvos favoritos (KRISTOL, 1974).

Mais moderado, Daniel Bell (1972) criticou Jencks, Rawls e a redefinição da desigualdade em termos de resultados, e não de oportunidades, e rearticulou, meio desanimado, sua crença nas narrativas benignas da sociedade aberta e meritocrática. Rawls também foi atacado duramente por Nisbet (1974), que, como muitos desses autores, opunha a liberdade à igualdade e considerava o fervor igualitário de Jencks, Rawls e afins como uma religião autoritária e em total descompasso com as percepções da população em geral. Por sua vez, Peter Drucker (1969) e James Q. Wilson (1975) acusaram o Estado de ser o principal agente de burocratização da vida social. Drucker falou na "doença" de um governo inchado, que gastava muito, fazia pouco, acumulava fracassos e provocava o desencantamento das novas gerações, com sua burocracia desgovernada e ingovernável. Wilson, que veio a se tornar conhecido na criminologia pela "teoria das janelas quebradas", quis traçar a origem e as consequências do clientelismo burocrático, que sempre acabava por gerar grupos de interesses capazes de defender seus privilégios com unhas e dentes, e da regulação estatal que impelia a burocratização do setor privado.

A frequência desses argumentos é mais interessante do que seu conteúdo, que cobre todo o espectro entre o risível e o persuasivo. Os nomes dos envolvidos e a angústia de muitos textos também chamam a atenção. Sem juízo de valor, não há dúvida de que a eclosão do radicalismo delineou uma polarização política mais clara, e que o lado vencedor, política e academicamente, organizou-se em torno de certos esquemas interpretativos mais ou menos compartilhados por todos. Notavelmente, tais teorias e esquemas interpretativos foram fluidos o suficiente tanto para atrair a franja mais conservadora quanto para acomodar parte das demandas vocalizadas pela crítica estética do status quo. 
Dessa forma, as narrativas benignas saíram de cena, embora não de modo instantâneo. A celebração da liberdade dizia respeito mais à preservação de algo frágil e precioso do que à vitória de uma utopia. Qualquer suposição de que a estratificação correspondia a sentimentos morais consensuais desapareceu, o que representava um grande problema para os mais conservadores. No auge da crise, Irving Kristol (1970) chegou a criticar Hayek e Friedman nesse ponto: como poderiam os homens viver por muito tempo em uma sociedade livre, mas não necessariamente justa? O vínculo parsoniano entre o valores subjetivos e as instituições reguladoras da vida social havia se perdido, produzindo indivíduos "vazios de substância moral, mas ainda impelidos por aspirações morais primordiais" (KRISTOL, 1970, p. 13). Politicamente, é fácil ver como, nos Estados Unidos, essa inquietação foi mitigada pela aliança com o conservadorismo religioso. No meio acadêmico, isso não ocorreu nem foi necessário. As narrativas benignas totalizantes deram lugar a explicações e justificativas muito mais instrumentais e utilitárias.

O novo espírito quanto à desigualdade foi resumido, em 1975, por Arthur Okun, economista americano com fortes laços com o Partido Democrata. Seu Equality and Efficiency: The Big Trade-off (2015) trouxe já no título o abandono das antigas visões otimistas totalizantes. Okun não descobriu tal trade-off; o que fez foi enunciar o conflito com uma clareza e inevitabilidade pouco vistas desde a $2^{a}$ Guerra. Longe de radicalismos, o livro é nuançado o suficiente ao tentar conciliar o respeito pelas escolhas racionais das pessoas com a noção de direitos e a preferência do autor por uma sociedade relativamente igualitária. Ou seja, "colocar alguma racionalidade na igualdade e alguma humanidade na eficiência" (OKUN, 2015, p. 116). O livre funcionamento do mercado foi abraçado em termos puramente instrumentais, os avanços sociais desde o New Deal celebrados, e os limites da redistribuição reconhecidos em função da eficiência. Para superar a tensão entre princípios, Okun reafirmou sua crença nos efeitos positivos de uma menor desigualdade de oportunidades sobre a distribuição de renda e sobre o crescimento, porém suas conclusões não foram nem poderiam ser taxativas, com muitas incertezas.

No prefácio à reedição comemorativa do livro, Lawrence Summers (2015) observou que essa visão de mundo manifestou-se nos programas de governo de Bill Clinton, nos Estados Unidos, e de Tony Blair, no Reino Unido. No nível retórico, Summers estava correto, o que, aliás, mostra o deslocamento do centro político para a preocupação com a eficiência nas últimas décadas do século passado. Summers especulou que, entre os desdobramentos imprevistos que perturbariam Okun se ele estivesse vivo, estava a rápida concentração de renda no topo. É plausível: pelo contexto, arcabouço teórico e informações disponíveis, o livro de Okun oscila entre concepções hierárquicas ou triádicas da desigualdade de renda. Com efeito, a derrocada das narrativas benignas ensejou um menor zelo pela estratificação não mudando as visões básicas hierárquicas e triádicas que dominaram no pós-guerra. 


\subsection{Kuznets nos trópicos?}

A transposição das narrativas benignas para a América Latina e para o Brasil não seguiu tão de perto os países desenvolvidos. Desde cedo, adaptações fizeram-se necessárias. Não há dúvidas de que a urgência da modernização e o fascínio pelo desenvolvimento arrebataram políticos e intelectuais em meados do século passado, e que a linha de chegada era a equiparação com a "modernidade organizada" (WAGNER, 1996) do Primeiro Mundo. O liberalismo clássico estava em baixa e o Estado foi alçado a piloto do processo. $\mathrm{O}$ estruturalismo de Raul Prebisch (1949) era em essência uma defesa intransigente do ativismo estatal para promover a industrialização, e sua visão animou a produção da Comissão Econômica para a América Latina (Cepal), propondo um caminho em "sintonia com as tendências mais gerais do capitalismo mundial e com os grupos sociais hegemônicos na periferia" (COLISTETE, 1992, p. 35). Politicamente, os "50 anos em 5" de Juscelino Kubitschek ilustram bem a profissão de fé no desenvolvimentismo.

No entanto, certa ambivalência sempre foi inevitável. As narrativas benignas eram a expressão intelectual do triunfo contra a volatilidade econômica e a polarização social. Os países subdesenvolvidos podiam ver nelas a esperança de dias melhores, não a validação de si mesmos. Nosso trabalho ainda estava por ser feito, por assim dizer, e os percalços do desenvolvimento, as afinidades político-partidárias e os conflitos sociais inescapáveis da nossa realidade injetaram uma dose de indeterminação nos diagnósticos da intelligentsia. A repetição, em muitos textos, de que o subdesenvolvimento era produto do desenvolvimento, isto é, não era uma etapa similar a algo já vivido nos países ricos, exprime essa incerteza. Sendo o Brasil subdesenvolvido, desigual e em crescimento, nem o mais exaltado conservador podia defender o status quo ou fazer a apologia da integração social à americana; ao mesmo tempo, a esquerda mais radical sempre procurou em vão pelo proletariado marxista.

Uma saída comum foi aceitar o que as teorias benfazejas falavam do Primeiro Mundo, inserindo as adaptações necessárias - conforme as simpatias teóricas e ideológicas de cada um - para discutir como o Brasil poderia chegar lá, o que quase sempre redundava em misturas peculiares de otimismo e pessimismo. Se no países ricos o equilíbrio social virtuoso era comemorado, por aqui o problema era o da mudança induzida pelo Estado.

Nossos funcionalistas centraram-se mais nas assincronias e conflitos da modernização do que na apologia da integração social, que só poderia aparecer no fim do processo. Na América Latina, o argentino Gino Germani (1965) foi um desses nomes. No Brasil, Costa Pinto (1965) reinseriu a polarização no arcabouço funcionalista para entender como a mudança social gerava obstáculos à sua continuação. Sua interpretação não era de todo pessimista, haja vista a máxima de que o desenvolvimento cria ou agrava problemas que só mais desenvolvimento poderia resolver (PINTO, 1965, p. 295). Só que os obstáculos não podiam ser menosprezados. A aceleração deliberada e indispensável do desenvolvimento pelo Estado aumentava a assincronia em particular entre a base econômica e a organização 
social, gerando resistências de grupos sociais antigos e novos. As dicotomias aparecem com força, seja na oposição entre arcaico/moderno, seja entre elites dirigentes e massas, como dores do parto de uma nova estratificação hierárquica.

A combinação tensa de otimismo e pessimismo também vingou no campo antidesenvolvimentista, como se vê nos ensaios e colunas de jornal de Roberto Campos (1964) nos primeiros anos da década de 1960. Premido entre o reinado do desenvolvimentismo e a ameaça do socialismo, Campos afirmou como ideal o "capitalismo social" em vigor nos Estados Unidos e na Europa ocidental, "aperfeiçoado por preocupações de equidade e justiça distributiva e purificado de seus aspectos predatórios, porém não castrado em seu vigor produtivo ou nas liberdades básicas da democracia" (CAMPOS, 1964, p. 53), exatamente como descrito pelas narrativas benignas mais triunfalistas. As economias mistas da Europa ocidental, para ele, conciliavam liberdade, distribuições mais equitativas da renda e mercados internos fortes, com o aumento do poder de barganha dos operários e o uso de tributos e transferências com fins redistributivos. Em sua origem, estavam verdadeiras "revoluções consentidas", como o New Deal, que sinalizavam a superação do liberalismo clássico e o fracasso das profecias marxistas (CAMPOS, 1964, p. 117 e 162). Campos admitia até que o papel do Estado nas economias subdesenvolvidas tinha que ser maior do que na Europa do século XIX, listando, como motivações válidas, a necessidade ocasional de "intervir para atenuar desigualdades penosas na distribuição de renda entre diferentes classes e diferentes regiões do país" (CAMPOS, 1964, p. 53).

Essa visão rósea do exterior era trespassada por avaliações muito mais lúgubres do Brasil. A referência às motivações válidas para o intervencionismo estatal prenuncia a discussão extensa das motivações espúrias. O elogio ao capitalismo social e à distribuição equitativa da renda no Primeiro Mundo transformava-se em crítica feroz à redistribuição precoce ou "populista", ao "estado assistencial prematuro" ou à "ilusão distributivista" quando o assunto era o Brasil (CAMPOS, 1964, p. 39, 124 e 185). Enquanto a teoria do industrialismo de Kerr et al. (1964) era invocada para alegar que o desenvolvimento brasileiro deveria ser de "classe média", Kuznets era simplificado para justificar que a hora de redistribuir ainda não havia chegado e que a "elevação do padrão de vida das massas" tinha que ser um "subproduto do desenvolvimento econômico", não de medidas regulatórias do "egoísmo capitalista" (CAMPOS, 1964, p. 185). Em suma, fazer o bolo crescer para depois dividi-lo, tal como na frase atribuída a Delfim Netto anos depois.

Os intelectuais à esquerda reproduziram a ambivalência, embora as causas do otimismo ou do pessimismo fossem vistas na chave oposta. Muita tinta foi gasta para discutir a consciência de classe do proletariado brasileiro. O Brasil continuou sendo interpretado por conceitos derivados da realidade (idealizada) europeia, olhando-se muito para o que faltava aos atores para se adequarem ao modelo pressuposto.

O pessimismo aparecia em quem não vislumbrava a possibilidade de uma polarização 
marxista entre classes, como Alain Touraine (1961) e Fernando Henrique Cardoso (1962). Para eles, grosso modo, o caráter descontínuo dos surtos industriais, a expansão mais rápida da urbanização do que da industrialização e a bagagem cognitiva e cultural dos migrantes rurais, entre outros fatores, levavam à busca individualista por mobilidade social, à manipulação pelos sindicatos oficiais e à política populista, resultando em uma classe operária subordinada e não-revolucionária. ${ }^{14}$ Outros eram mais otimistas, como Theotônio dos Santos (1962) e Octavio Ianni (1963), que argumentaram que o sindicalismo "pelego" e a falta de consciência de classe eram só momentos transitórios de acomodação do proletariado. Em uma dessas brutais ironias do destino, Theotônio dos Santos (1962, p. 118) concluiu, meros dois anos antes do golpe militar, que o "movimento operário entrou, no Brasil, na sua fase revolucionária".

O golpe de 1964 e a brutalidade do Estado foram divisores de águas, polarizando discursos. Os militares e seus prepostos apostaram todas as fichas no ufanismo e nas narrativas benignas, enquanto as oposições se tornaram cada vez mais céticas. O ceticismo foi impulsionado, primeiro, por suspeitas quanto ao prosseguimento da industrialização, com a crise de 1964-1967, e, depois, em meio ao "milagre", quanto à possibilidade de que o crescimento econômico culminasse em uma sociedade mais próspera e menos desigual. A teoria da dependência, de Fernando Henrique Cardoso e Enzo Faletto (1979), publicada em livro originalmente em 1970, é o produto mais conhecido internacionalmente do período, não o único. Nos ensaios que escreveu entre o golpe e 1968, Celso Furtado (2003) colocou a concentração de renda no centro da questão:

\footnotetext{
Em síntese: em países de mercados relativamente pequenos, a coexistência de um setor pré-capitalista com um setor industrial que absorve tecnologia cada vez mais orientada para economias de escala e impõe um coeficiente de capital em rápido crescimento, o padrão de distribuição de renda tende a aplicar os recursos produtivos de forma a reduzir sua eficiência econômica, concentrando ainda mais a renda, num processo causal circular. [...] Há um conflito de interesses entre os grupos que controlam o processo de formação de capital e os da coletividade, pois o bem-estar coletivo é incompatível com a discrepância crescente de níveis de vida e em particular com a exclusão da maioria da população dos benefícios do desenvolvimento. (FURTADO, 2003, p. 148 e 150)
}

Tratava-se de uma espécie de perversão da teoria da modernização, que, bem ou mal, permanecia como referência, algo evidenciado nas críticas a W. W. Rostow e em outras passagens (e.g., FURTADO, 2003, cap. 2). Em tese, o início do "milagre econômico", em 1968, deveria enterrar esses ataques e reafirmar o ufanismo do discurso oficial, ainda mais com a imposição do Ato Institucional 5 (AI-5). Nas palavras do futuro ministro da Fazenda do general Geisel, Mário Henrique Simonsen (1972, p. 63), o "crescimento

${ }^{14}$ Curiosamente, Seymour Lipset (1964) atribuiu consequências opostas ao mesmo fenômeno, explicando a pacificação do proletariado europeu pelo fato de que as ideias revolucionárias teriam maior apelo apenas para os recém-chegados do meio rural. 
explosivo do produto real brasileiro a partir de 1968 deixou os estruturalistas bastante engasgados, e muitos deles foram obrigados a rezar o mea culpa".

A oposição viu-se obrigada a reformular a teoria de Furtado, como fizeram Maria da Conceição Tavares e José Serra (2000) em 1970, quando postularam a retroalimentação entre a desigualdade elevada e o dinamismo econômico. Essa via estimulou o ceticismo nos anos seguintes entre os intelectuais não alinhados. O próprio Furtado (1974, p. 88) chegou à conclusão de que o subdesenvolvimento brasileiro era uma questão de dependência e que "o crescimento econômico tende a depender mais e mais da habilidade das classes que se apropriam do excedente para forçar a maioria da população a aceitar crescentes desigualdades sociais". O barco das narrativas benignas fora definitivamente abandonado.

O discurso oficial aferrou-se à modernização, alardeando as taxas de crescimento, o combate à inflação e o compromisso com a distribuição de renda, moderado pelos ditos imperativos do desenvolvimento. Por medo da censura, simpatia ideológica, interesses comerciais ou outros motivos, a imprensa deu ampla repercussão a essa visão. A revista Veja, por exemplo, cedeu diversas capas à "versão oficial" da ditadura. Em 7 de janeiro de 1970, o otimismo do então ministro da Fazenda, Antônio Delfim Netto, estampou a capa da revista. As dez páginas da reportagem retrataram Delfim como um workaholic movido por convicções e em luta para racionalizar a burocracia. Afora uma menção protocolar ao fato de que agricultores e assalariados "arcaram com a maior parte dos sacrifícios na luta contra a inflação" (O SALDO..., 1970, p. 46), o texto comprava a tese de que a maré alta do crescimento estava de fato levantando todos os barcos:

A filosofia do ministro pode ser assim entendida: se a riqueza nacional cresce de 100, não é possível distribuir senão êsses 100; daí uma política ter que optar: quem ficará com essa nova fatia, ou com a maior parte dela? A resposta é esta: o assalariado vai querer ganhar mais apenas para consumir; a emprêsa desejará maiores lucros para investir, criar novas fábricas, novos empregos, de que o país precisa - logo, ela tem prioridade. [...] "Se vamos fazer o jôgo da verdade", acentua o ministro, "temos que reconhecer que os salários reais só podem crescer quando crescer a produtividade. [...] Aliás, a fórmula de reajuste salarial, já pelo segundo ano, proporcionou reajuste acima do aumento do custo de vida, exatamente porque o govêrno deseja manter a participação dos trabalhadores no produto." [...] [E]sta afirmação do ministro deixa grande margem de esperança ao assalariado. Êle deve ter a seu crédito um aumento de salário em potencial, que o Ministro Delfim Netto certamente concederá quando achar oportuno, isto é, quando não houver riscos inflacionários. (O SALDO..., 1970, p. 51)

O argumento de Delfim era fantasioso diante dos diversos mecanismos usados pelo governo para comprimir a massa salarial. Não à toa, o aumento da concentração de renda no topo nesses anos recebe tratamento privilegiado nos capítulos 5 e 6 . Por ora, vale notar que outras edições da Veja foram na mesma direção. A reportagem de capa de 18 de fevereiro de 1970 dramatizou o cerco da Receita Federal à sonegação e comemorou a maior 
eficiência na coleta do imposto de renda. Os leitores foram devidamente informados que o tributo era o mais justo dos impostos e que "a máquina fiscal não quer mais funcionar apenas para arrecadar: quer inclusive orientar a melhor distribuição de renda no país" (O CÊRCO. .., 1970, p. 36), mas sem sufocar o contribuinte.

Em 17 de março de 1971, o tema voltou à capa da Veja. Mais uma vez, os leitores foram informados sobre os enormes esforços do governo federal para modernizar o fisco e sobre as virtudes distributivas do imposto de renda. O contribuinte não precisava temer, pois não haveria radicalismos. No longo prazo, o governo almejava transformar o imposto de renda no pilar do sistema tributário nacional. O então vice-presidente da Federação das Indústrias do Estado de São Paulo (Fiesp), Mário Amato, que se tornaria uma figura controversa na eleição de 1989, concordava na época com os pendores redistributivos, afirmando que o imposto de renda não era um castigo, "pois só pode pagar aquêle que ganha; êle está sendo premiado na sua capacidade" (UNIVERSO. .., 1971, p. 40).

Um último exemplo é outra capa da Veja sobre o imposto de renda, em 22 de março de 1972, que trazia o título "Um imposto para redistribuir a renda". A reportagem foi mais incisiva do que as anteriores, citando o nível alto da carga tributária brasileira e que "a prioridade governamental não [era] distribuir renda imediatamente" (A POLÍTICA..., 1972 , p. 72), haja vista os incentivos fiscais concedidos pelo governo, que diminuíam a progressividade do imposto de renda. A mudança de tom, todavia, foi apenas marginal. De novo, o ministro Delfim Netto apareceu para apaziguar as preocupações, esclarecendo que o uso redistributivo do imposto demandava a reorganização prévia do aparelho de arrecadação e que o importante era o imposto ser "progressivo até o ponto em que interessa ao sistema que se [estava] construindo" (A POLÍTICA..., 1972, p. 72). Além disso, a reportagem relatou em detalhe os aprimoramentos em curso no imposto de renda para combater desigualdades e injustiças. No fim das contas, o discurso oficial era ratificado, inclusive com a reprodução de uma definição um tanto peculiar de "redistribuição":

\footnotetext{
Não convém punir indiscriminadamente os de maior renda - porque, afinal, o sistema não deve desencorajar ninguém a aumentar seus rendimentos - nem premiar sem critério os menos remunerados. "Distribuir renda não é tirar de quem ganha 100000 para entregar a quem ganha $1000 "$, explica José Rodolfo Hulse, assessor do Grupo de Política Tributária do Ministério da Fazenda. "Distribuir é retirar recursos da mão do indivíduo e entregá-los ao setor público, que, por sua vez, o aplicará em benefício de toda a sociedade." (A POLÍTICA. .., 1972, p. 69)
}

A divulgação dos resultados do Censo Demográfico de 1970 bateu de frente com o otimismo do discurso oficial. Salvo engano, os primeiros a registrar empiricamente a elevação da desigualdade foram Rodolfo Hoffmann e João Carlos Duarte, em teses defendidas na Universidade de São Paulo em 1971. No primeiro semestre do ano seguinte, os dois consolidaram seus trabalhos em artigo escrito conjuntamente. A piora da desigualdade na década de 1960 era inequívoca. Os autores observaram distribuições mais desiguais de renda 
em quase todas as regiões do país, sobretudo nas mais industrializadas, e contrastaram as perdas relativas da metade mais pobre da população ao aumento rápido da fração da renda dos 5\% mais ricos. A interpretação polarizada da desigualdade brasileira permeou o trabalho, inclusive com referências à "elite do poder" de Mills (1959) para defender que os estratos superiores dos empregados assalariados, como executivos de grandes empresas, faziam parte, junto com os detentores do capital, da nossa classe dominante. A explicação combinou o argumento estruturalista acerca da industrialização oligopólica e intensiva em capital com a crítica explícita à compressão salarial promovida pela política econômica da ditadura, evidenciada pela queda de 30\% do salário mínimo real entre 1961 e 1970 e pelas intervenções em sindicatos (HOFFMANN; DUARTE, 1972).

Quase simultaneamente a Hoffmann e Duarte, o economista americano Albert Fishlow (1972) publicou análise parecida da trajetória da desigualdade de renda no Brasil entre 1960 e 1970. Fishlow não era um radical, aceitando, com ressalvas, muitas das implicações da teoria do capital humano. A questão, para ele, é que a educação só poderia explicar parte do fenômeno brasileiro, caracterizado por grande concentração no topo. Ademais, ele especulava que o aumento da desigualdade poderia ser uma consequência não intencional mais da estabilização entre 1964 e 1967 do que do crescimento propriamente dito. Com certo otimismo tipicamente americano para a época, ele não considerava que o trade-off entre crescimento e desigualdade era necessário, acreditando ser possível conciliar ambos com a promoção da produtividade no campo e maior igualdade de oportunidades. Ainda assim, sua avaliação das políticas implementadas pelos militares foi muito dura, batendo de frente com a propaganda oficial:

A concentração de renda resultante da estabilização não foi inteiramente intencional. [...] Em sentido mais amplo, contudo, o resultado foi um indicador preciso de prioridades: a destruição do proletariado urbano enquanto ameaça política, e o restabelecimento de uma ordem econômica direcionada para o acúmulo de capital privado. Como esses objetivos persistem, não é fácil ser esperançoso quanto às implicações distributivas de um crescimento mais rápido ao longo de um período mais extenso. A própria força da expansão recente, afinal, decorre parcialmente da concentração prévia da renda. [...] As políticas do governo tal como aplicadas no presente, além de tudo, dificilmente favorecem a equidade. [...] Em suma, na ausência de alterações efetivas e de grande escopo nas atitudes do governo, é provável que haja pouco progresso e, muito possivelmente, regressão na distribuição de renda. (FISHLOW, 1972, p. 400 e 402)

O problema para os defensores do regime tornou-se maior ainda quando Robert McNamara, ex-secretário de Defesa dos governos Kennedy e Johnson e então presidente do Banco Mundial, usou os resultados (ainda não publicados) de Fishlow para criticar a distribuição de renda brasileira em reunião da Conferência das Nações Unidas sobre o Comércio e Desenvolvimento (UNCTAD, na sigla em inglês) em Santiago, no Chile, em 1972, com imediata repercussão na imprensa brasileira (ALMEIDA, 2008). 
A ditadura viu-se obrigada a refutar o espectro da polarização e reafirmar que todos estavam ganhando. Não é fácil estabelecer a cronologia exata dos eventos. A diversidade de respostas mostra hesitação entre a insistência nas narrativas benignas, devidamente adaptadas ao Brasil, e a adesão a um realismo duro que, em consonância com o declínio do otimismo nos países desenvolvidos, pregava a inevitabilidade do trade-off entre crescimento e igualdade e decretava que um país como o Brasil só poderia escolher o primeiro, apesar dos sacrifícios envolvidos. Um artigo de Jorge e Lucia Kingston (1972) encaixa-se nesses moldes. Embora ostensivamente empírico, o texto apelou repetidamente a prescrições normativas para minimizar o problema distributivo. Com base em dados dos Censos e do imposto de renda - em parte cedidos pelo então ministro Delfim Netto (KINGSTON; KINGSTON, 1972, p. 249, nota 15) -, os autores partiram da desigualdade para em seguida dizer que a evolução da renda média era mais importante (KINGSTON; KINGSTON, 1972, p. 248). Depois, olharam para a dicotomia entre "pobres" e "ricos" em termos das desigualdades internas a eles, para concluir que os resultados brasileiros eram comparáveis aos americanos e que "a desigualdade entre os 'pobres' seria, assim, mais áspera que entre os "ricos"' (KINGSTON; KINGSTON, 1972, p. 253). Por fim, o rápido exame da desigualdade entre os dois grupos foi sucedido pela reiteração do trade-off entre desigualdade e igualdade e elogios abertos aos "magníficos artigos" de Roberto Campos (KINGSTON; KINGSTON, 1972, pp. 256) e à política econômica: Há que haver uma opção: concentração ou baixa renda média. Mas tudo
leva a crer que os malefícios da segunda são de muito piores que os
da primeira. Desde a revolução de 64 , tendo à testa do Ministério da
Fazenda timoneiros de alta competência - os Professores Octávio Bulhões
e Delfim Netto - o Brasil vem experimentando extraordinário surto de
progresso. Nada há que objetar às diretrizes adotadas. Elas colimam
o escopo fundamental, que é elevar a renda dos que hoje são "pobres',
mas amanhã não mais o serão ... (KINGSTON; KINGSTON, 1972, p.
255-256)

Nem uma resposta tão convicta pôde escapar ao desconforto e a deslizes reveladores. Afinal, tratava-se de um artigo abertamente relacionado à desigualdade de renda e que se viu obrigado a enfrentar a questão dos "pobres" e "ricos" de frente. Não surpreende, portanto, que outras manifestações de participantes e porta-vozes do regime fossem mais ambivalentes entre o otimismo e o realismo duro. O livro Brasil 2002, de Mário Henrique Simonsen entra nessa categoria. Por um lado, seu primeiro capítulo trazia uma boa crítica tanto ao pessimismo das teorias marxistas quanto ao otimismo de Rostow e das teorias da modernização, rejeitando o etapismo e a noção de que o desenvolvimento promoveria a convergência para um mesmo arranjo institucional (SIMONSEN, 1972, cap. 1). Por outro, sua tentativa de minimizar o "problema" da desigualdade de renda foi menos coerente.

Simonsen atirou para todos os lados e recorreu a argumentos díspares. De saída, ele lançou dúvidas sobre os dados, comentando em minúcias suas deficiências, para concluir 
que "o debate sobre o aumento de concentração de rendas de 1960 para 1970 só pode ser sustentando com uma boa dose de leviandade estatística" (SIMONSEN, 1972, p. 50). Em seguida, aceitando temporariamente as evidências, especulou que o aumento da desigualdade fora um efeito colateral do ajuste de 1964 a 1967, admitindo que a legislação autorizara reajustes salariais abaixo da inflação, algo já corrigido (SIMONSEN, 1972, p. 52). O reconhecimento das causas políticas foi rapidamente deixado de lado, pois, em terceiro lugar, Simonsen voltou ao refrão de que, em termos absolutos, todos os grandes grupos sociais se beneficiaram do crescimento e que preocupações distributivistas seriam inconciliáveis com o progresso. Um welfare state à inglesa poderia maximizar o bem-estar, só que mesmo em países desenvolvidos estaria associado a taxas "muito reduzidas" de crescimento real (SIMONSEN, 1972, pp. 53-56). Em quarto lugar, Simonsen culpou a explosão demográfica e a falta de planejamento familiar pelo excesso de mão de obra não qualificada e, por tabela, pelo aumento da desigualdade (SIMONSEN, 1972, p. 54). Por fim, ele rendeu-se aos encantos do "U invertido" e das teorias da modernização para refutar o "distributivismo prematuro" com o argumento kuznetsiano de que a desigualdade aumenta com "os primeiros impulsos do desenvolvimento" e que, em fases mais avançadas, as disparidades individuais seriam reduzidas (SIMONSEN, 1972, pp. 56-57). A única outra opção seria a opressão burocrática em moldes soviéticos:

\footnotetext{
A transição de uma fase de estagnação ou semi-estagnação para uma de crescimento acelerado costuma exigir sacrifícios que naturalmente envolvem certo aumento da concentração de rendas, ou nas mãos de determinados indivíduos, ou em poder do Estado. [...] Usando a classificação de Rostow, a transição para um processo de arranco parece envolver como corolário inevitável certa fase de aumento no grau de concentração de rendas. Os países comunistas tiveram uma forma de evitar que essa concentração se processasse no nível das rendas individuais, transferindo-a para o âmbito do Estado. O resultado talvez tenha sido o embelezamento do coeficiente de Gini, mas à custa de tremenda centralização burocrática e da mutilação das liberdades individuais. (SIMONSEN, 1972, p. 56)
}

Como aumentos salariais generosos matariam a "galinha dos ovos de ouro" e apertar a progressividade do imposto de renda minaria os "incentivos a trabalhar, a correr riscos", nada restava a fazer senão continuar na linha praticada pelo governo. Sem querer reduzir abruptamente a desigualdade, a única alternativa era expandir o sistema educacional e criar mecanismos de poupança que, no médio prazo, resultariam em uma distribuição de renda mais equitativa. Em que pese o obstinado realismo acerca dos trade-offs necessários, Simonsen considerava que o alto nível do coeficiente de Gini brasileiro "não pod[ia] deixar de nos causar certa dor de consciência" (SIMONSEN, 1972, p. 57-59).

Justificativas tão hesitantes só poderiam ser insatisfatórias para o regime. Como observou Lopes (1973), a questão distributiva tornou-se porta de entrada para o ataque ao "modelo brasileiro", com os trabalhos críticos contrapondo-se ao discurso oficial no próprio terreno estatístico em que ele se baseava. Coube, então, a Carlos Geraldo Langoni 
(1973) fazer do limão uma limonada, elaborando uma interpretação teoricamente elegante, metodologicamente refinada e politicamente benigna do aumento da desigualdade. Langoni jogou para escanteio a influência de escolhas políticas, explicando a elevação da desigualdade por meio de uma leitura do "U invertido" de Kuznets à luz da teoria do capital humano. O trade-off entre crescimento e igualdade seria só um fenômeno passageiro, já que o crescimento econômico acelerado, devido ao progresso tecnológico, aumentaria a demanda por mão de obra qualificada, cuja elasticidade de oferta seria baixa no curto e médio prazos, provocando, portanto, um desequilíbrio temporário no mercado de trabalho, que, de resto, não implicaria redução de bem-estar. No longo prazo, com o amadurecimento das mudanças setoriais e da composição educacional da força de trabalho, as mesmas forças colaborariam para um novo equilíbrio de alta renda e baixa desigualdade. Com isso, Langoni elevou a educação mais do que nunca à condição de variável central para explicar a desigualdade brasileira, amarrando as pontas soltas das respostas anteriores.

A repercussão foi imediata. Antes mesmo da publicação do livro, a revista Veja dedicou sua capa de 7 de junho de 1972 à questão, novamente repetindo sem ressalvas o discurso oficial na reportagem principal. ${ }^{15} \mathrm{O}$ texto não questionou a legitimidade da preocupação com a desigualdade nem ignorou a controvérsia acadêmica, comentando en passant a declaração de Robert McNamara e as disputas sobres os resultados dos censos. A tranquilidade foi restaurada, dessa vez, por Mário Henrique Simonsen, que reiterou suas críticas aos dados disponíveis. Por isso, informa a reportagem, o Ministério da Fazenda estava patrocinando uma nova análise, dando acesso a Langoni a dados inéditos do imposto de renda e do Ministério do Trabalho. As cifras e conclusões de Langoni, continua o texto, eram "provavelmente mais exatas" que as anteriores (A RENDA..., 1972, p. 68):

Segundo esses números compilados por Langoni, a distribuição de renda no Brasil seria possivelmente muito melhor se, como durante muito tempo, o país ainda fosse "essencialmente agrícola" [...] e se ninguém ousasse ultrapassar os umbrais de uma escola primária. Chega-se também à conclusão de que o desenvolvimento econômico brasileiro - como o de qualquer país - é um mecanismo que naturalmente diferencia as pessoas, principalmente através da educação. [...] A situação brasileira seria grave se a concentração de renda estivesse aumentando ao mesmo tempo que diminuíssem as possibilidades de acesso à educação.

O que acontece é exatamente o contrário. Parece estar havendo uma ampliação das oportunidades [...]. No momento em que a oferta se for ajustando à demanda, haverá uma redução das desigualdades - o país será mais qualificado e a renda melhor distribuída. Os números sobre a distribuição de renda indicam que o Brasil está apenas pagando o preço do seu desenvolvimento. (A RENDA..., 1972, p. 70)

15 Como outras reportagens de capa, o texto não era assinado. Na "Carta ao Leitor", o então editor da Veja, o jornalista Mino Carta, creditou o trabalho ao repórter Paulo Henrique Amorim. A reportagem ganhou o Prêmio Esso de Informação Econômica naquele ano. Ver < https://web.archive.org/web/20150907020916/http://www.premioexxonmobil.com.br/site/ premio_principal/index.aspx?year=1972>. Agradeço ao jornalista Fábio Pannunzio por ter divulgado a reportagem e essa informação em seu blog. Ver < https://web.archive.org/web/20160715221135/http: //www.pannunzio.com.br/archives/9884>. Acessos em 7 set. 2015. 
O material que acompanhou a reportagem principal foi menos chapa branca. A revista reproduziu um artigo de Fishlow, advertindo os leitores que considerava "pouco realistas" muitas de suas teses (A RENDA..., 1972, p. 70). A entrevista com o ministro Delfim Netto foi mais dura, questionando o caráter elitista da política educacional, que priorizava os níveis superiores de ensino, os efeitos distributivos da contenção salarial entre 1964 e 1967 e "em que desconhecido reduto eleitoral" o governo descobrira que a sociedade brasileira priorizava o crescimento em detrimento de uma distribuição menos desigual da renda. Delfim retrucou que isso seria autoevidente, exceto para intelectuais "suficientemente rico[s]" (A RENDA..., 1972, pp. 72-74). O fantasma da polarização reapareceu na pergunta sobre o poder econômico e político dos $5 \%$ mais ricos, descartado por Delfim. O ministro fez coro à interpretação de Langoni e, em resposta um tanto truncada, admitiu que a pesquisa "sem dúvida, foi aparentemente provocada por algumas análises do Censo consideradas insatisfatórias" (A RENDA. ., 1972, p. 74). Em 1983, Langoni foi nomeado presidente do Banco Central durante o governo do general Figueiredo.

A controvérsia não se encerrou aí. No âmbito acadêmico, Langoni virou alvo preferencial dos críticos. A coletânea organizada por Ricardo Tolipan e Arthur Tinelli (1975) reuniu alguns dos principais textos do período. O inevitável caráter politizado do debate refletiu-se já no prefácio, escrito por Fernando Henrique Cardoso (1975, p. 9), que atacou a "pouca credibilidade que tem a posição dos justificadores tecnocráticos do status quo que persistem em tentar fazer crer à opinião pública que a 'ciência' [.. . ] aponta sempre em favor dos ricos", contrapondo, portanto, a visão mais polarizada da estratificação à apologética da ditadura. A proximidade de Langoni com o regime despertou suspeitas óbvias nos críticos, potencializada pela sua minimização dos aspectos políticos.

Rodolfo Hoffmann $(1973 ;$ 1975), por exemplo, insistiu nos efeitos da contenção do salário mínimo, do controle sobre os sindicatos e das reformas que visaram tornar o mercado de trabalho brasileiro mais flexível, como a instituição do Fundo de Garantia por Tempo de Serviço (FGTS). Sem rejeitar o papel das habilidades escassas, ele argumentou que a correlação entre educação e renda não podia ser entendida fora desse contexto nem representava uma relação causal tão direta, ressaltando o quão discutível era recorrer a explicações em termos do livre mercado diante de tantas intervenções governamentais (HOFFMANN, 1975, p. 121). A contrapartida da repressão salarial era o aumento dos lucros das empresas, que beneficiaria também os escalões superiores dos assalariados.

Edmar Bacha (1975) trilhou caminho parecido, recorrendo à teoria da estratificação de Dahrendorf e à teoria das organizações de Oliver Williamson para afirmar a dicotomia entre trabalhadores e executivos: pela natureza das firmas modernas, os salários dos primeiros seriam determinados, grosso modo, segundo os postulados neoclássicos, e a remuneração do segundo grupo estaria vinculada aos lucros e distribuída de acordo com a hierarquia gerencial. A contenção dos salários dos trabalhadores poderia ter como contrapartida o aumento da remuneração dos gerentes: "seria a hierarquia e não a qualificação a variável 
chave para explicar a abertura do leque salarial na década de sessenta" (BACHA, 1975, p. 151; ver também BACHA; TAYLOR, 1978). Um ponto interessante e, salvo engano, ainda não observado é o paralelo entre a visão proposta por Bacha e a teoria por trás do esquema de classes que John Goldthorpe que se tornou grande referência na sociologia nas últimas décadas, inclusive com influências em comum (e.g., GOLDTHORPE, 2000a).

A hostilidade entre os campos ficou evidente no debate entre Langoni e Pedro Malan e John Wells. Em sua resenha, Malan e Wells (1973), como outros, acusaram Langoni de ignorar de propósito interpretações alternativas à sua, lembraram a importância dos fatores políticos e sociais e apontaram contradições e limites do argumento, como o tratamento insatisfatório da riqueza, a ausência de medidas independentes de produtividade e a admissão de que os anos de estudo captam outros elementos além do capital humano puro. O livro, reclamaram, seria mais uma "justificativa para o que efetivamente ocorreu" do que uma "tentativa científica de explicar o porquê do ocorrido" (MALAN; WELLS, 1973, p. 1120). Em sua réplica, Langoni (1974) foi igualmente duro, classificando as críticas em "ingênuas" e "radicais". As primeiras decorreriam da incompreensão de Malan e Wells da relação entre teoria e análise empírica, argumento, aliás, parecido com o usado por Kingsley Davis para desqualificar os críticos da sua teoria funcionalista da estratificação. Já as críticas "radicais" mostrariam o rompimento de Malan e Wells com a teoria econômica. Na sua tréplica, Malan (1974, p. 117) acusou Langoni de ter "optado definitivamente pela miopia maniqueísta" e reiterou que a polarização em "ciência" e "política" era falaciosa, porque se tratava apenas de reconhecer o papel das instituições e das decisões políticas, que não seriam tão afeitas à formalização matemática.

A resposta de Wells (1974) tentou organizar toda a controvérsia. Ele reconheceu as dificuldades das explicações político-institucionais em demonstrar empiricamente os mecanismos que provocaram a redistribuição para o topo e a relação incerta entre as distribuições funcional e pessoa da renda. Ao mesmo tempo, reafirmou as implicações normativas e ideológicas da interpretação de Langoni e repetiu as críticas anteriores à ausência de medidas independentes da produtividade e da demanda pelo trabalho e à desconsideração do aumento das desigualdades dentro de cada grupo educacional. Com base em dados administrativos anuais, ele tentou, como Hoffmann (1973), julgar o mérito das hipóteses a partir do timing das mudanças na distribuição de renda. Suas conclusões foram essencialmente desfavoráveis à interpretação de Langoni, reforçando a ideia de interdependência entre as perdas dos empregados mais pobres e os ganhos dos mais ricos: 
[N]ão há nenhuma dúvida de que o maior aumento na desigualdade pode ser atribuído ao período de mais severa estabilização salarial, 1965-66. Os que dão ênfase ao período de expansão e ignoram totalmente o impacto da política de estabilização, como Langoni, estão gravemente em erro. [...] O fato de o processo redistributivo ocorrer desta maneira - isto é, no sentido do cume da distribuição - é consistente com uma visão alternativa à abordagem do tipo "escassez de fatores" [...]. [D] urante o período de recessão e estabilização, a compressão dos salários do trabalho não-qualificado permitiu que os situados no topo da distribuição melhorassem e subsequentemente mantivessem seus diferenciais de rendimentos. Durante a expansão, a crescente diferenciação resultou de uma pressão contínua sobre as taxas salariais mais baixas combinadas com lucros crescentes; o limite a este processo é estabelecido pelas exigências da acumulação de capital. (WELLS, 1974, pp. 31-32)

Wells é mais persuasivo na crítica a Langoni do que na especificação dos mecanismos por trás da interdependência entre pobres e ricos. De todo modo, o diagnóstico de Langoni também foi rejeitado por Bacha e Taylor (1978), ainda que seja forçoso reconhecer que todos trabalharam com dados limitados. Uma das contribuições da Parte II desta tese é ajudar a iluminar essa controvérsia que, no fim das contas, produziu mais calor do que luz, em boa parte por causa da precariedade das informações. Apesar de tanto investimento, a querela terminou sem produzir consensos, como é típico nas ciências sociais.

A falta de consenso não impediu que a controvérsia tivesse um vencedor. Analogamente ao que aconteceu nos países desenvolvidos, a abordagem de Langoni tornou-se amplamente dominante nas décadas seguintes. Para além das suas implicações políticas, há motivos acadêmicos para isso. A simplicidade elegante, a especificação plausível dos mecanismos causais e a compatibilidade com as principais fontes de dados - as pesquisas domiciliares - trouxeram ganhos analíticos, ainda mais em um país como o Brasil. É impensável desconsiderar o impacto da desigualdade educacional sobre a distribuição de renda - por sinal, nem os críticos mais ferrenhos de Langoni fizeram isso.

Não obstante sua fecundidade, a abordagem em termos de capital humano direciona o olhar para determinados tipos de desigualdade - i.e.: diferenças salariais entre grandes grupos educacionais -, sem esgotar o fenômeno e, em certos casos, nem sequer arranhar sua superfície. Teorias moldam as categorias básicas que usamos para selecionar fenômenos relevantes e elaborar explicações. Mudar o ponto de vista, por conseguinte, ajuda a iluminar novas dimensões de antigos objetos de estudo e a trazer à tona novos aspectos da realidade. A emergente literatura sobre top incomes conseguiu operar tal mudança nas interpretações da desigualdade nos países desenvolvidos, como discuto no próximo capítulo. A ambição da análise da Parte II é contribuir para isso no Brasil. 


\subsection{Considerações finais}

Os "trinta gloriosos" ficaram para trás há décadas e, ainda assim, mantêm sua mística. Em retrospecto, várias virtudes andaram juntas, da moderação da desigualdade ao crescimento acelerado, ao menos nos países mais ricos. Ao contrário de outros casos, o idílio não foi construído a posteriori. Desde cedo, intelectuais e políticos debruçaram-se sobre o contraste com os traumáticos anos entre o fim do século XIX e a $2^{a}$ Guerra, elaborando todo um repertório teórico que, em última instância, elevou a combinação de prosperidade e igualdade à posição de desdobramento natural das sociedades industriais modernas. $\mathrm{O}$ temor disseminado no fim dos anos 1940 converteu-se, então, em otimismo.

A domesticação das desigualdade socioeconômicas estava no âmago dessas teorias, embora nem sempre de forma explícita. Não à toa, David Grusky (2011) caracterizouas como "narrativas benignas" sobre a desigualdade. É possível até ir além: elas foram narrativas benignas do Ocidente sobre o Ocidente, em que a extirpação das grandes fraturas sociais e da dicotomia entre ricos e meros mortais operava como evidência do progresso social. Em boa medida, o fardo da prova permaneceu do lado da justificação da desigualdade, feita ora por argumentos estritamente funcionalistas, ora por discursos mais abertamente normativos, que insistiam na congruência entre liberdade e igualdade em uma estratificação social sobretudo hierárquica, sem grandes contrastes, com substancial igualdade de oportunidades e aumentos contínuos da renda média.

Com a consolidação do Estado de Bem-Estar social e o arrefecimento dos conflitos ideológicos, o aparato conceitual prévio foi declarado obsoleto. A luta marxista de classes e interpretações binárias da desigualdade foram descartadas por autores à direita e à esquerda. Muitos passaram a priorizar as hierarquias de status à custa de distinções de renda ou riqueza; quase todos tomaram as gradações do sistema ocupacional, em especial os degraus hierárquicos da burocracia, como o eixo central de estratificação. A polarização tornou-se apenas uma lembrança histórica, ou, com maior frequência, algo que caracterizaria os outros, isto é, os países em desenvolvimento.

De fato, a transposição dessas ideias para o Brasil não foi tão simples assim e, especialmente após o golpe militar de 1964, houve uma nítida oposição entre defensores e críticos do regime, com os primeiros reafirmando versões das narrativas benignas e os últimos apontando contradições e, em muitos casos, a permanência de antagonismos e conflitos de interesses. Toda a querela acerca do aumento da desigualdade nos anos 1960 pode ser lida nessa chave, o que ilustra o caráter precário da aceitação das narrativas benignas para além das fronteiras dos países ricos.

Afinal, tamanha mudança intelectual nos países desenvolvidos estava longe de ser uma ilusão ou puro embuste ideológico. Toda interpretação põe em relevo algumas características e minimiza outras e, se é verdade que muitos conflitos permaneceram invisíveis na época, a experiência recente de toda uma geração tornava compreensível o 
fascínio dos contemporâneos por si mesmos. Em retrospecto, muitos argumentos soam deslumbrados ou mesmo ingênuos, e alguns deles evidentemente o eram: todo triunfalismo produz excessos que se tornam particularmente lamentáveis depois que a festa acaba. A eclosão da questão racial nos Estados Unidos nos anos 1960 é evidência suficiente do quão longe da realidade estavam as descrições mais exaltadas. Ou, então, pode-se perguntar: quem hoje argumentaria que distinções de status são mais relevantes que as de renda?

Ainda assim, prever o passado sempre é muito fácil. Com efeito, muitos autores contribuíram não intencionalmente para tamanha virada intelectual ao tentar dar conta das mudanças que percebiam como relevantes. Outros foram mais autoconscientes, com sensibilidade particular ao contexto ideológico da Guerra Fria. Alguns uniram as duas características, como Talcott Parsons, cuja produção talvez seja a expressão máxima das narrativas benignas de meados do século, no bom e no mau sentidos, seja por sua influência sobre a sociologia americana, seja por sua contribuição à teoria da modernização. Parsons desenvolveu de forma coerente uma interpretação totalizante e integrada das sociedades ocidentais, articulando as mudanças sociais como elementos congruentes de um sistema.

E, de repente, tudo mudou. Se, antes, dissidentes como Dahrendorf, Wright Mills e Young encontraram pouca receptividade, o tumulto político e social do final dos anos 1960 trouxe as questões distributivas de novo à superfície. Junto com a "crítica social" à distância entre discursos e realidade, ganhou visibilidade, de forma inédita, a "crítica estética" das sociedades modernas, que acabou sendo muito mais facilmente acomodável. De fato, o renovado igualitarismo também evidenciou o amadurecimento de alternativas em moldes liberais clássicos ou libertários, que, deixando de lado as narrativas benignas, elegeram prioridades claras em detrimento da comunhão de todas as virtudes e, acima de tudo, souberam dar respostas concretas - e ocasionalmente muito duras - aos crescentes problemas macroeconômicos e à ansiedade quanto ao sufocamento da liberdade.

O resto é história, e é disso que trata o próximo capítulo. Por ora, cabe apenas antecipar como tal reviravolta abateu o interesse pela desigualdade sem mudar sua concepção geral hierárquica ou, no máximo, triádica. O que mudou de lado foi o fardo da prova. Se, antes, Milton Friedman ainda podia reclamar que aquele recaía sobre quem se opunha a novos programas governamentais e Talcott Parsons reconhecia a exigência de que todas as desigualdades fossem justificadas, a partir de meados dos anos 1970 a situação inverteu-se rapidamente. Em boa medida, somos todos ainda herdeiros dessa mudança. 


\section{O ocaso e o retorno da desigualdade, $1975 / 2015$}

Of all the tendencies that are harmful to sound economics, the most seductive, and in my opinion the most poisonous, is to focus on questions of distribution.

Robert Lucas, The Industrial Revolution: Past and Future (2004)

[T]he elites are not unreasonably concerned about studies of inequality: every mention of inequality raises in people's minds questions about its acceptability.

Branko Milanovic, Why we all care about inequality...(2007)

\subsection{Introdução}

Para além das controvérsias teóricas, disputas metodológicas e tensões políticas, a produção recente das ciências sociais é atravessada por um mesmo refrão: entre o final dos anos 1970 e o início dos anos 1980, o mundo passou por uma guinada intelectual, política e econômica de proporções épicas. Para alguns, foi o momento de abandonar a asfixia burocrática e os entraves ao crescimento rumo à liberdade e à prosperidade. Andrei Shleifer (2009), por exemplo, decretou o período pós-1980 como a "Era de Milton Friedman". Para outros, como Tony Judt (2010), tivemos o colapso do equilíbrio social democrata dos anos dourados do pós-guerra em prol de uma era de desigualdade, insegurança e empobrecimento cívico. Na sociologia, o ímpeto profético usual ganhou impulso, com a proliferação de rótulos como "pós-modernidade", "sociedade de risco", "capitalismo tardio", "sociedade pós-industrial" e afins, como criticou Mike Savage (2009).

Exageros e paixões à parte, é difícil negar que algo de fato mudou, ao menos temporariamente, e que tal mudança foi percebida e instrumentalizada pelos protagonistas dos campos acadêmico e político. O clima intelectual tornou-se quase tão diferente do prevalecente nas primeiras décadas do pós-guerra quanto estas haviam sido das turbulências da virada do século XX. Reconhecer isso não chancelar nenhum tipo de fim da história utópico ou distópico, mas é essencial para dar inteligibilidade aos debates das últimas décadas acerca da estratificação social, principalmente por permitir também apreender como alguns desdobramentos recentes recuperam, sob nova forma, enquadramentos e interpretações cujo auge se deu no período anterior à $2^{a}$ Guerra. 
O estudo da desigualdade não poderia ficar imune ao clima intelectual mais amplo. Sua proeminência no meio acadêmico oscilou, atingindo um ponto particularmente baixo nos anos 1980, conforme reconheceram Atkinson (1997), Atkinson e Bourguignon (2000), Kanbur e Lustig (2000), Levy e Murnane (1992) e outros. A situação começou a mudar na década de 1990 e, a partir de meados dos anos 2000, o tema voltou ao debate público, obtendo em muitos países a maior visibilidade em décadas. O que não foi revertido foi o fardo da prova: o ônus de justificar a relevância dos argumentos continuou recaindo, de modo geral, sobre a problematização da desigualdade. Durante boa parte da história recente, o que esteve sub judice foi a legitimidade da desigualdade enquanto problema ou objeto de estudo digno, e não os desvios em relação a um padrão igualitário, como antes.

O objetivo deste capítulo é contar essa história e detalhar a gênese das interpretações contemporâneas. Assim como nos capítulos anteriores, reservo atenção especial às concepções gerais da estratificação e reitero, com qualificações, o argumento de que o tema adquire maior preponderância quando a desigualdade é concebida em termos binários ou dicotômicos. Nesse sentido, o período desde 1975 mostra que a atenção ao assunto não é apenas um resultado mecânico de crises econômicas, como supõem alguns autores. A intensa crise entre meados dos anos 1970 e o início da década de 1980 redundou na situação oposta. A reaparição recente do tema na esfera pública e seu enquadramento a partir da oposição entre os ricos ou o "1\%" e o resto da população tampouco pode ser considerada um subproduto puro e simples do colapso econômico de 2008-2009.

Dessa forma, este capítulo complementa a narrativa iniciativa nos anteriores e serve como matéria-prima e motivação para as análises desenvolvidas na Parte II. A construção do objeto - o olhar para a questão distributiva com foco nos mais ricos - se faz acompanhar pela apresentação das hipóteses e lacunas do conhecimento que orientam a investigação empírica subsequente. Nesse quesito, o capítulo também destaca a tensão entre explicações baseadas exclusivamente em mecanismos de mercado e as interpretações que incorporam em maior ou menor grau elementos institucionais e históricos, mostrando como essas últimas vêm ganhando espaço considerável.

A tarefa deste capítulo é mais ambiciosa do que a dos anteriores por pelo menos dois motivos. Primeiro, a brutal explosão da literatura acadêmica torna qualquer exercício do tipo cada vez mais arriscado. Se, no capítulo anterior, o aumento do número de publicações entre 1945 e 1975 representou um obstáculo a mais em relação ao período coberto no capítulo 1, desta vez o problema é muito maior. Por isso, este capítulo incorpora resultados quantitativos úteis para reforçar o argumento. Segundo, abordar controvérsias atuais, ainda não resolvidas e relativamente fluidas, torna muito mais difícil separar a interpretação da história do campo das disputas internas do próprio campo acerca do seu estado atual e dos seus rumos futuros. Não por acaso, é muito mais complicado identificar nestas últimas décadas uma tendência central clara, como nos capítulos anteriores. 
Para cumprir esses objetivos, o capítulo está dividido em cinco seções. A seção 3.2 dá substância à percepção de que a desigualdade saiu de cena nos anos 1980, recapitulando a lógica das mudanças intelectuais do período. A seção 3.3 examina o aparentemente interminável mal-estar das teorias de classe na sociologia e a redução progressiva das suas ambições. A seção 3.4 narra o reaparecimento da desigualdade como assunto academicamente relevante, a popularidade inicial das explicações puramente tecnológicas e, finalmente, a reorientação da questão em termos da concentração de renda no topo e da oposição entre o "1\%" e as "pessoas comuns". A seção 3.5 destaca como a literatura brasileira seguiu, à sua maneira e com muitas especificidades, pelo menos parte das tendências internacionais e como o otimismo com o dito crescimento pró-pobre parece ter chegado ao fim. A seção 3.6 resume as principais conclusões deste capítulo e da Parte I desta tese.

\subsection{O breve ocaso da desigualdade}

Em 1982, no aniversário de 20 anos do seu Capitalism $\&$ Freedom, Milton Friedman (2002) observou uma notável metamorfose no clima intelectual desde a publicação original do livro. Enquanto Capitalism \& Freedom fora praticamente ignorado pela grande imprensa, apesar do seu sucesso editorial, Free to Choose (1980), escrito em coautoria com sua esposa, Rose Friedman, recebeu grande atenção dos principais veículos, estando associado, inclusive, a um documentário em dez episódios exibido pela emissora americana PBS. Como o próprio Friedman insistiu, não há diferenças profundas entre os dois livros, exceto pelo tom mais assertivo de Free to Choose. Por exemplo, ambos possuem capítulos dedicados à desigualdade, expondo argumentos semelhantes - e trechos quase idênticos - para criticar a preocupação com a desigualdade de resultados, reiterar a incompatibilidade desse tipo de igualitarismo com a liberdade e insistir nos efeitos perversos de políticas e regimes que tentam redistribuir renda e riqueza (FRIEDMAN; FRIEDMAN, 1980, cap. 10).

Friedman não se sentia um vitorioso solitário. Para ele, houve a percepção coletiva do fracasso das experiências socializantes, demonstrada no plano político pelo contraste entre a derrota acachapante de Barry Goldwater na eleição americana de 1964 e a vitória incontestável de Ronald Reagan em 1980. Afinal, os dois tinham "essencialmente o mesmo programa e a mesma mensagem" (FRIEDMAN, 2002, p. xiii).

A constatação de Atkinson, Bourguignon e outros de que a desigualdade perdeu importância nas discussões acadêmicas entre meados dos anos 1970 e o início dos anos 1990 é indissociável da mudança intelectual e política comemorada por Friedman. Após os tumultos dos anos 1970 e seus espasmos igualitaristas, o desmoronamento das narrativas benignas deu lugar a uma constelação de teorias que oscilavam entre a indiferença e a antipatia ao questionamento e, mais ainda, à politização das questões distributivas, e não raro com boa dose de fatalismo. 
A análise da literatura da época dá contornos mais precisos a esse diagnóstico geral, com algumas qualificações importantes. As Figuras 4 e 5 trazem evidências quantitativas, mostrando a frequência relativa de artigos sobre desigualdade ou estratificação em alguns dos principais periódicos internacionais de economia e sociologia desde $1970 .{ }^{1}$ Como o número de publicações indexadas varia com o tempo, foram selecionados em cada disciplina os cinco periódicos de interesse geral, não especializados em sub-áreas, existentes desde 1970, com maior média de citações por artigo. ${ }^{2}$ Como ilustração, todos os artigos do American Journal of Sociology ou do Quarterly Journal of Economics que continham no título expressões como income distribution ou occupational mobility, foram marcados como textos sobre desigualdade ou estratificação. Evidentemente, os resultados devem ser interpretados cum grano salis, pois há erros de inclusão e de omissão, ainda que em magnitude baixa, ao menos de acordo com os procedimentos de validação. A própria natureza do exercício sugere cautela, devido à fluidez natural da linguagem, à necessidade de estabelecer ex ante uma lista de termos apropriados e ao fato de que os títulos dos artigos fornecem informação limitada sobre seu conteúdo.

Os gráficos apresentam, para os periódicos de cada disciplina, a incidência não ponderada e a ponderada pelo número de citações recebidas dos artigos sobre desigualdade ou estratificação. Antes de tudo, salta aos olhos como os percentuais dos periódicos de sociologia (Figura 5) são muito mais elevados do daqueles de economia (Figura 4), em consonância com argumento de Mike Savage (2005) de que o estudo da estratificação serviu historicamente como força unificadora da sociologia, acomodando assim a falta de consensos e fronteiras claras quanto a métodos e teorias. Ao longo de todo o período, os percentuais na sociologia são pelo menos quatro ou cinco vezes maiores. Mesmo nos períodos de maior incidência a preocupação com desigualdade ou estratificação permaneceu periférica entre economistas, algo já mencionado por Anthony Atkinson (1997). Obviamente, isso não implica o completo desprezo pelo tema, como atesta a discussão do capítulo 1 sobre o sucesso de Piketty. Com efeito, "Income inequality in the United States 1913-1908", de Piketty e Saez (2003), foi o $32^{\circ}$ artigo mais citado entre os quase 1.400 publicados no quinquênio 2000-2004 pelos periódicos econômicos selecionados.

A tendências temporais são consistentes com a percepção de que o interesse pela desigualdade perdeu força nos anos 1980 e revigorou-se posteriormente. Nos periódicos de economia, a ascensão do tema entre 1970 e 1980 foi revertida na década seguinte, de modo

$\overline{1}$ O procedimento consistiu na elaboração de uma lista de termos típicos de trabalhos sobre desigualdade ou estratificação e seu pareamento, via expressões regulares, com os títulos dos artigos da base de dados da Web of Science (WoS), mantida pela Thomson Reuters. A validação dos resultados foi feita pela verificação manual de subamostras aleatórias de artigos pareados e não pareados. Mais detalhes, incluindo a lista de termos utilizados, podem ser obtidos com o autor.

2 Em economia, os periódicos selecionados foram, em ordem alfabética: American Economic Review, Econometrica, Journal of Political Economy, Quarterly Journal of Economics, Review of Economic Studies. Na sociologia, os incluídos foram: American Journal of Sociology, American Sociological Review, British Journal of Sociology, Politics 8 Society, Social Forces, Sociology. 
Figura 4. Frequência relativa de artigos sobre desigualdade ou estratificação em periódicos selecionados de economia, 1970-2014 (\%)

a) Não ponderado

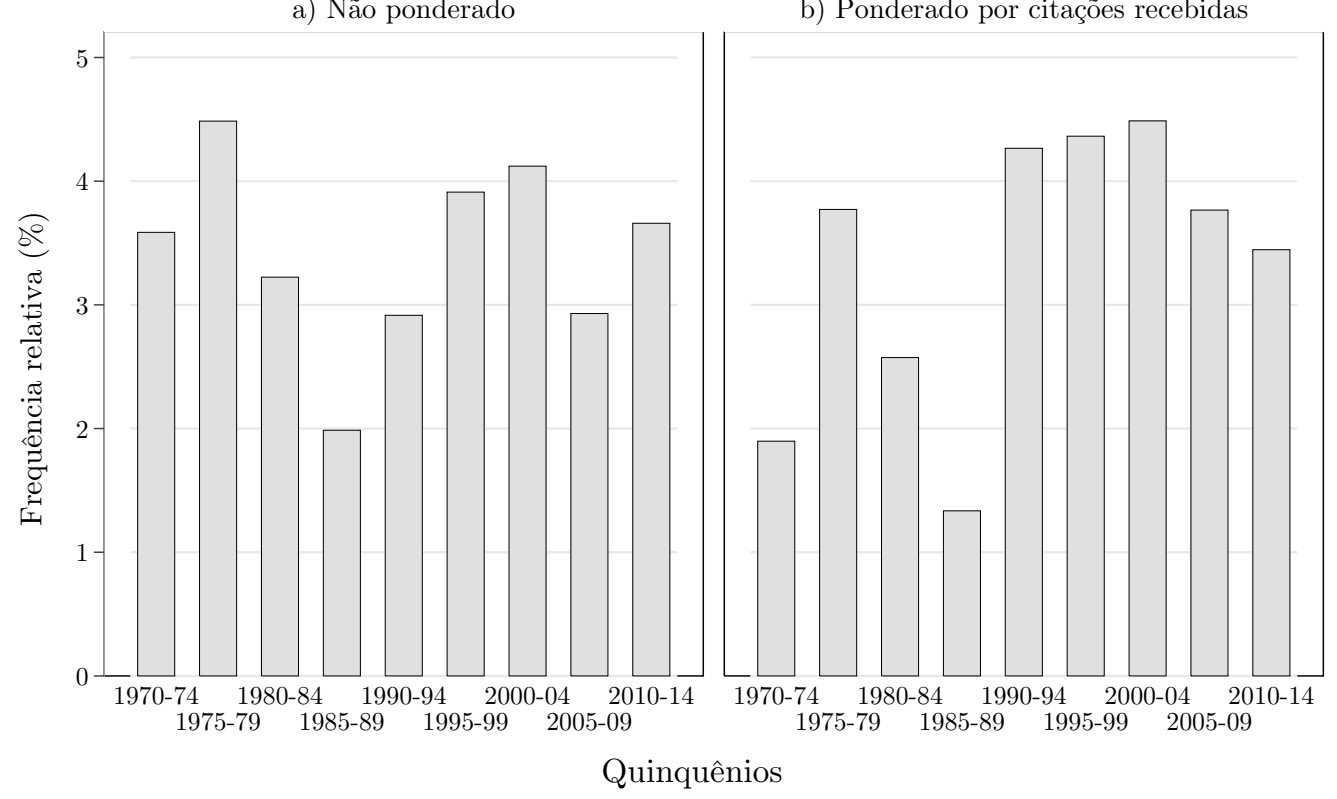

Fonte: elaboração do autor a partir da Web of Science, da Thomson Reuters.

N.B.: artigos identificados, via expressões regulares, pela presença de termos típicos em seus títulos. Os periódicos selecionados são, em ordem alfabética: American Economic Review, Econometrica, Journal of Political Economy, Quarterly Journal of Economics, Review of Economic Studies.

Figura 5. Frequência relativa de artigos sobre desigualdade ou estratificação em periódicos selecionados de sociologia, 1970-2014 (\%)

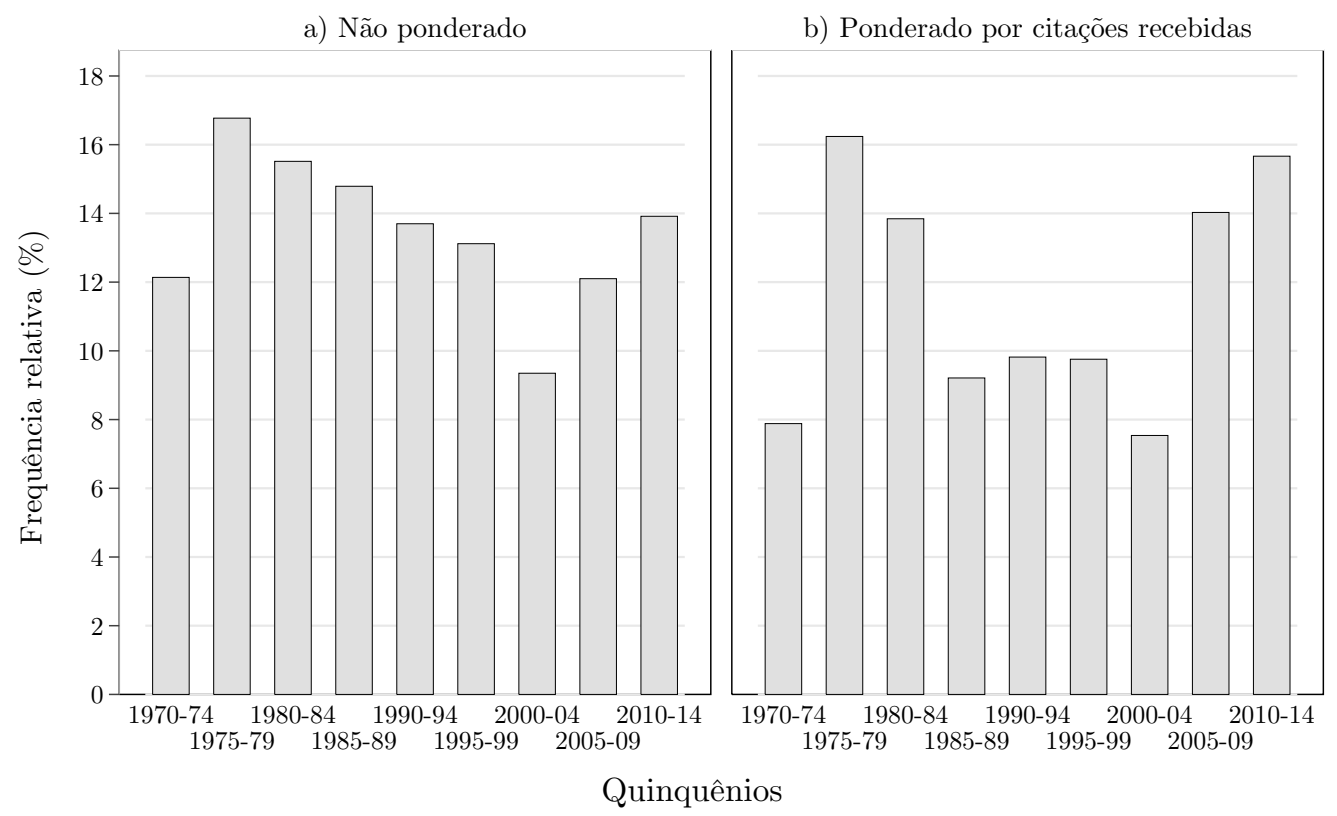

Fonte: elaboração do autor a partir da Web of Science, da Thomson Reuters.

N.B.: N.B.: artigos identificados, via expressões regulares, pela presença de termos típicos em seus títulos. Os periódicos selecionados são, em ordem alfabética: American Journal of Sociology, American Sociological Review, British Journal of Sociology, Politics \& Society, Social Forces, Sociology. 
que o quinquênio 1985-1989 apresenta os menores percentuais, em particular nos resultados ponderados: não apenas foram publicados menos trabalhos, mas também houve queda mais do que proporcional no número de citações recebidas. Com exceção do quinquênio mais recente (2010-2015), o período 1985-1989 foi o único em que o número mediano de citações dos artigos sobre desigualdade foi inferior ao dos demais artigos publicados pelos cinco periódicos escolhidos. A tendência inverteu-se nos anos 1990, com alguma estabilidade ou leve decréscimo nos anos 2000 a partir da crise de 2008.

Na sociologia, a diferença foi só de timing: nos dados não ponderados, há uma diminuição contínua até o quinquênio 2000-2004, seguida pela recuperação do tema; nos dados ponderados, as inflexões foram mais abruptas, com queda rápida na segunda metade da década de 1980 e reaparição igualmente forte na segunda metade dos anos 2000. O número mediano de citações de artigos sobre desigualdade ou estratificação permaneceu mais baixo do que o dos demais artigos durante os quatro quinquênios entre 1985 e 2004 .

As evidências qualitativas confirmam a marginalização do assunto. A próxima seção discute como as teorias sobre classes foram chacoalhadas pelas mudanças sociais e intelectuais; por ora, vale a pena tratar especificamente das interpretações acerca da distribuição de renda e riqueza. Uma das características da época foi o fato de que, empiricamente, percebia-se uma estabilidade notável nessas distribuições. Como escreveu Henry Aaron (1978, p. 17), acompanhar as estatísticas americanas desde os anos 1960 era como "ficar assistindo à grama crescer". Alan Blinder (1980) chegou à mesma conclusão, apontando que tendências opostas acabaram por se cancelar e, com isso, a distribuição de renda americana havia mudado pouco desde 1947. Com esses resultados, Irving Kristol (1980) pôde ser ainda mais taxativo quanto à irrelevância da desigualdade de renda. Para ele, a estabilidade dos indicadores, as limitações cada vez mais reconhecidas dos dados e das medidas utilizadas, a falta de provas indiscutíveis de consequências nefastas da desigualdade e a relação complexa entre distribuição de renda e bem-estar econômico sugeriam que o assunto era animado por motivos meramente ideológicos:

Qual é, de fato, o ponto deste interesse agudo de economistas e sociólogos pelo tema da desigualdade? Há pouca evidência de que ele corresponde a uma preocupação popular disseminada e muitas evidências do contrário. [...] Minha visão - reconhecidamente um pouco extrema - é que, quando precisamos que economistas e sociólogos elucidem para nós as desigualdade de renda ou classe social, isso é em si mesmo prova de que nenhum dos dois assuntos é objeto de preocupação para os cidadãos. [...] [Trata-se] de uma manifestação de como as ideologias do século XIX especialmente a ideologia socialista - moldaram decisivamente as ciências sociais modernas. (KRISTOL, 1980, p. 483-485)

Kristol era antes de tudo um ideólogo, mas ele abriu as páginas da cada vez mais influente Public Interest - revista que fundara em 1965 com Daniel Bell - para argumentos mais técnicos que, explicitamente ou não, minimizavam a questão distributiva, 
em especial face à inflação e à estagnação econômica. Edgar Browning (1976) alegou que os Estados Unidos haviam chegado ao limite da redistribuição, pois qualquer iniciativa para aumentar ainda mais as transferências para os mais pobres implicaria alíquotas marginais proibitivamente altas para os mais ricos, destruindo os incentivos à produção. Mark Lilla (1984) debruçou-se sobre as deficiências dos dados utilizados para quantificar a distribuição de renda. Pechman e Mazure (1984) documentaram, com base em dados tributários, a estabilidade da fração da renda bruta apropriada pelo $1 \%$ mais rico no pós-guerra e notaram como o sistema de tributos e transferências era altamente progressivo.

Um corolário dessas tendências foi a inversão do fardo da prova: diante do conflito cada vez mais aceito entre eficiência e igualdade e da crise macroeconômica, consolidou-se de vez o padrão de que as críticas e apelos igualitaristas é que tinham que justificar sua relevância, ao contrário do que ocorrera nas primeiras décadas do século XX, quando ao menos no plano retórico eram os desvios em relação ao igualitarismo que tinham de ser legitimados. A renovação do interesse pela desigualdade a partir dos anos 1990 não alterou esse padrão, o que, como veremos, impôs certas estratégias retóricas e estimulou uma grande literatura sobre as consequências da desigualdade.

Outro corolário é que a concepção da desigualdade em termos binários ou polarizados esmoreceu junto com o interesse pelo tema. A noção de que os ricos constituiriam um grupo à parte foi combatida, por exemplo, por Stanley Lebergott (1975), que argumentou empiricamente que a concentração de riqueza no topo havia diminuído no longo prazo e que os patrimônios milionários dissipavam-se entre uma geração e outra, de modo que o $1 \%$ mais rico seria composto sobretudo por indivíduos recrutados das classes mais baixas. Lebergott também quis justificar a concentração de riqueza no topo em termos éticos. Os desvios da distribuição de riqueza em relação à de renda foram atribuídos à maior propensão a poupar verificada entre os mais ricos, que, por sua vez, teria efeitos altamente benéficos para o resto da população, acarretando preços e juros mais baixos e, portanto, melhorando as condições de vida de consumidores e pequenos empreendedores.

Todas essas mudanças na sensibilidade e na interpretação da desigualdade remetem a uma constelação de teorias centrais para a guinada comemorada por Friedman, teorias que não necessariamente tinham como objetivo prioritário explicar a distribuição de renda ou riqueza, mas que inevitavelmente resvalaram no tema. As teorias da "economia pelo lado da oferta" (supply-side economics) são bons exemplares, partindo da intenção precípua de analisar os bloqueios ao crescimento e, no caminho, recolocando com força total o trade-off entre equidade e eficiência. A ênfase nos incentivos negativos gerados pela tributação progressiva na prática estabeleceu a desigualdade como solução para a estagnação. Desde o início dos ano 1970, a teoria neoclássica da tributação ótima da renda progressivamente formalizou a natureza do trade-off entre redistribuição e eficiência, com resultados iniciais duros que, com o tempo, foram consideravelmente matizados (PIKETTY; SAEZ, 2013). A saliência da Curva de Laffer não se deu pela sua capacidade de ilustrar a elasticidade da 
renda tributável agregada, e sim pelo pressuposto de que os países ricos estariam além do ponto da tributação que maximizaria a arrecadação e que, desse modo, seria possível simultaneamente reduzir impostos e aumentar a receita (e.g., WANNISKI, 1978).

A mesma estrutura de sentimentos era ecoada pelos adeptos da economia da escolha pública, cujo prestígio traduziu-se nos prêmios Nobel de George Stigler, em 1982 e James Buchanan, em 1986. Ao elevar a maximização do interesse pessoal a objetivo último de eleitores, políticos e burocratas, os teóricos da escolha pública conseguiram elaborar explicações para falhas de governo que respondiam ao mal-estar com a burocratização e aparente ineficiência de muitas políticas públicas. Os participantes do programa de pesquisa interpretavam assim sua missão: como recapitulou Buchanan (2003, p. 11), a "escolha pública é como o garotinho que disse que o rei estava nu", explicando o que todos já reconheciam, porém sem percebê-lo em toda sua extensão. Como argumentou Gordon Tullock (1987), todo o projeto sempre teve um forte componente normativo, com um intuito reformista de tornar o Estado mais parecido com o mercado, com aumento da competição entre agências públicas, terceirização, privatização e afins. Não obstante alguma diversidade ideológica, o pendor libertário era predominante e, no fim das contas, próximo à visão advogada por Milton Friedman desde os anos 1960, em substância e em militância. O apelo de William Niskanen por uma coalizão entre libertários, conservadores e populistas que colocasse a redução do governo como objetivo principal mostra como nem toda a virada produzida por Reagan e Thatcher fora suficiente para alguns. As demandas por redistribuição e o modus operandi da democracia só favoreciam interesses especiais, escreveu ele. O problema essencial não decorria da lógica das instituições, o que recolocava a oposição entre elites e massas em termos estritamente políticos:

O cálculo de benefícios concentrados e custos difusos cria um forte incentivo para organizar a atividade política em defesa de programas específicos, mesmo se a soma dos custos difusos é muito maior do que a dos benefícios. [...] [O]s processos da democracia representativa levam a um nível de gastos, tributos e regulações governamentais que é maior do que o preferido pela maioria dos eleitores. Uma oligarquia está usando os processos democráticos para explorar a maioria [...]. Muita redistribuição, assim, se dá não dos ricos para os pobres, mas da população em geral para aqueles com maior influência sobre os agenda-setters. [...] Minha perspectiva cada vez mais rabugenta é que nossos grandes partidos operam como um cartel implícito entre Democratas ideológicos e Republicanos acomodatórios, no qual os Democratas aceitam a estrutura básica da economia e os Republicanos aceitam as grandes atividades do estado moderno. (NISKANEN, 1994, p. 90-91 e 93)

Se a supply-side economics e a teoria da escolha pública eram francamente hostis à politização da desigualdade e às medidas redistributivas consagradas pelo arranjo institucional do pós-guerra, a teoria do capital humano oferecia uma via positiva para a compreensão da estratificação. Sob o risco de certa simplificação, é plausível apontar os anos 1980 como o período em que sua aceitação tornou-se incontroversa, em contraste com 
o clima dos anos 1950 e 1960, como observou Gary Becker (1993) em sua conferência ao receber o prêmio Nobel. A teoria trouxe um vocabulário e um enquadramento específicos para a discussão da desigualdade em termos de diferenciais salariais explicados como retornos a investimentos educacionais, que, por sua vez, resultavam de decisões racionais de agentes interessados em maximizar sua utilidade. Um ponto marcante é a ênfase no papel ativo de famílias e indivíduos na escolha entre a combinação de consumo e investimento capaz de maximizar sua utilidade, assumindo gostos e preferências estáveis no tempo e entre pessoas (e.g., STIGLER; BECKER, 1977). Com isso, temas caros a sociólogos e economistas institucionalistas, como a estruturação social das preferências e as heterogeneidade das experiências de classe, foram varridos do rol de explicações aceitáveis, ao mesmo tempo que intervenções no mercado de trabalho tornaram-se mais perigosas por diminuir a eficiência no presente e distorcer os incentivos futuros.

Como acontece com toda teoria, enquanto alguns aspectos do mundo social foram deixados de lado, outros foram colocados sob os holofotes. As diferenças médias entre grupos educacionais e os esforços para a identificação de efeitos causais deram o rumo do debate futuro. Nesses termos, a hipótese alternativa atribuía o gradiente salarial a diferenças de inteligência ou talento, noções fantasmagóricas mais assumidas do que exploradas. O próprio Becker (1993) lembrou que, desde o início, seu trabalho tentou isolar os efeitos atribuídos à educação da influência das habilidades inatas. Sem dúvida, um dos avanços das ciências sociais nas últimas décadas foi acumular, contra as teorias que imputavam à educação função meramente de sinalização, resultados empíricos que apoiam o papel causal positivo da escolaridade sobre os rendimentos. Soares (2011, cap. 2) fez uma boa revisão da extensa e engenhosa literatura empírica sobre o assunto.

Uma consequência desse enquadramento foi relegar ao segundo plano o estudo dos mais ricos e do capital. Como grandes categorias educacionais dão conta dos extremos da distribuição de renda, só restava atribuir talentos especiais aos mais ricos. Os artigos teóricos de Sherwin Rosen sobre superstars (1981) e executivos (1982) são exceções parciais que confirmam a regra: como o pressuposto era que o mercado apenas revela os diferenciais de produtividade, Rosen tratou de explicar a concentração no topo pela combinação de diferenciais de talento com condições específicas de economias de escala e tecnologias de consumo. Os artigos são impecáveis ao aplicar o arcabouço neoclássico a um objeto até então subteorizado; porém, parafraseando Edmond Malinvaud, há motivos para criticá-los por "traçar uma linha torta de pressupostos não provados até conclusões inevitáveis".

Para além do impacto acadêmico, toda essa constelação de sentimentos e teorias teve repercussões políticas que amplificaram a marginalização da crítica à desigualdade. Ao contrário, uma maior desigualdade era vista como solução para as agruras da época, algo bem distante das narrativas benignas do pós-guerra, que, do ponto de vista simbólico, tiveram seu réquiem em 1979, com o famoso discurso do então presidente americano Jimmy Carter sobre o malaise nacional. Aturdido pela deterioração econômica associada 
ao segundo choque do petróleo, Carter apareceu em rede nacional para anunciar que o país passava por uma crise de confiança capaz de destruir seu tecido social e político. Ele admitiu fracassos, repetiu críticas e lamentou o pessimismo e a perda de respeito pelas instituições tradicionais, denunciando o vazio moral provocado pelo consumismo de modo apocalíptico. Em contrapartida, Carter só ofereceu propostas burocráticas. ${ }^{3}$ Ainda que o diagnóstico quanto ao declínio da confiança nas instituições estivesse correto (e.g., LIPSET; SCHNEIDER, 1983), sua popularidade só se recuperou temporariamente. No ano seguinte, Ronald Reagan foi eleito com facilidade com uma plataforma basicamente oposta ao consenso do pós-guerra, prometendo "tornar a América grande novamente".

Reagan não foi o único. No Reino Unido, o "inverno do descontentamento" de 19781979 trouxe consigo greves generalizadas, enfraquecendo o primeiro ministro trabalhista James Callaghan. Margaret Thatcher foi eleita em 1979 com uma retórica que substituía a primazia de classes e produtores pela dos consumidores (CANNADINE, 1999, p. 176-184). Na sua famosa formulação, "classe" era um "conceito comunista", que "enfeixa as pessoas em grupos e os atiram uns contra os outros" (CANNADINE, 1999, p. 2). Nas palavras elogiosas de Irwin Seltzer (1993, p. 116), pela primeira vez a política dos Estados Unidos e do Reino Unido era dominada por políticos com convicções que "ameaçavam tudo que a academia preza - igualitarismo, anti-materialismo, coletivismo, engenharia social". Da Espanha de Felipe González à China de Deng Xiaoping, a tendência liberalizante varreu o mundo. Como notou Dahrendorf (1990), o súbito colapso do socialismo fora ainda mais dramático do que o do liberalismo no início do século. Para ele, os avanços social-democratas haviam sido levados longe demais nos países ricos, calcificando-se em um corporativismo burocratizado com governos inchados. No resto do mundo, a promessa de desenvolvimento virara "modernização sem modernidade", dada a incapacidade do socialismo burocrático de promover a participação política e a iniciativa econômica.

A associação entre o momento político e o intelectual foi percebida por críticos e entusiastas. Entre os primeiros, Galbraith (1984, p. 262) lamentou a filosofia de que "os ricos não trabalham porque ficam com pouco e os pobres não trabalham porque ganham muito". Entre os últimos, George Gilder (1983) deliciou-se com a aceitação tardia de próceres democratas do fracasso das políticas sociais e da validade da supply-side economics. A prescrição de que tributos e transferências deveriam ser reduzidos para fortalecer os incentivos à produção motivou muitos países a cortar rapidamente o número de alíquotas e a progressividade da tributação sobre a renda nos anos 1980 (PIKETTY; SAEZ, 2013, p. 396). Mesmo o Brasil, que passou imune à onda liberal, viveu reduções sucessivas na alíquota marginal máxima do imposto de renda (ver seção 4.3 do capítulo 4).

O Brasil, por sinal, serve como cautionary tale. É sempre tentador reduzir toda essa transformação a um embuste ideológico, e a militância caricata de alguns dos seus expoentes

3 Transcrição disponível em <https://web.archive.org/web/20150925020345/http://www.pbs.org/wgbh/ americanexperience/features/primary-resources/carter-crisis/>. Acesso em 25 set. 2015. 
só reforça isso. Não é preciso aplaudir Milton Friedman para considerar essa postura um equívoco. O filão editorial aparentemente inesgotável das críticas ao neoliberalismo muitas vezes perde de vista como, afora maquinações políticas e interesses particulares, tamanha guinada só pôde ocorrer porque o programa liberal deu respostas concretas, consistentes e relativamente eficazes - com custos só admitidos anos depois - a problemas reconhecidos, enquanto as outras opções do cardápio intelectual giravam em falso. Nossa enxurrada de planos econômicos fracassados é um bom lembrete disso.

Ademais, é sintomático que na mesma época até um intelectual de credenciais progressistas impecáveis como o sociólogo Peter H. Rossi (1987) tenha enunciado como "lei de ferro" que "o valor esperado da avaliação de impacto de qualquer programa social de grande escala é zero". Na academia, a debandada dos grandes redutos marxistas foi pronunciada. O ponto de partida de David Cannadine (1999, cap. 1), aliás, é justamente a derrocada da ortodoxia marxista entre historiadores ingleses e o ceticismo crescente quanto à interpretação da dinâmica social pelos conflitos econômicos. Não é coincidência que muitos intelectuais de origem marxista tenham se tornado ícones da literatura sobre a pós-modernidade. Outros, como os marxistas analíticos, optaram por dar um banho de rigor e precisão conceitual na ortodoxia e, no processo, colapsaram o marxismo no liberalismo (LEVINE, 2004). Tudo isso teve grandes consequências sobre as teorias de classes que historicamente ocuparam lugar de prestígio na sociologia da estratificação.

\subsection{Teorias de classes: de aspirações elevadas à luta para sobreviver}

"Classe" é uma categoria sociológica chave. Irving Kristol não estava delirando ao apontar a insistência dos sociólogos sobre o conceito; seu erro foi assumir um conteúdo unívoco. Se Arthur Stinchcombe pôde declarar o conceito a única variável dependente da sociologia, sua apropriação teórica sempre foi camaleônica, como escreveu Erik Olin Wright (1979, p. 3). Apesar disso, há características mais ou menos comuns às múltiplas abordagens, como a ideia de que a estrutura da desigualdade deve ser compreendida pelas relações entre grupos relativamente homogêneos, definidos por sua inserção nas relações de produção ou por sua posição de mercado. O apelo da capacidade imputada às classes de condicionar comportamentos, interesses e/ou reivindicações dos atores sociais é evidente. Nas vertentes mais ambiciosas, seria esse o mecanismo crucial para a compreensão da dinâmica social e política, moldando os conflitos, alianças e compromissos que ditam os rumos de uma sociedade, tal como no modelo abstrato e dicotômico marxista.

Nem todos os sociólogos subscrevem ou subscreveram às ambições mais elevadas para o conceito, ainda mais quando se considera toda a sua carga política. Como discutido no capítulo 2, desde pelo menos os anos 1950 a concepção realista de classe foi periodicamente declarada morta, como se fosse um conceito-zumbi que insiste em sair da cova. O declínio da visão parsoniana de classe e estratificação como uma hierarquia de prestígio e a agitação 
social da virada dos anos 1960 provocaram um desses despertares. No entanto, a situação rapidamente mudou e já nos anos 1980 o conceito tornou-se de novo moribundo.

Parte dessa crise recente remete ao fracasso das novas teorias de classe em assentar as aspirações mais altas atribuídas ao conceito em um conjunto de proposições precisas, bem fundamentadas e empiricamente confirmáveis. Não é coincidência que os desdobramentos das teorias mais influentes para os estudos empíricos tenham caminhado para a redução da pretensão explicativa e até rumo a um terreno mais próximo da teoria econômica. Tampouco é coincidência que a essa crise tenha se dado junto uma nova crise existencial da sociologia, que embarcou em um debate obsessivo sobre suas inadequações (e.g., BAUMAN, 1988; COLLINS, 1986; GIDDENS, 1975; GOLDTHORPE, 2000a).

A queda no percentual de artigos sobre estratificação nos periódicos de sociologia a partir dos anos 1980, apresentada acima no gráfico 5, ocorreu concomitantemente à mudança do vocabulário utilizado para abordar o assunto, com o progressivo abandono do enquadramento nos moldes tradicionais dos sociólogos. A Figura 6 compara a frequência relativa, nos títulos dos artigos sobre desigualdade nos periódicos selecionados de sociologia, de termos ligados à estrutura social ou produtiva (i.e.: class, occupation e afins) e a questões distributivas (i.e.: earnings, income etc.). Embora os dois conjuntos não sejam mutuamente excludentes nem exaustivos, o primeiro grupo remonta ao enfoque histórico da sociologia, enquanto o segundo está mais próximo do enquadramento dado por economistas. O gráfico para os periódicos de economia foi omitido porque a incidência de termos como class, occupation, status ou stratification é ínfima.

Nos dois painéis, a frequência relativa dos termos tipicamente "sociológicos" cai quase monotonicamente desde o início dos anos 1970, enquanto as referências a renda, salários e riqueza aumentam. No quinquênio 1970-1974, cerca de 80\% dos artigos sobre desigualdade nos cinco periódicos analisados faziam referência explícita a classe, ocupação e afins nos seus títulos, percentual que caiu para menos de 50\% em 2010-2014. Nesse período, as referências explícitas à questão distributiva saíram de $3 \%$ para $22 \%$. Nos dados ponderados pelas citações recebidas, a mudança é ainda mais expressiva.

É improvável e indesejável que o vocabulário de "classe" e afins desapareça; afinal, não é à toa que se trata de um conceito-zumbi. Mesmo após décadas de questionamento, os termos classificados no gráfico como classe lato sensu ainda são encontrados em um percentual significativo dos artigos sobre desigualdade em sociologia. Mais ainda, o declínio para esse conjunto foi mais acentuado, como seria de se esperar, para status do que para os outros termos. Ainda assim, é sintomático que os sociólogos tenham sentido cada vez mais desconforto em empregar o vocabulário canônico da disciplina.

A análise qualitativa das principais teorias de classe põe em relevo as dificuldades, os dilemas e a incapacidade do campo de produzir consensos. As teorias mais ambiciosas e rebuscadas desde meados dos anos 1970 mostraram-se empiricamente estéreis ou puramente 
Figura 6. Frequência relativa de termos associados a classe lato sensu e à questão distributiva nos títulos dos artigos sobre desigualdade nos periódicos selecionados de sociologia, 1970-2014 (\%)

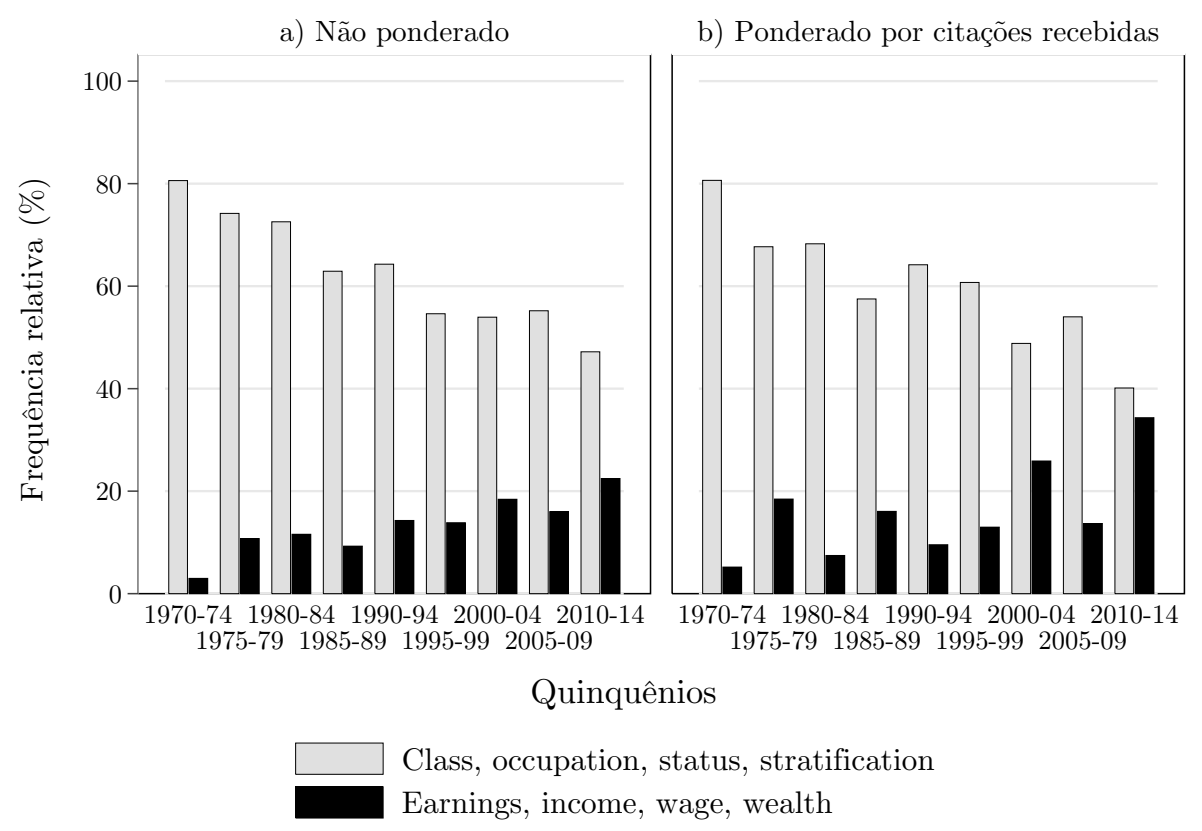

Fonte: elaboração do autor a partir da Web of Science, da Thomson Reuters.

N.B.: as duas séries não são mutuamente excludentes nem exaustivas. Os periódicos selecionados são, em ordem alfabética: American Journal of Sociology, American Sociological Review, British Journal of Sociology, Politics 86 Society, Social Forces, Sociology.

escolásticas, com objetivos contraditórios, vale dizer, gerar uma explicação estrutural para o conflito social e manter ampla margem de liberdade para a ação social. Os esforços mais modestos encontraram problemas para conceber oposições dicotômicas ou binárias a partir das relações de produção e contribuíram para murchar as pretensões analíticas do conceito. Boa parte da literatura faz um enorme esforço intelectual para teorizar um esquema triádico ou tripartite basicamente descritivo, em que acesso à propriedade, escolaridade e/ou títulos ocupacionais servem como bússola para classificar os indivíduos.

O esforço erudito de Anthony Giddens (1975) para atualizar as grandes teorias partiu, previsivelmente, da crise da sociologia como crise do socialismo e da social-democracia, propondo uma combinação não muito elegante entre Weber, Marx e as teorias das elites. A premissa era que o mercado operaria como uma estrutura de poder que diferenciaria grupos em função dos seus recursos e geraria uma pluralidade de interesses entrecruzados; o problema era explicar como essa pluralidade se converte propriamente em classes, i.e., agrupamentos sociais observáveis. Para isso, ele recorreu à noção de estruturação e elencou uma longa lista de mecanismos que condicionariam a emergência de classes, preservando com isso uma margem de manobra para a alquimia misteriosa da ação social. O preço a pagar foi o inchaço teórico de ter que abarcar desde diferenças em padrões de consumo até as relações de autoridade dentro das empresas, sem se comprometer com a especificação 
precisa das relações entre as diversas partes desse complexo. Como uma espécie de deus ex machina, Giddens resolveu o problema sugerindo a existência de fundamentos para um sistema básico triádico, com classes alta, média e trabalhadora. O fato de que o senso comum jamais precisou de tanta ginástica intelectual para chegar a conclusões semelhantes talvez explique o baixo impacto de sua teoria sobre os trabalhos empíricos subsequentes.

Pierre Bourdieu foi mais influente e bem-sucedido do que Giddens, em boa parte porque abandonou a pretensão de identificar classes bem definidas em prol da missão proclamada de definir apenas distâncias preditivas de encontros e afinidades. Seu espaço social é relacional, mas com grandes componentes hierárquicos: o ponto de partida é a ideia de que, associado à gênese do Estado moderno, há um espaço social unificado e diferenciado em termos do volume e da composição das formas de capital efetivas em dada sociedade. O conceito de habitus faz o meio de campo entre estrutura e ação, pois, como incorporação do passado em "estruturas estruturadas estruturantes", o habitus atuaria como princípio gerador e unificador das práticas, garantindo a adequação entre a ação e a realidade objetiva sem a necessidade de decisões conscientes ou normas onipotentes. O habitus consistiria na interiorização de sistemas de classificação em disposições duráveis e, acima de tudo, seria um habitus de classe, na medida em que emerge dos condicionamentos impostos pelas condições de existência e da posição dos indivíduos no espaço social diferenciado (BOURDIEU, 1983; 1998; 2004; 2006).

A abordagem de Bourdieu foi mais fecunda na sua aplicação a gostos e padrões de consumo (e.g., BOURDIEU, 2006) - área em que, não por acaso, a economia neoclássica é particularmente frágil - e à estruturação de mercados específicos (e.g., BOURDIEU, 2005) do que aos objetos normalmente alvejados pelas grandes teorias de classes, como as mudanças políticas gerais ou a evolução da estratificação e da mobilidade social. Na prática, toda a sua teoria relacional, complexa e multidimensional baseou-se empiricamente no uso puro e simples de títulos ocupacionais e credenciais educacionais. Além disso, seu modelo produz um mundo notavelmente organizado, com correspondências íntimas entre classe, condições de vida e habitus, o que o torna pouco afeito à interpretação de processos de mudança. Pior, o esquema acaba inflado ao absurdo para funcionar: ao inserir, de forma subordinada, questões de gênero, idade, raça e outras na constituição das relações de classes, Bourdieu produziu uma teoria até certo ponto infalsificável ou pelo menos extremamente endógena, que, assim como os Borg de Jornada nas Estrelas, é capaz de assimilar tudo. Frank Parkin (1979) já havia diagnosticado essa tendência em muitas reelaborações marxistas: se tudo faz parte da "classe", então sobra pouco a ser explicado e a análise corre o risco de terminar exatamente onde começou.

Parkin, por sinal, percebeu com clareza o cul-de-sac das grandes teorias de classes. Sua autointitulada "crítica burguesa" - vale dizer, weberiana - das teorias marxistas centrou-se na dificuldade em identificar a "falha estrutural" que geraria as grandes contradições e antagonismos no capitalismo contemporâneo. Marxistas, segundo ele, deparavam-se 
constantemente com o "problema da fronteira", ou seja, a necessidade de estabelecer grupos bem delineados a partir das relações de produção em sociedades bastante diferenciadas, e viam-se obrigados a importar conceitos alienígenas ao marxismo, como autoridade e chances de vida, para dar conta de um mundo em que as relações estruturais propostas não se refletiam adequadamente em conflitos sociais. "[D]entro de cada neo-marxista há um weberiano querendo sair", provocou Parkin (1979, p. 25).

A inovação de Parkin foi deixar de lado as relações de produção e debruçar-se sobre os arranjos distributivos. Nessa visão, a estrutura da estratificação resultaria das diversas estratégias de fechamento operada por grupos sociais, quaisquer que fossem suas bases, e as reações organizadas pelos grupos excluídos. O problema óbvio é que esse enfoque gera uma infinidade de conflitos e estratos; assim como Giddens e Dahrendorf, Parkin foi forçado a apelar à história para delimitar, de modo mais ou menos arbitrário, a propriedade e as credenciais educacionais como os principais mecanismos de fechamento social e exclusão das sociedades modernas, permitindo-se tratar como classe dominante os privilegiados em alguma dessas duas dimensões. De novo, o ponto de chegada dificilmente poderia ser considerado revolucionário. Parkin, pelo menos, tinha consciência disso, reconhecendo, mais do que qualquer outro sociólogo, que sua teoria sequer poderia ser considerada uma teoria stricto sensu:

[O modelo] não constitui uma "teoria" de classes em sentido estrito [...]. A maior parte do que convencionalmente chamamos de teorias de classe são na verdade métodos conceituais desse tipo. Elas são, predominantemente, classificações morais do tipo pegar-ou-largar, e não conjuntos de proposições que se sustentam ou são derrubadas pelo impacto das evidências. [...] Como modelos conceituais não estão sujeitos ao ataque empírico direto, o motivos para preferir um e não outro dependem em parte da alegação de que um deles ilumina um conjunto de problemas e questões que estavam antes obscurecidos. (PARKIN, 1979, p. 112)

Para Parkin, o mérito da sua proposta era usar o mesmo arcabouço para explicar os contornos gerais das clivagens de classe, étnicas e afins. O conteúdo específico dessas clivagens, no entanto, só poderia ser entendido pela perspectiva histórica.

Não causa espanto, por conseguinte, que as teorias mais recentes e/ou voltadas para a pesquisa empírica tenham assumido objetivos mais modestos e que o vocabulário tradicional da sociologia da estratificação tenha se tornado menos comum. Mesmo Erik Olin Wright, como bom marxista analítico, sempre foi cauteloso, reconhecendo os limites do conceito de classe, admitindo quando os resultados destoavam das expectativas e reformulando constantemente seu esquema teórico (e.g., WRIGHT, 1989; 2004). Esses refinamentos miram em um objetivo último relativamente modesto, a caracterização satisfatória da estrutura de classes, passando em geral ao largo das questões mais espinhosas ligadas à formação, ao conflito e à consciência de classe (WRIGHT, 2004; 2005). 
Nem essa redução de expectativas nem o abandono da teoria do valor trabalho significaram vida fácil para Wright. Seu problema central, assim como para quase todos os marxistas, foi teorizar o lugar estrutural ocupado pelas ditas classes médias, o que desembocou primeiro em um modelo ancorado na dominação (WRIGHT, 1980), depois repudiado por ele por deixar em segundo plano o conceito de exploração e por depender excessivamente de divisões hierárquicas ou gradacionais que destoavam do enquadramento desejado em termos relacionais e antagônicos. Dada a dificuldade em estabelecer relações binárias entre grandes grupos sociais, seu modelo posterior não conseguiu descartar esses elementos e ainda precisou lançar mão de um conceito de exploração altamente abstrato, baseado nos "jogos de retirada" de John Roemer, e da multidimensionalidade dos ativos produtivos (WRIGHT, 1984; 2004; 2005). Essas peripécias teóricas apenas acrescentaram os chamados "ativos organizacionais" à propriedade e à educação como eixos relevantes para a estrutura de classes. Pior, o custo foi uma teoria cujos requisitos informacionais não são atendidos pela maior parte das pesquisas domiciliares disponíveis, de modo que, em muitos casos, sua operacionalização se dá pelos títulos ocupacionais.

Ao reduzir ainda mais as ambições imputadas à teoria de classes, John Goldthorpe e seus associados evitaram muitos desses problemas, ao mesmo tempo que incorporaram o individualismo metodológico e conceitos oriundos da teoria econômica. Seu projeto intelectual estuda basicamente a relação entre a organização do mercado de trabalho e os padrões de mobilidade social. A justificativa mais recente para defender que, no longo prazo, as chances de vida dos indivíduos dependem de sua posição de classe é uma versão sociológica das teorias de custos de transação e dos problemas de agente/principal. O insight é que o empregador tem que motivar, via recompensas e sanções, os empregados a agir em seu nome em meio a interesses potencialmente divergentes e assimetria de informações que beneficia estes últimos. Goldthorpe (2000a) ofereceu como solução típica ideal a diferenciação de contratos de "serviço" e de "trabalho" em função das duas dimensões fundamentais: a dificuldade de monitoramento do trabalho e o grau de especificidade de recursos necessários para desempenhar a tarefa. Na impossibilidade de monitoramento fácil e na presença de conhecimento técnico ou expertise que dificultam a avaliação externa, os empregadores recorreriam a contratos de "serviço", com benefícios e estabilidade no longo prazo para garantir o alinhamento de interesses das duas partes. Já o contrato de trabalho seria eficiente no caso oposto, estabelecendo relações de curto prazo.

Goldthorpe aplicou seu esquema para criticar as teorias liberais da modernização discutidas anteriormente e postular que o padrão e o grau de fluidez social são relativamente constantes ao longo do tempo nas sociedades industriais (ERIKSON; GOLDTHORPE, 1992). Apesar das críticas ocasionais ao seu eurocentrismo (MALOUTAS, 2007) e à ênfase em eficiência (BREEN, 2005), seu trabalho tornou-se um clássico, motivando uma ampla literatura empírica (e.g., BREEN, 2004) e inspirando o padrão classificatório adotado pela União Europeia (ROSE; HARRISON, 2007). Marshall et al. (2005) compararam 
sua capacidade explicativa à do esquema mais antigo de Wright, concluindo a seu favor, enquanto Evans (1992), Evans e Mills (1998) e Evans e Mills (2000) avaliaram positivamente sua validade de critério e de constructo. No Brasil, Carlos Costa Ribeiro (2006, 2007, 2012) é o principal expoente desta vertente.

O escopo restrito e as categorias puramente nominais são o calcanhar de Aquiles da tipologia de Goldthorpe. O surpreendente é que as tentativas mais recentes de atacar esses problemas buscaram uma aproximação ainda maior com a teoria econômica. Aage Sorensen $(1996,2000)$ essencialmente tentou adaptar a economia neoclássica à sociologia: o motor dos conflitos sociais estaria no jogo de soma zero entre os detentores de ativos que geram rents - i.e., retornos acima do ponto de equilíbrio em um mercado perfeitamente competitivo - e os que dependem deles para realizar o valor dos seus próprios ativos. Não obstante sua originalidade, a proposta permanece mais uma curiosidade do que um programa de pesquisa pujante. A morte prematura do seu autor contribuiu para isso, assim como o velho problema da infinidade de classes possíveis. Outras dificuldades incluem o pressuposto de que o conflito de classes é impossível em uma economia competitiva e a conclusão contraintuitiva de que quem ganha salário mínimo ou recebe assistência social seria também "explorador” (GOLDTHORPE, 2000b; WRIGHT, 2000).

David Grusky e seus associados recorreram à bênção de Durkheim para legitimar uma abordagem de classes que assume de vez o foco estritamente ocupacional, tentando vencer o nominalismo puro de Goldthorpe pelo recurso aos processos de fechamento social que geram as ocupações publicamente reguladas (GRUSKY; GALESCU, 2005; GRUSKY; SORENSEN, 1998; GRUSKY; WEEDEN, 2001). Embora a retórica esteja ancorada na sociologia clássica, a premissa é calcada em mercados competitivos, como em Sorensen. Longe de pleitearem qualquer explicação especificamente sociológica, Grusky e seus colaboradores consideram rents e falhas de mercados as causas principais do aumento da desigualdade nos Estados Unidos (GRUSKY; WEEDEN, 2011; WEEDEN; GRUSKY, 2014). Sua análise empírica assume que o fechamento social opera como a cereja do bolo por cima dos diferenciais de produtividade revelados pelo mercado (WEEDEN, 2002).

Não se deve desmerecer esses esforços. A aproximação com a teoria econômica é promissora, até por não ser uma via de mão única; basta ver a sensibilidade atual de economistas aos efeitos de instituições. O ponto central é que estamos em território muito diferente do sugerido pelas grandes teorias. "Classe" permanece um conceito-zumbi: todos esses debates foram acompanhados, mais uma vez, de diagnósticos contundentes sobre seu status teórico (e.g., GRUSKY; SORENSEN, 1998; PAKULSKI, 2005; SAVAGE, 2005).

Para piorar, há um agravante não desprezível: as teorias sobre classes não só falharam em cumprir suas pretensões mais elevadas, como obscureceram, por seu foco na esfera ocupacional e na procura por grandes grupos homogêneos, a maior mudança na estratificação social dos países ricos nas últimas décadas: o aumento da desigualdade de renda 
provocado pela maior concentração entre os mais ricos (DIPRETE, 2007; KENWORTHY, 2007; MORRIS; WESTERN, 1999; MYLES, 2003). Em meio a elogios a Sorensen, Myles foi particularmente feliz em sua crítica:

[A] maior parte dos esforços recentes para "resgatar" a análise de classes é defeituosa porque seu ponto de partida é equivocado. Ele começa pela teorização da variável independente - classes - e não com o resultado a ser explicado - tendências na desigualdade econômica em sociedade capitalistas avançadas. O objetivo do exercício ainda é explicar quem recebe o que e por quê. A teoria do valor trabalho de Marx podia estar errada, mas pelo menos ela partiu do lugar certo. (MYLES, 2003, p. 556)

A maior preocupação de sociólogos com a distribuição de renda e riqueza reflete esses sentimentos. A procura, por ora, é por uma contribuição especificamente sociológica nessa seara (e.g., KENWORTHY, 2007). No mínimo, cabe uma familiaridade ou aproximação maior com a teoria econômica. Afinal, o próprio foco sugerido por DiPrete (2007) sobre as instituições tem encontrado repercussão entre economistas. Não faz sentido as diversas ciências sociais se tratarem como universos estanques. Nessa perspectiva, teorias sobre o papel de classes e ocupações deixam de ser a via privilegiada de acesso ao real para se tornar explicações potenciais, entre muitas outras, para os resultados que de fato interessam, como a desigualdade de renda ou riqueza.

O que pode ser acrescentado é que o sabor sociológico pode decorrer da transformação de uma fraqueza em virtude: justamente pelo fato de a disciplina não possuir um paradigma tão claro nem estar tão aferrada à centralidade dos mercados, talvez sociólogos possam ter graus adicionais de liberdade para evitar - como ensina a boa sociologia econômica recente - oposições duras e inconciliáveis entre "mercados" e "sociedade" - como no próprio Grusky - e uma maior propensão a considerar os aspectos históricos e o papel do Estado na problematização e construção dos próprios mercados. Esse tipo de abordagem pode ser útil, até porque, como discuto na próxima seção, a teoria econômica também tem suas dificuldades para lidar com os problemas colocados pela volta da desigualdade como tema relevante, o que é menos um sintoma de sua inadequação do que do fato de que há muito ainda a ser explorado pelos estudos sobre estratificação.

Seja como for, uma ironia que não pode deixar de ser notada é que a renovada atenção à desigualdade, nos últimos anos fez-se acompanhar da reaparição da interpretação binária da desigualdade que passou despercebida a teóricos que dedicaram sua carreira a construí-la, porque se afirmou em termos da distribuição de renda, e não das relações de produção. 


\subsection{A volta da desigualdade e dos ricos}

Depois do esquecimento nos anos 1980, o estudo da desigualdade ganhou novo impulso a partir dos anos 1990 e 2000. A análise qualitativa revela entre economistas a percepção de uma mudança mais abrupta do que os dados quantitativos. O próprio ocaso do tema nos anos 1980 foi percebido a partir do contraste com a década seguinte. Como observado na introdução, muitos participantes racionalizaram essa trajetória como uma volta de antigas preocupações após um período de baixo interesse, embora tanto o timing das inflexões quanto as suas causas variem entre autores (ATKINSON; BOURGUIGNON, 2000; KANBUR; LUSTIG, 2000; LEVY; MURNANE, 1992; MILANOVIC, 2014).

A primeira coisa a ser dita acerca dessa maior proeminência da desigualdade é que nem de longe ela traz consigo uma revolução intelectual como a observada a partir do declínio das narrativas benignas. A teoria neoclássica permanece como o arcabouço intelectual dominante, e as teorias de classes continuam com os mesmos problemas discutidos acima. O que é novidade é que o purismo teórico ficou para trás; como notado, mesmo a teoria econômica mainstream é menos monolítica hoje do que muitos imaginam. Ainda assim, essa organização do campo intelectual inevitavelmente implica que certos problemas e explicações ganhem mais relevância do que outros. Não é surpreendente que sociólogos se preocupem cada vez mais com a distribuição de renda ou riqueza.

Outra consequência é que o fardo da prova de sua relevância continuou recaindo sobre aqueles que se interessam pelo tema, algo que talvez só agora esteja começando a mudar. Mesmo depois de o aumento da desigualdade no mundo desenvolvido ter se tornado irrefutável, sua formulação em termos de um trade-off inevitável entre eficiência e igualdade permitiu que muitos pesquisadores assumissem o crescimento como prioridade autoevidente, diante da qual a questão distributiva só poderia ser prejudicial. As credenciais políticas e acadêmicas de muitos desses autores mostram tanto a sobrevivência, ainda que atenuada, do clima intelectual dos anos 1980 quanto o grau de politização do assunto.

Martin Feldstein (1999), diretor do conselho econômico da presidência americana no governo Reagan, escreveu já no fim dos anos 1990 contra o "igualitarismo rancoroso", afirmando que a desigualdade era irrelevante e que a pobreza era o problema real. Robert Lucas (2004), prêmio Nobel em economia em 1995, concluiu seu ensaio panegírico sobre o crescimento econômico com a passagem muito citada - inclusive na epígrafe a este capítulo - de que "[d]entre todas as tendências prejudiciais à boa economia, a mais sedutora e [... ] mais venenosa é o foco em questões de redistribuição". Recentemente, Greg Mankiw (2013), diretor do conselho econômico da presidência americana no governo de George W. Bush, assumiu explicitamente a bandeira da "defesa do 1\%".

Nesse contexto, a legitimação do interesse pela desigualdade foi perseguida por diferentes vias. Muitos invocaram repetidamente John Rawls e afins para assegurar o estofo filosófico e político necessário. A influente formulação de Amartya Sen (1992) de 
que todas as teorias normativas modernas exigem a igualdade em uma dimensão considerada fundamental cumpriu a funcão de apontar como mesmo os proponentes de teorias ostensivamente anti-igualitaristas têm que argumentar que determinadas desigualdades são desejadas e compatíveis com alguma igualdade prioritária. Outra estratégia foi recorrer à ressalva de que a desejabilidade da desigualdade não estava sendo posta em dúvida, e que o problema estava em ter um "excesso de uma coisa boa" (too much of a good thing”), como escreveu Alan Krueger (2008). Como é quase impossível encontrar alguém razoável que defenda que toda desigualdade de renda ou riqueza deva ser erradicada, tais platitudes são só ferramentas retóricas de inoculação, garantindo aos leitores que se está entre cavalheiros, e não entre radicais, reais ou imaginários.

A terceira estratégia foi polemizar diretamente com aqueles, como Feldstein, que separam a preocupação com a pobreza do interesse pela desigualdade. Branko Milanovic (2007), também citado na epígrafe, argumentou que a atração pelo tema decorre não de inveja, mas da simples existência de indivíduos dotados de senso de justiça que vivem em sociedade e, portanto, constituem grupos de referência uns para os outros. Como escreveu, a separação absoluta entre pobreza e desigualdade é logicamente inconsistente e possui uma carga ideológica evidente.

Uma última estratégia, talvez a mais academicamente desafiadora de todas, foi tentar justificar o estudo da desigualdade a partir de argumentos consequencialistas, ou seja, pelos efeitos da desigualdade sobre outras dimensões da vida social. Nessa vertente, os estudos sobre a relação entre desigualdade de renda e crescimento e sobre as consequências da desigualdade para a democracia são particularmente controversos. No primeiro caso, há resultados para todos os gostos. Porém, nos últimos houve um crescente número de trabalhos cujas conclusões vão de encontro à ideia de um trade-off entre crescimento e igualdade, sugerindo uma associação negativa robusta e quiçá causal entre desigualdade e prosperidade (CINGANO, 2014; THORBECKE; CHURAMILIND, 2002; OSTRY; BERG; TSANGARIDES, 2014). No segundo caso, a influência do poder econômico sobre a política é só um pouco menos controvertida, já que é difícil elaborar estratégias de identificação convincentes para isolar os efeitos causais relevantes. De todo modo, também aqui um número de trabalhos alega que o sistema político americano é cada vez mais dependente do financiamento de grandes doadores e mais permeável às opiniões e preferências dos mais ricos (BARTELS, 2008; BONICA et al., 2013; GILENS, 2005). No Brasil, Medeiros (2005) e Rodrigues (2006) documentaram a interseção entre elites econômicas e políticas, medida pela composição ocupacional e pelo patrimônio de políticos eleitos.

O acúmulo de indícios quanto a essas e outras dimensões pode impressionar, mas, verdade seja dita, evidências irrefutáveis de possíveis consequências nefastas da desigualdade são pouco comuns. Em boa parte, isso reflete a precariedade do conhecimento em ciências sociais, e contribui para o status ainda ambíguo das discussões recentes, abrindo espaço para posturas radicais como a de Lucas. Como observou Christopher Jencks (2002), a 
postura "pró-desigualdade" é ainda mais precária, porque, embora não definitivos nem incontestáveis, a maioria dos estudos encontra efeitos negativos ou nulos, e quase nunca positivos. Em outras palavras, a dúvida é se a desigualdade faz mal ou se ela é irrelevante, não havendo sinais de que ela possa de fato fazer bem. A permeabilidade ao tema depende, então, do lado sobre o qual se impõe o fardo da prova, o que variou ao longo do tempo em função do clima intelectual, valores dominantes e conjuntura política.

Se esses argumentos e seus desdobramentos teóricos, como os modelos econômicos com informação imperfeita (KANBUR; LUSTIG, 2000), ajudaram a amolecer a resistência, o que realmente impulsionou a renovação do interesse pela estratificação foi a magnitude dos fatos brutos desde os anos 1980. Ao contrário do início do século, quando a agitação social colocou o tema em pauta, foi o próprio monitoramento acadêmico e governamental que chamou a atenção para o aumento paulatino desigualdade nos Estados Unidos.

Na década de 1980, a característica principal desse aumento foi sua ubiquidade, com o alargamento dos diferenciais no topo e na parte debaixo da distribuição, e maior desigualdade não apenas entre níveis educacionais, setores da indústria e outros grupos, mas também intragrupos. Desde o início, diversas causas e hipóteses foram aventadas, como atestam as antigas e ainda indispensáveis resenhas de Levy e Murnane (1992) e Morris e Western (1999). Diante do clima intelectual da época, o modelo explicativo canônico rapidamente convergiu para a interação entre a oferta e a demanda por trabalho qualificado. A hipótese do "progresso técnico com viés para habilidades" (skill-biased technological change; doravante, SBTC) popularizou-se. Algumas variantes utilizavam-na para explicar os diferenciais educacionais; outras, para dar sentido à elevação da desigualdade residual. Nos dois casos, os argumentos flutuavam entre a aceleração da demanda por trabalhadores mais qualificados em função do progresso tecnológico e a desaceleração da oferta de trabalhadores com nível superior em um ambiente de crescimento contínuo e estável dessa demanda. Os trabalhos de Bound e Johnson (1992), Freeman e Katz (1994), Katz e Murphy (1992), Levy e Murnane (1992) cobrem essa gama de variantes, que compartilham a perspectiva de uma "corrida entre educação e tecnologia", frase de Jan Tinbergen que deu título ao livro de Goldin e Katz (2008), mais um exemplar dessa lavra.

As críticas à hipótese SBTC foram intensas e abalaram seu prestígio inicial. Em resumo, muitos apontaram inconsistências como: as diferentes trajetórias da desigualdade em países expostos às mesmas mudanças tecnológicas; o caráter tautológico da explicação em virtude da ausência de medições independentes de "habilidades" e das mudanças tecnológicas relevantes; o fato de que a desigualdade americana depois dos anos 1980 continuou aumentando em ritmo um pouco menor e basicamente só no topo; a relativa estagnação dos indicadores agregados de produtividade; a desaceleração do crescimento dos retornos salariais para o ensino superior e a estabilização dos diferenciais salariais entre grandes grupos educacionais; e o crescimento anterior desses diferenciais educacionais ter se dado mais pelo colapso dos salários dos menos escolarizados do que por ganhos 
salariais dos portadores de diploma universitário (ACEMOGLU; AUTOR, 2012; CARD; DINARDO, 2002; LEMIEUX, 2008; MISHEL et al., 2012; MORRIS; WESTERN, 1999).

A demolição da versão canônica da hipótese SBTC estimulou esforços para salvar a explicação tecnológica do aumento da desigualdade. A análise baseada em "tarefas", associada a David Autor, é o produto mais rigoroso e satisfatório dessa reconstrução. O pressuposto de correspondência perfeita entre habilidades dos trabalhadores e tarefas desempenhadas por eles foi relaxado, e o foco passou a ser as últimas, e não as primeiras, como unidade do processo produtivo. As explicações deixaram de insistir sobre a aceleração do progresso tecnológico, passando para as consequências distributivas do avanço das tecnologias de informação. Ao substituir o trabalho não manual de rotina, a informatização complementaria o trabalho não manual cognitivo e não possuiria grande efeito direto sobre o trabalho manual não rotineiro. Com isso, ela provoca um aumento da desigualdade de renda no topo e efeitos variáveis sobre o resto da distribuição: em um primeiro momento, a polarização ocupacional deslocaria trabalhadores com credenciais medianas para empregos piores, o que, sob certas condições, promoveria o esgarçamento de toda a distribuição de renda devido ao excesso de oferta; posteriormente, a autosseleção e a complementaridade das tarefas estabilizariam a desigualdade na parte de baixo da distribuição, culminando em um quadro de polarização ocupacional e salarial movido pela tecnologia (ACEMOGLU; AUTOR, 2012; AUTOR; LEVY; MURNANE, 2003; AUTOR; KATZ; KEARNEY, 2006; AUTOR; KATZ; KEARNEY, 2008; GOOS; MANNING, 2007)

Do ponto de vista teórico, a reformulação em termos de "tarefas" foi um passo à frente, mostrando capacidade de lidar com diferentes momentos da evolução da desigualdade a partir de um esquema abstrato relativamente simples. Do ponto de vista da narrativa desenvolvida nos capítulos anteriores, o mais interessante é a reintrodução da polarização como traço fundamental da desigualdade, ainda que a linguagem seja asséptica e decididamente não politizada. Não foi mera coincidência: em meio a um debate mais quente, a missão autoproclamada de Autor e afins foi adaptar o arcabouço da hipótese SBTC precisamente para dar conta dessa polarização. Para sociólogos, é notável que o caminho tenha sido via estrutura ocupacional, cuja vocação para capturar os contornos fundamentais da estratificação foi crescentemente questionada nas últimas décadas.

Apesar disso, a passagem da SBTC para "tarefas" e polarização tampouco conseguiu adequar-se plenamente aos fatos estilizados do mercado de trabalho americano. Mishel, Shierholz e Schmitt (2013) documentaram os embaraços empíricos das previsões desse modelo, com destaque para as evidências fracas de polarização ocupacional, em especial nos anos 2000, para a relação tímida entre tendências ocupacionais e os padrões de desigualdade salarial, e para a crescente heterogeneidade interna às ocupações. Thomas Lemieux (2008), mais simpático, também viu contratempos, como os ganhos tímidos das ocupações mais próximas à revolução computacional em comparação com outras mais tradicionais. 
Em última instância, a interpretação baseada em tarefas e polarização ocupacional foi menos refutada do que simplesmente relegada ao segundo plano em decorrência da profunda mudança operada pelos trabalhos de Piketty e seus colaboradores. Ao recuperar o uso de dados tributários, esses estudos sobre os chamados top incomes simultaneamente trouxeram de volta uma concepção muito mais polarizada da estratificação e elevaram o assunto para além do seu nicho acadêmico convencional e do foco no mercado de trabalho. ${ }^{4}$ Ou seja, o interesse maior pela desigualdade deu-se junto com sua interpretação dicotômica, em que um grupo mais ou menos bem delineado de ricos - ou "top 1\%", para usar o jargão - se opõe à massa amorfa representada pelos "99\%". A própria representação da estratificação mudou, com a substituição consciente de medidas sintéticas por gráficos intuitivos com a fração da renda total abocanhada pelos mais ricos. Analogamente, o rol de explicações plausíveis modificou-se. Se, no final dos anos 1990, Piketty (2004) recorria às disparidades educacionais para explicar boa parte do crescimento da desigualdade salarial desde os anos 1970 nos países ricos, sua produção recente ampliou o conceito de renda para além do trabalho assalariado e deu ênfase à distribuição do capital e às instituições. ${ }^{5}$

As pesquisas iniciais sobre a França (PIKETTY, 2001; 2003) e os Estados Unidos (PIKETTY; SAEZ, 2003) logo expandiram-se, possibilitando a construção de séries históricas da concentração de renda no topo para países anglófonos, como Canadá (SAEZ; VEALL, 2005) e Reino Unido (ATKINSON, 2005), e posteriormente para um conjunto muito maior e mais diverso (ALVAREDO, 2008; ATKINSON; PIKETTY, 2007; ATKINSON; PIKETTY, 2010; LEIGH; VAN DER ENG, 2009; MEDEIROS; SOUZA; CASTRO, 2015a; MEDEIROS; SOUZA; CASTRO, 2015b; VÉLEZ, 2012, entre outros).

Como discuto no próximo capítulo, a abordagem baseada em dados tributários tem vantagens sobre as pesquisas domiciliares, como a cobertura temporal mais longa e informações melhores sobre os rendimentos dos mais ricos. ${ }^{6}$ Porém, a reorientação para o estudo do topo da distribuição exigiu legitimação. Evitar definir o programa de pesquisa em função dos "ricos" e passar ao largo de linhas de riqueza certamente cumpriu um papel: expressões insípidas como top incomes ou top $1 \%$ escapam a qualquer carga ideológica suspeita, ainda que, ao fim e ao cabo, tudo gire de fato em torno dos ricos, como se vê pela mobilização política da oposição entre o $1 \%$ e os $99 \%$ promovida pelo Occupy Wall Street durante sua breve existência. Para além disso, a justificação direta também foi percebida

4 Piketty não foi o único a falar dos ricos. Antes dele, outros pesquisadores já haviam chamado a atenção para esse grupo, sem a mesma repercussão. Nos Estados Unidos, os trabalhos de Edward Wolff (1995, 1998, entre outros) sobre desigualdade de riqueza merecem ser mencionados, inclusive por proporem a tributação do patrimônio. A literatura sobre linhas de riqueza vem pelo menos desde os anos 1970, com Drewnowski (1978), fazendo-se mais presente nos últimos anos (e.g., BOSE; CHAKRAVARTY; D'AMBROSIO, 2014; MEDEIROS, 2006; PEICHL; SCHAEFER; SCHEICHER, 2010).

5 Essa mudança na variável de interesse faz com que os resultados de Piketty e associados sobre os mais ricos não possam ser usados diretamente para testar os modelos de Autor e afins para o mercado de trabalho stricto sensu, embora forneçam indícios em linha com muitas críticas.

6 O reconhecimento de que pesquisas amostrais são ruins para captar os rendimentos dos ricos e que os dados tributários são uma boa alternativa data pelo menos dos anos 1930 (e.g., BAIRD; FINE, 1939). 
como necessária, e Atkinson (2007) e Atkinson, Piketty e Saez (2011) insistiram sobre a interdependência das diferentes partes da distribuição da renda e o papel da riqueza como "comando sobre recursos" e como "comando sobre pessoas". Em combinação com os resultados empíricos, esses argumentos foram aceitos quase como inequívocos.

A Figura 7 apresenta a fração apropriada pelo 1\% mais rico em quatro países selecionados por expor bem os padrões identificados pela literatura; o capítulo 5 traz mais comparações históricas e dados para o Brasil. No início do século XX, a concentração no topo era alta em muitos dos países depois considerados desenvolvidos e igualitários. Tudo mudou nos anos turbulentos e catastróficos entre 1914 e 1945, com quedas abruptas em especial durante a $2^{a}$ Guerra. O perfil dos mais ricos se alterou, com declínio dos rendimentos de capital. A interpretação preferida por Piketty e seus colaboradores responsabiliza os choques exógenos ao capital dos grandes proprietários decorrentes das guerras e da Grande Depressão: além da destruição física, o período foi marcado por inflação alta e volátil, falências, elevações de tributos e intervenção dos governos na economia, inclusive com controles temporários de salários e políticas confiscatórias. Os Estados de Bem-Estar social e a tributação progressiva teriam proporcionado relativa estabilidade da concentração no topo no pós-guerra - as narrativas benignas sobre o capitalismo e a desigualdade não surgiram em um vácuo. A partir do fim dos anos 1970, a fração do $1 \%$ mais rico voltou a crescer: grosso modo, o aumento da desigualdade foi intenso nos países anglófonos e mais tímido ou inexistente em outros países ricos, como no caso da Europa Continental e do Japão. A composição de renda revela que a reconcentração deveu-se aos rendimentos do trabalho lato sensu, e não do capital. Por fim, os dados mostraram que as pesquisas domiciliares americanas subestimam o nível e até a tendência da desigualdade, e que a concentração no topo é um fenômeno potencialmente mais relevante do que as diferenças salariais entre níveis educacionais (ALVAREDO et al., 2013; ATKINSON; PIKETTY; SAEZ, 2011; PIKETTY, 2003; PIKETTY; SAEZ, 2003; PIKETTY; SAEZ, 2006). ${ }^{7}$

Há menos consenso sobre as causas desse aumento recente do que sobre as mudanças anteriores. A heterogeneidade das experiências nacionais deixou de lado as variantes da hipótese SBTC em favor de explicações institucionais, com peso para a redução da progressividade da tributação. Menos do que aprofundar a redistribuição, a tributação confiscatória servira mais para impedir a acumulação de grandes fortunas. Com os cortes nas alíquotas máximas em boa parte do mundo, essa trava foi relaxada, contribuindo para a reconcentração diretamente e ao gerar incentivos para executivos barganharem mais agressivamente em um jogo de soma zero com os demais trabalhadores. Nessa narrativa, a tributação altamente progressiva seria um componente fundamental para limitar o rent-seeking (ALVAREDO et al., 2013; PIKETY; SAEZ; STANTCHEVA, 2014).

A ênfase institucional de Piketty e companhia reverberou na extensa literatura que,

7 Para uma visão oposta, mas que reconhece a redefinição dos termos do debate, ver Autor (2014). 
Figura 7. Fração da renda total recebida pelo $1 \%$ mais rico em países desenvolvidos selecionados, 1910-2015 (\%)

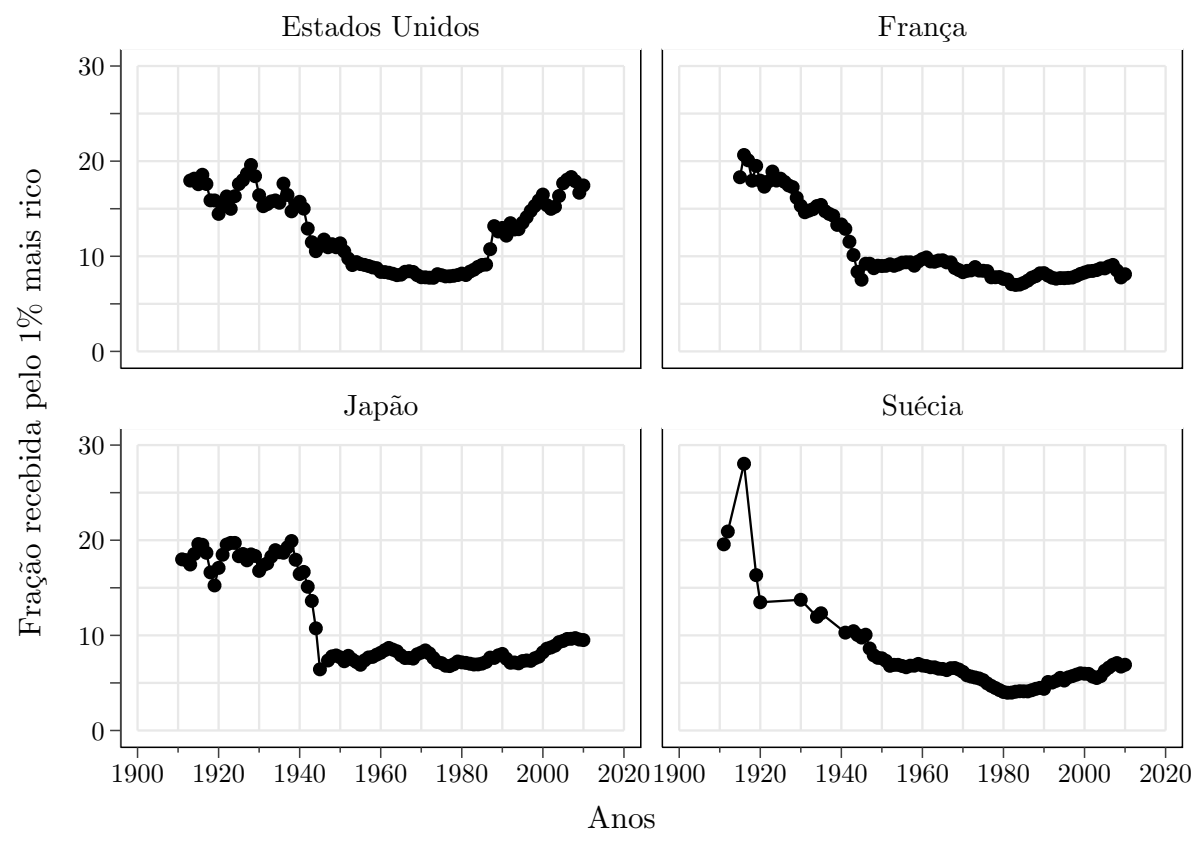

Fonte: World Wealth and Income Database (ALVAREDO et al., 2015).

N.B.: resultados relativos aos rendimentos brutos, exclusive ganhos de capital.

no bojo desses trabalhos, tentou oferecer interpretações e explicações alternativas para a concentração de renda no topo. Bartels (2008) e Hacker e Pierson (2010) privilegiaram a política stricto sensu na análise da desigualdade americana, chamando a atenção para o papel do Partido Republicano e dos lobbies e organizações empresariais, respectivamente. Levy e Temlin (2007) trataram a concentração no topo e o descolamento entre salários e produtividade nos Estados Unidos como consequência de uma passagem político-institucional do arranjo do "Tratado de Detroit" para o do "Consenso de Washington". Na visão deles, procurar por determinantes específicos, como educação ou salário mínimo, seria estéril, pois a magnitude das mudanças só poderia ser compreendida a partir da vitória política de um projeto específico que se ofereceu como resposta à crise dos anos 1970. Piketty e Saez (2003) arriscaram que mudanças em "normas sociais" vagamente definidas sobre desigualdade salariais foram um dos determinantes das tendências americanas recentes.

Mais modestamente, Bivens e Mishel (2013) atribuíram o aumento da desigualdade à extração ou deslocamento de rents para grandes executivos e para o setor financeiro devido à má governança corporativa e ao afrouxamento regulatório. ${ }^{8}$ Como esses dois grupos foram centrais para o recrudescimento da concentração de renda americana (e.g, BAKIJA; COLE; HEIM, 2012), não causa espanto que haja longas bibliografias sobre cada um. Os efeitos da expansão do setor financeiro, por exemplo, foram estudados e

\footnotetext{
8 No jargão econômico, rent é um pagamento a um fator de produção maior do que o custo necessário para estimular o uso daquele fator em um mercado perfeitamente competitivo.
} 
reafirmados por Volscho e Kelly (2012) e Lin e Tomaskovic-Devey (2013). Em uma linha qualitativa, Greta Krippner (2010) reuniu evidências que a financialização da economia americana foi em parte uma estratégia política para aliviar o conflito distributivo aguçado pela desaceleração do crescimento e pela influência do governo na alocação de crédito.

Apesar de sua proeminência, as explicações institucionais da concentração no topo não foram as únicas. Gabaix e Landier (2008), por exemplo, construíram um modelo competitivo de alocação de altos executivos a firmas, em que os executivos têm diferentes níveis de "talento administrativo" com impacto marginal proporcional ao valor ou tamanho da firma sob seu comando. No espírito da teoria dos superstars de Rosen, pequenas diferenças de talento podem traduzir-se em grandes desigualdades de remuneração. Ademais, a disparada na remuneração da elite dos CEOs surge como efeito do crescimento do tamanho ou capitalização das firmas, que geraria um novo equilíbrio em que a produtividade dos CEOs seria igualmente multiplicada. Kaplan e Rauh (2013) foram na mesma linha, atribuindo os ganhos do $1 \%$ a "talentos escassos e únicos" que teriam se tornado ainda mais valiosos e produtivos devido a mudanças tecnológicas e à expansão dos mercados.

O próprio Capital, de Piketty (2014a), investiu em uma explicação via mecanismos de mercado eficientes, diferindo dos trabalhos citados mais na avaliação e na sensibilidade histórica. A tese do livro, derivada das relações contábeis anunciadas como "leis fundamentais do capitalismo", pode ser expressa sucintamente por $r>g$, em que $r$ é a taxa média de retorno ao capital, e $g$ é a taxa de crescimento da economia:

A desigualdade $r>g$ implica que a riqueza acumulada no passado cresce
mais rapidamente do que o produto e os salários. [...] O empreendedor
inevitavelmente tende a se tornar um rentista, cada vez mais dominante
sobre aqueles que não possuem nada além de sua força de trabalho.
Uma vez constituído, o capital reproduz-se com mais rapidez do que o
crescimento do produto. O passado devora o futuro. [...] [É] provável
que $r>g$ se torne de novo o padrão no século XXI, tal como foi por toda
a história [...]. No século XX, foram necessárias duas guerras mundiais
para varrer o passado e reduzir significativamente o retorno ao capital,
criando assim a ilusão de que a contradição estrutural fundamental do
capitalismo $(r>g)$ havia sido superada. (PIKETTY, 2014a, p. $571-572)$

Piketty foi cuidadoso e negou a inevitabilidade do processo. Sua alegação principal é que forças poderosas e talvez predominantes de mercado podem desembocar em um equilíbrio eficiente, mas socialmente indesejável. Por mais pretensiosa que seja, a alusão a Marx no título do livro vai na contramão de muitas críticas à esquerda - como a alguns já citados - que associam a concentração de renda a rent-seeking e ineficiência, sugerindo ser possível conciliar crescimento e redistribuição. O mais inesperado do livro é que se trata de um trabalho histórico com teses sobre tendências futuras apenas antevistas no presente. Piketty não vai além de suas explicações anteriores sobre a desigualdade no século XX, e reitera que a explosão dos altos rendimentos do trabalho no topo parece ter pouco a ver com aumentos relativos da produtividade. Ou seja, a explicação histórico-institucional 
do passado convive com a previsão estritamente econômica do futuro. Por esses e outros motivos, a Parte II desta tese se abstém de avaliar a hipótese de Piketty.

É impossível recapitular aqui as críticas e comentários acerca do diagnóstico de Piketty e sua proposta de um imposto global sobre o capital. As dúvidas mais prejudiciais à sua tese questionam a elasticidade de substituição entre capital e trabalho assumida por ele e o papel da riqueza imobiliária no aumento da razão capital/produto (MILANOVIC, 2014; ROGNLIE, 2015). No primeiro caso, a elasticidade deve ser alta para que o retorno marginal ao capital não diminua conforme a razão capital/produto cresce, o que é incerto depois que se leva em conta a depreciação do estoque. O próprio Piketty apresentou suas conclusões apenas como regularidades empíricas, e não relações necessárias de algum modelo. No segundo caso, pelo menos nos Estados Unidos, parte significativa do crescimento da participação do capital na renda remete ao setor imobiliário, o que, por sua vez, desloca a atenção para as restrições institucionais à oferta, e não para o capital qua capital. Nesse caso, Henry George, discutido no capítulo 1, seria uma referência mais atual do que Marx. Em resposta às críticas, Piketty passou a dar menos peso à influência das "leis fundamentais do capitalismo" sobre a desigualdade, enfatizando a interação entre essas tendências e as respostas institucionais e políticas de cada país e insistindo que seu livro é uma narrativa histórica analítica de fenômenos multidimensionais, sem nenhuma primazia de modelos teóricos abstratos sobre a análise dos choques políticos e das mudanças nas representações da desigualdade (PIKETTY, 2014b; 2015).

O caráter prospectivo da interpretação de Piketty faz com que quaisquer conclusões sejam apenas preliminares. O que pode ser visto com clareza é que a tensão entre explicações políticas ou institucionais e modelos com base em mercados competitivos não é insuperável. As duas abordagens implicam diferentes ênfases ou pontos de partida, mas não são necessariamente antagônicas ou mesmo opostas. Por vezes, elas até se confundem ou se entrelaçam. Piketty não é o único a oscilar entre ou tentar conciliar ambas as visões. Lemieux, MacLeod e Parent (2009), por exemplo, destacaram a proliferação de arranjos em que a remuneração do trabalhador depende diretamente do seu desempenho (performance pay) como uma mudança institucional fundamental para traduzir mudanças na distribuição da produtividade - tal como preconizadas pela hipótese SBTC - em maior desigualdade salarial. A análise de Roine, Vlachos e Waldenstrom (2009) dos determinantes de longo prazo da concentração de renda no topo trilhou caminho parecido, incluindo variáveis econômicas e institucionais nos modelos de regressão de primeiras diferenças. A principal conclusão deles é que o crescimento acelerado da economia e a expansão do setor financeiro (pelo menos em países menos desenvolvidos) estiveram associados a maior concentração da renda nos mais ricos no século XX, enquanto o aumento dos gastos públicos e das alíquotas marginais máximas do imposto de renda atuaram no sentido oposto. Anteriormente, Frank e Cook (1995) já haviam atribuído a emergência de mercados do tipo "vencedor-levatudo" a mudanças tecnológicas para, em seguida, discutir as distorções e ineficiências de 
muitos desses mercados e sua interação com políticas públicas. Na sociologia, os trabalhos mencionados acima de Grusky, Weeden, Sorensen e outros também abordaram a interação entre mercados e instituições, em geral sob o ângulo de restrição da competição.

É difícil fugir à conclusão de que a literatura, ao recuperar a desigualdade e a polarização, encaminhou-se para uma visão muito mais rica do que o simples determinismo tecnológico, destacando a economia política da desigualdade e a interrelação entre governos e mercados. A volta recente do tema e a heterogeneidade das experiências nacionais faz com que não existam ainda - e talvez nunca venham a existir - consensos ou interpretações claramente predominantes, nem teorias gerais. A tensão entre impulsos analíticos e sintéticos é óbvia, com descrições pormenorizadas de países - principalmente dos Estados Unidos, que ocupa por larga margem o centro das atenções - convivendo com a dificuldade em explicar paralelos e diferenças internacionais. Ainda há muito a ser estudado e explicado.

O que é inequívoco é que o debate recente reorientou o debate sobre desigualdade em termos binários, esvaziando as interpretações hierárquicas ou triádicas anteriores e voltando a um padrão semelhante ao observado nas primeiras décadas do século XX. Isso não implica que as demais concepções desapareceram nem que o debate atual é uma mera reedição do passado: por todas as dificuldades e desdobramentos discutidos neste e nos capítulos anteriores, uma diferença clara é que hoje o enquadramento dicotômico se dá mais explícita e exclusivamente na dimensão distributiva e não parte do pressuposto de que o " $1 \%$ " ou o " $99 \%$ " formam classes no sentido realista do termo, grupos relativamente homogêneos e politicamente mobilizados em nome de causas coletivas. A discussão atual é herdeira de todas as controvérsias da era das narrativas benignas e das controvérsias sobre classes, empregando linhas demarcatórias puramente nominalistas para iluminar aspectos até então pouco comentados da distribuição de renda ou riqueza. As relações dos grupos assim definidos com classes ou mesmo lobbies políticos são hipóteses empiricamente testáveis, e não pressupostos da análise. Todos reconhecem a heterogeneidade do " $1 \%$ ". O enquadramento dicotômico é, portanto, um modelo conceitual, uma "classificação moral" no sentido de Parkin, e não uma afirmação ontológica sobre o mundo.

Com isso, é pouco provável que o tema caia de novo em esquecimento. Politicamente, a estratificação voltou à pauta junto com o enfoque binário. O sucesso editorial de Piketty e o discurso de Obama mencionados no capítulo 1 podem ser evocados como evidências. Angus Deaton (2014), prêmio Nobel em Economia em 2015, escreveu sobre essa "redescoberta da desigualdade" e a sua politização nos Estados Unidos, contrastando-as com a apatia em relação ao assunto nas décadas anteriores e traçando um paralelo com os eventos políticos do início do século XX - a época em que, como também visto no capítulo 1, o debate sobre estratificação social alcançou enorme visibilidade, dando-se principalmente em termos binários. Deaton, porém, é cauteloso quanto às similaridades entre os dois períodos. Embora a desigualdade também tenha vindo à tona nos discursos políticos de outros países, seria exagero afirmar que se trata de prioridade na agenda internacional. 
Para terminar, dois exemplos, distintos entre si e da literatura sobre top incomes, servem como evidências adicionais do apelo atual de concepções binárias da desigualdade. Crítico às previsões benfazejas de Kuznets e à teoria neoclássica, José Gabriel Palma (2011) vem insistindo sobre um fato estilizado na distribuição de renda dos países: o contraste entre a homogeneidade no "meio" e a heterogeneidade nos extremos. Com base em levantamentos domiciliares para 135 países, ele observou que a população entre o $5^{\circ}$ e o $9^{\circ}$ décimos tende a se apropriar de cerca da metade da renda nacional na maior parte dos países, de modo que as diferenças na desigualdade total decorrem do conflito distributivo entre os $40 \%$ mais pobres e os $10 \%$ mais ricos. Cobham e Summer (2013), de forma menos panfletária, forneceram evidências adicionais para essa hipótese.

Na outra ponta do espectro ideológico, Charles Murray, que nos anos 1990 adquirira notoriedade ao atribuir a desigualdade - grosso modo, a separação triádica entre pobres, classe média e ricos - à distribuição de inteligência (ver discussão em FISCHER et al., 1996), mudou de tom com seu livro sobre a polarização da sociedade americana desde os anos 1960, preocupando-se com a "formação de classes que são diferentes em caráter e em grau de separação de tudo que a nação já testemunhou" (MURRAY, 2012, p. 11). Ao contrário do seu trabalho anterior, Murray quis evitar as controvérsias raciais, focando sua análise na dicotomia entre brancos americanos. Por vezes ecoando o discurso de Jimmy Carter sobre a perda de confiança nas instituições americanas, Murray culpou as consequências supostamente nefastas das revoluções culturais dos anos 1960 e 1970: por um lado, a degeneração cultural que fez a classe baixa abandonar os ideais puritanos tradicionais e rumar para a anomia; por outro, a emergência de uma elite que adere a um código moral rígido, mas que se recusa a pregar o que pratica, "abdicando da sua responsabilidade de estabelecer e promulgar padrões” (MURRAY, 2012, p. 298).

\subsection{As idas e vindas da desigualdade brasileira}

O Brasil, à sua maneira, acompanhou as tendências internacionais nas últimas décadas do século passado. Depois da intensa querela no início dos anos 1970 sobre o aumento da desigualdade, o assunto perdeu visibilidade nos anos 1980. A causa, contudo, foi mais a grave crise econômica que afligiu o país até a primeira metade da década de 1990 do que qualquer guinada política neoliberal. A desigualdade não desapareceu de todo e um bom número de trabalhos de alta qualidade foram publicados; no entanto, a questão distributiva saiu das manchetes em um período em que as fontes de dados se tornaram mais numerosas, com a realização anual (exceto em anos censitários) das Pesquisa Nacional por Amostra de Domicílios (PNAD). A literatura brasileira também seguiu a internacional em outro aspecto: a priorização do modelo do capital humano como chave para explicar nossa elevada desigualdade. Muito embora as previsões róseas de Carlos Langoni sobre a evolução da distribuição de renda brasileira tenham fracassado miseravelmente, seu modelo 
explicativo tornou-se predominante, principalmente depois da redemocratização.

Muitos trabalhos usaram dados dos Censos e das PNADs para documentar que a desigualdade de renda medida pelo coeficiente aumentara nos anos 1970, com menos intensidade e com breve intervalo de queda entre 1976 e 1981, e mais fortemente nos anos 1980. Ou seja, a desigualdade aumentou tanto em períodos de crescimento quanto de estagnação. (BARROS; MENDONÇA, 1995b; BONELLI; RAMOS, 1993; BONELLI; SEDLACEK, 1988; REIS; BARROS, 1990). Ainda assim, a pobreza diminuiu, já que a piora na distribuição de renda não foi forte o suficiente para anular os ganhos absolutos nos anos de crescimento. Essa piora, por sinal, seguiu padrões diferentes nos dois períodos de aumento acentuado do Gini: entre 1960 e 1970, os décimos no meio da distribuição foram os que mais ficaram para trás, com renda real praticamente estagnada em um período de prosperidade; já na década de 1980, todos os décimos tiveram perdas reais, mas, em termos relativos, elas foram maiores para os mais pobres, diminuindo quase monotonicamente em direção ao topo da distribuição (BARROS; MENDONÇA, 1995a). ${ }^{9}$

Ao contrário do debate do início dos anos 1970, dessa vez a heterogeneidade educacional e a convexidade dos retornos à escolaridade foram aceitas mais amplamente como principais explicações sobretudo para os altos níveis de desigualdade registrados no Brasil (BARROS; MENDONÇA, 1995b; BARROS; RAMOS, 1992; JALLADE, 1978; LAM; LEVISON, 1990; REIS; BARROS, 1990). Nem todos compartilhavam esse foco, claro: por exemplo, Velloso (1979) voltou a insistir sobre a política econômica da ditadura militar, enquanto outros autores mais próximos à ênfase educacional reconheceram problemas e limites no que diz respeito à dinâmica de curto prazo. Com base nas PNADs de 1976 a 1985, Lam e Levison (1992) observaram que, para as coortes mais jovens, houve tanto aumento da escolaridade quanto diminuição da heterogeneidade educacional, e mesmo assim a desigualdade salarial aumentara, o que foi especulativamente atribuído por eles a efeitos cíclicos que, no longo prazo, seriam dominados por melhoras estruturais na distribuição da escolaridade. Bonelli e Ramos (1993), por sua vez, reconheceram a importância da educação e da teoria do capital humano, mas observaram que o contexto brasileiro provavelmente não supria as precondições necessárias para sua aplicabilidade tout court - em função de mercados imperfeitos ou incompletos, barreiras ao acesso à informação e outros fatores e que a escolaridade sozinha não parecia explicar muito da dinâmica da distribuição de renda. Esses autores buscaram suplementar o modelo levando em conta a inflação e o ciclo econômico, com especial influência para a literatura de labor hoarding, que previa que a

9 Em função das limitações do Censo de 1960, a maior parte dessas análises tomou como variável de estratificação a renda individual total da população economicamente ativa com rendimentos não nulos. Com as novas bases de dados e o avanço computacional, a variável privilegiada pelos estudiosos brasileiros, além da renda do trabalho, passou a ser a renda domiciliar per capita. Até onde foi possível apurar, o primeiro a utilizá-la foi Constantino Lluch (1981), em trabalho baseado no Censo de 1970. Não há uniformidade internacional quanto à variável de interesse: por exemplo, os estudos americanos tendem a usar simplesmente a renda familiar total e a maioria dos europeus utiliza a renda domiciliar com alguma escala de equivalência. 
desigualdade salarial teria comportamento anticíclico, isto é, aumentaria em períodos de crise, pois os trabalhadores menos escolarizados seriam os primeiros a serem demitidos, em função do menor custo de reposição para os patrões.

Até os defensores da explicação educacional da desigualdade brasileira reconheceram, muitas vezes tacitamente, que a hipótese de Langoni de um desequilíbrio de mercado (quase) autocorrígivel fora descabida e que, mesmo se a interpretação dele para os anos 1960 estivesse correta, ela era pouco aplicável aos anos 1980: como escreveram Bonelli e Ramos (1993), a ideia de que o desenvolvimento econômico aumentara a demanda por trabalho qualificado com oferta inelástica no curto prazo servia melhor ao período de expansão da década de 1960 do que aos anos 1980, época de expansão educacional e estagnação econômica. Surpreendentemente, muitos trabalhos do período ignoraram as críticas dos contemporâneos de Langoni quanto ao timing do aumento da desigualdade durante a ditadura, tal como discutido na seção 2.6, no capítulo anterior.

Apesar dessas ressalvas, não há dúvidas de que a interpretação da desigualdade em termos de capital humano tem muito a seu favor. Para começar, os diferenciais educacionais oferecem uma fundamentação plausível para o tipo de desigualdade que se desejava explicar, caracterizado pela combinação de concepções hierárquicas da estratificação, pelo uso de pesquisas domiciliares amostrais e pelo foco no mercado de trabalho. Com efeito, os imensos diferenciais registrados no Brasil implicavam que, dado esse enquadramento, a educação era uma resposta bastante intuitiva para o nosso alto nível de desigualdade. A situação podia ser diferente quando se tratava das nossas tendências temporais, mas, com o tempo, tais tendências pareceram menos relevantes do que a persistência dos altos índices de concentração de renda no país (e.g., BARROS; HENRIQUES; MENDONÇA, 2000). Como se tratava, justificadamente, de procurar causas relativamente fixas para o problema da persistência de diferenciais de renda ao longo de uma distribuição contínua, dificilmente haveria outra explicação mais satisfatória e parcimoniosa. Ademais, a maior parte dos autores dessa geração nunca negou a possibilidade de suplementar a explicação educacional com elementos institucionais e macroeconômicos, embora o caráter político das escolhas da ditadura militar tenha ficado em segundo plano (ver, por exemplo, a revisão de COELHO; CORSEUIL, 2002). O fim das políticas autoritárias mais criticadas da ditadura - como a repressão aos sindicatos - de fato não produziu melhorias distributivas imediatas. Em sua revisão da extensa literatura sobre o salário mínimo, por exemplo, Wells e Drobny (1982) reconheceram que as evidências empíricas acerca dos efeitos distributivos da sua desvalorização eram inconclusivas.

Em resumo, o debate brasileiro chegou à segunda metade dos anos 1990 menos controverso e menos visível do que antes, com uma nova sabedoria convencional cristalizada em torno do papel central da educação para explicar o nível alto da nossa desigualdade para padrões internacionais. Francisco Ferreira (2000) apresentou uma versão refinada dessa vertente ao incorporar a economia política das desigualdades educacionais: 
O debate dos anos 70 e 80 sobre a importância relativa da distribuição da educação e de seus retornos, por um lado, e de políticas salariais repressivas, por outro, como causas básicas da desigualdade brasileira, parece estar esgotado. [...] [U]m modelo formal simplificado [...] demonstra a possibilidade da existência de um tipo de equilíbrio político-econômico em que três desigualdades se reforçam mutuamente: uma grande desigualdade educacional gera um alto nível de desigualdade de renda como se observa no Brasil. Essa desigualdade de renda ou riqueza, por sua vez, pode implicar uma distribuição desigual de poder político, na medida me que a riqueza gera influência sobre o sistema político. E a desigualdade de poder político reproduz a desigualdade educacional, já que os detentores do poder não utilizam o sistema público de educação, e não têm interesse na sua qualidade, dependendo apenas de escolas particulares. (FERREIRA, 2000, p. 155)

Ferreira escreveu em um momento em que, assim como nos Estados Unidos e alhures, a distribuição de renda estava voltando ao centro das atenções no Brasil. Ao contrário dos países desenvolvidos, o que deu gás à reemergência do tema por aqui foi a queda da desigualdade medida nas pesquisas domiciliares, que se prolongou durante toda a primeira década dos anos 2000 .

É difícil precisar quais foram os primeiros trabalhos que detectaram essa queda, imprevista pelos estudiosos do tema. Porém, pode-se afirmar que já no início dos anos 2000 se sabia que a desigualdade de rendimentos individuais entre a população economicamente ativa com rendimentos não nulos estava em queda (HOFFMANN, 2002a), e, pouco anos mais tarde, muitos pesquisadores já haviam identificado uma redução perceptível da desigualdade de rendimentos domiciliares per capita desde 2001 (BARROS et al., 2006; FERREIRA et al., 2006; HOFFMANN, 2006; IPEA, 2006; NERI, 2005; SOARES, 2006). Alguns foram céticos, ao menos de início: Salm (2006), por exemplo, atirou para todos os lados, decretando a irrelevância da queda de 4\% do coeficiente de Gini entre 2001 e 2004 diante do alto nível de desigualdade ainda registrado.

Outro ponto levantado por ele foi a contradição entre os resultados da PNAD e a deterioração da distribuição funcional da renda registrada no Sistema de Contas Nacionais (SCN). A compatibilização entre PNAD e SCN feita por Barros, Cury e Ulyssea (2006), contudo, indicava que, levando em conta os rendimentos não monetários e alguns pressupostos fortes quanto à distribuição dos rendimentos de capital, a PNAD subestimaria apenas o nível da renda, e não o grau de desigualdade. Hoffmann e Ney (2008), por sua vez, mostraram que a nova série do SCN produzida pelo IBGE apresentava estabilidade, e não diminuição, da remuneração dos empregados na distribuição funcional da renda, e que a queda da desigualdade na PNAD era consistente com isso, pois havia se dado sobretudo em função da melhor distribuição dos rendimentos do trabalho.

A recuperação da remuneração dos empregados no SCN depois de 2003 e a continuação da queda da desigualdade nas PNADs sepultaram as dúvidas, e a volta do crescimento econômico fez com que o Brasil fosse comemorado como um caso raro de desenvolvimento 
com redistribuição. As Figuras 8 e 9 dão a dimensão dos resultados das PNADs, trazendo, respectivamente, os coeficientes de Gini e o valor médio real para várias definições de rendimentos: renda domiciliar per capita, renda individual total para indivíduos de 15 anos ou mais, renda total do trabalho para ocupados com remuneração positiva e renda horária do trabalho principal para indivíduos entre 15 e 65 anos ocupados com remuneração positiva que trabalharam entre 15 e 85 horas na semana. ${ }^{10}$

Na Figura 8, os Ginis das quatro variáveis de rendimentos têm comportamento muito semelhante: leve queda no final dos anos 1970, seguida por relativa estabilidade e, depois, aumento pronunciado da desigualdade no final da década de 1980 e, posteriormente, redução prolongada para os menores valores da série histórica. As séries divergem só quanto ao início desse último processo. No caso da renda domiciliar per capita, o Gini começou a declinar de forma consistente a partir de 2001; nas demais variáveis a queda já era perceptível na segunda metade dos anos 1990.

A Figura 9 demonstra a volatilidade da renda média durante o período. O Gini começou sua queda em anos ainda de crise; só a partir do biênio 2003-2004 as PNADs registraram crescimento da renda conjuntamente com o declínio da desigualdade. ${ }^{11}$ Entre 2001 e 2013, a renda média real subiu entre 28\% (renda total do trabalho) e $47 \%$ (renda domiciliar per capita), e o coeficiente de Gini caiu entre $12 \%$ e $14 \%$ nas PNADs. Por consequência, os índices de pobreza também diminuíram bastante. Souza (2015) concluiu que dois outros levantamentos domiciliares - a Pesquisa de Orçamentos Familiares (POF) e o Censo Demográfico - corroboram essas tendências gerais, principalmente depois de procedimentos de harmonização para mitigar as diferenças entre as pesquisas. Uma ressalva é que, em comparação com POFs e Censos, as PNADs subestimam o nível da desigualdade.

No plano político, o crescimento com redistribuição virou um pilar retórico das campanhas e dos governo Lula e Dilma Rousseff. Em alguns casos, a politização foi reforçada por trabalhos acadêmicos ou de divulgação acadêmica (e.g., NERI, 2007). Por alguns anos, a discussão da "nova classe média", iniciada por Neri (2008), pautou a imprensa e o governo, culminando em uma definição oficial da classe média (BRASIL. Secretaria de Assuntos Estratégicos, 2012), algo possivelmente inédito no contexto internacional.

No campo acadêmico, houve proliferação de estudos para explicar as causas da redução da desigualdade. ${ }^{12}$ Como nem a concepção hierárquica de um continuum de renda nem as ferramentas para monitorá-la mudaram, as explicações seguiram os moldes anteriores. Os estudos empíricos convergiram para a conclusão de que o mercado de trabalho era o grande herói por trás da queda do coeficiente de Gini, formando-se então

$\overline{10}$ Essa última série foi omitida da Figura 9 para facilitar a visualização. Sua tendência temporal é muito semelhante à da renda total do trabalho.

11 O pico das rendas médias em 1986 é uma anomalia causada pelos efeitos de curto prazo do Plano Cruzado.

12 Parte importante desses estudos foi reunida nos excelentes volumes organizados por Ricardo Paes de Barros, Miguel Foguel e Gabriel Ulyssea (2006, 2007). 
Figura 8. Coeficientes de Gini para a renda domiciliar per capita, renda individual total, renda total do trabalho e renda horária do trabalho principal - Brasil, 1976-2013

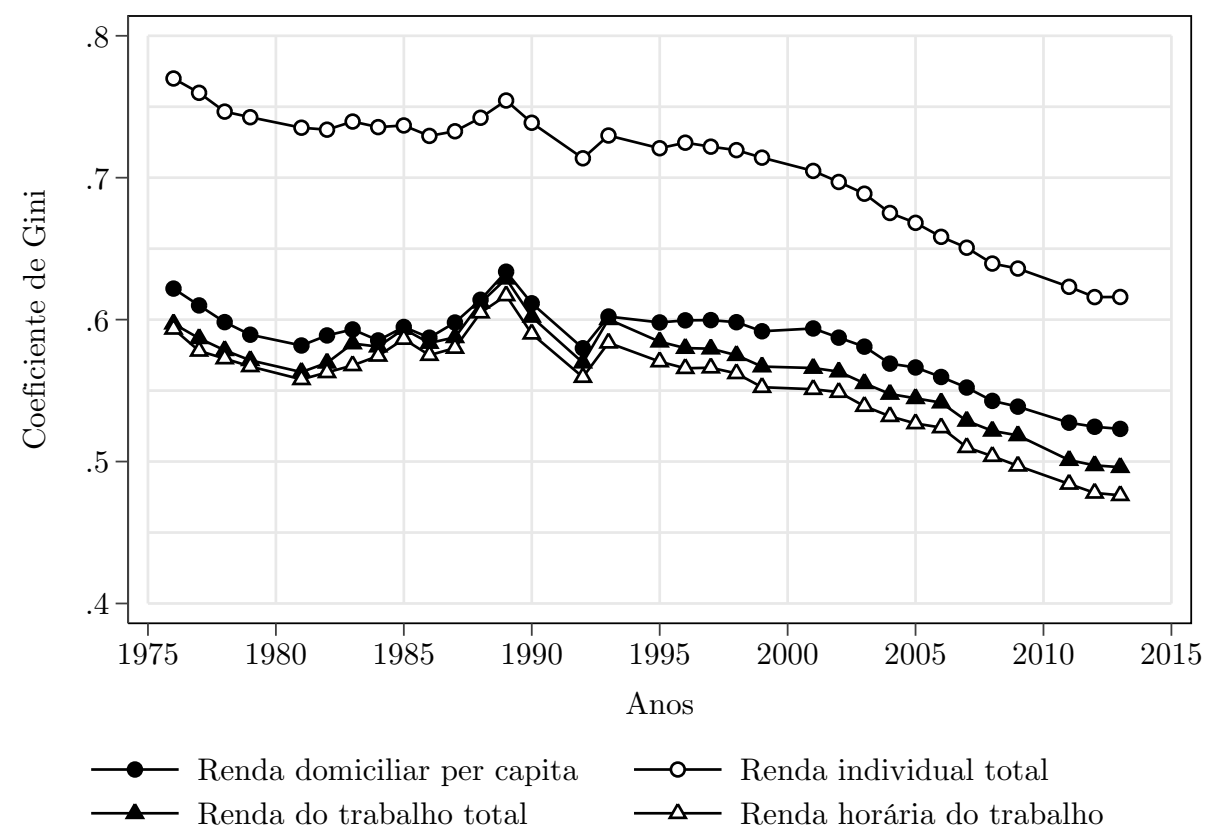

Fonte: elaboração do autor a partir dos microdados das PNADs.

N.B.: exclusive áreas rurais da região Norte (exceto Tocantins) e Centro-Oeste. A série per capita exclui domicílios com algum rendimento ignorado; a individual total inclui indivíduos com 15 anos ou mais sem rendimentos ignorados; a do trabalho inclui ocupados remunerados de qualquer idade; a horária do trabalho inclui ocupados remunerados, entre 15 e 65 anos, que trabalharam entre 15 e 85 horas por semana.

Figura 9. Médias mensais para a renda domiciliar per capita, renda individual total e renda total do trabalho - Brasil, 1976-2013 (R \$ 2013)

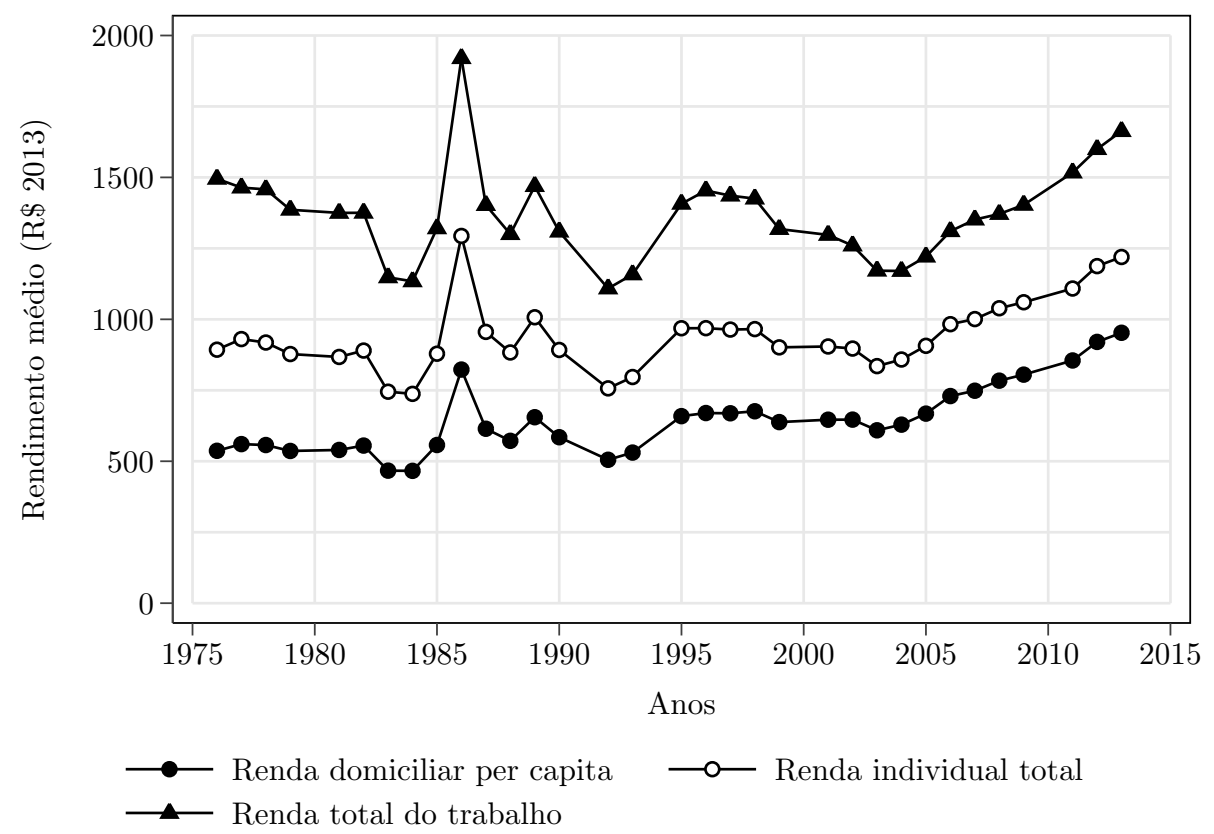

Fonte: elaboração do autor a partir dos microdados das PNADs.

N.B.: exclusive áreas rurais da região Norte (exceto Tocantins) e Centro-Oeste. Rendimentos deflacionados pelo Índice Nacional de Preços ao Consumidor (INPC), seguindo Corseuil e Foguel (2002). A série per capita exclui domicílios com algum rendimento ignorado; a individual total inclui apenas indivíduos com 15 anos ou mais sem rendimentos ignorados; a trabalho inclui ocupados com remuneração positiva de qualquer idade. 
relativo consenso acerca da influência dos avanços do sistema escolar no processo, com a diminuição da heterogeneidade educacional e a compressão dos retornos à educação concomitantes ao declínio da desigualdade (BARROS; FRANCO; MENDONÇA, 2007b; FERREIRA et al., 2006; FOGUEL; AZEVEDO, 2007; MENEZES-FILHO; FERNANDES; PICHETTI, 2007). Os sucessivos aumentos reais do salário mínimo, a geração de empregos formais, a redução da segmentação (setorial e geográfica) e da discriminação (por sexo e cor) foram causas secundárias da menor concentração de renda no mercado trabalho (BARROS; FRANCO; MENDONÇA, 2007a; FIRPO; REIS, 2007; SOUZA; OSORIO, 2014; ULYSSEA, 2007). ${ }^{13}$

As análises de classes chegaram a conclusões parecidas, considerando a perda de prêmios educacionais a transformação mais significativa (SANTOS, 2015a; SANTOS, 2015b; SOUZA; CARVALHAES, 2014). No caso da mobilidade intergeracional, Costa Ribeiro (2012) demonstrou que o declínio dos retornos educacionais foi a principal causa da queda da desigualdade de oportunidades no Brasil entre 1973 e 2008.

Essas explicações foram complementadas pelas análises de políticas públicas. Embora seja difícil quantificá-lo, as instituições e o Estado ganharam destaque inédito desde os anos 1970, impulsionado pela expansão das transferências desde a estabilização macroeconômica. O Programa Bolsa Família (PBF) foi objeto de inúmeros estudos, apesar de seu tamanho diminuto como proporção do PIB (em torno de 0,5\% na maior parte dos anos); certamente o PBF é, por margem colossal, o programa brasileiro com maior número de papers por real desembolsado. As conclusões invariavelmente assinalaram sua contribuição substantiva, ainda que minoritária, para a diminuição do Gini da renda domiciliar per capita, elegendo-o como a mais progressiva entre as transferências públicas brasileiras (BARROS; CARVALHO; FRANCO, 2007; HOFFMANN, 2006; HOFFMANN, 2013; SOARES et al., 2007; SOARES et al., 2009; SOARES et al., 2010b). Em grau menor, os efeitos indiretos do salário mínimo via Benefício de Prestação Continuada $(\mathrm{BPC})^{14} \mathrm{e}$ Previdência Social também foram considerados progressivos, contribuindo para reduzir a desigualdade, com efetividade muito mais baixa que a do PBF (BARROS, 2007).

O Brasil não foi o único país a conjugar crescimento e redistribuição nos anos 2000; muitos países latino-americanos viveram a mesma tendência. Entre 2000 e 2010, o PIB per capita nos principais países da região teve aumento real de $22 \%$, mais do que o dobro da Europa Ocidental e dos países anglófonos desenvolvidos, revertendo a relação observada nos anos 1980 e $1990 .{ }^{15}$ Lopez-Calva e Lustig (2010) observaram que o Gini

$13 \mathrm{Um}$ aspecto pouco estudado do período recente diz respeito aos efeitos do crescimento do número médio de empregados por estabelecimento sobre a desigualdade. Corseuil, Moura e Ramos (2009) identificaram o fenômeno e confirmaram que esse aumento generalizado do tamanho médio contribuiu decisivamente para a expansão do emprego formal nos anos 2000, revertendo a influência negativa observada entre 1995 e 1999.

14 O BPC é um benefício constitucional mensal indexado ao salário mínimo pago indivíduos portadores de deficiência e idosos cuja renda per capita mensal está abaixo de 1/4 de salário mínimo.

15 Dados do Maddison Project Database (2013). Os países latino-americanos considerados foram Argentina, 
caiu em 12 de 17 países da região entre 2000 e 2006 e atribuíram o fenômeno aos mesmos fatores destacados pela literatura nacional: compressão dos diferenciais salariais associados à escolaridade em função da expansão educacional e criação e/ou expansão dos programas de transferência de renda para os mais pobres.

Logo, o Brasil e a América Latina passaram de patinhos feios a vedetes no combate à desigualdade. O otimismo da comunidade acadêmica era palpável. Por exemplo, há alguns anos escrevi, para um público estrangeiro, uma análise essencialmente benevolente das tendências da desigualdade, pobreza e proteção social no Brasil, não obstante o reconhecimento de que ainda havia um longo caminho a seguir e de que provavelmente o crescimento econômico no curto prazo perderia o gás (SOUZA, 2012). Soares (2008, p. 16) especulou que podíamos "estar no início de uma revolução no nosso padrão civilizatório", projetando que, se o ritmo fosse mantido, o Brasil atingiria níveis americanos de desigualdade em uma década e chegaria ao patamar canadense em pouco menos de 25 anos. Ao comparar a evolução do Gini no Brasil com dados históricos esparsos para a Europa e América do Norte, Soares concluiu que nosso ritmo de redução da desigualdade era adequado e que o grande desafio seria mantê-lo por mais 20 ou 30 anos.

Os avanços empíricos incentivaram reinterpretações teóricas mais amplas sobre a trajetória de longo prazo do Brasil. Alston et al. (2013), Arretche (2016), Singer (2012) e outros procuraram dar sentido a esses acontecimentos por meio de abordagens historicamente enraizadas e teoricamente orientadas para a dinâmica institucional brasileira. Cada um o fez à sua maneira; em comum, havia a crença na possibilidade iminente de desenvolvimento. O capítulo 6 dialoga diretamente com alguns desses autores. Por ora, vale apenas notar como o contraste entre esse otimismo e o pessimismo de países ricos operou por cima de uma concordância quanto ao lugar central do Estado e das políticas públicas.

Em retrospecto, é fácil ver que o otimismo que à época parecia tão justificável era exagerado. As comparações internacionais históricas estavam claramente influenciadas pela narrativa kuznetsiana de melhorias graduais na distribuição de renda. Só com o trabalho de Piketty e afins conclusões antigas voltaram à tona: mesmo nos países ricos, a queda da concentração no topo foi abrupta e catastrófica, não havendo registros claros de países que caminharam devagar e sempre rumo a sociedades igualitárias.

A metanarrativa da queda da desigualdade e a confiança no aperfeiçoamento contínuo das nossas instituições obscureceu a literatura que apontava o caráter relativamente marginal das mudanças nas políticas públicas e a regressividade de algumas transferências sociais. Há muitos anos, Rodolfo Hoffmann (2003, 2004, 2009) vem chamando a atenção para a Previdência Social - maior gasto da União - e para os efeitos distributivos do

Brasil, Chile, Colômbia, México, Peru, Uruguai e Venezuela. Apesar dos bons números, o crescimento agregado nesses oito países foi inferior à média mundial (29\%) devido ao desempenho excepcional dos países asiáticos, cujo PIB per capita teve crescimento real de $66 \%$ na década. 
tratamento privilegiado historicamente concedido a funcionários públicos. Apesar das reformas, essa situação não se alterou radicalmente nos últimos anos (MEDEIROS; SOUZA, 2014; RANGEL, 2011; SILVEIRA, 2008; SOUZA, 2012, entre outros). Outros entraves a uma sociedade mais igualitária também permanecem, como o aumento do prêmio salarial associado ao funcionalismo público (BARBOSA; SOUZA, 2012; SOUZA; MEDEIROS, 2013b) e a má utilização do potencial redistributivo do imposto de renda e demais impostos sobre patrimônio em meio a uma carga tributária altamente dependente de impostos indiretos (HOFFMANN, 2002b; SILVEIRA, 2008; SOARES et al., 2010a; CARVALHO JR, 2010). Com efeito, a comparação entre as POFs 2002-2003 e 2008-2009 revela que seria um enorme exagero tratar a última década como um momento de profunda virada redistributiva das políticas públicas, embora o perfil distributivo dos fluxos monetários entre as famílias e o Estado tenha melhorado (SOUZA; MEDEIROS, 2013a).

A dissipação do otimismo foi forte nos últimos anos. A economia brasileira desacelerou e depois colapsou. ${ }^{16}$ Os prognósticos para o curto e médio prazo são ainda mais sombrios, reforçados por uma crise política inimaginável há poucos anos. Pior, mesmo nas PNADs, o declínio do coeficiente de Gini da renda domiciliar per capita perdeu fôlego desde 2008, praticamente chegando ao fim a partir de 2011. Se, entre 2003 e 2008, o Gini caiu em média 0,008 pontos ao ano (a.a.), no período 2008-2013 o ritmo caiu pela metade (0,004 pontos a.a.), sendo de apenas 0,002 pontos a.a. entre 2011 e 2013. A previsão de Soares de que o Brasil poderia atingir em 2030 o coeficiente de Gini observado hoje no Canadá (em torno de 0,4,$)$ precisa ser atualizada: se prosseguir o ritmo de 2008-2013, só chegaremos lá por volta de 2045; se continuarmos na toada de 2011-2013, só em 2070. O Brasil continua entre os países mais desiguais do mundo, como atestam os dados de pesquisas domiciliares internacionais compilados por Milanovic (2015): em 2008, os brasileiros mais pobres estavam em situação comparável aos mais pobres do mundo em desenvolvimento, os mais ricos estavam próximos dos mais ricos dos países desenvolvidos, e o Gini brasileiro era o $111^{\circ}$ mais alto em 117 países. ${ }^{17}$

Com o esgotamento do processo observado nas pesquisas domiciliares na última década, o momento é apropriado para reforçar a ponte entre o Brasil e os estudos internacionais, cobrindo dois tópicos ainda não devidamente explorados por aqui: a concentração

16 Entre 2003 e 208, o PIB real cresceu $4,8 \%$ ao ano. Com a crise mundial, houve um leve recuo de $0,1 \%$ em 2009, seguido por crescimento de 7,5\% no ano eleitoral de 2010. O triênio 2011-2013 teve média mais baixa, mas ainda positiva, em torno de $2,5 \%$ ao ano. Em 2014 a variação real do PIB foi de meros 0,1\% e, em 2015, houve queda de 3,8\%, conforme os dados do Banco Central do Brasil. Ver $<$ http://www.bcb.gov.br>. Acesso em 19 jul. 2016.

17 A ânsia nacional por títulos faz com que a imprensa e o senso comum proclamem o Brasil como $o$ país mais desigual do mundo. Não há motivo para tanto. É provável que o Brasil até mesmo pague o preço por possuir pesquisas domiciliares boas, dentro dos limites intrínsecos a elas, e que a menor desigualdade relativa em muitos outros países em desenvolvimento seja só resultado da precariedade das suas pesquisas. As dificuldades inerentes à harmonização de pesquisas internacionais impõem extrema cautela antes de apontar determinado país como o mais ou o menos desigual. Dado o estado atual do conhecimento, o máximo que se pode referendar é a afirmação menos sensacionalista de que estamos entre os mais desiguais. 
de renda entre os mais ricos e a evolução histórica de longo prazo da nossa desigualdade. A Parte II desta tese ambiciona justamente contribuir para isso.

No primeiro caso, uma característica do debate recente é que, ao contrário da literatura internacional discutida neste e nos capítulos anteriores, sua visibilidade se deu sem que os ricos ocupassem o centro das atenções, vale dizer, sem que concepções dicotômicas da estratificação se tornassem predominantes ou mesmo frequentes. Há muitas explicações plausíveis para isso, desde as mais cínicas (em um país tão desigual quanto o nosso, os pesquisadores provavelmente fazem parte ou estão próximos dos mais ricos) até as mais benevolentes (o movimento novo da última década foi a elevação do padrão de vida dos mais pobres). De todo modo, dados o clima intelectual, a adoção tácita de grupos de referência estrangeiros (as ditas classes médias dos países ricos, muitas vezes bastante idealizadas) e as ferramentas selecionadas para estudar o assunto, é pouco surpreendente que a concepção hierárquica de um continuum de renda tenha permanecido a mais usada para entender as mudanças na distribuição de renda em anos de crescimento econômico.

Ainda assim, a literatura nunca perdeu totalmente de vista que o traço distintivo da distribuição de renda brasileira é a concentração no topo. Há cerca de duas décadas, Bonelli e Ramos (1993, p. 78) descreveram a distribuição de renda brasileira por uma "forte assimetria entre os estratos mais pobres e a fina camada do percentil superior da distribuição", e Barros e Mendonça (1995b, p. 13) vaticinaram que "claramente, a desigualdade de renda no Brasil concentra-se na cauda superior da distribuição, isto é, entre os 10\% mais ricos". Eles não foram os únicos: a controvérsia do início dos anos 1970 destacou recorrentemente o topo da distribuição. O pensamento social brasileiro está repleto de reflexões semelhantes, sob diversas roupagens. Por sinal, um fato nem sempre reconhecido é que o Brasil possui uma pequena, mas pioneira, literatura quantitativa sobre os ricos, com contribuições importantes para a discussão internacional sobre linhas de riqueza (AFONSO, 2014; ALBUQUERQUE, 1994; CAMPOS et al., 2005; CASTRO, 2014; DEDECCA, 2014; FERREIRA, 2001; HOFFMANN, 2005; MEDEIROS, 2005; MEDEIROS, 2006). Alguns textos mais antigos, inclusive, usaram dados tributários de modo mais ou menos semelhante à prática então corrente nos Estados Unidos e alhures (KINGSTON; KINGSTON, 1972; MORTARA, 1949a; MORTARA, 1949b, entre outros).

Medeiros, Souza e Castro (2015a, 2015b) e Souza e Medeiros (2015) deram um passo para aproximar a literatura brasileira da internacional, produzindo estimativas para as frações mais ricas da população entre 2006 e 2012. Diferentemente do revelado pelas pesquisas domiciliares, os dados tributários apresentaram estabilidade na concentração no topo no período, resultado bastante robusto às decisões metodológicas dos autores. Diversos procedimentos para combinar dados tributários e levantamentos domiciliares indicaram que o coeficiente de Gini "corrigido" - levando em conta a subestimação da renda dos mais ricos nas PNADs e afins - também permaneceu estável no período. 
Um dos objetivos desta tese é aprofundar essa linha de pesquisa, recorrendo a dados tributários e, secundariamente, às pesquisas tradicionais para explorar a trajetória de longo prazo da desigualdade no Brasil a partir o enfoque nos mais ricos. A primeira série do tipo - i.e., com a evolução histórica da fração apropriada pelos 0,1\%, 1\%, 5\% e $10 \%$ mais ricos - foi apresentada preliminarmente por mim em Souza (2014); parte dos dados foi usada por Souza e Medeiros (2015). Desde então, foi possível enriquecer a série e refinar procedimentos metodológicos.

Esse tipo de abordagem também permite lidar com a segunda lacuna mencionada acima, a evolução histórica da desigualdade no Brasil. Nos últimos anos, as origens, causas e consequências da alta desigualdade de renda latino-americana voltaram à tona com tentativas de explicar o atraso econômico da região. As antigas teses sobre colônias de "exploração" e "povoamento" ganharam roupagem moderna com interpretações neoinstitucionalistas para o subdesenvolvimento. ${ }^{18}$ Nessa perspectiva, a divergência econômica entre Estados Unidos e Canadá e o resto das Américas seria um legado do período colonial, que introduziu no resto do continente instituições de cunho extrativo fundamentadas em uma distribuição profundamente desigual de renda e riqueza, cuja tendência a perpetuar-se ao longo do tempo acabou condicionando e limitando as possibilidades de desenvolvimento.

Stanley Engerman e Kenneth Sokoloff foram pioneiros nessa reelaboração. Para eles, os fatores de produção disponíveis no continente incentivaram diferentes formações econômicas e, por sua vez, diferentes graus de desigualdade de riqueza, renda e poder político. No Brasil e no Caribe, as condições climáticas e do solo eram apropriadas para o cultivo de itens com alto valor no mercado global, produzidos com maior eficiência em grandes propriedades. Com isso, o trabalho escravo foi introduzido em larga escala, originando distribuições de poder e riqueza muito concentradas. Já nas colônias americanas, as condições físicas e humanas favoreceram a proliferação de propriedades familiares médias, gerando uma estratificação mais igualitária. ${ }^{19}$

Esses arranjos teriam condicionado o desenvolvimento posterior: se, nos primeiros séculos de colonização, as diferenças eram pequenas ou nulas, com o tempo, o processo de industrialização só pôde ocorrer nas colônias do Norte, que ofereciam condições para a participação ampla da população em sociedades comerciais. No resto do continente, o grau de desigualdade teria limitado o desenvolvimento de mercados, e as elites teriam usado seu poder econômico e político para restringir a competição e manter seus privilégios (ENGERMAN; SOKOLOFF, 1997, 2002; SOKOLOFF; ENGERMAN, 2000):

18 Sobre a história do dualismo colônia de exploração/povoamento, ver Monasterio e Ehrl (2015).

19 Engerman e Sokoloff classificam o México, o Peru e outras colônias espanholas em uma terceira categoria, não discutida aqui. 
[M]aior igualdade ou homogeneidade na população levou, ao longo do tempo, a instituições políticas mais democráticas, maior investimento em bens públicos e infraestrutura e a instituições que ofereciam acesso mais amplo a oportunidades econômicas. Em contraste, onde havia desigualdade extrema, como na maior parte das sociedades das Américas, as instituições políticas eram menos democráticas, os investimentos em bens públicos e infraestrutura eram mais limitados, e as instituições que apareceram tenderam a oferecer acesso muito desequilibrado às oportunidades econômicas e, portanto, concediam muitas vantagens à elite. [...] Se os processos iniciais de industrialização eram baseados em participação ampla na economia comercial, como sugerido pelas evidências dos três líderes desses processos (Inglaterra, Estados Unidos e Países Baixos), então economias com instituições que ofereciam acesso restrito podem ter sido menos capazes de atingir o potencial das novas tecnologias, mercados e outras oportunidades econômicas que se desenvolveram ao longo do século XIX. (ENGERMAN; SOKOLOFF, 2002, p. 4-5)

Daron Acemoglu, Simon Johnson e James Robinson $(2001,2002)$ foram por caminho mais empírico e menos preocupado com a disponibilidade de fatores produtivos ou com a história da América Latina. As semelhanças com Engerman e Sokoloff, contudo, são maiores do que as diferenças. O colonialismo europeu teria introduzido ou fortalecido instituições extrativas em áreas até então ricas, em contraposição às "instituições de propriedade privada" estimuladas nas áreas mais atrasadas, que garantiram a segurança da propriedade para amplas camadas da população. Dessa forma, a emergência de tecnologias e arranjos que dependiam de participação em larga escala da população foi muito mais fácil nessas últimas regiões. Quando há muita desigualdade, em especial de poder político, não só o recrutamento de empreendedores é mais complicado, como também as elites tendem a bloquear inovações que possam alterar o equilíbrio de poder.

Tudo isso injetou fôlego a um debate que ficou em segundo plano desde as teorias da dependência nos anos 1960 e 1970. As críticas foram rápidas. John Coatsworth (2008) foi particularmente contundente ao questionar as relações causais e da caracterização das elites locais propostas por Engerman, Sokoloff e demais. Para os fins desta tese, é interessante notar a recuperação, por vias diversas, da antiga oposição entre elites e massas e o ímpeto ao estudo da desigualdade latino-americana no longo prazo. Um traço comum da onda neo-institucionalista é a hipótese de que a desigualdade na América Latina sempre foi alta, algo defendido pelas teorias clássicas sem evidências empíricas muito definitivas.

Muitos pesquisadores sentiram-se motivados a mudar essa situação, produzindo diversas novas estimativas para os países latino-americanos (BÉRTOLA et al., 2009; BÉRTOLA et al., 2010; PRADOS DE LA ESCOSURA, 2007; FRANKEMA, 2009; WILLIAMSON, 2010; WILLIAMSON, 2015). Não obstante os avanços, a precariedade dos dados ainda bloqueia o surgimento de consensos. Por exemplo, os trabalhos de Luis Bértola e seus coautores, que contêm de longe as melhores estimativas para o Brasil, reportam valores distintos para o Gini estimado em 1872:, respectivamente, 0,392 em Bértola et al. (2009, p. 466) e 0,548 em Bértola et al. (2010, p. 326). O que é relativamente bem 
estabelecido é que a desigualdade na região parece ter aumentado bastante, chegando a valores historicamente inéditos, na Belle Époque entre a década de 1870 e a $1^{a}$ Guerra.

Em meio a essas dúvidas, a interpretação revisionista, avançada sobretudo por Jeffrey Williamson $(2010,2015)$, é uma novidade desafiadora. Williamson prega que a desigualdade latinoamericana não teria sido muito maior do que a observada na Europa até o início do século XX e que, portanto, a divergência entre a América Latina e o mundo desenvolvido quanto à desigualdade teria origem no último século, pois o continente perdeu o "grande nivelamento" vivido por europeus, americanos e afins, como refletido, por exemplo, na literatura sobre top incomes.

A hipótese é ousada, e precisa de maior substrato empírico para ser avaliada. O próprio Williamson é cauteloso ao lembrar que, se definida em termos de "taxa de extração", ${ }^{20}$ aí sim a América Latina - e o Brasil, em particular - se apresentaria desde sempre mais desigual que a Europa: como os Ginis históricos estimados estão próximos, a menor renda em nosso continente reduz a desigualdade máxima plausível e, portanto, aumenta a taxa de extração.

Como Coatsworth, Williamson quis contestar a interpretação prevalecente das raízes coloniais do atraso econômico na região. Se, na Europa, as instituições associadas à alta concentração de renda não impediram o florescimento da indústria e o crescimento, não haveria por que alegar que isso ocorreu por aqui. Para esta tese, no entanto, o que importa é a avenida aberta por sua caracterização da desigualdade, que coloca o problema sob nova luz e gera perguntas ainda sem respostas definitivas.

Frankema (2009), por exemplo, sugeriu que a América Latina de fato não passou por uma grande compressão da desigualdade, mas que ela tampouco foi estável. Sua conjectura é que houve uma trajetória em ondas, partindo de um nível relativamente alto. Durante a primeira era da globalização, a desigualdade teria aumentado, com um ponto de inflexão nos anos 1920 ou 1930; em seguida, a era do protecionismo e substituição de importações teria promovido uma redução gradual, até o momento em que os desequilíbrios políticos e econômicos e as crises da dívida que afligiram os diversos países da região provocaram uma nova inflexão, com as reformas estruturais e a maior integração aos mercados globais ensejando novo aumento da desigualdade. Frankema explica essas idas e vindas de modo relativamente eclético, vinculando a primeira onda de ascensão da desigualdade à interação entre mercados internacionais e à herança colonial e culpando a mudança tecnológica orientada a habilidades a boa e velha skill-biased technological change, discutida acima pelo aumento mais recente.

20 A taxa de extração corresponde à razão entre a desigualdade observada e a desigualdade máxima possível. Esta última é calculada levando em conta um limiar de subsistência que restringe a desigualdade máxima em países pobres. A intuição é que comparar estimativas brutas em sociedades com renda média muito diferente pode ser problemático, porque a extensão da desigualdade máxima observável é positivamente correlacionada ao tamanho do "excedente econômico", isto é, a produção para além da necessidade de subsistência da sociedade. 
Ainda há muito a fazer nessa seara antes que uma resposta mais ou menos definitiva possa emergir. O estudo da história da desigualdade no Brasil e na América Latina avançou muito nos últimos anos, e pode avançar ainda mais. A análises empíricas da Parte II acrescentam novas informações à discussão e tentam responder diretamente à conjectura revisionista de Williamson.

\subsection{Considerações finais}

Muitas histórias intelectuais podem ser escritas sobre os últimos 40 anos. Poucas rivalizariam, na capacidade de ilustrar as rupturas e continuidades do clima intelectual e as disputas políticas do período, com a história das reflexões sobre a desigualdade. Este capítulo tentou recuperar essa história, completando a investigação das representações e explicações para a estratificação iniciada no capítulo 1. Se as questões distributivas voltaram à tona por um breve momento no início dos anos 1970, o aprofundamento da crise econômica dos países ricos acabou desaguando em um nova conjuntura que via na problematização da desigualdade uma distração ou um obstáculo à prosperidade. A situação, no entanto, logo mudou, junto com a representação básica da estratificação: conforme os discursos sobre o aumento da desigualdade nos Estados Unidos e alhures se acumularam, as concepções binárias voltaram à moda, atingindo visibilidade máxima no sucesso de Piketty e coautores com seus estudos sobre os ricos. No Brasil, a trajetória foi parcialmente semelhante, mas os motivos foram bem diferentes.

Por mais que as últimas duas décadas tenham caminhado rumo a certo ecletismo teórico, a guinada liberal dos anos 1980 permanece como referência básica para muitas das discussões atuais. Um dos seus efeitos foi não só colocar temporariamente a desigualdade em segundo plano, como sacramentar de vez a inversão do fardo da prova, colocando em dúvida a legitimidade das questões distributivas, em especial a ação redistributiva do Estado. A reaparição do assunto no centro do debate intelectual exigiu esforços para reafirmar sua relevância, em termos normativos ou consequencialistas. Apesar de esses esforços não serem mais tão necessários, a dúvida sempre paira no ar.

A virada intelectual e política que culminou na era Reagan-Thatcher representou a emergência de uma constelação de teorias e sentimentos que, bem ou mal, conseguiu dar respostas concretas e politicamente palatáveis para um mal-estar amplamente reconhecido. Determinados custos e consequências dessas respostas adquiriram maior evidência com o tempo, como se vê pela nostalgia pelos "trinta gloriosos". Isso não apaga o fato de que as principais alternativas à época estavam - e em boa medida ainda estão - em grandes dificuldades teóricas e políticas. As teorias de classes, mesmo as não marxistas, entraram em nova fase de intenso questionamento e, no fim, abandono das suas pretensões mais elevadas, aproximando-se inclusive do instrumental neoclássico. 
O que essas teorias não abandonaram foi a insistência tipicamente sociológica nas relações de produção ou na situação de mercado como o ponto de partida e às vezes até de chegada. Assim, abriu-se a porta para que o debate sobre estratificação fosse revigorado sobretudo por economistas, há muito acostumados a priorizar a análise da distribuição de renda. Com isso, não é surpreendente que as investigações tenham enveredado de início para os efeitos de mudanças tecnológicas e de deslocamentos da oferta e/ou da demanda.

Seria um exagero dizer que esse quadro mudou por completo nos últimos anos. Porém, não se deve subestimar os desdobramentos recentes. Sob risco de simplificação, o ressurgimento do interesse pela desigualdade veio associado a duas tendências: por um lado, a representação mais frequente da questão distributiva em termos binários ou dicotômicos, com os ricos sob escrutínio constante; por outro, o reconhecimento crescente da influência dos arranjos institucionais de cada país, considerados mais como processos históricos e políticos do que como tentativas racionais de maximizar a eficiência. Em suma, a economia política da desigualdade retornou à agenda, e os ricos estão sob escrutínio constante.

Até o momento, as respostas ainda são díspares, principalmente quanto à relação entre o aumento da desigualdade e a eficiência econômica. Se uns dizem que a concentração no topo é fruto de rent-seeking, outros falam o oposto, atribuindo-a à eficiência do mercado. Mais ainda, o nível de abstração adequado para as explicações está em disputa: enquanto a maioria dos pesquisadores tenta avaliar os efeitos distributivos de impostos, sindicatos, salário mínimo e afins, outros, como Levy e Temlin (2007) e Hacker e Pierson (2010), sugerem que se deve olhar para transformações mais profundas - e menos palpáveis ou quantificáveis - que explicariam, por exemplo, por que tantas mudanças com a mesma direção ocorreram ao mesmo tempo. A tensão entre impulsos analíticos e sintéticos tem sido produtiva, e a Parte II, especialmente o capítulo 6, explora essa via.

A pergunta acadêmica e política subjacente à discussão atual é simples: sob que condições sociedades capitalistas democráticas conseguem redistribuir renda? Apesar de ser ainda muito pautada pelo aumento recente da concentração no topo nos Estados Unidos, é evidente que se trata de uma questão fundamental também no contexto brasileiro. Nossa tradição de estudos sobre estratificação não foi imune à trajetória internacional, pelo menos até o momento em que o estudo dos mais ricos tornou-se preocupação central lá fora, algo que não ocorreu por aqui. Afinal, acreditávamos estar na contramão das tendências mundiais, com um declínio prolongado e pacífico da desigualdade de renda em um período marcado pela recuperação econômica. Era a situação dos sonhos de qualquer governante: o mítico crescimento pró-pobre.

Infelizmente, o ciclo virtuoso parece agora esgotado. As crises política e econômica de 2014-2016 minaram toda a euforia. Até os avanços da década passada foram mais incertos do que se pensava: as evidências baseadas em dados tributários revelam que pouco ou nada mudou no topo da distribuição de renda - o que não significa, evidentemente, que 
não tenham ocorrido mudanças na distribuição de renda ou nos percentuais de pobreza desde a virada do século. O momento é propício para variar o ponto de vista privilegiado nos últimos anos e adentrar o debate internacional contemporâneo, ainda mais porque as questões em jogo são cruciais para a compreensão da desigualdade brasileira. No mínimo por motivos empíricos, a concentração de renda entre os mais ricos e as tendências de longo prazo são fulcrais para o estudo da estratificação social no Brasil.

A Parte II vai nessa direção, combinando dados tributários e pesquisas domiciliares para investigar a distribuição de renda no Brasil desde o final dos anos 1920. A análise empírica é guiada por algumas das principais hipóteses apresentadas nesta Parte I. No caso dos níveis e tendências da desigualdade, o "U invertido" de Kuznets é o candidato óbvio, mas, como veremos, a possibilidade aventada por Jencks e Piketty de relativa estabilidade perturbada apenas por rupturas exógenas também faz jus a ser examinada, assim como as ondas de ascensão-queda-ascensão da desigualdade de Frankema. Quanto à especificidade da nossa trajetória, o debate com Williamson é tão inevitável quanto fecundo. Por fim, no que diz respeito aos determinantes do fenômeno, a industrialização, os choques exógenos e as instituições políticas merecem prioridade.

Antes da análise dos dados, contudo, é preciso discutir e documentar os procedimentos metodológicos por trás deles, como faço no próximo capítulo. 
Parte II

Os ricos no Brasil 


\title{
4 Dados tributários: modos de usar
}

\author{
[W]hen you can measure what you are speaking about, and express it in \\ numbers, you know something about it; but when you cannot measure it, \\ when you cannot express it in numbers, your knowledge is of a meagre \\ and unsatisfactory kind: it may be the beginning of knowledge, but you \\ have scarcely, in your thoughts, advanced to the stage of science, \\ whatever the matter may be.
}

Lord Kelvin, Electrical units of measurement (1883)

\subsection{Introdução}

A autoconfiança da concepção vitoriana de ciência pode ter ficado pelo caminho, mas a ânsia enunciada na epígrafe por Sir William Thomson, $1^{\circ}$ Barão Kelvin de Largs (Escócia), soa mais contemporânea do que nunca. Produzir números, contudo, quase nunca é algo tão direto e inocente quanto pode parecer, especialmente quando as informações primárias foram coletadas com outros propósitos.

O objetivo deste capítulo é, portanto, documentar e justificar as escolhas metodológicas e procedimentos adotados para transformar os dados brutos do imposto de renda em séries de longo prazo da concentração de renda entre os ricos no Brasil. Para deixar claras as qualidades e as limitações dos dados, o capítulo é abrangente, cobrindo desde os motivos para o uso de informações tributárias para o estudo da desigualdade até os detalhes das interpolações e imputações, passando por uma breve caracterização do nascimento e evolução do imposto de renda das pessoas físicas (IRPF) no Brasil.

Além de detalhar as etapas da produção de estimativas para o Brasil, o capítulo trata de um conjunto de questões e obstáculos comuns aos dados tributários de muitos países, consolidando e organizando questões metodológicas nem sempre discutidas explicitamente ou muitas vezes apresentadas de forma excessivamente resumida, em função dos limites tradicionais de espaço em artigos e capítulos de livros.

A mensagem central é que os dados do imposto de renda são a melhor fonte disponível para o estudo da concentração de renda no topo. No Brasil, há informações desde a década de 1920, o que permite expandir os horizontes do nosso debate sobre desigualdade. Seu uso exige uma série de cuidados e procedimentos que extrapolam a zona de conforto proporcionada pelas pesquisas domiciliares amostrais. A maior parte desses procedimentos é pouco controversa e/ou não influencia muito os resultados finais, mas alguns deles são cruciais e põem em relevo as lacunas e limitações das informações disponíveis, como a necessidade de imputação de rendimentos não tributários. 
Todas as análises desta Parte II definem os "ricos" de forma flexível, como os estratos no topo da distribuição de renda convenientemente delimitados por percentis de interesse, isto é, grupos como o $0,1 \%$, o $1 \%$ ou os $5 \%$ mais ricos. Por isso, este capítulo passa ao largo da discussão sobre linhas e indicadores de riqueza. Embora esse debate valha a pena, ele muitas vezes tende a se descolar dos objetivos práticos da pesquisa, assim como ocorre com as controvérsias acerca de linhas de pobreza. Leitores interessados podem consultar os trabalhos de Bose, Chakravarty e D'Ambrosio (2014), Drewnowski (1978), Inhaber e Carroll (1992), Medeiros (2006), Peichl, Schaefer e Scheicher (2010) e outros.

Algumas clarificações terminológicas são importantes. Neste e nos próximos capítulos, os dados das declarações do IRPF são chamados, de forma intercambiável, de "dados tributários", "dados do imposto de renda" e "dados do IRPF". Usos alternativos são sempre cercados de qualificações, como nas ocasiões em que a referência ao "imposto de renda" diz respeito à soma do IRPF com o imposto de renda de pessoas jurídicas (IRPJ).

Quanto à apuração dos rendimentos no IRPF, é importante lembrar que os rendimentos recebidos em um determinado "ano-base" ou "ano-calendário" são reportados nas declarações do ano ou "exercício" seguinte. Nesta tese, as referências dizem respeito aos anos-base. Por exemplo, os resultados para 2013 vêm das tabulações do exercício 2014, que trazem informações sobre os rendimentos auferidos no ano-base 2013.

O capítulo está organizado da seguinte forma: a seção 4.2 explica por que as informações do imposto de renda são tão boas para o estudo da concentração de renda entre os ricos, comparando-as com as das pesquisas domiciliares e elencando suas vantagens e desvantagens; a seção 4.3 fornece o contexto histórico do imposto de renda no Brasil, descreve a evolução do seu papel na nossa estrutura tributária e apresenta comparações internacionais; a seção 4.4 esclarece a lógica de apuração dos rendimentos ao longo do tempo, que afeta decisivamente as informações publicadas; a seção 4.5 traz a lista de fontes disponíveis publicamente com tabulações do IRPF, que são a matéria-prima para as estimativas da concentração de renda no Brasil; a seção 4.6 esclarece qual o conceito de renda compatível com as informações do IRPF e útil para análise da desigualdade; a seção 4.7 enumera os ajustes, correções e imputações iniciais às tabelas publicadas do IRPF; a seção 4.8 justifica a principal medida de desigualdade desta tese e discute os detalhes do método de interpolação escolhido para produzi-la; a seção 4.7 descreve os ajustes finais aos dados; e a seção 4.10 traz as considerações finais a este capítulo. 


\subsection{Por que usar dados do imposto de renda?}

\subsubsection{As limitações das pesquisas domiciliares}

A proliferação de pesquisas domiciliares amostrais supriu a matéria-prima básica dos cientistas sociais quantitativos do século XX e contribuiu para legitimar as próprias ciências sociais como produtoras de conhecimento especializado e de interesse do público em geral. O desenvolvimento dos surveys possibilitou aos sociólogos e afins afirmar um expertise particular de acesso ao "social", considerado valioso por outras instituições e grupos sociais (SAVAGE; BURROWS, 2007, p. 891).

Os censos populacionais modernos, conduzidos pelo menos desde o início do século XIX, já cumpriam em alguma medida esse papel. No entanto, o surgimento de pesquisas amostrais, muito mais baratas, mudou a situação de patamar, a ponto de alguns autores defenderem, um tanto dramaticamente, que as amostras representativas foram tão importantes para as ciências sociais do século XX quanto o telescópio fora para as ciências naturais no século XVI, permitindo a criação de novas esferas de realidade e fatos sociais, como a "opinião pública" (OSBORNE; ROSE, 1999).

Como visto na Parte I, os estudos sobre desigualdade foram muito impactados pela disseminação de pesquisas domiciliares amostrais, não só pela quantidade de informações disponíveis como também pela abordagem da questão. Basta lembrar que quase todas as generalizações empíricas duradouras mencionadas por Hout e DiPrete (2006) como grandes contribuições do comitê de pesquisa sobre estratificação social da Associação Internacional de Sociologia ${ }^{1}$ foram desenvolvidas e/ou testadas a partir de microdados de pesquisas domiciliares amostrais. A mesma generalização vale para o Brasil: a grande maioria dos trabalhos empíricos sobre a nossa distribuição de renda citados nos capítulos 2 e 3 teve como fontes as PNADs, os Censos e outras pesquisas domiciliares.

Nos últimos anos, o primado dos surveys vem sendo contestado por uma série de motivos teóricos e empíricos, como: o grau de rigidez e padronização que privilegia a captação de informações institucionalmente sancionadas; as quedas seculares na disposição dos entrevistados a participar; o interesse crescente por desenhos de pesquisa capazes de isolar relações causais de forma mais convincente, aproximando-se do padrão-ouro experimental das ciências naturais; e a disponibilidade também crescente de fontes alternativas de dados (ANGRIST; PISCHKE, 2010; EINAV; LEVIN, 2013; SAVAGE; BURROWS, 2007).

O mesmo movimento se deu entre as pesquisas sobre desigualdade. Como comentado no capítulo 3 (seção 3.4), um dos méritos dos trabalhos recentes da área foi recuperar o uso de dados tributários. Apesar de alguns dos motivos para isso terem sido citados, vale a pena discuti-los em detalhes. A subestimação dos rendimentos dos mais ricos nas pesquisas domiciliares é reconhecida desde pelo menos a década de 1930 (e.g., BAIRD; FINE, 1939),

1 Em inglês, Research Committee on Social Stratification - RC28. 
e permanece até hoje nos manuais internacionais (e.g., CANBERRA GROUP, 2011). As razões para a dificuldade em captar com precisão os maiores rendimentos incluem:

Taxas de não participação e não resposta mais elevadas: os mais ricos tendem a apresentar taxas de não participação (recusa ou indisponibilidade em ser entrevistado) e de não resposta (recusa em responder às questões sobre rendimentos) bem maiores do que a média. A não participação ocorre pela dificuldade de localização, contato e acesso às moradias, preocupação com segurança e privacidade, escassez de tempo e altos custos de oportunidade, entre outros motivos. A não resposta é afetada por alguns desses fatores, além de questões como a falta de conhecimento total ou parcial da própria renda (ATKINSON; PIKETTY; SAEZ, 2011; BAIRD; FINE, 1939; CANBERRA GROUP, 2011; KENNICKELL, 2009).

Subdeclaração de rendimentos: alguns dos motivos acima fazem com que os rendimentos efetivamente informados muitas vezes estejam subestimados, tendência que em geral aumenta em função da renda realmente recebida. Rendimentos mais irregulares e de cálculo mais complexo, como os rendimentos mistos de empregadores e trabalhadores por conta própria e os rendimentos de capital, são particularmente suscetíveis à subdeclaração. O uso de categorias muito agregadas para captar a renda, a confusão dos informantes entre rendimentos brutos e líquidos e o constrangimento em revelar rendimentos elevados para entrevistadores de nível socioeconômico mais baixo agravam a situação (CANBERRA GROUP, 2011; DAVERN et al., 2005; GOTTSCHALK; SMEEDING, 2000; HOFFMANN, 1988; HOFFMANN; NEY, 2008; ROCHA, 2003; WEINBERG et al., 1999).

Limitações no processamento dos dados: como nem sempre as agências responsáveis conseguem identificar e resolver os erros na coleta dos dados, é comum a imposição de top coding, isto é, truncamento dos rendimentos em um valor máximo, normalmente não muito elevado, para evitar que um pequeno número de erros tenham efeitos significativos sobre as estatísticas agregadas. O top coding também costuma ser empregado para proteger o anonimato dos entrevistados e em função de limitações técnicas de armazenamento e processamento dos dados (ATKINSON; PIKETTY; SAEZ, 2011; CANBERRA GROUP, 2011).

Alguns desses e outros problemas também afetam os rendimentos dos mais pobres. Por exemplo, a participação em programas de transferência de renda costuma ser subestimada em pesquisas domiciliares, inclusive com tendência de piora ao longo do tempo em alguns casos (SOUZA, 2015; SOUZA; OSORIO; SOARES, 2011; WEINBERG et al., 1999; WHEATON, 2007). Com isso, não é surpreendente que a renda total registrada em pesquisas domiciliares regularmente fique bem abaixo da observada nos agregados dos 
Sistemas de Contas Nacionais e em registros administrativos (BARROS; CURY; ULYSSEA, 2006; GOTTSCHALK; SMEEDING, 2000; HOFFMANN, 1988).

Não é claro ex ante qual a direção do viés das pesquisas domiciliares quanto à desigualdade total. Na prática, a maior parte dos pesquisadores admite que os problemas parecem ser bem mais graves para os mais ricos, o que implica no mínimo uma subestimação do nível da desigualdade (tal como medida pelo coeficiente de Gini) e, em alguns casos, de sua trajetória ao longo do tempo (ALVAREDO, 2011; ATKINSON; PIKETTY; SAEZ, 2011; HOFFMANN, 1988; HOFFMANN; NEY, 2008; LLUCH, 1981; MEDEIROS; SOUZA; CASTRO, 2015b). ${ }^{2}$

A análise de Székely e Hilgert (1999) para 18 países latino-americanos concluiu que as diferenças no grau de desigualdade entre países dependem sobremaneira da concentração de renda no topo, mas destacou também a enorme subdeclaração da renda dos mais ricos. $\mathrm{Na}$ maior parte dos países, os rendimentos mais elevados apresentados nas pesquisas domiciliares são comparáveis à remuneração de gerentes em firmas de porte médio ou grande, um grupo que, embora privilegiado, tipicamente não corresponde ao perfil dos mais ricos em nenhuma dessas sociedades. ${ }^{3}$

Em suma, as pesquisas domiciliares, valiosas para muitos fins, são instrumentos de pesquisa insatisfatórios para o estudo da concentração no topo. Mesmo o estudo da desigualdade lato sensu é possivelmente prejudicado por essas inadequações.

\subsubsection{Vantagens e desvantagens dos dados do imposto de renda}

O uso de dados tributários constitui uma volta ao passado com vantagens importantes em relação a pesquisas domiciliares, sendo particularmente indispensável quando se trata dos mais ricos (e.g., CANBERRA GROUP, 2011, p. 93-96). Essas vantagens incluem:

Minimização de problemas amostrais para o 1\% mais rico e afins: as tabulações de dados do imposto de renda baseiam-se normalmente no universo das declarações e, portanto, escapam aos erros amostrais típicos de pesquisas domiciliares quanto ao topo da distribuição de renda.

Minimização da não participação e das não respostas: há obrigatoriedade de preenchimento das declarações e sanções legais contra a não participação, não havendo opção para os contribuintes se recusarem a fornecer as informações solicitadas.

2 No Brasil, Barros, Cury e Ulyssea (2006) são uma exceção: os autores concluem que, incluindo rendimentos não monetários, a subestimação da renda na PNAD é semelhante entre pobres e ricos.

3 Curiosamente, a versão final do artigo, publicada em Székely e Hilgert (2007), não incluiu, entre outras, a seção em que os autores comparam os rendimentos dos mais ricos nos surveys com os dos gerentes. 
Redução da subdeclaração: o caráter compulsório do imposto de renda e a possibilidade de punição deixam menos espaço para a subdeclaração de rendimentos por preferência individual ou por desconhecimento dos valores corretos.

Fontes de rendimentos mais abrangentes: as legislações nacionais do imposto de renda em geral exigem detalhamento de um número de fontes de rendimentos muito mais abrangente do que seria viável incluir em qualquer pesquisa domiciliar.

Períodos de referência mais longos: tipicamente o imposto incide sobre rendimentos recebidos em todo o ano anterior à declaração, o que implica um período de referência (12 meses) mais longo do que o utilizado em grande parte das pesquisas domiciliares, captando melhor os rendimentos recebidos de forma intermitente ou irregular.

Disponibilidade de séries históricas de longo prazo: as pesquisas domiciliares só se tornaram regulares, comparáveis e abundantes a partir de meados do século XX. ${ }^{4}$ Os dados do imposto de renda permitem a construção de séries históricas muito mais longas em virtude da disseminação do imposto pelo mundo já por volta da $1^{a}$ Guerra Mundial (ver próxima seção).

Ausência de limitações de coleta e processamento: ao contrário de muitas pesquisas domiciliares, as informações do imposto de renda não estão sujeitas a restrições de coleta e processamento dos dados nem ao top coding.

As desvantagens dos dados do imposto de renda são igualmente intuitivas. Como argumentam Atkinson, Piketty e Saez (2011) e Canberra Group (2011), entre outros, as principais são:

Indisponibilidade de microdados: na maior parte dos casos, não há microdados disponíveis. O material básico consiste de tabulações de rendimentos, deduções e afins por faixas de renda, o que impossibilita certos tipos de análise.

Cobertura populacional restrita: por definição, o imposto de renda abarca apenas a fração da população obrigada a declarar rendimentos, que pode ser muito restrita.

Evasão e elisão fiscal: os contribuintes têm óbvio incentivo para minimizar sua renda declarada e, por consequência, o imposto a ser pago. Há evasão quando isso é feito de forma ilícita e elisão quando se recorre, dentro da lei, a estratégias de planejamento tributário para escapar ao imposto.

4 No Brasil, o Censo de 1960 foi o primeiro com informações sobre rendimentos. O Censo de 1890 coletou dados sobre rendimentos, que nunca foram tabulados nem divulgados, provavelmente em função da má qualidade das informações (MÉDICI, 1986). As PNADs assumiram seu padrão anual em 1976; para uma discussão da evolução temporal de suas variáveis de renda, ver Médici (1988) e Rocha (2003). 
Rigidez do conceito de renda e das unidades de análise: como ocorre com dados administrativos em geral, as definições de alguns conceitos importantes - como os rendimentos em consideração e as unidades de análise - podem ser muito distintas das preferências dos pesquisadores.

Alterações na legislação e na fiscalização: a comparabilidade temporal dos dados pode ser comprometida por reformas na legislação do imposto de renda que alterem o escopo de rendimentos tributáveis, as unidades de análise e as possibilidades e incentivos para a elisão fiscal via income shifting, isto é, deslocamentos de investimentos e rendimentos para fontes menos tributadas. Outro tipo de flutuação artificial ocorre quando há aperfeiçoamento ou relaxamento da fiscalização.

Necessidade de tratamento dos dados: os dados tributários com frequência exigem muitos procedimentos de limpeza, compatibilização e interpolação para se tornarem úteis, inclusive com o recurso a controles exógenos para a população e a renda total.

Nenhuma dessas desvantagens é insuperável e, para o estudo dos ricos, elas são menos problemáticas do que as limitações das pesquisas domiciliares. Em alguns casos, são até úteis: por exemplo, a cobertura populacional restrita ajuda a colocar em foco a concentração no topo e a empurrar a abordagem da desigualdade de volta para a dicotomia entre ricos/não ricos. Ademais, há sempre a possibilidade de combinar dados de surveys e do imposto de renda para a obtenção de estimativas corrigidas da desigualdade que levem em conta toda a distribuição de renda, como na seção 5.4 .2 do capítulo 5 .

Outras limitações, como a falta de microdados e conceitos rígidos, são desafortunadas, não impeditivas. Os efeitos da evasão/elisão fiscal e de mudanças na legislação e/ou na fiscalização são potencialmente mais preocupantes. Em sua revisão da literatura, Atkinson, Piketty e Saez (2011) concluem que a evasão per se não constitui um problema grave no topo nem em países ricos nem nos poucos países em desenvolvimento para os quais é possível estimar seus efeitos. Alvaredo (2008) reportou estimativas produzidas pelas autoridades fiscais argentinas em decorrência da anistia oferecida em 1962, com a conclusão de que a evasão era proporcionalmente menor nos extremos da distribuição de renda entre declarantes, isto é, entre os mais pobres e os mais ricos. Mudanças na elisão fiscal em decorrência de reformas na legislação são mais difíceis de avaliar, pois variam conforme o caso. De todo modo, Atkinson, Piketty e Saez (2011) julgam que o tratamento tributário favorável a rendimentos de capital, quando implica a não necessidade de incluí-los nas declarações de renda, constitui problema maior.

As próximas seções discutem o caso específico do Brasil, recapitulando a história e a lógica de apuração do IRPF, de forma a descrever não só os procedimentos usados para limpeza e tratamento dos dados, mas também suas limitações. 


\subsection{Breve história do imposto de renda no Brasil}

O imposto de renda moderno surgiu em resposta a grandes crises fiscais, principalmente causadas por guerras. Apesar de suas raízes históricas profundas, o marco zero convencional é a sua introdução no Reino Unido, em 1798, pelo primeiro ministro William Pitt, como medida emergencial para financiar as guerras napoleônicas. A primeira versão do imposto foi abolida com o tratado de paz temporário de Amiens, em 1802, e a continuação da guerra ensejou sua reintrodução em 1803; em seu trabalho clássico, Sabine (2006, p. 26) concedeu-lhe o epíteto de "imposto que derrotou Napoleão". Com o fim da guerra, o imposto foi novamente abolido, retornando em 1842, no governo de Robert Peel, mais uma vez como solução temporária para o déficit orçamentário; embora muitas vezes ameaçado, o imposto foi cobrado continuamente desde então. Seu uso como instrumento redistributivo, contudo, só ganhou força no final do século XIX, com a campanha para tornar o imposto progressivo, culminando com a supertax do People's Budget, de Lloyd George, em 1909, discutido no capítulo 1. As duas guerras mundiais acabaram por fortalecer a progressividade e o escopo do imposto (SABINE, 2006).

A $1^{a}$ Guerra, em especial, foi um marco na história do imposto de renda. O fardo fiscal da guerra levou muitos países - como a França, em 1914, e o Canadá, em 1917 - a instituí-lo pela primeira vez. Em outros, como Alemanha (em 1919), Austrália (em 1915) e Holanda (em 1914), a guerra motivou a federalização e/ou substanciais reformas nos impostos existentes. Nos Estados Unidos, a história foi mais próxima do caso britânico: o tributo fora introduzido originalmente em nível federal em 1864 para financiar a Guerra Civil, sendo repelido em 1872; em 1895, houve nova tentativa de instituí-lo, bloqueada sob argumento de inconstitucionalidade pela Suprema Corte, de modo que seu estabelecimento definitivo deu-se apenas em 1913, com a aprovação da $16^{a}$ emenda constitucional, motivada principalmente por preocupações quanto à concentração de poder econômico. Assim como nos outros casos, a eclosão da guerra aumentou consideravelmente seu papel (AULT; ARNOLD, 2004; MORGAN; PRASAD, 2009).

No Brasil, as raízes do imposto de renda remontam ao Império, e incluem um conjunto de impostos parciais e mais ou menos temporários sobre fontes específicas de renda ou riqueza. A Lei 317, de 21 de outubro de 1843, por exemplo, instituiu como cobrança extraordinária um imposto progressivo sobre rendimentos recebidos dos cofres públicos, com duração de dois anos, conforme regulamentação posterior. Esse tipo de tributo foi recuperado e logo extinto diversas vezes nas décadas seguintes. A Guerra do Paraguai (1864-1870) foi uma dessas ocasiões: em 1867, os vencimentos dos cofres públicos voltaram a ser tributados e foi instituído temporariamente um imposto patrimonial semelhante ao atual Imposto Predial e Territorial Urbano (IPTU). Essas e outras cobranças resultaram, nas palavras de Souza Reis (1927), em "30 annos de tributação cedular com taxas meramente proporcionaes ou imperfeitamente progressivas"; o autor, que liderou 
a criação e implementação do imposto de renda no Brasil, arrolou dez impostos sobre rendimentos específicos em vigor entre o fim do século XIX e o início do século XX, com frequência definidos em leis orçamentárias. Com isso, as discussões e propostas a favor de um imposto geral sobre a renda avolumaram-se, em especial nos períodos de crise fiscal mais aguda, como nos primeiros anos da República e durante a $1^{a}$ Guerra Mundial.

O relatório da Comissão de Reforma do Ministério da Fazenda (1966) e o trabalho seminal de Nóbrega (2014) narram com detalhes esses desdobramentos, reservando destaque para a defesa do imposto de renda feita por Rui Barbosa (1966) em seu relatório ministerial de 1891. O então ministro da Fazenda criticou a dependência excessiva do sistema tributário em impostos indiretos - principalmente os alfandegários - e baseou sua defesa do imposto de renda em dois argumentos gerais, a solidez das finanças nacionais e a justiça social. No primeiro caso, Barbosa observou que a instauração da República retirara recursos do governo central e que, como demonstrado pelo Reino Unido e pelos Estados Unidos, o imposto de renda era fundamental durante grandes crises. No segundo caso, seu desejo era corrigir os aspectos regressivos da tributação indireta e as desigualdades horizontais geradas pela multiplicidade de leis, e não efetivamente usar o imposto de renda como grande ferramenta redistributiva. Ainda assim, sua proposta continha pelo menos um baixo grau de progressividade (pela isenção a rendimentos mais baixos) e diferenciação (com alíquotas mais elevadas para os rendimentos de capital).

Apesar de moderada, a proposta de Rui Barbosa, como outras, não foi adiante. O momentum, porém, estava a favor do imposto de renda. Os desafios fiscais do estado brasileiro, a tentativa de racionalizar os tributos parciais sobre rendimentos e a influência das mudanças nos sistemas tributários internacionais finalmente levaram à implementação, pelo artigo 31 da Lei 4.625, de 31 de dezembro de 1922, do imposto para pessoas físicas (IRPF) e jurídicas (IRPJ) no Brasil. A cobrança começou em 1924, substituindo os diversos tributos sobre rendimentos específicos que em geral incidiam na fonte, como os impostos sobre dividendos, vencimentos de funcionários públicos, juros hipotecários e lucros líquidos da indústria fabril, do comércio e de profissionais liberais (SOUZA REIS, 1930).

O modelo original - que separava os rendimentos em cédulas e aplicava alíquotas progressivas a cada uma, mas não à renda total - durou pouco. No exercício de 1926 (anobase 1925) o formato foi alterado, seguindo o modelo francês, mantendo suas características básicas constantes até o exercício de 1989 (ano-base 1988). A próxima seção narra os contornos da apuração dos rendimentos e do cálculo do imposto nessas duas fases.

Antes disso, vale a pena examinar o papel do imposto na nossa carga tributária ao longo do tempo e algumas peculiaridades da tributação no Brasil. Como documentou Nóbrega (2014), depois de um começo tímido, o imposto de renda (IRPF e IRPJ) tornou-se fonte importante de financiamento do Estado a partir da $2^{a}$ Guerra Mundial. Nesse período, com a queda do comércio internacional, a receita do imposto sobre importação - até então 
a principal fonte de arrecadação federal - declinou abruptamente e coube em grande parte ao IRPF e ao IRPJ cobrir essas perdas, algo obtido sem grandes alterações nas regras, e sim com melhorias administrativas. Em 1943, o imposto de renda tornou-se pela primeira vez o principal imposto federal, alternando-se com o imposto sobre o consumo - atual Imposto sobre Produtos Industrializados (IPI) - nas décadas seguintes, até se tornar, desde 1979, o líder indiscutível entre os impostos federais.

No entanto, pela complexidade da estrutura tributária brasileira, ser o principal imposto federal significa menos do que parece. No nosso sistema atual, as contribuições sociais que financiam a Seguridade Social têm volume muito maior do que o do imposto de renda (IRPF + IRPJ): entre 1990 e 2013, elas arrecadaram anualmente, em média, quase o dobro. ${ }^{5}$ Entre os impostos propriamente ditos, o imposto de renda está longe do líder, o Imposto sobre a Circulação de Mercadorias e Serviços (ICMS), de âmbito estadual: entre 1990 e 2013, o ICMS arrecadou em média quase 40\% a mais por ano.

A Figura 10 traz a participação no PIB da carga tributária bruta total (CTB total), da carga tributária bruta federal (CTB federal) e do imposto de renda como um todo (IRPF + IRPJ). Nos três casos, a tendência de longo prazo é de crescimento relativamente linear, e hoje todos estão nos seus picos históricos ou próximos deles. Apesar disso, suas trajetórias nem sempre coincidiram. A participação do imposto de renda no PIB saiu de $0 \%$ para $2 \%$ entre 1920 e o pós-guerra, passou por algumas décadas de relativa estabilidade e voltou a crescer a partir de 1980, atingindo $6 \%$ em meados dos anos 2000 e flutuando em torno disso desde então. Já a CTB total e a federal apresentam fases distintas: primeiro, crescimento constante e linear entre 1920 e 1960; depois, queda temporária com as turbulências do período, seguida por um aumento de quase 10 pontos percentuais (p.p.) na primeira década após o golpe de 1964, quando a ditadura atacou o problema fiscal e começou a levar a cabo seu projeto desenvolvimentista; terceiro, volatilidade sem direção bem definida nos anos 1970 e 1980; por fim, crescimento sustentado entre a Constituição de 1988 e 2010, com nova elevação de cerca de 10 p.p. para a CTB total e para a federal.

A Figura 11 evidencia esses movimentos, mostrando como a participação do imposto de renda na arrecadação total e federal progrediu rapidamente nos primeiros anos, com um salto durante a $2^{a}$ Guerra, e, depois, oscilou entre dois regimes razoavelmente estáveis: participação na CTB total em torno de 15\% nos anos 1960-1970 e de $25 \%$ a partir do final da década de 1990. Nos anos 1980 o comportamento destoou, com muita volatilidade.

Ou seja, tanto no que diz respeito à participação no PIB quanto ao seu peso na CTB, o imposto de renda estabilizou-se como um imposto importante, mas minoritário. Afora períodos extraordinários, sua contribuição relativa para o financiamento do Estado

5 As contribuições sociais incluem as contribuições previdenciárias, a Contribuição para o Financiamento da Seguridade Social (Cofins), a Contribuição sobre o Lucro Líquido (CSLL) e as contribuições para o Programa de Integração Social (PIS) e para o Programa de Formação do Patrimônio do Servidor Público (PASEP). 
Figura 10. Carga tributária total e federal e arrecadação do imposto de renda em relação ao PIB - Brasil, 1920-2013 (\%)

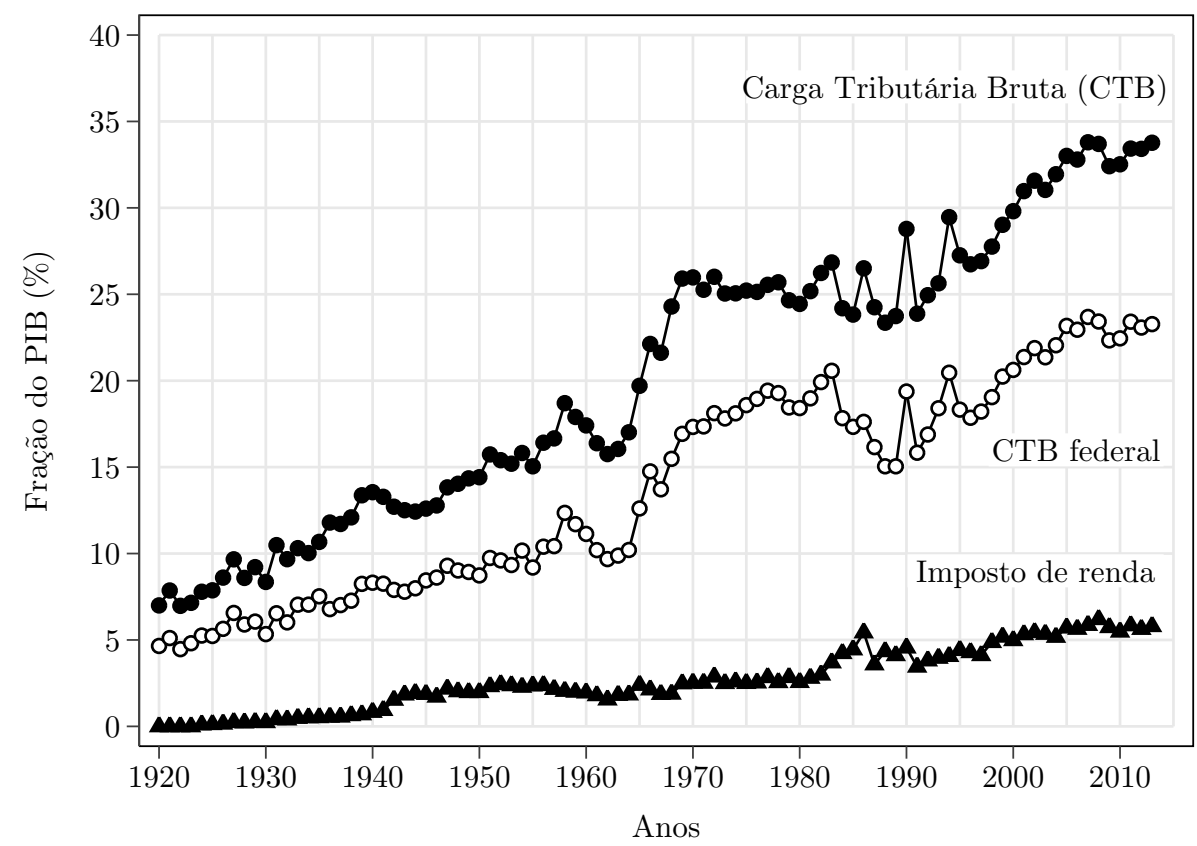

Fonte: para os tributos, em 1920-1989, IBGE, "Estatísticas do Século XX" (IBGE, 2006); em 1990-2013, estatísticas de arrecadação da Secretaria da Receita Federal. Para o PIB, Haddad (1974); IBGE, "Séries Históricas e Estatísticas"; IBGE, Sistema de Contas Nacionais (IBGE, 2015); e Banco Central do Brasil.

N.B.: a série para o imposto de renda inclui pessoas físicas (IRPF) e jurídicas (IRPJ).

Figura 11. Participação do imposto de renda na carga tributária bruta e na arrecadação federal - Brasil, 1920-2013 (\%)

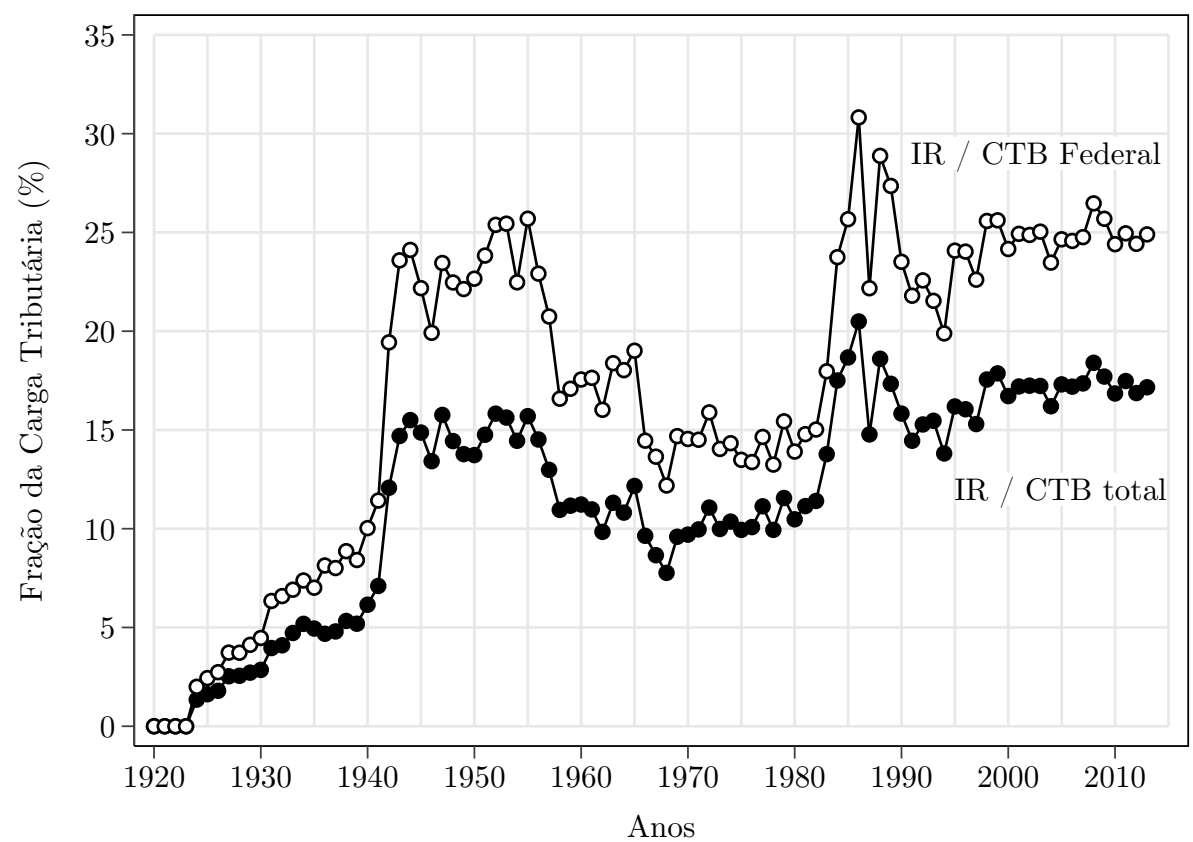

Fonte: para os tributos, em 1920-1989, IBGE, "Estatísticas do Século XX" (IBGE, 2006); em 1990-2013, estatísticas de arrecadação da Secretaria da Receita Federal.

N.B.: dados para o imposto de renda incluem pessoas físicas (IRPF) e jurídicas (IRPJ). 
brasileiro cresceu em ritmo glacial. O aumento de sua participação no PIB foi apenas um pouco mais ligeiro do que a tendência geral de expansão da carga tributária bruta.

Por isso, as comparações internacionais revelam um descompasso entre o nível da CTB total e a sua composição: o Brasil tributa muito no agregado, mas recorre pouco ao imposto de renda. A Figura 12 compara a relação entre a CTB e o PIB no Brasil e em alguns conjuntos de países entre 1965 e 2013. Como se vê, o peso relativo da tributação no Brasil é alto para padrões internacionais. A CTB brasileira representa um percentual do PIB mais próximo ao dos países mais ricos do que ao dos da América Latina.

A Figura 13 mostra a participação do imposto de renda (mais uma vez, IRPF + IRPJ) na CTB para os mesmos países. O quadro é distinto, e o Brasil aparece agora abaixo até da América Latina como um todo, bem distante dos países mais ricos. Por aqui, há três décadas o imposto de renda oscila entre $15 \%$ e $20 \%$ da arrecadação total, enquanto até na América Latina e no sul da Europa esse percentual está entre 25\% e 30\%. Em termos de participação no PIB, o mesmo padrão se verifica: combinando as Figuras 12 e 13, percebe-se que a relação IR/PIB é quase idêntica no Brasil e na América Latina como um todo (por volta de 5\%), ${ }^{6}$ apesar da menor CTB da região, e representa pouco mais de metade do observado no sul da Europa (cerca de 10\%).

A comparação com o sul da Europa é instrutiva porque esse grupo inclui os países mais pobres da região e, assim como no Brasil, houve nesse grupo uma expansão considerável da CTB nas últimas décadas, como mostrou a Figura 12. A diferença em relação a nós é que essa expansão foi impulsionada em grau muito maior pelo crescimento do imposto de renda, como visto na Figura 13. Entre 1975 e 2000, a CTB no sul da Europa cresceu quase 15 p.p., e o imposto de renda respondeu por quase $40 \%$ dessa expansão. Já no Brasil, entre 1988 e 2013, a CTB subiu pouco mais de 10 p.p., mas o imposto de renda contribuiu para menos de $15 \%$ desse aumento.

Outra forma de dimensionar o IRPF e sua evolução é pelo número relativo de declarantes e contribuintes, algo particularmente importante pois impõe limites às medidas de desigualdade que podem ser construídas a partir dos dados tributários. A Figura 14 traz o percentual de declarantes e de contribuintes em relação à população com 20 anos ou mais. Até o final da década de 1960, o IRPF tinha escopo restrito, com o percentual de contribuintes crescendo lentamente e nunca ultrapassando muito o patamar de $1 \%$ da população com 20 anos ou mais. O IRPF pôde se destacar rapidamente entre os tributos federais e aumentar sua participação na CTB porque o governo arrecadava pouco em relação ao PIB, já que o tributo estava muito longe de representar um imposto de massas.

Há uma descontinuidade clara no final dos anos 1960, quando os percentuais de contribuintes e de declarantes aumentam rapidamente. Nesse último caso, o salto foi

6 No caso latino-americano, a maior importância relativa do IR parece decorrer majoritariamente da tributação de empresas, isto é, do IRPJ, como indicado pelos números citados mais adiante. 
Figura 12. Carga tributária bruta no Brasil e em grupos de países selecionados em relação ao PIB, 1965-2013 (\%)

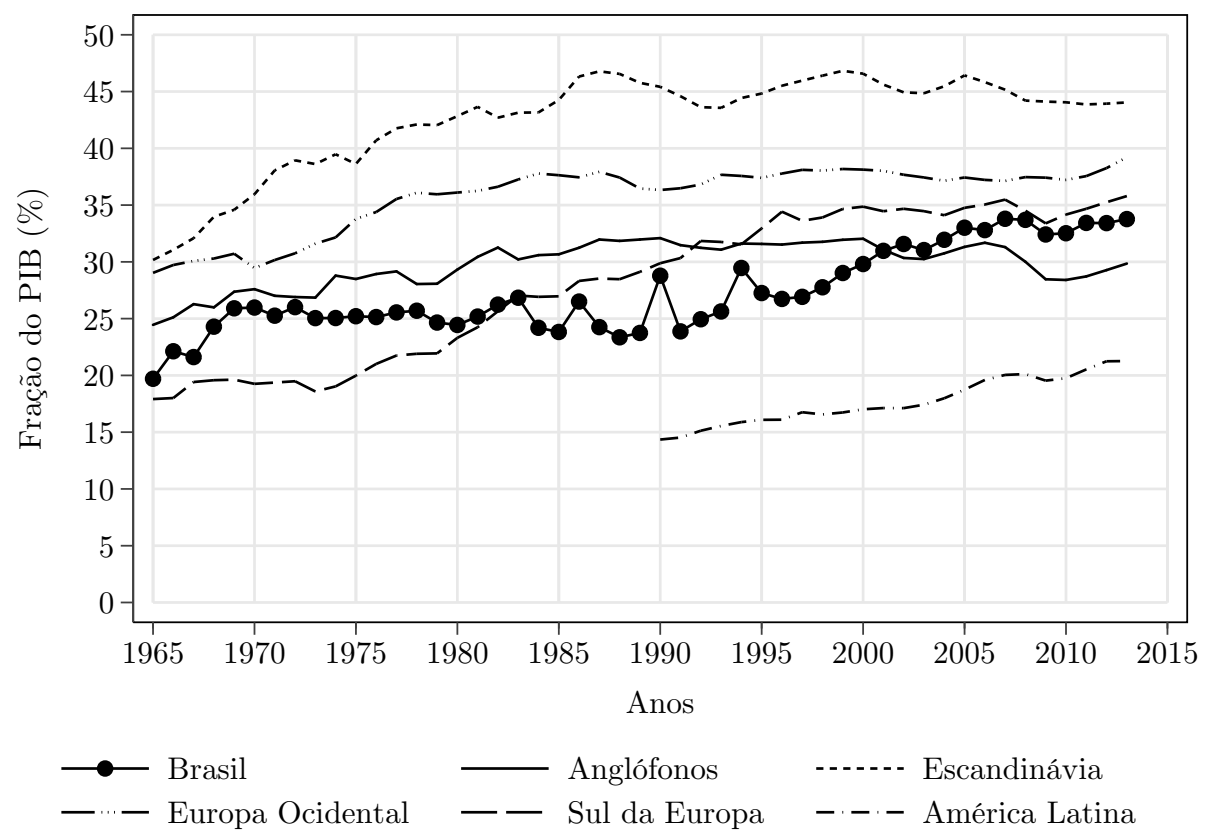

Fonte: para o Brasil, IBGE, "Estatísticas do Século XX" (IBGE, 2006), "Séries Históricas e Estatísticas" e Sistema de Contas Nacionais (IBGE, 2015); Secretaria da Receita Federal; Banco Central do Brasil. Para os demais países, Organização para a Cooperação e Desenvolvimento Econômico, OECD.Stat.

N.B.: Anglófonos: AUS, CAN, GBR, IRL, NZL, USA; Escandinávia: DNK, NOR, SWE; Europa Ocidental: AUT, BEL, CHE, DEU, FRA, LUX, NLD; Sul da Europa: ESP, GRC, ITA, PRT, SVN; América Latina: 19 países.

Figura 13. Arrecadação do imposto de renda no Brasil e em grupos de países selecionados em relação ao PIB, 1965-2013 (\%)

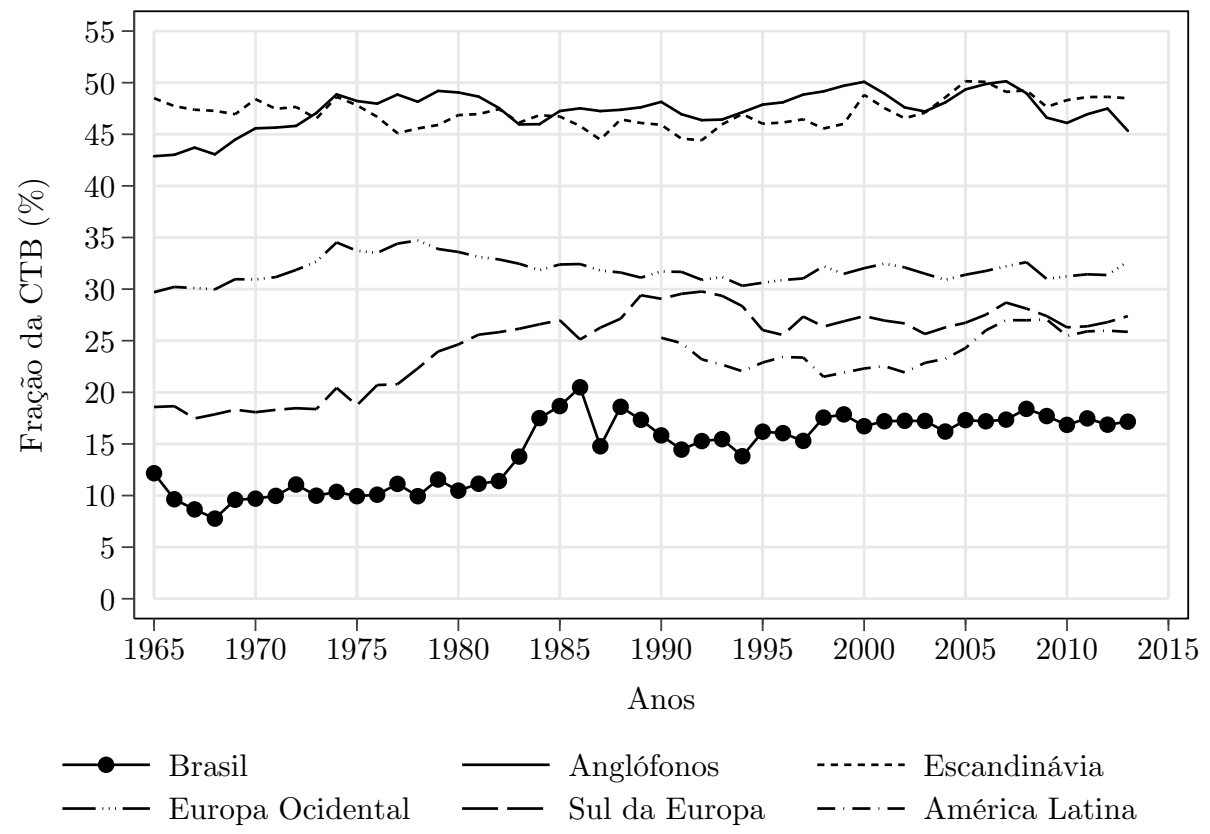

Fonte: para o Brasil, IBGE, "Estatísticas do Século XX" (IBGE, 2006), "Séries Históricas e Estatísticas" e Sistema de Contas Nacionais (IBGE, 2015); Secretaria da Receita Federal; Banco Central do Brasil. Para os demais países, Organização para a Cooperação e Desenvolvimento Econômico, OECD.Stat.

N.B.: Anglófonos: AUS, CAN, GBR, IRL, NZL, USA; Escandinávia: DNK, NOR, SWE; Europa Ocidental: AUT, BEL, CHE, DEU, FRA, LUX, NLD; Sul da Europa: ESP, GRC, ITA, PRT, SVN; América Latina: 19 países. 
Figura 14. Frequência relativa de declarantes e contribuintes do IRPF na população de 20 anos ou mais - Brasil, 1927-2013 (\%)

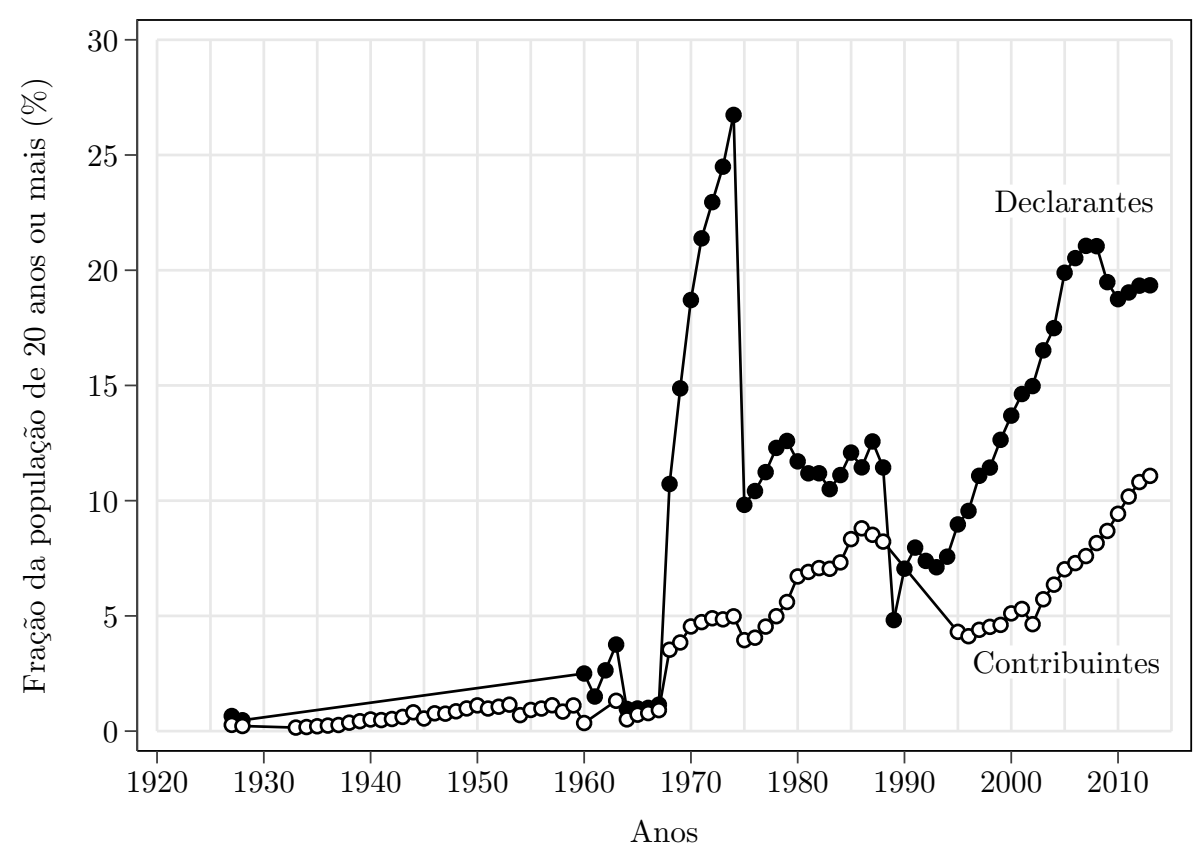

Fonte: elaboração própria a partir das fontes listadas na Tabela 4, Comissão de Reforma do Ministério da Fazenda (1966), Nóbrega (2014); Receita Federal do Brasil, "Grandes Números - DIRPF" (anos-calendário 1999-2013) (BRASIL. MF. SRF, 2015); e dados populacionais dos Censos Demográficos (ver seção 4.8.3).

N.B.: contribuintes são os declarantes cuja renda líquida ficou acima do limite de isenção e, portanto, estavam sujeitos ao imposto progressivo.

enorme: o número de declarações foi multiplicado por 10 de 1967 para 1968 e continuou aumentando até atingir a cifra inédita de 13,2 milhões (quase $27 \%$ da população com 20 anos ou mais) em 1974, antes de despencar para 5 milhões (pouco menos de 10\%) em 1975. Tanto o aumento vertiginoso quanto a queda repentina explicam-se por mudanças nas linhas de corte para obrigatoriedade de apresentar a declaração (NÓBREGA, 2014, p. 128). No período mais recente, chama a atenção a queda inicial de ambos os percentuais no fim da década de 1980 e sua recuperação desde então. Hoje, o percentual de contribuintes sobre a população de 20 anos ou mais está em seu pico histórico, em torno de 10\%, e o de declarantes, cerca de 20\%, está próximo do recorde dos anos 1970.

Nosso percentual de declarantes é, por um lado, muito maior do que o da Argentina e da Colômbia, que estão em torno de 5\% (ALVAREDO, 2008; VÉLEZ, 2012) e, por outro, muito inferior aos dos países desenvolvidos. Em muitos desses últimos, o IRPF tornou-se abrangente durante a $2^{a}$ Guerra, e há décadas cobre mais de $80 \%$ ou $90 \%$ da população. ${ }^{7}$ Em outros, a expansão foi mais recente, como em Portugal, onde o percentual era de apenas 1-4\% até a Revolução dos Cravos (1974), deslanchando a partir daí até atingir mais de $70 \%$ da população. Espanha e Itália seguiram trajetória semelhante, tendo estendido o imposto para a maioria da população somente nos últimos anos (ALVAREDO, 2008).

$\overline{7}$ Como cada país define a unidade de tributação à sua maneira, a população relevante pode ser composta por indivíduos, famílias etc. 
Figura 15. Número de alíquotas de tributação do IRPF no Brasil e nos Estados Unidos, 1920-2013

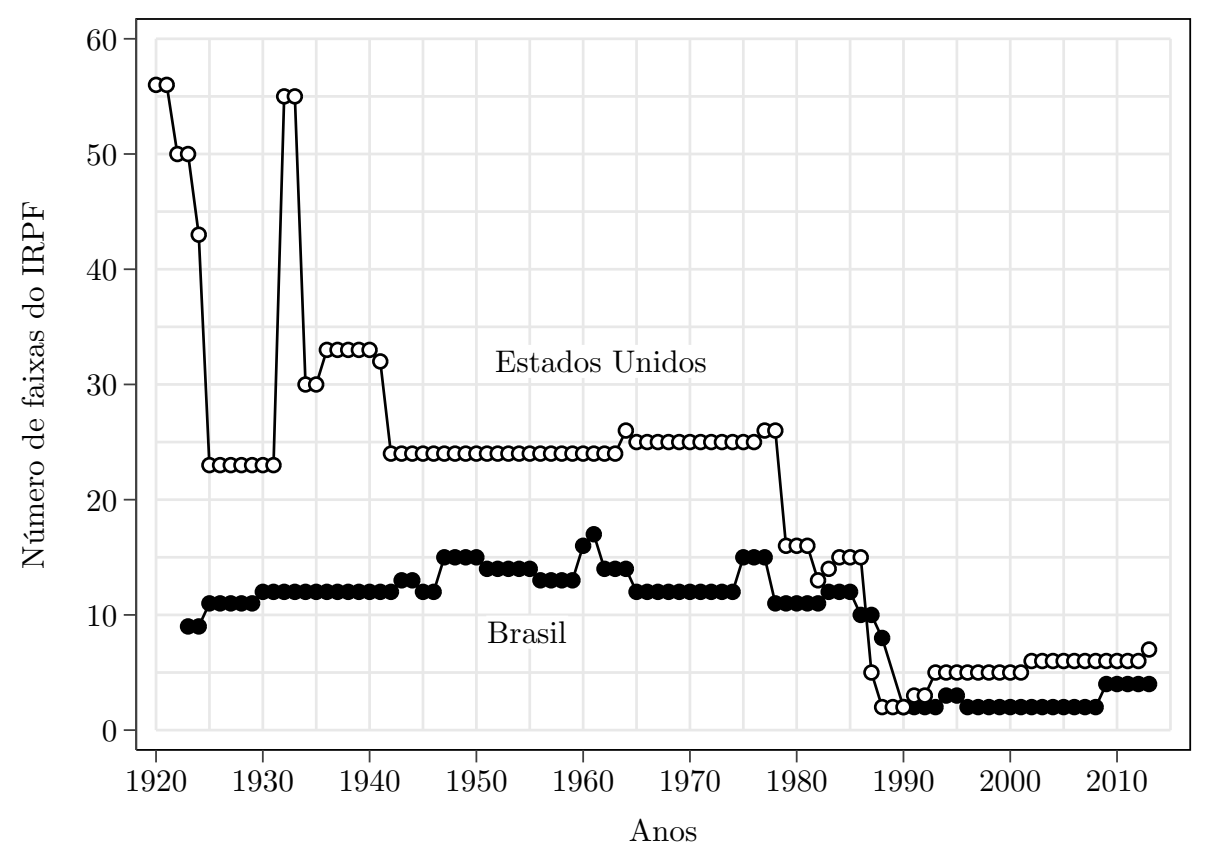

Fonte: para o Brasil, Nóbrega (2014) e legislação do IRPF; para os Estados Unidos, The Tax Foundation (2013).

Quanto à estrutura de alíquotas do IRPF no Brasil, houve muitas variações ao longo das décadas, acompanhando em geral as tendências internacionais, que, por sua vez, estiveram umbilicalmente ligadas aos grandes acontecimentos políticos e ao clima intelectual, como caracterizado na Parte I. Nossa diferença foi somente de intensidade: nem a quantidade de faixas nem os percentuais das alíquotas marginais máximas chegaram perto do adotado em muitos países ricos.

A Figura 15 traz o número de alíquotas do IRPF no Brasil e nos Estados Unidos desde a década de 1920. O padrão geral é o mesmo, com alíquotas altamente diferenciadas até os anos 1980. A particularidade brasileira é que nossa diferenciação nunca atingiu os extremos do caso americano, e nós fomos ainda mais radicais na simplificação do sistema. Nos Estados Unidos, o governo Reagan reduziu as faixas de 15 para apenas duas entre 1986 e 1988; com o tempo o número voltou a crescer até chegar a sete em 2013. No Brasil, a reforma ocorreu quase simultaneamente, com redução das 12 faixas do ano-base 1985 para apenas duas em 1990, número relativamente constante até 2009, quando houve modesta ampliação para quatro alíquotas.

O Figura 16 compara as alíquotas marginais máximas nos dois países. Nos Estados Unidos, as elevadas alíquotas máximas introduzidas durante a $1^{a}$ Guerra foram reduzidas nos anos 1920, disparando novamente entre a década de 1930 e a $2^{a}$ Guerra. Por duas décadas, até meados dos anos 1960, as alíquotas máximas continuaram acima de $90 \%$. Os Estados Unidos não foram um caso isolado, servindo como modelo de tendências internacionais: "Let me tell you/ how it will be/ There's one for you/Nineteen for me/ 
Figura 16. Alíquotas marginais máximas do IRPF no Brasil e nos Estados Unidos, 1920-2013

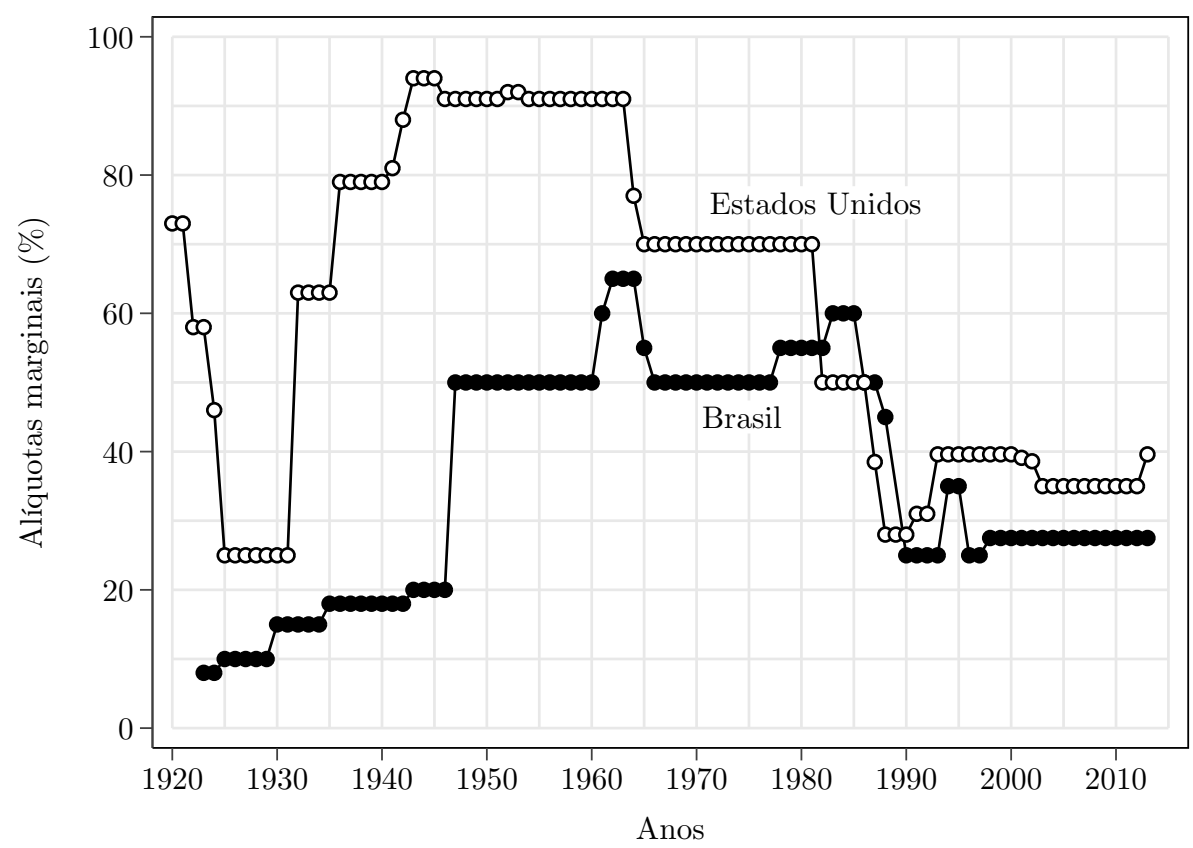

Fonte: para o Brasil, Nóbrega (2014) e legislação do IRPF; para os Estados Unidos, The Tax Foundation (2013).

'Cause I'm the taxman", 8 cantavam os Beatles em 1966, em resposta à supertax introduzida no Reino Unido pelo governo trabalhista de Harold Wilson. (Em tom sarcástico, os Kinks também fizeram referência ao imposto em Sunny Afternoon, lançada no mesmo ano, que abre com versos como "The tax man's taken all my dough/ And left me in my stately home/ Lazing on a sunny afternoon/And I can't sail my yacht/ He's taken everything I've got/ All I've got is this sunny afternoon". ${ }^{9}$ )

A alíquota máxima americana caiu para $70 \%$ após os cortes realizados por John F. Kennedy nos anos 1960 e despencou para valer nos anos 1980, quando o governo Reagan aprovou duas grandes reformas que derrubaram a tributação marginal máxima para abaixo de $30 \%$ pela primeira vez em mais de cinco décadas. O governo Clinton reverteu parcialmente essa queda, elevando a alíquota máxima para 39,6\%. Mais recentemente, o governo Obama desfez o pequeno corte promovido por George W. Bush, levando a alíquota de volta ao patamar dos anos 1990.

O Brasil demorou muito mais do que os Estados Unidos para adotar alíquotas mais progressivas, o que só ocorreu entre 1946 e 1947, quando o percentual máximo foi catapultado de $20 \%$ para 50\%. Nosso recorde histórico de $65 \%$ foi registrado entre 1962 e

8 Em tradução livre, "Deixe-me te dizer/ como vai ser/ fica uma parte para você/ e dezenove para mim/ Porque eu sou o fisco". Escrita por George Harrison, Taxman é a primeira faixa do disco Revolver.

9 Em tradução livre, "O homem do fisco levou toda a minha grana/ E me deixou em minha mansão/ vagabundeando em uma tarde de sol/ Eu não posso navegar no meu iate/ Porque ele levou tudo que eu tenho/ E eu só tenho agora essa tarde de sol”. A canção de Ray Davies chegou ao primeiro lugar das paradas britânicas e foi o carro chefe do álbum Face to face, lançado também em 1966. 
1964, antes de a ditadura militar trazê-lo de volta para a casa de 50\%. As necessidades financeiras do Estado exigiram novo aumento leve das alíquotas máximas no final dos anos 1970, que foi prontamente desfeito durante a redemocratização: a influência internacional se fez sentir drasticamente, com a tributação marginal máxima caindo de $60 \%$ em 1985 para $25 \%$ em 1990. Desde então, as mudanças foram discretas e o IRPF estacionou na alíquota máxima de 27,5\% desde 1998, atravessando o segundo governo Fernando Henrique Cardoso e três administrações petistas sem alterações. O valor atual é bem mais baixo do que o americano e também fica muito atrás dos de países tão diversos quanto Austrália (45\%), Alemanha (45\%), Chile (40\%), França (45\%), Itália (43\%) México (35\%) e Turquia $(35 \%)$, entre outros. ${ }^{10}$

Por fim, os dois painéis da Figura 17 mostram a razão entre as linhas de corte para as alíquotas marginais mínima - ou seja, o limite de isenção - e máxima do IRPF e a renda média brasileira ao longo do tempo. Durante as primeiras décadas do imposto, seu alcance foi muito restrito porque o limite de isenção esteve sempre acima de quatro vezes da renda média. Como essas alíquotas são aplicadas apenas à renda líquida - isto é, depois de subtraídos deduções, abatimentos e afins - apenas uma fração minúscula da população estava sujeita a elas. Comparando com os gráficos anteriores, pode-se ver que a elevação da alíquota máxima para 50\% em 1947 não se aplicou a todos que antes pagavam 20\%, e sim àqueles com renda líquida mais de 500 vezes maior do que a média nacional. As duas razões diminuíram progressivamente, sem grandes sobressaltos, até o fim dos anos 1980.

Hoje, o limite de isenção está próximo à renda média nacional, o que não significa que todos que ganham mais do que a média (cerca de $\mathrm{R} \$ 26$ mil em 2013) estão sujeitos à alíquota mínima de 7,5\%, pois, como dito, ela se aplica à renda líquida, isto é, subtraída de deduções. A convergência da alíquota máxima em direção à renda média foi ainda mais veloz. Em 2013, a linha de corte para a alíquota de 27,5\% era aproximadamente o dobro da renda média.

Todas essas características e reformas tiveram consequências sobre o grau de redistribuição operada pelo IRPF no Brasil. Os próximos capítulos discutem em mais detalhe essa questão. Por enquanto, o importante é registrar como o IR no Brasil, em sua longa história, consolidou-se como uma fonte importante de recursos para o governo federal, mas ainda permanece relativamente subutilizado, representando apenas uma fração ainda baixa da CTB. O IRPF, em particular, jamais foi um imposto de massas nos moldes europeu e americano. Se o ritmo da expansão recente for mantido, somente em algumas décadas sua cobertura abarcará mais da metade da população.

Por isso, a construção de séries históricas da desigualdade brasileira com base nos dados tributários precisa se restringir aos grupos próximos ao topo, o que, para os

\footnotetext{
10 Dados da Organização para Cooperação e Desenvolvimento Econômico (OCDE). Ver < http://stats. oecd.org/>. Acesso em 22 abr. 2016. Os dados se referem apenas à alíquota marginal máxima do imposto de renda cobrado pelo governo central ou federal.
} 
Figura 17. Razão entre as linhas de corte para as alíquotas marginais máximas do IRPF e a renda média - Brasil, 1923-2013

(a) Alíquota mínima / Renda média

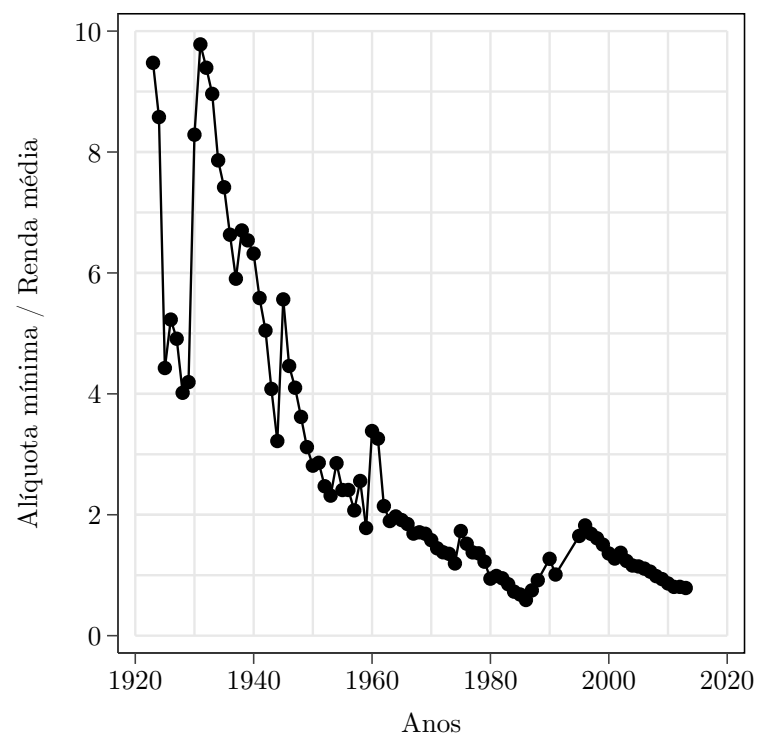

(b) Alíquota máxima / Renda média

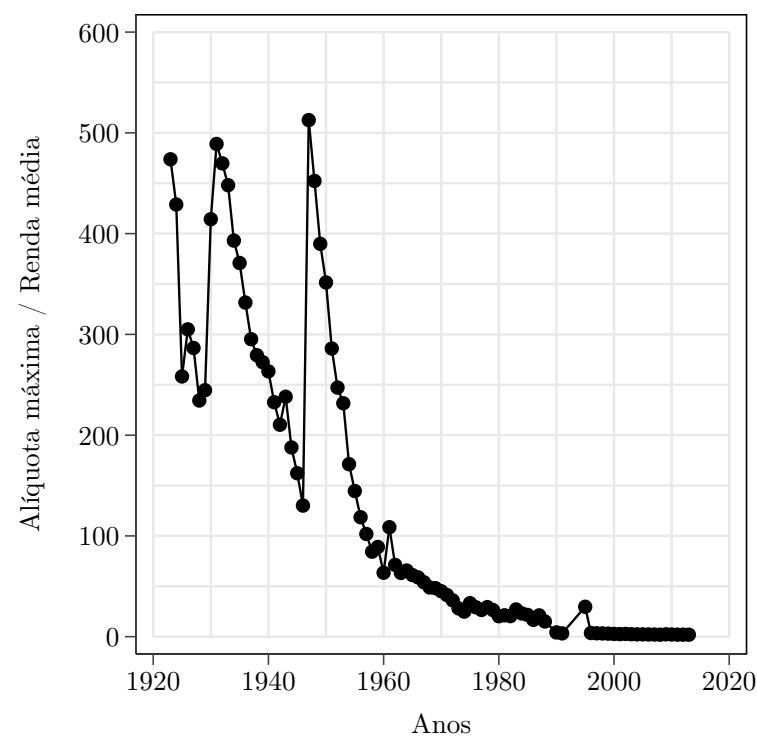

Fonte: elaboração própria a partir de Nóbrega (2014), legislação do IRPF e demais fontes citadas na seção 4.8.4. N.B.: a "renda média" é o controle para renda total dividido pela controle para população total, isto é, adultos de 20 anos ou mais. Ambos são definidos nas seções 4.8.4 e 4.8.3.

propósitos desta tese, é mais uma qualidade do que um problema. O uso desses dados, no entanto, demanda uma série de ajustes e procedimentos metodológicos, discutidos a seguir. Antes, para facilitar o entendimento, é útil comentar os contornos gerais da apuração dos rendimentos e do imposto ao longo do tempo.

\subsection{A apuração dos rendimentos no IRPF, 1922-2013 ${ }^{11}$}

\subsubsection{Modelo geral até o ano-base 1988}

O IRPF no Brasil passou por muitas reformas na sua fase inicial de implantação, mas, sob forte influência do modelo francês e capitaneado pelo trabalho de Francisco Tito de Souza Reis, logo convergiu para um modelo básico que vigorou até o fim dos anos 1980. Vale a pena, portanto, delinear essa estrutura básica e suas principais mudanças, com ênfase nos aspectos mais importantes para o estudo da desigualdade.

11 Esta seção baseia-se extensamente no trabalho de Nóbrega (2014) e nos regulamentos do IRPF, em especial os Decretos 16.581/1924, 17.390/1926, 4.178/1942, 5.844/1943, 24.239/1947, 36.773/1955, 40.702/1956, 47.373/1959, 51.900/1963, 55.866/1965, 58.400/1966, 76.186/1975 e 85.450/1980. 


\section{Rendimentos brutos tributáveis e rendimentos não tributáveis}

Os rendimentos eram, em primeiro lugar, separados entre rendimentos brutos tributáveis e rendimentos não tributáveis (isentos ou cobrados exclusivamente na fonte, como ocorre hoje). Até o ano-base 1970, o formulário do IRPF sequer tinha um campo para estes últimos, e os contribuintes só informavam seus rendimentos brutos tributáveis.

O escopo da tributação cresceu na primeira década do IRPF; depois a tendência mais forte foi para ampliação do rol de rendimentos não tributáveis. No início dos anos 1930, as principais rubricas não tributáveis eram doações, heranças e o capital de apólices de seguros de vida. A Constituição de 1934 incluiu na lista a remuneração de escritores, jornalistas e professores. Em 1949 a legislação explicitou que a imunidade valia tanto para o imposto cedular quanto para o complementar, o que só foi revogado em 1964.

Outras categorias também tentaram isentar seus rendimentos. Houve, por exemplo, uma longa querela judicial acerca da cobrança sobre os vencimentos de funcionários públicos estaduais e municipais, que foi considerada inconstitucional pelo Supremo Tribunal Federal (STF). A situação só se resolveu pelo Decreto 1.564, de 1939, que anulou essa decisão em nome do "interesse nacional". A tributação dos vencimentos dos magistrados entrou em disputa pouco depois, também sendo declarada inconstitucional. A Resolução 38, de 1960, suspendeu a cobrança, que foi restaurada em 1964 pela mesma emenda constitucional que tributou professores, jornalistas e escritores. Em todos esses casos, não é claro como era feita a declaração nos anos em que houve disputa judicial.

Para além dessas isenções a categorias profissionais, não houve outras mudanças tão significativas até os anos 1960. As alterações mais importantes possivelmente tiveram pouco impacto nos valores declarados, como no caso das isenções para indenizações por rescisão de contratos de trabalho, salário-família e aposentadorias e pensões motivadas por doenças graves. Na década de 1960, o quadro foi diferente, com a reforma tributária aprovada pela ditadura e modificações posteriores. Algumas, como a tributação de professores e magistrados, engordaram a lista de rendimentos tributáveis, mas a maioria expandiu o conjunto de rendimentos não tributáveis na declaração anual.

Esses acréscimos foram de três tipos. Primeiro, continuou a tendência de isentar benefícios sociais. Segundo, a política de estabilização da ditadura aumentou a lista de rendimentos não tributáveis, com a criação das Obrigações Reajustáveis do Tesouro Nacional e da correção monetária. Terceiro, a tentativa dos militares de alavancar os investimentos e um mercado nacional de capitais também redundou em uma redução do escopo ou flexibilização da tributação progressiva. Lucros, dividendos de ações, bonificações em dinheiro, juros de títulos públicos e de cadernetas de poupança e alguns outros rendimentos tornaram-se, sob certas condições, não tributáveis ou tributáveis exclusivamente na fonte com alíquotas mais baixas do que as do imposto progressivo (i.e.: Decretos-lei 401/1968, 427/1969, 1.338/1974 e 76.186/1975). Em alguns casos, o contribuinte podia declarar 
Figura 18. Participação dos rendimentos não tributáveis nos rendimentos totais declarados ao IRPF e inflação anual - Brasil, 1974-1988

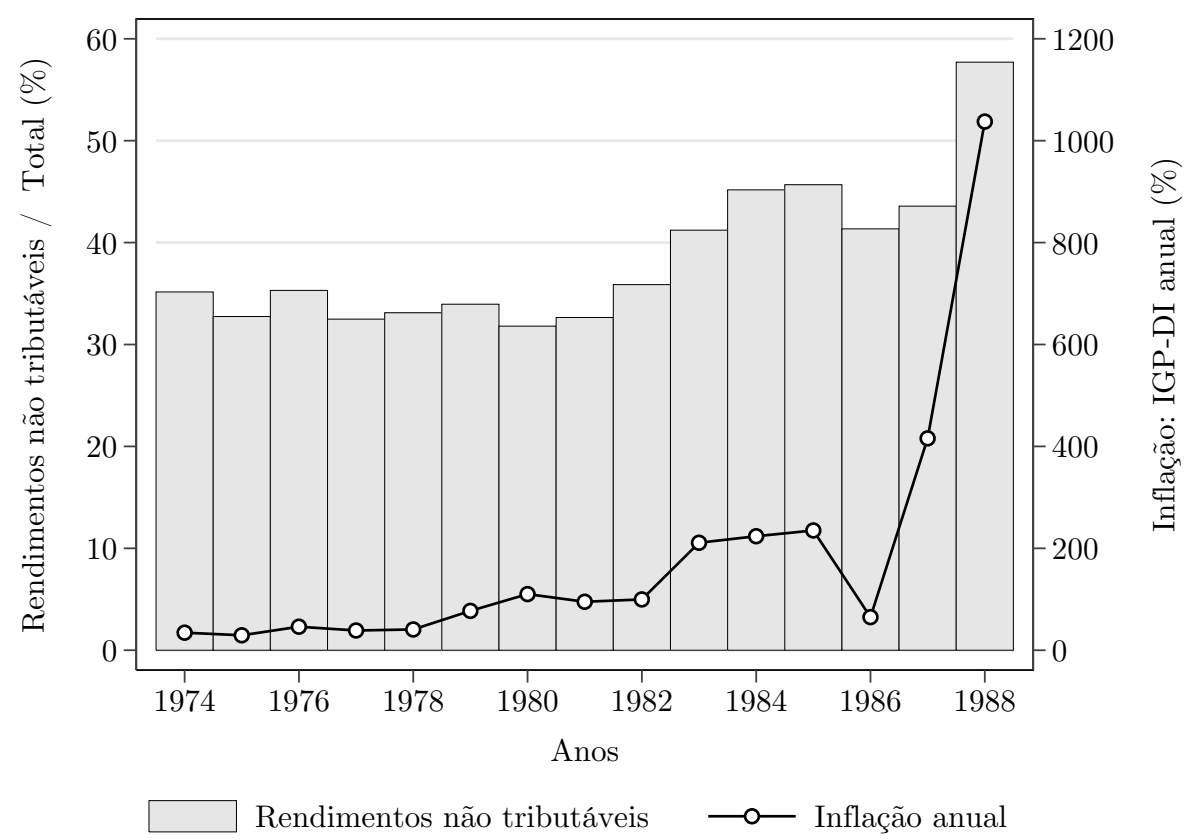

Fonte: fontes listadas na Tabela 4 e Ipeadata.

N.B.: inflação anual medida pelo Índice Geral de Preços - Disponibilidade Interna (IGP-DI), calculado pela Fundação Getúlio Vargas.

os rendimentos como tributáveis e usar algum múltiplo do valor retido na fonte como antecipação do imposto devido. Outros ganhos de capital também foram acrescentados aos rendimentos não tributáveis, refletindo o desenvolvimento do sistema financeiro nacional.

Em suma, houve tanto expansão quanto mudança no caráter dos rendimentos não tributáveis na declaração anual, que deixaram de ser principalmente privilégios corporativos para abarcar benefícios sociais, indenizações e uma série de rendimentos de capital, além das doações, heranças e outras categorias. Com isso, é razoável especular que os rendimentos não tributáveis constituíam uma fração menor da renda total no período 1926-1960 do que entre 1960 e 1988, ou seja, que os rendimentos brutos tributáveis são um bom indicador para a desigualdade total nas primeiras décadas do IRPF.

O outro lado da moeda é que, com a aceleração da inflação, é impossível decompor o crescimento dos rendimentos não tributáveis entre retornos reais e efeitos da correção monetária, cada vez mais importante. A Figura 18 apresenta, para o período em que há informações disponíveis, a participação dos rendimentos não tributáveis nos rendimentos totais das declarações do IRPF e a inflação anual medida pelo Índice Geral de Preços - Disponibilidade Interna (IGP-DI), da Fundação Getúlio Vargas. Há uma correlação positiva entre ambas as séries, o que, dada a hiperinflação dos anos 1980, recomenda alguma cautela na interpretação dos resultados para o período. 


\section{Rendimentos brutos cedulares e deduções cedulares}

Os rendimentos brutos tributáveis propriamente ditos eram declarados em cédulas, de acordo com a sua origem. Entre os anos-base 1925 e 1947, foram sete cédulas no total, de A a G, número ampliado para oito (de A a H) a partir de 1948. A organização das cédulas não variou radicalmente, sendo digna de nota apenas a diferença entre os períodos 1925-1941 e 1942-1988 quanto às cédulas A e F. Seu formato mais duradouro foi:

Cédula A: rendimentos do capital aplicado em títulos nominativos das dívidas públicas (anos-base 1942-1988).

Cédula B: juros e demais rendimentos de capitais e valores mobiliários (1942-1988).

Cédula C: salários, ordenados, subsídios e rendimentos do trabalho assalariado, empregos, cargos e pensões (1925-1988).

Cédula D: exercício de "profissões não comerciais", honorários de profissionais liberais e outros rendimentos do trabalho, principalmente não assalariado (1925-1988).

Cédula E: rendimentos de aluguéis e capitais imobiliários (1925-1988).

Cédula F: lucro real ou presumido, retiradas, dividendos, bonificações e rendimentos de negócios ou atividade empresarial, rendimentos de qualquer natureza produzidos no exterior, aumento de capital ou valorização do ativo (1942-1988).

Cédula G: rendimentos da exploração agrícola e pastoril e indústrias extrativas vegetal e/ou animal (1925-1988).

Cédula H: rendimentos não compreendidos nas outras cédulas (1947-1988).

Com exceção das cédulas F e G, as demais permitiam que se subtraíssem deduções cedulares dos rendimentos brutos cedulares, correspondentes aos custos incorridos para obtenção dos rendimentos. A lista de deduções foi mais ou menos constante e generosa: por exemplo, na cédula $\mathrm{C}$ (rendimentos do trabalho, principalmente assalariado), os declarantes podiam deduzir, entre outros, gastos com itens como publicações técnicas, uniformes e roupas especiais e locomoção para o desempenho da função. Em geral, as deduções representaram algo entre $15 \%$ e $20 \%$ do rendimento bruto tributável total.

A partir do ano-base 1975, foi criado o modelo simplificado de declaração, que oferecia uma alternativa às cédulas e deduções cedulares. Os declarantes com rendimentos não superiores a um teto (variável anualmente e relativamente baixo) e compostos por $90 \%$ ou mais de rendimentos do trabalho pertencentes à cédula C passaram a ter a opção de preencher um formulário simplificado e aplicar um desconto-padrão de 20\% (25\% em alguns anos) no lugar das deduções cedulares e de parte dos abatimentos. 
Para cada cédula, a diferença entre o rendimento bruto e as deduções correspondia ao rendimento cedular líquido. Até a Lei 4.506, de 1964, esses rendimentos estavam sujeitos a impostos proporcionais diferenciados por cédula. Ou seja, eram cobradas alíquotas fixas, não progressivas, que variavam de acordo com a fonte, sendo que os lucros de negócios (cédula F) e os rendimentos da agricultura (cédula $\mathrm{G}$ ) não sofriam cobrança. As alíquotas foram alteradas muitas vezes, mas eram em geral baixas: no último ano de cobrança, elas oscilavam entre 1\% (para o trabalho assalariado, na cédula C) e 10\% (para juros em geral, na cédula B) (NÓBREGA, 2014, p. 74).

\section{Renda bruta e abatimentos}

A soma dos rendimentos líquidos cedulares positivos compunha a renda bruta. Em seguida, o declarante podia subtrair de sua renda bruta um conjunto de abatimentos permitidos. Ao contrário das deduções cedulares, esses abatimentos não eram relacionados à atividade produtiva e variaram bastante ao longo do tempo, com tendência de expansão: enquanto o formulário para o ano-base 1940 continha cinco abatimentos possíveis da renda bruta, esse número subiu para oito em 1950, 10 em 1960 e 13 em 1970 e 1980.

Essa expansão foi contida pela diferenciação, a partir dos anos 1960, entre os abatimentos sem limites e aqueles cuja soma não podia ultrapassar um percentual predefinido da renda bruta, normalmente entre $40 \%$ e $50 \%$. O desconto-padrão do modelo simplificado substituía somente os abatimentos limitados, deixando os declarantes livres para subtrair de sua renda bruta os abatimentos os quais não havia um teto. Na maior parte do tempo os abatimentos representaram entre $20 \%$ e $40 \%$ da renda bruta.

A diversificação dos abatimentos mudou sua composição. Nas primeiras décadas, a expansão ocorreu mais pela inclusão de itens relacionados a necessidades sociais. Desde o início foram permitidos abatimentos de contribuições e doações, bem como por dependentes. Pensões alimentícias entraram na lista no início dos anos 1940, gastos com saúde e despesas médicas foram incluídos, com restrições, para o ano-base 1947 e progressivamente ampliados, e despesas com educação foram contempladas pela primeira vez no ano-base 1959. Ao lado dessa tendência, a ditadura inaugurou uma política de incentivos fiscais para "estimular os investimentos considerados de interesse econômico ou social" (NÓBREGA, 2014, p. 75). Entre os anos-base 1964 e 1973, o rol de investimentos passíveis de abatimentos cresceu; porém, a partir do ano-base 1974, os incentivos fiscais deixaram de ser abatimentos da renda bruta para virarem descontos do imposto bruto devido.

A Tabela 1, adaptada de Nóbrega (2014, p. 203), apresenta os abatimentos mais frequentes nos 66 anos entre a origem do IRPF e as grandes reformas que alteraram bastante seu formato no Brasil. Como os incentivos fiscais puderam ser usados como abatimentos apenas por um curto período, eles não entram na lista, que é dominada por itens de cunho social. 
Tabela 1. Abatimentos mais frequentes no IRPF - Brasil, 1923-1988

\begin{tabular}{|c|c|c|}
\hline Abatimentos & Vigência $^{a}$ & Número de anos \\
\hline Dependentes & $1925-1988$ & 64 \\
\hline Contribuição e doação & 1925-1941, 1943-1988 & 63 \\
\hline Juros de dívidas pessoais & $1925-1980$ & 56 \\
\hline Prêmios de seguro de vida & $1925-1980$ & 56 \\
\hline Perdas extraordinárias ${ }^{b}$ & 1923-1930, 1942-1988 & 55 \\
\hline Pensão alimentícia & $1941-1988$ & 48 \\
\hline Despesas médicas & $1947-1988$ & 42 \\
\hline Despesas com instrução & 1959-1961, 1964-1988 & 28 \\
\hline
\end{tabular}

Fonte: adaptado de Nóbrega (2014, p. 203).

${ }^{a}$ A vigência refere-se aos anos-base ou anos-calendário.

${ }^{b}$ Entre os anos-base 1923 e 1930, as perdas extraordinárias eram deduções cedulares, mas, se não fossem usadas como tal, podiam ser abatidas da renda bruta.

\section{Renda líquida e imposto progressivo}

A diferença positiva entre a renda bruta e os abatimentos representava a renda líquida, que era a base de cálculo para o imposto progressivo. O valor assim obtido era o imposto bruto devido, que não necessariamente correspondia ao montante a ser pago. Nos primeiros anos depois do golpe de 1964 alguns investimentos incentivados podiam ser deduzidos diretamente do imposto bruto devido, enquanto outros faziam parte dos abatimentos da renda bruta. A partir de 1974, como discutido, todos os incentivos fiscais tornaram-se descontos diretos do imposto bruto devido, gerando o imposto líquido devido. Para chegar aos valores a serem pagos ou restituídos, os contribuintes tinham então que subtrair os descontos feitos na fonte, instituídos pela Lei 2.354/1954 para os rendimentos do trabalho assalariado e posteriormente expandidos. ${ }^{12}$

Como visto, até o ano-base 1964, os contribuintes arcavam tanto com os impostos cedulares proporcionais quanto com o imposto progressivo. Além disso, ao longo do tempo, houve uma série de cobranças adicionais - algumas de caráter extraordinário, outras não e descontos ou perdões. Estes últimos ocorreram com maior frequência nos primeiros anos do IRPF no Brasil, como no caso do Decreto 5.138, de 1927, que concedeu abatimento de $50 \%$ sobre o imposto devido até o ano-base 1929.

As cobranças adicionais foram mais comuns e perduraram por todo o período. A mais duradoura foi o "imposto de renda do solteiro", estabelecido pelo Decreto-lei 3.200, de 1941, conhecido como "Lei de proteção à família". O decreto instituiu a cobrança adicional

12 A documentação disponível não usa categorias consistentes para descrever as etapas de apuração do imposto. Por isso, para simplificar o processo, a explicação acima emprega termos não necessariamente idênticos aos utilizados oficialmente e deixa de lado alguns detalhes do processo. 
de $15 \%$ sobre o imposto devido por solteiros ou viúvos maiores de 25 anos sem filhos, e de $10 \%$ para os casados em mesma situação, além do adicional de $5 \%$ para contribuintes maiores de 45 anos com apenas um filho, sob o pretexto de tornar o fardo tributário mais justo e fortalecer as famílias brasileiras (NÓBREGA, 2014, p. 56). A lei foi revogada em 1964, após o golpe, e a cobrança adicional ocorreu pela última vez em 1963.

As cobranças extraordinárias foram recorrentes. Um marco inicial, em função da $2^{a}$ Guerra Mundial, foi a emissão das Obrigações de Guerra (Decreto-lei 4.789/1942). Depois, nos anos 1950, foi cobrado um adicional de 15\% sobre o imposto para contribuintes com rendimentos mais altos para financiar investimentos públicos em portos, ferrovias e indústrias. Os recursos ajudaram a capitalizar o recém-criado Banco Nacional de Desenvolvimento Econômico (BNDE). No resto do período, as cobranças extraordinárias ocorreram via empréstimos compulsórios, prática empregada ao menos em três ocasiões, por governos civis e militares. Por exemplo, em abril de 1980, o governo Figueiredo abusou dos eufemismos para instituir um "empréstimo compulsório para absorção temporária de poder aquisitivo" (Decreto-lei 1.782/1980), logo após o encerramento do prazo para entrega das declarações. Com isso, quem recebeu rendimentos não tributáveis acima de Cr\$ 4.000.000 teve que pagar 10\% do valor recebido em dez parcelas, restituídas em 1982 (NÓBREGA, 2014, p. 110).

\section{Resumo}

A formalização das relações contábeis ajuda a resumir a apuração da renda e do imposto até 1988. Deixando de lado muitos dos detalhes discutidos acima, considere $k$ fontes de rendimentos não tributáveis $\left(R N T_{k}\right)$ e $j$ fontes de rendimentos brutos tributáveis $\left(R B T_{j}\right)$ que, para fins do IRPF, são classificadas em $i=1, \ldots, 8$ tipos de rendimentos brutos cedulares $\left(R B C_{i}\right)$. O rendimento total $(R T O T)$, o rendimento bruto tributável total $(R B T)$ e os rendimentos não tributáveis totais $(R N T)$ podem ser expressos como:

$$
R T O T=R B T+R N T=\sum_{j} R B T_{j}+\sum_{k} R N T_{k}=\sum_{i=1}^{8} R B C_{i}+\sum_{k} R N T_{k}
$$

A renda bruta $(R B)$ era a soma das diferenças positivas entre os rendimentos brutos cedulares $\left(R B C_{i}\right)$ e as deduções cedulares $\left(D E D_{i}\right)$, enquanto a renda líquida era a diferença positiva entre a renda bruta e os abatimentos $(A B A T)$. Ou seja:

$$
\begin{gathered}
R B=\sum_{i}^{8}\left(R B C_{i}-D E D_{i}\right) \mathbb{1}\left\{R B T_{i}>D E D_{i}\right\} \\
R L I Q=(R B-A B A T) \mathbb{1}\{R B>A B A T\}
\end{gathered}
$$


A renda líquida era a base de cálculo para o imposto progressivo, que pode ser expresso como uma função descontínua $T($.) que gerava o imposto bruto devido (ImpBruto). Em determinados anos, era possível deduzir desse valor bruto os investimentos em incentivos fiscais (IncFisc) para chegar ao imposto líquido devido (ImpLiq):

$$
I m p L i q=\text { ImpBruto }- \text { IncFisc }=T(R L I Q)-\text { IncFisc }
$$

\subsubsection{Modelo geral entre os anos-base 1989 e 2013}

Na segunda metade dos anos 1980, diversas reformas alteraram toda a estrutura de apuração do IRPF, o número de alíquotas e sua progressividade. A declaração para o ano-base 1988 foi a última nos moldes tradicionais, com rendimentos e deduções cedulares e abatimentos, que foram extintos pela Lei 7.713, de 22 de dezembro de 1988. Depois de uma experiência mal-sucedida com o sistema de bases correntes, nos anos seguintes o modelo estabilizou-se no formato em vigor até o momento. Para facilitar a comparação, a exposição nas próximas seções aproxima, dentro do possível, a terminologia atual dos termos usados para descrever o período anterior a 1988.

\section{Rendimentos brutos tributáveis e rendimentos não tributáveis}

A separação entre rendimentos brutos tributáveis e rendimentos não tributáveis (isentos ou sujeitos à tributação exclusiva na fonte) foi mantida. Ganhos de capital, transferências patrimoniais, correção monetária e determinados benefícios trabalhistas e previdenciários continuaram de fora do rol de rendimentos brutos tributáveis. A grande modificação inicial foi o acréscimo do $13^{\circ}$ salário aos rendimentos tributados exclusivamente na fonte. Desde sua criação em 1962 até o ano-base, o $13^{\circ}$ salário era classificado na cédula $\mathrm{C}$, em conjunto com os demais rendimentos tributáveis do trabalho assalariado.

A Lei 9.249/1995 isentou lucros e dividendos a partir do ano-base 1996. Como documentou Nóbrega (2014, p. 121), o tratamento concedido a esses rendimentos variou ao longo do tempo, mas eles nunca haviam sido considerados isentos: grosso modo, até o ano-base 1974 eles faziam parte dos rendimentos brutos tributáveis na cédula F e, entre 1975 e 1995, os declarantes podiam lançá-los como rendimentos brutos tributáveis ou como tributados exclusivamente na fonte. Uma das consequências dessa mudança foi a "transmutação do trabalho em capital" (AFONSO, 2014, p. 44), ou seja, o incentivo para que muitos declarantes fossem contratados como empresas, e não como assalariados, para fugir das alíquotas progressivas do IRPF e diminuir os custos dos encargos trabalhistas.

A Figura 19 traz a participação relativa nos rendimentos totais das duas categorias de rendimentos não tributáveis, isto é, isentos e tributados exclusivamente na fonte, entre 1996 e 2013. À parte o pico em 1997 - causado provavelmente pela reação inicial à Lei 9.249/1995 -, há um aumento de 10 p.p. ao longo do período, de algo em torno de 
Figura 19. Participação dos rendimentos isentos e dos tributados exclusivamente na fonte nos rendimentos totais declarados ao IRPF - Brasil, 1996-2013

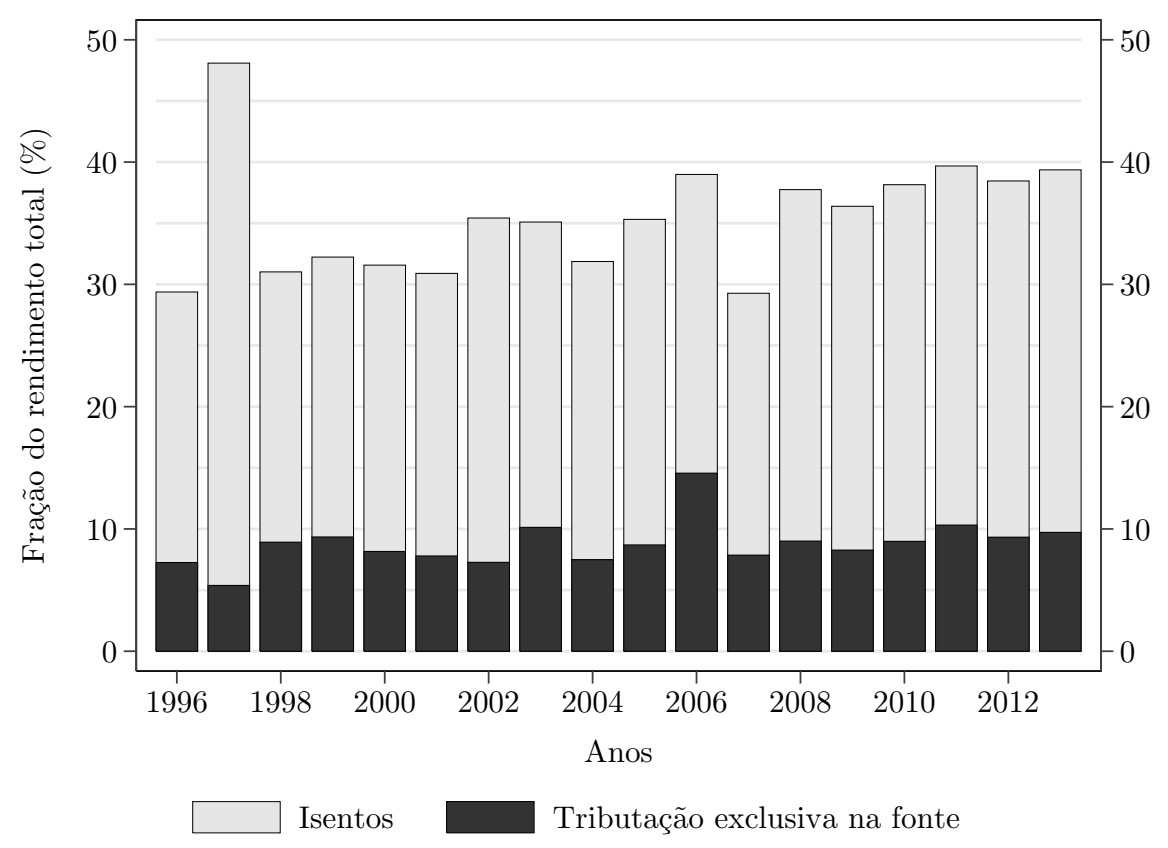

Fonte: fontes listadas na Tabela 4 e Receita Federal do Brasil, "Grandes Números - DIRPF" (anos-calendário 1999-2013) (BRASIL. MF. SRF, 2015).

30\% no fim da década de 1990 para cerca de 40\% desde 2010. O crescimento decorreu quase integralmente do maior peso relativo dos rendimentos isentos, já que os tributados exclusivamente na fonte oscilaram sem direção entre $8 \%$ e $10 \%$ dos rendimentos totais.

O detalhamento dos rendimentos não tributáveis só está disponível a partir de 2007, depois das reformas mais significativas, como apresentado na Tabela 2. Os lucros e dividendos são a rubrica mais importante, mas sua participação não aumentou no período, girando em volta de $10 \%$ da renda total. Com efeito, não houve grandes mudanças, apenas aumentos de um ou dois pontos percentuais em itens como a parcela isenta de aposentadorias e pensões (para maiores de 65 anos e portadores de doenças graves), os rendimentos de sócios/titulares de micro e pequenas empresas e os $13^{\circ}$ salários. Os reajustes do salário mínimo, a criação do programa Microempreendedor Individual (MEI) e sua expansão junto com o Simples, e o mercado de trabalho aquecido provavelmente estão por trás desses aumentos. No que diz respeito à composição média no período, os rendimentos ligados a atividades empresariais, ativos financeiros e ganhos/transferências de capital somam pouco mais de $50 \%$ do total de rendimentos não tributáveis, enquanto a outra metade está dispersa entre salários, pensões e categorias residuais.

Em suma, nos números agregados, os rendimentos não tributáveis representam uma fatia grande e crescente do rendimento total, principalmente em função do grande volume de rendimentos isentos. Ao contrário dos anos 1980, quando a inflação impunha cautela quanto à interpretação, agora é mais claro que eles correspondem a recursos 
Tabela 2. Composição dos rendimentos não tributáveis como percentual do rendimento total (\%) - Brasil, 2007-2013

\begin{tabular}{lrrrrrrrr}
\hline Tipos de rendimentos & 2007 & 2008 & 2009 & 2010 & 2011 & 2012 & 2013 & Média \\
\hline Isentos & 21.4 & 28.7 & 28.1 & 29.2 & 29.4 & 29.1 & 29.6 & 27.9 \\
Lucros e dividendos & 10.4 & 10.3 & 9.9 & 10.7 & 10.9 & 10.7 & 10.8 & 10.5 \\
Aposentadorias/pensões & 2.2 & 3.9 & 3.9 & 3.8 & 3.5 & 3.5 & 3.6 & 3.5 \\
Doações, heranças etc & 2.3 & 3.8 & 3.5 & 3.3 & 3.1 & 2.8 & 2.8 & 3.1 \\
Micro/peq. empresas & 0.5 & 1.6 & 1.7 & 1.9 & 2.1 & 2.4 & 2.6 & 1.8 \\
Atividades rurais & 0.8 & 1.6 & 1.7 & 1.7 & 1.7 & 1.7 & 1.5 & 1.5 \\
Poupança e letras & 0.4 & 0.7 & 0.8 & 0.8 & 0.9 & 0.9 & 1.0 & 0.8 \\
Outros rendimentos & 4.8 & 6.9 & 6.7 & 7.0 & 7.3 & 7.1 & 7.3 & 6.7 \\
Tributo exclusivo na fonte & 7.9 & 9.0 & 8.3 & 9.0 & 10.3 & 9.3 & 9.7 & 9.1 \\
13 ${ }^{o}$ salários & 2.2 & 3.0 & 3.3 & 3.2 & 3.1 & 3.1 & 3.2 & 3.0 \\
Aplicações financeiras & 2.4 & 2.8 & 2.5 & 2.5 & 2.9 & 2.6 & 2.1 & 2.5 \\
Ganhos de capital & 2.5 & 2.4 & 1.6 & 2.0 & 2.9 & 2.3 & 2.0 & 2.2 \\
Outros rendimentos & 0.8 & 0.9 & 0.9 & 1.3 & 1.5 & 1.3 & 2.4 & 1.3 \\
Total, não tributáveis & $\mathbf{2 9 . 3}$ & $\mathbf{3 7 . 7}$ & $\mathbf{3 6 . 4}$ & $\mathbf{3 8 . 1}$ & $\mathbf{3 9 . 7}$ & $\mathbf{3 8 . 5}$ & $\mathbf{3 9 . 4}$ & $\mathbf{3 7 . 0}$ \\
\hline
\end{tabular}

Fonte: elaboração própria a partir de Receita Federal do Brasil, "Grandes Números - DIRPF" (anos-calendário 2007-2013) (BRASIL. MF. SRF, 2015).

reais dos declarantes. Em relação ao período anterior, as principais modificações foram a transformação dos $13^{\circ}$ salários e dos lucros e dividendos em rendimentos não tributáveis.

Rendimentos brutos tributáveis, deduções e imposto progressivo

Os rendimentos brutos tributáveis deixaram de ser classificados em cédulas e as deduções cedulares e os abatimentos foram extintos. Os dois descontos foram substituídos por um conjunto limitado de deduções aplicadas ao rendimento bruto tributável total. Entre os anos-base 1989 e 1991, o modelo simplificado foi extinto, voltando em 1992 para contribuintes com renda até um limite. A partir do ano-base 1998, todos passaram a ter a opção de usar o modelo simplificado. ${ }^{13}$ Quem opta pela declaração simplificada aplica somente o desconto-padrão de $20 \%$, limitado a um teto variável anualmente, sobre o total de rendimentos brutos tributáveis, sem necessidade de comprovação.

A Figura 20 mostra a participação das principais deduções no rendimento bruto tributável total entre 1998 e 2013. A soma das deduções flutuou entre $22 \%$ e $25 \%$ dos rendimentos brutos tributáveis, com leve queda desde 2005. Sua composição não se alterou muito: as deduções com dependentes e saúde perderam peso relativo, enquanto as previdenciárias ganharam, passando da $4^{a}$ à $2^{a}$ colocação, atrás apenas do desconto-padrão.

A apuração do imposto bruto devido se dá pela aplicação das alíquotas progressivas

13 A rigor, há um número residual de contribuintes que não podem optar pelo desconto-padrão. 
Figura 20. Participação das deduções no rendimento bruto tributável total (\%) - Brasil, 1998-2013

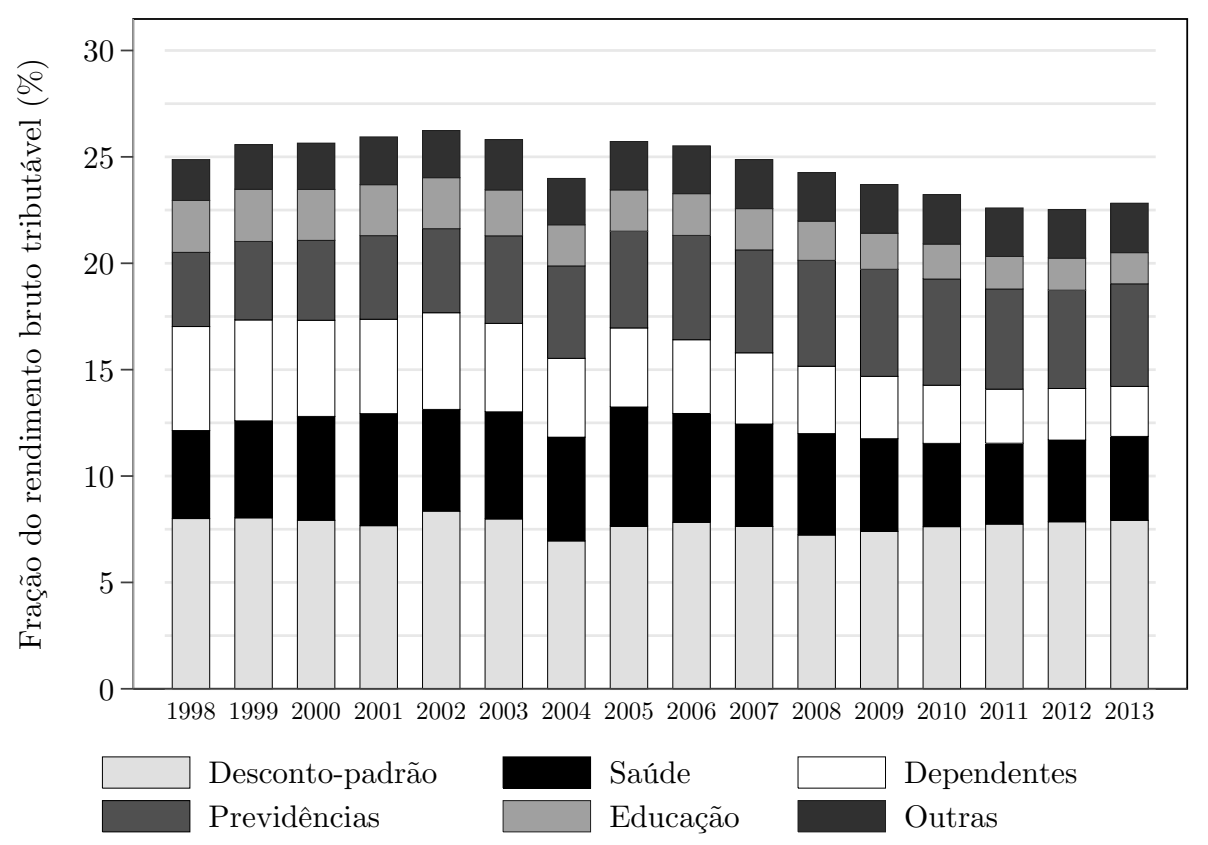

Fonte: elaboração própria a partir de Receita Federal do Brasil, "Grandes Números - DIRPF" (anos-calendário 1999-2013) (BRASIL. MF. SRF, 2015).

N.B.: "Outras" compreende deduções com pensões alimentícias e despesas registradas em livro-caixa.

à renda líquida ou base de cálculo, isto é, à diferença (positiva) entre os rendimentos brutos tributáveis e as deduções. O cálculo do imposto líquido devido tampouco apresenta grandes mistérios. Os incentivos fiscais foram limitados e tornaram-se residuais. Assim como no período anterior, o imposto líquido devido não necessariamente representa o montante a ser pago, pois é preciso levar em conta os valores retidos na fonte e outras tecnicalidades.

Em resumo, a estrutura do IRPF foi simplificada depois de 1988. À parte o maior volume e variedade de rendimentos não tributáveis, a apuração dos rendimento brutos tributáveis e do imposto permaneceu estável nas últimas duas décadas.

\section{Resumo}

Como antes, considere $k$ fontes de rendimentos não tributáveis $\left(R N T_{k}\right)$ e $j$ fontes de rendimentos brutos tributáveis $\left(R B T_{j}\right)$. O rendimento total (RTOT) é:

$$
R T O T=R B T+R N T=\sum_{j} R B T_{j}+\sum_{k} R N T_{k}
$$

O imposto bruto (ImpBruto) devido é calculado como uma função descontínua $T($.$) que toma como argumento a renda líquida (R L I Q)$, dada pela diferença positiva entre os rendimentos brutos tributáveis e as deduções:

$$
\text { ImpBruto }=T(R L I Q)=T((R B T-D E D) \mathbb{1}\{R B T>D E D\})
$$


O imposto líquido devido (ImpLiq) é a diferença ImpBruto - IncFisc, isto é, entre o imposto bruto devido e os incentivos fiscais residuais.

\subsection{Fontes disponíveis com tabulações do IRPF}

Idealmente, as informações do IRPF estariam publicamente disponíveis em microdados, preservando o anonimato dos declarantes, como ocorre em alguns países, como nos Estados Unidos, desde os anos 1960 (PIKETTY; SAEZ, 2003). No Brasil, não é assim, e só muitos poucos pesquisadores tiveram acesso direto aos dados (e.g., CASTRO, 2014).

Na prática, a forma mais comum de divulgação de informações do IRPF é por tabulações agregadas por faixas de rendimentos. Por necessidades administrativas, busca por transparência, prestação de contas e outros motivos, os órgãos arrecadadores mundo afora historicamente produziram e publicaram tabulações do tipo, inclusive no Brasil. Os resultados desta tese baseiam-se nesses e em outros dados publicamente disponíveis.

Como exemplo, a Tabela 3 reproduz parte dos dados para 2013, que, diante da ausência de microdados, chegam perto do ideal. As faixas estão ordenadas pelos rendimentos totais, são numerosas e detalhadas, e os cruzamentos contemplam muitas variáveis de interesse. Assim, é possível aplicar procedimentos de interpolação para obter a fração da renda recebida por estratos como o $0,1 \%$ ou o $1 \%$ mais rico. Um dos poucos pontos negativos é a impossibilidade de isolar os ganhos de capital e transferências patrimoniais.

Tabulações com essa qualidade existem apenas de 2006 a 2013. Infelizmente, no Brasil, essas informações jamais foram produzidas de modo consistente e homogêneo por longos períodos, com lacunas e limitações que tornam seu uso muito laborioso. Embora disponíveis desde os anos 1920, elas foram divulgadas de modo intermitente e em formatos distintos, o que exige esforços consideráveis de coleta e harmonização dos dados.

A Tabela 4 lista as fontes encontradas para o período entre os anos-base 1926-1927 ${ }^{14}$ e 2013, cobrindo 69 dos 88 anos desse intervalo, o que permitiu a construção da mais completa série histórica para a desigualdade brasileira. Como referência, há dados para mais anos do que na maioria dos países estudados pela literatura internacional, incluindo Alemanha, Argentina, Colômbia, Espanha, Itália, Países Baixos, Portugal e Suíça. ${ }^{15}$ Como discutido anteriormente, as reformas no IRPF ao longo do tempo foram significativas, mas não há nada nelas que inviabilize a comparabilidade da série histórica.

Os períodos 1929-1932, 1989-1995 e 2003-2005 são as principais lacunas. De resto, a cobertura é bastante regular e, para alguns anos, existe mais de uma fonte com dados utilizáveis. Nos poucos casos em que foram reportados valores discrepantes para os mesmos

14 A seção 4.9.1 explica por que e como as informações de 1927 foram desagregadas para 1926 e 1927.

15 Alvaredo et al. (2015), World Wealth and Income Database, <http://www.wid.world/>. Acesso em 21 out. 2015 . 
Tabela 3. Principais categorias das tabulações disponíveis do IRPF para o ano-base 2013

\begin{tabular}{lrrrrr}
\hline $\begin{array}{c}\text { Faixas de } \\
\text { rendimentos } \\
\text { totais }(\mathrm{R} \$ \text { mil })\end{array}$ & $\begin{array}{c}\text { Número de } \\
\text { declarantes }\end{array}$ & $\begin{array}{c}\text { Rend. } \\
\text { Total } \\
(\mathrm{R} \$ \text { milhões })\end{array}$ & $\begin{array}{c}\text { Rend. Bruto } \\
\text { Tributável } \\
(\mathrm{R} \$ \text { milhões })\end{array}$ & $\begin{array}{c}\text { Rend. Não } \\
\text { Tributável } \\
(\mathrm{R} \$ \text { milhões })\end{array}$ & $\begin{array}{c}\text { Renda } \\
\text { líquida } \\
(\mathrm{R} \$ \text { milhões })\end{array}$ \\
\hline 0 a 4,0 & 1.268 .688 & 310 & 210 & 100 & 169 \\
4,0 a 8,1 & 518.341 & 3.856 & 3.571 & 285 & 2.934 \\
8,1 a 16,3 & 1.075 .827 & 13.547 & 11.490 & 2.058 & 9.504 \\
16,3 a 24,4 & 2.692 .915 & 57.843 & 52.210 & 5.633 & 42.587 \\
24,4 a 40,7 & 7.882 .026 & 250.018 & 215.200 & 34.818 & 164.146 \\
40,7 a 81,4 & 7.300 .376 & 418.815 & 331.748 & 87.067 & 243.231 \\
81,4 a 162,7 & 3.522 .174 & 399.587 & 285.867 & 113.719 & 219.628 \\
162,7 a 325,4 & 1.507 .344 & 341.072 & 212.060 & 129.012 & 172.429 \\
325,4 a 650,9 & 518.567 & 228.584 & 109.013 & 119.571 & 90.551 \\
650,9 a $1.301,8$ & 136.718 & 121.171 & 34.452 & 86.719 & 29.216 \\
Mais de $1.301,8$ & 71.440 & 297.934 & 37.384 & 260.550 & 30.118 \\
Total & $\mathbf{2 6 . 4 9 4 . 4 1 6}$ & $\mathbf{2 . 1 3 2 . 7 3 8}$ & $\mathbf{1 . 2 9 3 . 2 0 5}$ & $\mathbf{8 3 9 . 5 3 3}$ & $\mathbf{1 . 0 0 4 . 5 1 2}$ \\
\hline
\end{tabular}

Fonte: Secretaria da Receita Federal, Grandes Números DIRPF 2014 - ano-calendário 2013, Tabela 9 (BRASIL. MF. SRF, 2015).

N.B.: o "rendimento total" é a soma do rendimento bruto tributável e do rendimento não tributável $(R T O T=$ $R B T+R N T)$. O "rendimento não tributável" é a soma dos rendimentos isentos e dos rendimentos tributados exclusivamente na fonte. A "renda líquida" é a diferença entre os rendimento bruto tributável e as deduções $(R L I Q=R B T-D E D)$. A tabulação desconsidera rendas líquidas negativas.

anos, a escolha baseou-se na quantidade e qualidade das informações e, secundariamente, na preferência por publicações oficiais. A referência completa para todas as publicações pode ser encontrada na bibliografia.

As tabulações variam em termos de cobertura geográfica, variáveis de ordenamento das faixas e tipos de rendimentos reportados, além de outros aspectos menos importantes. As próximas seções detalham todos os procedimentos desenvolvidos para superar esses obstáculos. No entanto, três pontos merecem ser já citados, por representarem os problemas de maior vulto e mais difíceis de avaliar empiricamente.

Primeiro, só há tabulações ordenadas por rendimentos totais a partir de 2006. Para todo o período anterior, as faixas são ordenadas por componentes da renda total. A consequência é que, no limite, os resultados anteriores a 2006 representam um extremo inferior da desigualdade, ou seja, potencialmente subestimam a concentração de renda no topo. No próximo capítulo, apresento indícios de que essa subestimação provavelmente não é muito significativa, mas não há como avaliar isso empiricamente de modo satisfatório, porque as informações para 2006-2013 não são um bom guia em função das reformas do IRPF no final dos anos 1980. 
Tabela 4. Fontes publicamente disponíveis com tabulações do IRPF para o Brasil, 1927-2013

\begin{tabular}{|c|c|c|c|c|}
\hline Anos & Fontes & Cobertura & Ordenamento $^{a}$ & Rendas reportadas $^{b}$ \\
\hline 1927 & Souza Reis (1930) & $\mathrm{DF}^{c}$ & RLIQ & $\mathrm{RLIQ}, \mathrm{RBT}^{d}$ \\
\hline 1928 & Souza Reis (1930) & $\mathrm{DF}^{c}$ & RLIQ & RLIQ, $\mathrm{RBT}^{d}$ \\
\hline 1929 & $\mathrm{n} / \mathrm{d}$ & $\mathrm{n} / \mathrm{d}$ & $\mathrm{n} / \mathrm{d}$ & $\mathrm{n} / \mathrm{d}$ \\
\hline 1930 & $\mathrm{n} / \mathrm{d}$ & $\mathrm{n} / \mathrm{d}$ & $\mathrm{n} / \mathrm{d}$ & $\mathrm{n} / \mathrm{d}$ \\
\hline 1931 & $\mathrm{n} / \mathrm{d}$ & $\mathrm{n} / \mathrm{d}$ & $\mathrm{n} / \mathrm{d}$ & $\mathrm{n} / \mathrm{d}$ \\
\hline 1932 & $\mathrm{n} / \mathrm{d}$ & $\mathrm{n} / \mathrm{d}$ & $\mathrm{n} / \mathrm{d}$ & $\mathrm{n} / \mathrm{d}$ \\
\hline 1933 & AEB 1941-1945 (IBGE, 1916-) & $\mathrm{DF}^{c}$ & RLIQ & RLIQ \\
\hline 1934 & AEB 1946 (IBGE, 1916-) & $\mathrm{DF}^{c}$ & RLIQ & RLIQ \\
\hline 1935 & AEB 1946 (IBGE, 1916-) & $\mathrm{DF}^{c}$ & RLIQ & RLIQ \\
\hline 1936 & AEB 1946 (IBGE, 1916-) & $\mathrm{DF}^{c}$ & RLIQ & RLIQ \\
\hline 1937 & AEB 1946 (IBGE, 1916-) & $\mathrm{DF}^{c}$ & RLIQ & RLIQ \\
\hline 1938 & AEB 1946 (IBGE, 1916-) & $\mathrm{DF}^{c}$ & RLIQ & RLIQ \\
\hline 1939 & AEB 1946 (IBGE, 1916-) & $\mathrm{DF}^{c}$ & RLIQ & RLIQ \\
\hline 1940 & AEB 1946 (IBGE, 1916-) & $\mathrm{DF}^{c}$ & RLIQ & RLIQ \\
\hline 1941 & AEB 1946 (IBGE, 1916-) & $\mathrm{DF}^{c}$ & RLIQ & RLIQ \\
\hline 1942 & AEB 1946 (IBGE, 1916-) & $\mathrm{DF}^{c}$ & RLIQ & RLIQ \\
\hline 1943 & AEB 1946 (IBGE, 1916-) & $\mathrm{DF}^{c}, \mathrm{SP}, \mathrm{RS}, \mathrm{MG}$ & RLIQ & RLIQ \\
\hline
\end{tabular}


Tabela 4. Continuação da página anterior

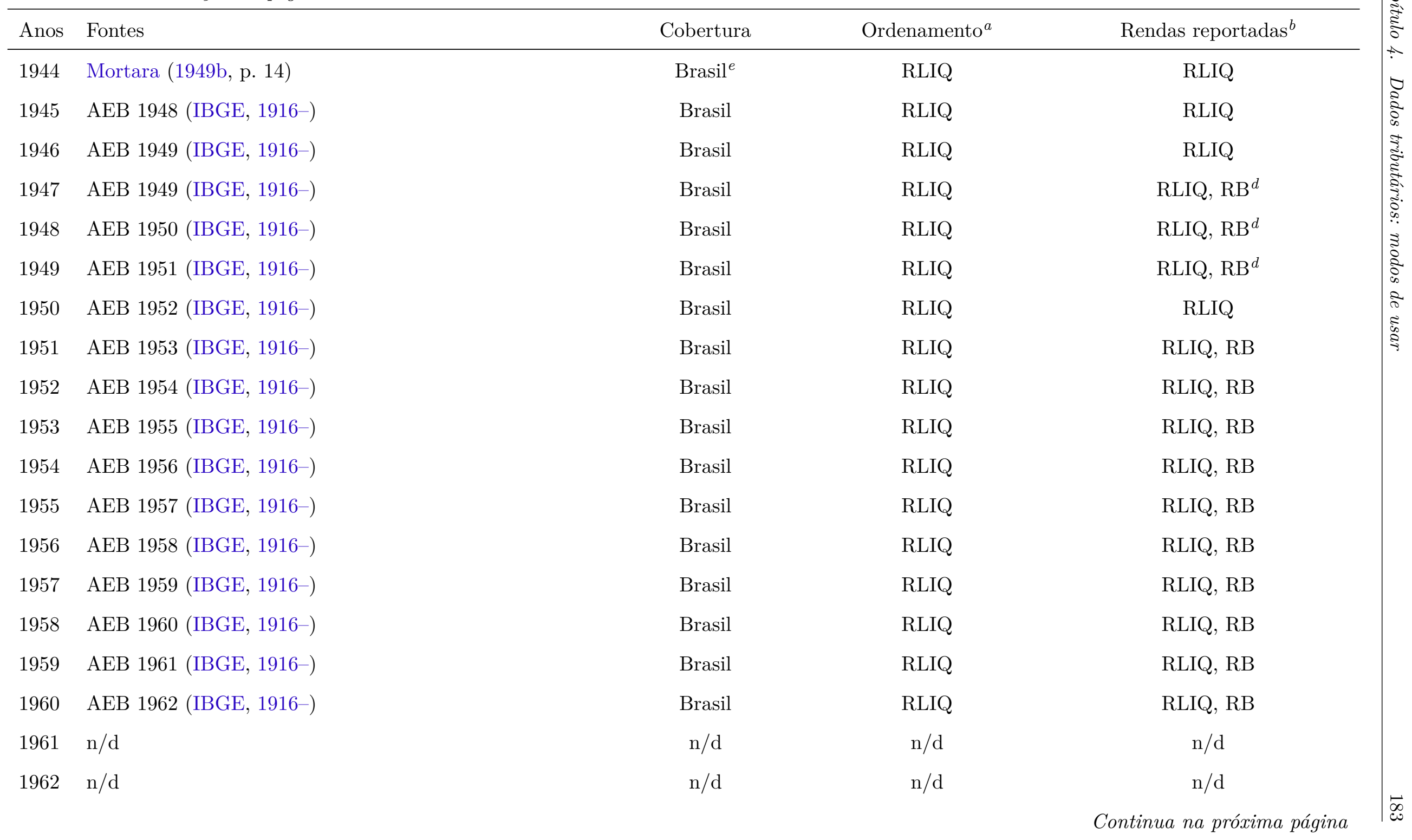


Tabela 4. Continuação da página anterior

\begin{tabular}{|c|c|c|c|c|}
\hline Anos & Fontes & Cobertura & Ordenamento $^{a}$ & Rendas reportadas ${ }^{b}$ \\
\hline 1963 & Relatório 1964 (BRASIL. MF. DIR, 1965) & Brasil & RLIQ & RLIQ, RB \\
\hline 1964 & Boletim Estatístico n. 23 (BRASIL. MF. DIR, 1966) & Brasil & RLIQ & RLIQ, RB, RBT \\
\hline 1965 & Boletim Estatístico n. 28 (BRASIL. MF. DIR, 1968a) & Brasil & RLIQ & RLIQ, RB, RBT \\
\hline 1966 & Boletim Estatístico n. 32 (BRASIL. MF. DIR, 1968b) & $\mathrm{SP}$ e $\mathrm{GB}^{c}$ & RLIQ & RLIQ, RB, RBT \\
\hline 1967 & IR e proventos ... (BRASIL. MF. DIR, 1968) & Brasil & RLIQ & RLIQ, RB, RBT \\
\hline 1968 & AEF 1970 (BRASIL. MF. SRF, 1970-1980) & Brasil & RLIQ & RLIQ, RB, RBT \\
\hline 1969 & AEF 1971 (BRASIL. MF. SRF, 1970-1980) & Brasil & RLIQ, RBT & RLIQ, RB, RBT \\
\hline 1970 & AEF 1972 (BRASIL. MF. SRF, 1970-1980) & Brasil & RLIQ, RBT & RLIQ, RB, RBT \\
\hline 1971 & AEF 1973 (BRASIL. MF. SRF, 1970-1980) & Brasil & RLIQ, RBT & RLIQ, RB, RBT \\
\hline 1972 & AEF 1974 (BRASIL. MF. SRF, 1970-1980) & Brasil & RLIQ, RBT & RLIQ, RB, RBT \\
\hline 1973 & AEF 1975 (BRASIL. MF. SRF, 1970-1980) & Brasil & $\mathrm{RBT}$ & RLIQ, RB, RBT \\
\hline 1974 & AEF 1976 (BRASIL. MF. SRF, 1970-1980) & Brasil & RLIQ, RBT & RLIQ, RB, RBT, RNT, RTOT \\
\hline 1975 & AEF 1977 (BRASIL. MF. SRF, 1970-1980) & Brasil & RLIQ, RBT & RLIQ, RB, RBT, RNT, RTOT \\
\hline 1976 & AEF 1978 (BRASIL. MF. SRF, 1970-1980) & Brasil & RLIQ, RBT & RLIQ, RB, RBT, RNT, RTOT \\
\hline 1977 & AEF 1979 (BRASIL. MF. SRF, 1970-1980) & Brasil & RLIQ, RBT & RLIQ, RB, RBT, RNT, RTOT \\
\hline 1978 & AEF 1980 (BRASIL. MF. SRF, 1970-1980) & Brasil & RLIQ, RBT & RLIQ, RB, RBT, RNT, RTOT \\
\hline 1979 & IRPF 1980 (BRASIL. MF. SRF, 1979-1989) & Brasil & RLIQ, RBT, RNT & RLIQ, RB, RBT, RNT, RTOT \\
\hline 1980 & IRPF 1981 (BRASIL. MF. SRF, 1979-1989) & Brasil & RLIQ, RBT, RNT & RLIQ, RB, RBT, RNT, RTOT \\
\hline 1981 & IRPF 1982 (BRASIL. MF. SRF, 1979-1989) & Brasil & RLIQ, RBT, RNT & RLIQ, RB, RBT, RNT, RTOT \\
\hline
\end{tabular}


Tabela 4. Continuação da página anterior

\begin{tabular}{|c|c|c|c|c|}
\hline Anos & Fontes & Cobertura & Ordenamento $^{a}$ & Rendas reportadas ${ }^{b}$ \\
\hline 1982 & IRPF 1983 (BRASIL. MF. SRF, 1979-1989) & Brasil & RLIQ, RBT, RNT & RLIQ, RB, RBT, RNT, RTOT \\
\hline 1983 & IRPF 1984 (BRASIL. MF. SRF, 1979-1989) & Brasil & RLIQ, RBT, RNT & RLIQ, RB, RBT, RNT, RTOT \\
\hline 1984 & IRPF 1985 (BRASIL. MF. SRF, 1979-1989) & Brasil & RLIQ, RBT, RNT & RLIQ, RB, RBT, RNT, RTOT \\
\hline 1985 & IRPF 1986 (BRASIL. MF. SRF, 1979-1989) & Brasil & RLIQ, RBT, RNT & RLIQ, RB, RBT, RNT, RTOT \\
\hline 1986 & IRPF 1987 (BRASIL. MF. SRF, 1979-1989) & Brasil & RLIQ, RBT, RNT & RLIQ, RB, RBT, RNT, RTOT \\
\hline 1987 & IRPF 1988 (BRASIL. MF. SRF, 1979-1989) & Brasil & RLIQ, RBT, RNT & RLIQ, RB, RBT, RNT, RTOT \\
\hline 1988 & IRPF 1989 (BRASIL. MF. SRF, 1979-1989) & Brasil & RLIQ, RBT, RNT & RLIQ, RB, RBT, RNT, RTOT \\
\hline 1989 & $\mathrm{n} / \mathrm{d}$ & $\mathrm{n} / \mathrm{d}$ & $\mathrm{n} / \mathrm{d}$ & $\mathrm{n} / \mathrm{d}$ \\
\hline 1990 & $\mathrm{n} / \mathrm{d}$ & $\mathrm{n} / \mathrm{d}$ & $\mathrm{n} / \mathrm{d}$ & $\mathrm{n} / \mathrm{d}$ \\
\hline 1991 & $\mathrm{n} / \mathrm{d}$ & $\mathrm{n} / \mathrm{d}$ & $\mathrm{n} / \mathrm{d}$ & $\mathrm{n} / \mathrm{d}$ \\
\hline 1992 & $\mathrm{n} / \mathrm{d}$ & $\mathrm{n} / \mathrm{d}$ & $\mathrm{n} / \mathrm{d}$ & $\mathrm{n} / \mathrm{d}$ \\
\hline 1993 & $\mathrm{n} / \mathrm{d}$ & $\mathrm{n} / \mathrm{d}$ & $\mathrm{n} / \mathrm{d}$ & $\mathrm{n} / \mathrm{d}$ \\
\hline 1994 & $\mathrm{n} / \mathrm{d}$ & $\mathrm{n} / \mathrm{d}$ & $\mathrm{n} / \mathrm{d}$ & $\mathrm{n} / \mathrm{d}$ \\
\hline 1995 & $\mathrm{n} / \mathrm{d}$ & $\mathrm{n} / \mathrm{d}$ & $\mathrm{n} / \mathrm{d}$ & $\mathrm{n} / \mathrm{d}$ \\
\hline 1996 & Trib. da renda no Brasil ... (BRASIL. MF. SRF, 2001) & Brasil & $\mathrm{RBT}$ & $\mathrm{RBT}$ \\
\hline 1997 & Trib. da renda no Brasil ... (BRASIL. MF. SRF, 2001) & Brasil & RBT & RBT \\
\hline 1998 & Análise Econ. DIRPF 1999 (BRASIL. MF. SRF, 2000) & Brasil & $\mathrm{RBT}$ & RLIQ, RBT \\
\hline 1999 & $\mathrm{n} / \mathrm{d}$ & $\mathrm{n} / \mathrm{d}$ & $\mathrm{n} / \mathrm{d}$ & $\mathrm{n} / \mathrm{d}$ \\
\hline 2000 & Torres (2003) & Brasil & $\mathrm{RBT}$ & RBT \\
\hline
\end{tabular}


Tabela 4. Continuação da página anterior

\begin{tabular}{|c|c|c|c|c|}
\hline Anos & Fontes & Cobertura & Ordenamento $^{a}$ & Rendas reportadas ${ }^{b}$ \\
\hline 2001 & $\mathrm{n} / \mathrm{d}$ & $\mathrm{n} / \mathrm{d}$ & $\mathrm{n} / \mathrm{d}$ & $\mathrm{n} / \mathrm{d}$ \\
\hline 2002 & O IR das pessoas ...(BRASIL. MF. SRF, 2004) & Brasil & RBT & $\mathrm{RBT}$ \\
\hline 2003 & $\mathrm{n} / \mathrm{d}$ & $\mathrm{n} / \mathrm{d}$ & $\mathrm{n} / \mathrm{d}$ & $\mathrm{n} / \mathrm{d}$ \\
\hline 2004 & $\mathrm{n} / \mathrm{d}$ & $\mathrm{n} / \mathrm{d}$ & $\mathrm{n} / \mathrm{d}$ & $\mathrm{n} / \mathrm{d}$ \\
\hline 2005 & $\mathrm{n} / \mathrm{d}$ & $\mathrm{n} / \mathrm{d}$ & $\mathrm{n} / \mathrm{d}$ & $\mathrm{n} / \mathrm{d}$ \\
\hline 2006 & Castro (2014), Medeiros, Souza e Castro (2015a) & Brasil & RTOT & RBT, RNT, RTOT \\
\hline 2007 & GNIRPF ano-calendário 2007 (BRASIL. MF. SRF, 2015) & Brasil & RLIQ, RBT, RNT, RTOT & RLIQ, RBT, RNT, RTOT \\
\hline 2008 & GNIRPF ano-calendário 2008 (BRASIL. MF. SRF, 2015) & Brasil & RLIQ, RBT, RNT, RTOT & RLIQ, RBT, RNT, RTOT \\
\hline 2009 & GNIRPF ano-calendário 2009 (BRASIL. MF. SRF, 2015) & Brasil & RLIQ, RBT, RNT, RTOT & RLIQ, RBT, RNT, RTOT \\
\hline 2010 & GNIRPF ano-calendário 2010 (BRASIL. MF. SRF, 2015) & Brasil & RLIQ, RBT, RNT, RTOT & RLIQ, RBT, RNT, RTOT \\
\hline 2011 & GNIRPF ano-calendário 2011 (BRASIL. MF. SRF, 2015) & Brasil & RLIQ, RBT, RNT, RTOT & RLIQ, RBT, RNT, RTOT \\
\hline 2012 & GNIRPF ano-calendário 2012 (BRASIL. MF. SRF, 2015) & Brasil & RLIQ, RBT, RNT, RTOT & RLIQ, RBT, RNT, RTOT \\
\hline 2013 & GNIRPF ano-calendário 2013 (BRASIL. MF. SRF, 2015) & Brasil & RLIQ, RBT, RNT, RTOT & RLIQ, RBT, RNT, RTOT \\
\hline \multicolumn{5}{|c|}{$\begin{array}{l}\text { N.B.: } R L I Q \text { é o rendimento líquido; } R B \text {, a renda bruta; } R B T \text {, o rendimento bruto tributável; } R N T \text {, o rendimento não tributável; } R T O T \text {, o rendimento total. As } \\
\text { fontes abreviadas são, em ordem alfabética: "Análise Econômica da DIRPF 1999" (Análise Econ. DIRPF 1999); "Anuário Estatístico do Brasil" (AEB); "Anuário } \\
\text { Econômico-Fiscal" (AEF); "Grandes Números IRPF" (GNIRPF); "Imposto de Renda Pessoa Física" (IRPF); "Imposto sobre a renda e proventos de qualquer } \\
\text { natureza" (IR e proventos ...); "O imposto de renda das pessoas físicas no Brasil" (O IR das pessoas ...); "Tributação da renda no Brasil pós-Real" (Trib. da } \\
\text { renda no Brasil ....). "n/d" significa "não disponível". }\end{array}$} \\
\hline \multicolumn{5}{|c|}{ a $\mathrm{O}$ ordenamento por renda bruta $(R B)$ está disponível para alguns anos, mas foi omitido da lista. } \\
\hline \multicolumn{5}{|c|}{$\begin{array}{l}\text { c Até 1960, o Distrito Federal era o município do Rio de Janeiro, que virou o estado da Guanabara até 1975, quando houve a fusão com o estado do Rio de Janeiro. } \\
\text { d Apenas totais não desagregados. }\end{array}$} \\
\hline
\end{tabular}


Segundo, só depois de 1974 as publicações passaram a reportar os rendimentos não tributáveis por faixas de renda e, mesmo assim, há alguns anos sem essas informações. Como explicado, até o ano-base de 1970 os formulários do IRPF sequer tinham campo próprio para esses rendimentos. Por isso, como o objetivo é estimar a renda total recebida pelos ricos, foi necessário imputá-los com base nos valores observados nos anos mais próximos. Portanto, os resultados para rendimentos totais em todo o período 1926-1973 dependem de relações observadas na década de 1970. As mudanças na legislação permitem imaginar a direção de um possível viés, ao menos na década de 1960, como comentado no próximo capítulo; de toda forma, uma boa dose de cautela é sempre recomendada.

Terceiro, há a questão espinhosa da evasão e da elisão fiscal. A literatura internacional, como visto, tende a não encontrar efeitos sobre os mais ricos a ponto de lançar dúvidas sobre os resultados. No Brasil, há poucos trabalhos empíricos sobre o tema e, salvo engano, nenhum que examine a questão no longo prazo. ${ }^{16}$ Ao mesmo tempo, há indícios de que a fiscalização de fato tornou-se mais rígida em determinados momentos, como durante a $2^{a}$ Guerra (NÓBREGA, 2014, cap. 5 e 6). Os próximos capítulos passam ao largo da avaliação quantitativa da evasão e da elisão, voltando ao tema esporadicamente nos períodos mais problemáticos. Embora não seja possível chegar a conclusões definitivas, nada indica que a evasão e a elisão sejam graves a ponto de anular as principais conclusões.

Não obstante essas questões e obstáculos, os dados brasileiros não são sistematicamente piores do que os de outros países analisados pela literatura internacional. As imperfeições não devem ser ignoradas; contudo, é reconfortante que os resultados sejam plausíveis e não apresentem descontinuidades inexplicáveis.

\subsection{Definição do conceito de renda}

Boa parte das deficiências e qualidades dos dados tributários depende da definição prévia do conceito de renda mais apropriado para a análise. Em termos abstratos, há muitas definições disponíveis, com sabores nem sempre idênticos. Economistas que trabalham com finanças públicas costumam partir do conceito abrangente de Haig-Simons, que considera a renda como a capacidade do indivíduo de pagar impostos, sendo equivalente ao seu consumo potencial anual, ou seja, o consumo efetivado somado aos acréscimos a seu estoque de riqueza (e.g., GRUBER, 2012, p. 536). Já os manuais de análise da distribuição de rendimentos entre domicílios estabelecem como renda todos os fluxos, monetários ou em espécie, recebidos pelas famílias com frequência anual ou maior, excluindo ganhos inesperados e/ou irregulares (e.g., CANBERRA GROUP, 2011, p. 9).

16 Um desses é o de Silva (2003), que usa dados agregados em nível estadual para estudar os efeitos do percentual de contribuintes fiscalizados e das multas sobre o valor médio por declarante do imposto pago e o percentual de declarantes per capita entre 1996 e 2002. Sua conclusão é que gastos adicionais em fiscalização têm produtividade marginal elevada. 
Não há um único conceito certo para todas as ocasiões, e a decisão deve ser norteada pelos objetivos da pesquisa e pelas características das informações existentes. Em essência, assumindo um nível mínimo de qualidade das fontes de dados, trata-se de um problema de otimização sujeito a restrições: qual o conceito mais adequado do ponto de vista teórico que pode ser operacionalizado?

Atkinson (2007) resumiu, como visto, dois motivos gerais para o estudo dos rendimentos dos ricos. Primeiro, a renda implica "comando sobre recursos", no sentido clássico de que a desigualdade de renda traduz-se em diferentes capacidades de consumo e bemestar. O volume de recursos nas mãos dos mais ricos não apenas acarreta um potencial de consumo enorme para o pequeno grupo no topo como também é normalmente grande o suficiente para afetar tanto o nível quanto as tendências nas medidas de desigualdade que levam em conta toda a distribuição. Mais ainda, esse volume pode ser entendido em termos de "capacidade tributável", uma vez que qualquer projeto de redistribuição ou financiamento não regressivo de bens públicos dependerá em boa medida desses recursos. ${ }^{17}$

O segundo motivo remete ao poder, ou, nas palavras de Atkinson, à renda como "comando sobre pessoas". Entre os ricos, essa capacidade expressa-se sobretudo como "exclusão social voluntária": a opção de recorrer a estratégias de "saída" em relação à provisão coletiva de serviços em prol de soluções privadas. ${ }^{18}$ Dado o caráter intensivo em trabalho dos principais serviços nos quais os ricos buscam sua "autoexclusão", a renda como instrumento de poder via comando do trabalho alheio depende do grau de desigualdade vigente, em especial de sua concentração no topo.

Nessa perspectiva, o conceito mais interessante para os propósitos desta tese corresponderia aos rendimentos monetários definidos de forma abrangente, englobando os fluxos de renda recebidos e as variações nos estoques de patrimônio. Essa definição é bem próxima do conceito de Haig-Simons, exceto por um desvio comum: os custos incorridos para obtenção dos próprios rendimentos, como o consumo de capital fixo de empresas familiares e/ou despesas com funcionários e custeio de quem exerce trabalho não assalariado, devem ser subtraídos dos rendimentos totais. Além disso, seria desejável desagregar os rendimentos propriamente ditos das variações patrimoniais, permitindo a comparação dos resultados com e sem ganhos de capital e transferências patrimoniais.

$\mathrm{Na}$ prática, alguns compromissos e vários filtros e imputações precisam ser feitos para que as informações do IRPF cheguem perto dessa definição. Nem todas as limitações podem ser superadas, mas os resultados são satisfatórios e muitos dos pressupostos necessários para as imputações são relativamente incontroversos.

17 Medeiros (2005) justificou sua linha de riqueza de forma análoga: ricos seriam aqueles cujo "excesso" de renda - o volume de recursos acima da linha de riqueza - seria suficiente para erradicar a pobreza.

18 Atkinson baseia-se fortemente na análise de Barry (2002) sobre exclusão social e distribuição de renda. A "saída" como uma das respostas possíveis diante da deterioração de instituições é discutida no livro clássico de Hirschman (1970). 
Portanto, o conceito de renda privilegiado aqui abarca os rendimentos monetários tributáveis e os não tributáveis (isentos ou com tributação exclusiva na fonte) das declarações anuais do IRPF, incluindo rendimentos do trabalho assalariado e não assalariado; da atividade empresarial; da exploração agrícola, pastoril e afins; de propriedades imobiliárias e intelectuais; do capital financeiro; de pensões, aposentadorias e transferências públicas; e ganhos de capital e transferências patrimoniais. Os rendimentos são brutos, isto é, antes da incidência do imposto de renda e das contribuições trabalhistas que recaem sobre os empregados, mas omitem os encargos patronais sobre a folha de pagamento e o imposto de renda de pessoas jurídicas (IRPJ). Os rendimentos não monetários são desconsiderados.

Conceitualmente, essa definição é bem próxima à usada pela literatura internacional. As idiossincrasias estão nos procedimentos exigidos para adequar os dados disponíveis, que variam entre países. As próximas seções descrevem esses procedimentos em detalhes.

Antes, cabe apenas notar algumas limitações e desvios que os dados disponíveis impõem em relação a esse conceito de renda. Primeiro, não há como desagregar fluxos de rendimentos e variações no patrimônio. Na maior parte dos países pesquisados, os resultados contemplam somente os fluxos de rendimentos, deixando de fora ganhos de capital e afins, o que dificulta as comparações internacionais. Além disso, as variações de patrimônio incluem heranças e meações, o que infla a concentração no topo no Brasil mesmo em comparação com os países para os quais há informações sobre ganhos de capital. É difícil avaliar a extensão do problema: nos dados agregados, a participação de ganhos de capital, heranças e afins é pequena, mas ela pode ser maior entre os mais ricos, ainda que provavelmente não a ponto de afetar muito os resultados. ${ }^{19}$

Segundo, rigorosamente falando, nem todos os rendimentos reportados nas declarações anuais de IRPF são brutos. De acordo com a legislação atual, por exemplo, os contribuintes informam apenas os valores líquidos de alguns rendimentos tributados exclusivamente na fonte, como ganhos em renda variável e rendimentos de aplicações financeiras. Por conseguinte, a concentração no topo estaria subestimada. Empiricamente, essa subestimação deve ser pequena, porque as alíquotas sobre esses rendimentos tributados na fonte são em geral baixas e eles representam um percentual pequeno da renda total (ver Tabela 2). Mesmo que eles estejam muito concentrados entre os mais ricos, é provável que seu impacto afete mais o nível, e não a dinâmica da concentração no topo.

Terceiro, o conceito não corresponde estritamente a rendimentos econômicos reais e refere-se sempre a valores nominais. Grosso modo, isso não é um problema, pois o denominador para a renda é igualmente calculado da mesma forma. No entanto, em momentos de inflação muito alta a situação é mais problemática: não é coincidência que os resultados para 1988 sejam completamente implausíveis, tendo sido descartados.

$\overline{19}$ Como se vê na Tabela 2, entre 2007 e 2013 os ganhos de capital representaram em média 2,2\% da renda total e as heranças, doações e afins, $3,1 \%$. 


\subsection{Ajustes e imputações iniciais às tabulações}

\subsubsection{Ajuste da cobertura geográfica em 1927-1943 e 1966}

Nem todas as tabulações têm cobertura nacional: como visto na Tabela 4, até 1942, só há dados para o Distrito Federal (atual município do Rio de Janeiro), em 1943 as informações cobrem apenas os quatro estados com maior arrecadação geral do IR (São Paulo, Distrito Federal, Rio Grande do Sul e Minas Gerais, nessa ordem) e, em 1966, apenas os dois principais (São Paulo e Guanabara, atual município do Rio de Janeiro). Para construir uma série nacional, foi preciso extrapolar esses dados para todo o Brasil.

Para isso, foram usados os próprios resultados do IR e/ou do IRPF para o Brasil e por unidade da federação (UF) ao longo do tempo. As publicações encontradas desagregam a arrecadação total do IR (IRPF e IRPJ juntos) por UF desde o ano-base 1925 e, para os anos-base 1955-1964, há também dados regionalizados para o número de contribuintes e para a renda líquida total por UF (somente IRPF para ambos). ${ }^{20}$

A desagregação regional sugere que a falta de cobertura nacional não é um problema tão grave. As UFs para as quais há dados tinham participação muito expressiva nos totais. O antigo Distrito Federal ficou em primeiro lugar na arrecadação do IR em 15 dos 16 anos entre 1927 e 1952, obtendo participação média de 38\% na receita total do tributo, valor quase 10 p.p. maior do que sua média para os anos 1960. Os quatro estados para os quais há informações em 1943 foram responsáveis por 82\% da arrecadação naquele ano e, em 1966, São Paulo e Guanabara representaram $72 \%$ do montante arrecadado.

A extrapolação, portanto, usou os melhores dados disponíveis para transformar as tabulações com cobertura limitada em resultados nacionais:

1927-1928 e 1933-1942: as células das tabulações originais foram multiplicadas pelo inverso da participação do Distrito Federal na arrecadação total do IR de cada ano, $1 / \operatorname{arrec}_{(D F)}$. Os multiplicadores calculados oscilam entre 2,42 (em 1933, $\operatorname{arrec}_{(D F)}=$

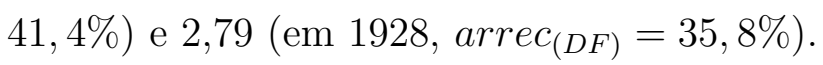

1943: as células das tabulações originais foram multiplicadas pelo inverso da participação de São Paulo, Distrito Federal, Rio Grande do Sul e Minas Gerais na arrecadação total do IR, ou seja, $1 / \operatorname{arrec}_{(S P, D F, R S, M G)}=1 / 0,823=1,216$.

1966: as células das tabulações originais foram multiplicadas pelo inverso da fração de contribuintes do IRPF que moravam em São Paulo e Guanabara, ou seja, $1 / \operatorname{contrib}_{(S P, G B)}=1 / 0,619=1,617$.

20 As informações estão em Souza Reis (1930); Anuário Estatístico Brasileiro 1938, 1939-1940, 1967, 1968 e 1969 (IBGE, 1916-); e Comissão de Reforma do Ministério da Fazenda (1966). 
O ajuste para 1966 poderia ter sido feito como os anteriores, o que produziria valores $15 \%$ menores. A escolha pela fração de contribuintes foi feita porque os números de arrecadação incluem o IRPJ, e São Paulo é sede de empresas com filiais em todo o Brasil, o que implicaria alguma distorção nos resultados.

O maior atrativo dessa técnica de extrapolação é a simplicidade. Os resultados não apresentam nenhuma descontinuidade preocupante entre os anos originalmente com cobertura nacional e aqueles em que foi preciso fazer a extrapolação. Esse procedimento é mais justificável do que o de Milá (2015), que calculou primeiro as frações da renda para os mais ricos apenas no Distrito Federal e, em seguida, adicionou aos resultados de 1933-1945 a diferença média entre os números cariocas e nacionais vista no período 1945-1950, estratégia que envolve mais estimações e palpites arriscados quanto ao controle para a renda total no município do Rio de Janeiro. ${ }^{21}$

\subsubsection{Imputação dos declarantes por faixa de renda em 1963 e 1964}

Apesar de bem completas, as tabulações para os anos-base 1963 e 1964 estranhamente não fornecem o número de declarações em cada faixa de renda. Para 1964, uma opção seria usar os números de Kingston e Kingston (1972), obtidos, segundo eles, com a assessoria do então Ministro da Fazenda, Delfim Netto. Porém, ou a assessoria do ministro foi incompetente ou houve algum erro tipográfico, porque duas das faixas intermediárias têm renda média fora do intervalo válido. O problema parece estar justamente no número de declarantes por faixa, já que os valores dos rendimentos são próximos aos divulgados no Boletim Estatístico n. 23 (BRASIL. MF. DIR, 1966).

A saída foi atribuir a todas as faixas, com exceção da última, renda média igual ao ponto médio do intervalo e derivar daí o número de declarações. Nos anos mais próximos com informações, a renda média das faixas intermediárias ficou de fato bem próxima ao seu ponto médio. A etapa seguinte foi imputar o número de declarações das faixas superiores, isto é, sem limite máximo de renda. A opção foi assumir um $\beta$ de Pareto igual a 1,8, de modo que a renda média dessas faixas fosse $80 \%$ maior do que seu limite inferior. Os $\beta$ análogos nos anos mais próximos ficaram perto disso; de todo modo, o número de casos na última faixa é tão pequeno que a escolha do $\beta$ é irrelevante, ao menos dentro de um intervalo plausível.

Em 1964, os números produzidos por esse método foram muito próximos aos de Kingston e Kingston (1972), exceto nas faixas problemáticas, reforçando a confiança na imputação. O total de declarações apresentou pequenas diferenças em relação aos totais publicados: em 1963, o valor imputado ficou 1\% abaixo do total e, em 1964, 7\%. Para harmonizar a imputação com as informações disponíveis, portanto, o número de declarações em cada faixa foi multiplicado por 1,007 em 1963 e 1,07 em 1964.

21 Milá (2015) não incluiu 1963 em sua análise e usou a tabulação de 1943 apenas para o Distrito Federal. 


\subsubsection{Imputação dos rendimentos brutos tributáveis em 1927-1963}

Como indicado na Tabela 4, até 1964, as tabulações não informam os rendimentos brutos tributáveis por faixas de renda e, para vários anos, não apresentam sequer a renda bruta, só os rendimentos líquidos, que equivalem aos rendimentos brutos tributáveis menos as deduções e abatimentos. Logo, foi necessário imputar as deduções e abatimentos correspondentes para chegar ao conceito de rendimentos brutos tributáveis.

Felizmente, elas são relativamente previsíveis e fáceis e imputar e, em vários casos, há disponibilidade de valores agregados para os rendimentos líquidos cedulares e afins. Assim, a imputação foi dividida em duas etapas: primeiro, imputou-se a renda bruta para o período 1933-1949 e, em seguida, os rendimentos brutos tributáveis de 1927 a 1963.

Em Souza (2014), imputei diretamente os rendimentos brutos tributáveis a partir da renda líquida com base nos anos mais próximos com informações. Milá (2015) optou pela mesma estratégia, aplicando as relações de 1969-1972 às décadas anteriores. A abordagem em duas etapas aproveita melhor as informações disponíveis do que essas estratégias mais simples, respeitando as mudanças na composição dos rendimentos tributáveis no período 1947-1960 e controlando a influência da expansão dos abatimentos. ${ }^{22}$

Imputação da renda bruta, 1933-1949

Entre 1933 e 1946, temos apenas a renda líquida por faixas de renda líquida e o número de declarantes por faixa. Para transformar a renda líquida em renda bruta é necessário somar os abatimentos permitidos por lei. A imputação assumiu que, para cada faixa, os abatimentos equivaliam a $20 \%$ da renda bruta, o que, na prática, implicou a multiplicação das rendas líquidas por 1,25 (1/1,25=80\%).

O valor de $20 \%$ foi calculado a partir dos cinco anos mais próximos com informações: os agregados para 1947-1951 registram abatimentos médios de 22\% da renda bruta. Esse valor foi arredondado para baixo, pois o rol de abatimentos aumentou a partir do ano-base 1947, com a inclusão das despesas médicas. O uso de um percentual único para todas as faixas não é problemático, uma vez que os dados desagregados para os anos 1950 não revelam nenhuma variação entre as faixas mais pobres e mais ricas.

O procedimento foi diferente para 1947, 1948 e 1949. Nesses casos as tabulações informam os valores totais da renda bruta e dos abatimentos, sendo necessário, portanto, apenas desagregá-los por faixas de renda. Isso foi feito da maneira mais simples, multiplicando-se a renda líquida de cada faixa pela razão $R B / R L I Q$ verificada em cada ano para os dados agregados. Ou seja, a imputação assumiu que todas as faixas de renda tiveram abatimentos de 16\% da renda bruta em 1947, $23 \%$ em 1948, e $27 \%$ em 1949.

22 Apenas para 1927 e 1928 a imputação deu-se diretamente da renda líquida para o rendimento bruto tributável, pois nesses anos há informações sobre o valor agregado dessa última categoria. 
Imputação dos rendimentos brutos tributáveis, 1927-1963

Para os anos-base 1927 e 1928, a imputação aproveitou os dados agregados para rendimentos brutos tributáveis: a renda líquida de cada faixa foi multiplicada pela razão RBT/RLIQ observada: $149 \%$ em 1927, e 156\% em 1928, o que implica que deduções cedulares e abatimentos representaram, respectivamente, $33 \%$ e $36 \%$ dos rendimentos brutos tributáveis. Mais uma vez, como o número de declarações é muito pequeno, o ganho marginal em introduzir multiplicadores variáveis por faixa seria desprezível.

Antes de falar dos anos-base 1933-1946, é melhor tratar do período 1947-1960: para esses anos, os valores totais dos rendimentos líquidos de cada cédula (cuja soma equivale à renda bruta) foram usados para o cálculo do rendimento bruto tributável. Assim, esses rendimentos líquidos cedulares foram primeiro divididos pelas faixas de renda proporcionalmente à participação de cada faixa na renda bruta total (ou seja, composição idêntica da renda em todas faixas) e, em seguida, multiplicados por valores variáveis conforme a cédula para se obter o rendimento bruto tributável de cada cédula e, por tabela, o rendimento bruto tributável total.

Como as deduções cedulares mudaram pouco ao longo do tempo, o multiplicadores foram calculados como a razão média entre o rendimento bruto tributável e o rendimento líquido de cada cédula nos anos mais próximos com informações (1964-1967), isto é: 1,214 para as cédulas A e B; 1,14 para a cédula C; 1,638 para a cédula D; 1,326 para a cédula E; e 1,173 para a cédula H. (Não havia deduções permitidas nas cédulas F e G.) Ou seja, os multiplicadores implicam deduções cedulares entre 12\% (cédula C) e 39\% (cédula D) dos rendimentos brutos cedulares. O mérito dessa estratégia de imputação é levar em conta as mudanças na composição total dos rendimentos declarados.

Com isso, a razão agregada entre rendimentos brutos tributáveis e renda bruta estimada para 1947-1960 variou entre 1,126 e 1,160, com leve tendência de crescimento ao longo do tempo e média de 1,141. Logo, nos números imputados, as deduções cedulares representam em média pouco mais de $12 \%$ do rendimento bruto tributável.

Para imputar os rendimentos brutos tributáveis para 1933-1946, o multiplicador foi igual à média arredondada dos cinco anos mais próximos (1947-1951), isto é, 1,13, implicando deduções médias de 11,5\% do rendimento bruto tributável. Em conjunto com o passo anterior, isso significa que os rendimentos brutos tributáveis de cada faixa foram estimados como $1,13 \cdot 1,25=1,41$ vezes a sua renda líquida originalmente observada.

Por fim, a imputação para 1963 deu-se pela multiplicação da renda bruta observada de cada faixa por 1,19, ou seja, assumiu que a soma das deduções cedulares correspondia a pouco menos de $16 \%$ do rendimento bruto tributável total, valor correspondente à média arredondada de 1964-1968, os anos mais próximos com essas informações. 


\subsubsection{Imputação do consumo de capital fixo}

Em tese, os lucros, dividendos e demais pagamentos realizados por empresas organizadas como pessoas jurídicas a seus proprietários já são líquidos dos custos incorridos durante o processo produtivo. O caso de empresas informais, familiares, profissionais liberais e pequenos empreendedores é diferente. O modelo cedular do IRPF em vigor até 1988 permitia deduções em quase todas as cédulas (ver seção 4.4.1), e o modelo atual permite a dedução de despesas escrituradas em livro-caixa (ver seção 4.4.2).

A questão é como subtrair o consumo ou depreciação de capital fixo - entendido de forma ampla, o que inclui despesas com funcionários e afins - para os pequenos empresários e profissionais liberais. As deduções legais fornecem informação valiosa, mas não podem ser inteiramente aceitas: por exemplo, o rol de deduções aceitas até 1988 era muito generoso, com categorias pouco críveis. Para além de todo o incentivo dado aos declarantes para exagerar o valor das deduções, a legislação era liberal quanto aos itens permitidos, como a assinatura de jornais, revistas e livros técnicos (cédulas C e D), aluguel ou custeio de veículos usados por médicos e auxiliares (cédula D). Pela legislação atual, muito mais restritiva, somente despesas com funcionários, emolumentos e custeio escrituradas em livro-caixa podem ser deduzidas.

A solução foi considerar parcialmente as deduções declaradas no antigo modelo cedular e integralmente as despesas com livro-caixa no modelo atual:

Período até 1988 com rendimentos e deduções por cédula: a depreciação foi equivalente a $50 \%$ das deduções para cada faixa de renda nas cédulas D (trabalho não assalariado) e E (aluguéis e capital imobiliário). O valor de $50 \%$ representa o ponto médio entre a aceitação e a rejeição total das deduções declaradas. A depreciação foi calculada dessa forma para quase todos os anos entre 1947 e 1988.

Período até 1988 sem rendimentos e deduções por cédula: devido à falta de informações, o consumo de capital fixo foi estimado como $6 \%$ do rendimento bruto tributável de cada faixa de renda, valor equivalente à média arredondada do percentual observado para os anos com esses dados entre 1947 e 1967. A depreciação foi calculada dessa forma para o período anterior a 1947 e também para 1963. As tabulações de 1947 a 1967 não permitem discernir nenhuma relação entre o peso relativo das deduções das cédulas D e E e as faixas de renda, não havendo, portanto, nenhuma perda significativa com o uso de um único percentual para todas elas.

Período após 1988 com deduções por livro-caixa: para os anos em que há informações (1998 e 2007-2013), as deduções escrituradas em livro-caixa foram consideradas integralmente como despesas incorridas para obtenção da renda e, portanto, consumo de capital fixo no sentido amplo aqui adotado. 
Período após 1988 sem deduções por livro-caixa: para os anos em que não há dados para deduções com livro-caixa por faixa de renda (1996, 1997, 2000, 2002 e 2006), o consumo de capital fixo foi calculado como um percentual do rendimento bruto tributável variável por faixa de renda, com valores entre $0,05 \%$ (para faixas até $\mathrm{R} \$$ $45 \mathrm{mil}$ ) e $4 \%$ (para faixas com renda mínima acima de $\mathrm{R} \$ 120 \mathrm{mil}$ ), ${ }^{23}$ representando, grosso modo, as relações observadas em 1998 e 2007-2013.

Embora imperfeita, essa solução parece mais apropriada do que minha opção anterior de ignorar por completo o consumo de capital fixo (SOUZA, 2014) e do que a escolha de Milá (2015) de simplesmente usar a média entre rendimentos brutos tributáveis e renda total, isto é, considerar válidas a metade de todas as deduções cedulares.

Como o consumo de capital fixo também é subtraído do controle para a renda total (ver adiante), seu efeito sobre os principais resultados desta tese é bem modesto. Em comparação com a série bruta, a dedução para custos e depreciação do capital fixo altera a fatia do $1 \%$ em no máximo 1 p.p. a cada ano.

\subsection{A estimação da desigualdade}

\subsubsection{Medidas de desigualdade}

Em sua defesa da "razão de Palma" como medida de desigualdade, Cobham e Summer (2013) argumentaram que a escolha de uma medida de desigualdade não pode ser simplesmente técnica, devendo também obedecer a critérios de transparência e comunicabilidade e, principalmente, ser apropriada aos objetivos das análises e compatíveis com os julgamentos de valor subjacentes. Esse ponto de vista remete aos trabalhos clássicos de Dalton (1920) e Atkinson (1970), que exploraram como as medidas de desigualdade trazem embutidas determinadas funções de bem-estar social.

A principal medida de desigualdade em jogo nos próximos capítulos é a fração da renda total recebida pelos mais ricos, com atenção especial para o 1\% mais rico. Para os objetivos dessa tese, essa escolha é natural porque a) coloca em primeiro plano a concentração de renda no topo e a dicotomia entre ricos e não-ricos; b) ancora-se em uma dimensão inegavelmente importante da vida em sociedades de mercado, a renda; e c) evita o atoleiro das teorias de classe, abdicando de suas pretensões teóricas mais elevadas, raramente atingidas (ver seção 3.3 do capítulo 3). Como escreveu Thomas Piketty (2014a, p. 252), "a beleza de décimos e centésimos é precisamente que eles nos permitem comparar desigualdades que seriam incomparáveis de outra forma, empregando uma linguagem comum que deve em princípio ser aceitável para todos".

23 Como a faixa superior em 2006 começa em um valor relativamente baixo, $\mathrm{R} \$ 80$ mil, o percentual nesse caso foi diminuído para $3 \%$. 
Por definição, a fatia apropriada pelos mais ricos não atende a todos os axiomas considerados desejáveis para medidas de desigualdade, como o princípio de Pigou-Dalton, que postula que a desigualdade medida deve cair com uma transferência, sem alteração de ordenamento, de um indivíduo mais rico para outro mais pobre (e vice-versa).

Para os objetivos específicos deste trabalho, trata-se de uma qualidade, e não de um problema. Por desconsiderar quaisquer transferências entre os não-ricos, a fração recebida pelo topo é insensível a toda e qualquer redistribuição que afete apenas a base e o meio da distribuição de renda. De todo modo, para evitar equívocos na interpretação, é bom ter em mente que a estabilidade das frações recebidas pelos mais ricos não garante que a distribuição de renda como um todo tenha permanecido inalterada.

Nos próximos capítulos, os termos "desigualdade" e "concentração no topo" são usados de forma intercambiável, salvo quando houver qualificação ou indicação do contrário. A medida de desigualdade mais tradicional da literatura, o coeficiente de Gini, aparece apenas na seção 5.4 do capítulo 5, que compara os resultados baseados em dados tributários com os das pesquisas domiciliares brasileiras e explicita as fórmulas utilizadas para "corrigir" o coeficiente de Gini nas PNADs e Censos.

\subsubsection{A interpolação de Pareto}

O uso de tabulações por faixas de renda demanda a aplicação de uma técnica de interpolação para que os rendimentos de frações exatas da população, como o 1\% mais rico, sejam calculados. A interpolação de Pareto, que assume que a cauda superior da renda segue a distribuição de Pareto, é de longe o método mais popular, usado em 15 do 22 países cobertos pela revisão de Atkinson, Piketty e Saez (2011). A alternativa nos demais países foi o mean split histogram, defendido por Anthony Atkinson (2005) por substituir a imposição de uma forma funcional por pressupostos menos restritivos. A boa aderência empírica e a robustez da interpolação de Pareto fizeram com que a maior parte dos trabalhos mais recentes continuasse optando por ela (MEDEIROS; SOUZA; CASTRO, 2015a; MILÁ, 2015; SOUZA, 2014; SOUZA; MEDEIROS, 2015; VÉLEZ, 2012).

A distribuição de Pareto vem do fim do século XIX, quando foi introduzida pelo italiano Vilfredo Pareto, de quem já falamos no capítulo 1, para modelar matematicamente o topo das distribuições de renda e riqueza. Em sua análise pioneira, Pareto observou o caráter assimétrico das distribuições de renda, bastante destoante de distribuições normais ou gaussianas, e desenvolveu a primeira distribuição de lei de potência (power law distribution, no termo comumente usado em inglês), base de sua "lei geral" acerca da constância da estratificação social. Desde então, embora a teoria paretiana das elites tenha caído em obscuridade, as distribuições de leis de potência mostraram-se úteis para caracterizar inúmeras regularidades empíricas em diversos campos do conhecimento. ${ }^{24}$

$\overline{24}$ Para boas revisões da "lei de Pareto" e suas controvérsias, ver Hoffmann (1973) e Persky (1992). 
A distribuição de Pareto de Tipo I é matematicamente simples, definida por parâmetros de escala ( $k$, normalmente irrelevante) e de forma ( $\alpha$, chamado de coeficiente de Pareto). Seja $F($.$) a função de distribuição acumulada, \bar{F}($.$) a função de distribuição$ acumulada complementar, $f($.$) a função de densidade de probabilidade e x$ uma variável aleatória com distribuição de Pareto, então, para $x \geq k>0$ e $\alpha>0$ :

$$
\begin{aligned}
& F(x)=\operatorname{Pr}(X<x)=1-\left(\frac{k}{x}\right)^{\alpha} \\
& \bar{F}(x)=\operatorname{Pr}(X>x)=1-F(x)=\left(\frac{k}{x}\right)^{\alpha} \\
& f(x)=\frac{\alpha k^{\alpha}}{x^{\alpha+1}}
\end{aligned}
$$

Os momentos da distribuição de Pareto só existem e são finitos para valores restritos de $\alpha$. Seja $\beta=\alpha /(\alpha-1)$ o coeficiente invertido de Pareto, o enésimo momento e o valor esperado (isto é, o primeiro momento) de $x$ são dados, respectivamente, por: ${ }^{25}$

$$
\begin{array}{rlrl}
\mu_{n}^{\prime} & =\mathbf{E}\left(x^{n}\right)=\frac{\alpha}{\alpha-n} k^{n}, & \text { se } \alpha>n>0 \\
\mu_{1}^{\prime}=\mathbf{E}(x)=\frac{\alpha}{\alpha-1} k=\beta k, & \text { se } \alpha>1
\end{array}
$$

A variância - i.e., o segundo momento central - de $x$ é calculada por:

$$
\operatorname{Var}(x)=\mathbf{E}\left(x^{2}\right)-\mathbf{E}(x)^{2}=\frac{\alpha k^{2}}{(\alpha-1)^{1}(\alpha-2)}, \quad \text { se } \alpha>2
$$

A distribuição de Pareto possui ao menos três propriedades interessantes. Primeiro, como se depreende da discussão acima, ela comporta uma cauda superior mais "gorda" e por isso se presta bem à modelagem dos rendimentos dos mais ricos, ainda que a estabilidade dos parâmetros propalada por Pareto não tenha obtido respaldo empírico.

As Figuras 21 e 22 ilustram isso com base em amostras aleatórias com 20 mil casos simuladas para $k=1$. A Figura 21 compara distribuições de Pareto com quatro coeficientes

Referências contemporâneas sobre o uso dessa distribuição para interpolação dos rendimentos dos mais ricos incluem Atkinson (2005), Atkinson (2007) e Atkinson, Piketty e Saez (2011). Gabaix (2016) oferece uma introdução didática às aplicações de distribuições de leis de potência em diversas áreas, incluindo o caso especial da "lei de Zipf". Gabaix (2009) e Mitzenmacher (2004) fornecem tratamentos mais técnicos, explorando modelos matemáticos que podem funcionar como mecanismos geradores de distribuições desse tipo. Rytgaard (1990) caracteriza a distribuição de Pareto como parte da família de distribuições exponenciais e compara diferentes estimadores do parâmetro $\alpha$. Amoroso (1948) e Kingston (1952) são dois exemplos pioneiros da discussão sobre a "lei de Pareto" e suas propriedades estatísticas na literatura acadêmica brasileira. Esta seção deve muito a todos esses textos.

25 É fácil observar que os momentos divergem se $n \geq a$, pois $\mathbf{E}\left(x^{n}\right)=\int_{k}^{\infty} x^{n} \frac{\alpha k^{\alpha}}{x^{\alpha+1}} d x=\int_{k}^{\infty} \frac{\alpha k^{\alpha}}{x^{\alpha+1-n}} d x$ é uma integral imprópria que só converge se $\alpha+1-n>1$, ou seja, se $\alpha>n$. 
distintos. As curvas com $\alpha=1$ e $\alpha=4$ têm coeficientes extremos; no mundo real, a maior parte dos coeficientes estimados para o topo da distribuição de renda oscila entre 1,5 e 3 , como nas duas distribuições intermediárias. Como se vê, quanto menor o $\alpha$ (ou seja, quanto maior o coeficiente invertido $\beta$ ), mais frequente é a ocorrência de rendimentos extremos. Quando $\alpha=1$, cerca de $20 \%$ dos casos têm rendimentos acima de 5 unidades, percentual que cai para $10 \%$ com $\alpha=1,5$ e despenca para valores próximos de zero com $\alpha=3$ ou $\alpha=4$.

A Figura 22 contrasta o décimo superior da distribuição de Pareto simulada com $\alpha=3$ e $k=1$ com valores sorteados aleatoriamente de uma distribuição normal com a mesma média e variância (mais uma vez, $n=20.000$ ). A "cauda superior mais gorda" da distribuição de Pareto, mesmo quando o $\alpha$ é relativamente alto, é evidente. Para os $3 \%$ mais ricos, a densidade complementar é maior na distribuição de Pareto.

A segunda propriedade atraente da distribuição de Pareto é que a razão entre a renda média acima de uma determinada linha de corte e a própria linha de corte é constante. Matematicamente, essa função $\bar{x}($.) que produz a renda média acima de determinado ponto pode ser expressa como:

$$
\bar{x}(x)=\frac{\int_{x}^{\infty} y f(y) d y}{\int_{x}^{\infty} f(y) d y}=\frac{\int_{x}^{\infty} y^{-\alpha} d y}{\int_{x}^{\infty} y^{-(\alpha+1)} d y}=\frac{\alpha}{\alpha-1} x=\beta x
$$

Portanto, a razão entre $\bar{x}(x)$ e a linha de corte $x$ é equivalente ao coeficiente invertido de Pareto, seja qual for o valor de $x$ :

$$
\frac{\bar{x}(x)}{x}=\frac{\beta x}{x}=\beta=\frac{\alpha}{\alpha-1}
$$

A terceira propriedade relevante é a log-linearidade: assintoticamente, a relação entre o logaritmo da função de distribuição acumulada complementar e o logaritmo de $x$ é uma linha reta com inclinação negativa. Matematicamente, seja $A=\alpha \ln (k)$, então:

$$
\ln (\bar{F}(x))=\ln (1-F(x))=A-\alpha \ln (x)
$$

O desafio com as tabulações do imposto de renda é realizar a interpolação de Pareto estimando os coeficientes a partir de dados agrupados por faixas de renda. Essas duas últimas propriedades são úteis justamente porque permitem isso. Nesta tese, como em Piketty (2001) e Piketty e Saez (2003), entre outros, a técnica de interpolação escolhida baseia-se na segunda propriedade, utilizando as informações disponíveis sobre o número de declarantes e a renda total das faixas de renda nos dados tributários. Como os parâmetros da função de Pareto podem variar conforme as faixas de renda, segue-se aqui o procedimento de Feenberg e Poterba (1993), que estimaram os coeficientes adotando o limite inferior da faixa de renda mais próxima da fração da população desejada. 
Figura 21. Probabilidades acumuladas de distribuições de Pareto com diferentes coeficientes de forma

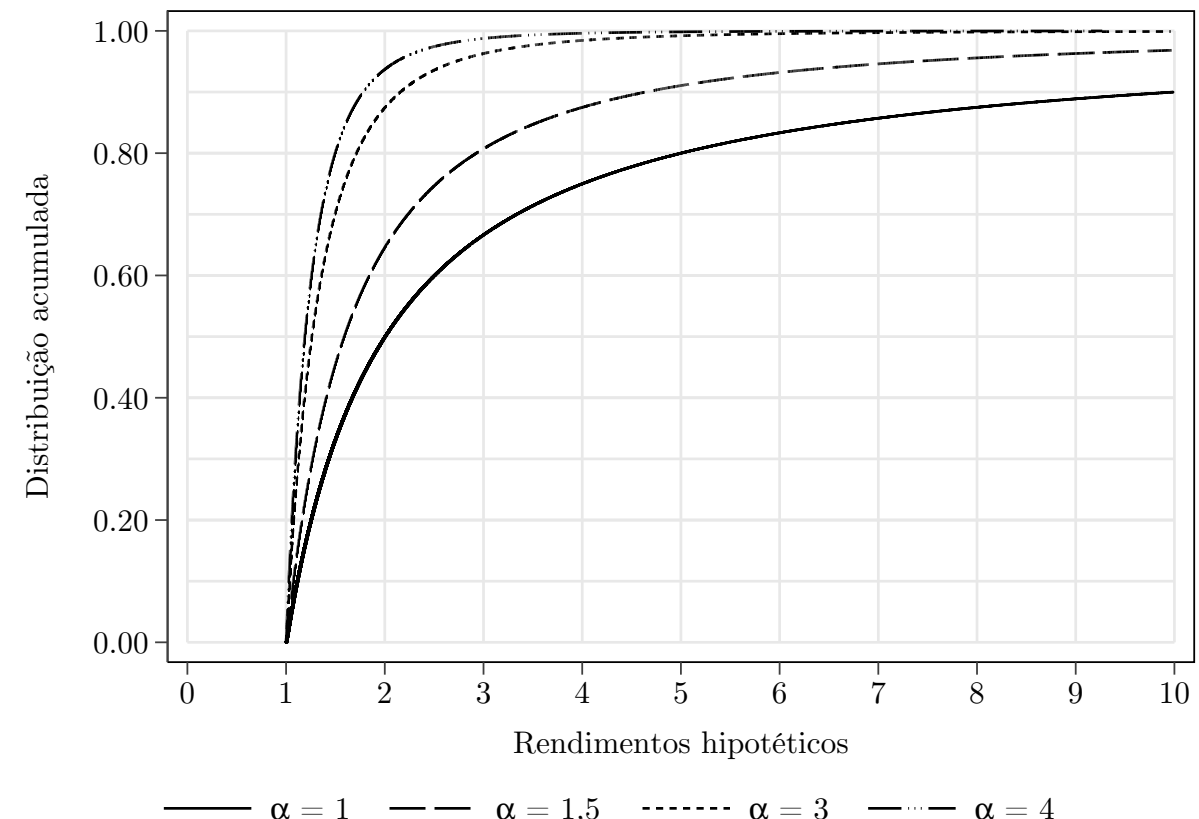

Fonte: elaboração própria.

N.B.: simulações a partir de amostras aleatórias $(n=20.000)$ de distribuições de Pareto com $k=1$.

Figura 22. Probabilidades acumuladas de distribuição de Pareto e da Normal

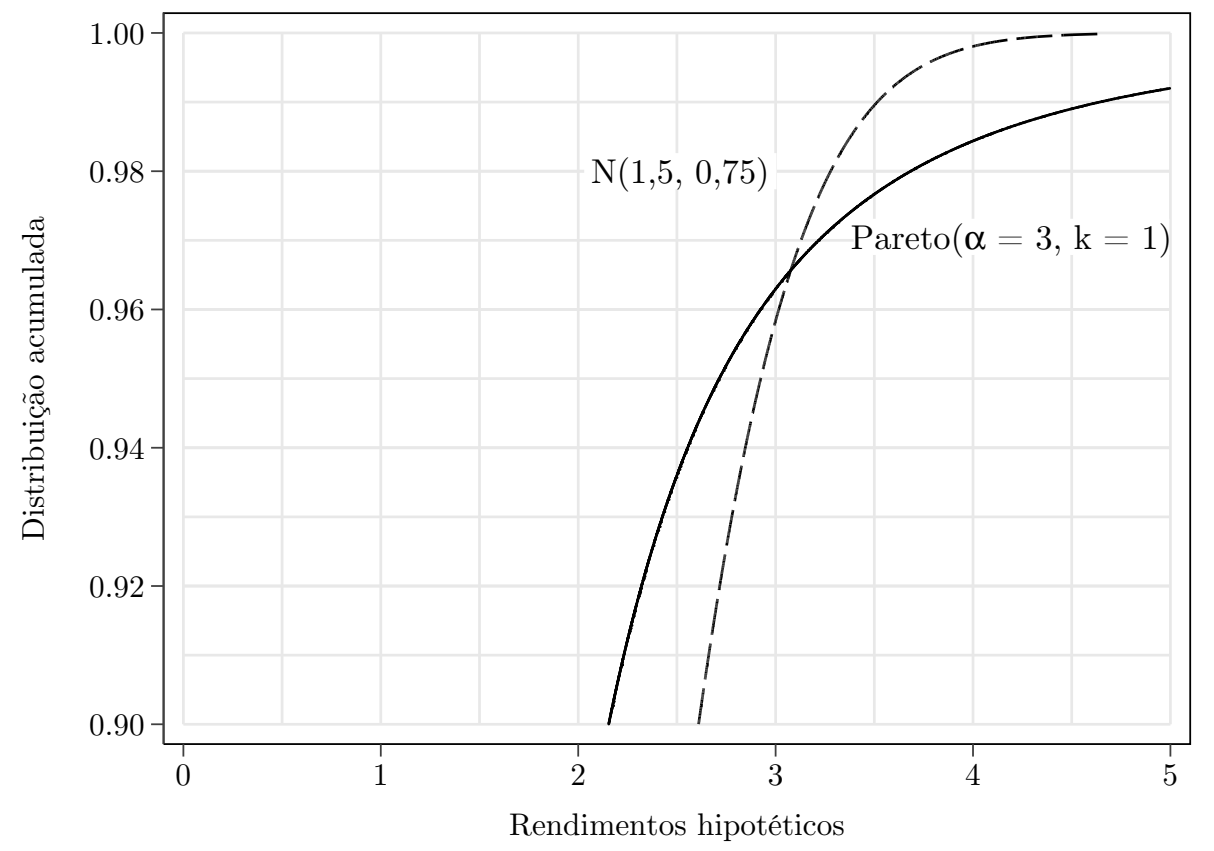

Fonte: elaboração própria.

N.B.: simulações a partir de amostras aleatórias $(n=20.000)$. Os parâmetros da distribuição normal são iguais à média e à variância da distribuição de Pareto com $\alpha=3$ e $k=1$, pois $\mu=\beta k=1,5$, ou seja, $\alpha=\frac{1,5}{1,5-1}=3$, e $\sigma^{2}=\frac{1}{(3-1)^{2}} \frac{3}{3-2}=0,75$. 
Assim, para um dado denominador de população, considere $s_{i}$ o limite inferior de determinada faixa de renda, $p_{i}$ a proporção da população com renda superior a $s_{i}$ nos dados observados, $\bar{x}($.$) a função para a renda média acima de um determinado valor, e$ $\alpha$ e $k$ os parâmetros de Pareto, com $\beta=\alpha /(\alpha-1)$. Os parâmetros para uma fração de interesse qualquer - por exemplo, o $1 \%$ mais rico - são estimados pelas fórmulas:

$$
\begin{aligned}
\beta & =\frac{\bar{x}\left(s_{i}\right)}{s_{i}} \\
\alpha & =\frac{\beta}{\beta-1} \\
k & =s_{i} p_{i}^{1 / \alpha}
\end{aligned}
$$

Depois, os coeficientes estimados são usados para computar as quantidades de interesse. No caso do $1 \%$ mais rico, por exemplo, a renda mínima, equivalente ao percentil $99 \%$, é dada por $P 99=\frac{k}{0,01^{1 / a}}$; para obter a renda média, basta calcular $\beta P 99$.

Um método alternativo, mais tradicional, baseia-se na terceira propriedade, a log-linearidade, e utiliza apenas as informações acerca do número de declarantes e dos limites inferiores das faixas. Nesse caso, estima-se primeiro o coeficiente de Pareto $\alpha$ :

$$
\begin{aligned}
\alpha & =\frac{\ln \left(p_{i} / p_{i+1}\right)}{\ln \left(s_{i+1} / s_{i}\right)} \\
\beta & =\frac{\alpha}{\alpha-1} \\
k & =s_{i} p_{i}^{1 / \alpha}
\end{aligned}
$$

Na prática, os dois métodos produzem resultados quase idênticos quando aplicados aos dados tributários brasileiros, e o primeiro foi escolhido por ser mais simples e intuitivo. O método log-linear foi empregado na interpolação dos rendimentos no Censo de 1960, porque os dados só reportam o número de declarantes, e não a renda total por faixa.

\subsubsection{Controle para a população total}

A interpolação acima exige a especificação de um controle para a população total, que, neste trabalho, foi definido como os indivíduos com 20 anos ou mais de idade.

Qualquer definição implica decisões sobre duas dimensões centrais: a unidade de referência e o recorte etário. A primeira questão refere-se principalmente ao tratamento dado pela legislação aos moradores de um mesmo domicílio, em especial se casais são obrigados ou não a declarar seus rendimentos conjuntamente. A segunda serve para delimitar o universo da população adulta. 
A legislação brasileira nunca foi unívoca quanto à unidade de referência. O segundo regulamento do IRPF, que vigorou entre 1926 e 1942, deu possibilidade aos cônjuges de apresentar rendimentos em separado ou conjuntamente com o chefe da família (Decreto 17.390/1926, art. 19). Já os dois regulamentos seguintes estipularam que a declaração só poderia ser feita separadamente caso o regime fosse de separação de bens (Decreto-Lei 4.178/1942, art. 67; Decreto-Lei 5.844/1943, art. 67), mas pouco depois os cônjuges casados em regime de comunhão de bens voltaram a ter essa opção para rendimentos do trabalho e de bens gravados com cláusulas de incomunicabilidade e afins (Lei 154/1947). Essa situação perdurou, com pequenas modificações, nos regulamentos seguintes. O primeiro regulamento a dar total liberdade aos casais para escolher entre a declaração conjunta e em separado entrou em vigor em 1994 (Decreto 1.041/1994, seção II).

Infelizmente, não há informações completas sobre o número de declarantes por gênero e estado civil desde a criação do IRPF. As fontes listadas na Tabela 4 permitem apenas a reconstrução parcial do quadro. Entre 1965 e 1988, o percentual de mulheres casadas sobre o total de declarantes cresceu de 1,5\% para quase $12 \%$. Até 1974, não há dados sobre o total de mulheres; daí em diante, sua participação subiu de 15-20\% do total de declarações para 25-30\% no fim da década de 1980. As casadas aumentaram sua presença entre o total de mulheres, saindo de menos de $20 \%$ em 1974 para $43 \%$ em 1988. Desde 2005, as mulheres equivalem a cerca de $40 \%$ das declarações.

A maior presença de mulheres no IRPF parece estar mais associada à sua entrada maciça no mercado de trabalho do que à legislação, ou seja, o pequeno número de declarações de mulheres casadas deve refletir mais a ausência de rendimentos próprios do que impeditivos legais. Por exemplo, no Censo 1960, só pouco mais de $5 \%$ das mulheres casadas tinham rendimentos próprios. Em boa parte do tempo, e até hoje, houve incentivos para casais submeterem declarações em separado quando ambos possuem rendimentos tributáveis elevados, já que a perda da dedução/abatimento por dependente costuma ser mais do que compensada pelo duplo gozo do limite de isenção.

Por tudo isso, o controle para população total toma como unidade de referência os indivíduos. No passo seguinte, o corte etário em 20 anos ou mais seguiu a prática mais comum da literatura internacional, cujas escolhas tendem, de todo modo, a oscilar em um intervalo estreito entre 15 e 21 anos (ATKINSON; PIKETTY; SAEZ, 2011). Nesse ponto, não há mudança em relação à versão preliminar dos resultados (SOUZA, 2014). Para garantir a robustez dos resultados, a seção 5.6 do capítulo 5 avalia também outros denominadores plausíveis, com diferentes unidades de análise e recortes etários.

O cálculo do denominador populacional foi feito a partir dos Censos Demográficos, ${ }^{26}$ com interpolação por spline cúbico para os anos intercensitários. A Figura 23 apresenta

${ }_{26}$ Dados disponíveis em <http://seriesestatisticas.ibge.gov.br/series.aspx?no=10\&op=0\&vcodigo= POP22\&t=populacao-grupos-idade-populacao-presente-residente > . Acesso em 14 mai. 2015. 
Figura 23. População total e controle para população adulta (milhões) - Brasil, 1925-2014

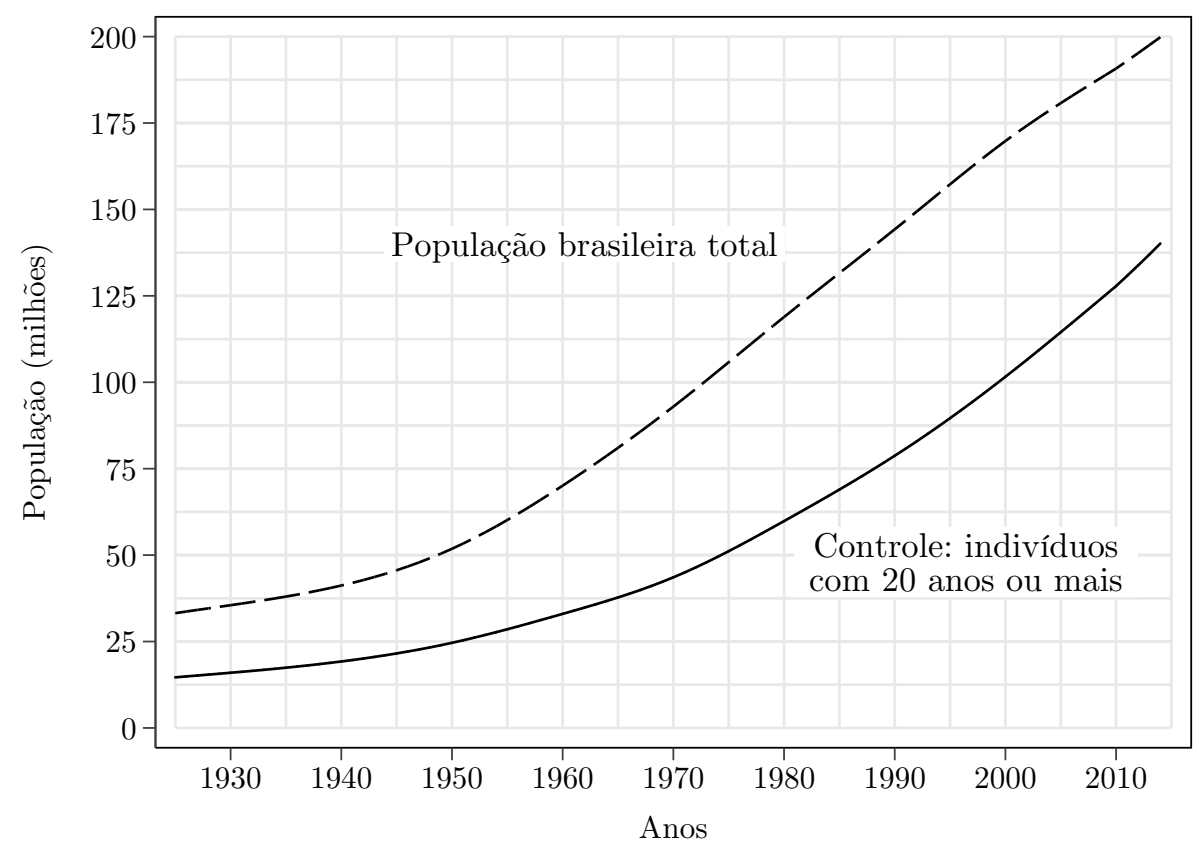

Fonte: elaboração própria a partir dos Censos Demográficos de 1920 a 2010.

N.B.: valores para anos intercensitários obtidos por interpolação por spline cúbico.

a evolução da população total e do controle para a população adulta entre 1925 e 2014 . Além do vertiginoso crescimento populacional - o controle para a população adulta passou de 14,6 para 140,1 milhões de pessoas -, as mudanças na composição etária da população total foram marcantes: na primeira metade do século, a população adulta estava entre 40 e $50 \%$ da população total, percentual que aumentou continuamente desde a década de 1970, atingindo hoje mais de $70 \%$.

\subsubsection{Controle para a renda total}

O controle para a renda é necessário para transformar os montantes interpolados em frações da renda total. Neste trabalho, a opção foi por percentuais variáveis do PIB, calculados de acordo com as informações macroeconômicas disponíveis.

De modo geral, há duas abordagens para a escolha do controle: a primeira parte das informações declaradas e imputa rendimentos aos não declarantes, simulando um cenário sem limites de isenção, enquanto a segunda recorre a um controle externo, normalmente obtido das contas nacionais, tratando a renda dos não declarantes como um resíduo (ATKINSON, 2007; ATKINSON; PIKETTY; SAEZ, 2011). A primeira abordagem é mais intuitiva quando o percentual de declarantes em relação à população de interesse é elevado e tipicamente imputa aos não declarantes uma fração fixa da renda média dos declarantes. A segunda é mais comum e teoricamente justificável, e depende da construção do conceito de renda apropriado a partir dos agregados das contas nacionais. 
No Brasil, em virtude do percentual historicamente baixo de declarantes (ver Figura 14), a abordagem via contas nacionais é a única apropriada. As Contas Econômicas Integradas (CEI) e as Tabelas de Usos e Recursos (TRU) contêm quase todas as informações para gerar um agregado compatível com a definição da renda da seção 4.6. As fórmulas 4.17 e 4.18 mostram como os mesmos resultados podem ser obtidos por diferentes caminhos:

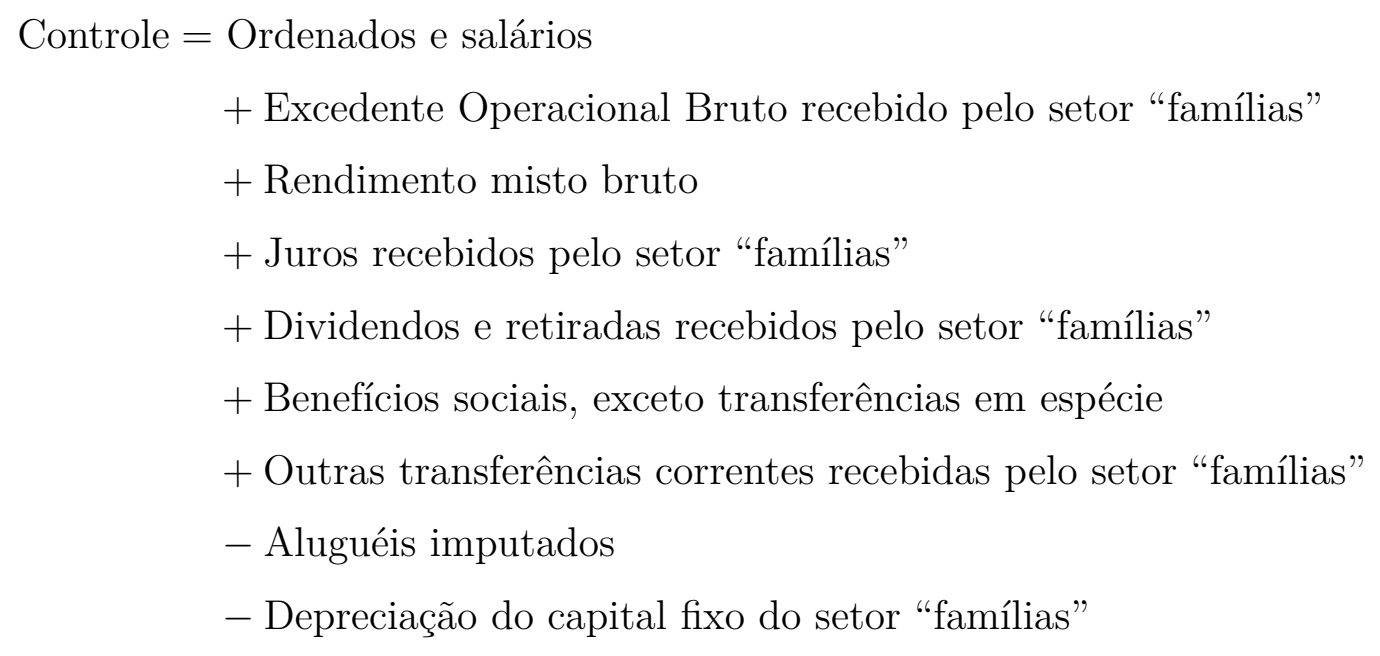

Controle = Despesa de consumo final do setor "famílias"

+ Poupança bruta do setor "famílias"

+ Rendas de propriedade pagas pelo setor "famílias"

+ Impostos sobre a renda e patrimônio pagos pelo setor "famílias"

+ Contribuições sociais pagas pelo setor "famílias"

+ Outras transferências correntes pagas pelo setor "famílias"

- Contribuições sociais dos empregadores

- Rendas de propriedade atribuídas a detentores de apólices de seguros no setor "famílias"

- Ajustamento pela variação das participações líquidas das famílias nos fundos de pensões, FGTS e PIS/PASEP

- Aluguéis imputados

- Depreciação do capital fixo do setor "famílias"

O controle é igual ao de Vélez (2012) para a Colômbia, entre outros, e difere do conceito preferido por Souza (2014) e Medeiros, Souza e Castro (2015a) pela subtração do consumo de capital fixo das famílias. Por sinal, essa é a única informação não disponível nas contas nacionais, sendo imputada como 5\% da poupança bruta, seguindo Vélez (2012). Os demais valores são reportados nas CEI, exceto os aluguéis imputados para famílias que moram em domicílio próprio, que estão nas TRU. 
As CEI e as TRU são produzidas pelo IBGE e, até o momento de elaboração deste texto, estavam disponíveis de 1995 a 2011 (IBGE, 2000, 2011, 2015. O passo seguinte, portanto, foi decidir o que fazer quanto ao período anterior a 1995 e ao biênio 2012-2013.

O procedimento mais comum na literatura é calcular a razão média entre o controle ideal e o PIB para os anos disponíveis e aplicar esse percentual aos anos sem informações ou a todo o período de análise. Por exemplo, Alvaredo (2008) utilizou percentuais fixos entre $60 \%$ e $66 \%$ do PIB para Argentina, Espanha e Portugal; Banerjee e Piketty (2010) escolheram 70\% da renda nacional na Índia; e Souza (2014) e Milá (2015) usaram, respectivamente, $67 \%$ e $60 \%$ do PIB para o Brasil.

O preço de tanta simplicidade é considerável, uma vez que não há motivo para crer que um percentual fixo do PIB seja uma boa aproximação para a renda monetária disponível das famílias no longo prazo. A expansão das transferências governamentais e contribuições sociais ao longo do tempo é uma óbvia fonte de dificuldades, como admitido por Atkinson (2007, p. 30-31). No Brasil, os 67\% do PIB usados em Souza (2014) são muito inferiores ao consumo final das famílias de 1947 a 1968, o que faz pouco sentido, como se vê pela equação 4.18 e pelos resultados empíricos para 1995-2011. ${ }^{27}$

Não haveria alternativa se o PIB fosse o único agregado macroeconômico disponível para a maior parte do período. Não é esse o caso. Desde 1947, há estimativas oficiais para muitas proxies das variáveis da equação 4.18. Com isso, em vez de usar uma única média - o controle estimado como fração do PIB - é possível usar médias para variáveis mais detalhadas, de modo que o controle leve em conta as principais mudanças na composição da renda nacional.

A equação 4.19 traz os coeficientes e as variáveis usados na construção do controle para a renda total para o período entre 1947 e 1994. Como na abordagem tradicional, os coeficientes representam os valores médios observados nos anos em que há informações das CEI e das TRU, isto é, de 1995 a 2011:

$$
\begin{aligned}
\text { Controle }_{1947-94}= & 1,080 \cdot \text { Despesa de consumo final das famílias } \\
& \quad \text { e instituições sem fins lucrativos } \\
+ & 0,412 \cdot \text { Impostos diretos } \\
+ & 0,012 \cdot \text { PIB } \\
& -0,784 \cdot \text { Valor agregado pelo setor de serviços imobiliários } \\
& -0,050 \cdot \text { Poupança bruta }
\end{aligned}
$$

27 Entre 1995 e 2011, o controle ideal foi, em média, 108\% do consumo final das famílias e instituições sem fins lucrativos (ISFLs). Entre 1947 e 1968, o controle de 66\% do PIB representaria, em média, só $91 \%$ do consumo final das famílias e ISFLs. 
O primeiro termo corresponde aos dois primeiros da equação 4.18; a fração dos impostos diretos equivale, na equação 4.18 aos impostos sobre a renda e patrimônio mais as contribuições sociais pagas menos as contribuições sociais dos empregadores; a fração do valor agregado pelo setor de serviços imobiliários representa os aluguéis imputados; a fração da poupança bruta corresponde à depreciação do capital fixo das famílias; e, por fim, o termo com percentual fixo do PIB engloba todo o resíduo, isto é, rendas de propriedade pagas mais as transferências correntes pagas menos os rendimentos atribuídos a detentores de apólices de seguros menos os ajustes atrelados a variações em fundos de pensão e afins. As informações para o PIB, consumo final e poupança bruta foram obtidas das "Séries Históricas" do IBGE; para o valor agregado pelos serviços imobiliários, a fonte foi o Ipeadata; para os impostos diretos, IBGE (2006) e as estatísticas de arrecadação da Secretaria da Receita Federal. ${ }^{28}$

Para os anos anteriores a 1947, o controle foi um percentual fixo de 74,2\% dos PIBs estimados por Haddad (1974), também obtidos no Ipeadata. Esse percentual equivale ao valor observado em 1947. Para 2012 e 2013, o controle foi computado como 69,1\% do PIB preliminar estimado pelo IBGE e reportado pelo Banco Central do Brasil, percentual equivalente à média do controle para o triênio 2009-2011. ${ }^{29}$

Em resumo, o controle para a renda total foi estipulado como 74,2\% do PIB para 1926-1946; segundo a equação 4.19 para 1947-1994; de acordo com as equações 4.17 e 4.18, que produzem números idênticos, para 1995-2011; e como 69,1\% do PIB para 2012 e 2013. O resultado não é perfeito, mas chega bem mais próximo do ideal do que o uso de uma única fração do PIB para todos os anos.

A Figura 24 ilustra as diferenças entre esse controle para a renda total e duas alternativas obtidas do modo tradicional: $66 \%$ do PIB e 108\% do consumo final das famílias e ISFLs, valores iguais às razões médias em 1995-2011 entre o controle ideal (equações 4.17 ou 4.18) e esses agregados macroeconômicos. Para facilitar a visualização, as três séries são apresentadas como percentuais do PIB.

Na maior parte do tempo, esse controle preferido ocupa posição intermediária entre o controle fixo em $66 \%$ do PIB e o fixo em $108 \%$ do consumo final das famílias, estando em geral mais próximo do primeiro nos últimos 30 anos e do último no resto do tempo. A oscilação desse controle preferido entre $60 \%$ e $75 \%$ do PIB é compatível com a composição da renda nacional, pelo menos de acordo com as informações disponíveis, e com os valores

28 IBGE, "Séries Históricas": <http://seriesestatisticas.ibge.gov.br/>; IBGE, "Estatísticas do século XX": <http://seculoxx.ibge.gov.br>; Ipeadata: <http://www.ipeadata.gov.br>; SRF: <http://idg.receita.fazenda.gov.br/dados/receitadata/estudos-e-tributarios-e-aduaneiros/ estudos-e-estatisticas/carga-tributaria-no-brasil/carga-tributaria-no-brasil-capa $>$. Acessos entre nov. 2014 e mai. 2015.

29 Os dados do Banco Central para esses anos são estimativas preliminares feitas pelo IBGE e estão disponíveis em <http://www.bcb.gov.br>. Acesso em 19 abr. 2015. A média do triênio 2009-2011 foi usada para minimizar a flutuação observada de 2010 para 2011. 
Figura 24. Controle preferido para renda total e dois controles alternativos em relação ao PIB (\%) - Brasil, 1925-2013

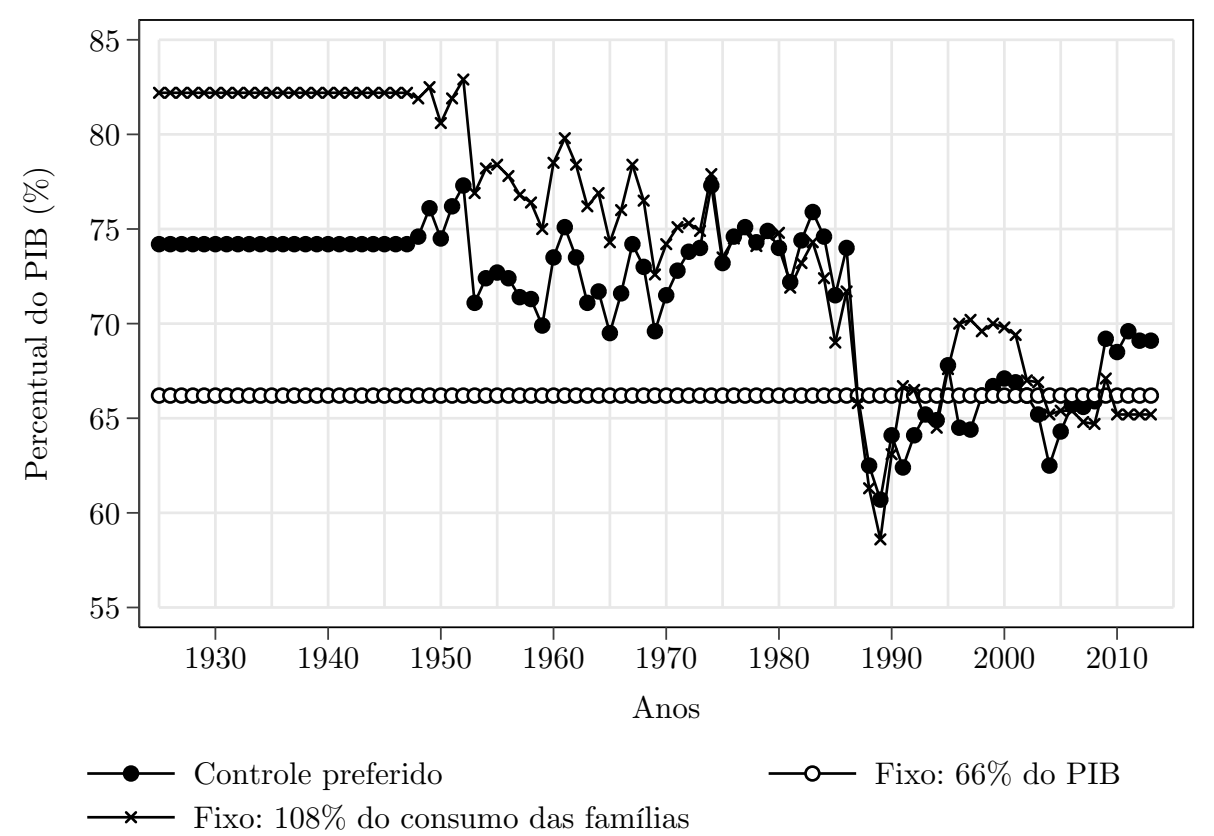

Fonte: elaboração própria a partir de informações do Sistema de Contas Nacionais (IBGE, 2000; IBGE, 2011; IBGE, 2015); IBGE, "Séries Históricas"; IBGE, "Estatísticas do século XX" (IBGE, 2006); Ipeadata; Banco Central do Brasil; e estatísticas de arrecadação da Secretaria da Receita Federal.

normalmente estimados pela literatura internacional (ATKINSON; PIKETTY; SAEZ, 2011). O controle fixo em $66 \%$ do PIB subestima a renda total disponível das famílias pelo menos até meados da década de 1980, enquanto o controle fixo em 108\% do consumo das famílias apresenta valores excessivamente elevados de início e flutuações mais bruscas ao longo do tempo. Para garantir mais uma vez a robustez dos resultados, a seção 5.6 do capítulo 5 compara as estimativas para a fração do $1 \%$ mais rico obtidas com o controle preferido e com esses dois outros denominadores para a renda total.

\subsection{Ajustes finais e construção das séries preferidas}

\subsubsection{Desagregando os resultados de 1926-1927}

Segundo Souza Reis (1930, p. 27), as tabulações publicadas para o ano-base 1927 incluem declarações e rendimentos correspondentes a anos anteriores, ao contrário dos valores para o ano-base 1928. Com efeito, o número de contribuintes, a renda líquida e o imposto bruto devido reportados para 1927 são muito superiores aos de 1928 (90\%, 46\% e $35 \%$, respectivamente). Por consequência, o resultado da interpolação indica uma queda grande e implausível da concentração no topo de 1927 para 1928.

A magnitude desse "erro de inclusão" não é informada por Souza Reis, que, entretanto, afirma que, no ano-base 1928, cerca de $25 \%$ da arrecadação total no Distrito 
Federal decorreu da apuração de rendimentos auferidos em anos anteriores (SOUZA REIS, 1930, p. 23). Logo, a opção natural foi assumir que o mesmo percentual é válido para 1927, de modo que os resultados para esse ano foram todos multiplicados por 0,75.

O pressuposto é que a distribuição dos rendimentos auferidos antes do ano-base relevante é idêntica à dos rendimentos recebidos no período correto. Se acrescentarmos os pressupostos de que esses rendimentos foram todos percebidos no ano anterior (ano-base 1926) e constituem uma amostra representativa daquele ano, então podemos replicar os números absolutos (corrigidos pelo multiplicador de 0,75) de 1927 para 1926, aproveitando a informação disponível ao máximo e acrescentando um ponto à série. Como as mudanças de um ano para outro tendem a ser pequenas, essa é uma opção razoável.

Os resultados principais adiante fazem precisamente isso. Cabe notar que os percentuais - por exemplo, a fração apropriada pelo 0,1\% mais rico - não são idênticos em 1926 e 1927 porque os controles para população e renda total variam entre os dois anos.

\subsubsection{Escolha dos melhores dados para cada ano}

A disponibilidade para vários anos de tabulações ordenadas por diferentes conceitos de renda fez com que, após os ajustes iniciais (seção 4.7) e as interpolações (seção 4.8), fosse preciso escolher quais informações seriam utilizadas nas séries preferidas para a concentração de renda no topo no Brasil. O critério básico foi usar os resultados baseados no conceito de renda mais próximo da renda total:

1926 a 1968: todas as frações dos mais ricos foram calculadas a partir de tabulações por faixas de renda líquida, as únicas disponíveis.

1969 a 1978: todas as frações baseiam-se em tabulações ordenadas por faixas de rendimentos brutos tributáveis.

1979 a 1988: as frações do $0,01 \%, 0,1 \%$ e $1 \%$ mais ricos foram obtidas das tabulações por faixas de rendimentos não tributáveis, enquanto as frações dos $5 \%$ e $10 \%$ mais ricos derivam das tabulações por rendimentos brutos tributáveis.

1996-1998, 2000 e 2002: mais uma vez, todas as frações foram calculadas com base em faixas de rendimentos brutos tributáveis.

2006-2013: todas as frações usam dados ordenados por rendimentos totais.

A única escolha controversa é o uso das tabulações por faixas de rendimentos não tributáveis para os mais ricos entre 1979 e 1988. Como os rendimentos não tributáveis são extraordinariamente concentrados, as tabulações ordenadas por eles são uma aproximação melhor para a renda total dos mais ricos entre os ricos. A seção 5.6 do capítulo 5 avalia a robustez da série preferida. 


\subsubsection{Interpolação e imputação de componentes da renda}

Em todos os casos, a interpolação foi calculada sobre a mesma variável de ordenação das faixas de renda. Ou seja, quando as tabulações disponíveis eram ordenadas por faixas de renda líquida, a interpolação de Pareto foi aplicada à variável de renda líquida. Em consonância com a prática corrente da literatura, os demais componentes dos rendimentos foram alocados por interpolação linear na mesma proporção obtida para a variável da interpolação de Pareto. Se necessário, as linhas de corte interpoladas (e.g., os percentis $99 \%, 99,5 \%$ e afins) foram atualizadas levando em conta os novos totais e os coeficientes de Pareto estimados.

Um problema mais grave foi a ausência de informações para os rendimentos não tributáveis no período anterior a 1974 e em 1996-1998, 2000 e 2002. Em termos substantivos, a falta desses dados impede a estimação dos rendimentos totais dos mais ricos e, em termos mais pragmáticos, gera a obrigação de reportar em todos os gráficos duas séries desconexas, uma para os rendimentos brutos tributáveis e outra, mais reduzida, para os rendimentos totais, como fizeram Souza (2014) e Milá (2015). Em parte por esse motivo, aliás, Souza e Medeiros (2015) apresentam apenas resultados históricos para os rendimentos brutos tributáveis.

Por isso, o último passo foi a imputação dos rendimentos não tributáveis para os anos com informações faltantes, o que representou o mais arriscado e incerto entre todos os procedimentos e ajustes mencionados neste capítulo. A imputação deu-se de forma diferente para os períodos 1926-1973 e 1995-2002, utilizando as melhores informações entre os escassos dados disponíveis.

Para o período de 1926 a 1973, acrescentei à fração dos mais ricos a diferença média verificada em 1974-1979 entre a fração dos rendimentos totais e a fração considerando apenas os rendimentos brutos tributáveis, conforme a lista abaixo:

$\mathbf{0 , 0 1 \%}$ mais rico: $1,62 \%$ do controle da renda total a cada ano.

0,1\% mais rico: $4,55 \%$ do controle da renda total a cada ano.

0,5\% mais rico: $8,29 \%$ do controle da renda total a cada ano.

$\mathbf{1 \%}$ mais rico: $10,33 \%$ do controle da renda total a cada ano.

Como ilustração, depois de todos os procedimentos, os resultados indicaram que os rendimentos brutos tributáveis do 1\% mais rico em 1950 equivaliam a 15,01\% do controle para a renda total. Os rendimentos não tributáveis foram então imputados como 10,33\% da renda total, de modo que a fatia apropriada pelo $1 \%$ ficou em 15, $01+10,33=25,34 \%$.

Essa forma de imputação é reconhecidamente crua, mas razoável. Entre 1974 e 1979 a relação é tão estável que não faz nem sentido recorrer a regressões para obter 
os percentuais a serem imputados. Estender o intervalo para 1974 a 1987 também não alteraria os valores médios a serem imputados em mais de $0,2 \%$.

Para cada série, essa imputação altera apenas o nível, não a trajetória da concentração de renda, que continua inteiramente determinada pelos rendimentos brutos tributáveis. Trata-se de uma consequência desejável e que reflete bem a dinâmica de 1974 a 1979. Não é fácil, porém, julgar quão realista é a alteração de nível. Por um lado, o escopo dos rendimentos não tributáveis aumentou ao longo do tempo, o que implica uma superestimação da concentração no topo nos anos iniciais e uma subestimação do aumento da desigualdade nos anos 1960. Por outro, rendimentos como a remuneração de magistrados, professores, escritores e jornalistas passaram um longo tempo sem estar sujeitos à tributação. Além disso, a inexistência de tabulações ordenadas por rendimentos totais para todo o século XX sugere que os resultados podem estar subestimados.

Para os anos 1996-1998, 2000 e 2002 a imputação foi diferente, pois há dados sobre os valores agregados para esses anos e também tabulações detalhadas para anos bem próximos (2006-2013). Assim, a imputação foi feita por regressão. Primeiro, os coeficientes para cada estrato dos $x \%$ mais ricos foram obtidos de regressões, para 2006-2013, da fração dos rendimentos totais desses $x \%$ mais ricos sobre a fração apenas considerando os rendimentos brutos tributáveis (calculada com base nas tabulações ordenadas por faixas de rendimentos brutos tributáveis) e a participação dos rendimentos não tributáveis nos rendimentos agregados. Depois, os coeficientes foram usados para prever a fração dos rendimentos totais em 1996-1998, 2000 e 2002.

\subsection{Considerações finais}

Até o momento, não há fonte de dados melhor para o estudo dos ricos e da concentração de renda no topo do que as declarações do imposto de renda das pessoas físicas. Em comparação com as pesquisas domiciliares, os dados tributários oferecem pelo menos dois grandes atrativos: a possibilidade de construção de longas séries históricas e a captação muito mais precisa dos rendimentos dos mais ricos.

No Brasil, a história não é diferente. O IRPF não tem aqui o mesmo peso verificado nos países desenvolvidos, mas os órgãos responsáveis pelo tributo vêm desde a década de 1920 coletando e publicando tabulações valiosas para a análise da desigualdade de renda em nosso país. O objetivo principal deste capítulo foi descrever e justificar todas as etapas necessárias para transformar essas tabulações em séries de longo prazo com a fração da renda total recebida pelos estratos no topo da distribuição de renda.

Para além da comparação com as pesquisas domiciliares e a contextualização histórica do imposto de renda no Brasil, o capítulo documentou as definições gerais e os numerosos ajustes, imputações e interpolações essenciais para remediar as lacunas e 
insuficiências dos dados tributários disponíveis. A maior parte destes procedimentos é relativamente pouco controversa. De todo modo, por sua quantidade e pelo caráter mais arriscado de algumas etapas, vale sempre lembrar que certo grau de incerteza é o preço a ser pago pelas vantagens dos dados tributários.

As principais limitações dos dados decorrem da ausência de tabulações ordenadas por rendimentos totais antes de 2006 e da necessidade de imputação de rendimentos não tributáveis no período anterior a 1974 e em 1996-1998, 2000 e 2002. Somente a partir de 2006 as tabulações aproximam-se do ideal, estando livres desses e de outros problemas. Portanto, mais do que nunca, recomenda-se não fetichizar os números obtidos para anos específicos nem dar importância excessiva a flutuações pequenas de curto prazo.

Embora reais, essas limitações também não devem ser exageradas. A literatura baseada em dados tributários é pródiga em idiossincrasias nacionais e muitos dos procedimentos descritos neste capítulo também são necessários alhures. A definição de controles para população e renda, por exemplo, é imperativa por todo lado e, nesse aspecto, as informações para o Brasil são melhores do que as de muitos países.

Em resumo, apesar de todas as suas deficiências, não há nada que indique que os dados brasileiros sejam sistematicamente piores ou menos confiáveis do que a média dos casos analisados pela literatura internacional. Diferentemente de alguns países já estudados, temos um imposto de renda bem estabelecido e com vida longa e contínua, mudanças na legislação que não arruínam a comparabilidade histórica das séries, tabulações por faixas de renda bastante detalhadas e sem grandes lacunas temporais, e boas estimativas históricas de agregados macroeconômicos. 


\section{Os ricos e a desigualdade no Brasil ao longo de nove décadas}

That King's reign (...) will be remembered by at least a few discerning
historians as a peaceful and elegant one. (...) Harmony, indeed, was the
reign's password. (...) Taxation had become a thing of beauty. The poor
were getting a little richer, and the rich a little poorer. (...) Everybody,
in a word, was content (...). But let us not pursue this tiresome object.
Vladimir Nabokov, Pale Fire (1962)

\subsection{Introdução}

A história da desigualdade de renda no Brasil é repleta de incógnitas, controvérsias e lacunas, que não dizem respeito só às explicações apropriadas, estendendo-se à própria caracterização da desigualdade no longo prazo. Felizmente, é possível, com base nos dados do IRPF e nos procedimentos descritos no capítulo anterior, fazer avançar o conhecimento nessa área, pela perspectiva da concentração de renda no topo. Para entender o padrão e as tendências da nossa estratificação social, não há nada melhor do que examinar os ricos.

As informações coletadas permitem construir séries de longo prazo com as frações da renda total recebidas pelos estratos no topo da distribuição de renda - como o centésimo ou o milésimo mais ricos - desde as primeiras décadas do século passado, com dados para 69 anos entre 1926 e 2013. Estudos anteriores construíram séries similares, mas sem as imputações para obter os rendimentos totais nos anos faltantes. Primeiro, em Souza (2014), apresentei resultados preliminares desta pesquisa, cobrindo 57 anos entre 1933 e 2012. Em seguida, Souza e Medeiros (2015) estenderam os resultados para os rendimentos brutos tributáveis para 66 anos entre 1928 e 2012. Depois, Milá (2015) publicou séries com informações para 61 anos entre 1933 e 2013.

O objetivo deste capítulo é apresentar os resultados dos dados tributários e caracterizar a trajetória da desigualdade nas últimas nove décadas de forma abrangente. Além da concentração no topo propriamente dita, o capítulo aborda a repartição da renda entre os mais ricos e a comparação com pesquisas domiciliares nacionais e com as séries para os ricos disponíveis para outros países. Em conjunto, as diversas seções compõem uma visão panorâmica da estratificação social brasileira, situando o nível e a dinâmica da concentração de renda entre os ricos do ponto de vista histórico e internacional. O próximo capítulo, por sua vez, aprofunda a interpretação e explora em maior detalhe a relação entre o vai e vem da fração recebida pelos mais ricos e a história política brasileira. 
Nesse sentido, os capítulos da Parte I não serviram apenas para construir o objeto e justificar a premência dos estudos sobre os ricos. A discussão foi útil também para arrolar hipóteses acerca do nível e da dinâmica da desigualdade no Brasil. Em particular, três perguntas extraídas da literatura organizam a investigação neste capítulo: a) há alguma tendência nítida de longo prazo para a desigualdade brasileira?; b) de que forma a alternância entre ditaduras e democracia afetou a nossa desigualdade?; c) quando ficamos muito desiguais em comparação com o resto do mundo?.

A primeira pergunta remete às grandes mudanças estruturais do Brasil no último século, capitaneadas pela urbanização e pela industrialização, que se refletiram em um vertiginoso aumento do PIB real e da população. Sem dúvida, o modelo mais famoso de explicação da desigualdade a partir de tais mudanças é o de Kuznets, cuja conjectura do "U invertido" jogou lenha na fogueira das narrativas otimistas do pós-guerra, como discutido no capítulo 2. Embora já não goze de tanto prestígio, a hipótese de Kuznets foi historicamente influente inclusive no Brasil e permanece proeminente no debate internacional, até mesmo pela ausência de outras teorias gerais capazes de produzir previsões inequívocas partindo de pressupostos relativamente simples. Assim, uma das hipóteses investigadas nas seções abaixo é se houve algum tipo de tendência nítida de longo prazo, com destaque para o "U invertido" de Kuznets, na concentração no topo no Brasil.

A segunda pergunta é inevitável diante da conturbada história política brasileira no século XX e, em especial, das controvérsias sobre o aumento da desigualdade entre 1960 e 1970 (ver seção 2.6 no capítulo 2). Em termos bem sucintos, trata-se de saber se há alguma associação discernível entre democracia e menor desigualdade, isto é, se os golpes e redemocratizações deixaram sua marca na trajetória da desigualdade brasileira. Do ponto de vista teórico, há uma série de correntes que ligam a democracia à maior redistribuição, incluindo as populares e empiricamente controversas teorias baseadas na influência do eleitor mediano (e.g., MILANOVIC, 2000). No Brasil, a discussão recente sobre a queda da desigualdade observada nas PNADs pressupõe essa relação e, como será visto neste e no próximo capítulos, muitas das interpretações otimistas dos últimos anos passam por aí. Apesar de as pesquisas domiciliares mostrarem que as alterações recentes no perfil distributivo do Estado são menos significativas do que às vezes se imagina (SOUZA; MEDEIROS, 2013a), a pergunta permanece relevante e não respondida, devido à falta até agora de informações relativas ao período do Estado Novo e do interregno democrático de 1945-1964. Mais ainda, ela tem o mérito de chamar a atenção para os determinantes políticos e institucionais da desigualdade, retirando a conversa do campo mais mecânico ou determinístico dos condicionantes econômicos estruturais.

A terceira e última pergunta põe em relevo a comparação entre o Brasil e os países desenvolvidos, mirando as origens da nossa alta desigualdade. Como discutido na seção 3.5, esse questionamento reapareceu na literatura internacional preocupada, em primeiro lugar, com o atraso relativo da América Latina. A visão tradicional, articulada recentemente 
por Engerman e Sokoloff (1997, 2002), postula que a alta desigualdade latino-americana remonta ao período colonial, enquanto a corrente revisionista de John Coatsworth (2008) e Jeffrey Williamson (2015) insiste que, em termos comparativos, o continente estava próximo dos níveis de concentração de renda observados na Europa e em outros países ricos até as primeiras décadas do século passado. A "anormalidade" da desigualdade latino-americana e brasileira - seria relativamente recente, decorrente do "grande nivelamento" que mudou o caráter das sociedades ricas em uma direção mais igualitária. Nas palavras de Williamson (2015, p. 338), "[é] a história da desigualdade latino-americana no século XX que é única, não sua história colonial, nem sua experiência republicana inicial, nem sua Belle Époque".

As três perguntas abarcam, em graus distintos, a descrição e a explicação da concentração de renda. Por consequência, este capítulo possui a mesma característica, buscando estabelecer fenômenos e interpretar seu sentido geral. Evidentemente, há limites estreitos e incontornáveis quanto ao grau de formalização dos testes dessas e de outras hipóteses. Como em toda a literatura que usa dados históricos do imposto de renda, não há como lançar mão nem de estratégias de identificação rigorosas nem do estado das artes dos modelos estatísticos para avaliar as tendências e interpretações propostas.

Alguns esclarecimentos e caveats precisam ser feitos. Quanto à terminologia, cabe lembrar que "desigualdade" e "concentração no topo" são usados de forma intercambiável, a menos que se diga o contrário. Decerto há muitas desigualdades possíveis; a concentração no topo não é a única que merece ser discutida e nada diz sobre qualquer redistribuição entre os não ricos. A seção 5.4.2 alarga o escopo da investigação e, excepcionalmente, olha para a distribuição como um todo, diferenciando os dois termos. No resto do capítulo, "desigualdade" e "concentração" são usadas como sinônimos, assim como as expressões "os mais ricos" e os "ricos". Além de facilitar a leitura, a escolha baseia-se nos argumentos da Parte I e do capítulo anterior, que defendem os mais ricos como objeto legítimo de estudo ao mesmo tempo que abdicam, em nome do pragmatismo, de uma interminável controvérsia acerca da linha "correta" de riqueza. Em todos os casos, a dimensão relevante para esta tese é a renda: "desigualdade" e "concentração" dizem respeito sempre à renda, e não à riqueza ou qualquer outro aspecto da estratificação social.

Quanto às definições básicas, as séries apresentadas neste capítulo seguem os procedimentos descritos no capítulo 4. Recapitulando brevemente, o controle para a população total equivale aos indivíduos com 20 anos ou mais (a "população adulta") e o denominador para a renda total é um percentual variável do PIB. As séries incorporam todos os procedimentos listados anteriormente, sendo o mais importante a imputação de rendimentos não tributáveis (isentos ou tributados exclusivamente na fonte) para os anos anteriores a 1974 e para 1996-1998, 2000 e 2002. Os resultados sem a imputação são exibidos para fins ilustrativos e para os testes de robustez.

Os caveats decorrem das limitações e imperfeições dos dados, também documentadas 
no capítulo 4. As mudanças na legislação, a imputação de rendimentos não tributáveis, a evasão e a elisão fiscais e a inexistência de tabulações ordenadas por rendimentos individuais totais para o período anterior a 2006 são os principais problemas. Ou seja, os resultados estão sujeitos a erros e omissões que, na maior parte dos casos, são inverificáveis, pois dependem de informações inexistentes. Como discutido, não há indícios de que esses problemas inviabilizem a análise ou sejam sistematicamente maiores no Brasil do que em outros países. Pelo contrário, as estimativas são plausíveis e as fontes de dados são mais confiáveis do que muitas outras utilizadas em estudos de histórica econômica e social. Seja como for, é evidente que os resultados devem ser interpretados com cautela.

Como seria muito tedioso relembrar continuamente esse ponto, o resto do capítulo passa ao largo dessas questões, reiterando as incertezas e imprecisões dos resultados só em alguns dos casos possivelmente mais graves, como nas comparações internacionais. Como sempre, esse tipo de comparação sofre das limitações dos dados nacionais e dos demais países e de escolhas metodológicas nem sempre idênticas. Por isso, recomenda-se não dar peso excessivo a valores específicos nem cair na ilusão de objetividade gerada por números com muitas casas decimais, apenas usá-los como referência de magnitudes de interesse.

As seções deste capítulo partem de uma breve apresentação geral dos resultados e contemplam progressivamente as dimensões histórica e internacional. A seção 5.2 vai direto ao ponto, mostrando alguns dos principais achados, que são discutidos ao lado de indicadores socioeconômicos que descrevem os traços gerais da experiência brasileira no século XX. Com isso, essa seção antecipa algumas conclusões e estabelece o contexto histórico da discussão posterior. A seção 5.3 mergulha nos detalhes das estimativas mais importantes do capítulo - as frações recebidas pelos mais ricos - e investiga a repartição da renda entre eles. Assim, além de contrastar os ricos com o resto da população, essa seção avalia a sua heterogeneidade interna. A análise orienta-se pelas perguntas apresentadas acima e culmina com o esboço de uma interpretação geral, desenvolvida mais a fundo nas seções seguintes e, principalmente, no capítulo 6. A seção 5.4, por sua vez, coteja os resultados dos dados tributários com os das duas principais pesquisas domiciliares brasileiras, as PNADs e os Censos Demográficos, deixando claro como os resultados desta tese contribuem para o conhecimento empírico sobre estratificação no Brasil. A seção também aproveita os resultados tributários para corrigir o coeficiente de Gini estimado nessas pesquisas, saindo do foco no topo para considerar temporariamente a distribuição de renda como um todo. A seção 5.5 compara a fração da renda recebida pelo $1 \%$ mais rico no Brasil e em outros países e investiga se é possível encontrar algo parecido com a curva de Kuznets aqui ou alhures, complementando as análises anteriores ao situar a trajetória do Brasil no contexto internacional. A seção 5.6 é eminentemente técnica, investigando a robustez dos resultados e o efeito de algumas das principais escolhas metodológicas. Por fim, a seção 5.7 resume as principais conclusões do capítulo. 


\subsection{Prévia dos resultados e breve contexto histórico}

O objetivo principal de todos os procedimentos de coleta, homogeneização, imputação, interpolação e afins descritos no capítulo anterior é estimar a fração da renda recebida pelos mais ricos no Brasil desde a segunda metade dos anos 1920. Sendo assim, não há por que fazer mistério nem lenga-lenga: embora os resultados sejam analisados em mais detalhes nas próximas seções, vale a pena adiantar os principais achados, em conjunto com estatísticas que fornecem um breve contexto histórico para a discussão posterior.

A Figura 25 traz a fatia da renda total recebida pelo centésimo mais rico no Brasil entre 1926 e 2013 (com valores no eixo à esquerda) e o coeficiente de Gini da renda individual dos adultos nas PNADs corrigido pelos resultados para a fração apropriada pelos $5 \%$ mais ricos nos dados tributários (eixo à direita).

A concentração entre o $1 \%$ mais rico não exibe nenhuma tendência unívoca de longo prazo: não é possível discernir nenhuma mudança duradoura, nem para maior nem para menor concentração no topo. Tampouco há estabilidade pura e simples. O que se vê são flutuações, por vezes súbitas e radicais, em diferentes direções, de modo que a fração do centésimo mais rico permaneceu num patamar muito alto, entre $20 \%$ e $25 \%$, na maior parte do tempo. As flutuações correspondem com surpreendente frequência a grandes eventos ou ciclos político-econômicos do país, como o Estado Novo, os anos dourados do desenvolvimentismo e o golpe militar nos anos 1960. Em compensação, o vínculo com variáveis estruturais, como a urbanização e a industrialização, é no mínimo ambíguo. Cabe notar também que, no tocante aos mais ricos, não houve modificações significativas no período mais recente: na melhor das hipóteses, pode-se postular uma queda da concentração no topo entre o final da década de 1980 e, com alguma generosidade, meados dos anos 2000. Desde 2006, houve estabilidade ou até leve aumento.

O coeficiente de Gini corrigido pelos dados tributários (explicado na seção 5.4.2) mostra um quadro mais positivo. Há uma tendência de queda desde a segunda metade dos anos 1970, que se torna mais pronunciada a partir da década de 1990 e persiste até meados dos anos 2000, estabilizando-se depois de 2006. Há sim, nesse caso, uma força estrutural de longo prazo em ação: a entrada progressiva das mulheres no mercado de trabalho, ao diminuir o percentual de adultos sem rendimentos próprios, contribuiu decisivamente para a redução do Gini. Entre 1976 e 2013, o percentual de mulheres com 20 anos ou mais com rendimentos próprios de qualquer fonte subiu de quase $35 \%$ para mais de $76 \%$, enquanto o dos homens encolheu de $93 \%$ para $89 \%$. Esse processo paulatino colaborou para derrubar o Gini até em momentos em que a desigualdade no mercado de trabalho piorou, como na década de 1980. Depois, a maior participação das mulheres e os fatores citados anteriormente - como os avanços educacionais e a expansão das políticas sociais caminharam juntos para reduzir o Gini. Desde 2006, o leve aumento da concentração no topo nos dados tributários foi suficiente para estancar o processo. 
Figura 25. Fração do $1 \%$ mais rico e coeficiente de Gini corrigido pelos dados tributários - Brasil, 1926-2013

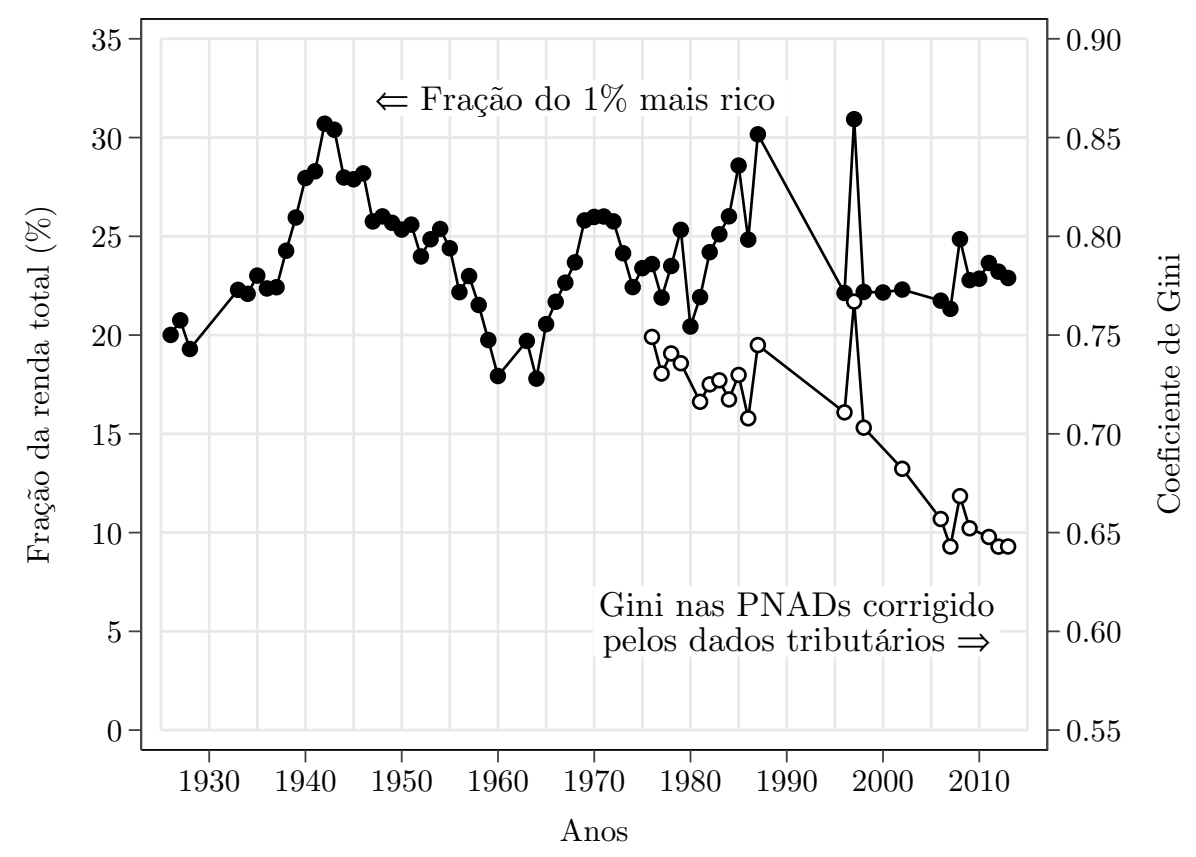

Fonte: elaboração própria a partir de tabulações de dados tributários, das Contas Nacionais e dos microdados das PNADs; ver capítulo 4.

N.B.: coeficiente de Gini da renda individual da população de 20 anos ou mais nas PNADs - exclusive áreas rurais das regiões Norte e Centro-Oeste - corrigido pela fração dos $5 \%$ mais ricos nos dados tributários.

Em outras palavras, ao que tudo indica, as mudanças mais radicais e positivas dos últimos tempos ocorreram na base ou no meio da pirâmide social, e não na fatia apropriada pelos mais ricos, que, dado o padrão de distribuição de renda no Brasil, afeta de forma importante até medidas sintéticas como o coeficiente de Gini.

A permanência desse traço distintivo da nossa desigualdade deu-se em meio às transformações profundas do último século. Não cabe aqui recapitulá-las em detalhes, apenas destacar contornos gerais, começando pelo crescimento econômico. ${ }^{1}$ A Figura 26 apresenta a evolução do PIB per capita e da renda disponível por adulto - o controle para a renda total dividido pelo da população -, em reais de 2014, desde a década de 1920.

O crescimento acumulado nesses quase cem anos foi considerável. Saímos de um patamar bem abaixo de $\mathrm{R} \$ 5$ mil para perto de $\mathrm{R} \$ 30$ mil por ano. O PIB per capita foi multiplicado por 12: seu valor mensal em 2014 é quase igual ao total anual dos anos 1920. A renda disponível por adulto aumentou quase sete vezes. O crescimento foi rápido até o final da década de 1970 e assombroso durante o "milagre econômico", de 1968 a 1974. O endividamento e a vulnerabilidade externa, contudo, desembocaram na "década perdida" dos anos 1980. A estagnação só ficou para trás com a recuperação embalada pelo boom de commodities dos anos 2000, com esgotamento perceptível nos últimos anos das séries.

1 Ver, entre muitos outros, Osorio, Soares e Souza (2010) e coletâneas como Giambiagi et al. (2005), IBGE (2006) e Bethell (2008a). O capítulo 4 também traz informações adicionais sobre mudanças demográficas e finanças públicas. 
Figura 26. PIB per capita e renda disponível per capita ( $\$$ 2014) - Brasil, 1925-2014

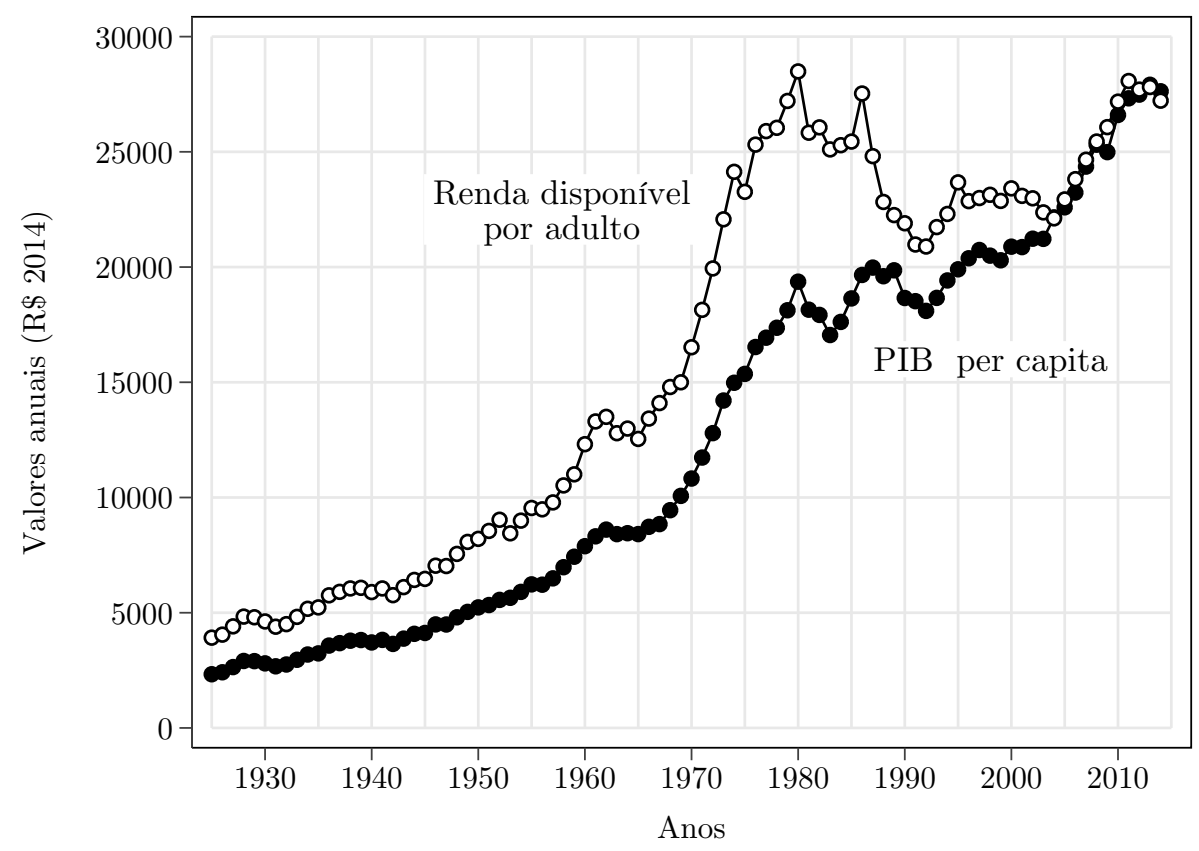

Fonte: elaboração do autor a partir de dados das "Séries históricas e estatísticas" do IBGE, do Ipeadata e do Banco Central do Brasil. O capítulo 4 detalha o cálculo da renda disponível.

N.B.: a renda disponível por adulto equivale ao denominador para renda total dividido pelo da população total, isto é, o número de indivíduos com 20 anos ou mais. Valores atualizados para 2014 pelo deflator do PIB.

A era de rápido crescimento entre os anos 1920 e 1970 não foi imune a flutuações econômicas e conviveu com inflação persistente. As Figuras 27 e 28 mostram, respectivamente, a variação anual real do PIB per capita e a inflação anual medida pelo deflator do PIB. ${ }^{2}$ No caso do crescimento, a desaceleração a partir de 1974 ou, mais ainda, de 1980, é evidente. A ressaca do desenvolvimentismo trouxe mais recessões e menor crescimento mesmo nos anos mais favoráveis. Antes disso, as crises eram pontuais e normalmente seguidas por recuperações fortes, como no caso da Grande Depressão de 1929 e da recessão de meados dos anos 1960. A inflação, no entanto, foi um problema crônico dos anos de crescimento que saiu completamente do controle nos anos 1980, quando a economia já não ia nada bem. Foram raros os anos em que ela ficou abaixo de $10 \%$ no pós-guerra, permanecendo acima desse patamar durante o longo intervalo entre 1953 e 1996. Pior, entre 1974 e 1995 foram 22 anos seguidos acima de $30 \%$.

Nem tudo marchou em uma direção unívoca. Em alguns aspectos centrais, a estrutura produtiva seguiu padrão cíclico. A Figura 29 traz dois exemplos cujas trajetórias se espelham: a contribuição percentual da indústria da transformação para o valor agregado, isto é, o PIB a preços básicos, e a taxa de abertura da economia, calculada como a participação do comércio exterior - a soma das exportações e importações - sobre o PIB.

$\overline{2}$ O gráfico para a renda disponível por adulto foi omitido porque é muito similar. Outros índices de inflação - como o Índice Nacional de Preços ao Consumidor Amplo (IPCA), o Índice de Preços ao Consumidor - Fundação Instituto de Pesquisa Econômica (IPC-Fipe) e o Índice Geral de Preços Disponibilidade Interna (IGP-DI) - geram resultados qualitativamente idênticos. 
Figura 27. Variação anual real do PIB per capita (\%) - Brasil, 1925-2014

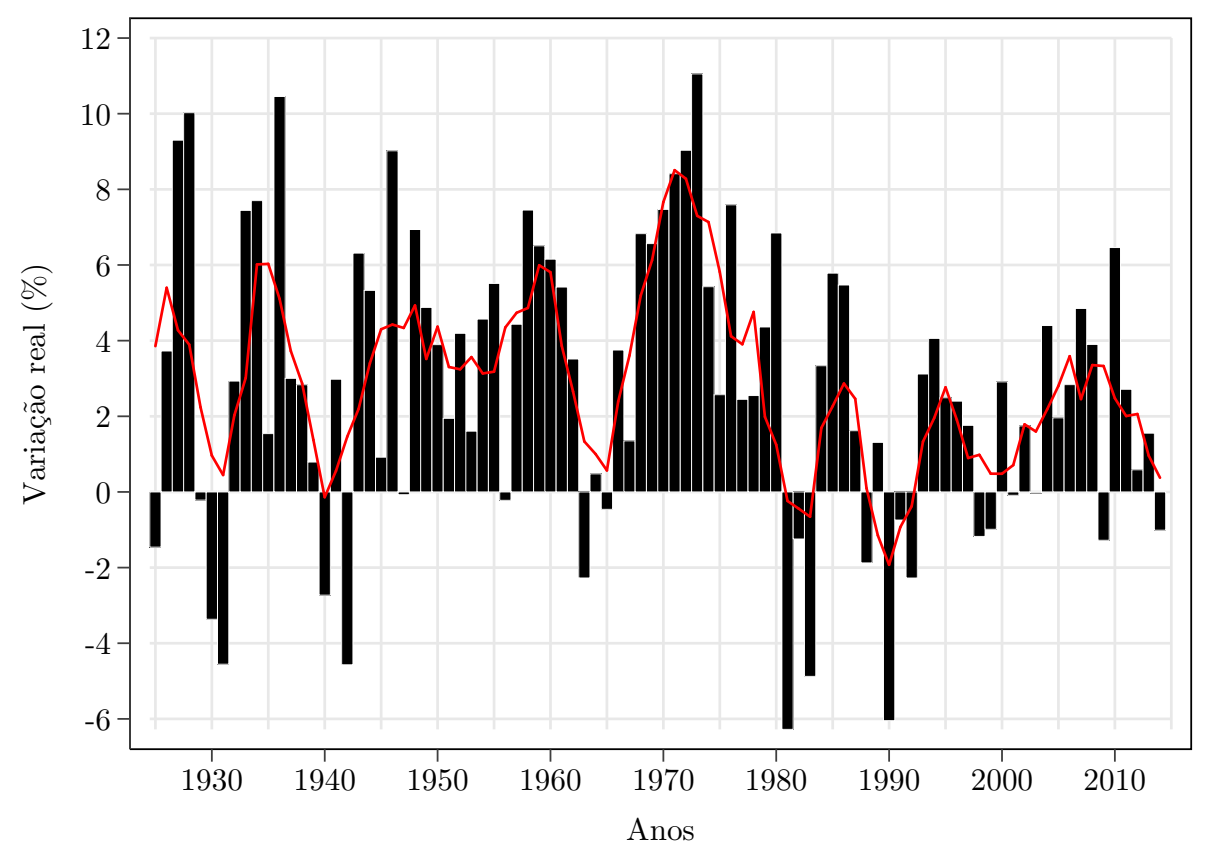

Fonte: elaboração do autor a partir de dados das "Séries históricas e estatísticas" do IBGE; do Ipeadata; e do Banco Central do Brasil.

N.B.: a linha em vermelho indica a média móvel em um intervalo de cinco anos.

Figura 28. Inflação anual de acordo com o deflator do PIB (\%) - Brasil, 1925-2014

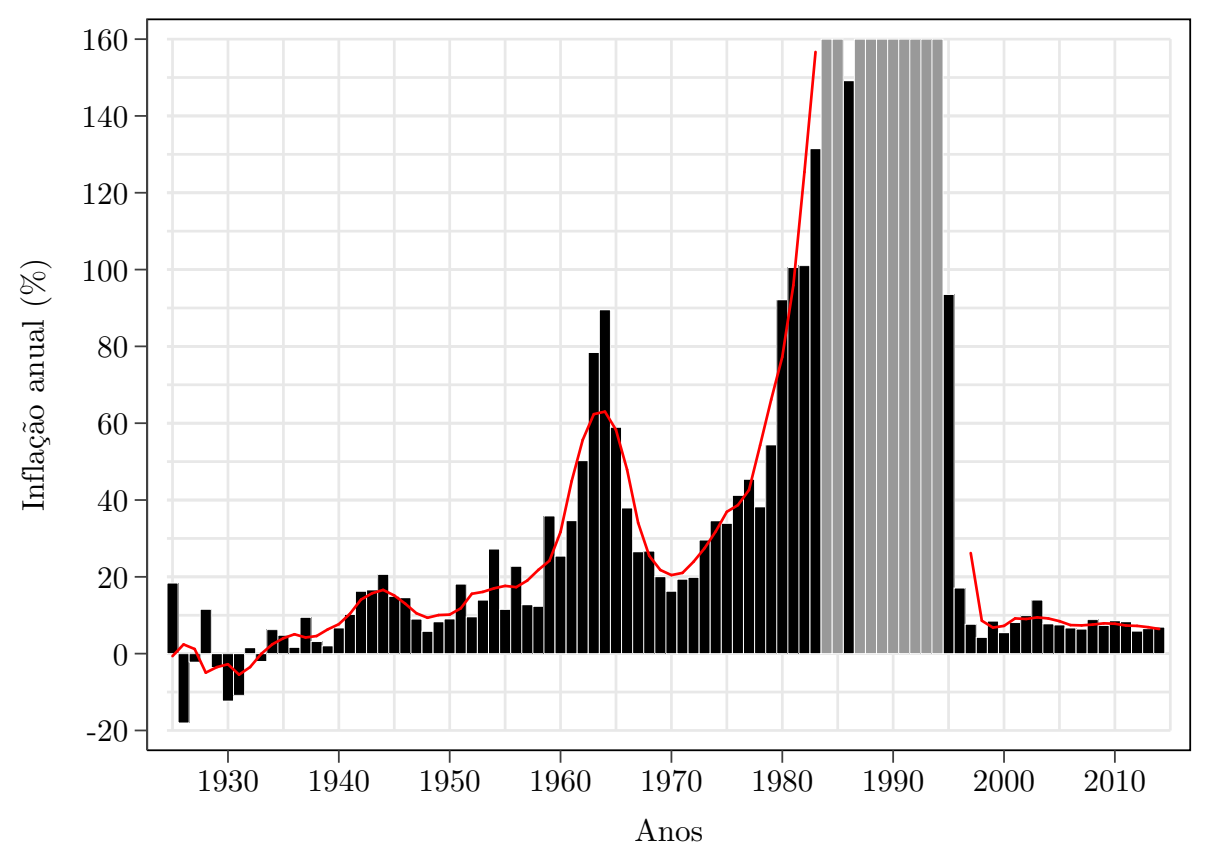

Fonte: elaboração do autor a partir de dados das "Séries históricas e estatísticas" do IBGE; do Ipeadata; e do Banco Central do Brasil.

N.B.: gráfico truncado em para facilitar a visualização. As barras cinzas marcam os anos com inflação acima de 160\%: 1984, 1985 e 1987-1994. A linha em vermelho indica a média móvel em um intervalo de cinco anos. 
Figura 29. Contribuição da indústria de transformação para o valor agregado e taxa de abertura da economia (\%) - Brasil, 1947-2013

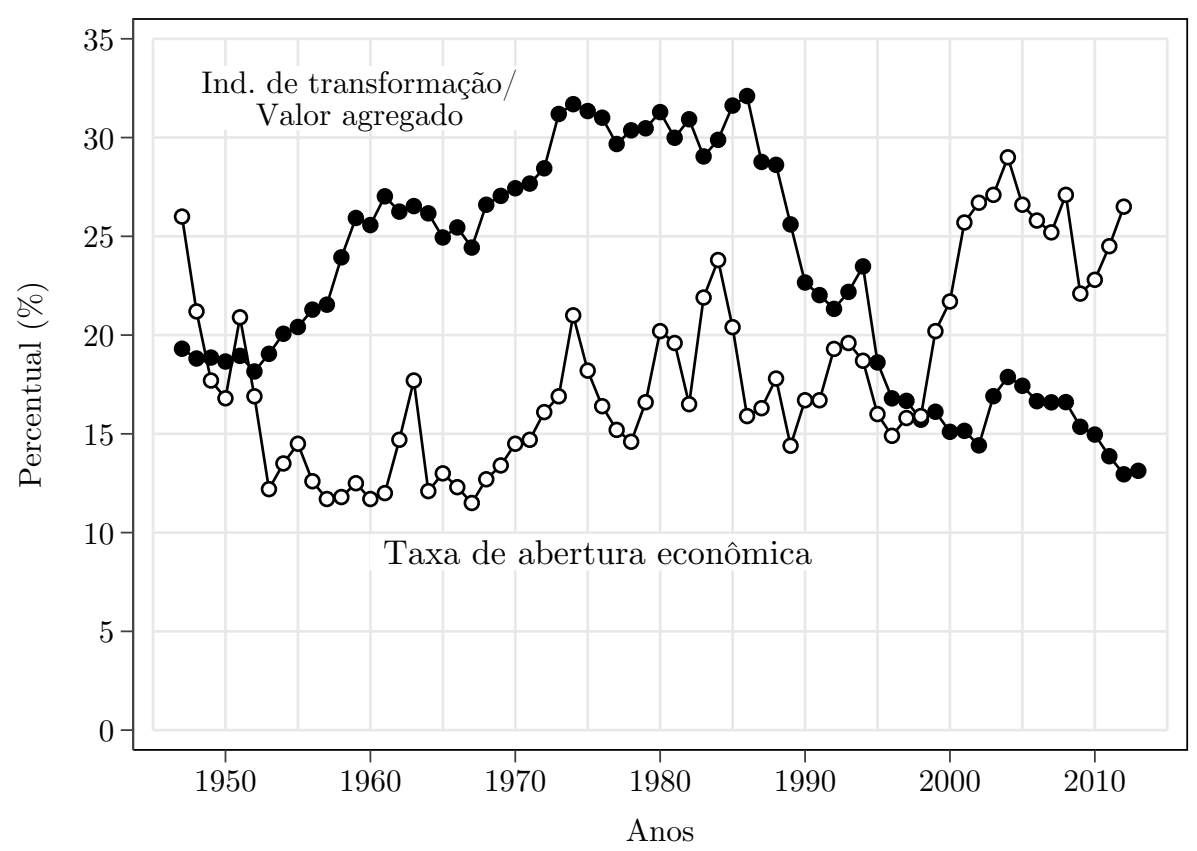

Fonte: elaboração do autor a partir de dados das "Séries históricas e estatísticas" do IBGE e do Ipeadata.

A primeira série mostra o avanço e o recuo da industrialização brasileira, percebida em uma trajetória de "U invertido". A contribuição da indústria de transformação para o valor agregado pulou de menos de $20 \%$ para pouco mais de $30 \%$ nas três décadas posteriores à $2^{a}$ Guerra Mundial e declinou rapidamente nos primeiros vinte anos da redemocratização, registrando em 2013 os menores percentuais da série, abaixo dos 15\%. A correlação inversa com a taxa de abertura da economia, que segue uma tendência em "U" tradicional, é evidente, embora não caiba aqui falar em causalidade. O comércio exterior perdeu peso na economia brasileira no pós-guerra, voltando a crescer apenas durante o "milagre", puxado mais por importações do que por exportações, e principalmente com o choque do petróleo de 1974. A instabilidade posterior resultou em uma tendência mais clara somente a partir de 2000, com novo aumento significativo, desta vez empurrado mais pelas exportações, em uma década conhecida pelo boom na demanda por commodities.

Em resumo, a flutuação sem direção clara na concentração de renda no topo entre 1926 e 2013 ocorreu ao mesmo tempo que a economia e a sociedade brasileira embarcavam em transformações profundas, algumas definitivas e outras de caráter mais cíclico. As próximas seções examinam essas tendências com mais cuidado e aprofundam o panorama apresentado com mais dados e comparações, inclusive internacionais. 


\subsection{A concentração da renda entre os mais ricos no Brasil}

\subsubsection{A fração da renda recebida pelos ricos}

A concentração de renda no topo é uma das características mais marcantes da desigualdade brasileira, algo reconhecido inclusive por estudos baseados em pesquisas domiciliares (e.g., MEDEIROS, 2005), cuja capacidade de captar o extremo superior da distribuição de renda é reconhecidamente limitada. Os dados tributários permitem preencher essa lacuna para o centésimo mais rico, como apresentado na seção anterior, e para outros estratos de interesse. A Figura 30 exibe os números para os 0,01\%, 0,1\% e 1\% mais ricos, enquanto a Figura 31 traz os resultados para os 1\%, 5\%, 10\% e 15\% mais ricos.

Nas duas figuras, os resultados dizem respeito às minhas séries preferidas, que, conforme discutido anteriormente, incluem a imputação de rendimentos isentos ou não tributáveis para diversos anos. Para não deixar dúvidas, os painéis da Figura 32 exibem os resultados efetivamente observados, separados em rendimentos brutos tributáveis e rendimentos totais, i.e.: sem imputações para obter os rendimentos totais para todos os anos. Devido ao baixo percentual de declarantes do IRPF, só foi possível estimar as frações recebidas por alguns estratos para um intervalo mais curto, começando em $1969 .^{3}$

O Brasil, de fato, não é um país para principiantes, exibindo uma combinação sui generis de estabilidade e mudança. A estabilidade se revela em um nível de desigualdade elevado ao longo de todo o período, sem nenhuma tendência de longo prazo, seja para o aumento ou para a queda da concentração no topo. A fração recebida pelo centésimo mais rico ficou entre $20 \%$ e $25 \%$ em 40 dos 69 anos para os quais há dados observados ou imputados (58\% dos casos).

O período recente não fugiu a esse padrão, com estabilidade ou no máximo um pequeno aumento da concentração entre os estratos mais ricos, corroborando o fenômeno originalmente observado por Medeiros, Souza e Castro (2015a) com base em tabulações e escolhas metodológicas um pouco diferentes das empregadas aqui. Como mostram as Figuras 30 e 31, em 2013, o milésimo mais rico da população com 20 anos ou mais - um grupo com pouco menos de 140 mil pessoas - recebeu $10 \%$ da renda total, o centésimo mais rico abocanhou quase $23 \%$, e o décimo mais rico teve mais de $51 \%$.

Houve situações atípicas em alguns dos anos com números muito discrepantes, como em 1997, que registrou uma explosão dos rendimentos não tributáveis. Provavelmente, isso reflete o impacto inicial da Lei 9.249/1995, que excluiu lucros e dividendos da base de cálculo do IRPF a partir de $1996 .^{4}$

3 A fração dos $15 \%$ mais ricos foi omitida da Figura 32 porque, como se vê na Figura 31, só pode ser calculada para um número muito pequeno de anos. Para compensar, incluí na Figura 32 os resultados para os 0,5\% mais ricos, que foram omitidos da Figura 30 para facilitar a visualização.

4 Não é possível descartar completamente a ocorrência de erro tipográfico na publicação das tabulações (BRASIL. MF. SRF, 2001). Essa possibilidade não é muito provável, porque há aumento não apenas 
Figura 30. Fração da renda recebida pelos 0,01\%, 0,1\% e 1\% mais ricos - Brasil, 1926-2013 $(\%)$

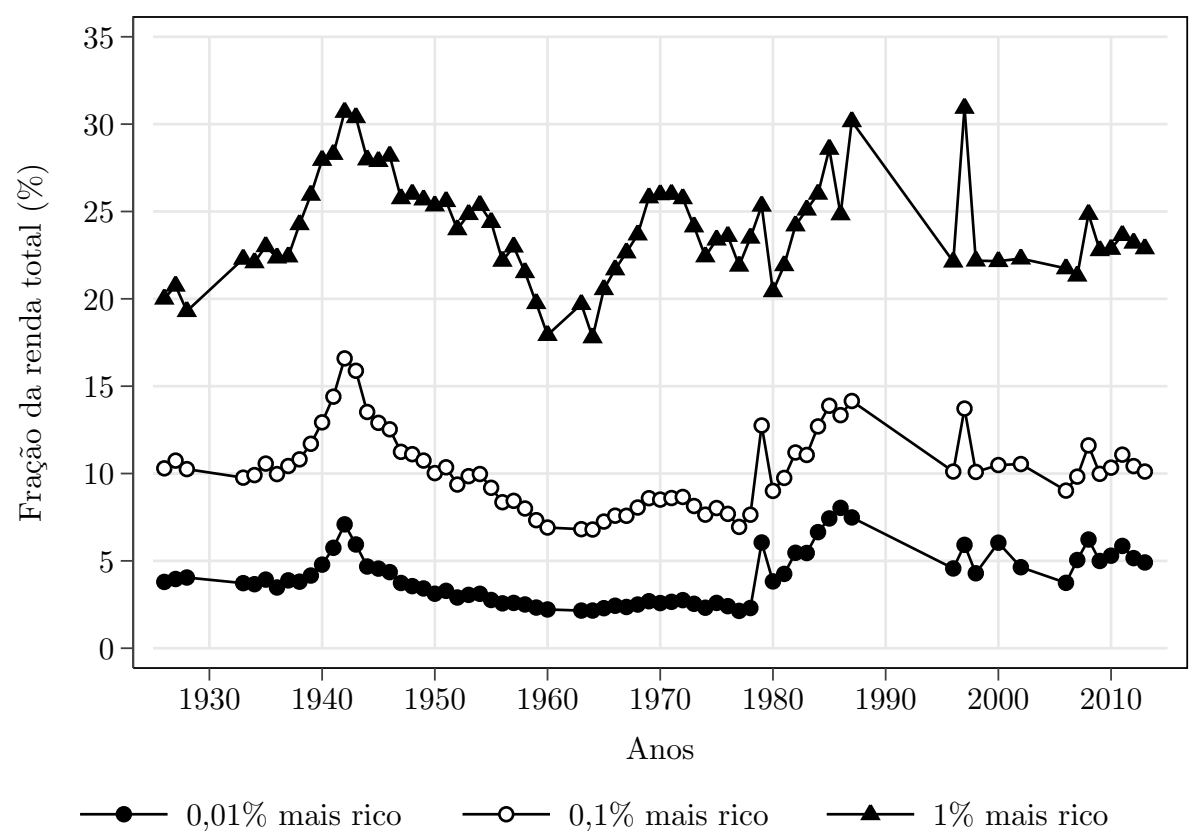

Fonte: elaboração própria a partir de tabulações de dados tributários e das Contas Nacionais; ver capítulo 4.

Figura 31. Fração da renda recebida pelos 1\%, 5\%, $10 \%$ e $15 \%$ mais ricos - Brasil, $1926-2013(\%)$

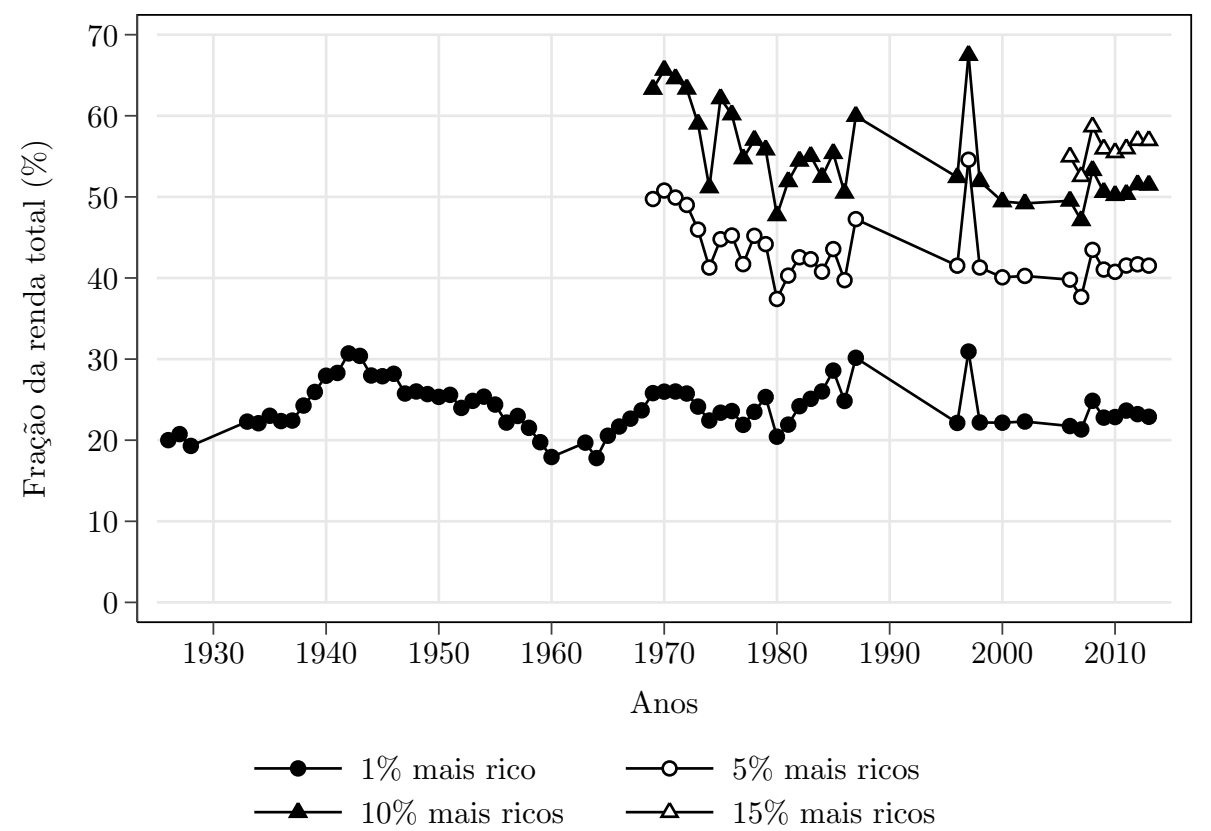

Fonte: elaboração própria a partir de tabulações de dados tributários e das Contas Nacionais; ver capítulo 4. 
Figura 32. Fração da renda recebida pelos $0,01 \%, 0,1 \% 1 \%, 5 \%$ e $10 \% \%$ mais ricos nos dados observados para rendimentos brutos tributáveis e rendimentos totais - Brasil, $1926-2013(\%)$

A) $0,01 \%$ mais rico

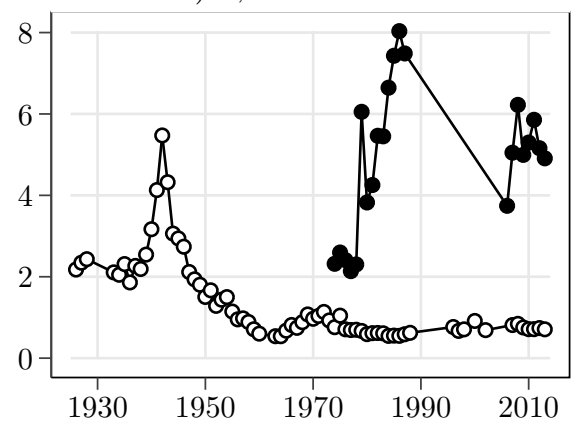

C) $0,5 \%$ mais rico

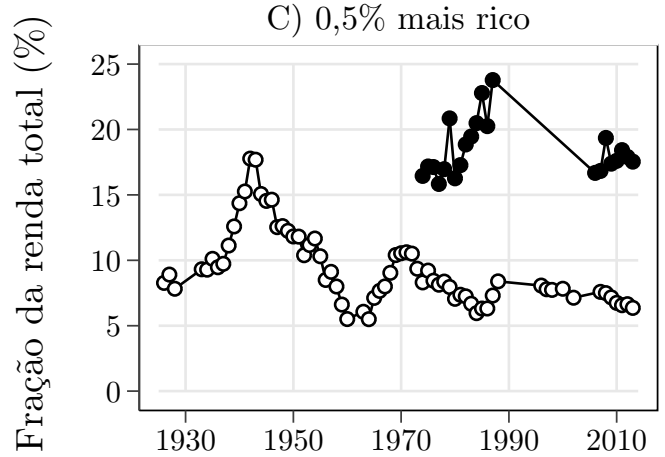

E) $5 \%$ mais ricos

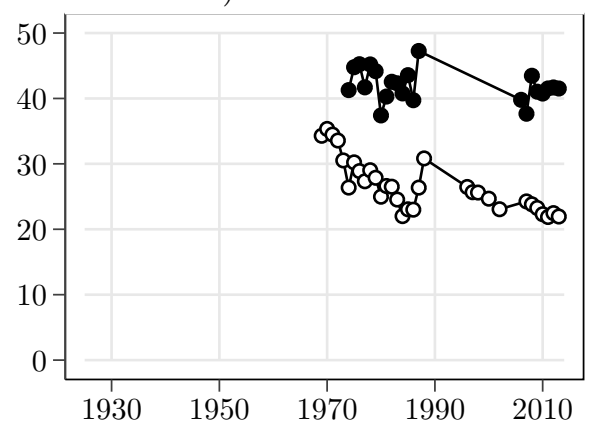

B) $0,1 \%$ mais rico

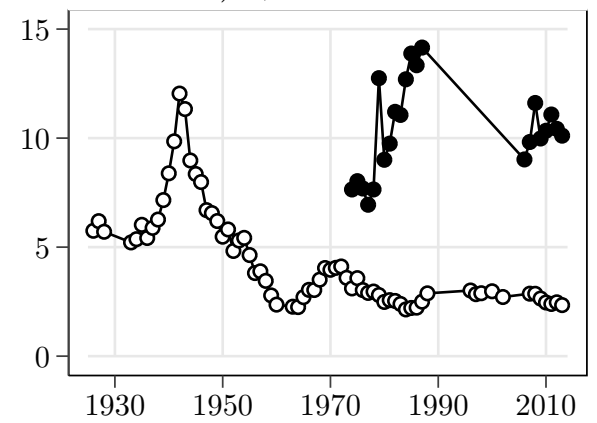

D) $1 \%$ mais rico

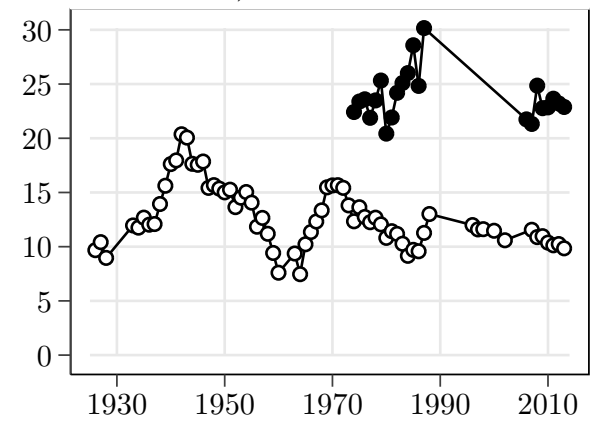

F) $10 \%$ mais ricos

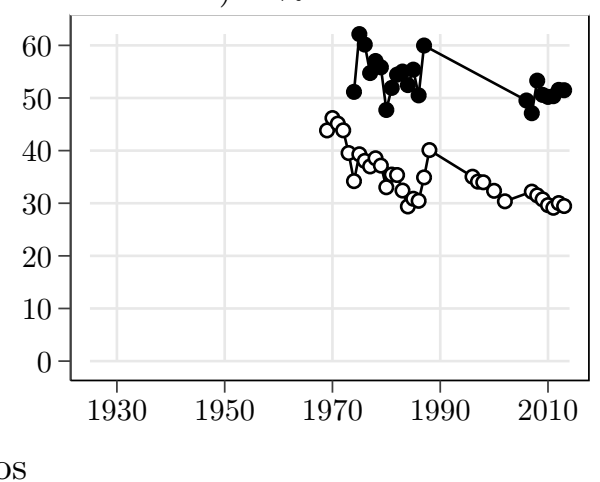

-

Fonte: elaboração própria a partir de tabulações de dados tributários e das Contas Nacionais; ver capítulo 4.

N.B.: resultados sem imputação de rendimentos isentos ou não tributáveis para os anos anteriores a 1974 e para 1996-1998, 2000 e 2002; ver capítulo 4.

no volume dos rendimentos isentos, mas também na frequência de declarações em que eles aparecem. A explicação mais plausível é que, após um ano de vigor da nova lei, muitas empresas decidiram então repassar lucros e dividendos acumulados a seus proprietários. Nos anos anteriores à Lei 9.249/1995, os lucros e dividendos comuns eram tributados exclusivamente na fonte com a alíquota de $15 \%$, recebendo o mesmo tratamento de ganhos de capital em geral (NÓBREGA, 2014). 
A permanência desses altos níveis de desigualdade não nos deve fazer perder de vista as tumultuosas mudanças que, mesmo sem se traduzirem em tendências seculares, produziram flutuações consideráveis nas frações apropriadas pelos mais ricos. No caso do $1 \%$ mais rico, há três períodos de clara elevação da desigualdade, sendo dois deles correspondentes à instauração das duas ditaduras vividas pelo país no século XX: a fração do centésimo mais rico aumentou durante o Estado Novo (1937-1945), principalmente durante a $2^{a}$ Guerra Mundial, e após o golpe militar de 1964. O terceiro período coincidiu com outro momento dramático: a crise econômica e política dos anos 1980. Nesse caso, a escalada da inflação introduz algum ruído nos resultados, possivelmente levando a uma superestimação do aumento da desigualdade. ${ }^{5,6}$

Em contrapartida, houve um período longo de queda da desigualdade durante o interregno democrático de 1945 a 1964, com particular intensidade logo após o fim do Estado Novo e da $2^{a}$ Guerra e na segunda metade dos anos 1950, época marcada pela presidência de Juscelino Kubitschek (1956-1961). Além disso, houve também um recuo mais tímido da concentração no $1 \%$ mais rico em meados dos anos 1970, quando o país vivia os últimos anos do dito "milagre econômico". Uma nova queda significativa ocorreu em algum momento entre 1987 e meados dos anos 1990, só que não há dados disponíveis para averiguar seu timing preciso. Depois disso, o quadro é menos definido em função das imputações para 1996-1998, 2000 e 2002 e porque só a partir de 2006 temos tabulações ordenadas pelos rendimentos totais, não sendo possível descartar nova redução leve da concentração no topo até meados dos anos 2000. Na última década, o cenário é de relativa estabilidade da fração do $1 \%$ mais rico, com um leve aumento nos últimos anos da série.

A história do 0,01\% e do 0,1\% mais ricos foi semelhante, com apenas algumas diferenças de intensidade. Para estratos maiores, como os $5 \%$ e $10 \%$ mais ricos, a trajetória foi distinta, com uma queda mais visível ao longo de toda a década de 1970 e, essencialmente, estabilidade nos anos 1980. Deixando de lado pontos atípicos como 1987 e 1997, não há diferenças claras entre o nível de concentração observado na primeira metade da década de 1980 e no período mais recente. Todos os estratos aumentaram levemente sua participação na renda nacional a partir de 2006.

Esse panorama permite dar algumas respostas iniciais às perguntas levantadas na introdução. Primeiro, com relação ao debate acerca das origens do "excepcionalismo" latino-americano em termos de desigualdade (ver discussão na seção 3.5 do capítulo 3): apesar de ser impossível estabelecer com base nos dados do IRPF quando o Brasil atingiu

5 Um indício dessa superestimação é que, como mencionado, os dados para 1988 - ano em que o IPCA saltou para 980\%, depois de registrar 363\% em 1987 - produzem resultados implausíveis, com a fração do $1 \%$ atingindo $58 \%$, quase o dobro dos cerca de $30 \%$ vistos em 1987. Não se pode descartar totalmente a hipótese de erro de transcrição/digitação nas tabulações de 1988, mas isso é menos provável porque esses resultados se repetem com dados de diferentes tabelas e variáveis de ordenação.

6 Em análise das PNADs de 1979 a 1996, Hoffmann (1998) encontrou um efeito positivo e estatisticamente significativo da inflação sobre diversas medidas de desigualdade de renda, que inclui tanto a redistribuição real quanto o "ruído" provocado pela piora na qualidade das informações. 
os níveis atuais de desigualdade - e os próprios dados dos anos 1920 e 1930 sejam menos confiáveis do que os mais recentes -, tudo indica que o argumento de Williamson (2015) precisa ser qualificado. Para ele, a grande idiossincrasia que tornou a América Latina muito mais desigual do que o mundo desenvolvido não se originou no período colonial, como na visão tradicional, e sim no século XX, porque o continente perdeu o "grande nivelamento" experimentado nos Estados Unidos e boa parte da Europa.

A qualificação necessária, como se vê na Figura 30, é que houve redução da concentração no topo nas duas décadas após a $2^{a}$ Guerra, que acabou interrompida e revertida nos anos seguintes ao golpe militar de 1964. Esse movimento não foi tão drástico nem abrupto quanto os choques às grandes fortunas causados pelas grande guerras e pelas reações políticas nos países ricos, e mesmo no início dos anos 1960 nossa desigualdade ainda era elevada. Tampouco há como garantir que, sem a ditadura, a fatia do centésimo mais rico continuaria a declinar suavemente até o patamar europeu. Ainda assim, não se pode minimizar 1964 como um ponto de inflexão para o aumento da desigualdade.

Com efeito, as idas e vindas da desigualdade estão mais relacionadas aos grandes ciclos políticos do país no último século do que às transformações estruturais esboçadas na seção anterior. Entre 1920 e 2012, o PIB real cresceu quase $8400 \%$ e a população aumentou de 30,6 para quase 200 milhões (639\%). O país tornou-se predominantemente urbano e passou por um período de industrialização rápida, com a participação da indústria no valor agregado aumentando muito entre 1947 e meados dos anos 1980 para depois recuar bruscamente, como vimos. Nada disso, contudo, refletiu-se mecanicamente em tendências robustas de longo prazo, como indagava outra das perguntas.

Seria descabido concluir que a industrialização, a urbanização e outras dimensões estruturais são irrelevantes para a dinâmica da desigualdade brasileira, até porque nem todas elas modificaram-se sensivelmente ao longo do tempo, como no caso da estrutura fundiária, cuja distribuição secularmente desigual condicionou o desenvolvimento do país no último século. Entretanto, a influência dos fatores estruturais não se manifesta mecanicamente nem é visível nas séries estimadas. Pelo contrário, com possível exceção do período entre 1945 e 1964, todas as variações na concentração no topo foram relativamente bruscas e de curta duração, em momentos críticos da nossa vida institucional.

A influência da conjuntura política não pode ser reduzida a uma oposição simples entre mais desigualdade em ditaduras e menos desigualdade em períodos democráticos, algo, por sinal, já verificado na dificuldade da literatura internacional em encontrar efeitos robustos da democratização sobre a distribuição de renda (e.g., ACEMOGLU et al., 2015).

No nosso primeiro ciclo de ditadura e democratização, ocorreu de fato aumento e depois queda da fração da renda recebida pelos mais ricos. Contudo, algumas ressalvas são necessárias, a começar pela lembrança de que os dados relativos à primeira metade do século XX são menos confiáveis. Mais importante ainda é que o aumento da concentração 
durante o Estado Novo coincidiu, em boa parte, com outro acontecimento político de impacto global, a $2^{a}$ Guerra. A velocidade e o timing da elevação da desigualdade sugerem fortemente que, assim como em outros países, sua causa principal remete mais à resposta das instituições políticas e econômicas aos efeitos da guerra do que apenas e tão somente à natureza do regime. O pós-guerra confirma isso: se, por um lado, é plausível atribuir a redução de quase 5 p.p. na fração do $1 \%$ mais rico ao fim das condições excepcionais vigentes de guerra, por outro, ninguém jamais acusou o governo de Eurico Gaspar Dutra (1945-1951) de ser radicalmente redistributivo (ver capítulo 6).

Por sinal, um dos efeitos da guerra foi o de incentivar o aperfeiçoamento do aparato administrativo do imposto de renda. Ao derrubar o comércio mundial, o conflito provocou forte queda dos impostos aduaneiros, obrigando o governo federal a procurar fontes alternativas de financiamento, com ênfase no imposto de renda. A criação da Comissão de Reorganização dos Serviços da Diretoria do Imposto de Renda, em 1940, e a Reforma Administrativa de 1942 são dois marcos do processo de racionalização administrativa, descentralização dos serviços e aperfeiçoamento da fiscalização do imposto, que duplicou sua participação na arrecadação tributária federal em poucos anos (COMISSÃO DE REFORMA DO MINISTÉRIO DA FAZENDA, 1966; NÓBREGA, 2014). Assim, é provável que parte do aumento acelerado da concentração no topo nos anos de guerra tenha resultado dessas melhorias, embora também haja motivos para crer que se tratou de uma parte relativamente pequena: o mesmo aumento foi observado na Argentina e, caso fosse inteiramente artificial, não haveria motivos para sua reversão parcial depois de 1945.

O segundo ciclo de ditadura e democratização foi ainda mais complexo. A piora na distribuição de renda após o golpe militar de 1964 já havia sido observada nos Censos Demográficos (ver seção 3.5 do capítulo 3) e aparece ainda mais nos dados tributários, revertendo a tendência anterior. É possível que o fenômeno tenha sido ainda mais intenso do que o mostrado pelas Figuras 30, 31 e 32, dado que o procedimento de imputação dos rendimento isentos e não tributáveis pressupõe que a relação observada nos anos 1970 é válida para todo o período, sendo que seu escopo foi alargado no início da ditadura.

Seja como for, na década seguinte, a concentração no topo apresentou um pequeno declínio, mais ou menos no período em que o regime dava sinais de abertura e até o momento em que o chamado "novo sindicalismo" eclodiu na esfera pública, com todas as suas inovações e continuidades com relação às práticas anteriores (SANTANA, 1998). A redemocratização em 1985 não trouxe nenhuma redução rápida da concentração no topo, que continuou a aumentar na segunda metade da década, embora esses resultados tenham que ser lidos com cuidado, em função das distorções introduzidas pela aceleração da inflação. Infelizmente, a falta de dados torna impossível interpretar adequadamente a posterior redução dessa concentração, que, diga-se de passagem, aparentemente voltou aos níveis dos anos 1970. De todo modo, é notável que não se veja nenhuma tendência bem delineada de queda da fração recebida pelos mais ricos nos últimos 20 anos, justamente 
quando o apelo "social" e por vezes explicitamente redistributivo ganhou mais força na retórica política brasileira, ao mesmo tempo que vários dispositivos constitucionais foram gradualmente implementados e os gastos sociais cresceram muito em valores reais e em relação ao PIB (CASTRO et al., 2012; RIBEIRO, 2010).

Ou seja, em termos de redução da concentração no topo, a Constituição de 1988 mostrou-se bem menos redistributiva do que normalmente se alega e, na prática, a democracia instaurou-se mais como uma transição negociada do que como ponto de inflexão. A melhora apenas marginal e o saldo líquido ainda regressivo de muitos dos fluxos monetários entre as famílias e o Estado refletem essa realidade (ver o capítulo 6).

Logo, a evolução da concentração de renda no topo não permite generalizações simples, nem é possível, nesse momento, propor teorias gerais. Dentre as possibilidades aventadas pela literatura, os resultados aproximam-se das ondas de ascensão-queda-ascensão descritas por Frankema (2009), apesar de não se encaixarem bem nas explicações propostas por ele, que destacam, no período inicial, a "primeira globalização" e, recentemente, o skill-biased technological change como causas dos aumentos da desigualdade. É difícil conciliar o timing e a duração dos movimentos com essas hipóteses.

Pode-se, no entanto, arriscar uma interpretação admitidamente vaga, porém apta a servir de linha condutora para a investigação. Ela começa pelo reconhecimento de que a desigualdade tem um forte caráter inercial, por fatores estruturais e sobretudo por ser em grande medida ditada por aspectos institucionais, constituindo o resultado acumulado de muitas políticas e pequenas e grandes decisões, que, em seu conjunto, expressam determinado padrão de relacionamento entre o Estado e as elites econômicas.

Com isso, qualquer explicação monocausal está fadada a ter aplicação limitada e, mais importante, é só em momentos de crise - principalmente crises políticas, mesmo que essas tenham por vezes origem econômica ou internacional - que se abre o espaço para rupturas e mudanças abruptas no arcabouço institucional capazes de afetar profundamente a concentração de renda. A plausibilidade do que chamei de "hipótese Jencks-Piketty", que postula que só rupturas exógenas reconfiguram fortemente a desigualdade, viria dessa característica. Em condições normais, por assim dizer, é difícil que instituições possam ser gradualmente reformadas de modo a resultar em processos tranquilos e duradouros de redução da concentração no topo, porque há sempre brechas e espaços para que grupos prejudicados consigam reverter suas perdas, inclusive por vias legítimas, por exemplo, instrumentalizando narrativas disponíveis e colocando-se como portadores do bem comum.

Essa interpretação não significa que a desigualdade possa ser totalmente reduzida à política. As instituições podem agir diretamente, como se vê pelos sistemas de tributos e transferências mundo afora, mas também criam e regulam mercados, favorecem maior ou menor competição e geram oportunidades (e prejuízos) que diferentes grupos são aptos a aproveitar. Ou seja, o sistema político-institucional atua como filtro, intermediário e, 
no limite, condutor dos conflitos distributivos da economia, com capacidade ímpar de influenciar a distribuição e os retornos dos ativos e o funcionamento dos mercados. ${ }^{7}$

No Brasil, a ruptura autoritária de 1964 é o caso por excelência de reforma institucional que resultou em maior desigualdade; movimentos na direção oposta também podem ocorrer. Para além de inovações concretas, cabe notar que a transformação institucional provocada por crises pode se dar pelo que Hacker e Pierson (2010, p. 168) chamaram de drift, ou seja, "quando grupos com poder de bloquear mudanças efetivamente impedem a atualização de políticas por um longo período, mesmo diante de fortes pressões opostas e fortes evidências de que a política não está atingindo seus objetivos iniciais".

Naturalmente, a margem de manobra aberta por cada crise sempre é relativamente delimitada e o controle do processo é por vezes demasiado frágil. As reações endógenas às mudanças no conflito distributivo e a própria necessidade de normalização das relações torna difícil que a desigualdade mude radicalmente de patamar, salvo em situações especiais em que a conjunção do clima intelectual com as condições políticas facilita isso. A combinação do choque e da mobilização de massa impostos pela $2^{a}$ Guerra Mundial com o clima intelectual e político descrito na Parte I em alguns países desenvolvidos foi uma dessas situações capazes de gerar transformações profundas. Nada parecido houve no Brasil. Nem mesmo a Constituição de 1988, com todos os seus méritos, sequer chegou perto de representar uma inflexão da concentração no topo.

\subsubsection{A repartição da renda entre os ricos}

Os dados tributários permitem sofisticar os resultados anteriores pelo exame da repartição da renda entre os mais ricos, ou seja, da heterogeneidade interna desse grupo. Com efeito, há muita diferença em definir os "ricos" como o $0,01 \%$ ou os $15 \%$ mais ricos da população adulta. Para ficar apenas no ponto de vista demográfico, no primeiro caso estamos falando, em 2013, de cerca de 140 mil pessoas e, no segundo, de mais de 21 milhões. A escolha por uma ou outra linha de demarcação certamente pode e deve variar de acordo com o contexto, desde que informada por critérios mais objetivos.

Há várias maneiras de ilustrar a repartição entre os mais ricos. Continuando a discussão anterior, as Figuras 33 e 34 mostram o percentual da renda total apropriado por subgrupos dentro do $1 \%$ e dos $10 \%$ mais ricos, respectivamente. Basta somar verticalmente as três curvas da Figura 33 para obter o percentual total do centésimo mais rico (já exibido nas Figuras 30 e 31); o mesmo vale para o décimo mais rico na Figura 34.

No caso dos subgrupos dentro do centésimo mais rico, a Figura 33 mostra que houve diferenças nos dois períodos de aumento da desigualdade. Durante a $2^{a}$ Guerra, a concentração foi puxada pelo estrato mais no topo, o milésimo mais rico. O subgrupo logo

7 Devo a José Alcides Figueiredo Santos a sugestão para esclarecer melhor esse ponto e a ênfase nas oportunidades econômicas geradas pelas instituições. 
Figura 33. Fração da renda total recebida por subgrupos dentro do $1 \%$ mais rico - Brasil, 1926-2013(\%)

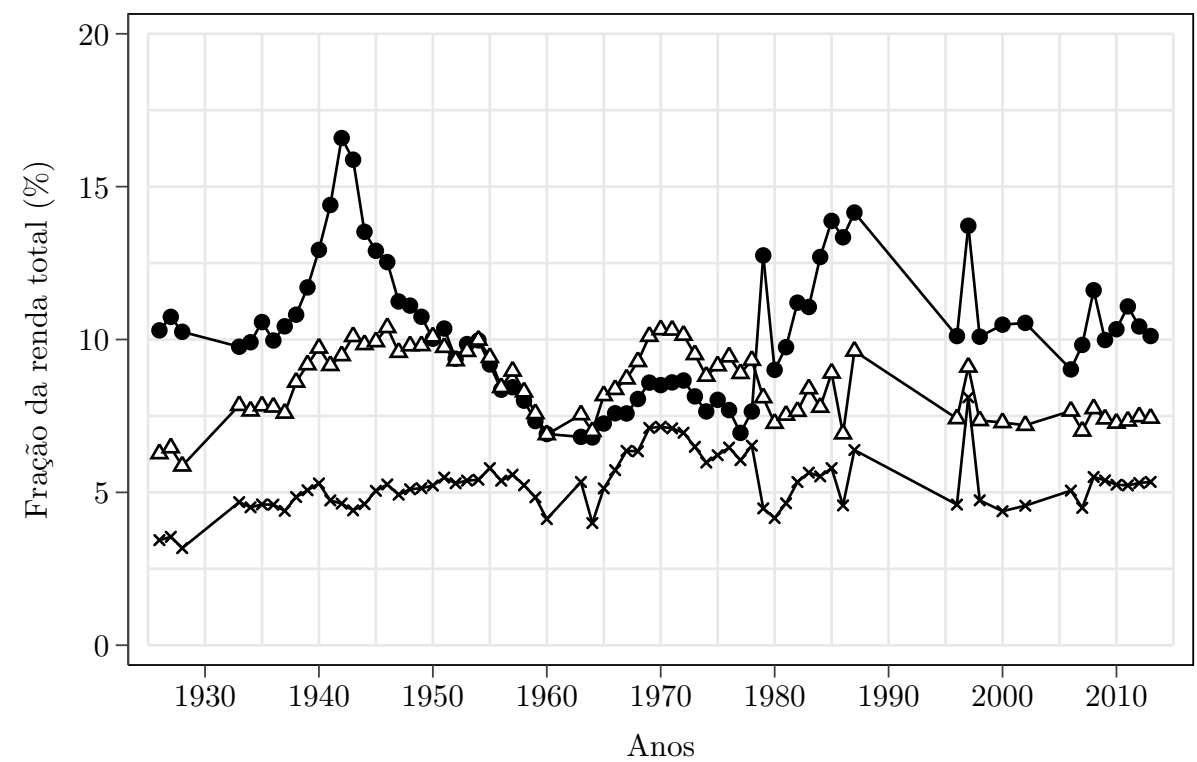

$\longrightarrow 0,1 \%$ mais rico $\longrightarrow-0,5 \%$ a $0,1 \%$ mais rico $\longrightarrow \quad 1 \%$ a $0,5 \%$ mais rico

Fonte: elaboração própria a partir de tabulações de dados tributários e das Contas Nacionais; ver capítulo 4.

Figura 34. Fração da renda total recebida por subgrupos dentro dos $10 \%$ mais ricos Brasil, 1969-2013 (\%)

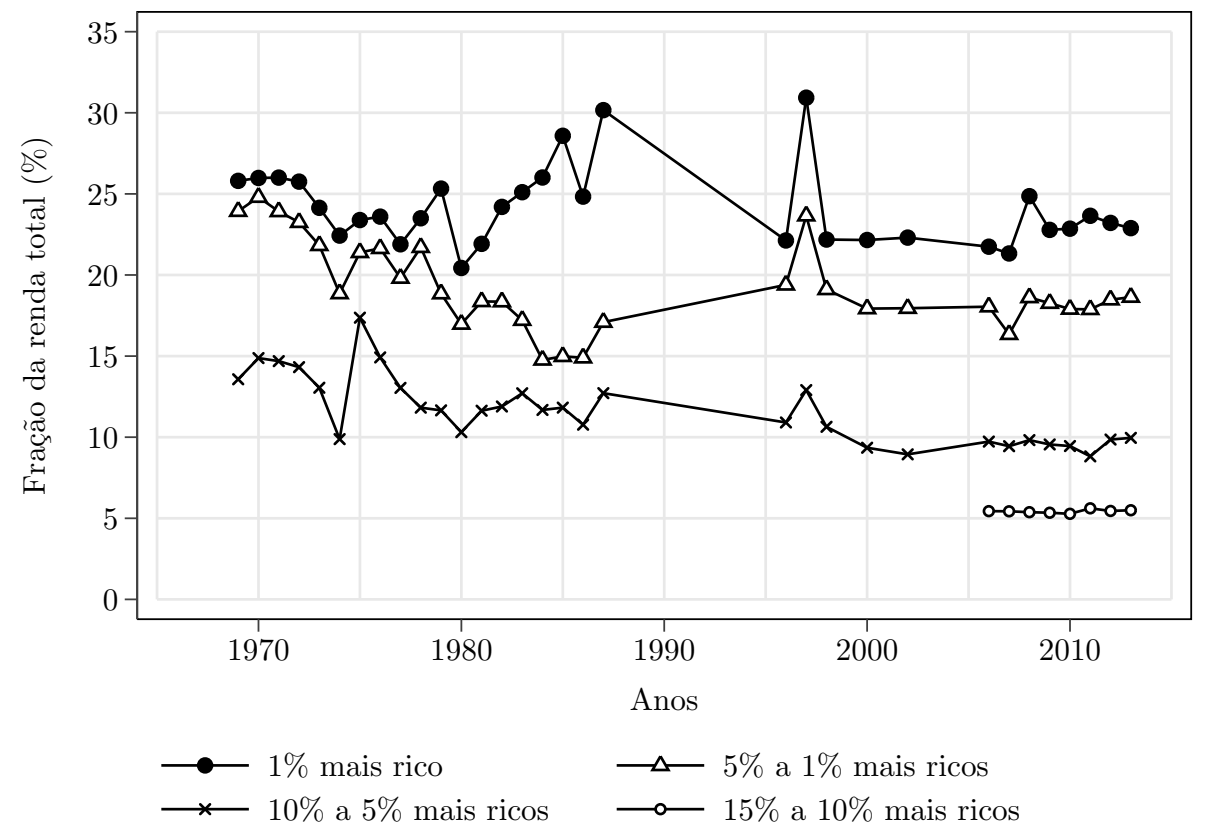

Fonte: elaboração própria a partir de tabulações de dados tributários e das Contas Nacionais; ver capítulo 4. 
abaixo, aqueles entre o $0,1 \%$ e $0,5 \%$ mais ricos (i.e., entre os percentis $99,5 \%$ e $99,9 \%$ ), teve ganhos relativos menores, enquanto o resto do $1 \%$ (entre os percentis $99 \%$ e $99,5 \%$ ) viu sua fração praticamente inalterada. Já nos anos após o golpe militar de 1964, deu-se o inverso: a variação em pontos percentuais da fração recebida pelo milésimo mais rico foi menor do que a do resto do centésimo superior. Os maiores ganhadores, surpreendentemente, não foram os mais ricos entre os mais ricos, e sim aqueles logo atrás. Nos anos 1980, tivemos o mesmo padrão da $2^{a}$ Guerra. Na última década, a pequena elevação foi mais concentrada bem no topo, entre os $0,1 \%$, do que nos outros subgrupos.

Na Figura 34, a curva que destoa é a do centésimo mais rico, havendo maior semelhança na trajetória dos grupos entre os percentis 95-99\% e 90-95\%, em função principalmente do comportamento divergente do $1 \%$ durante a década de 1980. Mais recentemente, a relativa estabilidade parece ser generalizada. Também em termos de níveis vemos um grande contraste entre o $1 \%$ mais rico e os subgrupos logo abaixo, em especial quando descemos abaixo do percentil $95 \%$.

Em conjunto, os dois gráficos reforçam o ponto de que nem todos os aumentos ou quedas - da concentração no topo são iguais, pois nem sempre a variação em pontos percentuais é uma função crescente e monotônica do percentil de riqueza. Eles também dizem algo sobre robustez: se aceitarmos o pressuposto razoável de que melhorias na fiscalização tendem a atingir mais fortemente os mais ricos de todos - por possuírem maior renda e mais recursos para elisão e/ou evasão -, então cabe examinar possíveis vieses em momentos em que há combinação de aumento mais acelerado da fração dos mais ricos entre os mais ricos e reformas administrativas importantes. Até onde foi possível apurar, isso só ocorreu nos anos 1940, havendo, no entanto, motivos para supor que o viés porventura existente deve ser pequeno, como argumentado na seção anterior.

Uma segunda maneira de apresentar esses resultados é deixar de lado a renda total e olhar só dentro dos grupos para visualizar com mais clareza a divisão do bolo dentro dos mais ricos, o que é feito, respectivamente, nas Figuras 35 e 36 . Um atrativo adicional para essa forma de exibir os dados é que, por se tratar de frações sobre frações (por exemplo, a fração do milésimo mais rico sobre a do centésimo mais rico), os resultados são independentes da escolha do denominador da renda.

Um exemplo facilita a interpretação desses gráficos: de acordo com a Figura 35, no último ponto da série, em 2013, o 0,1\% mais rico detinha pouco mais de $21 \%$ da renda total recebida pelo 1\% mais rico. O subgrupo logo abaixo, formado por indivíduos entre os percentis 99,9\% e 99,99\%, apropriava-se de um percentual quase igual, por volta de $22 \%$. Já o subgrupo formado por aqueles entre os $0,1 \%$ e $0,5 \%$ mais ricos recebia cerca de um terço da renda total do centésimo mais rico. As pessoas entre os percentis $99 \%$ e $99,5 \%-$ a metade mais "pobre" do $1 \%$ mais rico - tinha uma fatia semelhante à dos subgrupos mais ricos (e menores), pouco superior a $23 \%$. 
Figura 35. Distribuição da renda dentro do 1\% mais rico - Brasil, 1926-2013 (\%)

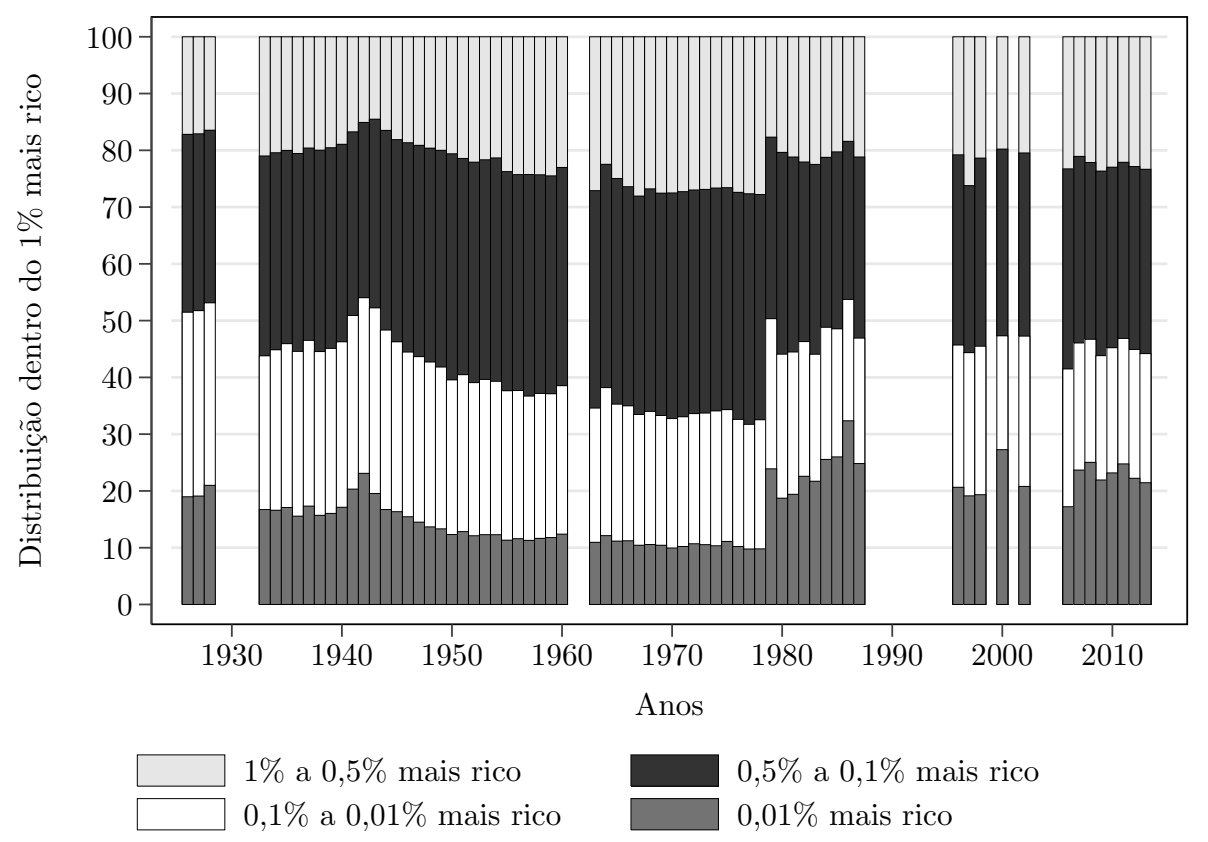

Fonte: elaboração própria a partir de tabulações de dados tributários e das Contas Nacionais; ver capítulo 4.

Figura 36. Distribuição da renda dentro dos 10\% mais ricos - Brasil, 1969-2013 (\%)

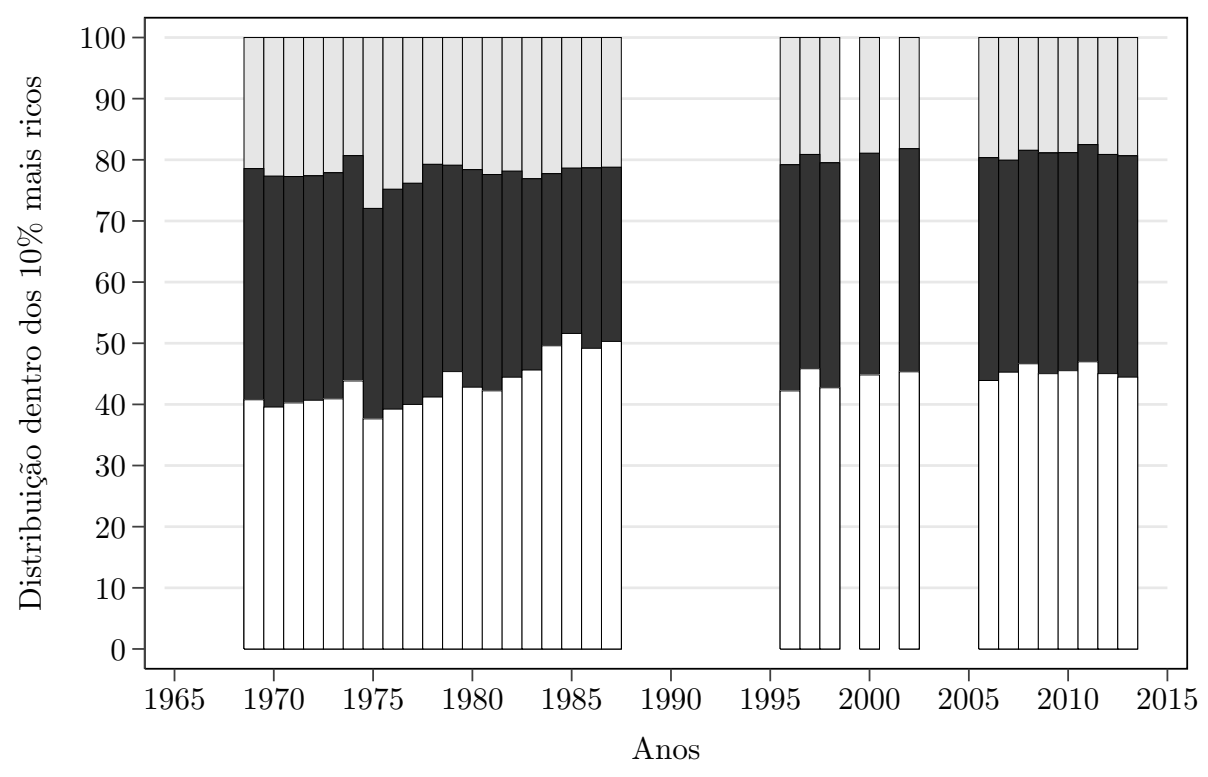

$10 \%$ a $5 \%$ mais ricos

$5 \%$ a $1 \%$ mais ricos $1 \%$ mais rico

Fonte: elaboração própria a partir de tabulações de dados tributários e das Contas Nacionais; ver capítulo 4. 
A Figura 35 confirma o aumento da participação dos mais ricos entre os mais ricos na renda total do centésimo superior durante a $2^{a}$ Guerra. Depois disso, há um processo suave e contínuo de redução dessa participação até o fim dos anos 1970; em outras palavras, a desigualdade interna dentro do 1\% mais rico diminuiu após 1945. O salto em 1979 deve-se exclusivamente à quebra de série, pois nesse ano os resultados passam a usar tabulações ordenadas pelos rendimentos não tributáveis, e não mais pelos rendimentos tributáveis (líquidos ou brutos). Como esses rendimentos isentos e não tributáveis são muito mais desigualmente distribuídos, há um pulo de patamar. Nos anos seguintes, o percentual dos mais ricos entre os mais ricos continuou a subir, como visto antes. Desde os anos 1990, a repartição da renda dentro do centésimo mais rico parece relativamente estável.

A Figura 36, que trata da repartição dentro do décimo mais rico, mostra maior estabilidade, com uma única mudança relevante, o aumento da participação do $1 \%$ na renda total dos $10 \%$ mais ricos ao longo dos anos 1980, com reversão na década seguinte. Logo, nas últimas quatro décadas não houve variações significativas e permanentes na repartição da renda no décimo mais rico. O centésimo mais rico fica com algo em torno de $40 \%$, o resto do vigésimo superior fica com outros $40 \%$, e os indivíduos entre os percentis 90\% e $95 \%$ recebem cerca de $20 \%$ da renda do décimo. A Figura 36 sofre menos com o problema da alteração de variável de ordenação em 1979, porque seus efeitos concentram-se nos indivíduos bem no topo da distribuição e, de todo modo, a mudança não se aplica aos subgrupos fora do centésimo superior.

Por fim, em nome da completude, as Figuras 37 e 38 apresentam, respectivamente, as rendas médias e mínimas para vários estratos no topo da distribuição de renda, do 0,1\% aos 10\% mais ricos, em valores deflacionados para reais de 2014. A Figura 37, com as médias, possui estimativas mais confiáveis e robustas do que a Figura 38, que tem as rendas mínimas para pertencer a cada grupo, por ser menos afetada por choques temporários e pela variável de ordenação das tabulações usadas. Como de hábito, os valores expressos são brutos, antes da tributação do imposto de renda e outros descontos (exceto a depreciação do capital fixo de empreendedores), e incluem transferências, como as previdenciárias.

Assim, no que diz respeito à renda média, o que se vê é um crescimento real expressivo durante a maior parte do período, em grande medida propalado pelo crescimento real do PIB brasileiro. A partir dos anos 1980, quando a taxa de crescimento se reduziu e as condições macroeconômicas tornaram-se erráticas, as rendas médias passaram pela primeira vez a ter quedas visíveis. Nos anos 1990, elas praticamente pararam de crescer, retomando a alta só depois de meados da década de 2000.

Esses dois últimos gráficos reforçam a heterogeneidade dos mais ricos. No que diz respeito à renda média, em 2013, o 0,1\% mais rico recebia pouco mais de $\mathrm{R} \$ 2,8$ milhões anuais, o que equivale a uma renda média mensal de quase $\mathrm{R} \$ 235$ mil. Esses valores são quase 4,5 vezes maiores do que os observados para o $1 \%$ mais rico como um todo, que, 
Figura 37. Renda anual média dos estratos mais ricos - Brasil, 1926-2013 (R\$2014)

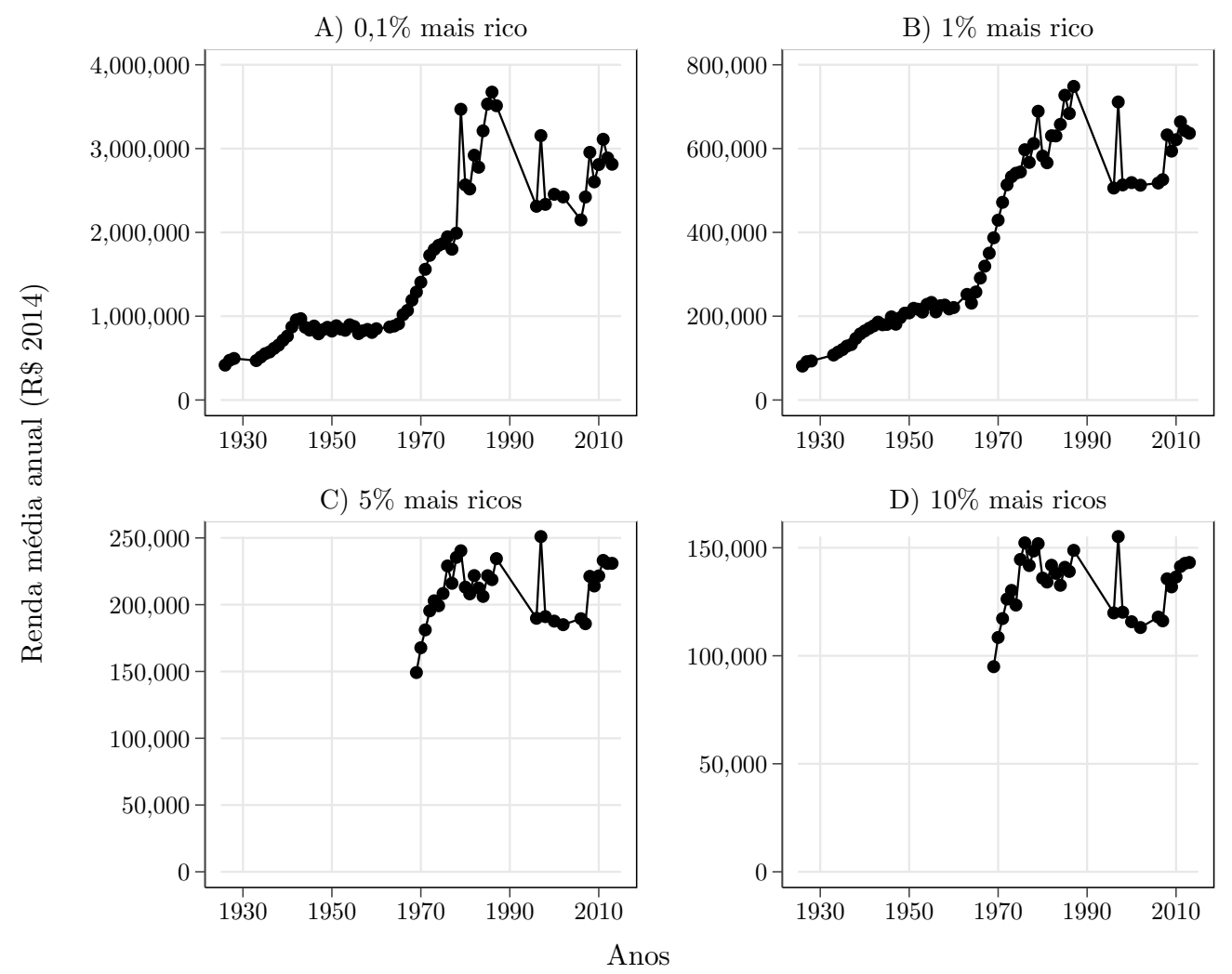

Fonte: elaboração própria a partir de tabulações de dados tributários e das Contas Nacionais; ver capítulo 4. N.B.: valores deflacionados pelo deflator do PIB.

no entanto, também teve rendimentos muito elevados: $\mathrm{R} \$ 636$ mil por ano ou $\mathrm{R} \$ 53$ mil mensais. Quando se olha para os 5\% e 10\% mais ricos, não só a distância relativa continua aumentando muito - o 0,1\% ganha 12,2 e 19,6 vezes mais, respectivamente - como os próprios valores médios se tornam mais próximos da experiência cotidiana do que muitas vezes se chama de "classe média assalariada": as médias de $\mathrm{R} \$ 230$ mil anuais $(\mathrm{R} \$ 19$ mil mensais) para os $5 \%$ e de $\mathrm{R} \$ 140$ mil anuais ( $\mathrm{R} \$ 12$ mil mensais) para os $10 \%$ mais ricos são compatíveis com os salários de grandes contingentes do funcionalismo público federal. Em média, o 0,1\% mais rico ganha por mês mais do que os $5 \%$ e os $10 \%$ mais ricos recebem por ano. Como esperado, a renda média de toda a população adulta era bem mais baixa, atingindo $\mathrm{R} \$ 26$ mil anuais, pouco menos de $\mathrm{R} \$ 2,2$ mil mensais.

O padrão é ainda mais claro quanto às rendas mínimas necessárias para pertencer a cada estrato. Em 2013, estavam no milésimo mais rico aqueles que receberam mais do que $\mathrm{R} \$ 913$ mil anuais ( $\mathrm{R} \$ 76$ mil mensais), valor quase quatro vezes maior do que os cerca de $\mathrm{R} \$ 235$ mil anuais ( $\mathrm{R} \$ 19,5$ mil mensais) exigidos para estar no centésimo mais rico, 13,4 vezes superior aos $\mathrm{R} \$ 68$ mil anuais ( $\mathrm{R} \$ 5,7$ mil mensais) dos $5 \%$ mais ricos e 25,5 vezes maior do que os $\mathrm{R} \$ 35,8$ mil anuais ( $\mathrm{R} \$ 2,9$ mil mensais) do décimo mais rico. Os números para esses dois últimos estratos podem até surpreender por seu baixo valor, 
Figura 38. Renda anual mínima para pertencer aos estratos mais ricos - Brasil, 1926-2013 $(\mathrm{R} \$ 2014)$

A) $0,1 \%$ mais rico

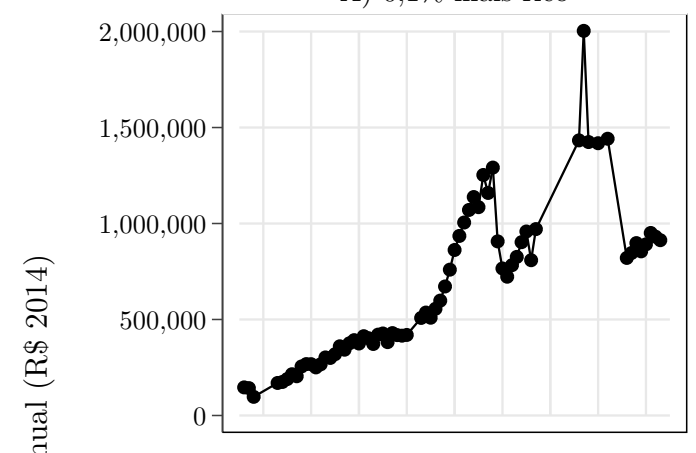

C) $5 \%$ mais ricos

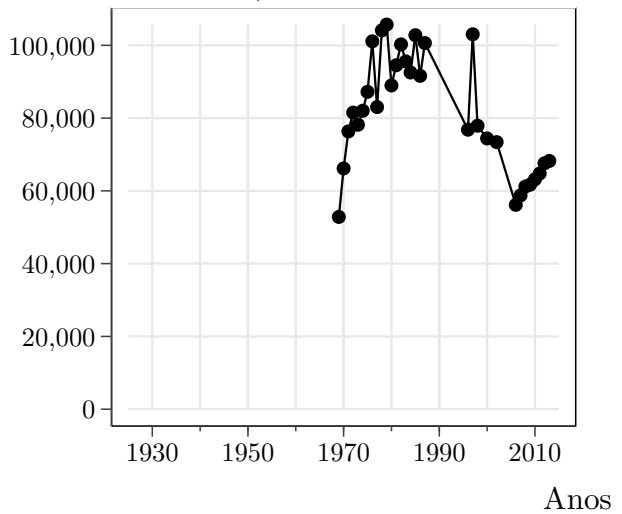

B) $1 \%$ mais rico

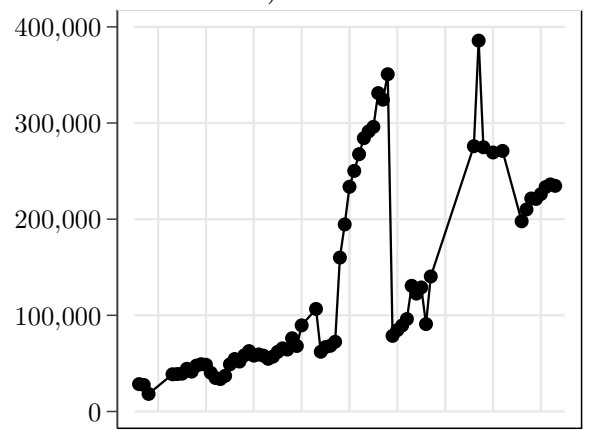

D) $10 \%$ mais ricos

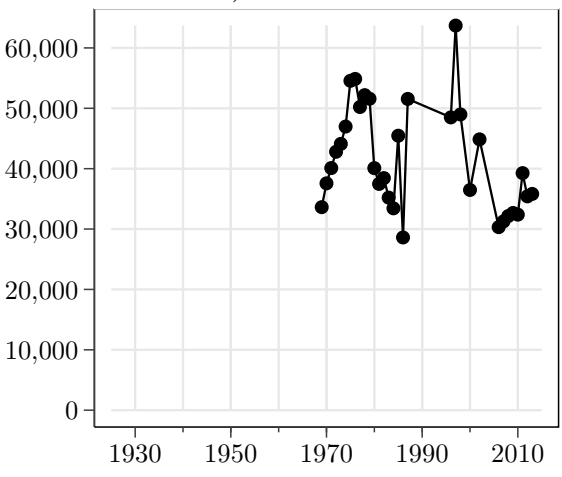

Fonte: elaboração própria a partir de tabulações de dados tributários e das Contas Nacionais; ver capítulo 4. N.B.: valores deflacionados pelo deflator do PIB.

resultante da combinação da renda média relativamente baixa do Brasil com uma grande concentração acima do percentil $99 \%$.

Em suma, a análise da repartição de renda entre os mais ricos confirma o caráter heterogêneo das alterações na concentração de renda destacadas na seção anterior. Enquanto nos anos 1940 e nos anos 1980 a desigualdade aumentou por conta dos mais ricos entre os ricos, nos anos 1960 foram os estratos logo atrás do 0,1\% mais rico que mais ganharam. Além disso, fica claro o quanto a concentração é maior bem no topo da distribuição de renda, e como são grandes as disparidades dentro do décimo mais rico. Grosso modo, o centésimo mais rico vive em condições muito diferentes dos estratos mais abaixo e, mesmo dentro desse estrato, o 0,1\% desfruta de uma situação ainda mais privilegiada. 


\subsection{Dados tributários vs. pesquisas domiciliares: da concentração no topo ao coeficiente de Gini}

Nas seções anteriores, o termo "desigualdade" foi utilizado basicamente como sinônimo de "concentração no topo". As próximas seções e o capítulo 6 mantêm essa definição; esta seção altera temporariamente o foco, voltando à acepção mais corriqueira do termo, que leva em conta as disparidades em toda a distribuição. Afinal, a base da distribuição de renda não é insignificante e, mais ainda, a fração da renda apropriada pelos mais ricos afeta até mesmo indicadores sintéticos, como o coeficiente de Gini. Antes, vale a pena comparar a concentração no topo nos dados tributários e nas pesquisas domiciliares e dimensionar a subestimação dos maiores rendimentos nestas últimas.

\subsubsection{A fração dos mais ricos nos dados tributários, PNADs e Censos}

O capítulo anterior discutiu os problemas que afligem as pesquisas domiciliares, com potencial para torná-las muito enviesadas, quando o interesse recai sobre os mais ricos. Para recapitular brevemente, as principais dificuldades dizem respeito à subestimação dos rendimentos mais elevados, dos rendimentos de capital e dos rendimentos de trabalhadores não assalariados (como empregadores e trabalhadores por conta própria). Por isso, boa parte da literatura especializada recente passou a recorrer a dados administrativos e tributários para analisar a evolução da distribuição de renda (ver capítulo 3).

As pesquisas domiciliares brasileiras não são diferentes. As Figuras 39, 40 e 41 comparam as frações da renda recebidas, respectivamente, pelo $0,1 \%, 1 \%$ e $10 \%$ mais ricos nos dados tributários e nas duas pesquisas domiciliares mais tradicionais do Brasil, as PNADs e os Censos Demográficos. O padrão geral é unívoco: quanto mais perto do topo da distribuição, maior a distância entre o que dizem os dados do IRPF e o que se observa nas pesquisas domiciliares. Os números dos Censos são muito mais próximos dos dados tributários do que os das PNADs, o que indica que a subestimação da renda no topo é mais forte nesta última. A fração do $0,1 \%$ mais rico é, nos dados tributários, em média quase três vezes maior do que nas PNADs e $75 \%$ maior do que nos Censos (Figura 39). Essa razão é substancialmente menor no caso do $1 \%$ e, quando passamos aos $10 \%$ mais ricos, há, durante boa parte do tempo, um virtual empate entre as três fontes de dados.

De modo geral, os dados tributários, as PNADs e os Censos discordam tanto em relação ao nível quanto às tendências. Na Figura 39, os Censos mostram pouca variação no percentual do milésimo mais rico, com algum aumento ao longo do tempo; em comparação, os dados tributários, além de apontar para níveis mais elevados de concentração, são mais caóticos. Já as PNADs indicam níveis bem menores, replicando a piora da concentração nos anos 1980. Se, na década de 1980, Censos e PNADs produziram números parecidos, as duas pesquisas divergiram depois de 2000, com tendência de queda só nas PNADs. 
Figura 39. Fração recebida pelo $0,1 \%$ mais rico nos dados tributários, PNADs e Censos Demográficos - Brasil, 1960-2013 (\%)

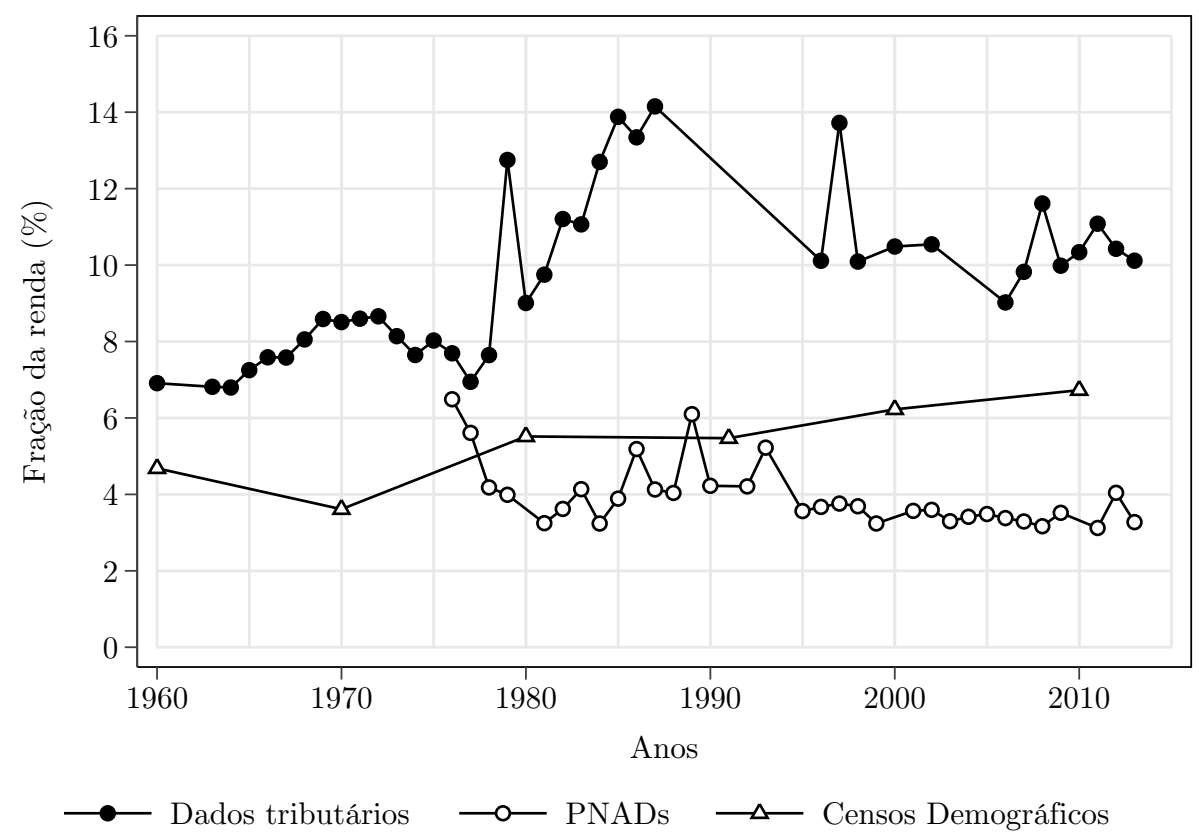

Fonte: elaboração própria a partir de tabulações de dados tributários, das Contas Nacionais e dos microdados das PNADs e Censos Demográficos; ver capítulo 4.

N.B.: as informações do Censo 1960 são provenientes do IPUMS International (MINNESOTA POPULATION CENTER, 2015) e excluem 11 UFs (AC, AM, AP, ES, GB, MA, PA, PI, RO, RR e SC). Os percentuais para 1960 foram obtidos por interpolação, porque o Censo continha apenas uma variável categórica para a renda.

Figura 40. Fração recebida pelo $1 \%$ mais rico nos dados tributários, PNADs e Censos Demográficos - Brasil, 1960-2013 (\%)

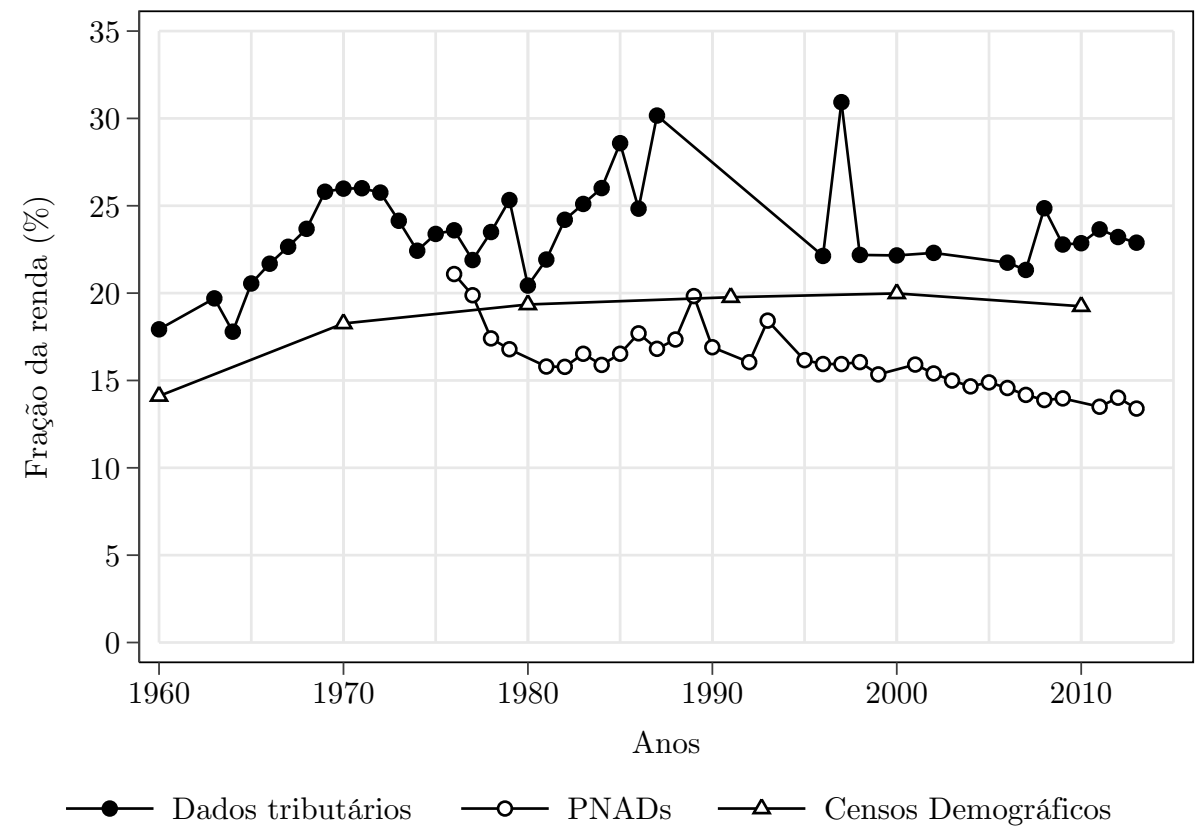

Fonte: elaboração própria a partir de tabulações de dados tributários, das Contas Nacionais e dos microdados das PNADs e Censos Demográficos; ver capítulo 4.

N.B.: as informações do Censo 1960 são provenientes do IPUMS International (MINNESOTA POPULATION CENTER, 2015) e excluem 11 UFs (AC, AM, AP, ES, GB, MA, PA, PI, RO, RR e SC). Os percentuais para 1960 foram obtidos por interpolação, porque o Censo continha apenas uma variável categórica para a renda. 
Figura 41. Fração recebida pelo $10 \%$ mais rico nos dados tributários, PNADs e Censos Demográficos - Brasil, 1960-2013 (\%)

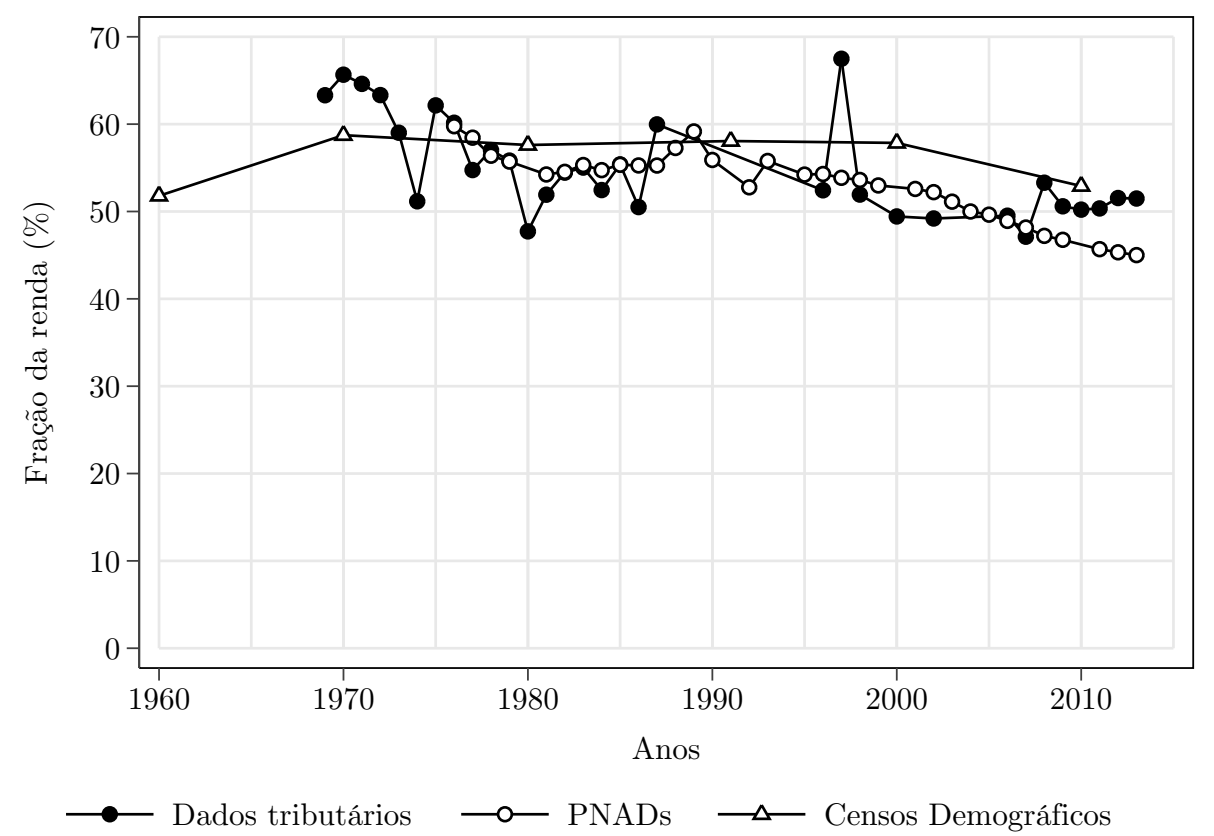

Fonte: elaboração própria a partir de tabulações de dados tributários, das Contas Nacionais e dos microdados das PNADs e Censos Demográficos; ver capítulo 4.

N.B.: as informações do Censo 1960 são provenientes do IPUMS International (MINNESOTA POPULATION CENTER, 2015) e excluem 11 UFs (AC, AM, AP, ES, GB, MA, PA, PI, RO, RR e SC). Os percentuais para 1960 foram obtidos por interpolação, porque o Censo continha apenas uma variável categórica para a renda.

Algo semelhante ocorre com o centésimo mais rico. Na Figura 40, vê-se para os dados tributários as tendências já discutidas anteriormente. Para os Censos, há, mais uma vez, relativa estabilidade depois de um aumento sensível nos anos 1960. Nas últimas duas décadas, os números dos Censos são razoavelmente próximos dos verificados nas tabulações do IRPF. As PNADs, por sua vez, são mais otimistas e divergem dos Censos ao sugerir uma progressiva redução da concentração no topo a partir do início dos anos 1990.

A Figura 41, que trata do décimo mais rico, mostra outro cenário. Dados tributários, PNADs e Censos apresentam níveis e tendências bem parecidos, salvo por algumas discrepâncias nos últimos anos. Ao contrário dos gráficos anteriores, em diversos anos os números das pesquisas domiciliares chegam a ser mais altos do que os das tabulações do imposto de renda. Em parte, isso ocorre devido à indisponibilidade de tabulações ordenadas por rendimentos totais antes de 2006, o que produz alguma subestimação dos rendimentos principalmente quando se consideram grupos mais amplos do que o $1 \%$ ou os 5\% mais ricos. Nos três casos, a tendência geral indica, nos últimos 10-15 anos, uma concentração no topo menor do que se observava nos anos 1970.

Em termos comparativos, portanto, a mensagem principal dos gráficos é que a subestimação dos rendimentos dos mais ricos de fato ocorre nas pesquisas domiciliares brasileiras, afetando com mais intensidade as PNADs, e diminuindo até praticamente 
desaparecer conforme a definição de "ricos" engloba todo o décimo superior. Os Censos estão mais próximos das tabulações do IRPF em nível e - em menor grau - em tendência, discrepando das PNADs com mais força nas últimas décadas. Até o Censo de 1991 os resultados das duas pesquisas domiciliares eram muito mais próximos.

Em termos substantivos, os Censos exibem o mesmo padrão para os anos 1960 dos dados tributários: o aumento da concentração no topo dá-se não pela expansão da fatia apropriada pelo milésimo mais rico, e sim pela elevação do naco dos estratos logo atrás. Entre 1960 e 1970, a fração do 0,1\% nos Censos chega a cair, enquanto a do 1\% mais rico sobe bastante. Em contrapartida, não se vê nenhuma piora da concentração no topo nos anos 1980 nos Censos, em oposição ao registrado nos dados tributários e, em menor grau, nas PNADs. No período mais recente, a relativa estabilidade dos Censos está mais próxima das estimativas tributárias do que a progressiva desconcentração vista nas PNADs.

\subsubsection{Corrigindo o coeficiente de Gini}

Fica a pergunta: qual o efeito da subestimação dos rendimentos dos ricos nos coeficientes de Gini calculados nas PNADs e nos Censos? Os dados tributários podem ser usados para corrigir essa subestimação no topo e reestimar o Gini. A literatura internacional, entretanto, não costuma fazê-lo e não há consenso sobre a melhor metodologia.

No Brasil, os primeiros trabalhos nessa linha foram os de Medeiros, Souza e Castro (2015b) e Souza e Medeiros (2015), que "encaixaram" as distribuições observadas nos microdados das PNADs com as interpoladas nas tabulações do imposto de renda para os anos de 2006 e 2012. O "encaixe" consistiu em usar a distribuição da PNAD até determinado ponto de corte e a distribuição interpolada dos dados tributários acima disso. O ponto de corte foi escolhido como o percentil a partir do qual os valores absolutos dos rendimentos passam a ser sistematicamente maiores nas tabulações do IRPF, o que, empiricamente, correspondeu ao percentil 90\%. Com isso, os autores concluíram que a correção pelos dados tributários faz com que a aparente queda do Gini na PNAD seja bastante atenuada, aproximando-se mais de estabilidade do que de grandes mudanças, resultado que se mostrou robusto à maior parte dos testes de sensibilidade aplicados.

Neste trabalho, optei por uma metodologia mais usada internacionalmente (ALVAREDO, 2011; ATKINSON, 2007; ATKINSON; PIKETTY; SAEZ, 2011; VÉLEZ, 2012), que se baseia na decomposição do Gini por subgrupos com rendimentos não sobrepostos (DAGUM, 1997; KAKWANI, 1980; YITZHAKI, 2002). Além de fácil implementação, essa escolha é mais apropriada nos anos em que a inflação alta inviabiliza a comparação dos valores absolutos devido aos diferentes períodos de referência das informações. Como as PNADs e Censos referem-se a meses específicos e o IRPF cobre o ano todo, a comparação direta dos valores passa a depender crucialmente do deflator. Os trabalhos que "encaixaram" as distribuições não sofreram esse problema porque trataram do período pós-Plano Real. 
O procedimento consiste em decompor o Gini em subgrupos não sobrepostos - os $x \%$ mais ricos e o resto da distribuição - e em seguida alterar as fórmulas para refletir a fração da renda apropriada pelos ricos nos dados tributários. A estrutura da decomposição é simples, estipulando de saída que a desigualdade total medida pelo Gini $(G)$ é igual à soma da desigualdade entre os grupos $\left(G_{\text {entre }}\right)$ e da desigualdade intragrupos $\left(G_{\text {intra }}\right):^{8}$

$$
G=G_{\text {entre }}+G_{\text {intra }}
$$

Considere $P$ a fração da população do grupo mais rico, $S$ a fração da renda recebida por esse grupo, e $G_{\text {ricos }}$ e $G_{\text {resto }}$ os coeficientes de Gini dentro dos grupos. Os componentes entre grupos $\left(G_{\text {entre }}\right)$ e intragrupos $\left(G_{\text {intra }}\right)$ podem ser expressos por:

$$
\begin{aligned}
G_{\text {entre }} & =S-P \\
G_{\text {intra }} & =P \cdot S \cdot G_{\text {ricos }}+(1-P) \cdot(1-S) \cdot G_{\text {resto }}
\end{aligned}
$$

Em bom português, a contribuição da desigualdade entre grupos para a desigualdade total (equação 5.2a) é a diferença entre a fração da renda e a da população do grupo mais rico. Se o centésimo mais rico possuir $25 \%$ da renda, esse componente é igual a 0,24. Em oposição a outras medidas, o componente entre grupos não pode ser interpretado contrafactualmente: o Gini não necessariamente cairá 0,05 se a fatia do $1 \%$ descer de $25 \%$ para 20\%. O componente intragrupos (equação 5.2b) é a soma dos Ginis de cada grupo, ponderados por seu tamanho relativo vezes sua fração da renda. No exemplo, se o Gini do $1 \%$ mais rico for 0,4 , sua contribuição para a desigualdade via componente intragrupos é $0,01 \cdot 0,25 \cdot 0,4=0,001$.

Para corrigir a subestimação das pesquisas domiciliares, basta substituir os valores de $S$, a fração da renda recebida pelos ricos, pelos observados nos dados tributários, e tomar uma decisão quanto à desigualdade interna a esse grupo. Caso a decomposição envolva um grupo rico infinitesimal (e.g., o 0,1\% mais rico), pode-se ignorar sua contribuição via componente intragrupos, e simplificar a decomposição para:

$$
G=(1-S) \cdot G_{\text {resto }}+S
$$

Neste trabalho, optei em todos os casos por considerar o grupo rico não infinitesimal, o que implica usar $\frac{\beta-1}{\beta+1}$ para estimar sua desigualdade interna, em que $\beta$ é o coeficiente

8 Para exposição mais detalhada e/ou prova das equações apresentadas no texto, ver Alvaredo (2011), Dagum (1997), Kakwani (1980), Yitzhaki (2002), entre outros. 
invertido de Pareto, ou seja, $\beta=\frac{\alpha}{(\alpha-1)}$, como definido na seção 4.8 do capítulo 4 . Com isso, a fórmula para o Gini passa a ser:

$$
\begin{aligned}
G & =G_{\text {entre }}+G_{\text {intra }} \\
G_{\text {entre }} & =S-P \\
G_{\text {intra }} & =P \cdot S \cdot \frac{\beta-1}{\beta+1}+(1-P) \cdot(1-S) \cdot G_{\text {resto }}
\end{aligned}
$$

Nas correções, os valores de $S$ e $\beta$ vêm dos dados tributários, e o de $G_{\text {resto }}$ vem das pesquisas domiciliares. O valor de $P$ é idêntico nas duas bases e escolhido previamente, correspondendo à proporção da população no grupo rico. Medeiros, Souza e Castro (2015b) e Souza e Medeiros (2015) argumentaram que os dados tributários deveriam ser preferidos, pelo menos no período 2006-2013, para os 5\% ou 10\% mais ricos da distribuição de renda.

A Figura 42 traz o coeficiente de Gini observado nas PNADs de 1976 a 2013 e o Gini corrigido, de acordo com as fórmulas acima, para três pontos de corte, dados pelos $1 \%, 5 \%$ e $10 \%$ mais ricos. Os resultados para a correção pelos $5 \%$ mais ricos são os mesmos apresentados na seção 5.2 acima.

Comecemos pelo coeficiente de Gini não corrigido. A diminuição da concentração no topo vista na seção anterior nas PNADs aparece com mais força nos Ginis. Depois de uma queda entre 1975 e 1980 e do seu agravamento entre 1985 e 1990, a desigualdade medida pelo Gini nos dados originais registrou redução quase monotônica na década seguinte, com aceleração a partir de 2001. Em 2013 o Gini para rendimentos individuais dos indivíduos com 20 anos ou mais apresentou seu menor valor em toda a série, $0,587 .^{9}$

Como mencionado, há uma força de longo prazo em ação: a entrada das mulheres no mercado de trabalho, que, ao provocar a redução do percentual da população adulta sem rendimentos, contribuiu para diminuir a desigualdade medida pelo coeficiente de Gini. O aumento paulatino, desde a década de 1960, de cerca de 1 p.p. por ano no percentual de mulheres com rendimentos próprios contrabalançou inclusive a tendência para maior desigualdade verificada nos anos 1980 em diversos estudos que analisaram a renda domiciliar per capita ou os rendimentos do trabalho dos ocupados (e.g., SOARES, 2006). Por exemplo, enquanto o Gini da população adulta como um todo registra queda de $4 \%$ entre 1976 e 1990, o Gini apenas para a população com rendimentos individuais positivos aponta aumento de $1 \%$.

A partir da década de 1990, a discrepância entre esses dois Ginis desaparece, ainda que o indicador calculado para a população adulta como um todo caia sempre um pouco mais rápido. Ou seja, a expansão da força de trabalho remunerada e os outros fatores

9 O coeficiente de Gini da renda domiciliar per capita - medida mais utilizada de desigualdade no Brasil - também atingiu em 2013 seu menor valor em toda a série: 0,523. 
Figura 42. Coeficiente de Gini observado nas PNADs e corrigido de acordo com dados tributários - Brasil, 1976-2013 (\%)

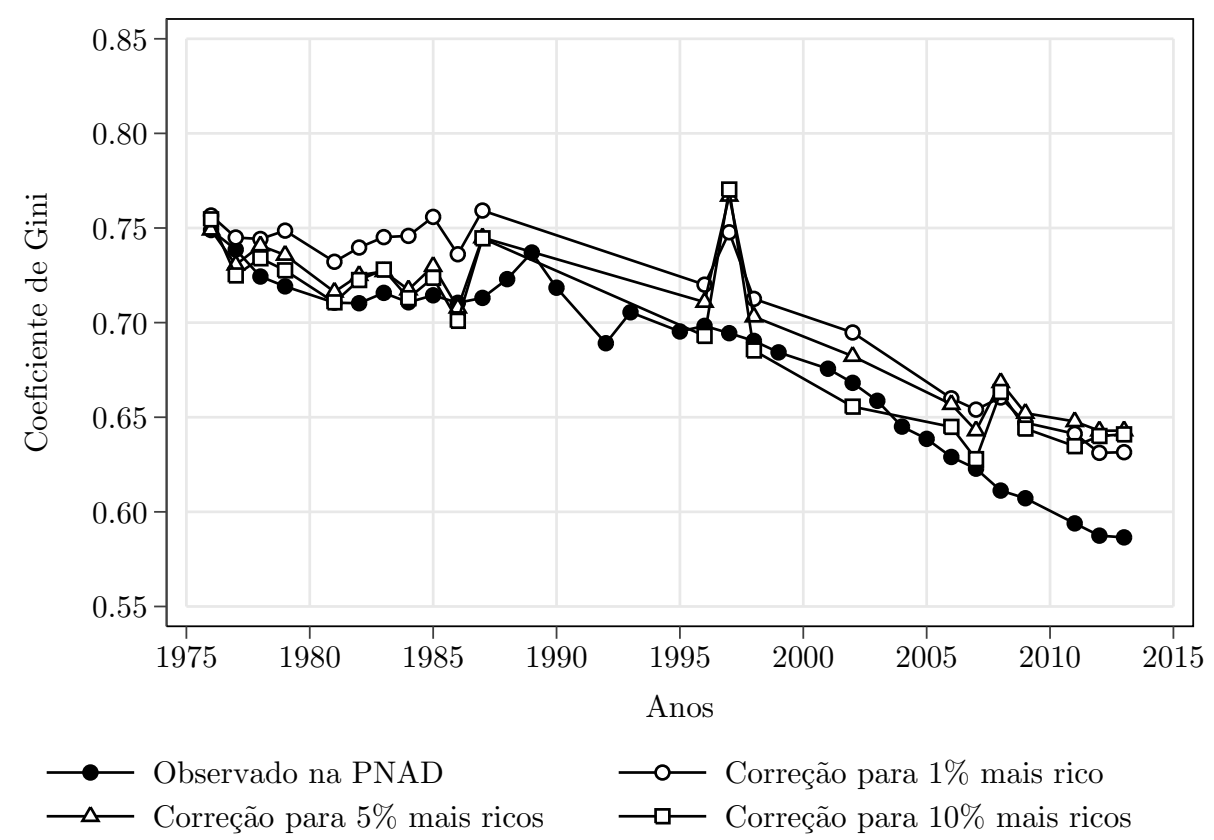

Fonte: elaboração própria a partir de tabulações de dados tributários, das Contas Nacionais e dos microdados das PNADs; ver capítulo 4.

enumerados na seção 3.5 do capítulo 3 - melhoria do nível educacional e diminuição das desigualdades de acesso à educação, menor segmentação regional, valorização do salário mínimo e expansão das transferências sociais, entre outros - contribuíram para uma queda prolongada de cerca de 15\% no coeficiente de Gini observado entre 1995 e 2013.

Os Ginis corrigidos pelos resultados dos dados tributários qualificam esse diagnóstico. Neles, o progresso foi bem menor. As três correções reiteram o pico da desigualdade nos anos 1980 e a redução posterior; a diferença é que o declínio é bem mais tímido do que contam os dados originais das PNADs, chegando ao fim em meados dos anos 2000. De lá para cá, há apenas estabilidade, o que vai ao encontro das conclusões de Medeiros, Souza e Castro (2015b) e Souza e Medeiros (2015), apesar das diferenças de metodologia. Em 2013, os Ginis corrigidos variam entre 0,632 (correção para o 1\% mais rico) e 0,643 (correção para os $5 \%$ mais ricos), valores entre $8 \%$ e $10 \%$ maiores do que nos dados originais. Com as correções, a queda observada de $12 \%$ entre 2002 e 2013 passa a ser de $9 \%$ (correção para o $1 \%$ mais rico), $6 \%$ (correção para os $5 \%$ mais ricos) ou mesmo $2 \%$ (correção para os $10 \%$ mais ricos).

Como a subestimação no topo afeta todo o décimo superior (Figuras 39, 40 e 41), é razoável concluir que os resultados das PNADs são excessivamente otimistas quanto ao nível e à evolução do Gini da população adulta brasileira. A desigualdade realmente recuou, só que permanece alta e seu ritmo de queda foi muito mais lento do que o imaginado, com aparente esgotamento a partir da segunda metade dos anos 2000. 
Figura 43. Coeficiente de Gini observado nos Censos Demográficos e corrigido de acordo com dados tributários - Brasil, 1960, 1970, 1991, 2000 e 2010 (\%)

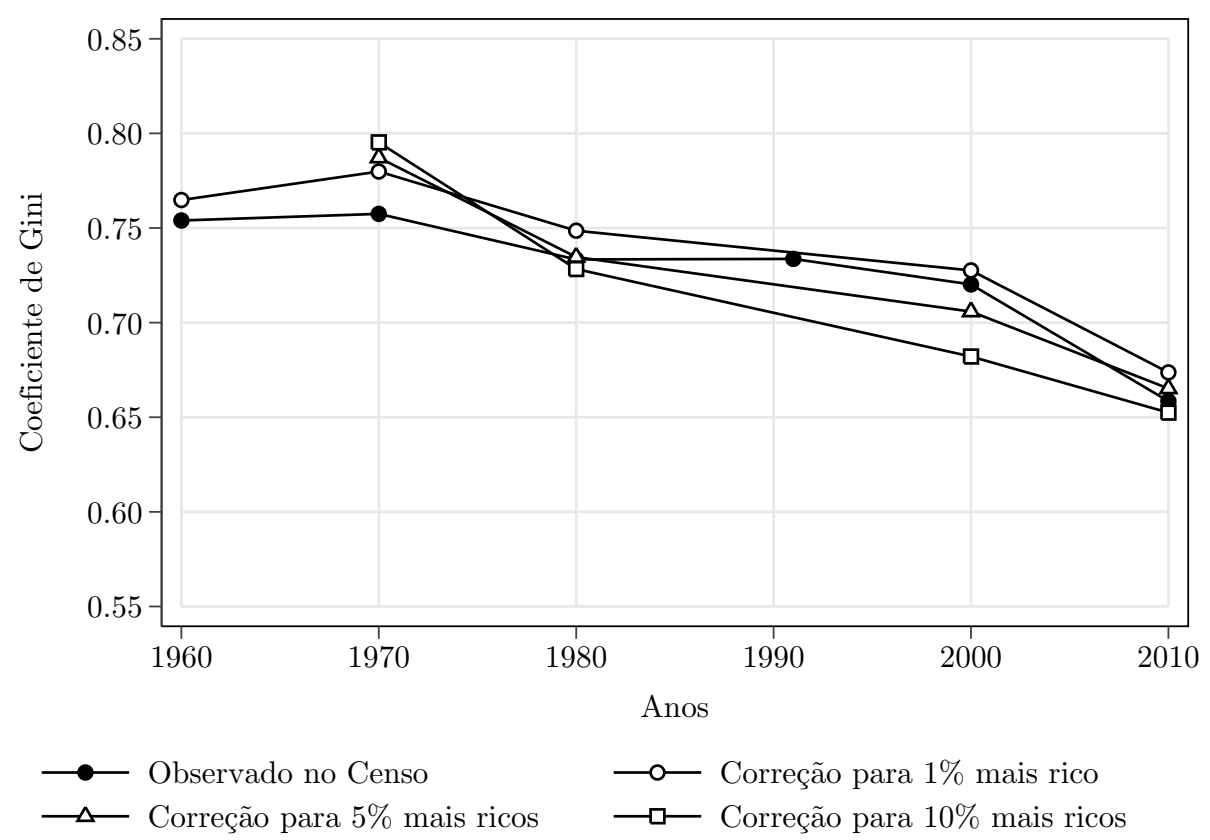

Fonte: elaboração própria a partir de tabulações de dados tributários, das Contas Nacionais e dos microdados das Censos Demográficos; ver capítulo 4.

N.B.: as informações do Censo 1960 são provenientes do IPUMS International (MINNESOTA POPULATION CENTER, 2015) e excluem 11 UFs (AC, AM, AP, ES, GB, MA, PA, PI, RO, RR e SC). Os percentuais para 1960 foram obtidos por interpolação, porque o Censo continha apenas uma variável categórica para a renda. A correção para 1980 foi feita pelas frações médias entre 1978 e 1982, exceto 1980.

A Figura 43 repete o mesmo exercício para os Censos Demográficos. Uma ressalva, nesse caso, é que não há dados tributários para 1991. Além disso, o cronograma decenal dos Censos prejudica os cálculos, uma vez que há informações somente para poucos anos, o que amplifica os ruídos introduzidos por flutuações no ciclo econômicos e afins. O caráter atípico dos resultados de 1980, inclusive, obrigou o uso das frações médias observadas nos dados tributários em 1978, 1979, 1981 e $1982 .^{10}$

Nos dados originais dos Censos, os coeficientes de Gini observados são razoavelmente estáveis, exceto pela queda pronunciada entre 2000 e 2010. Grosso modo, eles são bem mais altos do que os das PNADs, repetindo o que foi visto quanto à fração da renda apropriada pelos mais ricos. Ao contrário de Hoffmann e Duarte (1972), Fishlow (1972), Hoffmann (1973), Langoni (1973) e outros, a Figura 43 não mostra aumento significativo do Gini entre 1960 e 1970. O principal motivo para isso é que a população de interesse nesses

10 O Decreto-Lei 1.782, de 16 de abril de 1980, instituiu, para os rendimentos recebidos em 1979, um "empréstimo compulsório para absorção temporária de poder aquisitivo": uma cobrança de 10\% sobre os rendimentos isentos ou tributados exclusivamente na fonte superiores a Cr\$4,000,000. Em comunicação com o autor, o auditor fiscal e historiador do IRPF Cristóvão Barcelos da Nóbrega informou que a lei só foi promulgada após o prazo para entrega de declaração sem multa. A melhor explicação para o caráter atípico dos resultados tributários para 1980 (e, em menor grau, em 1981) é que os contribuintes, depois de serem pegos de surpresa pelo DL 1.782 no ano anterior, postergaram ou omitiram o recebimento de rendimentos isentos ou não tributáveis, com medo de nova cobrança, que acabou não ocorrendo. O empréstimo compulsório foi devolvido em parcelas a partir de 1982. 
trabalhos englobava apenas a população economicamente ativa e/ou com rendimentos. Com efeito, se o Gini para a população adulta - reportado no gráfico - sobe apenas de 0,754 para 0,757 entre 1960 e 1970 (0,5\%), o Gini entre adultos com rendimentos positivos vai de 0,533 para $0,553(3,8 \%)$. Outra razão para a divergência é que a amostra do Censo de 1960 disponível no IPUMS-I não contém informações para 11 estados que representam cerca de um sexto da população. O uso de técnicas de interpolação parecidas, mas não idênticas, é outra explicação possível. ${ }^{11,12}$

A correção dos coeficientes de Gini dos Censos de acordo com os dados tributários não muda radicalmente os resultados originais, diferentemente das PNADs recentes. $\mathrm{O}$ nível de desigualdade permanece mais ou menos o mesmo, em consonância com a maior proximidade entre as frações recebidas pelos mais ricos em Censos e nos dados tributários.

Quanto às tendências temporais, as correções trazem só duas diferenças dignas de nota. A primeira é a queda surpreendente do Gini entre 1970 e 1980. É difícil julgar o mérito dessa mudança, porque ela depende da imputação dos rendimentos não tributáveis em 1970 e o uso de médias para vários anos só mitiga parcialmente o problema dos resultados atípicos dos dados tributários em 1980, já que as estimativas de 1981 também parecem contaminadas, em grau menor, pelas alterações na legislação (ver Figuras 40 e 41). A segunda mudança é, assim como nas PNADs, a atenuação da queda da desigualdade nos anos 2000, ao menos nas correções relativas aos $5 \%$ e $10 \%$ mais ricos: a redução observada de 8,6\% no coeficiente de Gini entre 2000 e 2010 cai para algo entre 4,3\% (correção para os $10 \%$ mais ricos) e $7,4 \%$ (correção para o $1 \%$ mais rico).

Em resumo, em um país como o Brasil, a fatia dos ricos influi muito no comportamento até de medidas sintéticas da desigualdade, como o Gini, cuja sensibilidade aos extremos da distribuição de renda é limitada. Quando se corrigem as PNADs para a subestimação dos rendimentos mais altos, o coeficiente de Gini torna-se mais elevado e sua trajetória é alterada, sobretudo no período mais recente. Com isso, a tendência rósea de declínio continuado da desigualdade perde vigor, e o Gini parece estacionar já em meados dos anos 2000. Nos Censos, o panorama é um pouco diferente e as correções não provocam grandes alterações nem no nível, nem na tendência da desigualdade, embora também nesse caso a queda recente do Gini seja atenuada.

$\mathrm{Na}$ esteira das perguntas formuladas na Introdução, os resultados desta seção corroboram as conclusões anteriores quanto ao baixo impacto da redemocratização em 1985 sobre as fatias da renda apropriadas pelos ricos. Por sinal, o fato de as pesquisas

11 O Integrated Public Use Microdata Series - International (IPUMS-I) é um repositório de microdados harmonizados de Censos Demográficos de todo o mundo, mantido pelo Minnesota Population Center (2015), da Universidade de Minnesota. Todas informações dos Censos discutidas nesta tese são provenientes dos dados fornecidos pelo IPUMS.

12 No Censo de 1960, os rendimentos foram captados em uma variável categórica. Os estados para os quais não há informações na amostra do IPUMS-I são Acre, Amapá, Amazonas, Espírito Santo, Guanabara, Maranhão, Pará, Piauí, Rondônia, Roraima e Santa Catarina. 
domiciliares sugerirem mais continuidade do que rupturas nas frações recebidas pelos mais ricos se alinha com a interpretação esboçada acima, que enfatizou o caráter inercial da concentração no topo e sua determinação político-institucional.

Evidentemente, é necessário introduzir qualificações no argumento, uma vez que há mais mudanças no coeficiente de Gini do que nas frações recebidas pelos mais ricos. Em termos empíricos, isso significa que houve redistribuição na "base" - em sentido amplo, incluindo os 80-90\% mais "pobres" -, sem afetar o quinhão dos ricos. Em termos mais abstratos, reforça-se a ideia de que há muitas desigualdades e que diferentes partes da distribuição sofrem influências muitas vezes distintas. Na esteira das perguntas que orientam este capítulo, os resultados para a distribuição como um todo são um pouco mais favoráveis ao potencial redistributivo da democracia, ainda que o período seja curto demais e as variações demasiado modestas para que se possa chegar a conclusões mais taxativas. Parece haver maior margem de manobra para transformações na base via políticas de inclusão que, no entanto, não alteram significativamente a concentração entre os ricos.

\subsection{A concentração no topo no Brasil e no mundo}

\subsubsection{A fatia do $1 \%$ mais rico em comparação internacional}

Um dos saltos recentes da literatura sobre desigualdade foi abraçar de vez a perspectiva internacional. Os estudos sobre os mais ricos seguiram a mesma tendência: na sequência dos trabalhos de Piketty e seus colaboradores, pesquisadores de muitos países recorreram a dados tributários para construir séries históricas comparáveis. O trabalho de síntese dos resultados ainda está em seu início, mas há ao menos dois fatos estilizados relevantes: a compressão significativa dos altos rendimentos em muitos países ricos em meio aos choques do período 1914-1945 e a ascensão recente da concentração no topo sobretudo nos Estados Unidos e nos países anglófonos (ver seção 3.4 do capítulo 3). O fato de que outros países ricos passaram ao largo dessa mudança, por sinal, é um dos argumentos principais de Atkinson, Piketty e Saez (2011) e de Alvaredo et al. (2013) contra explicações puramente tecnológicas, em termos de oferta e demanda, e a favor do foco em diferenças em políticas e instituições.

A Figura 44 contrasta as fatias da renda recebidas pelo centésimo mais rico no Brasil e em três países desenvolvidos - Estados Unidos, França e Japão - selecionados por seu peso político e econômico e por encarnarem diferentes "variedades de capitalismo" (HALL; SOSKICE, 2001). De imediato, vê-se que nossa trajetória em nada lembra o ocorrido nesses países e nem em outros, como a Alemanha e o Reino Unido, cujos gráficos análogos são versões abrandadas do que se passou no Japão e nos Estados Unidos, respectivamente. Os países ricos, por sua vez, só foram semelhantes entre si até o fim dos anos 1970. Estados Unidos, França e Japão apresentaram quedas abruptas da fração da renda apropriada pelo 
Figura 44. Fração recebida pelo $1 \%$ mais rico no Brasil e em países desenvolvidos selecionados, 1920-2013

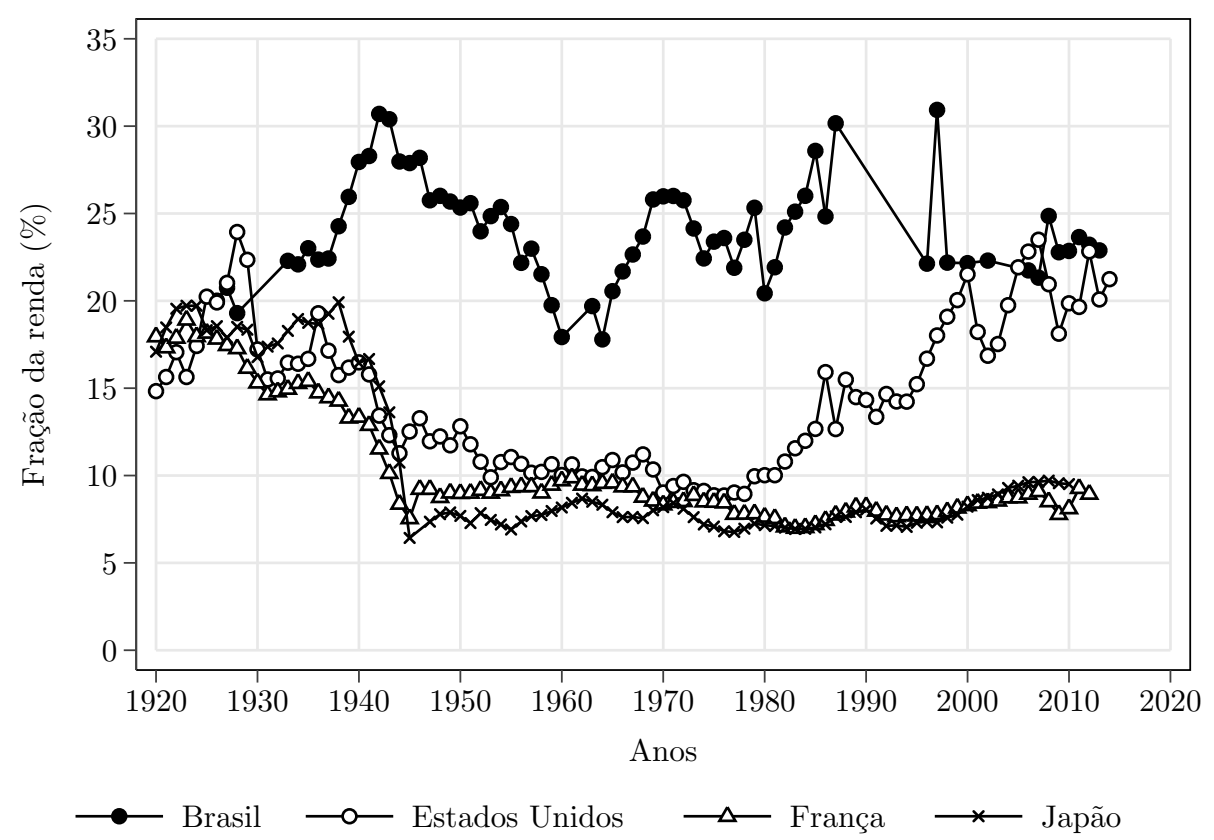

Fonte: para o Brasil, elaboração própria a partir de tabulações de dados tributários e das Contas Nacionais; ver capítulo 4. Para os demais países, World Wealth and Income Database (ALVAREDO et al., 2015).

N.B.: resultados para Brasil e Estados Unidos incluem ganhos de capital.

$1 \%$ mais rico durante a Grande Depressão e mais ainda na $2^{a}$ Guerra e testemunharam juntos um longo período de razoável estabilidade na concentração no topo. Contudo, seus caminhos bifurcaram em meados da década de 1970, quando a desigualdade americana começou a disparar, enquanto França e Japão permaneceram estáveis.

Se é verdade que o argumento de Jeffrey Williamson (2015) sobre a América Latina merece ser qualificado - como visto, o Brasil não perdeu totalmente o "grande nivelamento" -, é forçoso reconhecer que parte dele possui algum mérito. Por mais frágeis que sejam os dados para os anos 1920 e 1930, tudo indica que a concentração no topo no Brasil não era anormalmente alta um século atrás, estando apenas um pouco acima do observado alhures até a Grande Depressão. ${ }^{13}$ Deixando de lado os anos atípicos da guerra em nosso país, também é claro que tivemos, durante o interregno democrático de 1945 a 1964, um "mininivelamento", em comparação com o "grande nivelamento" representado pelo colapso da fração recebida pelos ricos tanto nos países mais afetados pela destruição física durante o conflito, como França e Japão, quanto em países que de todo modo tiveram que colocar sua economia em ritmo de guerra, como os Estados Unidos. Nada disso altera o que foi

13 Evidentemente, os dados tributários não permitem nenhuma especulação sobre a concentração de renda no Brasil antes de 1920, nem se trata de negar ou minimizar os efeitos terríveis da escravidão. O gráfico omitiu o período anterior a 1920 porque não há dados brasileiros para esses anos. Caso as séries estrangeiras fossem estendidas até seu início histórico, a proximidade com o Brasil ficaria mais clara: a concentração média no centésimo mais rico até 1929 ficou entre 17\% e 21\% na Alemanha, Estados Unidos, França, Japão, Países Baixos, Reino Unido e Suécia, sendo que em vários desses países os dados não incluem ganhos de capital. 
dito antes acerca da inflexão provocada pelo golpe militar de 1964, pois é impossível saber quanto tempo mais duraria o processo de nivelamento no Brasil.

Nos últimos anos a alta desigualdade deixou de ser uma jabuticaba brasileira, ou quiçá latino-americana, uma vez que a piora sem precedentes na concentração no topo nos Estados Unidos deu aos americanos o privilégio dúbio de estar quase no mesmo patamar observado por aqui. Embora a desigualdade lá venha recrudescendo por décadas, houve saltos consideráveis em períodos circunscritos, como na segunda metade dos anos 1980 (segundo governo Reagan), na segunda metade da década de 1990 (segundo governo Clinton) e em meados dos anos 2000, com a recuperação após a recessão de 2001 e o estouro da bolha das empresas "ponto-com" (primeiro governo de George W. Bush). ${ }^{14}$

Ou seja, mesmo no caso americano, a ascensão da desigualdade tende a se concentrar em arroubos relativamente curtos, só que, ao contrário do visto por aqui, há uma tendência sustentada de aumento. Já na França e no Japão, e em vários outros países, como Alemanha e Suécia, houve muito mais estabilidade depois do choque da guerra. Outros países anglófonos, como Austrália, Canadá e Reino Unido, seguiram a tendência americana, em grau mais diluído, com elevação um pouco mais modesta da concentração no topo, que, de todo modo, continua relativamente baixa.

São raros os casos de redução prolongada e significativa da concentração no topo quando comparados com as ocasiões de mudanças súbitas. Ainda assim, eles existem, contemplando em geral países pouco populosos do norte da Europa, como Dinamarca, Noruega e Países Baixos. A Austrália, que não foi afetada diretamente pela guerra nem passou por nenhum grande nivelamento nos anos 1940, também pode ser incluída nesse grupo. Muitas dessas reduções graduais foram só moderadas. No mundo desenvolvido, o maior progresso foi registrado nos Países Baixos, onde o centésimo mais rico ganhava cerca de $12 \%$ da renda total por volta de 1950 e apenas $6 \%$ no início dos anos 1980, com uma queda, portanto, de mais ou menos 6 p.p. em três décadas, um pouco maior em magnitude do que a verificada por lá durante a $2^{a}$ Guerra (em torno de $4-5$ p.p.).

A Figura 45 compara a fração recebida pelo centésimo mais rico no Brasil com os três países em desenvolvimento - África do Sul, Argentina e Colômbia - que encabeçam a lista dos mais desiguais no World Wealth and Income Database (WWID). ${ }^{15}$ As diferenças de trajetórias em relação aos países ricos são evidentes. O que mais chama a atenção é a relativa semelhança entre Brasil, África do Sul e Argentina até 1960, com divergência subsequente. Nos últimos anos, África do Sul e Argentina registraram algum aumento da concentração no topo, enquanto a Colômbia mostrou-se mais próxima do Brasil, com razoável estabilidade. A celebrada redução da desigualdade na América Latina - medida pelo coeficiente de Gini em pesquisas domiciliares - não dá as caras nos dados tributários.

14 Esses resultados não mudam significativamente com a exclusão dos ganhos de capital da série americana.

15 Colômbia, Argentina e África do Sul, nessa ordem, têm as maiores percentagens médias entre os 30 países com informações. Os resultados para a Colômbia cobrem somente a partir da década de 1990. 
Figura 45. Fração recebida pelo $1 \%$ mais rico no Brasil e em países em desenvolvimento selecionados, 1920-2013

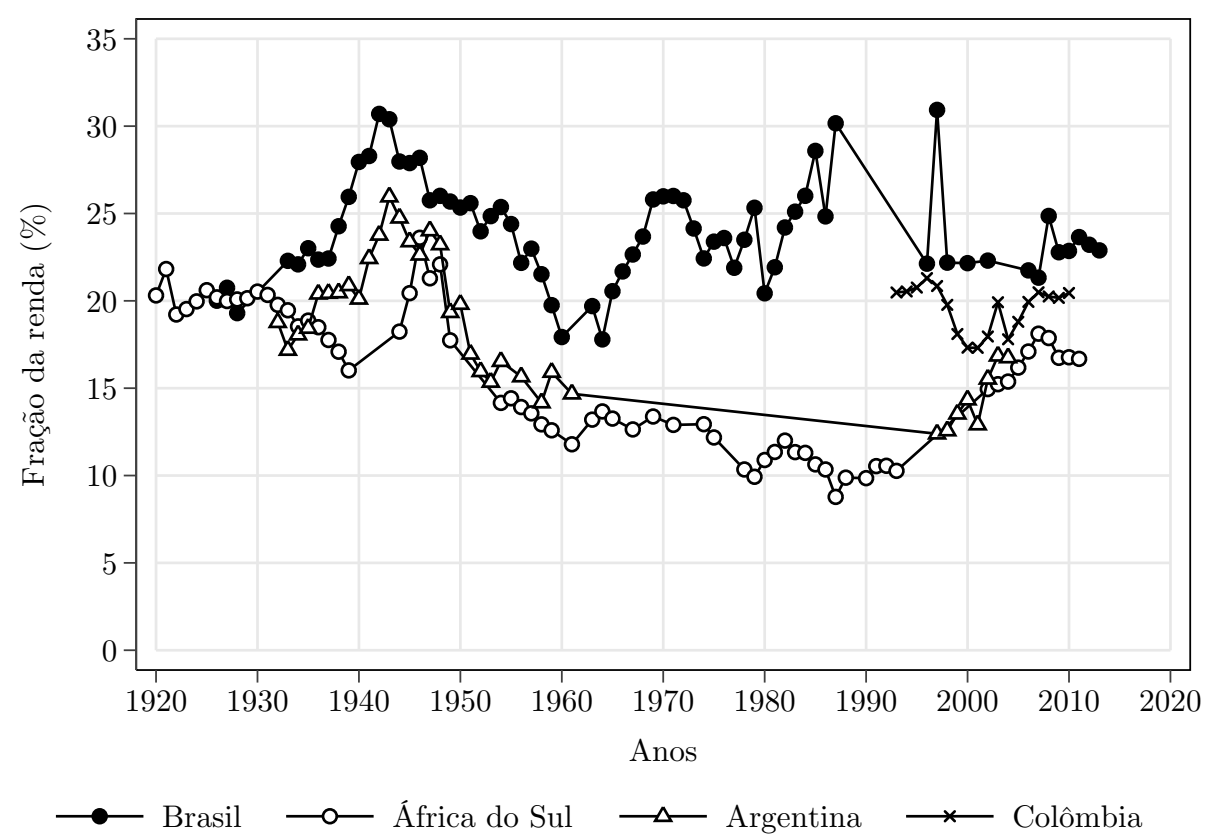

Fonte: para o Brasil, elaboração própria a partir de tabulações de dados tributários e das Contas Nacionais; ver capítulo 4. Para os demais países, World Wealth and Income Database (ALVAREDO et al., 2015).

N.B.: apenas os resultados para o Brasil incluem ganhos de capital.

No que diz respeito ao nível da desigualdade, o Brasil é historicamente ainda mais desigual do que os países mais desiguais da WWID. No entanto, algum cuidado é necessário, porque as informações para os demais países não contemplam ganhos de capital e transferências patrimoniais. As diferenças nas unidades de análise - indivíduos, famílias ou combinações híbridas - também influem nos resultados, bem como outros motivos, como eficiência administrativa na fiscalização do imposto de renda, definição legal de rendimentos tributáveis e/ou apurados nas declarações etc. É mais prudente, embora menos emocionante, afirmar apenas que estamos entre os mais desiguais entre os países para os quais há dados disponíveis.

A maior instabilidade da fração apropriada pelo 1\% mais rico nos países da Figura 45 em relação aos países ricos da Figura 44 - com exceção, talvez, dos Estados Unidos correlaciona-se à sua maior instabilidade institucional, em consonância com o argumento desenvolvido acima. Não à toa, Alvaredo (2008) interpretou a evolução da fatia recebida pelos mais ricos na Argentina principalmente a partir da interação entre choques externos - i.e.: o apetite europeu por commodities - e o sistema político-institucional argentino, em uma narrativa que guarda grandes paralelos com a história brasileira. O colapso da democracia após a Grande Depressão, com a restauração conservadora entre os dois golpes de estado - em 1930 e em 1943 - que delimitam a "década infame", desempenham para ele papel central para a compreensão do aumento subsequente da desigualdade, em conjunção com as condições favoráveis do mercado britânico e mundial durante a $2^{a}$ Guerra. A 
industrialização liderada pelo Estado e as políticas trabalhistas dos primeiros anos no poder de Juan Domingo Perón são as explicações favoritas de Alvaredo para a súbita queda da concentração do topo no imediato pós-guerra.

As similaridades com a experiência brasileira, ainda que não devam ser exageradas, são claras. O próximo capítulo aborda mais a fundo nossa história durante esse período; por ora, o importante é notar que, se os casos brasileiro e argentino forem típicos, as consequências distributivas da industrialização por substituição de importações merecem ser reavaliadas, em termos mais positivos, pelo menos até o golpe de 1964. Efetivamente, no Brasil e na Argentina, a concentração diminuiu nos períodos mais "desenvolvimentistas". A julgar pelos resultados da seção 5.3.2 e pelos números de Alvaredo (2008), em termos relativos, quem mais perdeu nessa época foram os mais ricos entre os ricos. Infelizmente, não é possível avaliar para onde fluíram os ganhos relativos, isto é, se os maiores beneficiados foram os estratos da base, do meio ou mais para o topo da distribuição de renda. O cenário mais plausível é que parcelas mais amplas da população tenham se beneficiado, afinal, as estimativas de Frankema (2009, cap. 6) e os trabalhos citados por Alvaredo (2008, p. 125) apontam que, tanto no Brasil quanto na Argentina, a participação dos salários na distribuição funcional da renda aumentou nesse período, alcançando um pico histórico em torno de 60\% durante a década de 1950 (FRANKEMA, 2009, p. 168). ${ }^{16}$

O caso sul-africano é mais complicado, porque vai na contramão das evidências prévias. As pesquisas domiciliares normalmente colocam o coeficiente de Gini da África do Sul entre os mais altos do mundo, bem à frente do brasileiro, ${ }^{17}$ mas os resultados da Figura 45 apontam na direção oposta: a fatia do centésimo mais rico não só é menor do que no Brasil como também está bem abaixo até dos Estados Unidos. Pior, há uma prolongada redução da concentração no topo justamente durante o período do apartheid.

Não é possível descartar a hipótese de que resultados tão contraintuitivos decorrem simplesmente das deficiências dos dados e das idiossincrasias da legislação tributária sulafricana. Alvaredo e Atkinson (2010), responsáveis pela construção das séries, confirmam e documentam as limitações e cuidados necessários, considerando que, apesar de tudo, os resultados são relativamente confiáveis.

16 A série estimada por Frankema (2009) termina em 2000. No Brasil, houve aumento da participação do fator trabalho na renda nacional na primeira década dos anos 2000 (BASTOS, 2012). As estimativas de Considera e Pessoa (2013) para o período 1959-2009 são diferentes, apontando aumento contínuo, a partir de um nível inicial bem mais baixo, na participação do fator trabalho até 1990, com exceção dos anos entre 1970 e 1975. Os autores, no entanto, reproduzem dados de Langoni para 1947-1969 que localizam a grande elevação da participação do trabalho na década de 1950, com pico em 1961-1962.

17 No banco de dados compilado por Milanovic (2015), por volta de 2008 a África do Sul possuía o maior Gini para a renda domiciliar per capita entre 118 países, com valor de 0,672. O Brasil estava em sétimo, com um Gini de 0,544, número quase $20 \%$ menor. Os dados harmonizados do LIS para a renda per capita com a aplicação de escalas de equivalência reafirmam esse quadro: por volta de 2010, a África do Sul possuía o maior Gini $(0,585)$ entre 36 países e o Brasil vinha em sexto $(0,460,21 \%$ a menos). Os dados do LIS estão em < http://www.lisdatacenter.org/data-access/key-figures/inequality-and-poverty/>. Acesso em 28 mar. 2016. 
Com efeito, a história sul-africana permite dar algum sentido a eles. Embora o apartheid propriamente dito tenha seu ponto de partida na vitória eleitoral do Partido Nacional em 1948, a legislação e as políticas segregacionistas e racistas começaram antes, intensificando-se a partir da $1^{a}$ Guerra. Ao mesmo tempo, a mobilização de parte significativa dos brancos africâneres envolvia o ressentimento contra a elite branca de ascendência inglesa, expressa na insatisfação com a entrada na $2^{a}$ Guerra ao lado dos ingleses. ${ }^{18}$ Em termos da discussão na Parte I, todo o brutal maquinário institucional do apartheid permitiu a ascensão dos brancos africâneres e, no que diz respeito à desigualdade, deslocou a dicotomia fundamental para o conflito entre brancos e negros - ou, melhor dizendo, não brancos -, promovendo alguma redistribuição entre os próprios brancos.

Em sua crítica a Piketty, Acemoglu e Robinson (2015) desenvolvem o mesmo argumento para o caso sul-africano, com o objetivo de mostrar que o foco no $1 \%$ mais rico pode ser enganoso, já que intervenções pesadas para garantir a supremacia da população branca coexistiram com a queda da concentração no topo. O que eles desconsideram é o quão atípica foi a situação, tanto em termos de aparato institucional quanto dos resultados com base no imposto de renda. Na comparação com o Reino Unido e outras ex-colônias britânicas, Alvaredo e Atkinson (2010) notam justamente que a África do Sul é muito desigual e que a distribuição da renda dentro do $1 \%$ mais rico é menos concentrada do que nos outros países, o que é consistente com a explicação do parágrafo anterior.

Por fim, a Tabela 5 completa o panorama internacional, exibindo a concentração média no topo em três quinquênios que representam momentos-chave da evolução da desigualdade no século XX: em 1930-1935, em meio aos choques que reduziram a fração do topo, antes do impacto grande da $2^{a}$ Guerra; em 1970-1975, logo antes da tendência de aumento verificada principalmente nos países anglófonos; e em 2010-2015, pegando o período posterior à crise de 2008.

Os resultados são compatíveis com toda a discussão anterior. Embora já fôssemos mais desiguais em 1930-1935, a diferença em relação ao resto do mundo era bem menor do que a verificada em 1970-1975, especialmente nos países ricos que tiveram que se mobilizar para a $2^{a}$ Guerra. No período mais recente, a concentração no topo recrudesceu muito nos Estados Unidos e, em menor grau, em outros países anglófonos e em alguns outros casos, e mudou muito pouco em países como França, Suíça e afins. Com isso, a dispersão entre os valores médios segue uma curva em "U", partindo de um valor alto no primeiro quinquênio, descendo bastante de patamar em 1970-1975 e voltando a níveis altos em 2010-2015. ${ }^{19}$ Do ponto de vista brasileiro, continuamos com a maior concentração, agora relativamente próximos dos americanos.

18 Esta recapitulação sucinta da complicada e, por vezes, francamente repugnante história política da África do Sul no século 20 baseia-se em Clark e Worger (2011), Seidman (1999) e Thompson (2001).

19 O desvio-padrão dos valores médios para os países sem ganhos de capital em 1930-1935, 1970-1975 e 2010-2015 é, respectivamente, 3,0, 1,9 e 3,7. 
Tabela 5. Fração média recebida pelo $1 \%$ mais rico nos quinquênios 1930-1935, 1970-1975 e 2010-2015

\begin{tabular}{lcrrr}
\hline País & Inclui ganhos de capital? & $1930-1935$ & $1970-1975$ & $2010-2015$ \\
\hline Brasil & Sim & 24.3 & 24.6 & 23.2 \\
Estados Unidos & Sim & 16.9 & 9.2 & 20.7 \\
Suécia & Sim & 12.3 & 5.8 & 8.8 \\
\hline África do Sul & Não & 17.6 & 12.7 & 16.7 \\
Austrália & Não & 10.5 & 5.7 & 9.2 \\
Canadá & Não & 16.8 & 8.8 & 12.2 \\
Dinamarca & Não & 13.9 & 8.0 & 6.4 \\
Estados Unidos & Não & 15.9 & 7.9 & 17.8 \\
França & Não & 14.3 & 8.5 & 8.8 \\
Japão & Não & 18.5 & 7.8 & 9.5 \\
Noruega & Não & 12.7 & 5.7 & 7.8 \\
Nova Zelândia & Não & 8.7 & 7.0 & 8.1 \\
Países Baixos & Não & 15.3 & 7.2 & 6.4 \\
Reino Unido & Não & 17.0 & 6.8 & 12.7 \\
Suécia & Não & 12.3 & 5.7 & 7.1 \\
Suíça & Não & 10.9 & 9.8 & 10.6 \\
\hline
\end{tabular}

Fonte: para o Brasil, ver capítulo 4. Para os demais países, World Wealth and Income Database (ALVAREDO et al., 2015).

N.B.: somente foram incluídos na tabela os países com pelo menos uma observação em cada quinquênio.

Em suma, as comparações corroboram que o Brasil é um dos países com maior concentração no topo, quiçá o maior. Por aqui, o $1 \%$ mais rico recebe em torno de $23 \%$ da renda total. Em outros países muito desiguais, esse percentual fica próximo a 20\%, como nos Estados Unidos e na Colômbia. Nos países mais igualitários, ele não ultrapassa os 10\%, como na França e no Japão. A trajetória da concentração no topo é bem diferente da observada em boa parte do mundo desenvolvido, aproximando-se mais da experiência argentina, pelo menos até a década de 1960. Como preconizou Williamson (2015), parte importante do excepcionalismo latino-americano quanto à desigualdade é razoavelmente recente: um século atrás as diferenças entre o $1 \%$ mais rico aqui e alhures eram bem menores. Nem passamos pelos choques nem adotamos o arranjo político-institucional que derrubaram e estabilizaram a desigualdade em níveis baixos nos países ricos, apesar de não termos escapado por inteiro do "grande nivelamento". Como na Argentina, o período áureo do desenvolvimentismo promoveu alguma redistribuição, anulada pelo golpe subsequente.

Adicionalmente, a explicação baseada sobretudo em instituições políticas e no modo como o aparato estatal foi utilizado em prol de diferentes estratégias de acumulação - inclusive para mediar os impactos de choques externos - parece aplicável para muito além da experiência brasileira. O caráter inercial da desigualdade e sua tendência a mudar 
depressa apenas em situações de crise e ruptura podem ser vistos em muitos outros países. É relativamente raro observar mudanças prolongadas, graduais e profundas na fatia apropriada pelo topo da distribuição.

Tudo isso produz ao menos uma implicação preocupante para o Brasil: não há exemplo de país que tenha saído do nosso patamar de concentração no topo e conseguido, em condições democráticas normais, reduzi-la de forma progressiva e suave para níveis franceses ou alemães, sem rupturas ou sobressaltos. Na melhor das hipóteses, teremos que inventar algo aparentemente inédito caso esse seja um objetivo político desejado.

\subsubsection{Em busca da curva de Kuznets}

Como discutido no capítulo 2, nenhum autor simboliza melhor a era das narrativas benignas sobre a desigualdade do que Simon Kuznets, economista russo naturalizado americano. A denominada "curva de Kuznets" foi central para o abandono das visões polarizadas da estratificação em prol de teorias otimistas da modernização. Por décadas a procura pelo "U invertido" e a explicação de sabor estrutural-setorial de Kuznets nortearam as pesquisas sobre desigualdade, em particular os estudos comparativos.

Em sua formulação mais famosa, Kuznets (1955) foi antes de tudo cauteloso. O texto evita o tempo todo fazer afirmações fortes e introduz entretantos, poréns e todavias. As imperfeições dos dados são lembradas e a generalidade das conjecturas é repetidamente colocada em dúvida. Apesar disso, a ambição de Kuznets era elevada: elaborar uma explicação causal para o nível e a trajetória da desigualdade, contrapondo forças que puxam para a divergência - por exemplo, a poupança dos mais ricos - com forças de convergência, passando por decisões políticas e demandas por serviços e redistribuição.

O âmago do argumento reside na dinâmica intrínseca ao desenvolvimento de sociedades economicamente livres, com ênfase na transição do setor agrícola para o urbano e industrial. Não à toa, a popularização da sua teoria - ou, melhor dizendo, das hipóteses derivadas do seu modelo - concentrou-se nesse aspecto. Em essência, o postulado é que o processo de crescimento econômico, ao transformar sociedades pobres e rurais em ricas, urbanas e industriais, põe em movimentos processos estruturais que geram um "U invertido" na evolução da desigualdade. Em um primeiro momento, a desigualdade total aumenta, puxada pela expansão de um setor urbano-industrial mais rico e inicialmente mais desigual do que o agrícola. Conforme o processo se desenrola, a desigualdade eventualmente se estabiliza para, em seguida, declinar, em função do tamanho dominante adquirido pelo setor urbano e, principalmente, da diminuição de sua desigualdade interna. Essa diminuição ocorre pela combinação de tendências demográficas, políticas e sobretudo econômicas, uma vez que as inovações tecnológicas e a competição no mercado de trabalho tendem a erodir o poder das indústrias e famílias já estabelecidas. ${ }^{20}$

20 A seção 2.2, no capítulo 2, discute mais a fundo as ideias e a importância histórica de Kuznets. 
Figura 46. Relação entre a fração recebida pelo $1 \%$ mais rico e renda per capita em 29 países, 2010

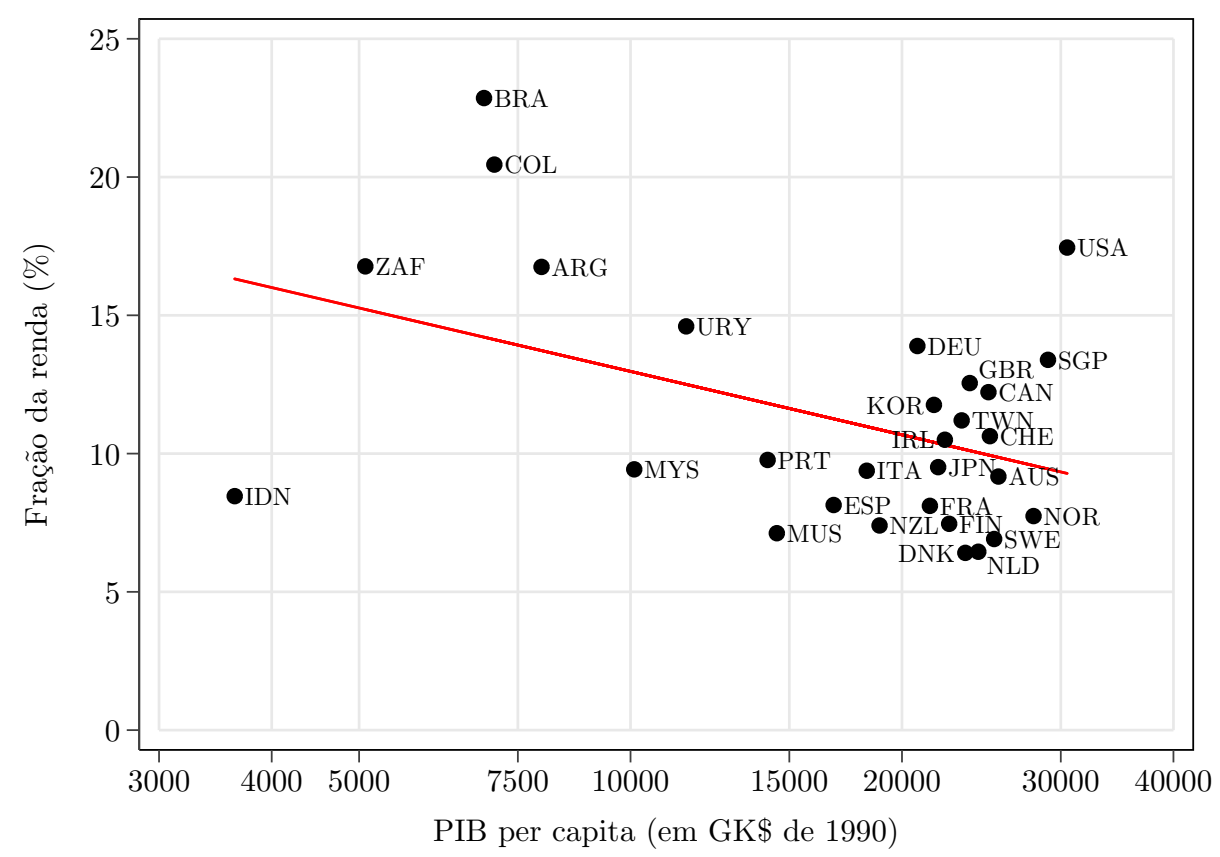

Fonte: para o Brasil, elaboração própria a partir de tabulações de dados tributários e das Contas Nacionais; ver capítulo 4. Para os demais países, World Wealth and Income Database (ALVAREDO et al., 2015). Os PIBs per capita para todos os países são provenientes do The Maddison Project (2013).

N.B.: devido à falta de dados, em oito países foram selecionados os anos disponíveis mais próximos a 2010.

Meio século depois, a hipótese de Kuznets anda em baixa, sem, contudo, perder a majestade, ainda atuando como eixo organizador do debate sobre desigualdade. Por isso, vale explorar os dados do IRPF para avaliar em que medida há algo a ser recuperado. No caso brasileiro, o "U invertido" de Kuznets é relevante até por razões históricas, pois boa parte do discurso legitimador dos primeiros anos da ditadura baseou-se em uma adaptação desse modelo, como discutido na seção 2.6 do capítulo 2. Ademais, pode-se aproveitar a existência de um banco de dados internacional como o WWID para comparar os países entre si, já que o próprio Kuznets trabalhou com dados tributários, destacou entre os fatores de divergência a concentração da propriedade e da poupança nos mais ricos e ainda por cima considerou a polarização entre os ricos e as massas empobrecidas como a característica definidora da distribuição de renda dos países em desenvolvimento.

Como os resultados mais próximos da curva de Kuznets são normalmente obtidos em dados transversais, a Figura 46 começa por aí, reportando, por volta de 2010, a relação entre a fração da renda total recebida pelo centésimo mais rico e o PIB per capita, em dólares internacionais de Geary-Khamis em valores reais de 1990.

Para os defensores tardios da hipótese de Kuznets, o gráfico apresenta no máximo um copo meio cheio. De fato, os países mais ricos são menos desiguais, com exceção do mais rico da amostra, os Estados Unidos, e a tendência linear tem inclinação negativa. Ainda assim, seria preciso cortar um dobrado para encaixar os resultados na previsão de 
Figura 47. Relação entre desigualdade e renda per capita - Brasil, 1926-2010 (\%)

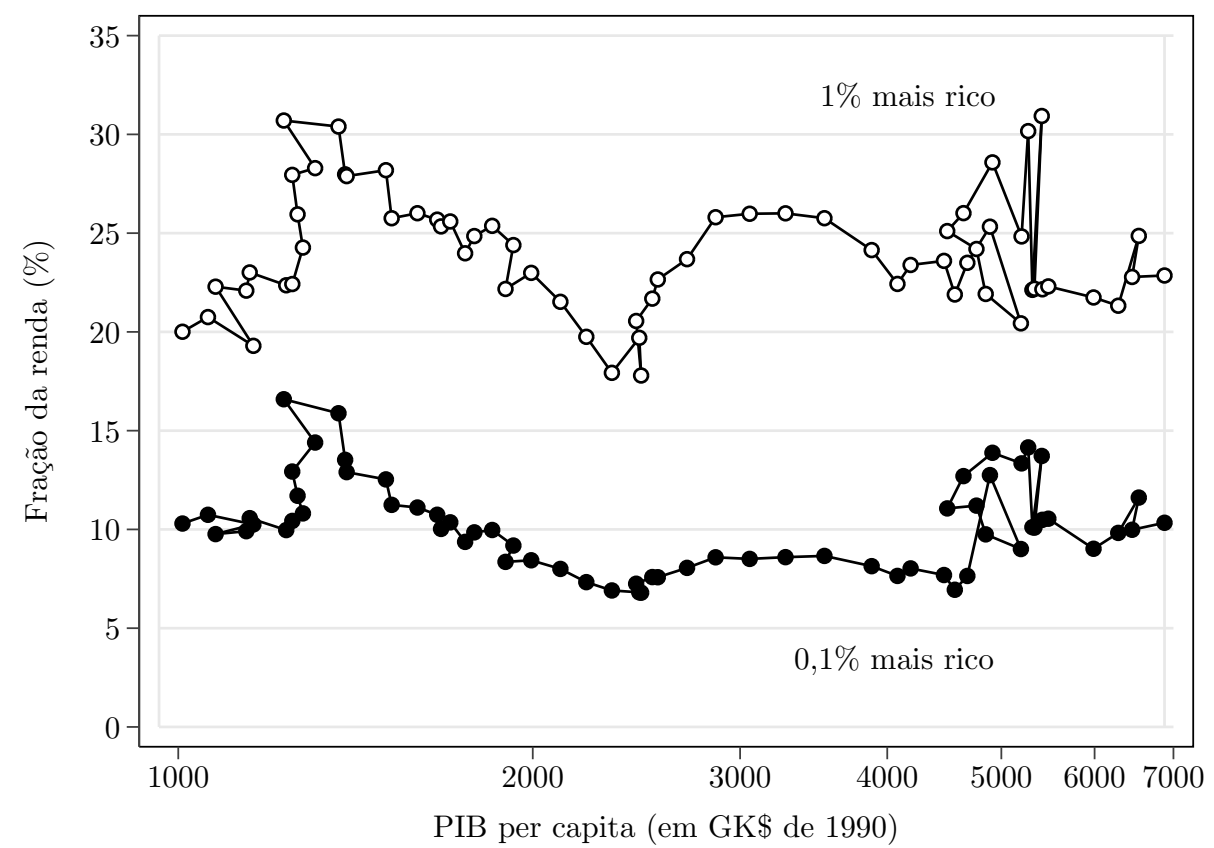

Fonte: elaboração própria a partir de tabulações de dados tributários e das Contas Nacionais; ver capítulo 4. PIB per capita proveniente do The Maddison Project (2013).

Kuznets. Mesmo os dados transversais indicam heterogeneidade substancial, com países com renda muito baixa, como a Índia, ou média, como a Malásia, mostrando concentração no topo até inferior à de muitos países ricos. O Brasil está muito acima do que seria predito somente pelo nosso PIB per capita, assim como os outros três países latino-americanos (Argentina, Colômbia e Uruguai). Por sinal, basta remover os quatro representantes da América Latina para a inclinação negativa da tendência linear desaparecer por completo.

Na prática, em quase todos os países, ricos ou não, o centésimo no topo da distribuição leva entre $5 \%$ e $15 \%$ da renda. Somente em cinco, incluindo três dos quatro latino-americanos, dos $29(17 \%)$ a fração do $1 \%$ mais rico está acima de 15\%. Em comparação, em 15 países (52\%) a concentração no topo está abaixo de $10 \%$.

A caracterização oferecida pelos dados transversais é útil para descrever os padrões atuais e fornecer parâmetros de comparação. Porém, um teste mais apropriado da hipótese de Kuznets se dá pela análise das séries temporais de cada país. A Figura 47 apresenta a evolução da relação entre a fatia dos mais ricos e o PIB per capita para dois estratos no topo da distribuição de renda no Brasil: o centésimo e o milésimo mais ricos.

Em termos gerais, nota-se que as séries do gráfico são semelhantes às suas contrapartes na Figura 30, que trouxe a evolução da fração do 0,01\%, 0,1\% e $1 \%$ mais ricos ao longo dos anos. Isso não é coincidência, refletindo o crescimento robusto da economia brasileira entre os anos 1930 e o fim da década de 1970. Em dólares internacionais de 1990, nosso PIB per capita saltou de cerca de GK\$1,000 em 1931 para GK\$ 5,200 em 1980 (taxa média de 3,4\% ao ano). A desaceleração econômica desde então faz com que os 
dados mais recentes sejam menos claros. De 1980 a 2010, o crescimento foi de apenas $32 \%$, ou pouco menos de $1 \%$ ao ano. ${ }^{21}$

No longo prazo, crescimento houve, e não foi pouco. O que faltou foi o "U invertido" de Kuznets. Assim como antes, a evolução da desigualdade em função do PIB per capita não revela nenhuma tendência secular com direção bem definida. Há, no máximo, duas ondas - mais pronunciadas para o $1 \%$ do que para o $0,1 \%$ - de ascensão e queda da fração dos ricos, próximas da caracterização de Frankema (2009), sem promover alterações permanentes no nível da concentração no topo. A relativa estabilidade recente dá-se no patamar de 20-25\% visto durante a maior parte do tempo.

Essas ondas correspondem aos períodos assinalados na seção 5.3.1, com um momento de inflexão no golpe de 1964. O gráfico permite uma nova visualização de algo já mencionado: a concentração no topo começou a aumentar já no início da ditadura e cresceu só até os primeiros anos do "milagre", estabilizando-se depois e até diminuindo um pouco no final da década de 1970; basta ver a parábola descrita na série para o $1 \%$ mais rico. Nesse sentido, para retomar a discussão da seção 2.6 do capítulo 2, as explicações de Fishlow (1972), Hoffmann e Duarte (1972) e Wells (1974) acerca da natureza política da piora na distribuição de renda são mais adequadas aos resultados do que a interpretação kuznetsiana e educacional de Langoni (1973). Não se pode concluir daí que a desigualdade de renda no Brasil seja sempre independente das profundas desigualdades educacionais, e sim que o timing e o caráter do aumento da concentração no topo nos anos 1960 não podem ser explicados simplesmente pelo recurso à inelasticidade da oferta de trabalhadores qualificados em um ambiente de livre mercado de uma sociedade em desenvolvimento.

Logo, o processo de crescimento rápido e urbanização não detonou no Brasil forças de convergência capazes de produzir o "U invertido". Resta saber se algo parecido ocorreu nos outros países para os quais temos dados. As Figuras 48 e 49 comparam os resultados brasileiros com os de países desenvolvidos e em desenvolvimento, respectivamente.

Nenhum caso chega sequer perto de um "U invertido" bem comportado. No contraste com os países desenvolvidos, para além de deixar patente a pobreza relativa e a instabilidade da concentração no topo no Brasil, o que se vê é que em vários deles a curva se aproxima de um "L", com inclinação quase vertical no início do período, em particular durante a $2^{a}$ Guerra. Em outros países, o formato é mais próximo de um "U" (não invertido) em função da reconcentração recente no topo, como nos Estados Unidos.

A Figura 48 também possibilita avaliar a hipótese de Williamson (2015) sob um novo ângulo, corroborando que ele estava ao menos parcialmente correto ao localizar, em termos comparativos, a origem da alta desigualdade latino-americana em um passado recente,

21 Os valores estão em dólares internacionais para facilitar a comparação com as outras figuras. Em reais de 2014, o PIB per capita pulou de menos de $\mathrm{R} \$ 2,700$ em 1931 para $\mathrm{R} \$ 19,365$ em 1980 e $\mathrm{R} \$ 26,601$ em 2010, com taxas anuais de crescimento de 4,1\% no período 1931-1980 e 1,1\% entre 1980-2010. 
Figura 48. Relação entre a fração recebida pelo $1 \%$ mais rico e renda per capita no Brasil e em países desenvolvidos selecionados, 1920-2010

A) Brasil

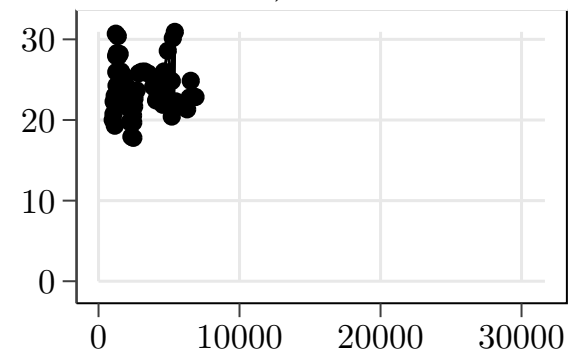

C) Austrália

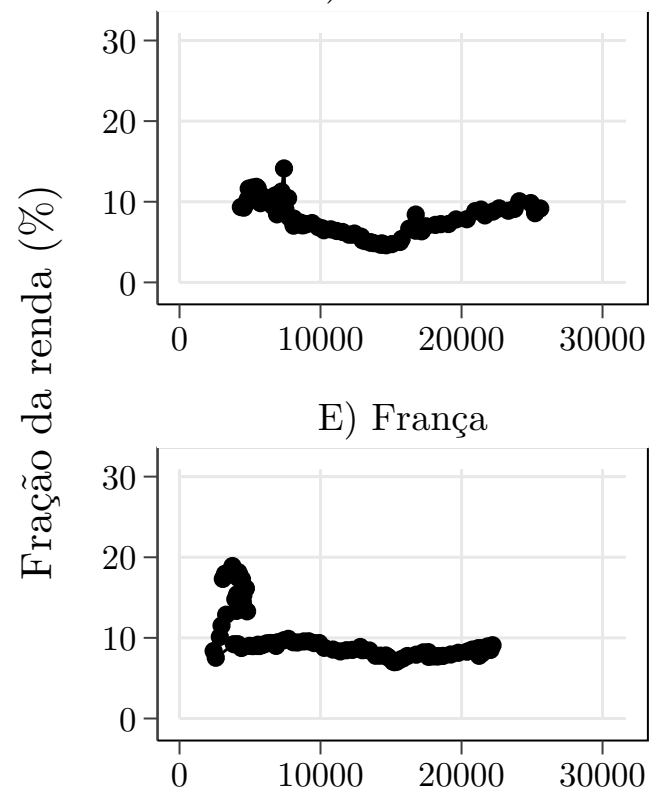

G) Reino Unido

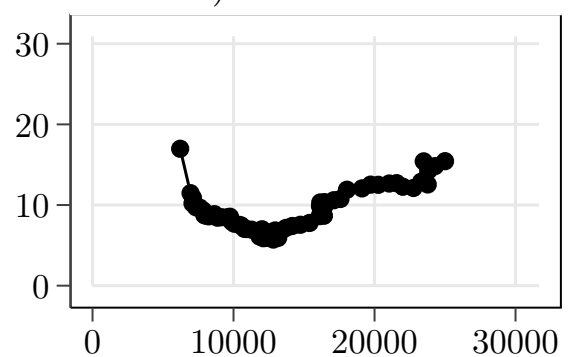

B) Alemanha

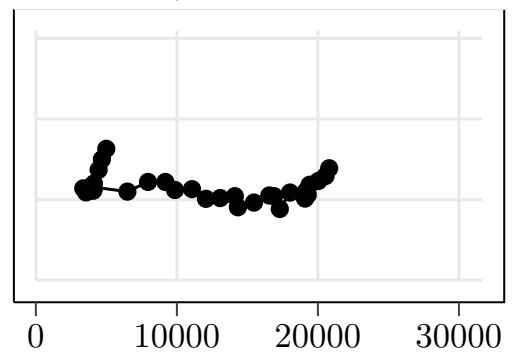

D) Estados Unidos

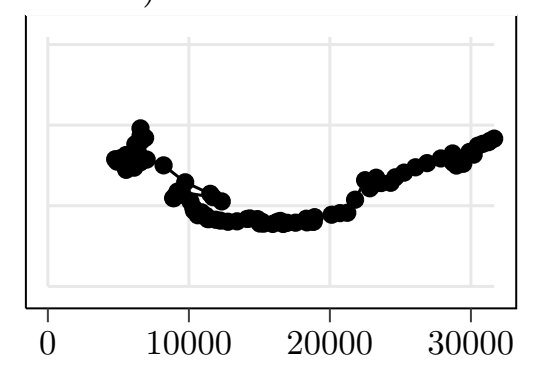

F) Japão

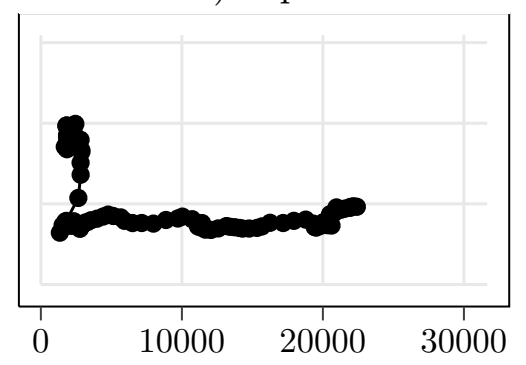

H) Suécia

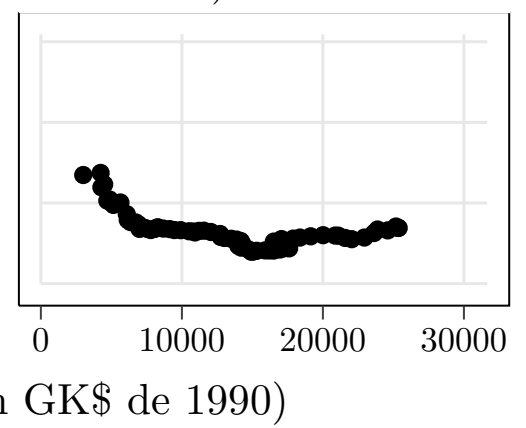

Fonte: para o Brasil, elaboração própria a partir de tabulações de dados tributários e das Contas Nacionais; ver capítulo 4. Para os demais países, World Wealth and Income Database (ALVAREDO et al., 2015). Os PIBs per capita para todos os países são provenientes do The Maddison Project (2013).

N.B.: apenas os dados para o Brasil incluem ganhos de capital e transferências patrimoniais. 
Figura 49. Relação entre a fração recebida pelo $1 \%$ mais rico e renda per capita no Brasil e em países em desenvolvimento selecionados, 1920-2010

A) Brasil

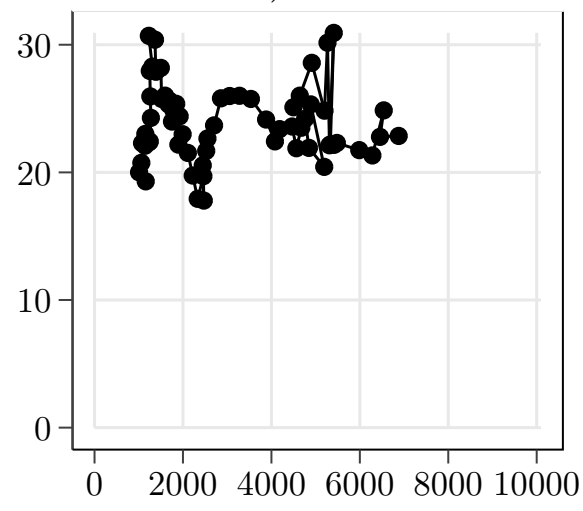

C) Argentina

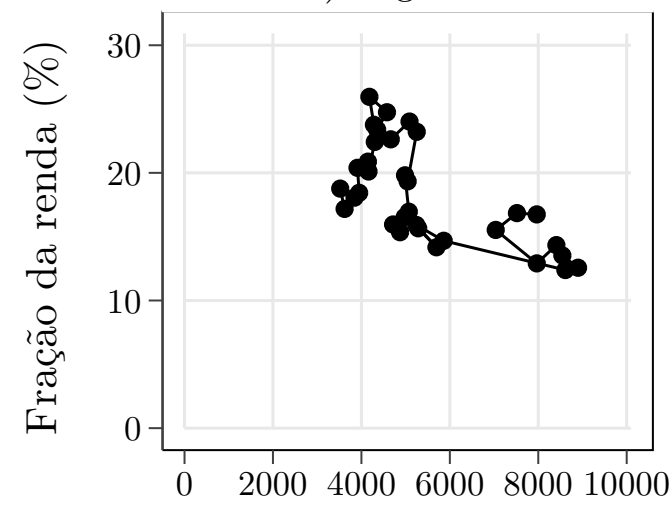

E) Indonésia

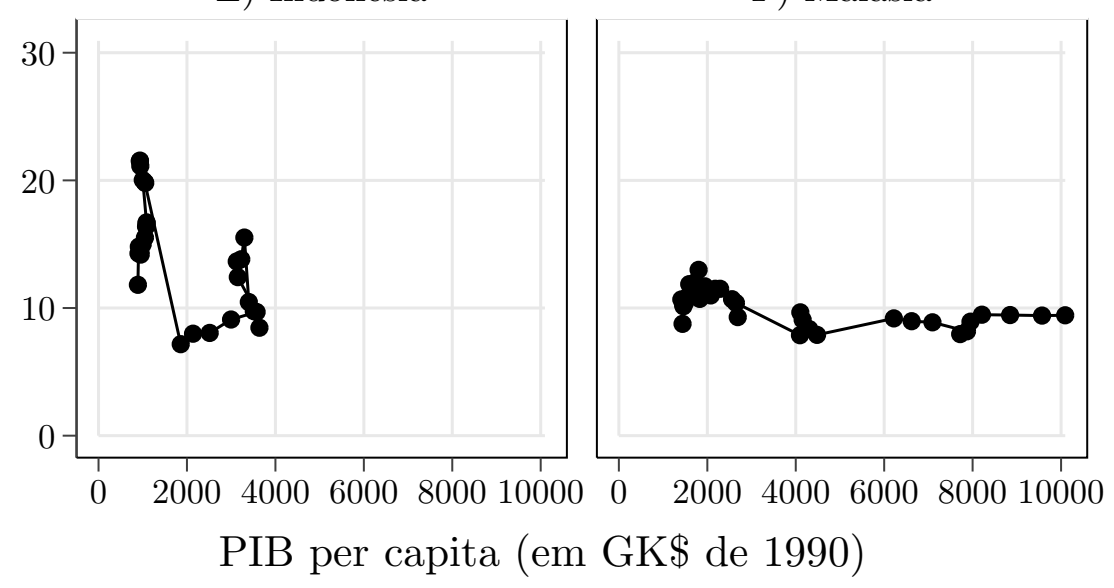

B) África do Sul

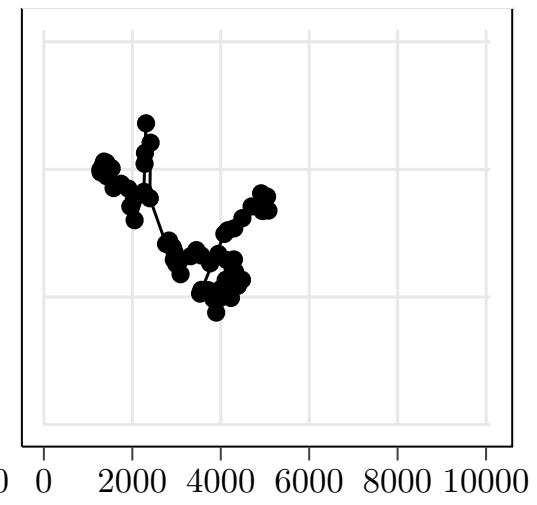

D) Índia

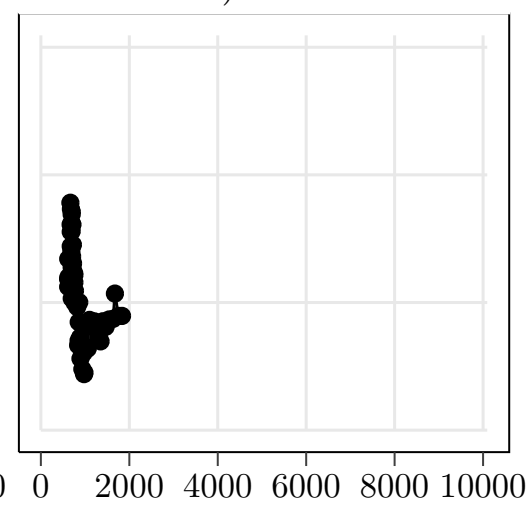

F) Malásia

Fonte: para o Brasil, elaboração própria a partir de tabulações de dados tributários e das Contas Nacionais; ver capítulo 4. Para os demais países, World Wealth and Income Database (ALVAREDO et al., 2015). Os PIBs per capita para todos os países são provenientes do The Maddison Project (2013).

N.B.: apenas os dados para o Brasil incluem ganhos de capital e transferências patrimoniais. 
por oposição às interpretações clássicas que destacam a herança colonial. Os gráficos não chegam a captar o momento em que os PIBs per capita dos países desenvolvidos selecionados eram iguais aos do Brasil no começo do século XX; de todo modo mostram que, quando esses países estavam abaixo de GK\$ 10,000 por pessoa, a fração apropriada pelo centésimo mais rico chegava, em vários casos, perto dos $20 \%$, valor não tão distante assim da média brasileira no século. A trajetória em "L" mencionada no parágrafo anterior, afinal, nada mais é do que o "grande nivelamento" de Williamson.

A Figura 49, com as comparações entre os poucos países em desenvolvimento com dados históricos, tampouco é animadora para a hipótese de Kuznets. Com exceção talvez da dupla Brasil-Argentina, cada país segue uma trajetória própria e pouco previsível. Contraste-se qualquer um dos painéis com os do gráfico anterior: afora a Malásia, a concentração no centésimo mais rico é bem mais errática ao longo do tempo nos países em desenvolvimento. A Índia, por exemplo, passou por grandes variações na fatia nos ricos, sem deixar de ser um país bastante pobre. O programa socializante e planificador implementado entre a independência em 1950 e os anos 1980 comprimiu a fração dos mais ricos, enquanto as reformas liberalizantes desde então promoveram maior crescimento e maior desigualdade (BANERJEE; PIKETTY, 2010).

Por fim, em nome da completude, a Figura 50 apresenta a relação entre as variações na fração do centésimo mais rico e as taxas anuais de crescimento econômico no Brasil e nos três países desenvolvidos selecionados na Figura 44. Destarte, a comparação deixa de se dar entre níveis de desigualdade e níveis de renda para relacionar explicitamente as variações nessas duas variáveis. Para tornar a apresentação mais clara, foram omitidos os pontos em que a variação na fatia do centésimo mais rico excedeu \pm 6 p.p. e/ou o PIB per capita oscilou mais do que \pm 15 p.p., o que acarretou a eliminação de $3 \%$ dos casos, em sua maior parte em função de guinadas abruptas do PIB per capita durante a $2^{a}$ Guerra.

A tendência linear com inclinação negativa observada para o Brasil vai na contramão da dos outros três países. Nos Estados Unidos, na França e no Japão, há uma tímida correlação positiva entre crescimento e aumento da concentração no topo. No Brasil, temos o oposto, indicando que, no século XX, o maior crescimento conviveu com reduções modestas na fração do $1 \%$ mais rico. Obviamente, essas associações não devem ser interpretadas em termos causais e, ainda por cima, são sensíveis a outliers. A mensagem principal do gráfico é outra: a diferença de padrão tem o sinal oposto do esperado caso o Brasil, por ser mais pobre, fosse um exemplo dos processos conjecturados por Kuznets.

O gráfico deixa claro, mais uma vez, como a fatia dos mais ricos no Brasil foi mais instável do que nos países desenvolvidos. Parte disso pode decorrer de limitações dos nossos dados. No entanto, é difícil ignorar o peso das nossas turbulências institucionais e econômicas ao longo do século. Isso se vê até nos três países ricos: como os rótulos indicam, os anos com maiores variações na desigualdade foram, via de regra, igualmente atribulados, 
Figura 50. Relação entre a variação da fração recebida pelo $1 \%$ mais rico e o crescimento do PIB per capita no Brasil e em países desenvolvidos selecionados, 1920-2010

A) Brasil

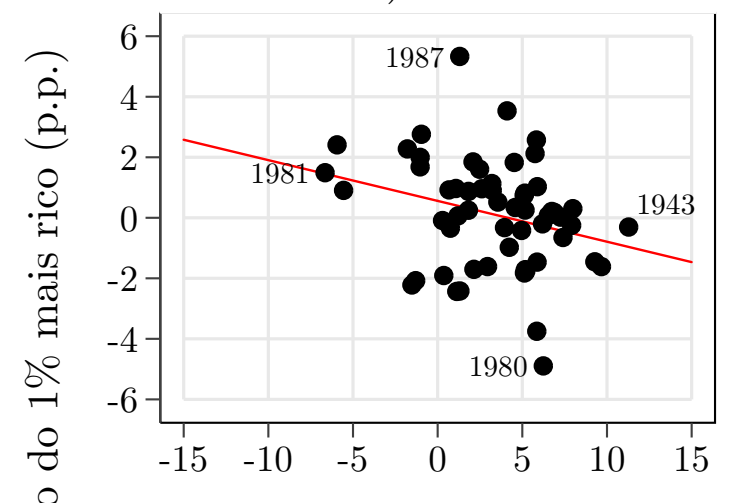

C) França

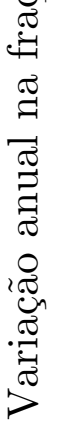

B) Estados Unidos

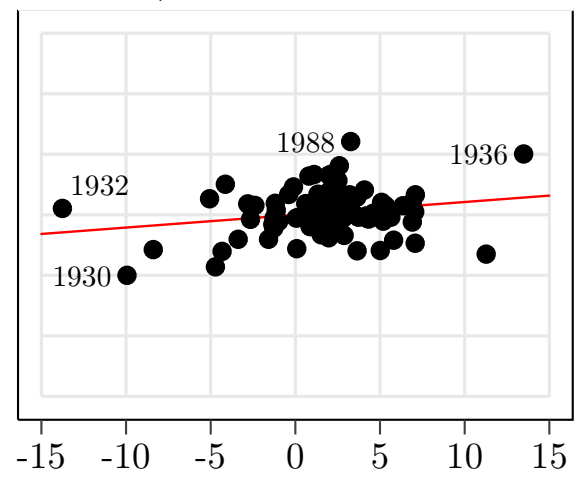

D) Japão

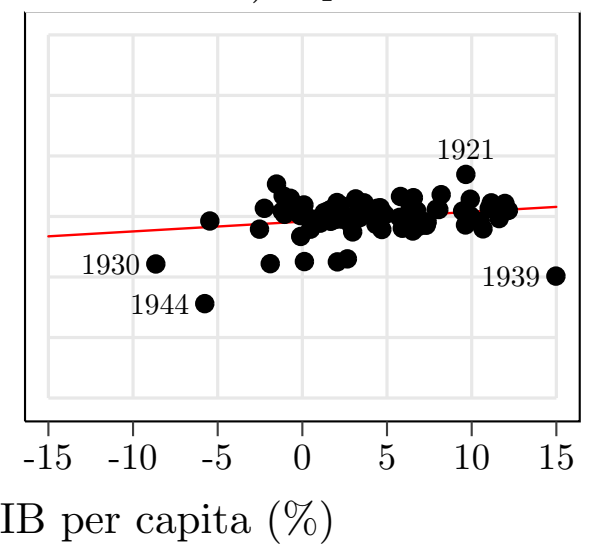

Fonte: para o Brasil, elaboração própria a partir de tabulações de dados tributários e das Contas Nacionais; ver capítulo 4. Para os demais países, World Wealth and Income Database (ALVAREDO et al., 2015). Os PIBs per capita para todos os países são provenientes do The Maddison Project (2013).

N.B.: apenas os dados para o Brasil incluem ganhos de capital e transferências patrimoniais. Para facilitar visualização, o gráfico omite anos atípicos, incluindo somente os pontos em que $x \in[-15,15]$ e $y \in[-6,6]$.

com grande presença do período tenso entre a Grande Depressão e a $2^{a}$ Guerra.

Portanto, apesar do seu apelo intuitivo, o "U invertido" de Kuznets passou longe da experiência brasileira e internacional no século XX, no que diz respeito à concentração de renda no topo. Mudanças estruturais como urbanização e industrialização - relativamente bem captadas pelo PIB per capita - certamente alteraram a estrutura de oportunidades disponíveis aos diversos grupos sociais, sem impor, todavia, nenhuma tendência unívoca à desigualdade, nem aqui nem alhures. No caso brasileiro, só a parte final do aumento da concentração no topo durante a ditadura ocorreu no período do "milagre", tornando pouco críveis explicações otimistas baseadas em narrativas benignas a la Kuznets.

A não relação aparente entre mudanças estruturais e desigualdade não significa ausência tout court de relação entre variáveis "estruturais" em sentido amplo e a concentração de renda. Afinal, muita coisa não mudou tanto assim no período. Para ficar em apenas dois exemplos óbvios, basta mencionar a concentração fundiária e o atraso educacional. O 
ponto principal é que não há motivos para esperar que forças intrínsecas ao crescimento provoquem transformações de maior magnitude nessas e em outras dimensões relevantes.

A comparação internacional corrobora a conclusão de que o Brasil de fato não é muito mais desigual do que eram os países hoje desenvolvidos quando tinham nossa renda per capita. Se oscilamos entre $20 \%$ e $25 \%$, muitos deles estavam em torno de $20 \%$ há cerca de um século, com percentuais muito mais próximos do nosso do que se viu depois da $2^{a}$ Guerra. Contra Kuznets ou qualquer vulgarização otimista, não se pode esquecer que esses países não seguiram uma trajetória tranquila de enriquecimento e redistribuição gradual. Pelo contrário, a concentração no topo mudou drasticamente quando os níveis de renda ainda eram baixos para os padrões atuais.

No que diz respeito aos países em desenvolvimento, além de não se ver o "U invertido", os resultados mostraram poucas semelhanças entre as suas trajetórias. Com exceção do par Brasil-Argentina, quando se controla pelo PIB per capita não há um padrão compartilhado claro, e quando se olha a evolução temporal, tendências gerais são apenas ligeiramente mais perceptíveis. Ninguém negaria que há em ação forças comuns, na esteira da globalização, ou estruturais. Porém, o filtro nacional ainda é decisivamente forte para moldar a concentração de renda no topo.

\subsection{Quão robustos são os resultados?}

As perguntas mais prementes que permanecem dizem respeito à confiabilidade e à robustez dos resultados discutidos nas seções anteriores. No primeiro caso, os problemas relacionam-se à natureza da coleta, fiscalização e publicação das tabelas com informações sobre as declarações do IRPF, assunto comentado no capítulo 4. Há certamente muitas deficiências nos dados, que em muitos casos - como a evasão e a elisão fiscais - sequer podem ser quantificadas. Apesar disso, pelo menos para os padrões da literatura internacional, não há motivos para crer que o Brasil se saia sistematicamente pior do que outros países. Os dados parecem ser confiáveis e de qualidade aceitável, e nenhum dos resultados é estapafúrdio ou inexplicável.

A pergunta relativa à robustez é mais pertinente, porque não foram poucos os procedimentos necessários para chegar aos resultados. Felizmente, é possível avaliar a influência das principais decisões metodológicas e das descontinuidades nas fontes de dados.

O único procedimento de maior vulto que não pode ser testado diretamente é a imputação de rendimentos não tributáveis para o período anterior a 1974 e para os anos 1996-1998, 2000 e 2002. Como dito anteriormente, o formulário do IRPF sequer registrava esses valores em suas primeiras décadas, e as tabulações disponíveis para os anos 1990 e início dos anos 2000 não incluem essas informações. Embora as técnicas de imputação sejam relativamente cruas, elas são as melhores opções diante dos dados 
disponíveis e produzem resultados plausíveis a partir de pressupostos aceitáveis (ver seção 4.9 do capítulo 4). Ademais, a imputação não altera as tendências reveladas apenas para o rendimento bruto tributável, constituindo, na pior das hipóteses, uma opção legítima para simplificar os gráficos e facilitar a exposição (ver Figura 32).

No que diz respeito às escolhas testáveis empiricamente, a análise de sensibilidade é encorajadora. Os resultados desta tese são substantivamente semelhantes aos obtidos em Souza (2014) e aos produzidos mais tarde, de forma independente, por Milá (2015). Isso é um sinal positivo de robustez, pois as séries apresentadas nesta tese são baseadas em várias escolhas metodológicas diferentes, pelos motivos expostos no capítulo 4.

O exame mais detalhado confirma essa robustez. Para começar, as próximas figuras comparam as séries para o centésimo mais rico a partir de tabulações ordenadas por diferentes conceitos de renda. A Figura 51 mostra a fatia relativa apenas aos rendimentos brutos tributáveis, enquanto a Figura 52 exibe a fração correspondente aos rendimentos totais. Nos dois gráficos, os pontos escolhidos para a série preferida estão em cinza.

Cinco observações podem ser feitas. Primeiro, a correção feita para 1927 faz sentido, porque a contaminação das tabulações desse ano por rendimentos recebidos no ano anterior produz resultados pouco críveis, com a fração do $1 \%$ mais rico caindo quase 5 p.p. de 1927 para 1928. Segundo, como já ocorrera nos resultados apresentados acima, os ajustes para a cobertura geográfica (em 1927-1943 e em 1966) e a imputação de abatimentos (1933-1949) e deduções cedulares (1927-1963) geram bons resultados, sem nenhuma descontinuidade perceptível nos anos relevantes. Terceiro, não há diferenças dignas de nota entre os resultados de tabulações ordenadas pela renda líquida ou pelo rendimento bruto tributável, como se vê na transição suave em 1969-1970 e na concordância entre elas em 2006-2013. Quarto, a discrepância entre os resultados das tabulações ordenadas pelos rendimentos brutos tributáveis e pelos rendimentos não tributáveis só aparece a partir de 1983, com a aceleração da inflação; antes disso, as duas séries estão próximas em nível e em tendência. Por sinal, mesmo as séries de rendimentos brutos tributáveis e de rendimentos totais para os dados ordenados pelo rendimento bruto tributável indicam aumento da fatia do $1 \%$ mais rico na segunda metade dos anos 1980, ainda que em menor grau do que a série preferida, baseada nas tabulações por rendimentos não tributáveis. Quinto, o maior problema de comparabilidade dos dados está na mudança para tabulações ordenadas por rendimentos totais a partir de 2006: como se vê na Figura 52, a concentração no topo medida assim é mais elevada do que nas outras séries e dá sinais de leve aumento. ${ }^{22}$

Dessa forma, o saldo é positivo para a comparabilidade dos dados ao longo do tempo. A principal inconsistência está na última década: como a série que mais se aproxima do ideal, a ordenada por rendimentos totais, está disponível somente de 2006 a 2013, há uma chance de que os resultados anteriores a esse período estejam subestimados e que,

$\overline{22}$ Os procedimentos mencionados neste parágrafo são descritos em detalhe no capítulo 4. 
Figura 51. Fração recebida pelo 1\% mais rico considerando apenas os rendimentos brutos tributáveis para a série preferida e séries observadas ordenadas por diferentes conceitos de renda - Brasil, 1926-2013 (\%)

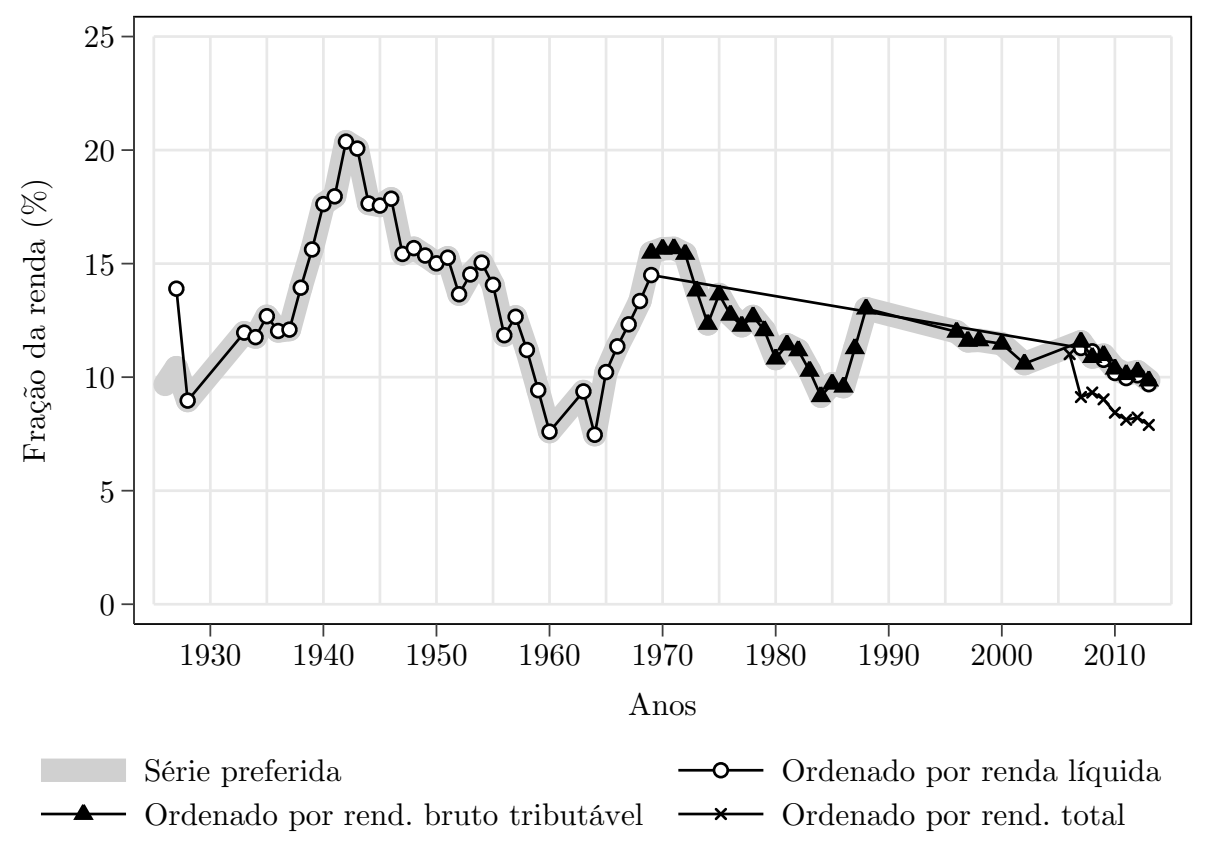

Fonte: elaboração própria a partir de tabulações de dados tributários e das Contas Nacionais; ver capítulo 4.

Figura 52. Fração recebida pelo $1 \%$ mais rico considerando os rendimentos totais para a série preferida e séries observadas ordenadas por diferentes conceitos de renda - Brasil, $1974-2013(\%)$

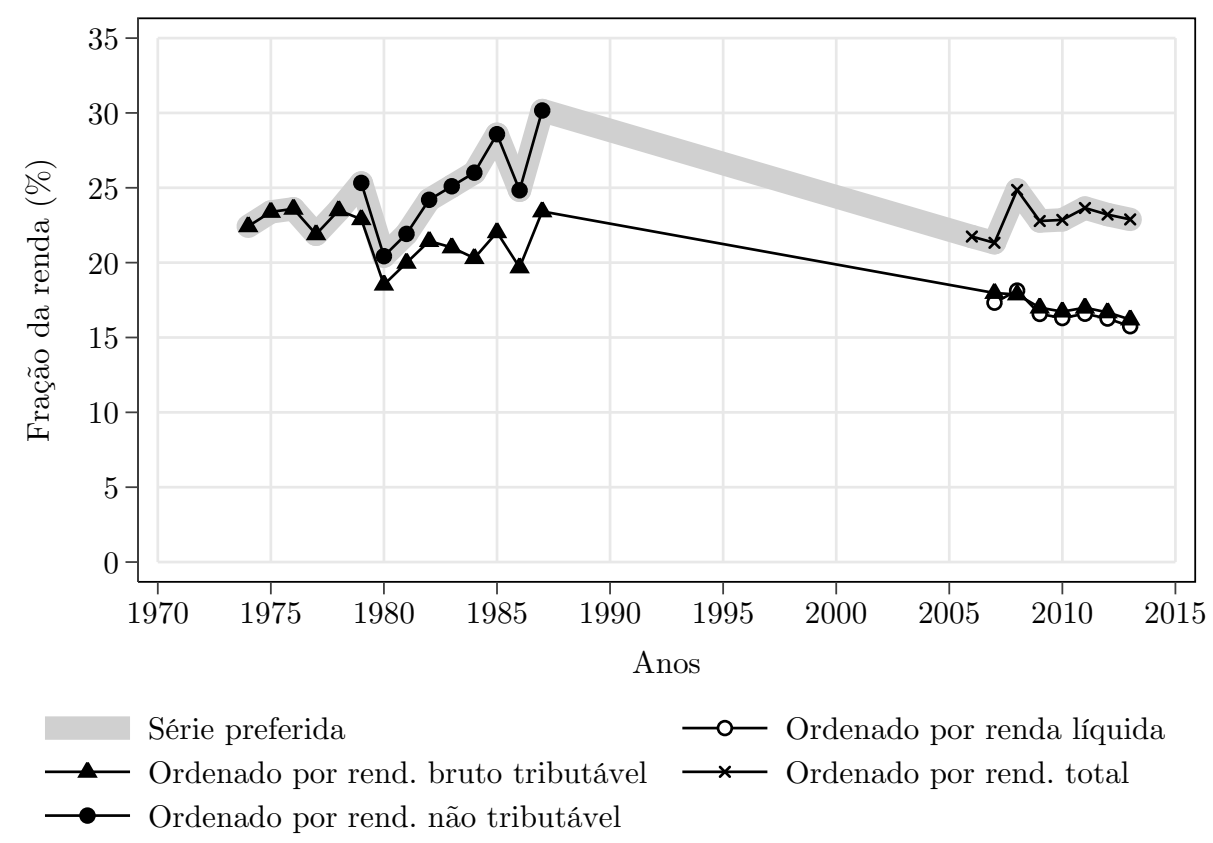

Fonte: elaboração própria a partir de tabulações de dados tributários e das Contas Nacionais; ver capítulo 4. 
como dito, a queda da concentração no topo desde o seu pico no fim dos anos 1980 tenha se prolongado até meados da década passada. Infelizmente, não é possível chegar a conclusões definitivas sobre isso. Seja como for, há pelos dois indícios de que a eventual subestimação não deve ser tão grave: primeiro, isso implicaria níveis de desigualdade implausivelmente altos em vários momentos no Brasil, jamais vistos em qualquer outro país; segundo, o escopo dos rendimentos não tributáveis aumentou nos últimos anos e a reformulação da lógica de apuração do IRPF depois de 1988 impossibilita qualquer transposição direta de relações atuais para os dados históricos.

O passo seguinte é testar como a escolha dos denominadores para a população e renda afetam os resultados. As Figuras 53 e 54 mostram o que aconteceria com a fração do centésimo mais rico - considerando, respectivamente, apenas os rendimento brutos tributáveis e os rendimentos totais - com quatro definições distintas para a população total. A primeira, representada pela série preferida em preto, corresponde aos indivíduos com 20 anos ou mais. Como não há consenso a respeito, os outros três cenários exploram opções relativamente intuitivas: indivíduos com 15 anos ou mais, famílias de indivíduos com 20 anos ou mais e um híbrido entre os dois, calculado para levar em conta as mudanças nos incentivos tributários à declaração conjunta de casais. O número de famílias foi obtido, como de praxe, subtraindo o número de mulheres casadas do total de indivíduos de 20 anos ou mais, e a variável híbrida somou ao número de famílias a quantidade de mulheres casadas que declararam separadamente IRPF ao longo do tempo. ${ }^{23}$

Em última instância, qualquer um desses quatro denominadores é razoável. A escolha de indivíduos com 20 anos ou mais deu-se por três motivos principais. Primeiro, a fidelidade aos incentivos tributários, já que há vantagens para os casais mais ricos declararem sua renda em separado se ambos tiverem rendimentos tributáveis mais elevados. Segundo, a manutenção de uma referência objetiva compreensível, a população adulta. Terceiro, por ser a definição que melhor combina duas razões importantes para o estudo dos ricos: a riqueza como fonte de poder e como disparidade de bem-estar. A base individual leva em conta inclusive a desigualdade intrafamiliar e, se o objetivo for priorizar a análise de bem-estar, considerar as famílias como referência só resolve parcialmente o problema, porque uma das maiores mudanças foi a redução da fecundidade e de sua dispersão ao longo da estrutura social, e as informações disponíveis não permitem o cálculo do número de filhos por domicílio. Por sua vez, a unidade de referência individual permite identificar a importância de outra transformação de longo prazo momentosa, a entrada das mulheres no mercado de trabalho, como ficou claro na seção 5.4.2.

Matematicamente, quanto maior a população total escolhida, maior a fração apropriada pelos estratos mais ricos, porque o número de indivíduos necessários para atingir $x \%$ da população aumenta, ao passo que o denominador de renda permanece constante (e

23 Vários desses valores tiveram que ser imputados ou interpolados; os detalhes podem ser obtidos com o autor. Durante a maior parte do tempo, o denominador híbrido e o familiar são pouco distinguíveis. 
Figura 53. Fração recebida pelo $1 \%$ mais rico considerando apenas os rendimentos brutos tributáveis, com diferentes denominadores de população total - Brasil, 1926-2013 (\%)

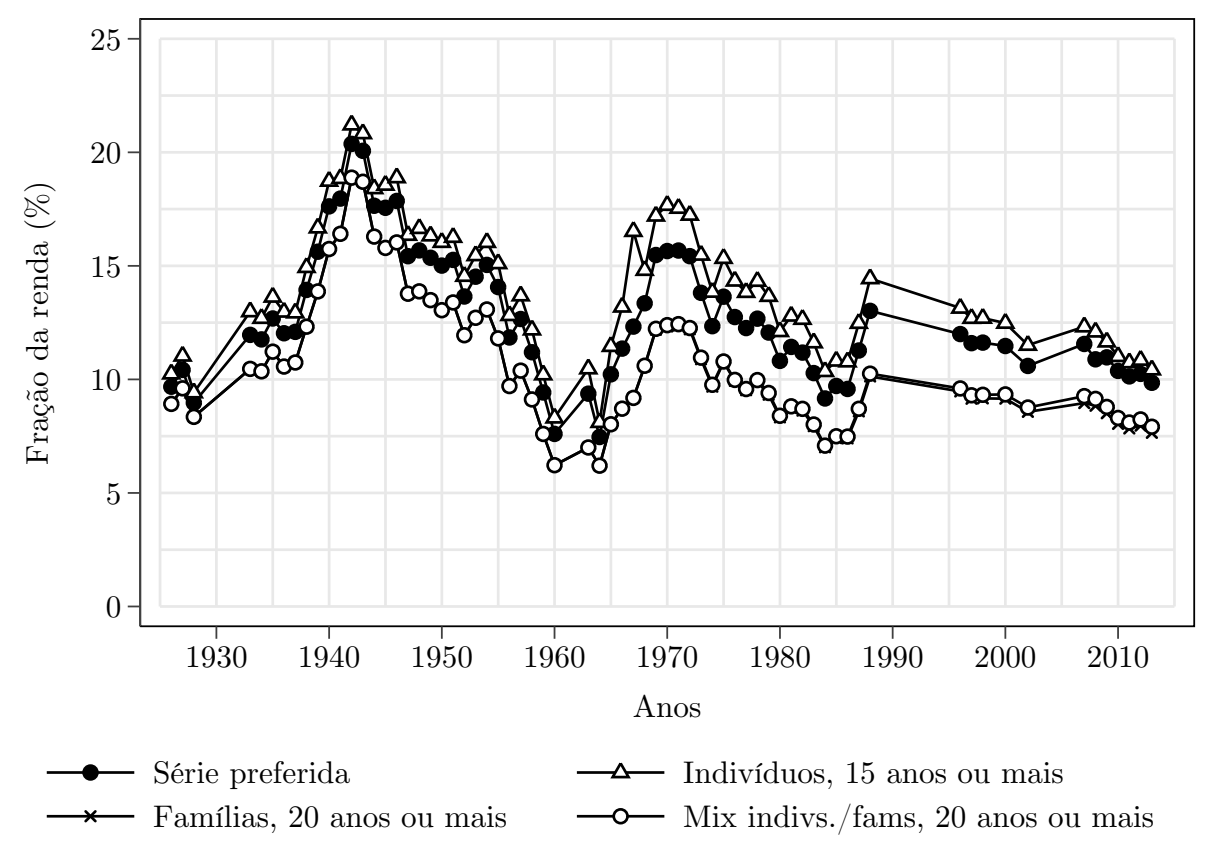

Fonte: elaboração própria a partir de tabulações de dados tributários e das Contas Nacionais; ver capítulo 4.

Figura 54. Fração recebida pelo $1 \%$ mais rico considerando rendimentos totais, com diferentes denominadores de população total - Brasil, 1974-2013 (\%)

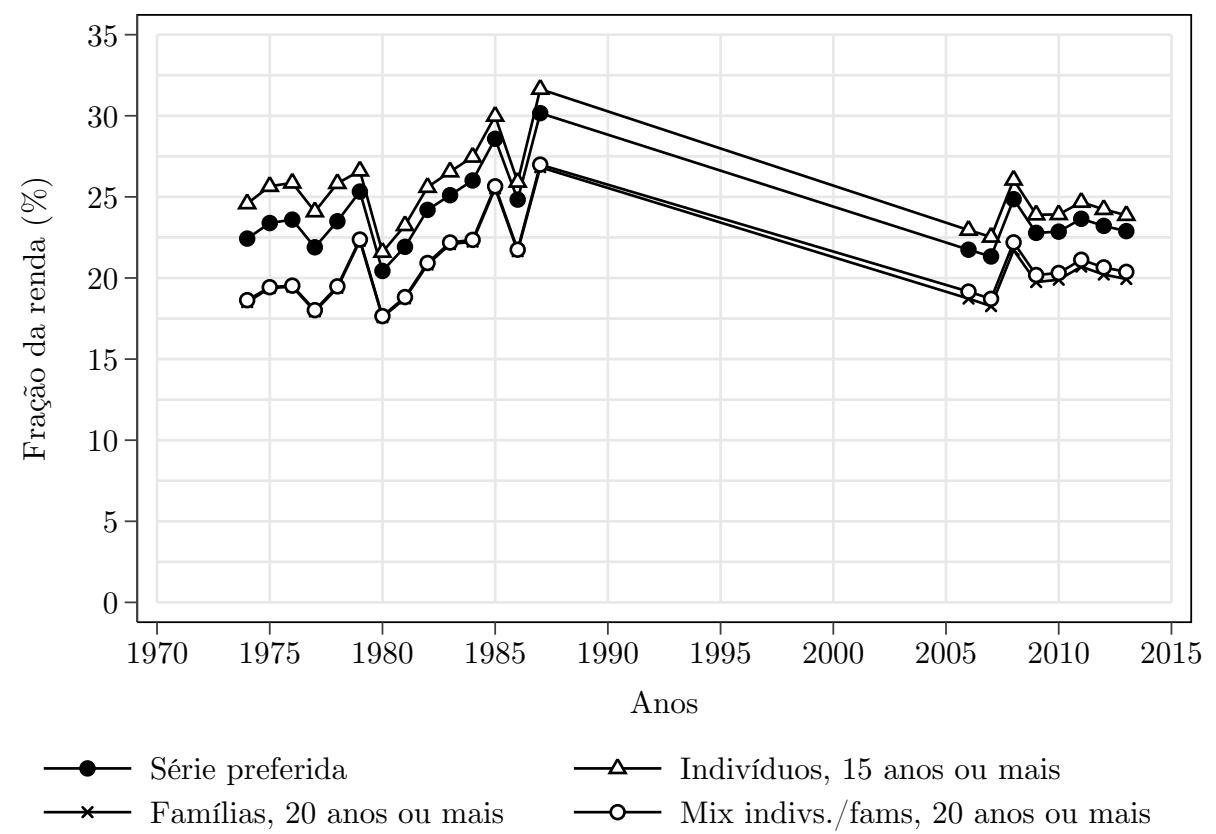

Fonte: elaboração própria a partir de tabulações de dados tributários e das Contas Nacionais; ver capítulo 4. 
vice-versa). Assumindo que o topo da distribuição de renda segue a fórmula de Pareto, podemos estimar ex ante o impacto de mudanças no denominador de população. Como mostrou Atkinson (2007), se um controle populacional for multiplicado por $(1+c)$, com um coeficiente de Pareto $a$, a fração recebida pelos $x \%$ mais ricos aumenta em:

$$
\Delta_{t o p x \%}(\%)=(1+c)^{1-\frac{1}{a}}
$$

Logo, se o $1 \%$ mais rico possui $25 \%$ da renda total e $a=1,6$ (valor médio para o Brasil), um aumento de $20 \%$ na população total $(c=0,20)$ eleva a fração recebida pelo centésimo mais rico em $7 \%$, de $25 \%$ para $26,8 \%$. Ou seja, trata-se de uma mudança apenas moderada em pontos percentuais. O acréscimo de $20 \%$ equivale, grosso modo, ao obtido com o rebaixamento da linha de corte do denominador de 20 para 15 anos de idade.

As Figuras 53 e 54 ilustram empiricamente essa mecânica. Como esperado, quanto mais restrita a população total, menor a desigualdade. Na comparação entre extremos, trocar a série preferida pela série baseada em famílias (ou no híbrido entre famílias e indivíduos) derrubaria a concentração no topo, em média, em pouco mais de 2 p.p. nos rendimentos brutos tributáveis e de 3 p.p. nos resultados para rendimentos totais. Nenhuma das conclusões quanto ao nível ou às tendências da desigualdade seria substantivamente alterada. No limite, o uso de indivíduos acima de 15 anos - em vez de 20 anos ou mais tornaria a elevação da desigualdade nos anos 1960 um pouco mais pronunciada.

O mesmo exercício pode ser repetido para o controle para a renda total. As Figuras 55 e 56 comparam a série preferida, em que o denominador é calculado a partir do máximo de informações disponíveis, com outras duas possibilidades intuitivas. A primeira segue a opção mais comum da literatura e escolhe como denominador o valor fixo de $66 \%$ do PIB, percentual igual à média observada para os anos em que todas as informações necessárias estão disponíveis. A segunda alternativa ancora o denominador em outro agregado macroeconômico, o consumo final das famílias, usando também o valor médio observado para o período com informações mais detalhadas. ${ }^{24}$

Os efeitos de mudanças no denominador de renda podem ser calculados com um pouco de aritmética básica: se o controle para a renda for multiplicado por $(1+c)$, a fração da renda total recebida pelos $x \%$ mais ricos diminui em $(1+c)^{-1 \%}$. Ou seja, se o centésimo mais rico tem $25 \%$ do total, a adoção de outro denominador de renda $20 \%$ maior reduz esse valor em quase $17 \%$, para $20,8 \%$ da renda total.

As Figuras 55 e 56 mostram que o uso de denominadores alternativos para renda total tem efeitos ainda menores do que o de controles alternativos para a população. De

$24 \mathrm{O}$ consumo das famílias entra no cálculo do PIB pela ótica da despesa, calculado por $P I B=$ $C+G+I+(X-M)$, em que $C$ é o consumo final de famílias e instituições sem fins lucrativos, $G$ é a despesa de consumo final do governo, $I$ é a soma da formação bruta de capital fixo e da variação de estoques, $X$ são as exportações de bens e serviços e $M$ são as importações de bens e serviços. 
Figura 55. Fração recebida pelo $1 \%$ mais rico considerando apenas os rendimentos brutos tributáveis, com diferentes denominadores de renda total - Brasil, 1926-2013 (\%)

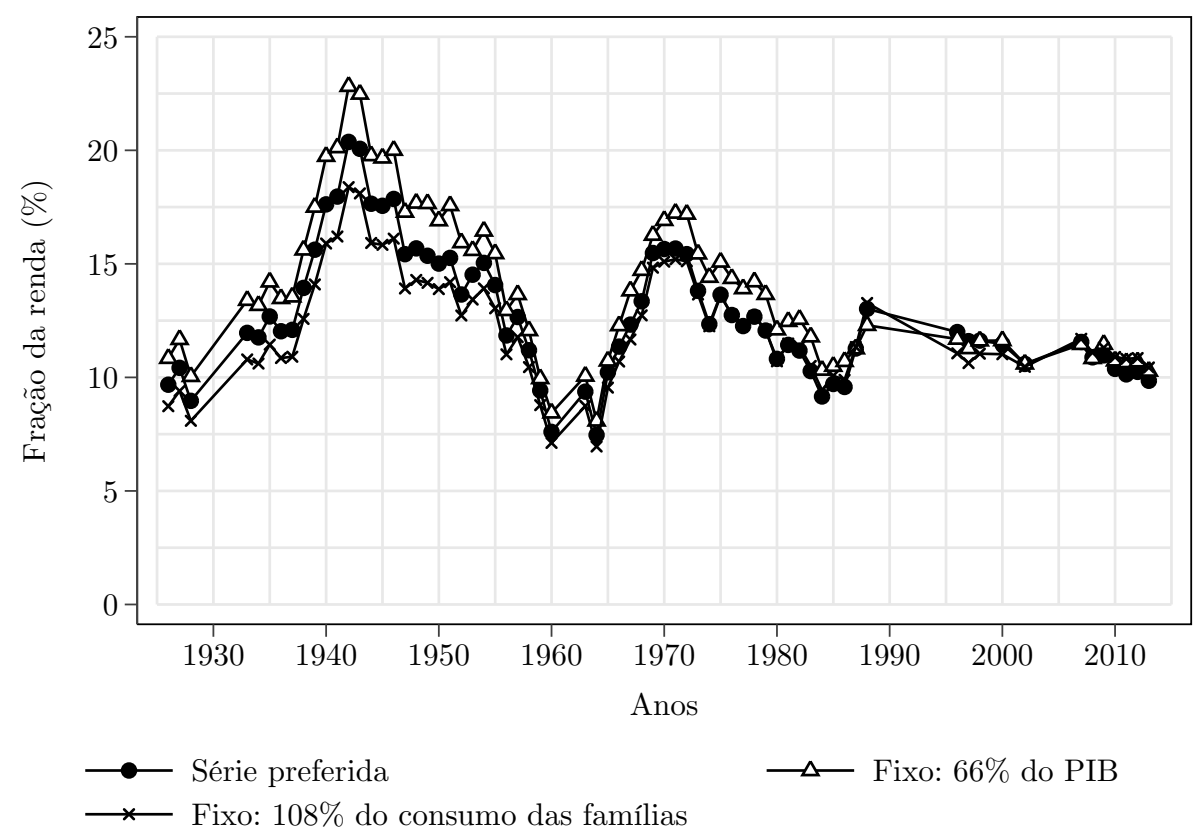

Fonte: elaboração própria a partir de tabulações de dados tributários e das Contas Nacionais; ver capítulo 4.

Figura 56. Fração recebida pelo $1 \%$ mais rico considerando os rendimentos totais, com diferentes denominadores de renda total - Brasil, 1974-2013 (\%)

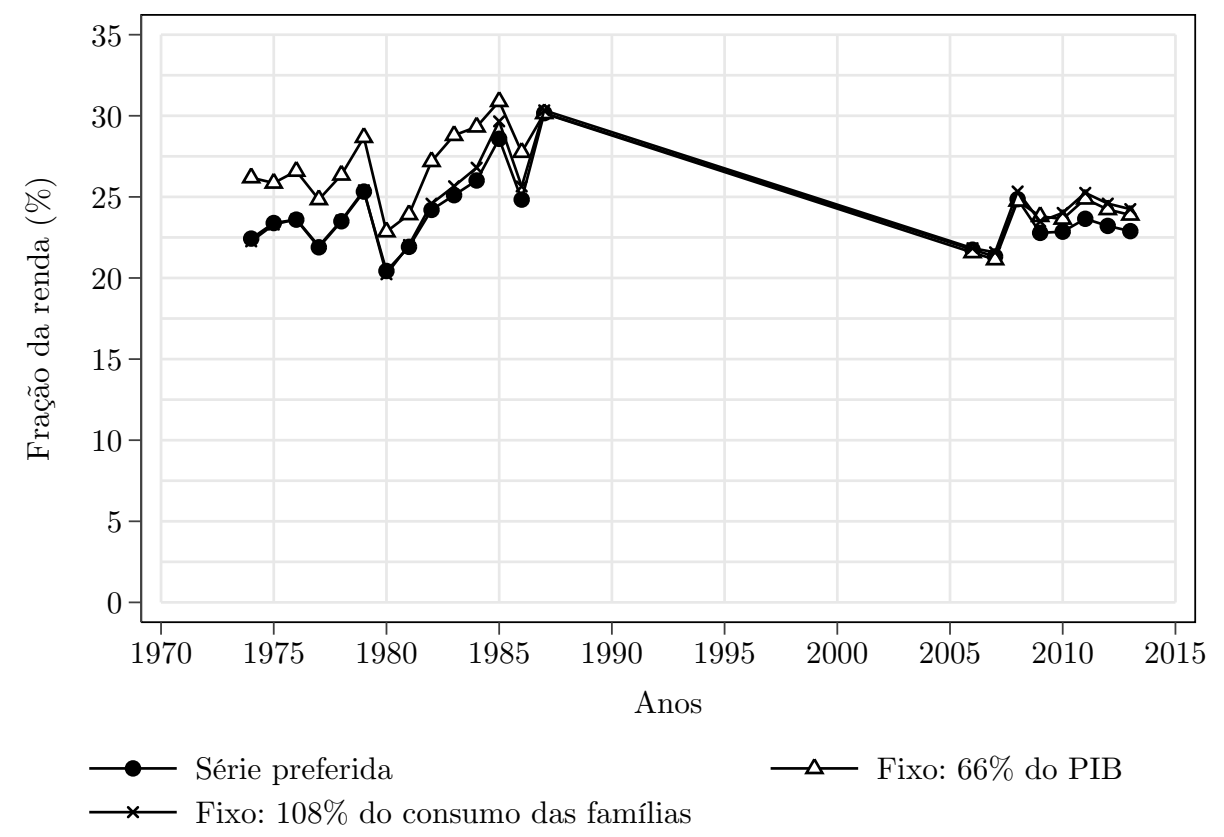

Fonte: elaboração própria a partir de tabulações de dados tributários e das Contas Nacionais; ver capítulo 4. 
novo, as tendências permanecem virtualmente idênticas e os níveis variam pouco, mais no início do que no fim do período. O denominador escolhido é mais justificável em termos lógicos e, na prática, serve como um meio termo entre as duas alternativas investigadas, pelo menos no período mais problemático entre os anos 1930 e 1960 . O uso de uma fração fixa do PIB, além de irrealista, acentua a montanha-russa das primeiras décadas, exagerando o aumento da concentração no topo nos anos 1940 e depois do golpe militar, bem como sua redução na segunda metade dos anos 1950.

A alteração simultânea dos controles para população e renda produz resultados semelhantes, não havendo interação relevante entre eles. Por motivos de espaço, os gráficos foram omitidos. Similarmente, não explorarei aqui os efeitos da dedução do consumo de capital fixo das famílias, que são diminutos, mal provocando mudanças de mais de 1 p.p..

Em resumo, as análises respaldam a robustez dos resultados deste capítulo a outras escolhas metodológicas razoáveis. A evolução da desigualdade, em particular, muda muito pouco em diferentes cenários, havendo só discrepâncias no patamar médio da concentração no topo, como esperado. Pelos motivos explicitados aqui e no capítulo 4, a série dita "preferida" é a mais apropriada, embora tenha suas limitações. As mais graves dizem respeito à impossibilidade de validar satisfatoriamente a imputação dos rendimentos não tributáveis e à chance de que a concentração esteja subestimada antes de 2006.

\subsection{Considerações finais}

A história da desigualdade de renda no Brasil no século XX não se presta a narrativas simples. Os resultados baseados em tabulações do IRPF mostram que, entre 1926 e 2013, a concentração no topo combinou estabilidade e mudança. A estabilidade expressa-se na ausência de tendências claras de longo prazo e na flutuação da fração da renda recebida pelo $1 \%$ mais rico entre $20 \%$ e $25 \%$ durante grande parte do tempo. Tamanha concentração destoa dos padrões internacionais e coloca sempre o Brasil entre os países mais desiguais dentre aqueles com dados disponíveis. Com isso, não é exagero reafirmar que o quinhão apropriado pelos ricos é o traço marcante da desigualdade brasileira.

A permanência da desigualdade deu-se em meio a mudanças econômicas e sociais muito profundas em um país cuja população multiplicou-se por seis e o PIB per capita aumentou 12 vezes ao longo de nove décadas. Para recuperar a boa e velha metáfora culinária, o bolo cresceu, mas não foi dividido, nem mesmo nos últimos anos: na contramão dos resultados mais positivos das pesquisas domiciliares, nos dados tributários a fatia da renda apropriada por todos os estratos no topo - do 0,01\% aos $15 \%$ mais ricos - ficou, na melhor das hipóteses, relativamente estável entre 2006 e 2013, com leves sinais de aumento.

Nada disso deve obscurecer o fato de que estabilidade não é sinônimo de tranquilidade. Pelo contrário, mesmo que o saldo líquido final tenha sido quase nulo, houve 
muitas idas e vindas significativas. Ao que tudo indica, a concentração no topo aumentou bastante no Estado Novo e especialmente durante a $2^{a}$ Guerra Mundial, com grandes ganhos relativos para os mais ricos entre os mais ricos, isto é, o $0,01 \%$ e $0,1 \%$. Com o fim da ditadura e das condições excepcionais de guerra, a concentração arrefeceu e em 1950 já estava de volta ao patamar de meados dos anos 1930. Depois de alguns anos de estabilidade, a fração dos mais ricos voltou a declinar de forma consistente nos últimos anos dos interregnos democrático de 1945-1964, sobretudo na segunda metade da década de 1950, quando atingiu os valores mais baixos da série histórica, em um movimento descendente puxado pelas perdas relativas do $0,01 \%$ e $0,1 \%$ mais ricos.

O golpe militar marcou um ponto de inflexão, com a fração do centésimo mais rico revertendo a tendência anterior e subindo de pouco menos de $20 \%$ para mais de $25 \%$ entre 1964 e 1970. Dessa vez, o recrudescimento da concentração no topo não foi movido pelos mais ricos entre os mais ricos, e sim pelos estratos logo atrás. Esse aumento não pode ser facilmente vinculado a narrativas benignas kuznetsianas que ligam a maior desigualdade ao crescimento, pois ocorreu em sua maior parte nos anos de estagnação e ajuste, antes da decolagem econômica em 1968. Na maior parte do "milagre", entre 1970 e 1974, a fração dos mais ricos pouco mudou, declinando de leve na segunda metade dos anos 1970. A instabilidade macroeconômica que se seguiu ensejou instabilidade também na concentração do topo, que, grosso modo, subiu muito durante a "década perdida" de 1980, mais uma vez puxada pelos mais ricos entre os mais ricos. Depois disso, a ausência de dados e as reformas do IRPF tornam a análise mais incerta. O que se pode dizer é que houve uma queda importante entre o fim dos anos 1980 e meados dos anos 1990, ou talvez até dos anos 2000, se levarmos em conta a ausência de dados ordenados por rendimentos totais e a necessidade de imputação dos rendimentos não tributáveis. A partir de 2006, como dito, não houve nenhuma mudança digna do nome.

Essas e outras evidências permitem retomar as três perguntas que organizaram a discussão do capítulo. A primeira dizia respeito à existência ou não de tendências de longo prazo na concentração de renda, sobretudo decorrentes de mudanças estruturais como industrialização e urbanização. A hipótese mais tradicional é a da curva em "U invertido" postulada por Kuznets, que destaca forças que primeiro aumentam e depois reduzem a desigualdade, conforme o processo de desenvolvimento econômico amadurece. Nada nos resultados autoriza essa interpretação. A concentração no topo no Brasil não apresenta nenhuma tendência unívoca de longo prazo, seja para o aumento ou para a diminuição da desigualdade. As ondas de ascensão e queda que tivemos dificilmente cabem no modelo de Kuznets, estando mais próximas da caracterização empírica de Frankema (2009). Isso, aliás, não é exclusividade brasileira: como visto, o "U invertido" de Kuznets foi virtualmente inexistente nos últimos cem anos nos países para os quais há informações.

A segunda pergunta dizia respeito à relação entre o regime político e a desigualdade, ou seja, se a democracia está associada a uma menor concentração no topo, como preconizam 
teorias do eleitor mediano e muitas interpretações recentes do Brasil. A resposta é que isso é só parcialmente verdadeiro. A fração dos mais ricos foi maior durante nossas duas ditaduras do último século e menor após as redemocratizações, mas não se podem deixar de fazer qualificações importantes. Primeiro, a combinação do Estado Novo com a $2^{a}$ Guerra parece ter sido mais relevante para a alta da desigualdade do que o regime ditatorial puro e simples, assim como a eliminação das condições excepcionais da guerra parecem ter sido fundamentais para sua redução imediata. Segundo, a piora da concentração no topo depois do golpe de 1964 ocorreu na primeira década da ditadura, com subsequente estabilidade e até certa queda. Terceiro, a redemocratização em 1985 não provocou nenhuma redistribuição imediata no topo, o que ocorreu apenas com a estabilização macroeconômica e o fim da prolongada crise política e econômica que assolava o país. Por fim, o amadurecimento recente da nossa democracia, com a progressiva implementação de dispositivos constitucionais e expansão de gastos e serviços sociais, não gerou quedas significativas da concentração no topo no período mais recente.

Já a terceira pergunta relacionava-se à excepcionalidade da desigualdade brasileira e latino-americana. A hipótese de Williamson (2015) é que, contra a sabedoria convencional, a América Latina só se tornou muito mais desigual do que o mundo desenvolvido no século XX, ao perder o chamado "grande nivelamento". Nós teríamos ficado no mesmo lugar no momento em que muitos países caminharam para sociedades mais igualitárias. Mais uma vez, as evidências indicam que, no caso brasileiro, Williamson está só parcialmente correto. Como visto, a distância entre as frações recebidas pelos mais ricos no Brasil e no mundo aumentou ao longo do tempo. Nove décadas atrás éramos apenas um pouco mais desiguais do que vários países ricos e, ao comparar a relação entre concentração no topo e o PIB per capita, vimos que o Brasil não está tão distante da posição ocupada por esses países quando tinham nosso nível de desenvolvimento. Ainda assim, é preciso fazer ressalvas importantes: primeiro, podíamos estar mais perto, só que já éramos um pouco mais desiguais, o que sugere que essa jabuticaba é mais antiga; segundo, o Brasil - assim como a Argentina também viveu um "mininivelamento" na era de ouro do desenvolvimentismo, nos anos 1950, revertido com o golpe militar.

Diante disso, há espaço para arriscar uma interpretação de caráter institucional das tendências da concentração de renda no topo. A desigualdade tem, aqui e em outros países, grande força inercial, com as maiores mudanças em geral concentradas em períodos curtos e turbulentos - o que chamei aqui de hipótese Jencks-Piketty de que grandes transformações só ocorrem com grandes choques. No Brasil, há uma correlação entre grandes ciclos políticos e o sobe e desce da fatia dos mais ricos, mesmo que essa relação não se encaixe perfeitamente com a oposição entre democracia e ditadura, e tenha a ver com a persistência institucional. Em condições normais, a desigualdade é produzida e reproduzida por uma série de pequenas e grandes decisões e acordos.

O $1 \%$ ou qualquer outro grupo estatisticamente definido como rico não constitui 
uma "elite do poder" no sentido de Wright Mills (1959), mas contém subgrupos com recursos e interesses em comum que se traduzem muitas vezes em organização e poder de barganha e de veto. Com isso, não obstante as pressões redistributivas em regimes democráticos, criam-se possibilidades para que perdas sejam compensadas e ganhos sejam obtidos - ganhos esses que, simetricamente, podem ser contestados e revertidos, dada a necessidade de todo governo de garantir uma ampla base social de apoio.

Essa determinação institucional da desigualdade não opera no vácuo, nem é preciso que os ganhos e perdas assumam a feição mais escancarada de favoritismo ou rentseeking. Instituições e políticas criam e organizam mercados e geram oportunidades econômicas, moldando a distribuição e os retornos dos ativos desigualmente distribuídos entre a população. O quid pro quo político permite a mobilização de recursos - inclusive intelectuais - para influir sobre a pletora de regulações, programas e afins que cumprem esse papel, e não raro com uma lógica de benefícios concentrados e custos difusos.

Tudo isso implica que reformas graduais e duradouras têm grande dificuldade em sair do papel, e apenas em momentos de crise e ruptura determinados atores adquirem a capacidade temporária de reformar profundamente as instituições em direções bem definidas. No mundo, a combinação de mobilização social com os imperativos e efeitos da $2^{a}$ Guerra levou à emergência nos Estados Unidos do aparato institucional denominado por Levy e Temlin (2007) de "Tratado de Detroit", ao passo que a crise econômica e social dos anos 1970 e as mudanças no clima intelectual gestaram o arranjo resumido pela alcunha já irritantemente desgastada - de "Consenso de Washington" (ver discussão no capítulo 3). No Brasil, o maior exemplo de "inovação" institucional foi dado pela ruptura autoritária de 1964 e suas consequências regressivas, que, por sinal, não tiveram seu par simétrico na redemocratização dos anos 1980 .

Se este esboço interpretativo estiver correto, então não há otimismo possível, do ponto de vista da redução da desigualdade, diante da difícil missão brasileira. Não há na literatura internacional exemplos de países que tenham partido do nível de concentração no topo registrado por aqui - próximo a $25 \%$ para o centésimo mais rico - e tenham avançado de forma lenta e segura, sem sobressaltos, tragédias ou quebras institucionais, para o patamar observado na maior parte dos países ricos e mesmo em muitos países em desenvolvimento, em torno de 10\%. O exemplo mais próximo ocorreu nos Estados Unidos e teve a direção oposta.

Dá para ser mais otimista quando o conceito de desigualdade é alargado do topo para toda a distribuição e avaliado por medidas sintéticas como o coeficiente de Gini, em vez da fração recebida pelos ricos. Como esperado, a comparação dos dados tributários com pesquisas domiciliares mostra que as PNADs e, em grau menor, os Censos Demográficos, de fato subestimam a participação dos mais ricos na renda total. Ao se corrigir o coeficiente de Gini para levar em conta essa subestimação, os resultados triunfantes das PNADs 
pioram em nível e trajetória, sem sumir por completo. Pelo menos entre o fim da década de 1980 e 2006, a combinação da entrada das mulheres na força de trabalho com os avanços educacionais e políticas sociais provocou uma redução razoável no Gini.

Desde então, a leve tendência de aumento da fração dos mais ricos acabou por anular os ganhos posteriores, o que atesta tanto sua influência sobre o nível e a dinâmica da desigualdade quanto a especificidade da interpretação esboçada acima. As possibilidades de redistribuição entre os "não ricos" parecem ser bem maiores e, de fato, tudo sugere que as celebradas mudanças sociais recentes afetaram muito mais a parte de baixo ou meio da distribuição de renda do que o topo. Em virtude do grau de concentração entre os ricos, os limites dessa estratégia são bem estreitos, e não é por acaso que até nos dados originais das PNADs o ritmo da queda da desigualdade diminuiu bastante nos últimos anos. Entre 2005 e 2009, o Gini dos rendimentos individuais da população adulta caiu 4,9\%, contra uma redução de apenas 3,4\% entre 2009 e 2013 e estabilidade entre 2012 e 2013. Algo parecido ocorreu com o Gini da renda domiciliar per capita.

Em função desses resultados e da interpretação proposta, a lacuna remanescente diz respeito às políticas e decisões específicas que embalaram tanto as variações quanto a estabilidade da concentração no topo. O próximo capítulo tenta preenchê-la ao menos parcialmente, examinando em mais detalhe a história brasileira ao longo dessas nove décadas e apresentando resultados e evidências adicionais para subperíodos relevantes.

Por fim, cabe relembrar que as tabulações do IRPF e o resultados obtidos a partir delas são imperfeitos. Muitos procedimentos foram necessários para transformar as tabelas disponíveis em séries para a concentração de renda no topo. Nem todos são controversos ou têm potencial para afetar decisivamente os resultados; alguns são mais significativos e, nos piores casos, impossíveis de serem validados. Felizmente, os resultados são muito plausíveis e os testes de robustez, muito satisfatórios. Nada indica que nossas informações são sistematicamente piores que as de outros países. Ainda assim, é bom temperar conclusões fortes com uma dose de cautela e admitir que a palavra definitiva sempre está por vir. 


\title{
6 Uma história política da desigualdade no Brasil
}

\begin{abstract}
José Bonifácio afirmou, em representação enviada à Assembléia
Constituinte de 1823, que a escravidão era um câncer que corroía nossa vida cívica e impedia a construção da nação. A desigualdade é a escravidão de hoje, o novo câncer que impede a constituição de uma sociedade democrática. A escravidão foi abolida 65 anos após a advertência de José Bonifácio. A precária democracia de hoje não sobreviveria a espera tão longa para extirpar o câncer da desigualdade. José Murilo de Carvalho, Cidadania no Brasil (2008)
\end{abstract}

\subsection{Introdução}

A realidade que levou José Murilo de Carvalho a encerrar seu livro sobre cidadania com a admoestação sinistra reproduzida na epígrafe não mudou muito, pelo menos no que diz respeito à concentração da renda entre os mais ricos. Os resultados discutidos no capítulo anterior mostram que, de acordo com os dados do IRPF, a concentração no topo no Brasil não se alterou radicalmente no último século. Ela tampouco permaneceu estagnada, caracterizando-se por idas e vindas significativas, cujas ocorrências apresentam paralelos marcantes com a história política e econômica do Brasil.

A interpretação esboçada enfatizou a determinação institucional da desigualdade e seu caráter inercial, e propôs que a correlação com os grandes ciclos políticos não é mera coincidência. Em condições políticas minimamente democráticas, é difícil alterar significativamente a distribuição de renda, que é moldada e reproduzida pelo efeito combinado - e muitas vezes não intencional - de políticas, programas e regulações. Com isso, grupos organizados e com poder de barganha têm sempre boas oportunidades para mitigar ou reverter perdas e ocasionalmente obter ganhos, resultando, grosso modo, em um jogo de soma zero, ao menos no que diz respeito à concentração no topo, dados os recursos políticos e econômicos à disposição dos mais ricos. ${ }^{1}$

O objetivo deste capítulo é explorar mais a fundo essa interpretação, a partir de uma perspectiva histórica. O argumento central é que a história política brasileira é compatível com essa leitura, sendo possível identificar ao menos parte das inovações

1 Os efeitos combinados de políticas díspares foram enfatizados explicitamente por Marta Arretche (2016). A diferença aqui é sobretudo de tom: em virtude do enfoque multidimensional e da análise da distribuição de renda como um todo em pesquisas domiciliares, a autora fez uma leitura otimista da evolução político-institucional do Brasil nas últimas décadas. A seção 6.6 volta a esse ponto. 
políticas e institucionais plausivelmente por trás dos movimentos da desigualdade. Não se afirma aqui, em absoluto, que a dinâmica político-institucional flutue no vazio ou seja o único determinante da concentração de renda; pelo contrário, em muitos casos, destaca-se explicitamente como o sistema político atuou para filtrar, amplificar, minimizar ou redistribuir choques e pressões econômicas, demográficas e afins. O ponto é que essa intermediação sempre possui alguma margem de manobra e, intencionalmente ou não, as decisões tomadas implicam em perdas e ganhos para diferentes grupos. As oportunidades econômicas criadas por essas decisões dificilmente são neutras em termos distributivos, beneficiando desproporcionalmente os grupos com os recursos mais apropriados para explorá-las, que, via de regra, tendem a mobilizar-se e a lançar mão de meios econômicos, políticos e intelectuais para obter as concessões desejadas.

Embora um objetivo secundário também seja o de apresentar mais evidências obtidas nos dados tributários, este capítulo, por sua própria natureza, é muito mais especulativo que o anterior. Não há aqui nenhuma ambição de identificar e mensurar econometricamente os impactos das políticas e programas mencionados, o que, de resto, seria na maior parte dos casos inviável, devido à falta de informações disponíveis. Por isso, a extensa literatura sobre a história política e econômica do Brasil é a principal fonte, em particular para o passado mais remoto. A ambição não é, nem de longe, entrar em detalhes de quase cem anos de história, o que tampouco seria viável no escopo deste trabalho. Tratase de recorrer à historiografia para dar substância à interpretação proposta, colocando em relevo alguns do principais acontecimentos e decisões políticas com consequências relevantes para a dinâmica da desigualdade.

Os mesmos esclarecimentos, caveats e definições mencionados no capítulo anterior valem aqui. Em particular, os resultados comentados dizem respeito às séries preferidas, com todas as imputações necessárias, para os estratos calculados com base na população de 20 anos ou mais e controle da renda variável em relação ao PIB. Como já ficou claro, esses dados possuem imperfeições e limitações, mas constituem a melhor maneira de estudar os mais ricos e talvez a única forma de obter estimativas históricas de longo prazo. Esse foco implica que os termos "desigualdade" e "concentração de renda no topo" continuam a ser usados de modo intercambiável, a não ser quando dito o contrário. Mais uma vez, é forçoso reconhecer que há muitos olhares possíveis sobre a desigualdade, e que a priorização dos mais ricos não é a única forma de abordar o tema.

Dessa forma, o recorte deste capítulo privilegia medidas e políticas com impactos específicos sobre o topo da distribuição. Nesse sentido, duas ressalvas adicionais precisam ser feitas. Primeiro, trata-se de um argumento que inevitavelmente destaca instituições políticas stricto sensu. Pouco ou nada é dito sobre o mercado enquanto instituição ou a construção social de um campo "econômico", temas caros à sociologia econômica. Segundo, nem sempre é possível isolar com clareza as medidas que afetam diferentes partes da distribuição. Se é verdade que nem todos estão expostos às mesmas influências, também é 
fato que há algumas influências comuns, seja por vias diretas ou indiretas. Por uma série de motivos, inclusive a maior disponibilidade de informações, esse exercício é mais fácil para o período mais recente, de modo que a discussão do passado mais afastado é mais especulativa, em particular o período entre 1946 e 1964, como reconhecido no texto.

Este capítulo evita deliberadamente entrar na questão das causas e entraves ao crescimento econômico, tecendo apenas comentários pontuais e esparsos. Muitas das políticas citadas nas próximas seções certamente tiveram efeitos relevantes, positivos ou negativos, sobre o desempenho econômico no curto e no longo prazo. Esses efeitos não são o objeto principal de interesse aqui, nem se trata de argumentar que há ou não relações causais unívocas entre menor desigualdade e maior crescimento. Dado o estado atual do conhecimento, é improvável que afirmações taxativas possam ser feitas em um futuro próximo. Por ora, basta reconhecer que, se por um lado há bons motivos para crer que a redução da desigualdade poderia elevar o potencial de crescimento do país, também é razoável supor que há limites para o grau de redistribuição factível no curto prazo sem transtornar a ordem social, ponto levantado por Alston et al. (2013, p. 64) que se relaciona à interpretação central proposta aqui.

O capítulo está organizado conforme a dinâmica da desigualdade apresentada anteriormente. Para evitar a repetição das figuras do capítulo 5, cada seção começa com uma recapitulação breve da trajetória da concentração no topo no período. No total, são sete seções, além desta introdução: a seção 6.2 trata dos anos entre 1926 e 1945, quando a fração dos mais ricos aumentou substancialmente; a seção 6.3 analisa o interregno democrático de 1945 a 1964, período em que houve um "mininivelamento"; a seção 6.4 aborda os anos entre o golpe militar de 1964 e o segundo choque do petróleo em 1979, que testemunharam um rápido aumento da desigualdade, seguido por volatilidade e relativa estabilidade; a seção 6.5 cuida dos anos de inflação, crise e redemocratização entre 1979 e 1988, em que a concentração no topo aprofundou-se; a seção 6.6 discute o período até 2013, em que os dados tributários revelam apenas uma queda moderada seguida por estabilidade na fração recebida pelos mais ricos; e a seção 6.7 resume as conclusões do capítulo.

\subsection{Do colapso da República Velha ao Estado Novo (1926-1945)}

Os anos de crise final da República Velha e a ascensão e queda de Getúlio Vargas correspondem a um dos três períodos de significativo aumento da desigualdade no Brasil nos últimos cem anos, principalmente entre o início do Estado Novo e a primeira metade da $2^{a}$ Guerra Mundial. Nas séries preferidas, com imputação de rendimentos não tributáveis, a fração recebida pelo centésimo mais rico saiu de cerca de $20 \%$ no fim da década de 1920 para 22\% em meados dos anos 1930 e disparou depois de 1938, atingindo 30\% em 1942 e 1943, para depois recuar levemente para $28 \%$ em 1945. As frações do $0,1 \%$ e do $0,01 \%$ mais ricos seguiram trajetória semelhante, apenas com maior estabilidade antes da guerra. 
A correlação entre essas flutuações e eventos que agitaram a vida nacional é notável. O período é dos mais estudados da historiografia brasileira justamente por suas rupturas e inovações institucionais, com a Revolução de 1930 normalmente considerada um divisor de águas na modernização do país (e.g., CARVALHO, 2008, p. 87; WEFFORT, 1978, p. 49). Seja por falta de dados ou pelas controvérsias das interpretações baseadas em conflitos de classe, a literatura faz poucas referências diretas à distribuição de renda, mas a história do período fornece um guia para a dinâmica da concentração no topo.

Grosso modo, é difícil negar a caracterização tradicional da República Velha como um arranjo liberal oligárquico, capitaneado por São Paulo e Minas Gerais, com predominância dos interesses agrários e em especial da cafeicultura, embora devam-se levar em consideração as ressalvas de Fritsch (1990) sobre outros grupos politicamente fortes e as restrições impostas por nossa vulnerabilidade externa crônica. Esse arranjo chegou combalido ao final dos anos 1920, desgastado pela necessidade de lidar com a ebulição oposicionista acumulada ao longo dos $\operatorname{anos}^{2}$ e por desentendimentos entre elites regionais. A vinculação observada no padrão ouro entre a estabilidade monetária doméstica e o balanço de pagamentos provou-se fatal quando as tendências recessivas de 1928 combinaram-se com a Grande Depressão de 1929, a safra abundante e estoques já elevados de café. A queda na demanda e as dificuldades de captação externa para a defesa do café provocaram redução brutal no seu preço, grande desequilíbrio no balanço de pagamentos e contração do crédito doméstico, desembocando em uma crise econômica aguda (FRITSCH, 1990).

Não cabe aqui discutir o quão "inevitável" era a Revolução de 1930 nem o grau de indeterminação política aberto pela deposição de Washington Luís e a instauração do Governo Provisório de Vargas. O que importa é que, longe de constituir uma "revolução burguesa" clássica, o conflito em 1930 foi mais "interregional, interoligárquico e (...) intergeracional, do que intersetorial (...) [ou] interclasses" (BETHELL, 2008c; ver também FAUSTO, 1988). O surrado epíteto "modernização conservadora" capta bem as acomodações do novo acordo, que abriu novas possibilidades ao mesmo tempo que assegurou a reprodução da desigualdade em novas bases.

No campo econômico, o Governo Provisório costuma receber crédito pela recuperação relativamente rápida da crise. Com o desaparecimento de reservas, houve suspensão dos pagamentos da dívida pública externa e a introdução de controles cambiais, além do abandono do padrão ouro. Sem rompimento drástico com o arranjo anterior, a política cafeeira assumiu em nível federal a sustentação dos preços, iniciando já em 1931 a destruição de estoques. Depois da derrota paulista em 1932, a acomodação tornou-se mais permanente, inclusive com o "Reajustamento Econômico" de 1933, que ensejou a redução nominal pela metade e a recontratação das dívidas dos cafeicultores. Em conjunto, essas medidas de proteção da renda do setor cafeeiro - com óbvios impactos distributivos -

2 Ver, por exemplo, o endurecimento da repressão estatal face às greves de 1917 a 1919 e o prolongado estado de sítio durante o governo de Arthur Bernardes, em função do movimento tenentista. 
são consideradas desde Celso Furtado um keynesianismo avant la lettre que sustentou a demanda agregada e estimulou a produção industrial na primeira metade dos anos 1930 (ABREU, 1990, 2008a; BAER, 2009; SANTOS, 1979).

Não causa espanto que as mudanças distributivas dos primeiros anos da Revolução de 1930 tenham sido pouco pronunciadas, dado que o próprio sucesso macroeconômico do regime varguista baseou-se - seja por restrições objetivas, seja por conveniências políticas ao menos em parte no amparo ao setor cafeeiro, mesmo no momento em que os antigos expoentes do tenentismo estavam no auge de sua influência, com toda sua confusa retórica nacionalista, intervencionista e reformista. A coalizão por trás da Revolução de 1930 era não só heterogênea e parcialmente antagônica, mas também bastante instável, pelo menos em seus primeiros anos (BETHELL, 2008c; FAUSTO, 1988).

A extensão dos direitos sociais nos primeiros anos da Revolução não alterou o quadro, embora seja digna de nota. O Ministério do Trabalho, Indústria e Comércio foi criado quase instantaneamente e, nos anos seguintes, foram tema de regulação estatal a jornada de oito horas, o trabalho de menores, a carteira de trabalho, o direito de férias, a criação das Comissões e Juntas de Conciliação e Julgamento e dos Institutos de Aposentadorias e Pensões (IAPs), entre outras medidas (CARVALHO, 2008, p. 112-113). Um marco particularmente importante foi o Decreto 19.770, de 1931, que regulou os sindicatos, trazendo-os para a esfera do direito público e definindo-os como órgãos de colaboração do poder público, sob fiscalização e controle crescentes da burocracia federal.

Os dilemas e ambiguidades das intervenções trabalhistas foram objeto de muitos trabalhos clássicos. Um dos destaques é a caracterização de Wanderley Guilherme dos Santos (1979) da "cidadania regulada", isto é, do "achado de engenharia institucional" que vinculou direitos e benefícios sociais à inserção dos trabalhadores no processo produtivo. O tratamento estratificado por categorias profissionais tornou-se ainda mais saliente com a expansão dos IAPs para além da esfera previdenciária, reproduzindo as disparidades entre categorias em serviços desiguais também de saúde, habitação e afins:

Por cidadania regulada, entendo o conceito de cidadania cujas raízes
encontram-se (...) em um sistema de estratificação ocupacional, e que,
ademais, tal sistema de estratificação é definido por norma legal. (...)
A expansão da cidadania se faz, pois, via regulamentação de novas
profissões e/ou ocupações, em primeiro lugar, e mediante ampliação do
escopo dos direitos associados a estas profissões, antes que por expansão
dos valores inerentes ao conceito de membro da comunidade. A cidadania
está embutida na profissão e os direitos do cidadão restringem-se aos
direitos do lugar que ocupa no processo produtivo, tal como reconhecido
por lei. Tornam-se pré-cidadãos, assim, todos aqueles cuja ocupação a lei
desconhece. (SANTOS, 1979, p. 75$)$

A legislação trabalhista encontrou resistência do patronato, e o novo padrão de intervenção social do Estado atraiu segmentos significativos dos trabalhadores. Apesar de 
criar uma estrutura institucional estratificada que reproduziu desigualdades e formatou por décadas as disputas por direitos e benefícios, não se pode deixar de reconhecer que ela gerou uma expectativa de proteção social, atuando como promessa universalizável - ainda que não efetivamente universalizada - de integração, e que a divisão entre "cidadãos" e "pré-cidadãos" era porosa e contingente (CARDOSO, 2010).

Não obstante, do ponto de vista do nível e da dinâmica da desigualdade, a legislação trabalhista foi praticamente inócua nos anos 1930. Para começar, o conjunto de medidas introduzidas no início dos anos 1930 e posteriormente reformadas e expandidas enquadramse bem no que Marcelo Medeiros (2016, p. 176) chamou de "políticas de igualdade por inclusão (...) que reconhecem certos avanços de uma parte da população, definindo-os como um marco absoluto, e buscam recuperar o atraso do restante das pessoas em relação a eles", com potencial reduzido para afetar a concentração no topo, tal como definida nesta tese.

Além disso, seu alcance foi deliberadamente limitado de início. A exclusão de trabalhadores rurais em um país ainda muito pouco urbanizado evidenciou a indisposição ou incapacidade das novas elites dirigentes em lidar com a secular concentração fundiária brasileira. ${ }^{3}$ Nas áreas urbanas, trabalhadores domésticos, autônomos e demais categorias não reconhecidas permaneceram fora do arcabouço legal. A própria obtenção dos documentos - vale dizer, a carteira de trabalho - para o ingresso no mundo legalmente protegido era repleta de obstáculos e exigências burocráticas por vezes intransponíveis para os mais pobres. Mesmo depois de obtidos, não garantiam de fato o acesso aos direitos, frequentemente burlados em meio à fraca fiscalização e à relutância dos empregadores (CARDOSO, 2010; FISCHER, 2006; PAOLI, 1989; SIMÃO, 1981).

O enquadramento burocrático e o controle crescente dos sindicatos, com a emergência da figura do "pelego", foram a outra face do processo, como documentado por acadêmicos (e.g., CARVALHO, 2008; PAOLI, 1989; RODRIGUES, 1968; SIMÃO, 1981; VIANNA, 1999) e militantes (e.g., DIAS, 1962). O uso da violência, principalmente entre 1932 e 1937, para reprimir e desmobilizar as organizações preexistentes não pode ser subestimado. Em um período de polarização ideológica tanto no plano internacional (ver capítulo 1) quanto no nacional (como nos embates entre a Aliança Nacional Libertadora e os integralistas), o anticomunismo tornou-se bandeira maior do regime varguista, lançando as bases do fechamento político posterior pelo silenciamento de qualquer oposição:

3 Em 1940, quase 69\% da população brasileira vivia em áreas rurais (IBGE, 1954, p. 25) e 70\% da população economicamente ativa com 10 anos ou mais (exclusive atividades domésticas e escolares) estava empregada na agricultura, pecuária, silvicultura ou em indústrias extrativas (IBGE, 1950, p. 6). 


\begin{abstract}
Mesmo antes de abril de 1935, quando foi aprovada a Lei de Segurança Nacional, houve muita intervenção nos sindicatos que reivindicavam ou organizavam greves. Intervenção, na época, significava em grande parte invasão policial e destruição virtual das sedes dos sindicatos, com abundantes espancamentos e prisões. (...) A Lei de Segurança Nacional e o fracasso da ANL (fechada em julho de 1935), seguidos do episódio da liquidação do levante conhecido como Intentona Comunista (novembro de 1935), tornaram a repressão implacável e a manutenção de qualquer tipo de resistência impossível. (...) A repressão ao comunismo tornaria inviável qualquer tipo de ação independente surgida do interior da classe trabalhadora. Um longo silêncio teve início em 1935, reforçando-se em 1937 e perdurando praticamente até 1942. (GOMES, 2005, p. 176-178)
\end{abstract}

Da Intentona ao Plano Cohen, o anticomunismo serviu como pretexto - e a repressão do dissenso como condição - para o fechamento do regime de Vargas. Entre novembro de 1935 e novembro de 1937, o Brasil viveu quase continuamente sob estado de sítio/guerra, com a prisão e/ou tortura de milhares de oponentes do regime e indivíduos identificados com a esquerda, processo completado com o golpe que instituiu o Estado Novo, com ampla adesão das elites econômicas (BETHELL, 2008c; CARVALHO, 2008). Não cabe aqui discutir o quão fascista foi o Estado Novo. ${ }^{4} \mathrm{O}$ fato é que o endurecimento, para além da dissolução dos partidos e do Congresso, também se fez sentir no controle sindical, com a proibição de greves a partir de 1937, e na maior concentração de poder nas mãos do governo federal, com expansão rápida da burocracia e de órgãos governamentais - nas palavras de Abreu (2008a, p. 318), "importantes inovações no campo do rent-seeking".

A correlação entre esses desdobramentos e o aumento da concentração no topo dificilmente pode ser reduzida a mera coincidência. Em um período já pouco democrático, os acontecimentos da segunda metade da década de 1930 representam o momento máximo de possibilidade de ruptura e redesenho institucional, face a uma oposição desmantelada. ${ }^{5}$ Não à toa, muitos trabalhos clássicos apontam o aprofundamento corporativo promovido pelo Estado Novo como favorável ao empresariado e destacam a contenção das demandas salariais, ainda que obviamente as interpretações gerais sobre a intencionalidade e o papel do Estado variem (e.g., FAUSTO, 1988; RODRIGUES, 1968; VIANNA, 1999).

Nessas condições, a eclosão da $2^{a}$ Guerra foi o fator decisivo para a elevação rápida da concentração de renda no topo, cenário em tudo diferente do observado nos Estados Unidos e em muitos países ricos, onde a desigualdade caiu bruscamente durante o conflito. Nesses países, a queda das frações da renda recebidas dos ricos decorreu, de modo geral, do colapso dos rendimentos de propriedade, com a destruição de capital físico, a aceleração da inflação em economias não indexadas, falências, regulação estatal e choques fiscais para financiamento do esforço bélico (ATKINSON; PIKETTY; SAEZ, 2011; PIKETTY; SAEZ, 2003, 2006). Seja por imperativos fiscais, pela necessidade de mobilização das massas, pelo

4 Ver, por exemplo, Bethell (2008c) e Rodrigues (1968) para diferentes avaliações sobre o assunto.

5 Não há muitos dados para outros países, mas vale destacar que a Alemanha nazista oferece um exemplo contemporâneo de regime com feições semelhantes - embora muito mais radicais e violentas - em que o mesmo processo de rápido aprofundamento da concentração no topo foi observado (DELL, 2007). 
enraizamento da democracia ou pela combatividade de sindicatos e afins, as mudanças institucionais implementadas deslocaram o fardo para os detentores de capital, o que, no longo prazo, resultou mais em desconcentração do capital do que em diminuição de sua participação na distribuição funcional da renda (PIKETTY; SAEZ, 2003, p. 19).

Dois exemplos são ilustrativos. Nos Estados Unidos, as duas guerras mundiais provocaram grande expansão e maior progressividade no imposto de renda de pessoas físicas e jurídicas, afetando negativamente a distribuição de dividendos para acionistas. Adicionalmente, na $2^{a}$ Guerra houve uma significativa compressão da estrutura salarial devido à atuação do National War Labor Board, órgão responsável por autorizar, entre 1942 e 1945, todos os reajustes salariais, sem grande recuperação das disparidades após o fim do conflito (PIKETTY; SAEZ, 2003). Já no Japão, um dos países com maior queda da concentração no topo entre 1939 e 1945 (ver Figura 7 no capítulo 3), as intervenções foram ainda mais extensivas, incluindo regulação de dividendos, redução dos retornos financeiros de ações e títulos (exceto títulos de guerra), padronização de salários, estabelecimento de conselhos de trabalhadores nas empresas, imposição de teto para os bônus pagos a executivos, reforma agrária e alterações de leis fundiárias que penalizaram os proprietários rurais, e expansão do imposto de renda de pessoas físicas e jurídicas, em um contexto inflacionário e de destruição em larga escala de capital físico (MORIGUCHI; SAEZ, 2008).

O Brasil escapou aos piores horrores da guerra. Aqui, como na Argentina (ALVAREDO, 2008), o conflito trouxe vantagens para certos setores que, diante da conjuntura externa, redundaram em aumento da concentração no topo. No plano externo, a perda inicial de mercados foi parcialmente revertida a partir de 1941, com a expansão de exportações e saldos comerciais pelo "efeito combinado dos acordos de suprimentos de materiais estratégicos aos Estados Unidos, do aumento da demanda por produtos brasileiros em mercados tradicionalmente supridos pelo Reino Unido e pelos Estados Unidos (...), de maciças compras de carne e algodão pelo Reino Unido e dos melhores preços de café garantidos pelo Acordo Interamericano" (ABREU, 1990, p. 94; ver também BETHELL, 2008c, p. 67). Alguns setores foram particularmente beneficiados, como a indústria: com a interrupção dos fluxos comerciais tradicionais, as exportações de manufaturados viveram momento excepcional, com destaque para os têxteis, entrando em decadência igualmente rápida com a normalização do comércio após 1945 (BAER, 2009, p. 59).

A guerra também trouxe grandes restrições às importações, inicialmente por escassez de reservas conversíveis e, depois, pelas limitações impostas pelas políticas dos países mais envolvidos no conflito. Essas restrições bloquearam a expansão da capacidade produtiva, devido à dificuldade de obtenção de bens de capital e algumas matérias-primas, mas, no cômputo geral, a existência de margem ociosa e a diminuição da competição externa favoreceram a aceleração do crescimento industrial - e a escalada da inflação, que a partir de 1942 tornou-se via preferencial de financiamento dos déficits públicos. ${ }^{6}$

\footnotetext{
$\overline{6}$ Entre 1942 e 1945, o produto industrial cresceu quase 10\% ao ano, contra 1,6\% em 1939-1942 (ABREU,
} 
A resposta política às condições de guerra potencializou as mudanças externas na direção do aumento da desigualdade. A ditadura de Vargas colocou ostensivamente seu projeto de desenvolvimento em um caminho bastante afinado ao empresariado. Com a entrada oficial na guerra, a propaganda de mobilização dos trabalhadores ocorreu junto com a promulgação de decretos que, respondendo às pressões dos industriais, suspenderam temporariamente a vigência de muitos direitos trabalhistas para as "indústrias de guerra" (GOMES, 2005, p. 224-225). Como documentou Maria Celia Paoli (1989):

O golpe mais baixo veio, no entanto, com a plena produção (sobretudo têxtil) trazida com a Segunda Guerra Mundial. Três decretos governamentais "restauraram" o dia de dez horas obrigatório (...), a produção ininterrupta e o acúmulo de turnos; aboliram as férias nas indústrias consideradas como de "segurança nacional"; e aboliram o direito de mudança de emprego nelas, sendo seus trabalhadores redefinidos como recrutas do trabalho e portanto como desertores se faltassem ou abandonassem o serviço. Além das fábricas de materiais de guerra, a indústria têxtil conseguiu definir-se como "indústria de guerra".

$(\ldots)$

Em junho de 1944, respondendo à pressão patronal que alegava estarem as fábricas já produzindo com sua máxima capacidade dentro da organização de trabalho prevalecente (... ) o governo emitiu a Lei de Mobilização Industrial, feita especialmente para a indústria têxtil. Nesta lei, muitos dos direitos dos trabalhadores foram suprimidos de vez. Tornou-se permitido o serviço de mulheres e crianças de mais de 16 anos em trabalho noturno; foi permitido o trabalho contínuo, isto é, aos domingos e feriados; reafirmou-se que nenhum trabalhador poderia mudar de emprego sem o consentimento do seu patrão e nenhum outro empregador poderia admiti-lo sem a prova deste consentimento; mais de oito faltas formava abandono de emprego, punidas com penas de prisão que variavam de 15 dias a 6 meses. (PAOLI, 1989, p. 61 e 64)

Logo, a guerra forneceu o pretexto para que até as disputas para tirar do papel os direitos trabalhistas fossem suprimidas em diversos setores. Em virtude das dificuldades de formação de capital, a capacidade produtiva existente precisava ser explorada ao máximo, até mesmo para tirar proveito das condições excepcionais. Com isso, a prosperidade de certos setores dependeu de medidas políticas extremamente repressivas em um regime já muito fechado, com reflexos na distribuição de renda.

A trajetória do IRPF nesse período reitera o pouco interesse do Estado Novo em distribuir sacrifícios de forma equitativa. Longe de ser uma ocasião para a sua transformação em um imposto de massas, a $2^{a}$ Guerra trouxe apenas reformas tímidas movidas por necessidades fiscais. Enquanto a progressividade das alíquotas aumentou brutalmente em boa parte dos países envolvidos no conflito, por aqui não houve nenhuma mudança digna de nota. Como visto na Figura 16 do capítulo 4, se em 1930 as alíquotas marginais máximas no Brasil e nos Estados Unidos eram relativamente próximas (15\% e 25\%, respectivamente),

1990, p. 94). Os produtos metálicos e têxteis, favorecidos pela restrição de importações, lideraram o crescimento (BAER, 2009, p. 59). A inflação medida pelo deflator do PIB pulou de 3,2\% em 1938 para 10,2\% em 1941 e 20,6\% em 1944, recuando para 14,9\% em 1945 (ver Figura 28 no capítulo 5). 
a distância entre elas deu muitos saltos na década seguinte, atingindo um pico em 1943, quando a alíquota marginal máxima no Brasil era de $20 \%$ e, nos Estados Unidos, alcançou inéditos 94\%. Analogamente, não houve no Brasil expansão da cobertura populacional do IRPF, grosso modo restrita ao $1 \%$ mais rico da população (ver Figura 14 do capítulo 4). Mesmo com as melhorias na fiscalização e administração do imposto, que dobraram sua participação relativa na carga tributária bruta (ver Figura 11 no capítulo 4), a arrecadação do imposto de renda - incluindo pessoas físicas e jurídicas - sequer chegou à marca de $2 \%$ do PIB (ver Figura 10 no capítulo 4).

Um aspecto peculiar desses acontecimentos é sua ocorrência concomitante a uma reorientação do regime após o alinhamento com o Estado Unidos. O trabalhismo consolidouse como uma possibilidade de manter o poder em uma eventual ordem democrática. O estabelecimento do salário mínimo (de início realmente mínimo), a aprovação da Consolidação das Leis do Trabalho (CLT), as palestras radiofônicas do ministro Alexandre Marcondes Filho e os esforços de construção mítica de Getúlio Vargas já foram analisados no trabalho clássico de Angela de Castro Gomes (2005), que destacou a opção pelo corporativismo como saída para o autoritarismo. Luiz Werneck Vianna (1999, p. 309-311) diagnosticou inflexão semelhante, notando que "até pelo menos 1943, a mobilização para a guerra não implicou em qualquer aceno distributivista para os assalariados", prejudicados pelo congelamento salarial, mas, já em 1944, a defecção das classes dominantes e o subsequente isolamento político de Vargas empurraram-no para uma aliança com as classes subalternas de caráter radicalmente distinto do controle e repressão anteriores.

Nesse quadro, o recuo modesto da concentração no topo entre 1943 e 1945 é compatível com os eventos do período. Por um lado, a aproximação do fim da guerra tornou os Estados Unidos menos simpáticos à opção brasileira por substituição de importações e bem menos generosos no apoio ao regime, com atritos crescentes a partir de 1943 e recusa, por exemplo, a reajustar os preços do café, no âmbito do Acordo Interamericano do Café (ABREU, 1990, 2008a). Por outro, a necessidade varguista de dotar os sindicatos de maior representatividade provocou medidas mais concretas. Depois de uma desvalorização real de quase 30\% desde sua implantação, na segunda metade de 1943 o salário mínimo obteve reajustes reais em mais de 40\%, voltando para o (baixo) patamar original. No mesmo ano, o regime engajou-se em amplas e relativamente bem-sucedidas campanhas de estímulo à sindicalização, recorrendo, para isso, a programas concretos e gastos reais nas áreas de previdência, saúde, alimentação e habitação (GOMES, 2005, p. 246-253).

Com a proximidade do fim da guerra, as crescentes e heterogêneas pressões internas e externas contra um regime visto como ilegítimo desembocaram em uma série de desdobramentos que expressam ambiguidades dos estertores do Estado Novo. A abertura política iniciada por Vargas descambou, em 1945, nos maiores protestos populares em muitos anos, repletos de reivindicações contra baixos salários, jornadas de trabalho longas, más condições de trabalho e afins. Como narrou Bethell (2008c, p. 76), entre outros, o 
movimento sindical ressurgiu da passividade, com participação decisiva dos comunistas, e promoveu centenas de greves nas principais cidades brasileiras. Porém, como atesta o "queremismo" e a aproximação do PCB, Getúlio Vargas não era o alvo principal, e seus apelos ao nacionalismo e, cada vez mais, ao trabalhismo e à mobilização de massas, bem como a desconfiança generalizada quanto à sua intenção real de promover eleições, acabaram por selar a reação de antigos aliados, que o depuseram em outubro de 1945.

\subsection{A era de ouro do desenvolvimentismo (1945-1964)}

Os resultados do capítulo anterior apontam o interregno democrático como um período radicalmente diferente da primeira era Vargas. A partir de 1945, a trajetória da concentração no topo tem uma clara inflexão, entrando até 1964 em um "mininivelamento" significativo, embora não tão dramático ou permanente quanto o "grande nivelamento" de muitos países ricos (Cf. WILLIAMSON, 2015). Nessas quase duas décadas, a fração da renda recebida pelo centésimo mais rico nas séries imputadas despencou de $30 \%$ para 20\%, puxada pelo declínio da fatia apropriada pelos mais ricos entre os ricos, como o $0,1 \%$ no topo da distribuição. Com isso, se 1945 marcou um dos picos históricos da desigualdade, a situação no início dos 1960 estaria no outro extremo.

À primeira vista, é tentador encaixar essa evolução em uma narrativa simples de um círculo virtuoso entre redemocratização, urbanização e industrialização: a participação política crescente teria condicionado o processo de industrialização liderado pelo Estado em uma direção que possibilitou um longo ciclo de crescimento econômico, intensa mudança estrutural e maior dispersão dos benefícios do progresso entre a população. Assim, a intencionalidade crescente da política de substituição de importações, o papel cada vez mais expandido do Estado e o confisco cambial imposto aos exportadores de café, entre outras medidas, teriam tido por aqui efeitos semelhantes aos observados em outros países que também testemunharam expressivas quedas da desigualdade nesse período, como a Argentina (ALVAREDO, 2008, p. 122-125).

Na prática, essa narrativa é insatisfatória, ainda que contenha um tanto de verdade. ${ }^{7}$ Embora haja alguma tendência de melhora ao longo de todo o período, a queda da concentração no topo dá-se majoritariamente no imediato pós-guerra e na segunda metade da década de 1950, correspondentes, grosso modo, aos governos de Eurico Gaspar Dutra (1946-1951) e Juscelino Kubitschek (JK, 1956-1961).

7 Ver, por exemplo, Abreu (2006) e Bonelli (2006) para a caracterização dos anos 1940 e 1950 como o auge da mudança estrutural em meio ao rápido crescimento do Brasil; Baer (2009, cap. 4) e Villela (2005) para a transformação do protecionismo de reação defensiva a política deliberada de modernização e crescimento; Nicolau (2012, cap. 4), Rodrigues (1968, p. 132-134) e Rodrigues (1981, p. 533-541) para a expansão do eleitorado, eleições relativamente limpas e crescente mobilização política e sindical no período; Silva e Barbosa (2006) para o aumento da expectativa de vida ao nascer e a queda da mortalidade infantil entre 1940 e 1960, em contraposição à sua estagnação entre 1960 e 1970. 
Nenhum dos dois é costumeiramente associado a grandes políticas redistributivas, para dizer o mínimo. Ministro da Guerra durante o Estado Novo e com reconhecida simpatia pelo nazifascismo, Dutra governou com uma coalizão conservadora formada pela União Democrática Nacional (UDN) e pelo Partido Social Democrático (PSD). No plano social, seu governo foi marcado pelo congelamento do salário mínimo, pelas articulações para cassar o registro do Partido Comunista Brasileiro (PCB), ${ }^{8}$ pela lei antigreve de 1946 e pelo uso violento do aparato institucional herdado do Estado Novo para sufocar o emergente movimento sindical do início de seu mandato (e.g., ALMEIDA JR., 1981; BETHELL; 2008b; FAUSTO, 1995, cap. 8; RODRIGUES, 1968, p. 130-132).

O governo de JK foi muito mais pacífico e livre, especialmente do ponto de vista dos direitos civis, e apresentou as maiores taxas de crescimento econômico do interregno democrático. Ainda assim, ele tampouco é associado à diminuição da desigualdade. Em seus discursos, o sempre conciliador JK mal abordou a questão distributiva (CAMPOS, 2007, cap. 4); em seus atos, assim como seus predecessores, fez pouco ou nada para reformar dimensões estruturantes da desigualdade brasileira, como a concentração fundiária e o atraso educacional (e.g,. CAMARGO, 1981; KANG, 2011). Pelo contrário, há análises tanto de sabor marxista quanto ostensivamente liberais que associam o desenvolvimentismo à moda de JK ao aumento da desigualdade (e.g., MARANHÃO, 1981; FRANCO, 2005).

Os resultados, contudo, são robustos. Como visto na seção 5.6 do capítulo anterior, o uso de diferentes denominadores de população e/ou renda total não altera a tendência observada. Mais ainda, Souza (2014) e Milá (2015) chegam a resultados parecidos com escolhas metodológicas distintas e, como mencionado acima, Alvaredo (2008) também observou queda na concentração no topo na Argentina, cuja história político-econômica no período guarda notáveis semelhanças com a brasileira.

Já as evidências empíricas baseadas em outras fontes são ambíguas, e não dizem respeito diretamente aos mais ricos. Há resultados para todos os gostos. Pelo menos parte considerável deles é compatível com a redução da concentração no topo no período. No lado da distribuição funcional da renda, por exemplo, as estimativas de Frankema (2009) e as tabulações oficiais da época indicam que a participação do fator trabalho aumentou, atingindo um pico histórico no início dos anos $1960 .{ }^{9}$ No plano regional, o

8 O PCB foi legalizado em 1945 e logo tornou-se o quarto maior partido do país, obtendo quase $10 \%$ dos votos para presidente com Iêdo Fiuza, além de eleger 14 deputados federais e um senador, Luis Carlos Prestes. Em 1947, o Tribunal Superior Eleitoral (TSE) cassou seu registro por motivos ideológicos, com base na Constituição de 1946. Em 1985, o PCB e sua dissidência, o PC do B, voltaram à legalidade. Em 1991, o PCB mudou seu nome para Partido Popular Socialista (PPS), que continua a existir. Para mais detalhes, ver Almeida Jr. (1981), Bethell (2008b), Nicolau (2012), Schmitt (2000), entre outros.

9 As tabulações do período seguem um padrão bem diferente das atuais, repartindo a renda nacional entre o "setor urbano" e a "agricultura", e subdividindo apenas o primeiro em remuneração do trabalho, rendimentos mistos e remuneração do capital. A participação do trabalho cresce de $41 \%$ para $47 \%$ da renda interna entre 1954 e 1959, com correspondente diminuição dos rendimentos mistos, de capital (lucros, juros e aluguéis) e da agricultura. Os dados estão disponíveis nos Anuários Estatísticos do Brasil 1958 (p. 280), 1960 (p. 214) e 1965 (p. 309) (IBGE, 1916-). 
desenvolvimentismo do interregno democrático parece ter sido muito menos concentrador do que normalmente se supõe, ao menos quando se olha para a desigualdade de PIB per capita entre estados, que, segundo Ferreira (1996), diminuiu sensivelmente entre 1950 e 1960, em um processo que foi totalmente revertido na década de 1960.

Na contramão desses resultados, os "pseudo-Ginis" estimados por Prados de la Escosura (2007) sugerem aumento da desigualdade na distribuição como um todo entre 1938 e 1950 e depois certa estabilidade até 1960, enquanto Colistete (2007, 2009) encontrou piora na distribuição funcional da renda no setor industrial, com descolamento entre salários e produtividade especialmente no governo JK.

Essas ambiguidades não refutam a queda na concentração no topo descrita no capítulo 5, mas reiteram o quanto o período é mais difícil de avaliar do que o anterior. O próprio "mininivelamento" visto nos dados tributários está longe de ser tão radical quanto o ocorrido alhures entre os anos 1930 e 1950. Dado o alto patamar inicial, mesmo no início dos anos 1960 a desigualdade estava em nível elevado para padrões internacionais.

Um olhar histórico ajuda ao menos a delinear hipóteses explicativas. No caso do governo Dutra, a queda parece estar intimamente associada ao fim das condições excepcionais externas e internas e às políticas adotadas na primeira metade do seu mandato. Logo após o fim da guerra, as expectativas do governo eram positivas para o setor externo no que diz respeito aos preços do café, à possível ajuda americana e à recuperação dos fluxos internacionais de capitais. Com isso, o foco do governo deslocou-se para a estabilização monetária e para recuperar investimentos, satisfazendo a demanda reprimida por importações nos anos de guerra. Assim, as restrições cambiais foram removidas e o câmbio foi mantido sobrevalorizado, também para estimular a entrada de capitais. No plano interno, o governo cortou o investimento público, freou a emissão de moeda e colocou em pauta uma reforma tributária para aumentar as receitas, de modo a combater os déficits públicos e as pressões inflacionárias associadas a eles.

O tiro saiu pela culatra, e o governo acabou fazendo nítida inflexão entre 1947 e 1949. O novo regime cambial provocou um grande aumento das importações e o esgotamento das pequenas reservas conversíveis em dólar, ao mesmo tempo que a sobrevalorização do câmbio e a maior competição internacional derrubaram as exportações de produtos industrializados e de outros itens que haviam se expandido muito durante a guerra, como algodão, têxteis e produtos de borracha. Mais ainda, os preços internacionais do café só começaram a se recuperar para valer a partir de 1948-1949, os Estados Unidos passaram longe de qualquer Plano Marshall para a América Latina, e o fluxo internacional de capitais só engrossou na década de 1950. Internamente, a oposição política e empresarial inviabilizou a reforma tributária, e a austeridade federal esbarrou no aumento concedido ao funcionalismo em 1946, nos recorrentes desequilíbrios dos estados e, em 1948, na expansão do crédito do Banco do Brasil para o setor industrial. 
Já em 1947-1948 o governo começou a mudar de rumo. Diante dos atrasados comerciais, o modelo liberal de câmbio foi abandonado: a sobrevalorização do câmbio foi mantida, mas foram introduzidos controles cambiais e de importações, com licenças prévias concedidas de acordo com uma escala de prioridades, uma política inicialmente defensiva que, em poucos anos, passou a ser usada conscientemente como ferramenta de industrialização via substituição de importações. Muitas exportações continuaram pouco competitivas e, em 1948, o governo começou a oferecer condições especiais para os "produtos gravosos", como o algodão. A inflexão completou-se em 1949: com a proximidade das eleições presidenciais e o lobby industrial, o governo Dutra abandonou de vez a ortodoxia, trocou o ministro da Fazenda e afrouxou as políticas monetária e fiscal, registrando déficits crescentes no orçamento da União e expansão do crédito do Banco do Brasil (ABREU, 2008a; BAER, 2009; VIANNA, 1990b; VIANNA; VILLELA, 2005).

Esses desdobramentos são compatíveis com a rápida e permanente queda de 2-3 p.p. na fração recebida pelo centésimo mais rico, ainda mais quando se leva em conta a ebulição social do período. Não se pode esquecer, contudo, que essa queda simplesmente trouxe a concentração no topo de volta para os níveis observados no início do Estado Novo. Sem a ofensiva repressiva, talvez a desigualdade tivesse caído ainda mais naquele momento. O próprio Colistete (2007) registra que no imediato pós-guerra os salários reais na indústria avançaram mais do que a produtividade, o que, para ele, possivelmente explica o apoio maciço dos industriais à ofensiva anti-sindical do governo Dutra, que não titubeou em reprimir o sindicalismo independente. Adicionalmente, pode-se mencionar ainda a elevação das alíquotas do IRPF em 1947 - principalmente da alíquota máxima, que pulou de $20 \%$ para $50 \%$ — , medida de cunho puramente fiscal, tomada em meio ao fracasso da reforma tributária e que não conseguiu elevar significativamente a receita do imposto, mas aumentou bastante sua progressividade para os milésimos mais ricos (ver seção 4.3 do capítulo 4). Por fim, a recuperação dos preços do café coincide em boa medida com o fim do declínio da concentração no topo.

Entre os últimos anos do governo Dutra e o breve governo de Café Filho, passando pela eleição e suicídio de Vargas, a fração recebida pelo centésimo mais rico oscilou em intervalo estreito de $24 \%$ a $26 \%$, com altos e baixos e sem direção muito clara. A tendência muito modesta de redução, marginalmente mais nítida quando se olha para o milésimo mais rico, ao menos é compatível com um período de idas e vindas políticas e econômicas.

Apesar de sua maior aproximação com as massas desde a campanha eleitoral, uma vez no governo Vargas tentou continuar se equilibrando em uma estratégia de "contentar amplo espectro da sociedade sem a realização de transformações estruturais e sem contar com uma sociedade civil organizada" (VIANNA, 1990a, p. 148-149). Inicialmente, seu ministério foi bastante conciliador e conservador, priorizando, como Dutra, a estabilização monetária e o saneamento do déficit público, na chamada estratégia "Campos SallesRodrigues Alves": combater a inflação com um ajuste ortodoxo (fase Campos Salles) para 
em seguida, com auxílio do capital estrangeiro, fazer deslanchar projetos de infraestrutura e estimular o crescimento (fase Rodrigues Alves) (VIANNA, 1990a). Na prática, seus planos ruíram diante da crise cambial de 1952, da interrupção do financiamento americano depois da vitória de Eisenhower na eleição presidencial, da volatilidade dos termos de troca, da necessidade de resgate financeiro do estado de São Paulo e das inúmeras pressões fiscais e monetárias contidas nas demandas - muitas vezes contraditórias - de muitos grupos sociais. Menos do que uma guinada nacionalista e popular, o governo Vargas foi marcado pelo fracasso em ser árbitro das forças sociais e por conflitos crescentes (e.g., BETHELL, 2008b; VIANNA, 1990a; VIANNA; VILLELA, 2005).

No campo trabalhista, o período marcou o ressurgimento da atividade sindical e o progressivo desalojamento dos "pelegos". O aumento das taxas de sindicalização e a formação de organizações de trabalhadores paralelas à estrutura oficial culminaram na volta das grandes greves já em 1953 e em concessões diretas do governo sob a forma de reajustes expressivos do salário mínimo em 1952 e 1954 (ALMEIDA JR., 1981; COLISTETE, 2007; FAUSTO, 1995; RODRIGUES, 1968; RODRIGUES, 1981). Ao mesmo tempo, o governo sacrificou sua meta de austeridade para sustentar os preços do café - inclusive com recuo do chamado confisco cambial, diante das pressões dos cafeicultores - e para expandir o crédito à indústria e aliviar os efeitos do aumento do salário mínimo e da Instrução 70, da Superintendência da Moeda e do Crédito (SUMOC) (VIANNA, 1990a). ${ }^{10}$

Por tudo isso, não chega a ser surpreendente que a concentração no topo tenha mudado pouco nesse período tão volátil e conturbado. Algo parecido pode ser dito acerca do governo de Café Filho, de agosto de 1954 a novembro de 1955, que torna qualquer análise muito arriscada por comportar duas fases muito distintas em intervalo tão curto de tempo: no período em que Eugênio Gudin ocupou o Ministério da Fazenda o governo adotou um profundo contracionismo fiscal e monetário, acarretando grande crise de liquidez; já na gestão de José Maria Whitaker, o foco passou para a eliminação do confisco cambial da cafeicultura, com uma reforma cambial frustrada (PINHO NETO, 1990).

Empiricamente, a concentração no topo aumentou levemente em 1953 e 1954, recuando em 1955 para níveis próximos aos de 1952. Nos anos seguintes, contudo, a queda tornou-se muito mais nítida, perpassando todo o governo JK. A fração do centésimo mais rico diminuiu mais até do que no imediato pós-guerra, e agora o recuo não se restringiu ao milésimo no topo (ver Figura 33 do capítulo 5). Não há dados para 1961 e 1962; a julgar pelos números de 1963 e 1964, não houve grandes mudanças no início dos anos 1960.

Essa queda da desigualdade nos anos 1950 é muito mais difícil de explicar do que a dos anos 1940 e exige mais estudos antes de qualquer resposta definitiva. Os escassos dados

10 A Instrução 70, de outubro de 1953, alterou o regime cambial brasileiro, restabelecendo o monopólio do Banco do Brasil e substituindo os controles quantitativos de importações por leilões de câmbio, realizados em categorias hierarquizadas de acordo com o grau de essencialidade dos produtos. Mais informações em Baer (2009) e Vianna (1990a), entre outros. 
Figura 57. Participação dos componentes dos rendimentos brutos tributáveis do $1 \%$ mais rico na renda total brasileira - Brasil, 1947-1960 (\%)

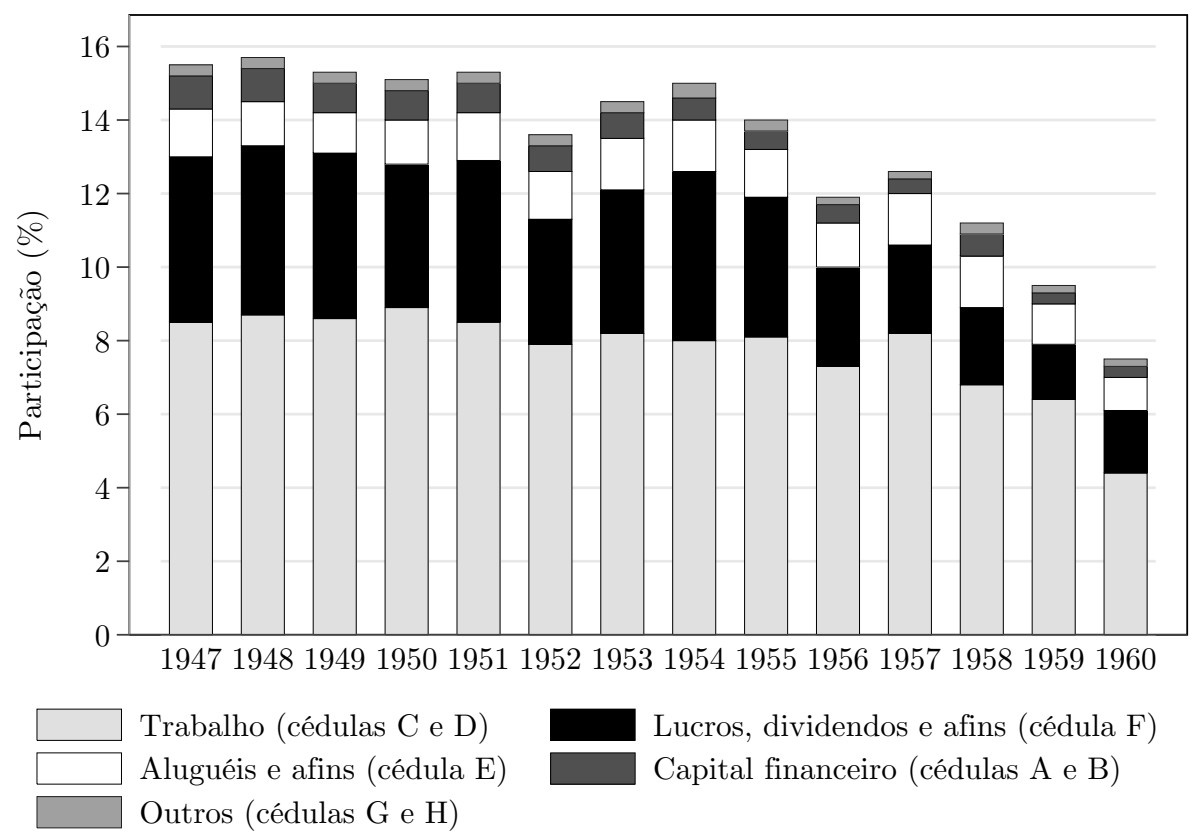

Fonte: elaboração própria a partir de tabulações de dados tributários e das Contas Nacionais; ver capítulo 4. N.B.: não há informações para os rendimentos não tributáveis.

adicionais mostram que a redução não se confinou a fontes de rendimentos específicas. A Figura 57 traz a participação na renda total dos componentes dos rendimentos brutos tributáveis do centésimo mais rico. O que mais chama a atenção é que os rendimentos brutos do trabalho - a fonte mais importante para esse grupo - oscilavam em torno de $8 \%$ da renda total até 1957, caindo para quase metade disso em 1960. ${ }^{11}$ As demais fontes também recuaram, com destaque para os lucros e dividendos, cujo declínio começou em 1955 e igualmente reduziu os percentuais pela metade, de cerca de $4 \%$ para $2 \%$. Em outras palavras, a composição dos rendimentos brutos tributáveis do $1 \%$ mais rico não mudou tanto, o que houve foi uma desconcentração de diversas fontes de rendimentos. Cabe apenas dizer que o recuo dos lucros e dividendos foi um pouco mais rápido do que a das demais fontes e o dos aluguéis, um pouco mais lento. As contas nacionais do período, com todas as suas limitações, não registram movimentos parecidos nos agregados, reforçando a tese de desconcentração, em especial dos rendimentos do trabalho.

Dado o ativismo estatal do período, é impossível considerar tais desdobramentos sem referência ao desenvolvimentismo de JK. Ao mesmo tempo, a redistribuição da renda jamais foi um objetivo explícito do governo, que, eleito pela mesma aliança de Vargas em 1950, também amparou-se em uma coalizão difusa, tendo de agradar e moderar o

11 Os dados para composição da renda só estão disponíveis a partir de 1947. Como mencionado no capítulo 4, as tabulações publicadas só permitem o cálculo dos totais agregados. Como o percentual de contribuintes do IRPF estava próximo de $1 \%$ da população adulta nesse intervalo, é razoável usar esses números para o centésimo mais rico. 
radicalismo dos dois "getulismos", o burocrático-conservador do PSD e o nacionalistasindical do PTB (FAUSTO, 1995, p. 425). JK foi mais bem-sucedido nessa tarefa do que Getúlio, levando o desenvolvimentismo à sua fase áurea e mitigando pressões sociais com crescimento acelerado. ${ }^{12}$ A redução da concentração no topo, ao que tudo indica, foi um efeito colateral não antecipado da dinâmica política e econômica do período.

JK herdou uma inflação razoável e problemas orçamentários, mas não deu nenhuma prioridade às restrições macroeconômicas. Seu Plano de Metas foi o programa desenvolvimentista mais ambicioso até então, canalizando investimentos maciços sobretudo para os setores de energia e transportes e aprofundando o processo de substituição de importações. Do ponto de vista externo, seu desafio foi conciliar a necessidade crescente de importações para aumentar a capacidade produtiva com a proteção requerida para estimular a produção interna. Com a decadência das exportações - em especial do café, cujos preços e valor total exportado despencaram a partir de 1956 - a situação só pôde ser mantida pelo estímulo à entrada de capitais estrangeiros e pelo grande endividamento externo. ${ }^{13}$

No plano interno, o outro lado do Plano de Metas foi o agravamento do desequilíbrio fiscal, a expansão monetária e escalada da inflação. Com a resistência a uma reforma tributária para aumentar receitas e da impossibilidade de emitir títulos, ${ }^{14}$ o financiamento inflacionário foi a única forma de viabilizar o Plano de Metas, já que a tentativa de acomodar ao menos parcialmente os mais diversos setores - do funcionalismo aos cafeicultores - e promover o crescimento implicou déficits públicos substantivos. ${ }^{15}$

Nesse cenário, não é fácil apontar de forma inequívoca os mecanismos e políticas por trás da redução da concentração no topo revelada pelos dados tributários. Alguns aspectos merecem ser comentados. Do lado estrutural, contra Kuznets, a urbanização e a mudança na composição setorial da economia possivelmente contribuíram, porque a incorporação de frações maiores da população à economia monetária, mesmo com baixos rendimentos, por definição colabora para reduzir a fatia apropriada pelos mais ricos. ${ }^{16}$ Essa influência não deve ser exagerada: como discutido no capítulo anterior, não há qualquer tendência de longo prazo facilmente perceptível e, ademais, ela vai na contramão do aumento da desigualdade verificado nos anos 1960. Ainda assim, é plausível que a urbanização tenha

12 Entre 1956 e 1961, o PIB per capita cresceu 6\% ao ano, contra apenas 3\% a.a. entre 1950 e 1956.

13 O principal instrumento de atração de capitais foi a Instrução 113 da SUMOC, decretada ainda no governo Café Filho, que permitia que, sob certas condições, empresas estrangeiras importassem equipamentos sem cobertura cambial, o que representava um subsídio ao capital estrangeiro, em detrimento de investidores nacionais (e.g., PINHO NETO, 1990, p. 154; VILLELA, 2005, p. 32).

$14 \mathrm{Na}$ época ainda estava em vigor a Lei da Usura, que limitava a taxa nominal de juros a $12 \%$ ao ano valor abaixo da inflação - e mecanismos de indexação eram proibidos.

15 Ver Abreu (2008a), Baer (2009), Orenstein e Sochaczewski (1990), Villela (2005), entre outros, para mais detalhes da política econômica do governo JK. Revisões dos eventos políticos do período podem ser encontradas em Bethell (2008b), Fausto (1995) e Maranhão (1981).

16 Como o denominador de renda total abarca apenas rendimentos monetários, ceteris paribus a simples substituição do autoconsumo e da lavoura de subsistência pelo ingresso na economia monetária aumenta a fração da renda recebida pelos mais pobres, mesmo que seu nível de consumo não se altere. 
tido algum efeito, mesmo que pequeno, ao menos nessa época de crescimento acelerado, mercado de trabalho aquecido e democracia, em que não houve iniciativas de contenção salarial como nos primeiros anos da ditadura.

O período também foi marcado por grande liberdade sindical e renovada militância, não obstante a manutenção da estrutura oficial. Se a cidadania regulada era uma promessa, os anos 1950 foram uma época em que a cidadania realmente se expandiu, até mesmo em função da urbanização, pois a regulação do trabalho abrangia apenas o setor formal urbano. O número de associados a sindicatos cresceu em ritmo acelerado, atingido quase 5,5\% ao ano entre 1952 e 1961 (RODRIGUES, 1968, p. 134), e grandes campanhas salariais foram às ruas para combater os efeitos regressivos do processo inflacionário. Com isso, os sindicatos e as organizações horizontais que proliferaram nesses anos atingiram o pico de sua influência (FAUSTO, 1995; RODRIGUES, 1968; RODRIGUES, 1981). Mesmo no campo houve inédita militância desde meados da década, começando com as Ligas Camponesas e a entrada definitiva da reforma agrária na pauta política do país, o que, inclusive, acirrou a polarização já no curto governo Jânio Quadros, que mostrou surpreendente simpatia pelo tema (CAMARGO, 1981; CARVALHO, 2008).

Dessa forma, é plausível que parte significativa dos trabalhadores urbanos tenha conseguido resistir bem melhor ao chamado imposto inflacionário do que normalmente se crê. Um indicador imperfeito, mas útil, é a evolução do salário mínimo real. A Figura 58 traz a evolução da fatia recebida pelo centésimo mais rico e o salário mínimo em valores de fevereiro de 2016. Desde os reajustes de Vargas o salário mínimo entrou em um forte ciclo de valorização. Com a inflação, os reajustes tornaram-se mais frequentes e redundaram em ganhos expressivos, de modo que o salário mínimo real atingiu seu pico histórico justamente no fim do governo JK. Nem mesmo o ciclo recente de reajustes contínuos entre 1995 e 2016 foi capaz de elevar o salário mínimo de volta ao mesmo patamar.

A correlação negativa entre o valor do salário mínimo real e a fração recebida pelo centésimo mais rico também chama a atenção, pelo menos no período entre meados dos anos 1950 e o fim da década de 1980. Evidentemente, seria injustificado deduzir do gráfico relações causais fortes, até mesmo porque o papel do salário mínimo na estruturação do mercado de trabalho mudou ao longo do tempo e a correlação negativa não se verifica nem no período 1940-1955 nem depois do Plano Real. De todo modo, o gráfico torna no mínimo plausível especular que, pelo menos no período mais pujante da industrialização por substituição de importações e intervenção estatal, o valor institucionalmente determinado do salário mínimo atuou como referência importante para o conflito distributivo.

Além disso, o período não foi de todo auspicioso para os mais ricos. A aceleração da inflação em uma economia não indexada provavelmente prejudicou os detentores de capital, favorecendo os devedores. Com a alta inflação e as restrições aos juros nominais, a dívida pública interna praticamente desapareceu (SOCHACZEWSKI, 2006, gráfico 8). Nos 
Figura 58. Fração recebida pelo $1 \%$ mais rico e salário mínimo real (R $\$$ fevereiro/2016) Brasil, 1925-2015 (\%)

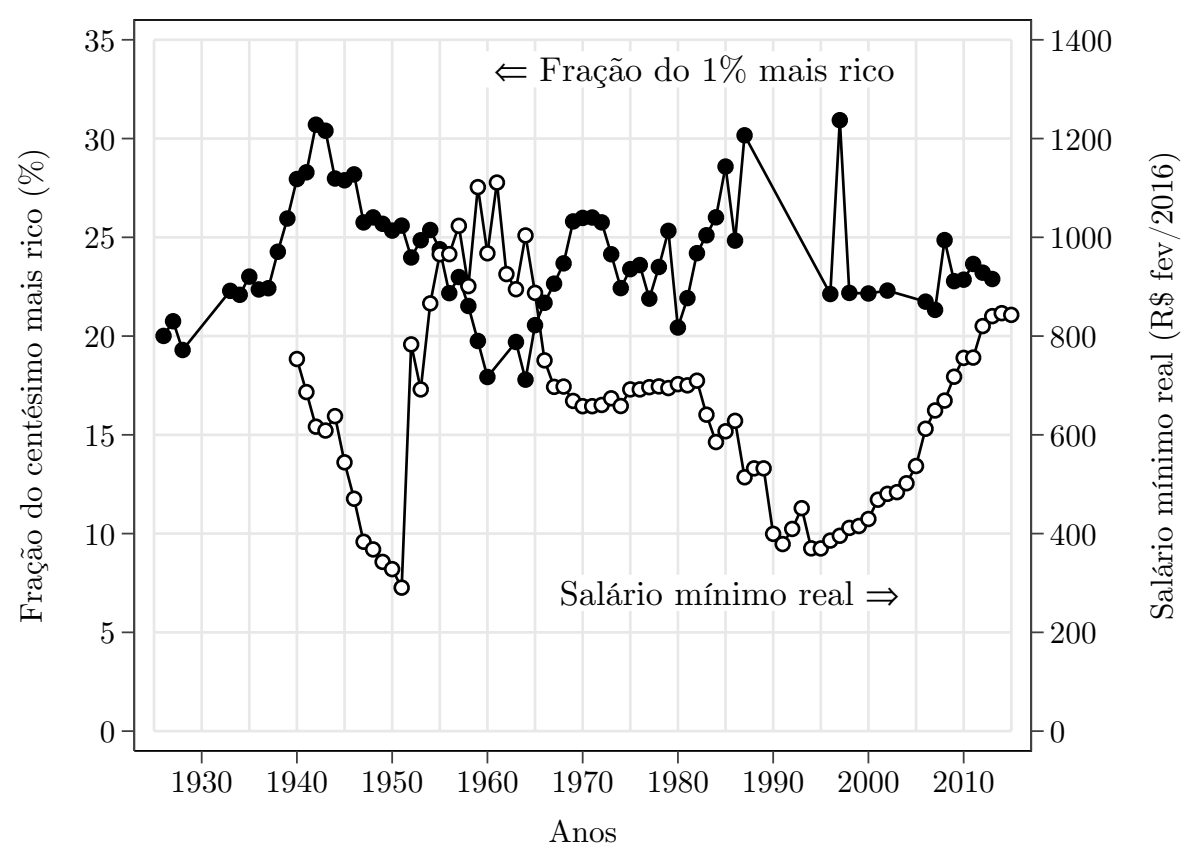

Fonte: elaboração própria a partir de tabulações de dados tributários e das Contas Nacionais; ver capítulo 4; e Ipeadata.

N.B.: valores relativos ao maior salário mínimo vigente no país no período anterior à sua unificação (mai/1984).

dados do imposto de renda, os rendimentos do capital financeiro dos mais ricos declarados nas cédulas A e B caem paulatinamente no interregno democrático, em especial entre 1953 e 1960: apesar de sua participação nos rendimentos brutos tributáveis do centésimo mais rico ser modesta desde o início do período, sua retração provocou queda de quase 0,5 p.p. na fração da renda total recebida por esse estrato.

No caso do café, depois do boicote de consumidores americanos em 1954, houve nova crise com superprodução e queda nos preços e nas quantidades exportadas, sobretudo entre 1957 e 1960. Embora o governo tenha acomodado os produtores com a compra de excedentes, as perdas só foram parcialmente atenuadas. Entre 1956 e 1960, as exportações de café declinaram de cerca de $4 \%$ para $2 \%$ do PIB, e o setor cafeeiro viu sua importância econômica relativa diminuir (VILLELA, 2005, p. 53; ver também BACHA, 1978).

O declínio das exportações pressionou o balanço de pagamentos e, como dito, descambou no aumento da dependência externa do país, pois a capacidade de importar só foi mantida graças à substancial entrada de capitais estrangeiros, com destaque para as multinacionais do setor automobilístico, que se tornaram símbolo da era JK. Com isso, se, por um lado, o subsídio ao capital estrangeiro contido na Instrução 113 da SUMOC pode ter tido efeitos redistributivos ao prejudicar setores do empresariado nacional (VILLELA, 2005, p. 52), por outro, as remessas de lucros das multinacionais para suas matrizes no exterior passariam ao largo das tabulações do imposto de renda, que, assim, indicariam desconcentração maior do que a efetivamente ocorrida. 
Só se pode especular quanto a esse último ponto. Diante dos indícios apresentados, é improvável que seu efeito tenha sido grande o suficiente para anular a queda da concentração no topo. O quadro continua a sugerir uma reavaliação mais positiva do impacto distributivo do desenvolvimentismo, ao menos enquanto foi possível sustentar o crescimento e administrar os desequilíbrios em um ambiente político relativamente aberto. Infelizmente, não há informações para todos os anos da primeira metade da década de 1960, quando o quadro político e o econômico saíram de controle. Se os resultados de 1963 e 1964 forem bons indicadores, o nivelamento chegou ao fim junto com crescimento, com a concentração no topo tendendo à estabilidade em meio à polarização política e ao acirramento dos conflitos distributivos. De novo, pode-se apenas elucubrar sobre o que teria acontecido caso não houvéssemos tido o golpe de 1964.

Essas ambiguidades são interessantes porque põem em destaque os limites desse declínio da desigualdade. Como dito, parte expressiva das mudanças configuram na realidade uma volta à situação encontrada antes da $2^{a}$ Guerra e, mesmo no fim do período, a desigualdade brasileira continuava muito alta, especialmente se a referência for o cenário internacional dos anos 1960. As políticas e conjunturas que permitiram o recuo da concentração no topo foram, mais uma vez, acomodacionistas ou, para retornar à classificação de Medeiros (2016), "inclusivas", e nem de longe explicitamente redistributivas.

A ausência de mudanças significativas no IRPF depois do governo Dutra é emblemática de tal acomodação. As faixas de renda que determinavam as alíquotas ficaram congeladas em termos nominais por mais de uma década, o que, por si só, deveria aumentar a progressividade e a abrangência do imposto ao empurrar mais contribuintes para alíquotas mais elevadas. No entanto, essa tendência foi contrabalançada pelo crescimento relativo das deduções e abatimentos. Com isso, tanto o percentual de contribuintes quanto a participação do IRPF no PIB e na carga tributária bruta ficaram estagnados.

\subsection{Ditadura, repressão e desigualdade (1964-1979)}

Depois de muitos apelos golpistas - principalmente em 1950, 1955, 1961 e 1963 - a ruptura autoritária finalmente consumou-se com o golpe militar de $1964 .{ }^{17}$ Mais uma vez,

17 Em 1950, Carlos Lacerda foi o ponta de lança da campanha contra a candidatura e posse de Getúlio Vargas, que não prosperou devido à falta de coesão política e ideológica do alto comando militar naquele momento. Em 1954, a oposição civil e militar a Vargas em seus meses finais foi muito mais ampla e a defesa de uma intervenção militar intensificou-se após o fracasso do pedido de impeachment do presidente e do atentado contra Lacerda, culminando com o suicídio de Vargas. Em 1955, setores das Forças Armadas defenderam abertamente o golpe e a UDN mobilizou-se repetidamente para impedir a candidatura e depois a posse de JK, que só foi garantida pela "Novembrada", o "golpe constitucional" dado pelo General Henrique Lott. Em 1961, Lacerda, que fora um dos mentores do apoio da UDN a Jânio, clamou por um golpe preventivo para impedir uma suposta ditadura janista, mas foi rechaçado pelos ministros militares. Com a renúncia de Jânio, o golpismo voltou à tona para impedir a posse de João Goulart, gerando a crise que só se pacificou com a mudança casuísta para o parlamentarismo. Em 1963, quando a vitória do presidencialismo no plebiscito de janeiro acirrou a polarização política, 
a correlação entre os grande ciclos políticos e a evolução da desigualdade é notável: nas séries preferidas, com imputação de rendimentos não tributáveis, ocorre uma óbvia inflexão na trajetória da concentração no topo. Mais do que interrompido, o "mininivelamento" do interregno democrático foi completamente revertido na primeira década da ditadura.

A fração do centésimo mais rico, que chegara a 17-19\% às vésperas do golpe, aumentou continuamente até 1971, quando atingiu 26\%, maior percentual desde os anos 1940. Curiosamente, desta vez a concentração não foi puxada pelos mais ricos entre os ricos: o aumento na fração recebida pelo $0,1 \%$ e pelo $0,01 \%$ no topo da distribuição de renda foi proporcionalmente um pouco menor do que o do grupo logo abaixo. Ou seja, a distribuição dentro do centésimo mais rico tornou-se menos desigual ao mesmo tempo que a fração total recebida por esse centésimo aumentou.

As escassas informações adicionais das tabulações do IRPF são prejudicadas pela falta de padronização e/ou documentação e principalmente pelas diversas alterações na legislação tributária nos primeiros anos da ditadura. Por um lado, o escopo dos rendimentos brutos tributáveis aumentou com o fim da isenção para professores, jornalistas, escritores e magistrados; por outro, foram criadas novas isenções. Entre 1964 e meados do anos 1970, os rendimentos de capital correspondentes à correção monetária, assim como bonificações em dinheiro e dividendos de ações, juros da dívida pública, lucros de empresas e outros rendimentos ligados ao capital ou à atividade empresarial passaram a ser isentos ou (compulsória ou opcionalmente) tributados na fonte com alíquotas menores do que as do IRPF (ver seção 4.4 do capítulo 4 e Nóbrega, 2014).

Tudo isso dificulta a análise da composição da renda dos mais ricos no período. De todo modo, a Figura 59 traz a participação dos componentes dos rendimentos brutos tributáveis do centésimo mais rico na renda total. Nos primeiros anos, todos os principais componentes aumentam sua participação, indicando que a maior concentração no topo não decorreu apenas de uma ou outra fonte de renda específica. Na década de 1970, o esvaziamento dos rendimentos de lucros e dividendos e o virtual desaparecimento dos rendimentos do capital financeiro sinalizam mais a mudança de regras do que alterações reais. O gráfico, afinal, mostra apenas os rendimentos brutos tributáveis, que, na prática, somam só pouco mais da metade dos rendimentos totais do centésimo mais rico. ${ }^{18}$

Os resultados gerais para o período corroboram as bases da querela acerca do aumento da desigualdade na década de 1960. Como a seção 2.6 do capítulo 2 recupera a controvérsia em detalhes, basta aqui resumir seus traços gerais. De um lado, diversos pesquisadores - muitos deles próximos à ditadura - interpretaram o aumento do coeficiente

o golpismo ganhou ainda mais força, em uma espiral que culminou com a deposição de Jango em $1^{o}$ de abril de 1964. Para mais detalhes, ver Bethell (2008b), entre outros.

18 Por motivos de espaço, o gráfico para o $0,1 \%$ mais rico foi omitido, mas a tendência a mesma; a única diferença é que, como esperado, de início os rendimentos do trabalho são um pouco menos importantes e os lucros e dividendos têm peso maior. 
Figura 59. Participação dos componentes dos rendimentos brutos tributáveis do $1 \%$ mais rico na renda total brasileira - Brasil, 1964-1978 (\%)

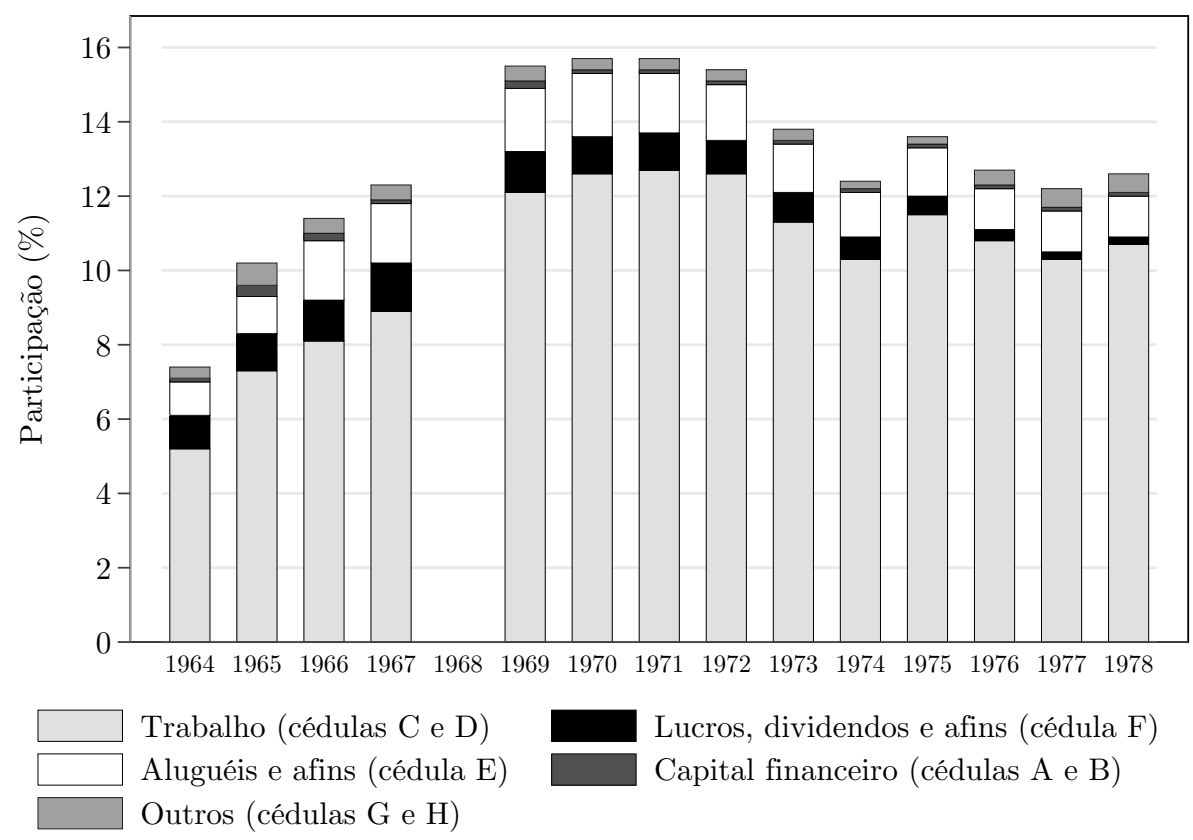

Fonte: elaboração própria a partir de tabulações de dados tributários e das Contas Nacionais; ver capítulo 4. N.B.: não há informações para os rendimentos não tributáveis.

de Gini como reflexo da curva de Kuznets associada a desajustes temporários entre oferta e demanda por trabalhadores qualificados em um contexto de rápido crescimento econômico. De outro, autores críticos destacaram a política de repressão salarial e o esgarçamento da hierarquia salarial em grandes empresas em benefício dos gerentes e executivos. Com isso, a redistribuição teria ocorrido a favor do capital, em detrimento do fator trabalho, e também entre os trabalhadores, favorecendo os ocupantes de posições hierarquicamente privilegiadas em grandes empresas (ver, por exemplo, Bacha e Taylor, 1978).

Como destacado no capítulo anterior, o avanço da concentração no topo já no período antes do "milagre econômico" torna as interpretações benignas centradas no "U invertido" de Kuznets e na educação pouco convincentes, e reforçam os pontos levantados por Albert Fishlow, Rodolfo Hoffmann, Edmar Bacha e outros. Isso não implica que mudanças estruturais e/ou a desigualdade educacional não tenham nenhuma importância; só é difícil dar primazia a elas. Afinal, o golpe de 1964 é o exemplo mais bem acabado no Brasil de ruptura que permitiu, pelo uso da força, o enfraquecimento da resistência e o redesenho de instituições de modo a alterar bruscamente a distribuição de renda. O golpe ilustra como um determinado padrão de desigualdade dificilmente tem raízes claras em uma ou outra política e, assim, muda rapidamente só com reformas abrangentes.

Em retrospecto, salta aos olhos como o conjunto de políticas e reformas implementadas pelos militares - com ajuda de seus aliados civis - em sua primeira década no poder favoreceu a maior concentração de renda. Não é necessário aqui entrar na questão da 
intencionalidade do processo; o que interessa são seus resultados. Como visto no capítulo 2 , no plano retórico os intelectuais do regime pagavam tanto tributo a um futuro mais igualitário quanto, nos meses seguintes ao golpe, os generais à defesa da democracia.

No plano político-sindical, a repressão começou imediatamente e atingiu em cheio a esquerda e os movimentos reivindicatórios que floresceram nos anos anteriores. Na esteira imediata do golpe, a sede da União Nacional dos Estudantes (UNE) foi invadida e incendiada; a Universidade de Brasília (UnB) foi igualmente ocupada; e os comandantes das Forças Armadas editaram o Ato Institucional no 1 (AI1), que, além de reforçar significativamente o Poder Executivo, suspendeu as imunidades parlamentares e autorizou suspensão por dez anos dos direitos políticos dos indivíduos que tivessem "tentado contra a segurança do país". Em seguida, deu-se a primeira leva de cassações, expurgos e aposentadorias compulsórias nos meios político, sindical, estudantil e militar: quase três mil pessoas foram punidas durante a vigência do AI1 e outras duas mil foram cassadas, demitidas e afins até 1973 (CARVALHO, 2008, p. 164). O PTB perdeu cerca de 15\% de sua bancada federal apenas nessa primeira rodada de cassações, as Ligas Camponesas foram violentamente reprimidas, e as intervenções em sindicatos foram maciças em 1964 e 1965: segundo Fausto (1995, p. 467), 70\% das organizações com mais de cinco mil membros foram afetadas, com prisão de dirigentes e fechamento de organizações de cúpula. Em junho de 1964, a Lei 4.330 tornou greves legais praticamente impossíveis.

O esforço de desarticulação de toda oposição organizada não parou por aí, como atestam os seguidos Atos Institucionais. O AI5 iniciou o período de fechamento máximo do regime, com a suspensão de direitos civis e políticos básicos, como a liberdade de opinião e de reunião e o habeas corpus, ao mesmo tempo que a máquina de repressão e tortura ganhava proporções cada vez maiores (BETHELL; CASTRO, 2008; CARVALHO, 2008; FAUSTO, 1995). Nem mesmo antigos aliados foram poupados, como se vê pelo rápido banimento da "Frente Ampla" de Carlos Lacerda e sua cassação em 1968.

A repressão pavimentou o caminho para políticas sociais e econômicas que dificilmente seriam aceitas em um regime mais livre. A crise política, o descontrole das contas públicas e o aperto excessivo de liquidez induzido pelo Plano Trienal jogaram o país em um quadro de estagflação em 1963-1964. O governo do general Castello Branco logo anunciou o Plano de Ação Econômica do Governo (PAEG), comandado por Otávio Bulhões, então ministro da Fazenda, e Roberto Campos, então ministro do Planejamento. O programa colocava a estabilização monetária, aliada a reformas tributária e financeira, como pré-condição para a retomada do crescimento.

Como argumentou Resende (1982), o PAEG não era "perfeitamente ortodoxo", com a preocupação constante em manter o crescimento forçando uma estratégia gradualista de combate à inflação (ver também Hermann, 2005b). Seu diagnóstico da inflação brasileira frisava o conflito distributivo como causa fundamental, além dos déficits públicos e da 
expansão monetária. Embora o programa falasse em "manter a participação dos assalariados no produto nacional", a política salarial desempenharia um papel fundamental no que se via como contenção do excesso de demanda e no controle dos custos de produção. Na prática, grande parte do fardo da estabilização foi transferido para os assalariados, o que marcou uma evidente diferença entre o PAEG e o Plano Trienal de Celso Furtado (RESENDE, 1982, p. 775-776).

A política salarial foi enormemente restritiva, caracterizando uma intervenção inédita na determinação dos preços no mercado de trabalho. Em 1964 e 1965 foram introduzidas, no setor público e depois no privado, regras de reajuste impositivas para o salário mínimo e para as negociações coletivas. Por lei, os dissídios e convenções só seriam homologados se estivessem de acordo com os parâmetros oficiais de reajuste. As sentenças da Justiça do Trabalho também deveriam estar em conformidade com as regras. Com greves basicamente proibidas e ameaças constantes, o poder de barganha dos sindicatos tornou-se nulo e as "negociações diretas entre trabalhadores e empregadores foram substituídas pela fórmula de reajuste fornecida pelo Governo" (RESENDE, 1982, p. 777).

Assim, "a política salarial passou a ser uma política de máximos e não de mínimos, como era de se esperar de uma legislação trabalhista" (OLIVEIRA, 1986, p. 233). Pela fórmula oficial, os salários deveriam ser reajustados anualmente de forma a restabelecer o salário médio real dos 24 meses anteriores, acrescido da taxa de aumento da produtividade e de metade da inflação prevista para o ano seguinte (resíduo inflacionário). Na prática, todos os três elementos contribuíram ao menos temporariamente para o arrocho salarial, com destaque para a subestimação do crescimento da produtividade e, principalmente, do resíduo inflacionário. Ao contrário do discurso oficial, a política fiscal e monetária mais flexível de Delfim Netto, que assumiu o Ministério da Fazenda no governo Costa e Silva, não reverteu de vez a situação, atenuando apenas parcialmente os prejuízos aos salários causados pela subestimação do resíduo inflacionário a partir de 1968 (CARVALHO, 1982; HERMANN, 2005b; RESENDE, 1982; SMITH, 1988).

Os efeitos dessa política sobre o salário mínimo real já foram mostrados na Figura 58, na seção anterior: depois de uma queda real de cerca de $30 \%$ nos primeiros anos da ditadura, o salário mínimo só voltou a apresentar crescimento real sustentado a partir de 1974, e mesmo assim em ritmo muito lento. Os salários médios de vários setores, em particular os dos trabalhadores ligados à produção industrial, também foram muito afetados, ainda que em escala menor. Estimativas como a de Frankema (2009, p. 168) indicam redução contínua da participação do fator trabalho na renda nacional desde seu pico no início dos anos 1960 até a estabilidade em meados dos anos 1970.

Não à toa, muitos destacaram a importância da política salarial para o aumento da desigualdade e apontaram que seus efeitos eram compatíveis com o crescimento particularmente baixo da renda em torno da mediana nos Censos de 1960 e 1970 (BACHA; 
TAYLOR, 1978; FISHLOW, 1972; HOFFMANN, 1973; RESENDE, 1982; WELLS, 1974). Os resultados do capítulo anterior reforçam a tese de que a piora na desigualdade deu-se em boa parte durante os anos de estabilização e crise de 1964-1967, e não apenas durante o "milagre". Por tudo isso, explicações baseadas majoritariamente em mudanças estruturais e na oferta e demanda de pessoal qualificado em um período de rápido crescimento soam insatisfatórias, ainda mais com tais intervenções autoritárias no mercado de trabalho.

A política salarial não foi a única iniciativa da ditadura com efeitos distributivos favoráveis aos mais ricos. A reforma tributária levada a cabo em meados dos anos 1960 tinha como objetivo aumentar a arrecadação e racionalizar o sistema, e foi muito bemsucedida nisso (ver Figura 10 do capítulo 4), contribuindo para a redução significativa do déficit público. Em termos distributivos, contudo, é muito provável que seu impacto tenha sido regressivo, como defendido por Hermann (2005b), uma vez que a maior parte do aumento da arrecadação decorreu de impostos indiretos.

O IRPF fornece um bom exemplo: como visto nas Figuras 10 e 11 do capítulo 4, o tributo não acompanhou a elevação forte da CTB e perdeu importância relativa para a arrecadação federal na segunda metade da década de 1960. Em seus primeiros anos, a ditadura logo reduziu a alíquota marginal máxima do pico histórico de $65 \%$ para 50\%, tentando expandir o imposto pelo alargamento da base de declarantes, o que teve efeito muito fraco sobre o número de contribuintes (ver Figura 14 do capítulo 4).

A Figura 60 apresenta as alíquotas efetivas do IRPF para os 0,01\%, 0,1\% e 1\% mais ricos ao longo do tempo, isto é, os percentuais dos rendimentos brutos tributáveis de cada estrato correspondentes ao imposto líquido devido. Como parte substancial dos rendimentos dos mais ricos era (e é) isenta ou tributada exclusivamente na fonte, as alíquotas efetivas sobre os rendimentos totais são bem menores, podendo cair à metade dos valores exibidos. Como é impossível obter informações sobre os impostos pagos na fonte e os rendimentos não tributáveis tiveram que ser imputados para parte do período, optei por apresentar as alíquotas efetivas com base apenas nos rendimentos brutos tributáveis.

Depois de algum crescimento nos anos 1950, não há mudanças significativas no período 1964-1974: para os mais ricos entre os ricos, a alíquota efetiva sobre os rendimentos brutos tributáveis cai pronunciadamente entre 1965 e 1970; para o centésimo mais rico como um todo, há uma leve tendência de aumento, partindo de um patamar muito baixo. Como o escopo de rendimentos isentos ou tributados na fonte com alíquotas preferenciais aumentou, é razoável supor que o peso do IRPF sobre a renda total de todos esses grupos manteve-se estável ou declinou na segunda metade dos anos 1960.

Se não fosse pelas restrições introduzidas a determinados abatimentos e aos reajustes da tabela inferiores ao crescimento da renda média, a progressividade do IRPF teria diminuído mais ainda, já que a proliferação de incentivos fiscais para pessoas físicas e jurídicas foi uma característica marcante do período. Essas medidas fizeram parte do esforço 
Figura 60. Alíquota efetiva do IRPF para os estratos mais ricos como fração dos rendimentos brutos tributáveis - Brasil, 1945-1978 (\%)

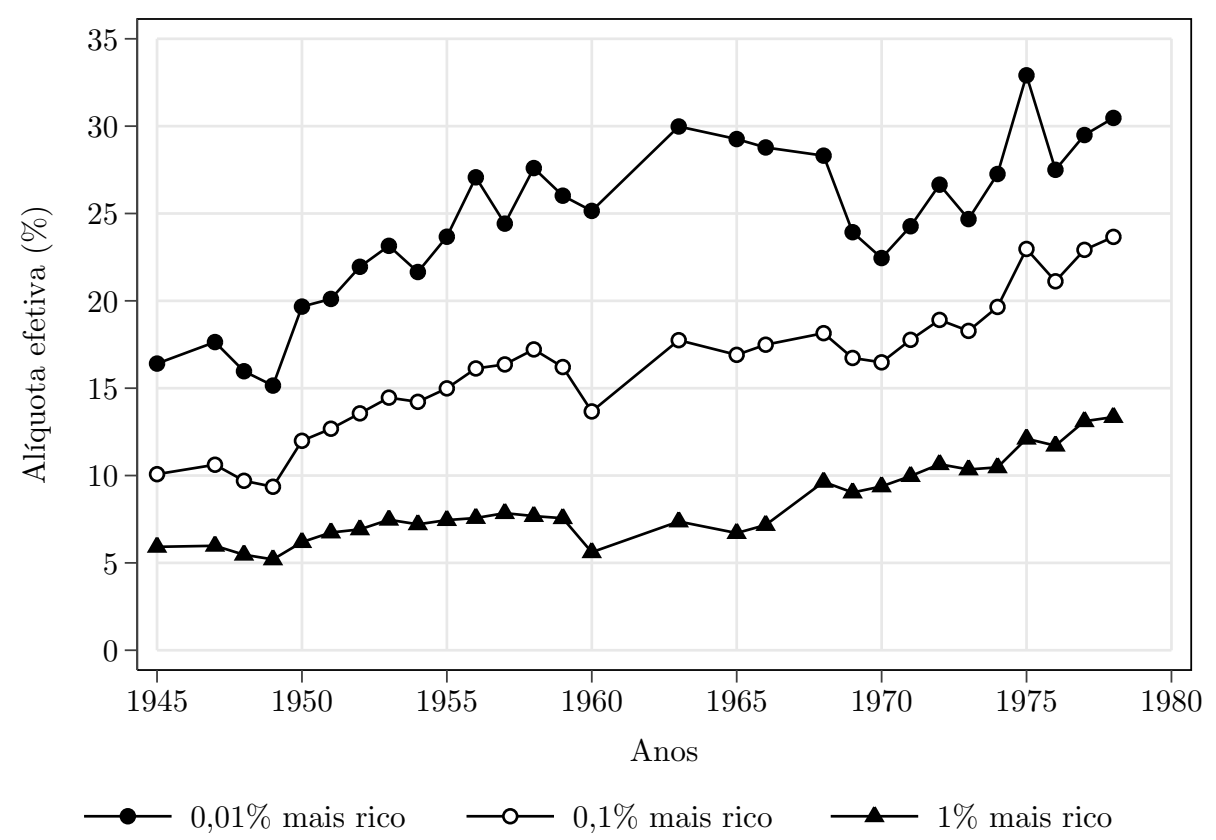

Fonte: elaboração própria a partir de tabulações de dados tributários e das Contas Nacionais; ver capítulo 4.

N.B.: as alíquotas apresentadas correspondem ao imposto líquido devido dividido pelo rendimento bruto tributável.

da ditadura para aumentar a poupança nacional e canalizar recursos para regiões e setores prioritários, favorecendo, portanto, os poupadores, que, empiricamente, correspondem aos indivíduos com renda mais alta. Notavelmente, buscou-se incentivar o mercado acionário pela criação dos Fundos 157 em 1967, que permitiam aos contribuintes fazer investimentos dedutíveis no IRPF e que colaboraram para um boom especulativo e o colapso do mercado em 1971 (BAER, 1973; HERMANN, 2005b; LAGO, 1990).

De modo mais amplo, apesar de a reforma do sistema financeiro ter permitido avanços, seus efeitos potencialmente negativos sobre a concentração de renda são plenamente compatíveis com os resultados empíricos do capítulo anterior. A criação da correção monetária contornou as restrições da Lei da Usura e efetivamente criou um mercado de títulos públicos, possibilitando o financiamento não inflacionário do déficit público. Ao proteger o retorno real dos ativos, beneficiou os estratos poupadores, em um momento que, vale lembrar, os salários mais baixos eram fortemente reprimidos. A ditadura promoveu ativamente a concentração bancária, sobretudo a partir de 1971, acreditando que economias de escala reduziriam os custos operacionais do sistema. O resultado foi apenas a limitação da concorrência e oligopolização do sistema bancário. Cabe ainda lembrar que boa parte do crédito oferecido por instituições oficiais originava-se de mecanismos de poupança forçada, muitas vezes desvantajosos para os trabalhadores que contribuíam para eles (e.g., BAER, 2009; HERMANN, 2005b; LAGO, 1990; RESENDE, 1982).

O Fundo de Garantia por Tempo de Serviço (FGTS) exemplifica o efeito distributivo 
de muitos desses mecanismos. Criado em 1966, ele substituiu o direito à estabilidade para os trabalhadores formais urbanos há mais de dez anos no mesmo emprego. Ao facilitar a rotatividade da mão de obra, o FGTS foi vantajoso para os empregadores, possibilitando a estratégia de demitir funcionários logo antes dos dissídios coletivos para recontratá-los depois sem conceder os reajustes (FAUSTO, 1995; VIANNA, 1999). Os recursos do fundo, por sua vez, eram direcionados para os financiamentos subsidiados do Sistema Financeiro de Habitação, que beneficiaram mais as classes média e alta (SANTOS, 1999, p. 17).

Outras políticas com efeitos regressivos podem ser mencionadas. Por exemplo, Resende (1982, seção 7) recapitulou como as políticas monetária e creditícia restritivas dos primeiros anos da ditadura tiveram efeitos negativos heterogêneos sobre as firmas, muito mais brandos para as sociedades anônimas (i.e., as grandes empresas com fontes alternativas de financiamento) e para os setores mais oligopolizados; Smith (1988) corroborou esses resultados, mostrando que entre 1966 e 1971 os trabalhadores das grandes empresas tiveram grandes ganhos relativos aos do setor competitivo; entre outros argumentos, Fishlow (1974, p. 35) contrastou a restrição salarial imposta aos trabalhadores com o aumento absoluto e relativo dos gastos com pessoal militar; Fausto (1995, p. 472) notou como a aprovação do Estatuto da Terra em novembro de 1964 não tirou a reforma agrária do papel; e Bacha e Taylor (1978) sugeriram o esgarçamento das escalas remuneratórias nas empresas estatais como motor da maior dispersão salarial que beneficiou gerentes e executivos.

Em suma, apesar de a política salarial merecer de fato um lugar privilegiado, não foram poucas as reformas instituídas nos primeiros anos da ditadura militar que potencialmente contribuíram para o aumento da concentração no topo, seja no que diz respeito à distribuição em prol do capital, por oposição ao trabalho, seja quanto à maior desigualdade entre os empregados. O processo aparentemente chegou ao fim em 19721973 e foi seguido por um período de volatilidade e leve tendência de reversão da maior desigualdade, fato que corresponde a grandes mudanças política e econômicas do período. No fim das contas, mesmo ditaduras encontram limites.

O "milagre econômico" começado em 1968 fora favorecido pela estabilidade política e por algumas das reformas do PAEG, dependendo também crucialmente da existência de capacidade ociosa - oferecida pela recessão de meados da década -, da situação externa positiva, da maior flexibilidade da política econômica na era Delfim e de pesados investimentos públicos. Com isso, conjugaram-se altas taxas de crescimento econômico com a desaceleração da inflação, pelo menos até o momento em que a capacidade ociosa foi se esgotando, no fim de 1972. Paralelamente à expansão dos investimentos, o regime começou então a lançar mão do controle de preços tabelados para conter, sem sucesso, o processo inflacionário em uma economia já superaquecida. No front externo, o "milagre" acarretou maior endividamento, principalmente para a formação de reservas, e maior dependência de importações, sobretudo do petróleo, para manter a taxa de crescimento (LAGO, 1990). 
Nesse contexto, o primeiro choque do petróleo no fim de 1973 exacerbou os desequilíbrios em meio à grande inflexão representada pela ascensão à presidência do general Ernesto Geisel, em março de 1974. Com a saída de Médici, a linha dura das Forças Armadas foi finalmente deslocada do poder, iniciando-se um ciclo de descompressão política. Apesar da ressurgência de alguma oposição política organizada - por exemplo, com a repercussão da "anticandidatura" presidencial de Ulysses Guimarães -, a literatura é razoavelmente consensual ao apontar a dominância da motivação corporativa para a abertura. Com a derrota da maior parte dos grupos armados de esquerda, Geisel e seus aliados preocuparam-se em restabelecer o controle sobre os órgãos de repressão e preservar a hierarquia militar (BETHELL; CASTRO, 2008; FAUSTO, 1995).

A abertura "lenta, gradual e segura" deu-se em meio a pressões que colocavam em jogo a legitimidade do governo. Geisel teve de navegar entre a massa de insatisfações que veio a público com a grande vitória política do Movimento Democrático Brasileiro (MDB) nas eleições legislativas de 1974 e as ameaças dos setores mais radicais das Forças Armadas. Entre idas e vindas, distensões e casuísmos, concessões e brutalidades, o grupo político do general conseguiu manter relativo controle sobre o processo.

A situação não dava margem para um ajuste recessivo, nem seria possível deslocar as perdas para os assalariados como no PAEG. Daí a opção por dobrar a aposta no crescimento e lançar o ambicioso II Plano Nacional de Desenvolvimento (PND), possibilitado, no plano externo, pela liquidez proporcionada pelos chamados petrodólares. Não cabe aqui entrar em detalhes do plano ou avaliar suas consequências macroeconômicas, bastando apenas assinalar como o II PND dificilmente pode ser interpretado à parte do processo de abertura política, constituindo, pois, uma estratégia de legitimação via desenvolvimento indispensável para os planos de institucionalização do regime (Cf. FONSECA; MONTEIRO, 2007). ${ }^{19}$ O próprio discurso da ditadura com relação à distribuição de renda mudou perceptivelmente, com promessas explícitas de "[a]umento substancial de renda real para todas as classes", em especial a classe trabalhadora e média (BRASIL, 1974, p. 54). Sem deixar de eximir o regime de qualquer culpa, o discurso oficial presente no documento do II PND mostrou sensibilidade inédita desde 1964 à questão distributiva:

19 Para mais detalhes sobre o II PND e a política econômica no governo Geisel, ver, por exemplo, Carneiro (1990) e Hermann (2005a). Sobre a controvérsia da racionalidade econômica vs. a racionalidade política do plano, ver Fonseca e Monteiro (2007). 
"[O] Governo não aceita a colocação de esperar que o crescimento econômico, por si, resolva o problema da distribuição de renda, ou seja, a teoria de 'esperar o bolo crescer'.

Há necessidade de, mantendo acelerado o crescimento, realizar políticas redistributivas 'enquanto o bolo cresce'.

A verdade é que, de um lado, o crescimento pode não resolver o problema da adequada distribuição de renda, se deixado à simples evolução dos fatores de mercado. E, de outro lado, a solução através do crescimento, apenas, pode demorar muito mais do que a consciência social admite $[\ldots]$.

A estrutura da distribuição de renda é insatisfatória, e com ela a Revolução não se solidariza, mesmo porque tal distribuição resultou de uma evolução de longo prazo da economia, e não de fatores recentes. (BRASIL, 1974 , p. 52)

Nessas condições, não causa espanto que a concentração no topo tenha apresentado comportamento volátil, com alguma tendência de queda, mais pronunciada para os $5 \%$ e $10 \%$ mais ricos do que para estratos menores, como o $1 \%$ ou o $0,1 \%$ no topo. Como visto na seção 5.4 do capítulo anterior, as PNADs também registram queda do coeficiente de Gini e da fração recebida pelos mais ricos na segunda metade da década de 1970, em magnitude muito maior e com tendência muito mais clara do que a dos dados tributários.

Curiosamente, o comportamento da desigualdade nesse período não recebeu grande atenção acadêmica. Com isso, não há consensos nem sobre a trajetória vista nas PNADs. A problematização da desigualdade no II PND, afinal, era acima de tudo um compromisso retórico. Ainda assim, há indícios mais concretos de alterações na condução política do país que podem ter colaborado para o recuo da desigualdade naquele momento. Em boa parte, esses indícios sugerem mais efeitos no resto da distribuição do que no topo, e não se pode esquecer que o declínio da fração dos mais ricos foi pequeno.

Diante de ameaças eleitorais e na esteira das críticas ao arrocho salarial e à desigualdade, o governo Geisel relaxou a política salarial em 1974, finalmente corrigindo as distorções que permitiam que a subestimação do resíduo inflacionário derrubasse os salários reais (CARNEIRO, 1990; CARVALHO, 1982). Os resultados de Colistete (2009) indicam um aumento contínuo dos salários reais do pessoal ligado à produção na indústria manufatureira desde 1972, com aumentos maiores em 1974-1978, período em que houve uma leve tendência de crescimento do custo unitário do trabalho, o que sugere uma melhora na distribuição funcional da renda no setor em favor dos trabalhadores. Entre 1971 e 1976, Smith (1988) encontrou ganhos dos trabalhadores industriais de pequenas e médias empresas com relação aos das maiores firmas, destacando o papel tanto das políticas salariais quanto da escassez de força de trabalho em 1973-1974. Sem apresentar dados, Oliveira (1986) deu mais destaque às conquistas salariais obtidas em 1978 e 1979 graças ao ressurgimento do movimento grevista. 
A ênfase retórica no plano social teve contrapartida em avanços maiores nos anos 1970 do que nos 1960 em outros indicadores importantes, como a expectativa de vida ao nascer (SILVA; BARBOSA, 2006) e o saneamento básico em áreas urbanas (MARQUES, 2016), embora o quadro geral tenha permanecido tétrico. Em linha com a priorização também dos investimentos em integração nacional, a desigualdade regional diminuiu na década de 1970, revertendo a tendência do período anterior (FERREIRA, 1996).

Como dito, a magnitude da redistribuição não deve ser superestimada. Em primeiro lugar, a aceleração da inflação, a deterioração fiscal e o endividamento externo foram o outro lado da moeda, plantando as sementes da crise da década seguinte. Além disso, não se deve menosprezar a falta de coerência da política econômica e a sensibilidade do governo à reação das "classes produtoras", apesar dos atritos ocasionais. Com efeito, o II PND aprofundou as tendências anteriores de concessão ad hoc de incentivos, subsídios e proteções a "campeões nacionais", com todos seus efeitos potencialmente regressivos de estimulação do rent-seeking (ABREU, 2008a, p. 388-393). Por fim, não obstante os avanços em relação à década anterior, os maiores investimentos sociais passaram longe de produzir mudanças realmente drásticas. O atraso educacional, por exemplo, foi apenas atenuado: apesar da melhora de 13 p.p. na década de 1970, em 1980 mais de três quartos da população economicamente ativa ainda possuía menos de oito anos de estudo, o equivalente ao ensino fundamental (MENEZES-FILHO; KIRSCHBAUM, 2016, p. 117).

Os limites da preocupação redistributiva e a resistência a promover a desconcentração da renda no topo podem ser vistos no comportamento do IRPF. Apesar de a alíquota marginal máxima ter sido elevada de 50\% para 55\% em 1978, o aparente aumento da alíquota efetiva sobre os rendimentos brutos tributáveis dos mais ricos visto na Figura 60 foi quase totalmente contrabalançado por novo alargamento do rol de rendimentos isentos ou (compulsória ou opcionalmente) tributados exclusivamente na fonte.

Seja como for, a progressiva rearticulação da sociedade civil limitou a capacidade de imposição de perdas por parte da política econômica, tornando a acomodação via crescimento o caminho de menor resistência avidamente procurado por um regime cuja legitimidade estava em xeque. O "novo sindicalismo" foi a face mais visível dessa rearticulação, promovendo grandes greves históricas e rompendo com o arcabouço legal existente (SANTANA, 1998), sem ser um caso isolado. Sindicatos rurais, associações de profissionais liberais, movimentos sociais dedicados a problemas urbanos e afins se multiplicaram no período e em muitos casos fizeram oposição aberta à ditadura (CARVALHO, 2008; FAUSTO, 1995). Nada disso significou uma ruptura para o regime; de todo modo, eram óbvios os obstáculos a intervenções ostensivamente redistributivas e é notável que a trajetória da concentração no topo tenha paralelos tão claros com essa história. 


\subsection{Inflação e redemocratização (1979-1988)}

Em 1979, o segundo choque do petróleo explodiu de vez os desequilíbrios da economia brasileira. Nossos termos de troca sofreram a pior deterioração do pós-guerra, e o aumento de juros nos países desenvolvidos foi fatal para o balanço de pagamentos, provocando contração das exportações, aumento brutal das despesas com a dívida externa - contratadas em boa parte a taxas de juros flutuantes - e inviabilizando a captação de novos empréstimos. A acomodação obtida pelo II PND não seria mais possível sem ter como financiar o déficit em conta corrente com superávits na conta de capital. A transição para a democracia seria feita então em meio a uma década de crise e tentativas díspares de estabilização (BATISTA, 2006; CARNEIRO; MODIANO, 1990; HERMANN, 2005a).

Os resultados dos dados tributários mostram que as turbulências foram acompanhadas por maior concentração no topo. Depois de algum recuo no fim dos anos 1970, a fração recebida pelos mais ricos aumentou paulatinamente ao longo da década de 1980, chegando nas séries preferidas a um patamar próximo ao pico histórico estimado para a $2^{a}$ Guerra Mundial. O recrudescimento da desigualdade concentrou-se nos estratos mais abastados, como o $0,01 \%$, o $0,1 \%$ e o $1 \%$ mais ricos, que começaram a aumentar sua participação na renda total desde o início do período em análise. Para estratos maiores, como os $5 \%$ e os $10 \%$ mais ricos, as mudanças são bem menos pronunciadas e quase inteiramente detonadas pelos mais ricos. Como argumentou a seção 5.3.2 do capítulo 5, os anos 1980 foram um período também de maior desigualdade entre os mais afluentes.

A composição dos rendimentos dos mais ricos evidencia que esse aumento da desigualdade foi motivado sobretudo pelos rendimentos não tributáveis, isto é, os rendimentos isentos ou sujeitos à tributação exclusiva na fonte. Isso se observa tanto nos cálculos a partir das tabulações ordenadas por rendimentos brutos tributáveis quanto nas estimativas produzidas com base em tabulações ordenadas por rendimentos não tributáveis (disponíveis apenas para os anos de 1979 a 1988). Como discutido na seção 4.9.2 do capítulo 4, os resultados privilegiados neste e no último capítulo - as "séries preferidas" - utilizam essas últimas tabulações para o período 1979-1988 para obter a fração da renda recebida do centésimo mais rico em diante.

A Figura 61 ilustra essas mudanças, apresentando a participação dos componentes dos rendimentos do centésimo mais rico na renda total. Deixando de lado a quebra de série de 1978 para 1979 em virtude da alteração na variável de ordenação dos dados, vê-se que, nos anos 1970, a relativa estabilidade da fração do 1\% mais rico decorreu da estabilidade dos dois componentes da renda (rendimentos brutos tributáveis e rendimentos não tributáveis). Nos anos 1980, a expansão dos rendimentos não tributáveis respondeu por todo o aumento da concentração no topo, enquanto os rendimentos brutos tributáveis pouco mudaram. Os 
Figura 61. Participação na renda total dos componentes dos rendimentos totais do $1 \%$ mais rico - Brasil, 1974-1987 (\%)

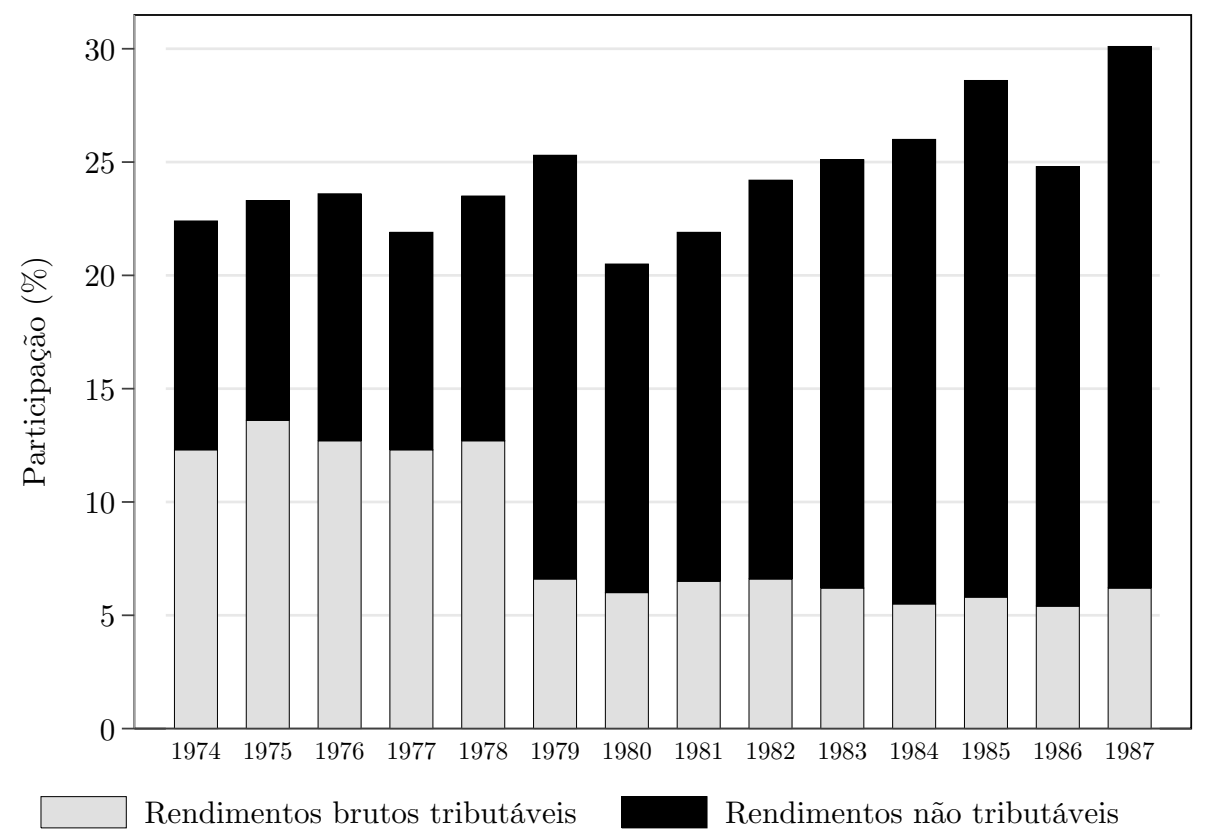

Fonte: elaboração própria a partir de tabulações de dados tributários e das Contas Nacionais; ver capítulo 4.

N.B.: há uma quebra de série de 1978 para 1979, pois a partir desse ano os resultados foram calculados com base nas tabulações ordenadas por rendimentos não tributáveis (em vez de tabulações ordenadas por rendimentos brutos tributáveis), conforme discutido no capítulo 4.

sub-estratos mais ricos dentro do centésimo mais abastado capitanearam esse processo. ${ }^{20,21}$

O fenômeno decorre da combinação das regras do IRPF com a escalada da inflação, a partir de meados dos anos 1980. Como mencionado no capítulo anterior, é possível que ao menos parte da piora na desigualdade observada na década de 1980 seja artificial, isto é, resultado de ruídos ou erros de medidas introduzidos pela inflação crescente. Em uma economia altamente indexada como era a brasileira, o problema torna-se ainda maior. Afinal, os rendimentos não tributáveis incluíam as variações correspondentes à correção monetária de muitos investimentos financeiros. Ou seja, é de se esperar que os rendimentos não monetários cresçam muito quando a inflação salta de 40\%, como no fim dos anos 1970, para mais de 200\%, como em meados dos anos 1980 (ver Figura 28 do capítulo 5). Ainda assim, é improvável que isso explique todo o aumento da desigualdade, até porque a variabilidade da inflação é muito maior do que a da concentração no topo. Pelo menos parte do fenômeno deve ter sido real, como corroboraram inclusive as pesquisas domiciliares da época (ver seção 5.4 do capítulo anterior).

20 Como dito, a série com base nas tabulações ordenadas por rendimentos brutos tributáveis apresenta a mesma tendência, embora em grau menos intenso. Além disso, como seria de se esperar, a composição dos rendimentos totais é bem diferente, com maior participação média dos rendimentos brutos tributáveis.

21 A proeminência dos rendimentos não tributáveis e a alteração na variável de ordenação faz com que informações relativas apenas aos rendimentos brutos tributáveis - como sua composição e a alíquota efetiva do IRPF - sejam pouco relevantes. Por isso, esta seção não apresenta gráficos nos mesmos moldes das seções anteriores. 
Do ponto de vista teórico, o efeito da aceleração da inflação sobre a distribuição de renda é menos obviamente deletério do que seu efeito sobre o crescimento, sendo possível postular mecanismos plausíveis que contribuem tanto para maior quanto para menor desigualdade, dependendo dos arranjos institucionais específicos (e.g., ROMER; ROMER, 1999, p. 23 e 32). A maior parte dos autores, contudo, dá mais peso aos efeitos regressivos do imposto inflacionário, que são mais intuitivos e potencialmente mais fortes (e.g., NERI, 1995). Empiricamente, os resultados internacionais não são unívocos, mas, mais uma vez, a maior parte das evidências aponta para uma associação positiva e talvez não linear, entre inflação e desigualdade, sugerindo efeitos regressivos mais fortes sobretudo em ambientes hiperinflacionários, ainda que não seja possível concluir peremptoriamente que se trata de uma relação causal (e.g., BULIR, 2001; ROMER; ROMER, 1999).

No Brasil, a maioria dos estudos tratou a associação positiva entre inflação e desigualdade na década de 1980 como real e causal. Por exemplo, Neri (1995) enumerou mecanismos que vinculariam maior inflação a maior desigualdade e reuniu algumas evidências empíricas de sua validade no Brasil. Cardoso, Barros e Urani (1993) concluíram, com base na Pesquisa Mensal do Emprego (PME), que variações no desemprego e na inflação explicavam cerca de um terço do aumento da desigualdade nas áreas metropolitanas. Para eles, a escolaridade da força de trabalho teve pouco a ver com o fenômeno, ponto de vista oposto ao de Ferreira e Litchfield (2001), que, de todo modo, reconheceram a aceleração da inflação como uma das causas da maior desigualdade nos anos 1980.

Nem a inflação nem a crise econômica que permeou toda a década podem ser entendidas fora do contexto político da época. O general Geisel foi o único presidente militar a escolher seu sucessor, o general João Figueiredo, que assumiu o poder em março de 1979 com a missão de dar prosseguimento e controlar a transição do regime. No plano político-eleitoral, as idas e vindas da abertura continuaram e pelo menos até a derrota da campanha das "Diretas Já", em 1984, o controle foi mantido. ${ }^{22}$

No plano econômico, os problemas mostraram-se incontornáveis muito mais cedo. Depois de uma última tentativa de escapar à crise, em 1980 o desequilíbrio externo empurrou o governo para um forte ajuste recessivo, com o objetivo de reduzir a demanda

22 Uma das primeiras medidas do novo presidente foi a Lei da Anistia, aprovada em agosto de 1979. Se, por um lado, a lei abriu caminho para o retorno dos exilados, por outro, garantiu imunidade aos torturadores ligados ao regime. Ainda em 1979 o Congresso aprovou o fim do bipartidarismo, o que, mais uma vez, teve implicações ambíguas: o novo sistema partidário tornou-se mais permeável ao pluralismo de correntes e manifestações políticas, mas tudo indica que a motivação real da reforma foi o enfraquecimento e fragmentação do MDB. Com o pluralismo, as eleições também perderiam seu caráter inevitável de plebiscito sobre o regime. Nos anos seguintes, foram aprovadas emendas constitucionais alterando a legislação eleitoral de forma a beneficiar o Partido Democrático Social (PDS) nas eleições de 1982. Os esforços deram certo: apesar do ótimo desempenho da oposição - principalmente nas eleições para governador -, o PDS manteve o controle do Senado (graças em parte aos senadores biônicos de 1978) e da Câmara dos Deputados, obtendo, portanto, maioria no Colégio Eleitoral que escolheria o novo presidente em janeiro de 1985. Para mais informações, ver, por exemplo, Bethell e Castro (2008) e Fausto (1995). 
interna e tornar a balança comercial superavitária. Juros altos, contenção de gastos e de investimentos e política salarial mais restritiva foram parte do arsenal que levou o país à pior crise desde 1930. Entre 1980 e 1983, o PIB real caiu 6\%, e o PIB per capita, 12\%.

Em meio à abertura política e à ressurgência da sociedade civil, o ajuste não pôde ser tão explicitamente regressivo quanto fora o de 1964. O próprio caráter da política salarial era radicalmente distinto: desde 1979, ela havia retomado em alguma medida o papel de política de "mínimos" e não mais de "máximos" (OLIVEIRA, 1986), com reajustes mais frequentes e diferenciados por faixas de salário, de modo que apenas os trabalhadores que recebiam até três salários mínimos teriam ganhos reais garantidos. A maior restrição imposta posteriormente não alterou isso, elevando a compressão salarial para rendimentos mais altos, que já tinham garantidas apenas reposições abaixo da inflação. Para rendimentos acima de 20 salários mínimos, não havia mais nenhum reajuste inflacionário garantido, devendo empregados e patrões negociar entre si, em meio à profunda recessão. Carvalho (1982, p. 74) argumentou que o alvo principal dessa mudança eram as empresas do setor público, que contavam com uma parcela significativa de funcionários com altos salários, que, no entanto, "seriam muito mais baixos se não fossem fixados institucionalmente". Mesmo o auge do arrocho salarial, promovido em 1983, manteve a progressividade do ajuste: pelo Decreto-Lei 2.012/1983, a correção garantida para até três salários mínimos foi reduzida para $100 \%$ da inflação semestral (sem ganhos reais), percentual progressivamente reduzido até atingir 0\% para a fração da remuneração que excedesse 20 salários mínimos.

Assim, não é surpreendente que a concentração de renda no topo tenha aumentado menos até 1983 do que nos anos 1960. Não obstante, o ajuste foi mal-sucedido. Apesar do empobrecimento do país, a recessão mundial até 1982 fez com que só em 1983 as contas externas melhorassem, empurradas pela crise interna, pela desvalorização cambial, pela recuperação americana e pelas quedas dos juros internacionais e do preço do petróleo. O estrago foi enorme: a indústria fora atingida em cheio pela recessão, e a desvalorização cambial, a situação fiscal e o choque agrícola mantiveram a inflação alta apesar da crise. Somente em 1984 a conjuntura melhorou, com a recuperação econômica puxada pelas exportações e a expansão da produção doméstica de petróleo, na esteira dos projetos ligados ao II PND. Finalmente o estrangulamento externo foi aliviado, a produção e os salários industriais responderam bem e o país voltou a crescer - junto com a inflação (e.g., ABREU, 2008a; CARNEIRO; MODIANO, 1990; FAUSTO, 1995; HERMANN, 2005a).

Em 1984, portanto, a situação parecia a inversa de antes: a economia dava sinais de recuperação ao mesmo tempo que, no plano político, o regime perdia o controle da sucessão. Figueiredo já havia anunciado que não influiria na escolha do candidato do PDS, que, em meio a disputas internas, acabou rachando, com a dissidência da Frente Liberal após a escolha de Paulo Maluf. O resto, como se diz, é história: a Frente Liberal apoiou Tancredo Neves, que foi eleito pelo Colégio Eleitoral e morreu antes de assumir. Com isso, coube a José Sarney - duas vezes deputado pela UDN, governador do Maranhão e senador 
pela Aliança Renovadora Nacional (Arena), fundador do PDS e aliado de longa data da ditadura - ser o primeiro civil a assumir a presidência desde o golpe de 1964.

Com pouca legitimidade, o governo Sarney foi marcado por volatilidade e tentativas de acomodar aliados fazendo uso "generalizado e predatório do aparato estatal", como descreveram Silva e Barbosa (2006, p. 511). Dado o desafio da estabilização e a pressão por crescimento, o governo apostou na possibilidade de resolver os problemas econômicos e sociais da forma mais benigna possível, com o Plano Cruzado. Afinal, o fracasso da ortodoxia em solucionar o problema da inflação dera fôlego às interpretações inercialistas do processo inflacionário, que priorizavam a desindexação da economia como forma de estabilização, e não a redução da demanda agregada.

O Plano veio a público no fim de fevereiro de 1986, com a reforma monetária e o congelamento de preços, salários e do câmbio, em um momento de folga temporária nas contas externas. A pressão por inclusão sem imposição de perdas refletiu-se na política salarial: a despeito da intenção declarada em evitar redistribuições de renda e riqueza, os salários foram convertidos pela sua média real dos seis meses anteriores mais um abono de 8\% (16\% para o salário mínimo) e passariam a voltar a ser reajustados anualmente nos dissídios coletivos e automaticamente quando a inflação acumulada ultrapassasse $20 \%$.

O Cruzado durou pouco. Apesar do seu sucesso inicial, ainda em 1986 já estava claro que o plano era insustentável; o calendário eleitoral, entretanto, fez o governo postergar seu fim para depois das eleições de novembro de 1986, que elegeram os membros da Assembleia Constituinte, com ótimo desempenho do PMDB de Sarney. Em retrospecto, muitos pecados do Plano são evidentes: a) as teses inercialistas pressupunham não haver problema de excesso de demanda, o que era falso desde o início, dado que a economia já estava aquecida, e a inflação era ascendente; b) o subsequente boom de consumo deu-se em momento em que a capacidade ociosa da indústria era baixa; c) a política monetária foi excessivamente frouxa no início do plano; d) muitos preços relativos estavam distorcidos na hora do congelamento, e as tarifas públicas e preços administrados estavam particularmente defasados; e) o déficit operacional do setor público foi muito maior do que o previsto, e a situação fiscal piorou sensivelmente com o fim do imposto inflacionário e a introdução de subsídios para manter o congelamento; f) o congelamento acabou provocando desabastecimento, ágios e a proliferação de estratégias para burlá-lo; g) o gatilho salarial repassava rapidamente choques desfavoráveis; h) o superaquecimento da demanda interna prejudicou as exportações e estimulou as importações, deteriorando as contas externas (ABREU, 2008b; BAER, 2009; CASTRO, 2005; FAUSTO, 1995; MARQUES, 1988; MODIANO, 1990).

Por tudo isso, a prosperidade e a queda na desigualdade registradas em 1986 tanto nos dados tributários quanto nas pesquisas domiciliares foi passageira, com nova aceleração da inflação e da concentração no topo já em 1987. A pletora de planos econômicos dos anos seguintes - o Cruzado II ainda em 1986, Plano Bresser em 1987, a política do "feijão 
com arroz" de Maílson da Nóbrega em 1988, o Plano Verão em 1989, e assim por diante obteve resultados ainda mais pífios. Em sua maioria, tratava-se de planos híbridos, com boas doses de heterodoxia para quebrar a indexação, sem nunca atacar diretamente o desequilíbrio fiscal. Eram, em suma, tentativas de estabilização sem recessão nem perdas. Nas palavras de Albert Fishlow (1990, p. 69), "fórmulas mágicas"; nas de Marcelo de Paiva Abreu (2008b, p. 409), "um truque sem custos".

O fim da ditadura, a mobilização social, os anos de crise e a persistente desigualdade tornariam impossível qualquer ajuste "responsável" como o de 1964. A grande expansão dos direitos sociais na Constituição Federal de 1988, mesmo com todo o peso do "Centrão", oferece a melhor ilustração possível da demanda por inclusão, obtida ao menos na letra da lei. Sem crescimento, essas demandas só poderiam ser acomodadas via redistribuição e/ou inflação. A disposição ostensivamente redistributiva, no entanto, só poderia ser bastante tímida nos estertores de uma transição democrática prolongada e negociada, em que boa parte da cúpula política civil da ditadura conseguiu manobrar para permanecer em posições de prestígio, a começar pelo próprio presidente.

Mais uma vez, o IRPF serve como exemplo, não por ter sido decisivo para a dinâmica da desigualdade, e sim por refletir a ambivalência e a tentativa de acomodação. Para além dos efeitos concentradores da inflação, entre 1985 e 1989 o IRPF passou pelo maior corte em suas alíquotas de toda a história: a alíquota marginal máxima despencou de $60 \%$ para $25 \%$, enquanto o número de alíquotas caiu de 12 para 2 . Como discutido na seção 4.4 do capítulo 4, toda a lógica do imposto foi alterada. Não há dados para avaliar se outras mudanças compensaram esses cortes; mesmo que isso tenha ocorrido, é provável que o saldo líquido tenha sido regressivo, isto é, que as reformas tenham beneficiado em boa medida os mais ricos. No fim dos anos 1980, os percentuais de declarantes e contribuintes em relação à população adulta diminuíram, e a arrecadação do IR (IRPF e IRPJ) também caiu em relação ao PIB, revertendo a tendência verificada entre 1980 e 1985.

A redemocratização fomentou a explosão de demandas sem nenhuma contrapartida redistributiva nem desmonte dos inúmeros privilégios, favores e benefícios corporativos cristalizados nos incentivos, isenções e subsídios concedidos pelo estado brasileiro, entre outras políticas. O descontrole fiscal piorou e a inflação ultrapassou qualquer parâmetro visto anteriormente por aqui, com todos seus efeitos concentradores, reais e artificiais. Apesar de sua descrição talvez equivocada da dinâmica distributiva durante o interregno democrático (ver seção 6.3 acima), o diagnóstico de Gustavo Franco para os primeiros anos da Nova República é condizente com o argumento desenvolvido aqui: 
[A] partir de meados dos anos 80, o Orçamento vai se transformando em uma coleção tão irreal quanto inconsequente de desejos, de modo que vão se tornando crescentes, em consequência, as discrepâncias entre desejos (valores orçados) e gastos efetivamente realizados (...). A sociedade brasileira parecia expressar com clareza o desejo que o Estado brasileiro ampliasse seu papel no plano social, mas não exibia qualquer disposição para fornecer ao Estado os meios financeiros para isso, ou seja, mais impostos. Não é outra a essência da crise fiscal brasileira: desejos que se tornaram direitos - às vezes extravasando o terreno orçamentário e inscrevendo-se mesmo na Constituição - maiores que as possibilidades fornecidas pela tributação.

$(\ldots)$

[O] mecanismo de frustração de despesa através da inflação ia provocando um superfaturamento generalizado de pleitos a fim de que o racionamento imposto pela inflação fosse menos efetivo. Era o conflito distributivo em sua forma mais pura, sendo travado no âmbito do Orçamento, e para a execução do qual a inflação vai assumindo o papel de fator de ajustamento forçado entre desejos e possibilidades. (FRANCO, 2005, p. 273-274)

\subsection{Novo contrato social? $(1988-2013)^{23}$}

A redemocratização trouxe menor transparência no que diz respeito à divulgação de tabulações dos dados tributários. As muitas reformas no IRPF no final da década de 1980 acabaram por interromper a trajetória inaugurada nos anos 1970 pelo Anuário EconômicoFiscal e aprofundada na década seguinte pelo anuário Imposto de Renda - Pessoa Física, que por cerca de dez anos trouxe tabulações padronizadas e com detalhamento até então inédito. Com isso, não foi possível localizar fontes e produzir estimativas da concentração no topo no período crucial de 1989 a 1995 e, nos anos seguintes, os dados encontrados foram apenas parciais, exigindo uma série adicional de imputações. A situação só mudou a partir de 2006, com a publicação, finalmente, de informações de alta qualidade que, embora não tão detalhadas quanto as da década de 1980, têm o grande mérito de incluir tabulações ordenadas por rendimentos totais (ver capítulo 4 para mais detalhes).

Por tudo isso, os resultados para o período posterior à Constituição Federal de 1988 contêm lacunas, insuficiências e mudanças conceituais que reduzem a precisão das afirmações que podem ser feitas, pelo menos até 2006. Como visto no capítulo anterior, tudo indica que a concentração no topo diminuiu em algum momento entre meados das décadas de 1980 e de 1990 para todos os estratos mais ricos, permanecendo relativamente estável desde então, em patamar semelhante ao observado na virada dos anos 1970 para os 1980. Nos anos mais recentes, houve até detectar uma leve tendência de maior concentração. Em 2013, o milésimo mais rico apropriou-se de 10\% da renda total, o centésimo mais rico recebeu quase $23 \%$ e o décimo mais rico como um todo obteve pouco mais de $51 \%$.

23 Por motivos de espaço, essa seção abstém-se de comentar os traços gerais da evolução política e econômica do país nesse período mais recente. 
Em virtude da natureza fragmentária dos dados e da discussão na seção anterior, algumas qualificações fazem-se necessárias. Primeiro, é provável que parte da queda entre 1987 e 1995 seja artificial, decorrente apenas da eliminação dos erros de medida causados pela alta inflação observada até o Plano Real. Segundo, não é possível rejeitar a hipótese de que a queda da desigualdade tenha se prolongado até meados dos anos 2000, já que os dados do período 1995-2005 exigiram imputações importantes e só a partir de 2006 as tabulações são ordenadas por rendimentos totais. Com efeito, mesmo nos dados disponíveis é possível vislumbrar pequena redução pelo menos na fração do 0,01\% mais rico entre 2000 e 2006. Terceiro, o aumento da concentração no topo a partir de 2006 é bem tênue e não deve ser superestimado, embora também apareça em outros estudos com metodologia um pouco distinta (e.g., MEDEIROS; SOUZA; CASTRO, 2015a). Afirmações mais fortes sobre esse aumento devem aguardar a divulgação de informações para anos mais recentes; por ora, o que se pode dizer com convicção é que os dados do IRPF não revelam nenhuma tendência de redução da desigualdade desde meados dos anos 2000.

Em outras palavras, pode-se falar em alguma redução da desigualdade durante os anos 1990, seguida por estabilidade em um patamar alto, equivalente, grosso modo, à concentração média observada desde os anos 1920. Infelizmente, só é possível analisar a composição dos rendimentos dos mais ricos no período mais recente; mesmo sem mudanças abruptas, o resultados marcam o aumento dos rendimentos isentos e a correspondente redução do peso dos rendimentos brutos tributáveis.

A Figura 62 apresenta essas tendências, trazendo a participação na renda total do componentes da renda do centésimo mais rico entre 2006 e 2013. A Figura 63 expressa os mesmos números em termos da composição da renda desse estrato. O primeiro gráfico mostra que, em termos da renda total, a expansão dos rendimentos isentos contrabalançou a diminuição dos rendimentos brutos tributáveis, mantendo basicamente constante a fração total do centésimo mais rico, salvo por pequena tendência de aumento. O segundo gráfico explicita como isso alterou a composição dos rendimentos desse estrato. Os rendimentos isentos correspondiam a algo entre $45 \%$ e $50 \%$ da renda do centésimo mais rico, percentual que caiu para cerca de $35 \%$ nos últimos anos. Em contraposição, os rendimentos isentos cresceram de $40 \%$ para $50 \%$, tornando-se a principal fonte de renda do $1 \%$ mais rico.

Algo semelhante ocorreu com os outros estratos no topo da distribuição, embora a composição inicial da renda, como esperado, variasse muito: quanto mais rico o estrato, menor a participação dos rendimentos brutos tributáveis em sua renda total. Por exemplo, esse componente nunca ultrapassou mais de $20 \%$ da renda do milésimo mais rico e sempre esteve entre $55 \%$ e $60 \%$ da renda do décimo mais rico como um todo.

A legislação do IRPF no Brasil não permite a equivalência perfeita entre esses componentes e as categorias normalmente utilizadas para analisar a composição da renda (rendimentos do trabalho, capital etc.). Apesar disso, os rendimentos brutos tributáveis 
Figura 62. Participação na renda total dos componentes dos rendimentos totais do $1 \%$ mais rico - Brasil, 2006-2013 (\%)

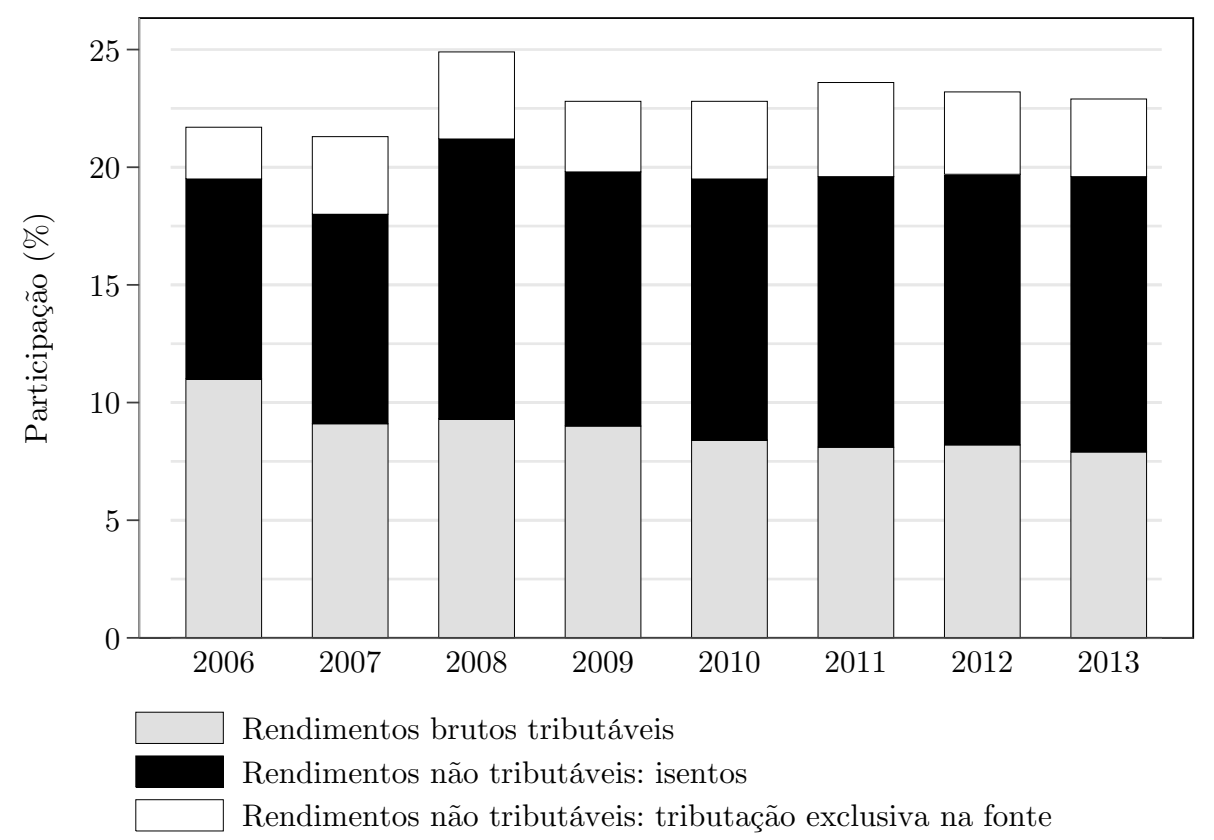

Fonte: elaboração própria a partir de tabulações de dados tributários e das Contas Nacionais; ver capítulo 4.

Figura 63. Composição dos rendimentos totais do 1\% mais rico - Brasil, 2006-2013 (\%)

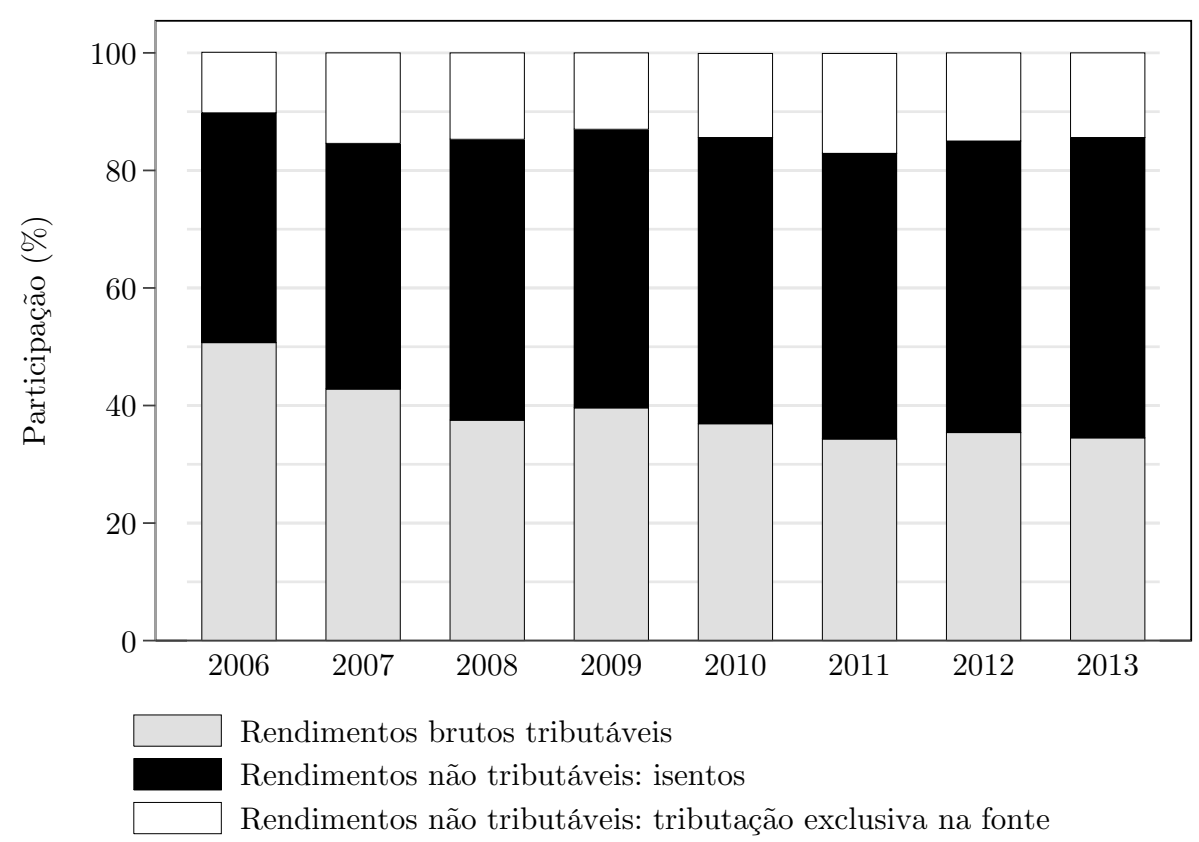

Fonte: elaboração própria a partir de tabulações de dados tributários e das Contas Nacionais; ver capítulo 4. 
correspondem sobretudo à remuneração do trabalho, enquanto o principal componente dos rendimentos isentos são os lucros e dividendos e, no caso da tributação exclusiva na fonte, os rendimentos financeiros e ganhos de capital (ver Tabela 2 no capítulo 4). À primeira vista, isso sugeriria que a estabilidade da concentração no topo coexistiu com a ascensão dos retornos à atividade empresarial, em detrimento dos rendimentos do trabalho. No entanto, não é possível descartar que parte desse movimento seja simplesmente o que Afonso (2014) chamou de "transfiguração do trabalho em capital", isto é, a transformação de pessoas físicas em pessoas jurídicas, com a migração crescente de trabalhadores com rendas mais elevadas para relações de trabalho alheias à CLT.

De um modo ou de outro, esses resultados dos dados tributários chocam-se com as conclusões da maior parte da produção acadêmica sobre desigualdade no país nos últimos anos, em especial os trabalhos baseados em pesquisas domiciliares como as PNADs. Como discutido em detalhe na seção 3.5 do capítulo 3, o crescimento econômico, a recuperação da remuneração dos empregados na distribuição funcional da renda e a queda do coeficiente de Gini nas PNADs fizeram com que o Brasil fosse celebrado como um caso exemplar de crescimento com redistribuição. Em vista dos objetivos deste capítulo, vale a pena recuperar brevemente os elementos centrais das explicações e interpretações eminentemente otimistas que proliferaram nos últimos anos, uma vez que as políticas públicas ocuparam um lugar central. Afinal, o consenso recente aponta a melhoria do sistema educacional, a expansão das transferências assistenciais, a formalização e inclusão previdenciária e a valorização do salário mínimo como emblemas de um novo perfil distributivo do Estado, com consequências fundamentais para a redução da desigualdade.

O papel da educação, em particular, foi muito destacado, não só porque o mercado de trabalho liderou a queda da desigualdade como também porque a compressão das disparidades salariais entre níveis educacionais deu-se concomitantemente à redução da heterogeneidade educacional e ao aumento da escolaridade média desde a década de 1990 (e.g., SOUZA, 2012, p. 10, Figura 5). Para dar concretude a esse aspecto tão ressaltado nos últimos anos, a Figura 64 traz os retornos à educação estimados por regressões nas PNADs de 1976 e 2013. Mais especificamente, o gráfico apresenta os ganhos médios estimados para alguns níveis educacionais relevantes em comparação com os trabalhadores sem nenhuma escolaridade, controlando por outras variáveis sociodemográficas. Assim, por exemplo, em 2013 os trabalhadores com ensino médio completo ganhavam em média pouco menos do que o dobro (100\% a mais) do que os trabalhadores sem escolaridade com características semelhantes, enquanto os trabalhadores com nível superior completo ganhavam quase 3,5 vezes mais $(350 \%)$.

Como se vê, houve ao longo do tempo um grande estreitamento da dispersão salarial entre níveis educacionais, denotando, ceteris paribus, menor desigualdade salarial. A tendência se manifesta desde a primeira metade da década de 1990, acelerando-se - em especial para os retornos ao Ensino Superior - nos anos 2000. No longo prazo, a compressão 
Figura 64. Retornos salariais à educação para níveis educacionais selecionados - Brasil, $1976-2013(\%)$

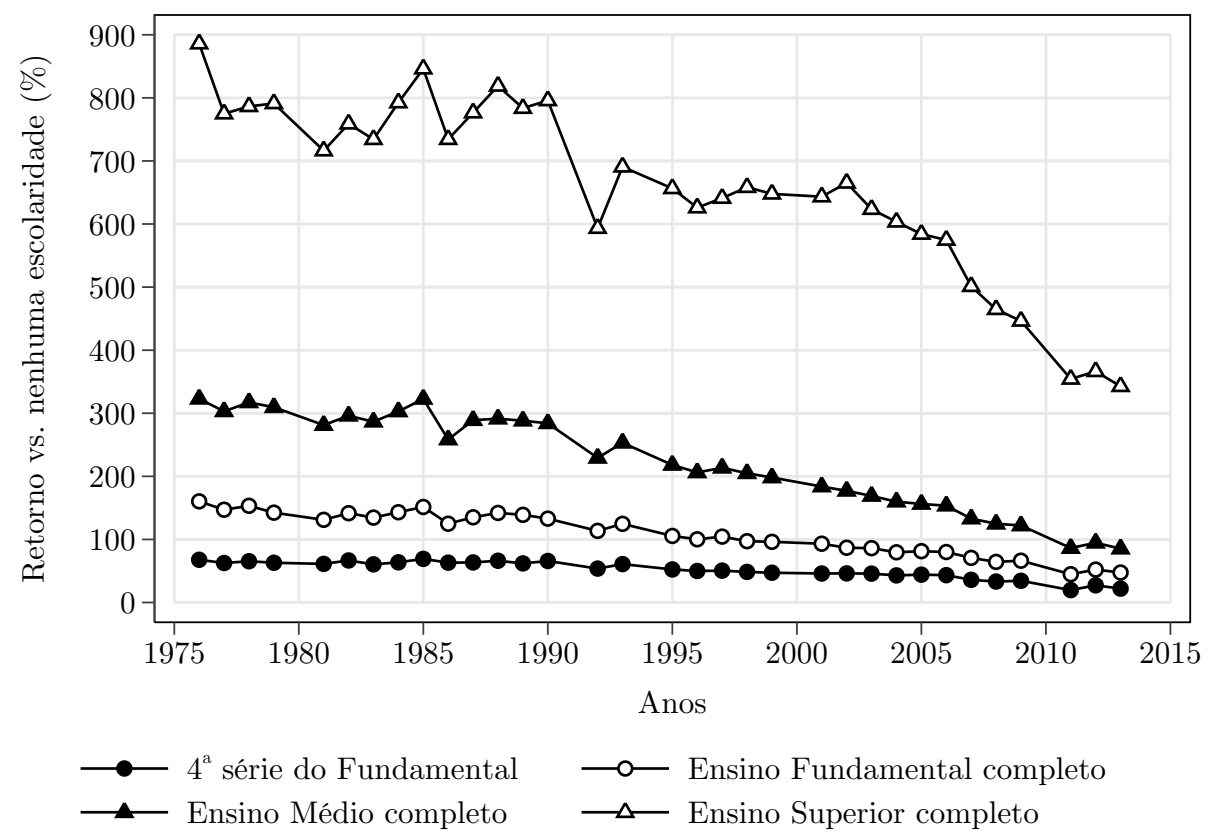

Fonte: elaboração própria a partir dos microdados das PNADs 1976-2013.

N.B.: coeficientes estimados a partir de regressões do logaritmo do salário por hora sobre variáveis de anos de estudo (0 a 15; representadas por 15 dummies), área censitária (regiões metropolitanas, municípios auto-representativos e não auto-representativos; duas dummies), regiões (as cinco macrorregiões do país; quatro dummies), empreendedorismo (dummy para trabalhadores por conta própria e empregadores), sexo (dummy para homens), urbanização (dummy para áreas urbanas), experiência e experiência ao quadrado. Foram considerados apenas indivíduos entre 16 e 64 anos moradores de regiões cobertas pelas PNADs desde 1976.

foi mais aguda até o Ensino Médio, de modo que atualmente pode-se falar que a grande clivagem se dá entre portadores de diploma universitário e os demais trabalhadores. De acordo com a interpretação prevalecente nos últimos tempos, essa compressão salarial pode ser entendida em termos da "corrida entre educação e tecnologia" (GOLDIN; KATZ, 2008), ou seja, decorreria de uma expansão da oferta de trabalho qualificado mais rápida do que o aumento da demanda por mais qualificação. Implícita ou explicitamente, a maior parte das análises recentes do Brasil - e da América Latina - concorda com isso. ${ }^{24}$

A combinação desses aparentes efeitos distributivos da educação e a maior proeminência das transferências sociais ensejou a proliferação de interpretações otimistas quanto à evolução política e social do Brasil. Ao lado de alguns esforços mais caricatos e partidários, muitos trabalhos instigantes e com insights importantes foram produzidos. ${ }^{25}$

24 Uma possível dificuldade para esse raciocínio é que tanto a escolaridade média quanto o coeficiente de Gini dos anos de estudo da força de trabalho ocupada vêm evoluindo quase linearmente nas PNADs desde os anos 1970, sem qualquer aceleração visível ao longo do tempo. Logo, seria preciso considerar outros fatores institucionais. Muitos pesquisadores fizeram isso, seja ao colocar a estabilização macroeconômica como pré-condição para a "normalização" do mercado de trabalho, seja por admitir que as reformas liberalizantes implementadas nos anos 1990 em toda a América Latina tiveram efeito regressivo ao menos em um primeiro momento, forçando muitas empresas a conviver com competição internacional e, assim, deslocando a demanda por mão de obra qualificada (e.g., OCAMPO, 2004).

25 Evidentemente, os trabalhos citados aqui e na seção 3.5 do capítulo 3 não esgotam a produção recente 
O já mencionado texto de Arretche (2016), por exemplo, adota uma perspectiva de longo prazo para sintetizar resultados empíricos relativos à múltiplas dimensões das desigualdades. A interpretação da autora refuta o pessimismo de parte da literatura nos anos 1990, apontando para a queda generalizada da desigualdade em muitas áreas. Para além do impacto direto da redemocratização, Arretche (2016, p. 455) salientou os efeitos cruciais da opção por certas políticas e das decisões acerca do seu desenho, concluindo que os avanços sociais resultaram da "combinação no tempo do efeito de diferentes políticas orientadas a públicos diferentes, cuja característica comum tem sido a perspectiva de reverter a longa trajetória de estabilidade da elevada desigualdade no Brasil", não de fatores isolados.

Alston et al. (2013) são ainda mais incisivos. Para eles, com o ocaso do desenvolvimentismo da ditadura, o Brasil passou por um raro momento de mudança de seu "contrato social", entendido como o mix de políticas redistributivas e regulação que influencia os níveis de desigualdade e desenvolvimento. A Constituição de 1988 seria a cristalização do novo contrato, tendo como espinha dorsal a priorização da inclusão social. De início, a nova onda inclusiva teria redundado sobretudo em hiperinflação, e apenas após a estabilização em 1994 a "inclusão social com sustentabilidade fiscal" tornou-se efetivamente a força dominante na elaboração de políticas públicas. Mais gastos sociais, mais tributação e mais redistribuição seriam as marcas do período, consubstanciadas na melhora da desigualdade.

A transição, contudo, não estaria completa, em vista do próprio patamar ainda elevado de desigualdade. Estaríamos vivendo um processo de "inclusão dissipativa", em que os antigos privilégios reagem às mudanças e os conflitos se acirram, com proliferação também de demandas particularistas, ineficiências e resistências com efeitos deletérios sobre o crescimento econômico, ao menos no curto prazo. Embora reconheçam a indefinição do processo, os autores apostam que, no longo prazo, os avanços na inclusão podem mudar endogenamente a distribuição de poder na sociedade, enfraquecendo as bases do rent-seeking, permitindo políticas menos ineficientes e dissipativas e, por conseguinte, um melhor desempenho econômico.

A caracterização de Singer (2012) do "lulismo" serve como último exemplo de interpretação nuançada, mas essencialmente esperançosa, dessa vez por uma matriz teórica completamente distinta. Elaborada ainda no auge do prestígio de Lula, a interpretação coloca menos peso na redemocratização ou em forças de longo prazo para salientar como a estratégia de acomodação do primeiro mandato do ex-presidente, calcada na "diminuição da pobreza com manutenção da ordem", atraiu para Lula e para o PT uma nova base social, o "subproletariado", que, por sua vez, permitiu o aprofundamento da agenda no segundo mandato. Essa agenda seria um "reformismo fraco", uma diluição das propostas históricas do PT, que, mais moderadas, evitariam o confronto direto com as elites e ao mesmo tempo viabilizariam um ciclo lento, porém real, de redução da desigualdade, com 
efeitos imediatos mais visíveis sobre a pobreza monetária absoluta. Embora, mais uma vez, evite fazer afirmações definitivas sobre o futuro, o sucesso do lulismo faz Singer postular que o "sonho rooseveltiano" de crescimento com redistribuição progressiva poderia se tornar o "marco regulatório da política brasileira por período extenso".

Por vias teóricas muito distintas, a visão de Singer aproxima-se do novo contrato social postulado por Alston e coautores. Apesar de todas as nuances e salvaguardas, todos os exemplos têm em comum uma visão benigna do desenvolvimento político-institucional do Brasil, associando-o diretamente à redução da desigualdade no passado recente e apontando para a possível continuidade do processo no futuro.

A grande questão, portanto, é como conciliar a estabilidade no topo nos dados tributários com essas evidências e interpretações benevolentes. Para os propósitos deste capítulo, e no espírito das seções anteriores, trata-se de estabelecer como a dinâmica política permitiu a reprodução dessa desigualdade e bater de frente com a ideia de que nossa evolução institucional deu-se em direção muito mais igualitária do que a anterior.

À parte as ressalvas de sempre, ${ }^{26}$ cabe notar, antes de tudo, que as crises política e econômica dos últimos anos solaparam muito do otimismo, inclusive quanto ao futuro da queda da desigualdade, que, como visto, desacelerou fortemente mesmo nas PNADs. Há alguns anos era sobretudo a esquerda marxista que questionava os méritos e as bases do crescimento com queda da desigualdade, o que não é grande surpresa, já que para muitos desse grupo tudo que não se expressa diretamente como antagonismo de classes tem cheiro de impostura. Mais recentemente, porém, analistas liberais, como Mendes (2015), e de outras estirpes tornaram-se bem mais céticos quanto às perspectivas de crescimento e de diminuição da desigualdade no país. Para Mendes, especificamente, a coexistência de democracia e alta desigualdade é a causa profunda do baixo crescimento brasileiro, acirrando o conflito distributivo, sem que haja qualquer garantia - somente uma possibilidade - de que, no longo prazo, as pressões redistributivas engendrem menor desigualdade e, por tabela, preparem o terreno para políticas mais eficientes.

Deixando de lado seus pressupostos e previsões sobre o crescimento econômico, que ultrapassam o escopo desta tese, a análise de Mendes sobre a desigualdade tem algum parentesco com a interpretação esboçada anteriormente e desenvolvida mais a fundo neste capítulo: a evolução da desigualdade - entendida como a concentração no topo - tem um forte caráter inercial, perceptível no longo prazo, que pode ser atribuído em boa parte ao arcabouço institucional vigente em cada sociedade, com ênfase no papel do Estado. Tributos, transferências, organização e regulação de mercados e relações de trabalho, incentivos, subsídios, garantia e escopo de direitos civis, políticos e sociais, entre muitos

26 Como dito, os resultados apresentados nesta tese não são incompatíveis com a ocorrência de redistribuição entre os $80 \%$ "mais pobres", nem com a queda da pobreza, tal como medida tradicionalmente, e muitos menos com avanços em outras dimensões do bem-estar, como o acesso a serviços públicos. As deficiências e limitações dos dados são discutidas no capítulo 4. 
outros itens, fazem parte desse arcabouço e afetam, muitas vezes de forma contraditória, a distribuição de renda. Embora alguns aspectos possam ser mais ou menos importantes do que outros, é a combinação de muitas políticas distintas, fruto de pequenas e grandes decisões e compromissos, que é decisiva, como observado por Arretche (2016).

É precisamente isso que torna difícil que, em condições democráticas normais, a distribuição de renda seja alterada rapidamente. Interesses entrincheirados, lobbies e grupos com poder de veto são comuns em democracias e em algum grau sempre refletem a distribuição de poder preexistente. Isso não implica necessariamente estagnação, é óbvio, mas a lógica de benefícios concentrados e custos difusos (ou vice-versa) é pervasiva e dificulta sobremaneira a emergência de coalizões duradouras contrárias.

Com isso, são as situações de crise e ruptura as mais propícias para mudanças bruscas na estratificação, porque abrem espaço para uma pluralidade de reformas institucionais possivelmente duradouras. Na experiência internacional, vê-se isso nitidamente no colapso da desigualdade em meio às duas guerras mundiais e, mais recentemente, em escala bem menor e muito mais localizada, no rápido recrudescimento da concentração no topo em alguns países. No Brasil, não parece ser coincidência que a trajetória da desigualdade, como visto, ande lado a lado com grandes eventos políticos.

A questão é se a ordem inaugurada pela redemocratização e pela Constituição de 1988 representou uma ruptura desse tipo. Empiricamente, a resposta é negativa. Os resultados apresentados no capítulo anterior e discutidos acima mostram algum abrandamento da concentração no topo, ligado ao que poderia se chamar de "normalização" do conflito distributivo com a estabilização monetária, sem nenhuma tendência clara de longo prazo. Esses resultados são robustos e similares aos de outros trabalhos que também usaram dados tributários. Mesmo nas PNADs, o recuo nas frações apropriadas pelo milésimo e pelo centésimo mais ricos é modesto, com mudanças maiores na distribuição abaixo do décimo mais rico (ver seção 5.4 do capítulo 5 e SOUZA; MEDEIROS, 2015).

Em termos político-institucionais, o caráter negociado ou pactuado da transição democrática é pouco controverso (e.g., BETHELL; NICOLAU, 2008). Não houve mera continuação do status quo, nem tampouco ruptura. A Constituição de 1988 tem muitos méritos e forneceu as bases para muitos avanços, inclusive para quebrar de vez muitos aspectos da "cidadania regulada", mas não derrotou o corporativismo e, em determinadas questões, até ajudou a fortalecê-lo (e.g., CARVALHO, 2008, p. 222-224; FAUSTO, 1995, p. 524-526). Do ponto de vista da desigualdade, a expansão dos direitos sociais deu-se pela via da inclusão, e não da redistribuição, para recuperar a classificação de Medeiros (2016). Boa parte dos avanços listados por Arretche (2016, p.450), por sinal, refere-se à "progressiva incorporação dos mais pobres" aos serviços públicos.

Não há dúvidas de que houve mais sensibilidade às demandas dos mais pobres e de que o gasto social elevou-se expressivamente, assim como a carga tributária. Mesmo 
nesses aspectos mais visíveis, porém, as mudanças foram menores do que se imagina. Com base na POF 2008-2009, Medeiros e Souza (2013, 2015) concluíram que o saldo líquido do fluxos monetários diretos entre o Estado e as famílias brasileiras - transferências e a remuneração dos servidores públicos menos os tributos diretos - continuava regressivo, isto é, mais concentrado entre os mais ricos do que as rendas obtidas no setor privado. Os rendimentos líquidos recebidos do Estado representavam 25\% da renda dos $50 \%$ mais pobres e chegavam a quase um terço da renda dos $5 \%$ mais ricos. Naturalmente, nem todos os fluxos estatais têm esse efeito; o problema é que as iniciativas mais redistributivas, como o Programa Bolsa Família (PBF) e o IRPF, têm um peso pequeno em comparação com os fluxos mais regressivos, como as remunerações e pensões dos funcionários públicos.

Comparando as POFs 2002-2003 e 2008-2009, Souza e Medeiros (2013a) não encontraram evidências de uma grande guinada redistributiva nos fluxos monetários estatais. Apesar de a contribuição do Estado ter se tornado um pouco menos regressiva, as mudanças foram marginais e em parte contraditórias. O "prêmio salarial" do setor público aumentou bastante ao longo da década e, por estar concentrado nos mais ricos, anulou os efeitos redistributivos da expansão de programas como o PBF. ${ }^{27}$ Com efeito, os autores observaram que os fluxos monetários estatais com maior peso na renda total contribuíram muito pouco para diminuir a desigualdade. O maior exemplo é o da Previdência Social, cujo papel redistributivo é seriamente comprometido pelos benefícios mais elevados recebidos por uma parcela dos servidores públicos inativos.

De fato, a elite do funcionalismo público conseguiu muitas vantagens desde a redemocratização. Mendes (2015, p. 196-200) documentou como a lei que instituiu o Regime Jurídico Único (RJU) para o setor público passou por cima dos requerimentos pré-estabelecidos e determinou a transferência imediata de cerca de 550 mil empregados do governo federal para o novo regime, concedendo-lhes, portanto, estabilidade e pensões integrais, com direito a reajustes paritários com os servidores ativos. Como resultado, nos anos seguintes houve um boom de aposentadorias no governo federal, já que indivíduos que haviam contribuído por toda a vida para a previdência nos moldes da CLT passaram a ter direito a benefícios muito mais altos. Mendes citou também outras vantagens, como privilégios na compra de imóveis federais durante a onda de privatizações do governo Collor e as generosas gratificações para servidores em cargos de confiança.

Parte dessas vantagens foram eliminadas, não todas. Em alguns casos, as reformas adotaram regras de transição generosas que limitam ganhos de progressividade nas próximas décadas (e.g., SOUZA; MEDEIROS, 2013b). Já a capacidade de organização de algumas categorias para defender com sucesso reajustes salariais não esmoreceu, como atesta o aumento do "prêmio salarial" na última década (ver também BARBOSA; SOUZA, 2012).

27 O "prêmio salarial" é o "excesso" (ou "déficit") recebido por funcionários públicos em comparação com o a remuneração no setor privado de trabalhadores com as mesmas características observáveis. 
Tabela 6. Ocupações com maior renda total média nas declarações de IRPF - Brasil, 2013

\begin{tabular}{rlrr}
\hline Posição & Ocupação & $\begin{array}{r}\text { Renda média } \\
\text { anual (R } \$ \text { mil) }\end{array}$ & $\begin{array}{r}\text { Declarantes } \\
(\text { mil })\end{array}$ \\
\hline 1 & Titular de Cartório & 1045 & 9,3 \\
2 & Membro do Ministério Público & 498 & 13,7 \\
3 & Membro do Judiciário e de Tribunal de Contas & 489 & 20,3 \\
4 & Diplomata e afins & 308 & 2,7 \\
5 & Médico & 279 & 318,4 \\
6 & Advogado do setor público & 257 & 27,2 \\
7 & Servidor do Banco Central, CVM e Susep & 257 & 5,4 \\
8 & Auditor Fiscal e afins & 254 & 68,2 \\
9 & Atleta, desportista e afins & 236 & 5,9 \\
10 & Piloto de aeronaves, comandante e afins & 231 & 12,1 \\
11 & Ator, diretor de espetáculos & 193 & 4,8 \\
12 & Engenheiro, arquiteto e afins & 177 & 484,0 \\
13 & Servidor das carreiras do Poder Legislativo & 155 & 44,8 \\
14 & Gerente de empresa pública ou de economia mista & 150 & 45,5 \\
15 & Físico, químico e afins & 148 & 37,7 \\
\hline
\end{tabular}

Fonte: elaboração do autor a partir dos Grandes Números do IRPF para o ano-calendário 2013 (BRASIL. MF. SRF, 2015).

As tabulações recentes do IRPF não discriminam a composição ocupacional por faixas de renda, oferecendo apenas os números agregados, que, ainda assim, são bastante informativos. A Tabela 6 traz a lista das 15 ocupações com maior remuneração média no IRPF em 2013. Apesar das limitações desse tipo de informação, ${ }^{28}$ há um padrão claro: nove das 15 ocupações são direta ou indiretamente ligadas ao poder público, incluindo as quatro primeiras da lista. Mesmo considerando que os números dizem respeito aos rendimentos totais, e não apenas à remuneração do trabalho, os resultados são expressivos. Como parâmetro de comparação, basta lembrar que a renda anual mínima para pertencer ao $1 \%$ mais rico em 2013 era cerca de $\mathrm{R} \$ 220$ mil, enquanto a renda média da população adulta estava em torno de $\mathrm{R} \$ 26$ mil por ano. Os dados disponíveis para os anos anteriores são muito parecidos, não indicando qualquer mudança substantiva no quadro. ${ }^{29}$

Uma ressalva é que, como se pode ver, as carreiras vinculadas ao Estado presentes

28 Por definição, os dados agregados desconsideram a desigualdade interna às ocupações e, portanto, a tabela favorece ocupações mais homogeneamente ricas. Por se basearem em autodeclarações, as informações ocupacionais provavelmente possuem qualidade aquém do desejável, o que se reflete em um alto percentual de ocupações não especificadas (15\%).

29 A lista em 2007 é virtualmente idêntica, assim como o ordenamento obtido quando se considera a posição média de cada ocupação entre 2007 e 2013. Em 2013, se alargarmos o filtro para as 30 ocupações com maior renda total média, as carreiras e funções ligadas ao Estado somam 14. Vale notar que essa contabilidade não inclui médicos e professores do ensino superior, ocupações com presença tanto no setor público quanto no privado. 
na Tabela 6 envolvem um número reduzido de declarantes. Ou seja, mesmo se a maior parte de seus membros estiver no centésimo mais rico, isso não significa que este estrato seja composto majoritariamente por servidores públicos e afins. Dado o tamanho da população adulta brasileira, o $1 \%$ mais rico equivale a quase 1,5 milhão de pessoas.

Do lado da tributação, o Estado tampouco atua de forma efetivamente redistributiva. Pelo contrário, como visto na seção 4.3 do capítulo 4, embora nossa carga tributária bruta seja relativamente alta para padrões internacionais, a participação do IRPF - e dos tributos sobre renda e patrimônio, de modo geral - é bem menor do que nos países da OCDE. A própria expansão recente da carga tributária baseou-se principalmente em tributos indiretos, cujos efeitos são neutros ou até regressivos e que muitas vezes ainda introduzem distorções severas no sistema de preços.

Decerto, parte do nó da questão tributária brasileira decorre das complicadas relações entre os entes da federação. Em boa medida, o avanço dos tributos indiretos, principalmente no segundo governo de Fernando Henrique Cardoso, resultou de um esforço de ajuste fiscal que, para aumentar ao máximo a receita, priorizou a criação e expansão de contribuições sociais, cuja arrecadação não precisa ser compartilhada com estados e municípios (ABREU; WERNECK, 2008).

Seja como for, a despeito de alegações ao contrário, o sistema tributário brasileiro permaneceu nas últimas duas décadas bem longe de cumprir seu potencial redistributivo. ${ }^{30}$ Silveira (2008) destacou como o peso desproporcional dos tributos indiretos amplifica seu efeito regressivo e acaba por arruinar a progressividade do sistema. Carvalho Jr (2010) analisou empiricamente a incidência do Imposto Territorial e Predial Urbano (IPTU) na POF 2002-2003, com ênfase nas pressões políticas e nos entraves burocráticos e jurídicos que fazem com que o potencial arrecadatório e, principalmente, redistributivo do imposto sejam desperdiçados.

Além de menos progressiva do que poderia ser, a tributação do patrimônio no país permanece estagnada em nível muito baixo: entre 2003 e 2013, os tributos sobre a propriedade pouco mudaram, mantendo-se abaixo de $2 \%$ do PIB e de $4 \%$ da carga tributária bruta, valores muito abaixo do observado nos países da OCDE. ${ }^{31}$ Diferentemente do que seria de se esperar, o principal tributo do tipo no Brasil é o Imposto sobre Propriedade de

30 Alguns autores, como Mendes (2015, p. 94), argumentam que não há espaço para aumentar a progressividade do sistema tributário, pois os tributos diretos já são muito concentrados nos mais ricos e, ao mesmo tempo, o alto grau de informalidade e a necessidade de estimular os investimentos em capital físico e humano redundam necessariamente em um grande papel para os tributos indiretos. Dado o nível de desenvolvimento e de desigualdade no Brasil, essa perspectiva soa exageradamente pessimista, embora não se possa esperar que o sistema tributário resolva sozinho a questão distributiva brasileira.

31 Em 2013, os tributos sobre a propriedade somaram 1,4\% do PIB brasileiro, contra uma média de $2 \%$ na OCDE. Nos maiores países da OCDE, com exceção da Alemanha, o percentual estava bem acima disso: 4,2\% no Reino Unido; 3,9\% na França; 3,3\% no Canadá; e 3\% nos Estados Unidos. Essas estatísticas estão disponíveis nas edições 2007 e 2013 da série "Carga Tributária no Brasil - Análise por Tributos e Bases de Incidência", da Secretaria da Receita Federal (BRASIL. MF. SRF, 2014). 
Veículos Automotores (IPVA), cuja arrecadação é quase igual à soma do IPTU, do Imposto Territorial Rural (ITR), ${ }^{32}$ do Imposto sobre a Transmissão Causa Mortis e Doação (ITCD) e do Imposto sobre a Transmissão de Bens Imóveis (ITBI). A despeito da falta de dados, eu desconheço argumentos que sustentem que a frota automotiva do país tem peso tão grande no estoque de riqueza nacional. O Imposto sobre Grandes Fortunas, previsto na Constituição de 1988, jamais saiu do papel.

No caso da renda, o potencial redistributivo e arrecadatório da tributação vem sendo igualmente enfatizado na literatura recente (CASTRO, 2014; HOFFMANN, 2002a; SOARES et al., 2010a). Como visto na 4.3 do capítulo 4, desde a redemocratização as alíquotas marginais máximas do imposto caíram muito em relação ao pico e à sua média histórica: entre 1947 e 1988, a alíquota máxima esteve sempre entre 45\% e 65\%, valores muito superiores aos 27,5\% vigentes desde 1998. Apesar de movimentos semelhantes terem ocorrido em boa parte do mundo, no Brasil os cortes foram mais extremos: em 25 do 34 países da OCDE a alíquota marginal máxima do imposto de renda cobrado pelo governo central é maior do que a brasileira, inclusive em países com renda média como México (35\%) e Turquia (35\%). Cinco dos nove países que ficam abaixo dos nossos 27,5\% também tributam a renda em nível subnacional, de modo que, na prática, em quase todos a alíquota marginal máxima supera a brasileira. ${ }^{33}$ Para além da OCDE, os dados da Heritage Foundation situam o Brasil na $103^{a}$ posição entre 185 países no ranking de maiores alíquotas marginais do imposto de renda, empatado com Burkina Faso. ${ }^{34}$

A alíquota marginal máxima relativamente baixa é só parte dos obstáculos que limitam a capacidade redistributiva da tributação da renda. O diabo está nos detalhes. Castro (2014) e Gobetti e Orair (2016) destacaram duas inovações introduzidas em 1995. O IRPJ tornou-se menos progressivo depois que as empresas puderam deduzir do lucro tributável os chamados "juros sobre capital próprio", uma despesa fictícia que, na prática, exime uma parcela do lucro real do pagamento de IRPJ e CSLL. Já o IRPF, como visto, foi modificado pela isenção concedida aos lucros e dividendos, que até então eram tributados exclusivamente na fonte à alíquota de 15\%, como os ganhos de capital.

Como argumentam os autores, essas inovações fizeram do Brasil um caso anômalo

32 O ITR é emblemático da baixa incidência dos tributos sobre o patrimônio no Brasil. Previsto na Constituição de 1988 como competência da União, o imposto é, grosso modo, o equivalente do IPTU (de competência municipal) para áreas rurais. Apesar da pujança agrícola do país, a arrecadação do imposto não chegou a 0,2\% do PIB em 2013 (BRASIL. MF. SRF, 2014).

33 Os cinco são Dinamarca, Espanha, Noruega, Suécia e Suíça. Com possível exceção da Suíça, nos demais as alíquotas marginais máximas chegam a pelo menos $40 \%$ quando se leva em conta a cobrança em nível subnacional. Os quatro que indubitavelmente aplicam alíquotas máximas menores do que a brasileira são Eslováquia (25\%), Estônia (20\%), Hungria (16\%) e República Tcheca (15\%), países muito menos desiguais do que o Brasil. De acordo com os dados de Milanovic (2015), o coeficiente de Gini da renda domiciliar per capita nesses quatro países em 2008 estava entre 0,25 e 0,30, contra 0,544 para o Brasil. As informações sobre tributação da renda na OCDE estão disponíveis em $O E C D$ Statistics, <http://stats.oecd.org/>. Acesso em 14 jun. 2016.

34 Ver 2016 Index of Economic Freedom, da Heritage Foundation: <https://web.archive.org/web/ 20160615004222/http://www.heritage.org/index/explore?view=by-variables $>$. Acesso em 14 jun. 2016. 
no cenário internacional. Na OCDE, apenas a Estônia faz algo semelhante no IRPF, e a tributação média dos lucros ultrapassa $40 \%$ entre os 34 países. Pior, não há evidências sólidas de que elas tenham provocado aumento nos investimentos. ${ }^{35}$ Em contrapartida, a isenção dos lucros, em especial, contribuiu para a "transformação do trabalho em capital" e para a erosão do efeito redistributivo do IRPF.

A Figura 65 mostra isso empiricamente, apresentando a alíquota efetiva do IRPF sobre a renda total dos estratos mais ricos. Um caveat é que se trata apenas do efeito das alíquotas progressivas do IRPF, ou seja, não incorpora os tributos pagos exclusivamente na fonte, que, de todo modo, incidem apenas sobre uma parcela minoritária dos rendimentos dos mais ricos e, portanto, teriam impacto limitado (ver Figuras 62 e 63 acima).

O imposto devido equivale a frações muito baixas dos rendimentos totais dos ricos, ocorrendo um declínio de 1 a 1,5 p.p. ao longo do tempo, em função do maior peso relativo dos rendimentos isentos. Em 2013, o imposto devido correspondeu a pouco menos de $7 \%$ dos rendimentos totais do centésimo mais rico e apenas a algo próximo de $3 \%$ no caso do 0,1\% e do 0,01\% mais abastados. Se considerarmos as alíquotas efetivas apenas em relação aos rendimentos brutos tributáveis, os valores são bem superiores e estáveis, flutuando em torno de $19 \%$ para o centésimo mais rico e entre $22 \%$ e $24 \%$ para os outros dois grupos.

Dessa forma, dificilmente se pode dizer que a ação do Estado via transferências, tributos e remuneração dos funcionários públicos tornou-se inequivocamente redistributiva. A incorporação de novas demandas não se fez por uma mudança de foco dos gastos públicos, e sim por uma acomodação que não extirpou muitas vantagens e privilégios dos grupos de maior renda, que, em alguns aspectos, conseguiram até melhorar sua posição.

Ademais, esse é apenas o lado mais visível e facilmente quantificável da atuação do Estado. Como escreveu Mendes (2015, p. 169), ao contrário dos benefícios direcionados para as massas, a redistribuição que favorece os ricos ocorre por excelência nas sombras, fora do escrutínio público, e gira muitas vezes em torno de tecnicalidades, filigranas regulatórias, disputas acionárias, incentivos fiscais e afins. Nem sempre se trata de favorecimento direto, podendo assumir a forma de regras e regulações que geram ou reforçam possibilidades de lucros para os grupos detentores dos recursos econômicos apropriados.

O próprio Mendes (2015, cap. 3) enumerou e trouxe evidências de alguns caminhos institucionais dessas vantagens dos mais ricos. De modo geral, a situação evoluiu pouco em muitas áreas nas duas décadas, inclusive com alguns retrocessos. Seu primeiro exemplo é o sistema judicial lento e pouco eficiente, que abre amplas oportunidades para que pendências legais sejam prolongadas ao máximo por litigantes com recursos financeiros para isso. A fraqueza institucional das agências regulatórias é outro caso citado: apesar

35 Gobetti e Orair (2016) identificaram, corretamente, a influência dos trabalhos pioneiros da teoria da tributação ótima nas inovações no IRPF. Como mencionado na seção 3.2 do capítulo 3 , os avanços nesse campo chegaram a resultados muito menos restritivos e mais favoráveis a alíquotas mais elevadas para a tributação da renda (e.g., PIKETTY; SAEZ, 2013; PIKETY; SAEZ; STANTCHEVA, 2014). 
Figura 65. Alíquota efetiva do IRPF para os estratos mais ricos como fração dos rendimentos totais - Brasil, 2007-2013 (\%)

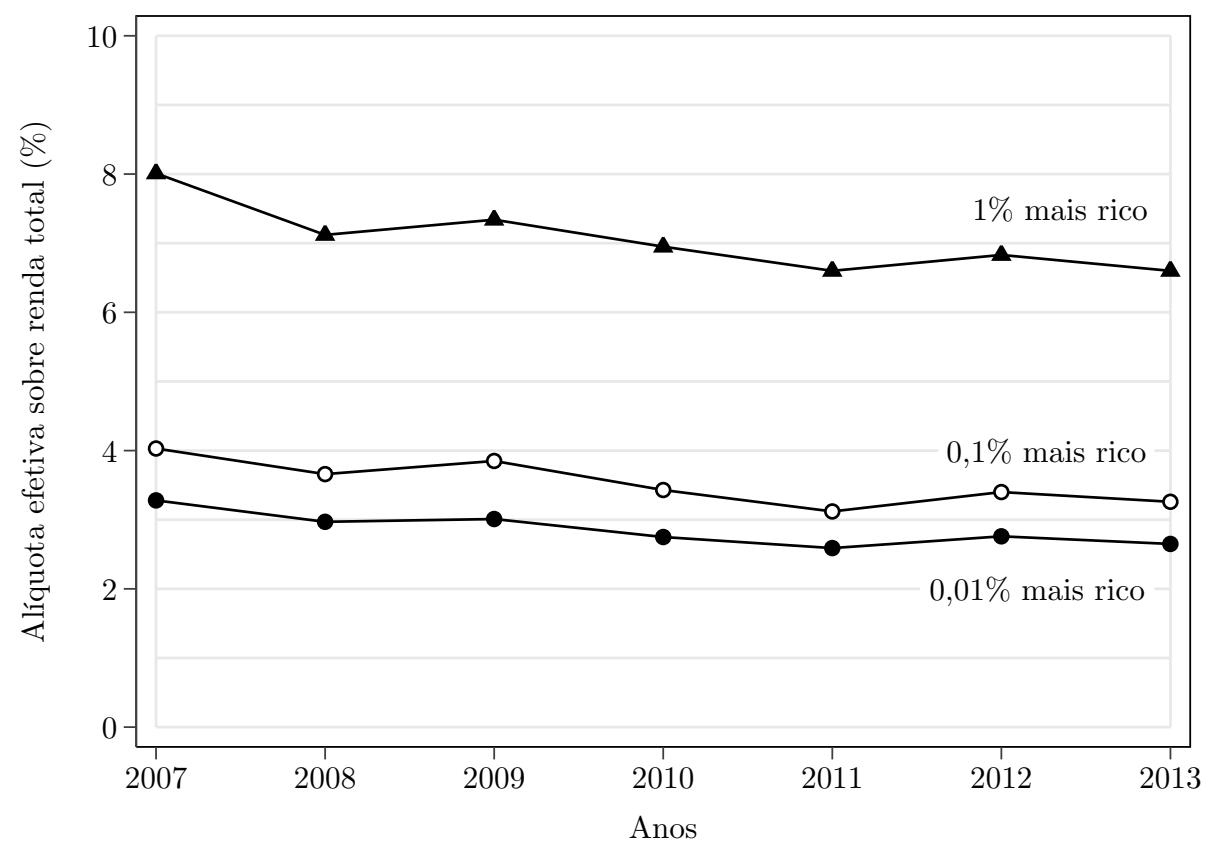

Fonte: elaboração própria a partir de tabulações de dados tributários ver capítulo 4 .

N.B.: as alíquotas efetivas dizem respeito apenas à incidência da estrutura progressiva do IRPF, não contemplando os impostos pagos sobre os rendimentos tributados exclusivamente na fonte.

de sua autonomia teórica, a falta de financiamento e nomeações muitas vezes de caráter explicitamente político geram comumente situações de incapacidade de monitoramento e de captura regulatória, dando grande margem para que os interesses privados a serem regulados acabem influenciando as regulações a seu favor. A proteção ad hoc à indústria nacional e a concessão de benesses setoriais, por sua vez, aparecem como um privilégio que recrudesceu ao longo dos anos, na medida em que as iniciativas de política industrial desde meados da década passada tornaram-se progressivamente mais agressivas e favoráveis a setores específicos, ou, nas palavras do autor, "velhos clientes" como os setores automotivo, têxtil, marítimo e outros (MENDES, 2015, p. 148).

Mendes mencionou também o "acesso privilegiado ao crédito público" subsidiado, cuja relevância dificilmente pode ser superestimada em uma economia com baixa taxa de poupança e juros elevados. Há muito, o Banco do Brasil, a Caixa Econômica e o BNDES canalizam enorme volume de recursos para os setores agrícola e imobiliário e para grandes investimentos com juros muito abaixo do mercado; nos últimos anos, o BNDES em particular adquiriu proporções inéditas. Ao mesmo tempo, acentuou-se a preferência por financiar grandes grupos empresariais, que em tese deveriam ser os menos afetados por restrições ao crédito no mercado. ${ }^{36} \mathrm{Em}$ muitos casos, o fomento aos ditos "campeões nacionais" bateu de frente com o interesse dos consumidores, promovendo a concentração de mercado em vários setores.

36 Em 2012, 63\% dos empréstimos do BNDES foram para grandes empresas (MENDES, 2015, p. 129). 
Como há demanda maior do que a oferta de crédito e falta de transparência na seleção de projetos, o escopo para rent-seeking e recurso a conexões políticas parece considerável, com efeitos distributivos perversos, ainda mais quando se consideram as fontes de financiamento do banco. A mais tradicional é o Fundo de Amparo do Trabalhador (FAT), o que, por si só, já implica um subsídio dado por todas as empresas e trabalhadores àqueles escolhidos para receber recursos. Além disso, nos últimos anos, o BNDES obteve recursos cada vez maiores do Tesouro Nacional (MENDES, 2015, p. 129), o que acarreta a emissão de dívida pública a juros altos para obter recursos que, em seguida, serão emprestados a taxas subsidiadas para empresas selecionadas por critérios opacos.

Em seu Capitalismo de Laços, Sérgio Lazzarini (2011) abordou a atuação do BNDES e dos fundos de pensão patrocinados por entes públicos na evolução das relações de propriedade no Brasil. Ao aplicar técnicas de análise de redes à estrutura acionária das grandes empresas do país, ele concluiu que, apesar da maior abertura ao capital e ao comércio externo, desde os anos 1990 o "capitalismo de laços" fortaleceu-se por aqui. Por um lado, aglomerações atreladas a controladores comuns tornaram-se mais frequentes; por outro, desde sua participação decisiva nas privatizações comandadas pelo governo Fernando Henrique Cardoso, o BNDES e os fundos de pensão adquiriram maior centralidade, conectando aglomerações diversas:

Embora seja inegável o aumento da participação do capital estrangeiro no país e a menor participação direta do governo via estatais, [...] a capacidade de intervenção do governo não diminuiu e [...] os principais atores centrais na economia continuam sendo entidades ligadas direta ou indiretamente ao governo, em associação com alguns grupos privados de maior envergadura. Na realidade, de forma até paradoxal, o fenômeno de privatização e a maior inserção global que se seguiu após a década de 1990 no Brasil ajudou a reforçar a influência do governo e de certos grupos domésticos. [...] O capitalismo de laços foi enraizado, e não dirimido, pelas diversas reestruturações que ocorreram no Brasil. (LAZZARINI, 2011, p. 19-20)

Lazzarini analisa os aspectos potencialmente positivos e os negativos desse processo, que são muito mais evidentes e, não raro, acabam nas páginas policiais. Práticas anticompetitivas, conluios e relações clientelistas com o governo provavelmente têm efeitos deletérios tanto para a desigualdade quanto para o crescimento.

Essa lista não esgota os muitos caminhos pelos quais o arcabouço institucional brasileiro favorece a reprodução da desigualdade e da concentração no topo. As próprias vias de redistribuição para a "classe média" mencionadas por Mendes (2015, cap. 4) beneficiam sobremaneira os mais ricos, como os privilégios do funcionalismo público (discutidos acima) e os contínuos refinanciamentos de dívidas de produtores rurais. A característica comum e o desafio imposto por todas essas vantagens de "bastidores" é que seu impacto distributivo não é fácil de quantificar, principalmente pela falta de informações publicamente disponíveis. Intuitivamente, é bem claro que se trata de mecanismos que 
colaboram para a concentração de renda no topo e que, no conjunto, dão poucos sinais de arrefecimento. Resta saber, porém, a magnitude do seu impacto e quão ricos são os seus beneficiários diretos e indiretos, o que depende de pesquisas futuras.

Para encerrar, vale a pena lembrar que algumas dimensões estruturais da desigualdade foram até agora pouco afetadas por políticas públicas, para dizer o mínimo. Embora talvez não seja mais tão determinante quanto no passado, a estrutura fundiária continua muito desigual, com o coeficiente de Gini da distribuição da posse da terra estacionado em 0,86 desde meados dos anos 1970 (HOFFMANN; NEY, 2010). Não há muitas informações sobre a distribuição de riqueza ou patrimônio, mas tampouco há indícios convincentes de que tenham ocorrido grandes transformações. A distribuição funcional da renda também não apresenta rupturas: o bem-vindo aumento da fração da remuneração dos empregados entre 2003 e 2011 ocorreu mais pela queda da fração do rendimento misto bruto (i.e., dos autônomos) do que pelo declínio dos rendimentos do capital (excedente operacional bruto), ${ }^{37}$ o que muito provavelmente se explica pela rápida geração de empregos formais no período. Em perspectiva um pouco mais longa, a fatia do capital está próxima da média observada desde meados dos anos 1990 ou 2000. Ou seja, a recuperação do fator trabalho basicamente reverteu a deterioração registrada nos anos anteriores (Cf. BASTOS, 2012).

Avanços maiores ocorreram no campo educacional. Em 1976, cerca de 80\% da força de trabalho não tinha completado o Ensino Fundamental; em 2013, quase 55\% possuíam pelo menos o diploma do Ensino Médio. ${ }^{38}$ Essa reviravolta, no entanto, não alterou significativamente a alta concentração da renda no topo da distribuição e nem mesmo na esfera educacional as distorções institucionais foram eliminadas. Para além das reconhecidas carências qualitativas e quantitativas de boa parte do ensino público, o viés favorável ao ensino superior foi atenuado, só que permanece saliente para padrões internacionais: em 2008, o gasto público por aluno no Brasil era 5,2 vezes maior no Ensino Superior do que no Ensino Fundamental, valor superado apenas pela Índia na comparação apresentada por Veloso (2011, p. 237). Em países como Argentina, Chile, Espanha, Estados Unidos, Japão e Reino Unido, essa razão estava entre 1 e 1,5. ${ }^{39}$

Em suma, a ideia de um novo contrato social igualitário e fiscalmente responsável é prematura. A redemocratização do país não representou uma ruptura capaz de alterar sensivelmente a concentração no topo, que, apesar de uma pequena melhora, conserva-se

37 Entre 2003 e 2011, a fração dos empregados subiu de 46,3\% para 50,3\%, com correspondente queda de $12,4 \%$ para $9,9 \%$ na fatia dos autônomos e de $41,3 \%$ para $39,8 \%$ na parcela do capital. Números calculados a partir do Sistema de Contas Nacionais (IBGE, 2011 e 2015).

38 Percentuais calculados nas PNADs para os indivíduos entre 16 e 64 anos ocupados em atividades remuneradas, exclusive moradores das áreas rurais das regiões Norte e Centro-Oeste.

39 Em 2000, a razão estava pouco acima de 11. Os dados mais recentes do Inep são um pouco diferentes dos citados por Veloso (2011). De todo modo, eles indicam que, a tendência de melhoria arrefeceu a partir de 2008, quando a razão entre o gasto público por aluno no Ensino Superior e no Fundamental chegou em 4,4, e recuperou-se brevemente entre 2011 e 2013, quando a razão chegou a 3,9. Se o ritmo médio de 2000-2013 persistir, o Brasil pode chegar ao patamar dos países ricos antes de 2020; caso o ritmo de 2008-2013 prevaleça, serão necessárias pelo menos mais duas décadas. 
acima de tudo estável em patamar bem elevado. Decerto, não se pode negar a possibilidade de que algo do tipo ainda venha a materializar-se; por enquanto, só se pode dizer que o otimismo de outrora perdeu seu lustre com as muitas crises de 2014-2016. A dissipação tem sido tão forte quanto a inclusão no que diz respeito à concentração no topo.

\subsection{Considerações finais}

Pode-se acusar o Brasil de tudo, menos de marasmo. Nossa história social, política e econômica nos últimos cem anos foi tão acidentada quanto as idas e vindas da concentração de renda no topo. Nos dois casos, por sinal, é difícil discernir tendências seculares unívocas. Por enquanto, pelo menos, acreditar que caminhamos inapelavelmente para conjugar crescimento rápido com aprofundamento da democracia e menor desigualdade permanece no reino do pensamento positivo.

O objetivo deste capítulo foi explicitar, ainda que de forma especulativa, a conexão entre o comportamento da desigualdade e a dinâmica política nacional. À moda da literatura internacional baseada em dados tributários, a histografia nacional e evidências adicionais do IRPF e de outras fontes foram mobilizadas para iluminar a relação entre políticas públicas e a concentração no topo. Com isso, procurou-se dar substância à interpretação delineada no capítulo anterior, que destacou a determinação institucional da concentração de renda no topo e o seu caráter inercial. Nessa perspectiva, o toma lá dá cá característico do jogo (minimamente) democrático torna improvável a ocorrência de mudanças significativas e duradouras na desigualdade, de modo que é em momentos de crise e ruptura que se abre o espaço propício a elas. Assim como em Arretche (2016), essa interpretação dá ênfase ao efeito combinado de múltiplas políticas públicas, cujos efeitos distributivos individuais são muitas vezes contraditórios.

No caso brasileiro, a correlação entre as variações na desigualdade e os grandes ciclos políticos não é apenas coincidência, e este capítulo procurou embasar essa afirmação examinando como uma séries de políticas, decisões, compromissos e rupturas plausivelmente podem estar por trás dessa associação. O IRPF, repetidamente destacado pela literatura internacional, teve um papel importante nessa narrativa, sem ser o protagonista, assim como Alvaredo (2008) já havia concluído para a Argentina. Em consonância com a interpretação proposta, o capítulo investiu em uma visão ampla do efeito combinado de várias decisões, grandes e pequenas. O preço a ser pago foi a impossibilidade de identificar e quantificar rigorosamente seus efeitos causais sobre a desigualdade; todavia, espera-se que em conjunto as evidências sejam persuasivas. No mínimo, a análise tem a pretensão de mostrar que a história político-institucional do Brasil é compatível com a trajetória da concentração de renda no topo, seja no que diz respeito à sua relativa estabilidade no longo prazo quanto, principalmente, nas mudanças abruptas observadas em períodos específicos. 
Não por acaso, o capítulo foi dividido em períodos correspondentes às variações mais significativas nas frações da renda recebidas pelos mais ricos. Cada seção tentou caracterizar o contexto histórico e as inovações institucionais capazes de tornar essas variações inteligíveis. Esse esforço, reconhecidamente, foi mais simples em alguns momentos do que em outros, o que, de resto, salienta como toda interpretação tem seus limites.

O período de 1926 a 1945 foi marcado por aumento na concentração no topo, impelido pelos mais ricos entre os mais ricos durante o Estado Novo e a $2^{a}$ Guerra Mundial. Como visto, a Revolução de 1930 esteve longe de uma ruptura com o arranjo anterior, alargando as bases sociais do estado sem chacoalhar a estrutura vigente, pelo menos no que diz respeito à estratificação social. O deslanchar da "cidadania regulada" não deve obscurecer o quanto o regime varguista acomodou interesses e pressões dos estratos mais abastados. O anticomunismo que serviu de pretexto para o fechamento do regime com o golpe que instituiu o Estado Novo é um bom exemplo; à moda de outras ditaduras fascistas ou fascistoides do período, por aqui também a repressão e o autoritarismo ensejaram maior desigualdade. Se em muitos países ricos os choques provocados pela $2^{a}$ Guerra e a necessidade de mobilização para o conflito redesenharam o conflito distributivo, por aqui, assim como na Argentina, as choques externos foram menos severos e encontraram um aparato institucional que promoveu o oposto, inclusive com a suspensão de direitos sociais. Somente nos últimos anos da guerra, conforme as condições externas e internas mudaram, houve alguma descompressão, ilustrada pelo grande investimento do regime em aproximar-se das classes trabalhadoras.

O interregno democrático de 1945 a 1964 trouxe o movimento oposto: de forma surpreendente, os resultados dos dados tributários sugerem um processo bem demarcado de nivelamento, que, mesmo não sendo capaz de trazer a desigualdade brasileira para perto dos padrões europeus, impressiona pela sua durabilidade. Ao menos nos primeiros anos, o declínio da concentração no topo parece resultar diretamente do fim das condições excepcionais da guerra e da frustração das expectativas do governo Dutra quanto ao cenário internacional, que levou, inclusive, a mais uma crise no balanço de pagamentos e ao abandono do modelo liberal. A maior parte do nivelamento, contudo, concentrou-se no governo JK, constituindo o movimento mais difícil de desvendar em todo o período analisado. Apesar de evidências um tanto contraditórias, a redução da desigualdade é ao menos compatível com a crescente liberdade civil e política, a mobilização social e sindical nas cidades e no campo, os grandes aumentos do salário mínimo, a decadência do setor cafeeiro e a elevação moderada das alíquotas efetivas do IRPF, entre outros acontecimentos. Ao que tudo indica, os trabalhadores resistiram à aceleração da inflação bem melhor do que se supõe, o que se vê tanto nos dados do IRPF quanto nas estimativas da distribuição funcional da renda feitas, por exemplo, por Frankema (2009).

O golpe militar de 1964 reverteu completamente essa tendência. Em linha com as estimativas baseadas nos Censos Demográficos, os dados do IRPF mostram clara 
deterioração da desigualdade na primeira década da ditadura, com as frações recebidas pelos mais ricos retornando ao patamar observado no início dos anos 1950. As interpretações mais benevolentes do fenômeno são muito menos convincentes do que a literatura crítica da época; afinal, não é fácil acreditar na operação suave de mecanismos de mercado e em desequilíbrios temporários em um momento em que a repressão e o autoritarismo tornaram-se cada vez mais maiores e a recuperação econômica proporcionada pelo "milagre" ainda estava distante. A política salarial profundamente restritiva dos primeiros governos militares merece o destaque dado pela bibliografia, mas dificilmente foi o único fator por trás da piora na concentração de renda. Em retrospecto, muitas das principais medidas do período presumivelmente tiveram efeitos regressivos.

A deterioração da desigualdade foi estancada em meio ao fim do "milagre" e ao início do lento processo de abertura. A maior instabilidade econômica do período refletiu-se em maior volatilidade das fatias recebidas pelos mais ricos, que, de todo modo, declinaram um pouco até o fim da década de 1970. Não por acaso, o II PND, carro-chefe da era Geisel, já expressava uma nova retórica do regime, com preocupação social muito maior e explicitando a indesejabilidade da alta desigualdade. Com os avanços do MDB e a progressiva reorganização da sociedade civil, dificilmente os generais poderiam ter escolhido outro caminho que não a aposta no crescimento depois do segundo choque do petróleo, aposta feita dessa vez com concessões maiores, como no caso da política salarial muito mais flexível.

Mais uma vez, um período de leve redistribuição foi sucedido pelo agravamento da concentração de renda. A transição para a democracia ocorreu junto a uma inédita crise econômica e fiscal, em uma década marcada pela inflação galopante. Como comentado, parte do aumento observado nas frações dos mais ricos entre 1979 e 1987 pode ser artificial ou espúrio, em função dos ruídos introduzidos pela própria inflação; porém, o conjunto das evidências sugere fortemente que em boa parte esse aumento foi real. A necessidade de acomodação e a proliferação de demandas reprimidas durante as décadas do regime militar - junto com o bloqueio a soluções mais claramente redistributivas - redundou na dita "década perdida", com o fracasso das diversas tentativas de atacar a inflação de modo indolor, e até relativamente redistributivo, como no Plano Cruzado. No fim das contas, o poder regressivo da inflação acabou por piorar a situação. Apesar da inexistência de dados para o início dos anos 1990, é provável que a situação tenha piorado ainda mais.

Um dos achados mais surpreendentes dos dados tributários é que não houve muitas novidades no período mais recente. Desde 1988, afinal, o Brasil virou aos poucos um país democrático normal, com uma Constituição bastante expansiva quanto aos direitos sociais e, a partir de 1994, inflação sob controle. O crescimento pró-pobre observado nos anos 2000 nas pesquisas domiciliares seria, então, o coroamento dessa transformação da sociedade e o marco de uma guinada no perfil distributivo do Estado, motivando muitas interpretações essencialmente otimistas quanto aos nossos rumos futuros. Na formulação de Alston et al. 
(2013), estaríamos vivendo uma transição para um novo contrato social, em que a inclusão social com sustentabilidade fiscal representaria o valor político dominante.

Essa interpretação tem méritos, e não há dúvidas de que a sensibilidade do poder público às demandas das camadas mais pobres aumentou nos último 20 anos. Só que os dados do IRPF mostram um quadro bem decepcionante para tanto otimismo: a despeito de alguma redistribuição ao longo dos anos 1990 - ou, generosamente, até meados da década de 2000 -, o período recente sobressai pela estabilidade da concentração no topo em níveis muito altos para o padrão internacional. Ao lado das evidências adicionais discutidas acima, esse cenário aponta mais para políticas de inclusão do que de redistribuição, para usar a tipologia de Medeiros (2016), com suas correspondentes pressões fiscais. Nada autoriza falar em uma guinada redistributiva profunda do Estado brasileiro, que, como descreveu Mendes (2015), incorporou novas demandas - com impacto até superestimado por ele sem realmente extirpar antigos privilégios.

A timidez da tributação direta sobre a renda e a propriedade, a política salarial e previdenciária para a elite do funcionalismo público, e o acesso privilegiado a crédito, isenções e subsídios para grandes grupos empresariais fazem parte da miríade de intervenções públicas que proporcionam ou facilitam a reprodução da desigualdade. Não à toa, algumas dimensões estruturais mudaram muito pouco, como a concentração fundiária e, possivelmente, a concentração industrial e a desigualdade de riqueza ou patrimônio. Mesmo com melhoras em alguns indicadores, é difícil comemorar o "copo meio cheio", pois o lado meio vazio salta aos olhos, ainda mais na esteira da crise política e econômica de meados dos anos 2010. A distribuição funcional da renda alterou-se menos do que muitas vezes se imagina e, no campo educacional, ainda há muito a fazer.

Naturalmente, há ressalvas que precisam ser feitas para não passar a ideia de que nada mudou nem nunca mudará. Do ponto de vista da redução da desigualdade, essas conclusões relacionam-se primordialmente à concentração de renda no topo. Nem a redução da pobreza nem as alterações na distribuição de renda entre a maior parte da população são incompatíveis com o que foi dito ou com a interpretação proposta. Da mesma forma, nenhuma previsão sobre a trajetória futura de crescimento econômico é feita aqui.

Seja como for, é prematuro apostar em mudança de contrato social ou atribuir alta probabilidade à hipótese de que estamos em um caminho mais igualitário, nem que seja no longo prazo. Nunca dá para descartar a possibilidade de uma "inclusão dissipativa" em que, com o tempo, as forças inclusivas prevalecerão; no entanto, apostar nisso agora requer muita fé. Se a interpretação delineada acima estiver correta, o próprio funcionamento normal da democracia não garante nem mesmo facilita esse cenário, só impede ou ao menos dificulta novas deteriorações significativas da desigualdade.

Empiricamente, a experiência internacional reforça o ceticismo sobre a dinâmica futura da concentração de renda no Brasil. Não há casos bem conhecidos de países que 
tenham saído de um patamar alto como o brasileiro e progredido de forma gradual e determinada, sem convulsões ou tragédias, até os níveis verificados nos países ricos depois da $2^{a}$ Guerra. Como ninguém deseja passar por choques violentos, cabe ao Brasil então o desafio de inventar uma receita inédita caso a redução da desigualdade para níveis moderados seja realmente uma prioridade política. Como o traço distintivo de nossa distribuição de renda é a concentração no topo, isso só poderá ocorrer se, em algum momento, políticas redistributivas forem capazes de impor perdas absolutas ou relativas aos mais ricos. 


\section{Conclusões}

A história da desigualdade é sinuosa. Hoje, as narrativas benignas que cativaram o mundo desenvolvido cerca de meio século atrás já não têm mais espaço. O aumento da concentração de renda no topo em diversos países, com destaque para os Estados Unidos, recolocou os ricos no centro do palco. Assim como há cem anos, ainda que em menor intensidade, o vocabulário da polarização social voltou a dar as caras, seja nos debates acadêmicos, seja nas controvérsias políticas. Não poderia ser diferente, afinal, a desigualdade é por excelência um assunto que desperta reações políticas e morais apaixonadas.

Desde o início deste século, o Brasil acreditou ser uma exceção a essas tendências. Por aqui, e na América Latina de modo mais amplo, os anos 2000 foram uma década de recuperação econômica e, pelo menos nas pesquisas domiciliares, prolongada redução do coeficiente de Gini. Muita tinta foi gasta para analisar os determinantes dessa queda, e interpretações otimistas multiplicaram-se, em geral apontando para a combinação virtuosa de democracia, responsabilidade fiscal e consolidação de um Estado de Bem-Estar mais redistributivo, atento às profundas carências que afligem parte considerável da população.

Infelizmente, o que era bom durou pouco. Os primeiros sinais de desaceleração do declínio da desigualdade apareceram nas PNADs já no início da década de 2010, e, mais recentemente, as graves crises política e econômica de 2014-2016 se encarregaram de solapar de vez o otimismo. Mais ainda, evidências recentes baseadas nas declarações de IRPF foram na contramão das pesquisas amostrais, indicando que a concentração de renda no topo e, quiçá, o coeficiente de Gini não teriam sofrido alterações significativas nos últimos anos.

O momento, portanto, torna oportuno não só revisitar a história recente da desigualdade brasileira como também conhecer melhor sua trajetória no longo prazo, com ênfase no papel dos ricos. Para isso, o objetivo desta tese foi construir e analisar a mais longa e completa série sobre a concentração de renda no topo no Brasil. As publicações históricas do IRPF permitiram estimar a fração da renda recebida pelos mais ricos de 1926 a 2013 e, assim, recontar nossa história recente do ponto de vista da distribuição de renda entre aqueles no topo e o resto da população.

O estudo da história da desigualdade dificilmente pode ser separado do estudo dos discursos sobre a desigualdade. As teorias e hipóteses usadas para explicar o mundo moldam nosso próprio olhar sobre esse mundo, conduzindo nossa atenção mais facilmente para determinados objetos e recortes da realidade. Com isso, certos temas e abordagens podem florescer, entrar em decadência e posteriormente reaparecer, conforme o clima intelectual e o contexto socioeconômico se transformam. 
O enquadramento da desigualdade a partir dos ricos seguiu uma trajetória nessa linha, voltando a ter maior destaque nos últimos anos. Ao reaparecer, deslocou os termos do debate internacional. A redescoberta dos ricos fortaleceu determinados tipos de teorias e explicações, com grande peso para a determinação institucional da desigualdade, em detrimento de outras, como as que se ancoravam predominantemente no capital humano e em mudanças tecnológicas. Apesar de continuarem úteis, estas últimas já não gozam mais do primado absoluto de outrora.

Dada a abordagem histórica desta tese, essas questões são incontornáveis. Por isso, o trabalho foi dividido em duas partes relativamente autônomas, mas que se complementam. A Parte I recapitulou os contornos gerais das controvérsias sobre desigualdade desde o fim do século XIX, particularmente no mundo anglo-saxão, oferecendo tanto uma espécie de genealogia dos estudos sobre os ricos quanto um panorama da discussão sobre estratificação e das principais hipóteses e perguntas levantadas pela literatura ao longo do tempo. A Parte II tratou da análise empírica propriamente dita, orientando-se pelos aspectos comentados anteriormente mais relevantes para o caso brasileiro.

Esta conclusão inverte a lógica da exposição, começando pelo resumo dos resultados empíricos e tratando dos aspectos teóricos e da história intelectual nas seções seguintes. A última seção discute as principais limitações e lacunas deste trabalho e especula sobre alguns caminhos futuros para a análise da desigualdade brasileira.

\section{A concentração de renda entre os ricos no Brasil}

As frações da renda recebidas pelos estratos mais ricos foram os resultados empíricos mais importantes desta tese. A desigualdade - entendida como concentração no topo - teve no Brasil uma trajetória muito peculiar se comparada às experiências europeia e americana, irredutível a narrativas simples. O que salta aos olhos é a combinação de estabilidade e mudança observada entre 1926 e 2013. Por um lado, não houve nenhuma tendência unívoca de longo prazo: a fração recebida pelo centésimo mais rico, por exemplo, oscilou entre $20 \%$ e $25 \%$ durante a maior parte do tempo, inclusive no período mais recente, quando apresentou razoável estabilidade em torno de $23 \%$. Algo parecido pode ser dito acerca do $0,01 \%$ e do $0,1 \%$ mais rico e, em menor grau, dos $5 \%$ a $15 \%$ mais ricos, para os quais só há dados para um período mais restrito.

Por outro lado, não se pode deixar de ressaltar as muitas idas e vindas observadas no decorrer do tempo. Mesmo que, no longo prazo, seu efeito líquido tenha sido pequeno, as variações foram por vezes abruptas e significativas, coincidindo, grosso modo, com grandes ciclos políticos do país. A concentração de renda no topo subiu muito durante o Estado Novo e, especialmente, a $2^{a}$ Guerra Mundial, empurrada pelos ganhos relativos dos mais ricos entre os ricos. Com a redemocratização e o fim das condições excepcionais 
de guerra, a desigualdade caiu bastante nos últimos anos da década de 1940 e, depois de um período de relativa estabilidade, voltou a despencar na segunda metade da década de 1950, em particular durante o governo de Juscelino Kubitschek. Essa desconcentração afetou não só o milésimo no topo, como também o centésimo mais rico como um todo.

O golpe militar de 1964 assinalou um ponto de inflexão na trajetória da desigualdade. A fração do $1 \%$ mais rico interrompeu a tendência de queda e pulou de $17-19 \%$ para mais de $25 \%$ entre 1964 e 1970. Ao contrário da escalada anterior da concentração de renda no topo, o recrudescimento não foi provocado pelos mais ricos entre os ricos, e sim pelos estratos logo atrás. O anos finais do "milagre econômico" e da década de 1970 foram marcados por instabilidade, com alguma tendência de desconcentração. A crise macroeconômica iniciada com o segundo choque do petróleo representou novo aumento da concentração, mais uma vez provocado pelos mais ricos entre os ricos, que persistiu ao longo dos anos 1980. A aceleração da inflação no fim do período coincidiu com um pico na desigualdade, talvez em parte artificial, porque um ambiente altamente inflacionário sempre introduz ruídos e erros na mensuração da renda.

Depois disso, as lacunas nos dados tornam a análise um tanto incerta. Não há informações para os anos subsequentes até 1996 e, na segunda metade da década de 1990, a qualidade das tabulações deixa a desejar, exigindo mais procedimentos de tratamento e imputação dos dados faltantes. O que pode ser dito é que houve uma redução significativa - de novo, talvez parcialmente artificial, decorrente da estabilidade monetária - da concentração no topo entre o fim dos anos 1980 e o dos anos 1990. Não é possível descartar de todo que essa redução tenha se estendido até meados da década de 2000, quando a qualidade das tabulações disponíveis melhora muito; dadas as evidências encontradas, essa é uma hipótese menos provável. Entre 2006 e 2013, tivemos essencialmente a estabilidade da concentração no topo, sem nenhuma tendência aparente de aumento ou redução para todos os estratos analisados, até os $15 \%$ mais ricos.

As comparações internacionais confirmaram que o Brasil é o país mais desigual entre aqueles com estimativas disponíveis com base em dados tributários. Já éramos muito desiguais desde o início do século passado, estando à frente dos países para os quais há dados. Ainda assim, naquele momento o contraste com a Europa e afins não era tão dramático quanto hoje. A situação mudou entre a Grande Depressão e a $2^{a}$ Guerra Mundial, quando a concentração no topo desabou bruscamente nos Estados Unidos e na maior parte dos países envolvidos no guerra, no que Jeffrey Williamson (2015) chamou de "grande nivelamento". A desconcentração registrada no Brasil no breve interregno democrático - replicada mais ou menos na mesma época na Argentina - representou apenas um "mininivelamento", totalmente revertido na primeira década da ditadura militar. Com isso, a distância que separa os nossos níveis de desigualdade daqueles do mundo desenvolvido alargou-se muito com o tempo, sendo apenas parcialmente mitigada pelo aumento mais recente da concentração no topo em alguns países anglo-saxões. Se, no 
Brasil, o centésimo mais rico apropria-se hoje de $23 \%$ da renda total, na maior parte dos países esse percentual está entre $5 \%$ e 15\%. Os Estados Unidos são uma exceção, com o $1 \%$ no topo recebendo algo próximo a $20 \%$ da renda total.

Além desses resultados, as estimativas baseadas nos dados tributários também foram contrastadas com os números produzidos a partir das PNADs e dos Censos, duas das principais pesquisas domiciliares brasileiras. A comparação foi feita em duas etapas: primeiro, apenas entre as frações recebidas pelos estratos mais ricos nas três fontes de dados. No que diz respeito ao nível de desigualdade, esse exercício evidenciou como as pesquisas domiciliares de fato subestimam os rendimentos dos mais ricos, reportando menor concentração no topo. O problema é mais grave nas PNADs do que nos Censos e, em cada pesquisa, afeta mais fortemente os milésimos mais ricos e diminui conforme a definição de "ricos" é alargada para abarcar estratos maiores da distribuição de renda, tornando-se bem menos relevante para o décimo superior como um todo. Quanto à trajetória da concentração no topo, as discrepâncias são igualmente perceptíveis, isto é, as tendências verificadas nos Censos e, mais ainda, nas PNADs não necessariamente são as mesmas reveladas pelos dados do IRPF. Em diversos momentos, há concordância, como com os Censos nos anos 1960 e com as PNADs na década de 1980; em outros, as divergências são salientes, como no período desde a virada do século, em que a estabilidade dos resultados tributários contrastou com a desconcentração vista nas PNADs.

A segunda etapa da comparação com as pesquisas domiciliares expandiu brevemente o escopo do trabalho para a distribuição de renda como um todo. Afinal, essas discrepâncias entre as fontes suscitam perguntas sobre o que aconteceria com o coeficiente de Gini se as pesquisas domiciliares não tivessem tantos problemas em captar adequadamente os rendimentos dos mais ricos. Para avaliar essa questão, foram estimados Ginis "corrigidos" de acordo com as frações da renda recebidas pelos estratos no topo nos resultados tributários. As diferenças em relação aos Ginis originais mostraram-se mais perceptíveis nas PNADs do que nos Censos: além de a desigualdade tornar-se mais alta nos coeficientes corrigidos, sua evolução recente é bem menos favorável, com atenuação da tendência de declínio do Gini e aparente esgotamento do processo já em meados dos anos 2000.

Seria insano testar alternativas a todas as decisões metodológicas necessárias para transformar as tabulações publicadas do IRPF em séries sobre a concentração no topo no Brasil. Até onde foi possível fazê-lo, como no caso dos denominadores de população e renda, os resultados foram substantivamente os mesmos. Como em muitos trabalhos de cunho histórico, é certo que as fontes estão aquém do desejável, mas a robustez dos achados é encorajadora. Ademais, alguns trabalhos prévios com metodologias distintas chegaram a estimativas muito próximas. Assim, embora os números devam sempre ser lidos cum grano salis, tudo indica que as conclusões desta tese são robustas. 


\section{Três perguntas e uma interpretação}

A análise desses resultados empíricos foi estruturada por três perguntas extraídas da literatura investigada na Parte I. A primeira pergunta tratou da identificação ou não de tendências de longo prazo, motivada pela a persistente hipótese do "U invertido" de Simon Kuznets, que mereceu atenção especial no texto. Kuznets não foi o único a teorizar sobre os efeitos redistributivos da urbanização e da industrialização, tema que permeou muitas discussões desde o pós-guerra, mas foi possivelmente o maior expoente nessa área. Sua ideia básica, já exposta em detalhes, era que as mudanças estruturais trazidas pelo desenvolvimento econômico inicialmente provocariam um aumento da desigualdade para, posteriormente, com o amadurecimento do processo, estimular sua redução, produzindo, portanto, uma trajetória de "U invertido".

Nenhum dos testes e comparações históricas ratificou essas esperanças. Como dito, a concentração de renda no topo não exibiu nenhuma tendência secular clara, podendose falar até em relativa estabilidade no longo prazo, com ondas de ascensão e queda dificilmente compatíveis com o modelo de Kuznets. É possível e até mesmo provável que as muitas mudanças estruturais que transformaram a sociedade brasileira tenham afetado também a desigualdade em um ou outro momento; no longo prazo, contudo, elas não manifestaram influência óbvia sobre a concentração no topo. O Brasil, aliás, não é o único país em que a curva de Kuznets não deu as caras no século XX: as comparações internacionais tampouco identificam qualquer "U invertido" kuznetsiano.

O apelo do "U invertido" no Brasil, vale dizer, deve muito à interpretação de Carlos Langoni (1973) e da ditadura militar para o recrudescimento da desigualdade entre 1960 e 1970. Em seu livro clássico, Langoni explicou o fenômeno aliando mudanças estruturais a la Kuznets à inelasticidade de curto prazo da oferta de trabalho qualificado em um contexto de rápido crescimento, urbanização e industrialização. Em retrospecto, essa interpretação é pouco convincente, e as críticas de Bacha, Fishlow, Hoffmann e vários outros são mais persuasivas do que nunca. A piora da concentração de renda ocorreu em boa medida antes das altas taxas de crescimento trazidas pelo "milagre econômico", em um momento de ajuste recessivo, arrocho salarial, perseguições políticas e violenta reforma institucional. O próprio processo de concentração estancou-se bem antes do fim do "milagre".

A segunda pergunta estruturante relacionou-se aos efeitos do regime político sobre a concentração no topo. Mais especificamente, a questão era se a democracia estaria associada a uma menor desigualdade. A motivação veio tanto de um primeiro impulso para a abordagem de cunho institucional quanto da crença difusa entre pesquisadores brasileiros de que a redemocratização e a Constituição Federal de 1988 constituíram divisores de águas, estabelecendo as bases para um novo perfil distributivo do Estado, com maior sensibilidade às demandas das camadas mais pobres da população. No plano teórico, trata-se de uma convicção razoável, otimista e, à luz dos parágrafos anteriores, plausível. 
Apesar disso, os resultados desta tese somente autorizam uma resposta parcialmente positiva. Ao que tudo indica, a fração recebida pelos mais ricos foi de fato maior durante nossas duas ditaduras do século XX e cresceu particularmente nos primeiros anos após os golpes de 1937 e 1964. Só que a história não é tão simples assim, exigindo qualificações. A interação entre as condições excepcionais da $2^{a}$ Guerra e o Estado Novo parece ter sido mais decisiva do que a ditadura em si, tanto é que a regularização do cenário internacional após 1945 se fez acompanhar de uma redução imediata na concentração no topo. O próprio aumento da desigualdade ensejado pelo golpe de 1964 exauriu-se bem antes do fim do regime e, nos anos 1970, houve estabilidade ou leve recuo. Por fim, a redemocratização em 1985 não trouxe nenhuma desconcentração imediata da renda no topo, e desde então o amadurecimento da democracia e a consolidação do Estado de Bem-Estar à brasileira tampouco se traduziram em redução persistente das fatias dos ricos.

A última pergunta explorou, em uma perspectiva de longo prazo, o excepcionalismo do alto grau de desigualdade da América Latina. A sabedoria convencional, familiar aos brasileiros desde a educação básica, atribui à forma de colonização espanhola e portuguesa as origens da elevada concentração de renda, contrastando nossos latifúndios com trabalho escravo às pequenas e médias propriedades do norte dos Estados Unidos. Não à toa, a oposição entre "colônias de exploração" e "colônias de povoamento" foi seguidamente reinventada para explicar os diferentes destinos das ex-colônias do Novo Mundo (MONASTERIO; EHRL, 2015). No período recente, Engerman e Sokoloff, entre outros, recauchutaram essa visão, vinculando o atraso da América Latina às instituições que emergiram em sociedades muito desiguais.

Mais recentemente ainda, John Coatsworth e, em especial, Jeffrey Williamson contestaram essa interpretação. Para Williamson, a desigualdade deve ser avaliada em termos comparativos e as escassas evidências disponíveis indicariam que a América Latina estava próxima dos níveis de concentração de renda da Europa e alhures até as primeiras décadas do século XX. Logo, o que tornou o continente muito desigual foi o "grande nivelamento" vivido pelos europeus, que não ocorreu por aqui. Longe de ter raízes coloniais, o excepcionalismo latino-americano seria um produto do século passado. Por isso, um dos objetivos da análise foi ajudar a responder uma pergunta surpreendentemente controversa: quando ficamos muito desiguais em comparação com o resto do mundo?

Os resultados foram em alguma medida favoráveis ao revisionismo de Williamson, novamente com qualificações. Com efeito, a distância entre o grau de concentração da renda no Brasil e nos países ricos aumentou ao longo tempo, não sendo tão grande no início do período analisado. Para os padrões atuais, tanto por aqui quanto no mundo desenvolvido a desigualdade era muito alta cem anos atrás. Ao se comparar a concentração no topo com o PIB per capita, vê-se que o Brasil está relativamente próximo da posição ocupada por vários países ricos quando tinham nosso nível de desenvolvimento. 
Quatro qualificações impedem que a resposta seja inequivocamente positiva. Primeiro, a análise cobriu apenas o século XX e, portanto, não tem nada a dizer sobre a evolução da desigualdade no Brasil e na Europa durante o período colonial e o século XIX. Segundo, as informações para as primeiras décadas são reconhecidamente mais imprecisas, sendo possível que haja algum grau de subestimação nos resultados e, mesmo que não haja, já éramos um pouco mais desiguais que os países ricos nos anos 1920 e 1930. Terceiro, o Brasil chegou a viver um "mininivelamento" entre 1945 e 1964, que foi abruptamente revertido pela ditadura militar, podendo-se, então, especular que o cenário teria sido completamente diferente na ausência do golpe. Quarto, o "grande nivelamento" vivido por Europa, Estados Unidos, Japão e outros não decorreu de processos suaves, e sim de grandes choques que fizeram a concentração no topo cair rapidamente.

Todos esses resultados motivaram um interpretação geral sobre a evolução da desigualdade, calcada na experiência brasileira e compatível com as estimativas disponíveis para o resto do mundo. Seu ponto de partida é a determinação institucional da concentração de renda no topo e a ideia de que não há um único fator capaz de explicar sozinho determinado padrão de desigualdade, que decorre muito mais do efeito combinado e cumulativo de uma série de políticas e programas, de pequenas e grandes decisões.

Em condições minimamente democráticas, a concentração no topo apresenta um forte caráter inercial, pois os mais ricos dispõem de recursos políticos e econômicos que facilitam a sua organização em grupos capazes de exercer poder de veto ou barganhar em posições vantajosas. Com isso, a redução prolongada da desigualdade via reformas graduais e duradouras tem grande dificuldade de sair do papel. Ao mesmo tempo, o próprio jogo democrático e o perigo de desorganização social tornam altamente improvável a adoção de medidas mais radicais e imediatas. Dessa forma, as mudanças na concentração de renda ocorrem sobretudo em momentos de crise e ruptura, que ocasionalmente fornecem a determinados atores a capacidade temporária de reformar profundamente o arranjo institucional vigente, alterando a distribuição dos ativos e suas taxas de retorno.

Essa interpretação se coaduna com a experiência internacional, que registrou as maiores e mais duradouras modificações em períodos relativamente curtos de crises e reformas profundas, como a $2^{a}$ Guerra Mundial. No Brasil, a coincidência das variações na concentração no topo e os grandes ciclos políticos também pode ser entendida por esse viés. Como argumentou o capítulo 6, nossa história política ao longo dos últimos cem anos é compatível com essa interpretação. Mesmo sendo impossível provar de forma econometricamente rigorosa o impacto de determinadas políticas e decisões, os efeitos mais prováveis das muitas mudanças políticas e institucionais comentadas naquele capítulo são coerentes com a trajetória da desigualdade. Como seria de se esperar, alguns períodos são mais facilmente interpretáveis a essa luz do que outros, sendo a era JK - com sua surpreendente queda da concentração no topo - o mais complicado entre eles. 
Como visto na Parte I, a intuição de que somente grandes rupturas ou catástrofes são os momentos propícios para transformações mais profundas na distribuição de renda está presente, de uma forma ou de outra, não só nos trabalhos recentes de Piketty e afins como também em obras muito mais antigas, como o livro seminal de Jencks (1972), que especulou explicitamente sobre isso. Nesse sentido, a interpretação proposta poderia ser resumida como uma espécie de "hipótese Jencks-Piketty", e implica que a ênfase da literatura recente sobre top incomes quanto aos efeitos do imposto de renda deve ser moderada. Em consonância com a abordagem de Arretche (2016), o argumento aqui desenvolvido destacou o papel combinado de diversas políticas; o IRPF é um instrumento importante, não o único, e por vezes não foi sequer decisivo para explicar variações nas fatias recebidas pelos mais ricos.

Uma consequência pessimista é que, se essa interpretação estiver correta, as perspectivas para que o Brasil caminhe progressivamente para níveis de desigualdade semelhantes aos dos países ricos são desanimadoras. Empiricamente, não há casos bem conhecidos de países que tenham partido de um grau tão alto de concentração de renda no topo e avançado de forma tranquila e gradual até percentuais próximos aos de um país europeu típico. Caso essa seja uma prioridade política, o desafio é realizar um feito inédito.

Infelizmente, ainda não estamos nesse caminho. Apesar de todas as conquistas desde a Constituição Federal de 1988, é no mínimo prematuro falar em um novo contrato social com baixa tolerância à desigualdade. As estimativas com base nos dados tributários apontam, ao menos até agora, para uma inequívoca estabilidade da concentração no topo nos últimos anos. A maior permeabilidade do Estado às reivindicações das camadas mais pobres resultou mais em uma acomodação do que em uma reviravolta no seu padrão de atuação. Como discutido no capítulo 6, muitos privilégios foram mantidos ou reforçados, e algumas dimensões estruturais tampouco passaram por grandes transformações. No limite, é razoável postular que a democracia pode servir mais para conter o aumento da nossa desigualdade do que para reduzi-la.

Essas conclusões, é bom lembrar, relacionam-se essencialmente à concentração no topo. É possível ser bem mais otimista quanto à redistribuição entre as camadas mais pobres ou menos afluentes da distribuição de renda, e mais ainda quanto à perspectiva de redução da pobreza absoluta e aumento do padrão de vida médio via crescimento econômico. Dada a intensidade da concentração de renda no topo, contudo, é difícil fugir ao pessimismo quanto à questão distributiva mesmo quando se olha para indicadores sintéticos, como o coeficiente de Gini.

Evidentemente, nem tudo é política. A interpretação aqui sugerida não deve ser entendida em uma chave puramente voluntarista, nem se deve ignorar a dinâmica própria dos mercados, as tendências demográficas e sociais mais amplas e a situação do setor externo, para citar apenas alguns exemplos. Muito menos se trata de afirmar que todas as 
decisões que afetam a distribuição de renda são tomadas maquiavelicamente com esse fim em mente. O ponto central é que, em condições normais, o arranjo institucional de uma sociedade reflete e sobretudo molda os conflitos distributivos, e a combinação de recursos econômicos e organização política é fiadora da persistência da concentração no topo. Só um louco acharia que é possível alcançar a prosperidade em um estalar de dedos ou com base em "vontade política". A história da concentração de renda mostra em todo lugar que a questão distributiva é igualmente resistente a arroubos retóricos.

\section{Limitações, lacunas e caminhos futuros}

O capítulo 4 discutiu detalhadamente a história e características do IRPF no Brasil e documentou todas as muitas etapas necessárias para transformar as tabulações publicamente disponíveis em estimativas de longo prazo para concentração de renda no topo. Como visto, também no Brasil o imposto de renda se mostra a melhor fonte de informações sobre os mais ricos e não há nenhuma indicação de que a qualidade dos dados nacionais seja sistematicamente inferior à dos de outros países.

De todo modo, nunca é demais lembrar as principais limitações, até para evitar a sempre perigosa fetichização dos números obtidos. Apesar da boa disponibilidade de informações, não foi possível encontrar tabulações para todos os anos, gerando alguns saltos na série, em particular 1988 e 1995. Além disso, as tabulações nem sempre continham todas as informações desejadas, como se vê pelos numerosos procedimentos de tratamento e imputação de dados. Sem dúvida, a deficiência mais grave é a ausência dos rendimentos não tributáveis até 1974, o que exigiu sua imputação para todo o período anterior a essa data. As estimativas resultantes são plausíveis, mas não puderam ser validadas por fontes externas. Algo parecido pode ser dito para os anos de 1996 a 1998, 2000 e 2002, que igualmente demandaram a imputação dos rendimentos não tributáveis. Outra limitação relevante é que somente no período 2006-2013 as tabulações estavam ordenadas pelos rendimentos totais, de modo que não se pode descartar alguma subestimação da desigualdade nos anos anteriores. A influência dos altos níveis de inflação verificados na década de 1980 sobre as estimativas é outro problema incontornável, sendo possível que o aumento das frações dos mais ricos naqueles anos seja parcialmente artificial.

As comparações internacionais amplificam essas limitações, já que as incertezas introduzidas pelo tratamento dos dados brasileiros também dão as caras em outros países, uma vez que as idiossincrasias nacionais quanto aos sistemas tributários e à divulgação dos dados são disseminadas. A literatura internacional tende até a minimizar demais essas limitações. Não há saída óbvia e, no fundo, é quase impossível realizar comparações que não esbarrem nesses problemas. Por ora, nada indica que tudo isso se traduza em incompatibilidades ou erros grosseiros. 
Além dessas limitações, esta tese tem lacunas importantes. Todos os resultados dizem respeito à distribuição de renda individual entre adultos e não à renda domiciliar per capita de toda a população ou aos rendimentos do trabalho dos ocupados, como normalmente ocorre na literatura baseada em pesquisas domiciliares amostrais. Ademais, pouco ou nada foi feito para avaliar a extensão da evasão e da elisão fiscal, principalmente por falta de informações. Nos países em que algo pôde ser feito, o viés detectado foi pequeno. Nada garante que no Brasil seja assim, mas também não há por que imaginar que somos particularmente piores nesse sentido. Outra lacuna diz respeito à avaliação empírica das políticas e decisões comentadas no capítulo 6. Pelo menos em alguns casos deve ser possível realizar análises quantitativas mais rigorosas, em comparação com o caráter um tanto especulativo da discussão.

Esse é um dos caminhos para a melhor compreensão da concentração de renda entre os ricos no Brasil. Outra possibilidade que não pode ser descartada, por mais improvável que seja, é a existência de tabulações para além do material encontrado para esta tese, tanto para os anos sem informações quanto para aqueles em que elas estão incompletas.

A experiência internacional mostra que os dados tributários e administrativos são uma fonte cada vez mais importante para muitas áreas das ciências sociais. A publicação periódica de tabulações detalhadas e em formato consistente das declarações do IRPF é condição sine qua non para o estudo dos mais ricos, para não falar do acesso direto a microdados, que já ocorre em diversos países do mundo. Os bancos de dados relativos a outros tributos, mesmo em âmbito estadual ou municipal, também têm muito a contribuir, ainda mais se for possível, no futuro, fazer o cruzamento de informações.

Inevitavelmente, tudo depende mais da disposição dos órgãos responsáveis do que da iniciativa exclusiva dos pesquisadores. Em alguns países e regiões, como na Escandinávia, o uso desse tipo de informação já é disseminado. No Brasil, continua sendo muito mais fácil estudar os pobres do que os ricos. Enquanto o acesso ao Cadastro Único para programas sociais é relativamente simples, as informações do IRPF permanecem guardadas a sete chaves. Com um pouco de boa vontade, é viável que isso mude no futuro próximo.

Do ponto de vista substantivo, o acesso a mais informações pode permitir avanços em particular no estudo da distribuição de riqueza ou patrimônio no país. Em todo o mundo, a riqueza costuma ser muito mais concentrada do que a renda, e nada sugere que o Brasil seja exceção à regra. Por isso, o próprio interesse pelos ricos leva à questão do patrimônio. Afora alguns trabalhos pontuais, conhecemos muito pouco sobre essa dimensão da desigualdade.

Por fim, em termos teóricos, a busca por uma teoria unificada da estratificação é tão inexorável quanto, no momento, pouco promissora. De um modo ou de outro, o crescente ecletismo teórico demandará tentativas de sistematização mais adiante. Como os modelos formais existentes têm um custo muito alto em termos de realismo, não é 
autoevidente que tal sistematização tenha que seguir nessa direção por enquanto. Talvez, inclusive, a tarefa mais imediata seja organizar o debate e sublinhar as limitações e o grau de complementaridade das teorias e hipóteses já formuladas.

A interpretação aqui sugerida sobre a dinâmica institucional da desigualdade precisa não só ser avaliada empiricamente de modo mais rigoroso como também ganhar contornos mais precisos. Seu grau de generalidade e abstração não a torna incompatível com várias outras explicações, ainda mais quando se leva em conta que diferentes mecanismos podem afetar diferentes degraus da distribuição de renda. Falta, porém, dar mais substância ao que é, reconhecidamente, apenas um primeiro passo.

Se os argumentos aqui defendidos estiverem corretos, a concentração de renda entre os ricos não sairá da agenda teórica, empírica e política no curto e no médio prazos. O Brasil tem tudo para seguir essa tendência: permanecemos um país altamente desigual em que a fração da renda recebida pelos mais ricos está longe dos níveis civilizados que cumpriram um papel fundamental para a construção simbólica do "Primeiro Mundo" no pós-guerra. Se quisermos romper com essa sina, teremos que encarar uma tarefa inédita, que exigirá reformas em muitas frentes e disputas políticas agudas. Não há motivos para sermos otimistas nem alternativas mais fáceis. Esperar que o crescimento puro e simples resolva nossa questão distributiva não funcionou no passado e dificilmente funcionará no futuro. 


\section{Referências}

A POLÍTICA do imposto de renda. Revista Veja, v. 185, p. 68-75, 22 de março 1972.

A RENDA dos brasileiros. Revista Veja, v. 196, p. 67-74, 7 de junho 1972.

AARON, H. J. Politics and the professors: The Great Society in perspective. Washington, DC: The Brookings Institution, 1978.

ABREU, M. de P. Crise, crescimento e modernização autoritária: 1930-1945. In: ABREU, M. de P. (Ed.). A ordem do progresso: cem anos de política econômica republicana, 1889-1989. Rio de Janeiro: Editora Campus, 1990.

ABREU, M. de P. O Brasil no século XX: a economia. In: IBGE (Ed.). Estatísticas do século XX. Rio de Janeiro: Instituto Brasileiro de Geografia e Estatística, 2006. Acesso em 14 abr. 2015. Disponível em: <http://seculoxx.ibge.gov.br/>.

ABREU, M. de P. The Brazilian economy, 1930-1980. In: BETHELL, L. (Ed.). The Cambridge History of Latin America IX - Brazil since 1930. Cambridge, Reino Unido; Nova York: Cambridge University Press, 2008.

ABREU, M. de P. The Brazilian economy, 1980-1994. In: BETHELL, L. (Ed.). The Cambridge History of Latin America IX - Brazil since 1930. Cambridge, Reino Unido; Nova York: Cambridge University Press, 2008.

ABREU, M. de P.; WERNECK, R. The Brazilian economy, 1994-2004: an interim assessment. In: BETHELL, L. (Ed.). The Cambdridge History of Latin America IX Brazil since 1930. Cambridge, Reino Unido; Nova York: Cambridge University Press, 2008.

ACEMOGLU, D.; AUTOR, D. What does human capital do? A review of Goldin and Katz's "The Race between Education and Technology". Journal of Economic Literature, v. 50, n. 2, p. 426-463, 2012.

ACEMOGLU, D.; JOHNSON, S.; ROBINSON, J. The colonial origins of comparative development: an empirical investigation. The American Economic Review, v. 91, n. 5, p. 1369-1401, 2001.

ACEMOGLU, D.; JOHNSON, S.; ROBINSON, J. Reversal of fortune: geography and institutions in the making of the modern world income distribution. The Quarterly Journal of Economics, v. 117, n. 4, p. 1231-1294, 2002.

ACEMOGLU, D. et al. Democracy, redistribution, and inequality. In: ATKINSON, A. B.; BOURGUIGNON, F. (Ed.). Handbook of Income Distribution. Amsterdã: North Holland, Elsevier, 2015. v. 2B.

ACEMOGLU, D.; ROBINSON, J. The rise and decline of general laws of capitalism. Journal of Economic Perspectives, v. 29, n. 1, p. 3-28, 2015.

AFONSO, J. R. Imposto de renda e distribuição de renda e riqueza: as estatísticas fiscais e um debate premente no Brasil. Revista de Estudos Tributários e Aduaneiros, v. 1, n. 1, p. 28-60, 2014. 
ALBUQUERQUE, P. M. Um estudo da população de altos rendimentos no Brasil nos anos recentes. Rio de Janeiro: Instituto de Pesquisa Econômica Aplicada, 1994. (Série Seminários n. 10).

ALMEIDA, A. M. F. O assalto à educação pelos economistas. Tempo Social, v. 20, n. 1, p. $163-178,2008$.

ALMEIDA JR., A. M. de. Do declínio do Estado Novo ao suicídio de Getúlio Vargas. In: FAUSTO, B. (Ed.). O Brasil Republicano - Sociedade e Política (1930-1964). São Paulo: Difel, 1981, (História Geral da Civilização Brasileira, Tomo III, $3^{\circ}$ Volume).

ALSTON, L. et al. Changing social contracts: beliefs and dissipative inclusion in Brazil. Journal of Comparative Economics, v. 41, p. 48-65, 2013.

ALVAREDO, F. Top incomes in historical and fiscal perspective: the cases of Spain, Argentina, Italy and Portugal. Tese (Tese de Doutorado em "Formation, analyse et politique economiques") — École des Hautes Études en Sciences Sociales, Paris, 2008.

ALVAREDO, F. A note on the relationship between top income shares and the Gini coefficient. Economics Letters, v. 110, p. 274-277, 2011.

AlvarEDO, F.; ATKINSON, A. B. Colonial rule, Apartheid and natural resources: top incomes in South Africa, 1903-200\%. Londres: Centre for Economic Policy Research, 2010. (CEPR Discussion Paper n. 8155). Disponível em: <https://web.archive.org/web/20160412183859/http://www.parisschoolofeconomics.eu/ IMG/pdf/DP8155_SouthAfrica.pdf>.

ALVAREDO, F. et al. The top 1 percent in international and historical perspective. Journal of Economic Perspectives, v. 27, n. 3, p. 3-20, 2013.

ALVAREDO, F. et al. The World Wealth and Income Database. 2015. Acesso em 21 out. 2015. Disponível em: < http://www.wid.world >.

AMOROSO, L. O índice de concentração das rendas, segundo Pareto. Revista Brasileira de Estatística, IX, n. 34, p. 157-161, 1948.

ANGRIST, J.; PISCHKE, J.-S. The credibility revolution in empirical economics: how better research design is taking the con out of econometrics. Journal of Economic Perspectives, v. 24, n. 2, p. 3-30, 2010.

ARON, R. Social structure and the ruling class, part 1. The British Journal of Sociology, v. 1 , n. 1, p. 1-16, 1950.

ARON, R. Social structure and the ruling class, part 2. The British Journal of Sociology, v. 1, n. 2, p. 126-143, 1950.

ARRETCHE, M. Conclusões: as políticas na trajetória da democracia à redução das desigualdades. In: ARRETCHE, M. (Ed.). Trajetórias das desigualdades: como o Brasil mudou nos últimos cinquenta anos. São Paulo: Editora Unesp; CEM, 2016.

ATKINSON, A. B. On the measurement of inequality. Journal of Economic Theory, v. 2, p. $244-263,1970$.

ATKINSON, A. B. Bringing income distribution in from the cold. The Economic Journal, v. 107, p. 297-321, 1997. 
ATKINSON, A. B. Top incomes in the UK over the $20^{\text {th }}$ century. Journal of the Royal Statistical Society, Series A (Statistics in Society), v. 168, n. 2, p. 325-343, 2005.

ATKINSON, A. B. Measuring top incomes: methodological issues. In: ATKINSON, A. B.; PIKETTY, T. (Ed.). Top incomes over the Twentieth Century: a contrast between Continental European and English-speaking countries. Londres: Oxford University Press, 2007.

ATKINSON, A. B.; BOURGUIGNON, F. Introduction: income distribution and economics. In: ATKINSON, A. B.; BOURGUIGNON, F. (Ed.). Handbook of Income Distribution. Amsterdã: Elsevier Science, 2000. v. 1.

ATKInSON, A. B.; PIKETTY, T. (Ed.). Top Incomes over the Twentieth Century: A Contrast Between Continental European and English-speaking Countries. Londres: Oxford University Press, 2007.

ATKInson, A. B.; PIKeTty, T. (Ed.). Top Incomes: A Global Perspective. Londres: Oxford University Press, 2010.

ATKInSON, A. B.; PIKETTY, T.; SAEZ, E. Top incomes in the long run of history. Journal of Economic Perspectives, v. 49, n. 1, p. 3-71, 2011.

AULT, H.; ARNOLD, B. (Ed.). Comparative income taxation: a structural analysis. Nova York: Aspen Publishers, 2004.

AUTOR, D. Skills, education, and the rise of earnings inequality among the "other 99 percent". Science, v. 334, n. 6186, p. 843-851, 2014.

AUTOR, D.; KATZ, L.; KEARNEY, M. The polarization of the U.S. labor market. The American Economic Review, v. 96, n. 2, p. 189-194, 2006.

AUTOR, D.; KATZ, L.; KEARNEY, M. Trends in U.S. wage inequality: revising the revisionists. The Review of Economics and Statistics, v. 90, n. 2, p. 300-323, 2008.

AUTOR, D.; LEVY, F.; MURNANE, R. The skill content of recent technological change: an empirical exploration. The Quarterly Journal of Economics, v. 118, n. 4, p. 1279-1333, 2003.

BACHA, E. Hierarquia e remuneração gerencial. In: TOLIPAN, R.; TINELLI, A. C. (Ed.). A controvérsia sobre distribuição de renda e desenvolvimento. Rio de Janeiro: Zahar Editores, 1975.

BACHA, E. Os mitos de uma década: ensaios de economia brasileira. Rio de Janeiro: Paz e Terra, 1978.

BACHA, E.; TAYLOR, L. Brazilian income distribution in the 1960s: 'facts', model results and the controversy. Journal of Development Studies, v. 14, p. 271-297, 1978.

BAER, W. A recente experiência brasileira de desenvolvimento: uma interpretação. Pesquisa e Planejamento Econômico, v. 3, n. 2, p. 265-302, 1973.

BAER, W. A economia brasileira. São Paulo: Nobel, 2009. 
BAIRD, E.; FINE, S. The use of income tax data in the National Resources Committee estimate of the distribution of income by size. In: Conference on Research in National Income and Wealth (Ed.). Studies in income and wealth. Nova York: National Bureau of Economic Research, 1939. v. 3.

BAKIJA, J.; COLE, A.; HEIM, B. Jobs and income growth of top earners and the causes of changing income inequality: evidence from U.S. Tax Return data. 2012. Acesso em 23 out. 2015. Disponível em: <https://web.archive.org/web/20151023042253/https://web. williams.edu/Economics/wp/BakijaColeHeimJobsIncomeGrowthTopEarners.pdf $>$.

BANERJEE, A.; PIKETTY, T. Top Indian incomes, 1922-2000. In: ATKINSON, A. B.; PIKETTY, T. (Ed.). Top Incomes: A Global Perspective. Londres: Oxford University Press, 2010.

BARBOSA, A. L. N. de H.; SOUZA, P. H. G. F. de. Diferencial salarial público-privado e desigualdade dos rendimentos do trabalho no Brasil. Ipea - Boletim de Mercado de Trabalho, v. 53, p. 29-36, 2012.

BARBOSA, R. Impôsto sobre a renda - noções. In: COMISSÃO DE REFORMA DO MINISTÉRIO DA FAZENDA (Ed.). Evolução do impôsto de renda no Brasil. Rio de Janeiro: Fundação Getúlio Vargas, 1966.

BARROS, R. P. de. A efetividade do salário mínimo em comparação à do Programa Bolsa Família como instrumento de redução da pobreza e da desigualdade. In: BARROS, R. P. de; FOGUEL, M. N.; ULYSSEA, G. (Ed.). Desigualdade de renda no Brasil: uma análise da queda recente. Brasília: Instituto de Pesquisa Econômica Aplicada, 2007. v. 2.

BARROS, R. P. de; CARVALHO, M. de; FRANCO, S. O papel das transferências públicas na queda recente da desigualdade de renda brasileira. In: BARROS, R. P. de; FOGUEL, M. N.; ULYSSEA, G. (Ed.). Desigualdade de renda no Brasil: uma análise da queda recente. Brasília: Instituto de Pesquisa Econômica Aplicada, 2007. v. 2.

BARROS, R. P. de et al. Uma análise das principais causas da queda recente na desigualdade de renda brasileira. Econômica, v. 8, n. 1, p. 117-147, 2006.

BARROS, R. P. de; CURY, S.; ULYSSEA, G. A desigualdade de renda no Brasil encontra-se subestimada? uma análise comparativa usando PNAD, POF e Contas Nacionais. In: BARROS, R. P. de; FOGUEL, M. N.; ULYSSEA, G. (Ed.). Desigualdade de renda no Brasil: uma análise da queda recente. Brasília: Instituto de Pesquisa Econômica Aplicada, 2006. v. 1.

BARROS, R. P. de; FOGUEL, M. N.; ULYSSEA, G. (Ed.). Desigualdade de renda no Brasil: uma análise da queda recente. Brasília: Instituto de Pesquisa Econômica Aplicada, 2006. v. 1. Disponível em: <http://www.ipea.gov.br/portal/index.php?option=com content\&view $=$ article\&id $=5553>$.

BARROS, R. P. de; FOGUEL, M. N.; ULYSSEA, G. (Ed.). Desigualdade de renda no Brasil: uma análise da queda recente. Brasília: Instituto de Pesquisa Econômica Aplicada, 2007. v. 2. Disponível em: <http://www.ipea.gov.br/portal/index.php?option=com_ content\&view $=$ article\&id $=5552>$.

BARROS, R. P. de; FRANCO, S.; MENDONÇA, R. Discriminação e segmentação no mercado de trabalho e desigualdade de renda no Brasil. In: BARROS, R. P. de; FOGUEL, 
M. N.; ULYSSEA, G. (Ed.). Desigualdade de renda no Brasil: uma análise da queda recente. Brasília: Instituto de Pesquisa Econômica Aplicada, 2007. v. 2.

BARROS, R. P. de; FRANCO, S.; MENDONÇA, R. A recente queda na desigualdade de renda e o acelerado progresso educacional brasileiro da última década. In: BARROS, R. P. de; FOGUEL, M. N.; ULYSSEA, G. (Ed.). Desigualdade de renda no Brasil: uma análise da queda recente. Brasília: Instituto de Pesquisa Econômica Aplicada, 2007. v. 2.

BARROS, R. P. de; HENRIQUES, R.; MENDONÇA, R. Desigualdade e pobreza no Brasil: retrato de uma estabilidade inaceitável. Revista Brasileira de Ciências Sociais, v. 15 , n. 42 , p. 123-142, 2000.

BARROS, R. P. de; MENDONÇA, R. A evolução do bem-estar, pobreza e desigualdade no Brasil ao longo das últimas três décadas. Pesquisa e Planejamento Econômico, v. 25, n. 1, p. 115-164, 1995.

BARROS, R. P. de; MENDONÇA, R. Os determinantes da desigualdade no Brasil. Rio de Janeiro: Instituto de Pesquisa Econômica Aplicada, 1995. (Texto para Discussão n. 377).

BARROS, R. P. de; RAMOS, L. A note on the temporal evolution of the relationship between wages and education among Brazilian prime-age males: 1976-1989. Rio de Janeiro: Instituto de Pesquisa Econômica Aplicada, 1992. (Texto para Discussão n. 279).

BARRY, B. Social exclusion, social isolation and the distribution of income. In: HILLS, J.; LE GRAND, J.; PIACHAUD, D. (Ed.). Understanding social exclusion. Oxford; Nova York: Oxford University Press, 2002.

BARTELS, L. Unequal Democracy: the Political Economy of the New Gilded Age. Princeton: Princeton University Press, 2008.

BASTOS, E. K. X. Distribuição funcional da renda no Brasil: estimativas anuais e construção de uma série trimestral. Rio de Janeiro: Instituto de Pesquisa Econômica Aplicada, 2012. (Texto para Discussão n. 1702).

BATISTA, J. C. O setor externo brasileiro no século XX. In: IBGE (Ed.). Estatísticas do século $X X$. Rio de Janeiro: Instituto Brasileiro de Geografia e Estatística, 2006. Acesso em 14 abr. 2015. Disponível em: <http://seculoxx.ibge.gov.br/>.

BAUMAN, Z. Is there a postmodern sociology? Theory, Culture 6 Society, v. 5, p. 217-237, 1988.

BECKER, G. Nobel lecture: The economic way of looking at behavior. Journal of Political Economy, v. 101, n. 3, p. 385-409, 1993.

BELL, D. The Power Elite - reconsidered. American Journal of Sociology, v. 64, n. 3, p. 238-250, 1958.

BELL, D. On meritocracy and equality. The Public Interest, v. 29, p. 29-68, 1972.

BELL, S. A.; WRAY, L. R. The War on Poverty after 40 years: a Minskyan assessment. The Levy Economics Institute of Bard College Public Policy Brief, v. 78, p. 7-30, 2004.

BÉRTOLA, L. et al. Income distribution in the Latin American Southern Cone during the first globalization boom and beyond. International Journal of Comparative Sociology, v. 50, n. 5-6, p. 452-485, 2009. 
BÉRTOLA, L. et al. Between the colonial heritage and the first globalization boom: on income inequality in the Southern Cone. Revista de Historia Económica / Journal of Iberian and Latin American Economic History, v. 28, n. edição especial 02, p. 307-341, 2010.

BETHELL, L. (Ed.). The Cambdrige History of Latin America IX - Brazil since 1930. Cambridge, Reino Unido; Nova York: Cambridge University Press, 2008.

BETHELL, L. Politics in Brazil under the Liberal Republic, 1945-1964. In: BETHELL, L. (Ed.). The Cambridge History of Latin America IX - Brazil since 1930. Cambridge, Reino Unido; Nova York: Cambridge University Press, 2008.

BETHELL, L. Politics in Brazil under Vargas, 1930-1945. In: BETHELL, L. (Ed.). The Cambridge History of Latin America IX - Brazil since 1930. Cambridge, Reino Unido; Nova York: Cambridge University Press, 2008.

BETHELL, L.; CASTRO, C. Politics in Brazil under military rule, 1964-1985. In:

BETHELL, L. (Ed.). The Cambridge History of Latin America IX - Brazil since 1930. Cambridge, Reino Unido; Nova York: Cambridge University Press, 2008.

BETHELL, L.; NICOLAU, J. Politics in Brazil under military rule, 1985-2002. In:

BETHELL, L. (Ed.). The Cambridge History of Latin America IX - Brazil since 1930. Cambridge, Reino Unido; Nova York: Cambridge University Press, 2008.

BIVENS, J.; MISHEL, L. The pay of corporate executives and financial professionals as evidence of rents in top 1 percent incomes. Journal of Economic Perspectives, v. 27, n. 3, p. $57-78,2013$.

BLAU, P.; DUNCAN, O. D. The American occupational structure. Nova York: John Wiley \& Sons, 1967.

BLINDER, A. S. The level and distribution of economic well-being. In: FELDSTEIN, M. (Ed.). The American economy in transition. Chicago; Londres: The University of Chicago Press, 1980.

BOLTANSKI, L. The Left after May 1968 and the longing for Total Revolution. Thesis Eleven, v. 69, n. 1, p. 1-20, 2002.

BONELLI, R. Nível de atividade e mudança estrutural. In: IBGE (Ed.). Estatísticas do século XX. Rio de Janeiro: Instituto Brasileiro de Geografia e Estatística, 2006. Acesso em 14 abr. 2015. Disponível em: <http://seculoxx.ibge.gov.br/>.

BONELLI, R.; RAMOS, L. Distribuição de renda no Brasil: avaliação das tendências de longo prazo e mudanças na desigualdade desde meados dos anos 70. Revista de Economia Política, v. 13, n. 2, p. 76-97, 1993.

BONELLI, R.; SEDLACEK, G. Distribuição de renda: evolução no último quarto de século. Rio de Janeiro: Instituto de Pesquisa Econômica Aplicada, 1988.

BONICA, A. et al. Why hasn't democracy slowed rising inequality? Journal of Economic Perspectives, v. 27, p. 103-124, 2013.

BOOTH, C. Life and Labour of the People in London, vol. 1. Londres: [n/a], 1889. Acesso em 16 jun. 2015. Disponível em: < https://archive.org/details/labourlifeofpeop01bootuoft>. 
BOSE, A.; CHAKRAVARTY, S.; D'AMBROSIO, C. Richness orderings. Journal of Economic Inequality, v. 12, n. 1, p. 5-22, 2014.

BOUND, J.; JOHNSON, G. Changes in the structure of wages in the 1980's: an evaluation of alternative explanations. The American Economic Review, v. 82, n. 3, p. 371-392, 1992.

BOURDIEU, P. Esboço de uma teoria da prática. In: ORTIZ, R. (Ed.). Pierre Bourdieu: Sociologia. São Paulo: Editora Ática, 1983.

BOURDIEU, P. Practical reason: on the theory of action. Stanford: Stanford University Press, 1998.

BOURDIEU, P. Condição de classe e posição de classe. In: MICELI, S. (Ed.). A sociologia de Pierre Bourdieu. São Paulo: Editora Perspectiva, 2004.

BOURDIEU, P. The social structures of the economy. Cambridge, Reino Unido: Polity Press, 2005.

BOURDIEU, P. A distinção: crítica social do julgamento. Porto Alegre: Editora Zouk; Edusp, 2006.

BOURGUIGNON, F.; MORRISSON, C. Inequality among world citizens: 1820-1992. The American Economic Review, v. 92, n. 4, p. 727-744, 2002.

BOWLES, S. Schooling and inequality from generation to generation. Journal of Political Economy, v. 80, n. 3, p. S219-S251, 1972.

BOWLEY, A. L. The British Super-Tax and the distribution of income. The Quarterly Journal of Economics, v. 28, n. 2, p. 255-268, 1914.

BOWLEY, A. L. The change in the distribution of the national income 1880-1913. Oxford: The Clarendon Press, 1920.

BRASIL. II Plano Nacional de Desenvolvimento (1975-1979). Brasília: Imprensa Oficial, 1974. Disponível em: < https://web.archive.org/web/20160605212450/http: //www.planalto.gov.br/ccivil_03/leis/1970-1979/anexo/ANL6151-74.PDF>.

BRASIL. Ministério da Fazenda. Departamento do Imposto de Renda. Relatório das atividades do ano de 1964. Brasília: Departamento de Imprensa Nacional, 1965.

BRASIL. Ministério da Fazenda. Departamento do Imposto de Renda. Boletim Estatístico, n. 28. [S.1.]: Ministério da Fazenda, 1968.

BRASIL. Ministério da Fazenda. Departamento do Imposto de Renda. Boletim Estatístico, n. 32. [S.l.]: Ministério da Fazenda, 1968.

BRASIL. Ministério da Fazenda. Divisão do Imposto de Renda. Boletim Estatístico, n. 23. [S.l.]: Ministério da Fazenda, 1966.

BRASIL. Ministério da Fazenda. Secretaria da Receita Federal. Imposto sobre a renda e proventos de qualquer natureza 1968. Rio de Janeiro: Ministério da Fazenda, 1968.

BRASIL. Ministério da Fazenda. Secretaria da Receita Federal. Anuário Econômico-Fiscal, anos 1-11. Rio de Janeiro; Brasília: Ministério da Fazenda, 1970-1980. (Anual). 
BRASIL. Ministério da Fazenda. Secretaria da Receita Federal. Imposto de Renda Pessoa Física, anos 1-11. Brasília: Ministério da Fazenda, 1979-1989. (Anual).

BRASIL. Ministério da Fazenda. Secretaria da Receita Federal. Análise econômica da DIRPF 1999. Brasília: Ministério da Fazenda, 2000. (Texto para Discussão n. 9). Disponível em: <http://www.receita.fazenda.gov.br/Publico/estudotributarios/ estatisticas/11AnaliseEconomicaDIRPF1999.pdf $>$.

BRASIL. Ministério da Fazenda. Secretaria da Receita Federal. Tributação da renda no Brasil Pós-Real. Brasília: Secretaria da Receita Federal, 2001.

BRASIL. Ministério da Fazenda. Secretaria da Receita Federal. O imposto de rendas das pessoas físicas no Brasil. Brasília: Secretaria da Receita Federal, 2004. (Estudos Tributários n. 14).

BRASIL. Ministério da Fazenda. Secretaria da Receita Federal. Carga Tributária no Brasil - Análise por Tributos e Bases de Incidência. Brasília: Secretaria da Receita Federal, 2014. Acesso em 20 nov. 2014. Disponível em: <http: //idg.receita.fazenda.gov.br/dados/receitadata/estudos-e-tributarios-e-aduaneiros/ estudos-e-estatisticas/carga-tributaria-no-brasil/carga-tributaria-no-brasil-capa > .

BRASIL. Ministério da Fazenda. Secretaria da Receita Federal. Grandes Números IRPF - anos-calendário 1999 a 2013. Brasília: Secretaria da Receita Federal, 2015. Acesso em 8 mar. 2015. Disponível em: <http://idg.receita.fazenda.gov. $\mathrm{br} /$ dados/receitadata/estudos-e-tributarios-e-aduaneiros/estudos-e-estatisticas/ 11-08-2014-grandes-numeros-dirpf/grandes-numeros-dirpf-capa > .

BRASIL. Secretaria de Assuntos Estratégicos. Relatório da Comissão para Definição da Classe Média no Brasil. Brasília: Secretaria de Assuntos Estratégicos, 2012.

BREEN, R. (Ed.). Social mobility in Europe. Oxford, Reino Unido; Nova York: Oxford University Press, 2004.

BREEN, R. Foundations of a neo-Weberian class analysis. In: Approaches to class analysis. Cambridge, Reino Unido: Cambridge University Press, 2005.

BROWNING, E. K. How much more equality can we afford? Public Interest, v. 43, p. 90-110, 1976.

BUCHANAN, J. Public choice: the origins and development of a research program. Fairfax, 2003. Acesso em 30 set. 2015. Disponível em: < https://web.archive.org/web/ 20151001010758/https://publicchoicesociety.org/content/general/PublicChoiceBooklet. $\mathrm{pdf}>$.

BUCHANAN, J. M. What kind of redistribution do we want? Economica, v. 35, n. 138, p. 185-190, 1968.

BUCKLEY, W. Social stratification and the functional theory of social differentiation. American Sociological Review, v. 23, n. 4, p. 369-375, 1958.

BUDD, E. C. Postwar changes in the size distribution of income in the US. The American Economic Review, v. 60, n. 2, p. 247-260, 1970. 
BULIR, A. Income inequality: does inflation matter? IMF Staff Papers, v. 48, n. 1, p. 139-159, 2001.

BURNS, A. F. Looking forward. In: BURNS, A. F. (Ed.). Looking Forward: $31^{\text {st }}$ Annual Report. Nova York: National Bureau of Economic Research, 1951. p. 3-18.

BUTLER, E. A short history of the Mont Pelerin Society. 2014. Acesso em $1^{o}$ set. 2015. Disponível em: <https://www.montpelerin.org/montpelerin/documents/ Short-History-of-MPS-2014.pdf $>$.

CAMARGO, A. de A. A questão agrária: crise de poder e reformas de base (1930-1964). In: FAUSTO, B. (Ed.). O Brasil Republicano - Sociedade e Política (1930-1964). São Paulo: Difel, 1981, (História Geral da Civilização Brasileira, Tomo III, $3^{\circ}$ Volume).

CAMPOS, A. et al. (Ed.). Os ricos no Brasil. São Paulo: Cortez Editora, 2005. v. 3. (Atlas da Exclusão Social no Brasil, v. 3).

CAMPOS, M. A. F. A política econômica do governo Kubitschek (1956-1961): o discurso em ação. Dissertação (Mestrado em "Economia do Desenvolvimento") — Universidade Federal do Rio Grande do Sul, Porto Alegre, 2007.

CAMPOS, R. de O. A moeda, o govêrno e o tempo. Rio de Janeiro: Apec Editôra, 1964.

CANBERRA GROUP. Canberra Group Handbook on Household Income Statistics. $2^{a}$. Genebra: United Nations, 2011.

CANNADINE, D. The rise and fall of class in Britain. Nova York: Columbia University Press, 1999.

CARD, D.; DINARDO, J. Skill-biased technological change and rising wage inequality: some problems and puzzles. Journal of Labor Economics, v. 20, n. 4, p. 733-783, 2002.

CARDOSO, A. Uma utopia brasileira: Vargas e a construção do Estado de Bem-estar numa sociedade estruturalmente desigual. Dados - Revista de Ciências Sociais, v. 53, n. 4, p. $775-819,2010$.

CARDOSO, E.; BARROS, R. P. de; URANI, A. Inflation and unemployment as determinants of inequality in Brazil: the 1980. Rio de Janeiro: Instituto de Pesquisa Econômica Aplicada, 1993. (Texto para Discussão, n. 298).

CARDOSO, F. H. Proletariado no Brasil: situação e comportamento social. Revista Brasiliense, v. 41, n. Maio-Junho, p. 98-122, 1962.

CARDOSO, F. H. Prefácio. In: TOLIPAN, R.; TINELli, A. C. (Ed.). A controvérsia sobre distribuição de renda e desenvolvimento. Rio de Janeiro: Zahar Editores, 1975.

CARDoso, F. H.; FALETTO, E. Dependency and development in Latin America. Berkeley; Los Angeles: University of California Press, 1979.

CARNEGIE, A. Wealth. The North American Review, v. 148, n. 391, p. 653-664, 1889.

CARNEIRO, D. D. Crise e esperança: 1974-1980. In: ABREU, M. de P. (Ed.). A ordem do progresso: cem anos de política econômica republicana, 1889-1989. Rio de Janeiro: Editora Campus, 1990. 
CARNEIRO, D. D.; MODIANO, E. Ajuste externo e desequilíbrio interno: 1980-1984. In: ABREU, M. de P. (Ed.). A ordem do progresso: cem anos de política econômica republicana, 1889-1989. Rio de Janeiro: Editora Campus, 1990.

CARVAlHO, J. M. de. Cidadania no Brasil: o longo caminho. $11^{a}$ edição. Rio de Janeiro: Civilização Brasileira, 2008.

CARVALHO JR, P. H. B. de. Aspectos distributivos do IPTU e do patrimônio imobiliário das famílias brasileiras. In: CASTRO, J. A. de; SANTOS, C. H. M. dos; RIBEIRO, J. A. C. (Ed.). Tributação e equidade no Brasil: um registro da reflexão do Ipea no biênio 2008-2009. Brasília: Instituto de Pesquisa Econômica Aplicada, 2010.

CARVALHO, L. de. Políticas salariais brasileiras no período 1964-1981. Revista Brasileira de Economia, v. 36, n. 1, p. 51-84, 1982.

CASTEL, R. From Manual Workers to Wage Laborers: Transformation of the Social Question. New Brunswick: Transaction Publishers, 2003.

CASTRO, F. A. de. Imposto de renda da pessoa física: comparações internacionais, medidas de progressividade e redistribuição. Dissertação (Mestrado em Economia) Universidade de Brasília, Brasília, 2014.

CASTRO, J. A. et al. Gasto social federal: prioridade macroeconômica no período 1995-2010. Brasília: Instituto de Pesquisa Econômica Aplicada, 2012. (Nota Técnica, n. 9). Acesso em 17 mar. 2016. Disponível em: <https://web.archive.org/web/ 20160429034523/http://www.ipea.gov.br/agencia/images/stories/PDFs/nota_tecnica/ 120904_notatecnicadisoc09.pdf >.

CASTRO, L. B. de. Esperança, frustração e aprendizado: a história da Nova República. In: GIAMBIAGI, F. et al. (Ed.). Economia brasileira contemporânea. Rio de Janeiro: Elsevier, Editora Campus, 2005.

CINGANO, F. Trends in income inequality and its impact on economic growth. OECD Social, Employment and Migration Working Papers, v. 163, p. 1-65, 2014.

CLARK, J. B. Social justice without socialism. Boston, Nova York: Houghton Mifflin Company, 1914. Acesso em $1^{o}$ jul. 2015. Disponível em: <https://archive.org/details/ socialjusticewi00clargoog $>$.

CLARK, N. L.; WORGER, W. H. South Africa: the rise and fall of Apartheid. Londres; Nova York: Routledge, 2011. (Seminar Studies in History).

COATSWORTH, J. Inequality, institutions and economic growth in Latin America. Journal of Latin American Studies, v. 40, n. 3, p. 545-569, 2008.

COBHAM, A.; SUMMER, A. Is it all about the tails? The Palma measure of income inequality. Washington, D.C.: Center for Global Development, 2013. (Working Paper n. $343)$.

COELHO, A. M.; CORSEUIL, C. H. Diferenciais salariais no Brasil: um breve panorama. Rio de Janeiro: Instituto de Pesquisa Econômica Aplicada, 2002. (Texto para Discussão n. 898). 
COLE, G. D. The conception of the middle classes. The British Journal of Sociology, v. 1, n. 4 , p. $275-290,1950$.

COLEMAN, J. Equal schools or equal students? Public Interest, v. 4, p. 70-75, 1966.

COLISTETE, R. P. Desenvolvimento, distribuição de renda e capital estrangeiro: um comentário sobre a Cepal nos anos 50. Revista de Economia Política, v. 12, n. 4, p. 27-36, 1992.

COLISTETE, R. P. Productivity, wages, and labor politics in Brazil, 1945-1962. The Journal of Economic History, v. 67, n. 1, p. 93-127, 2007.

COLISTETE, R. P. Salários, produtividade e lucros na indústria brasileira, 1945-1978. Revista de Economia Política, v. 29, n. 4, p. 386-405, 2009.

COLLINS, R. Is 1980s Sociology in the doldrums? American Journal of Sociology, v. 91, n. 6, p. 1336-1355, 1986.

COLLINS, R.; MAKOWSKY, M. The discovery of society. $5^{a}$ edição. Nova York, Londres: McGraw-Hill Book Company, 1993.

COLLINS, W.; MARGO, R. The economic aftermath of the 1960s riots in American cities: evidence from property values. The Journal of Economic History, v. 67, n. 4, p. 849-883, 2007.

COMISSÃO DE REFORMA DO MINISTÉRIO DA FAZENDA. Evolução do impôsto de renda no Brasil. Rio de Janeiro: Fundação Getúlio Vargas, 1966.

COMMONS, J. R. Is class conflict in America growing and is it inevitable? American Journal of Sociology, v. 13, n. 6, p. 756-783, 1908.

CONSIDERA, C. M.; PESSOA, S. de A. A distribuição funcional da renda no Brasil no período 1959-2009. Pesquisa e Planejamento Econômico, v. 43, n. 3, p. 479-511, 2013.

CORSEUIL, C. H.; FOGUEL, M. N. Uma sugestão de deflatores para rendas obtidas a partir de algumas pesquisas domiciliares do IBGE. Rio de Janeiro: Instituto de Pesquisa Econômica Aplicada, 2002. (Texto para Discussão n. 897).

CORSEUIL, C. H.; MOURA, R.; RAMOS, L. Determinantes da expansão do emprego formal: o que explica o aumento do tamanho médio dos estabelecimentos? Brasília: Instituto de Pesquisa Econômica Aplicada, 2009.

COSTA RIBEIRO, C. A. Classe, raça e mobilidade social no Brasil. Dados - Revista de Ciências Sociais, v. 49, p. 883-873, 2006.

COSTA RIBEIRO, C. A. Estrutura de classe e mobilidade social no Brasil. São Paulo: Edusc, 2007.

COSTA RIBEIRO, C. A. Quatro décadas de mobilidade social no Brasil. Dados - Revista de Ciências Sociais, v. 55, p. 641-679, 2012.

DAGUM, C. A new approach to the decomposition of the Gini income inequality ratio. Empirical Economics, v. 22, p. 515-531, 1997. 
DAHL, R. A critique of the ruling elite model. The American Political Science Review, v. 52, n. 2, p. 463-469, 1958.

DAHRENDORF, R. Out of utopia: toward a reorientation of sociological analysis. American Journal of Sociology, v. 64, n. 2, p. 115-127, 1958.

DAHRENDORF, R. Class and class conflict in industrial society. Stanford: Stanford University Press, 1959.

DAHRENDORF, R. Recent changes in the class structure of European societies. Daedalus, v. 93, n. 1, p. 225-270, 1964.

DAHRENDORF, R. The strange death of Socialism. Studies: an Irish Quarterly Review, v. 79, n. 313 , p. $7-17,1990$.

DALTON, H. The measurement of the inequality of incomes. The Economic Journal, v. 30, n. 119 , p. 348-361, 1920.

DAVERN, M. et al. The effect of income question design in health surveys on family income, poverty and eligibility estimates. Health Services Research, v. 40, p. 1534-1552, 2005 .

DAVIS, K. A conceptual analysis of stratification. American Sociological Review, v. 7, n. 3, p. 309-321, 1942.

DAVIS, K. Some principles of stratification: a critical analysis - a reply. American Sociological Review, v. 18, n. 4, p. 394-397, 1953.

DAVIS, K. The abominable heresy: a reply to Dr. Buckley. American Sociological Review, v. 24, n. 1, p. 82-86, 1959.

DAVIS, K.; MOORE, W. Some principles of stratification. American Sociological Review, v. 10, n. 2, p. 242-249, 1944.

DEATON, A. Letter from America: America wakes up to inequality (again). Royal Economic Society Newsletter, v. 166, p. 9-10, 2014. Disponível em: <https://web.archive. org/web/20151025224341/http://www.res.org.uk/view/art1Apr14Corresp.html>.

DEDECCA, C. S. A queda da desigualdade de renda corrente e a participação do $1 \%$ de domicílios de maior renda, 2000-2010. Revista de Economia Política, v. 34, n. 2, p. 249-265, 2014.

DELL, F. Top incomes in Germany throughout the twentieth century: 1891-1998. In: ATKInsON, A. B.; PIKETTY, T. (Ed.). Top Incomes over the Twentieth Century: A Contrast Between Continental European and English-speaking Countries. Londres: Oxford University Press, 2007.

DE MILLE, A. G. Who was Henry George? Nova York, 1979. Disponível em: <https: //web.archive.org/web/20150730074808/http://www.henrygeorge.org/whowashg.htm>.

DIAS, E. História das lutas sociais no Brasil. São Paulo: Edaglit, 1962.

DIPRETE, T. What has sociology to contribute to the study of inequality trends? A historical and comparative perspective. American Behavioral Scientist, v. 50, n. 5, p. 603-618, 2007. 
DOMINGUES, J. M. Teorias sociológicas no século XX. Rio de Janeiro: Civilização Brasileira, 2004.

DREWNOWSKI, J. The affluence line. Social Indicators Research, v. 5, p. 263-278, 1978.

DRUCKER, P. The sickness of government. Public Interest, v. 14, p. 3-23, 1969.

DUNCAN, O. D. A socioeconomic index for all occupations. In: REISS, A. (Ed.). Occupations and social status. Nova York: The Free Press, 1961.

DURKHEIM, E. The division of labour in society. Londres: MacMillan Press, 1984.

EINAV, L.; LEVIN, J. The data revolution and economic analysis. Innovation Policy and the Economy, v. 14, p. 1-24, 2013.

EINSTEIN, A. Why socialism? Monthly Review, v. 1, p. 9-15, 1949. Disponível em: <http://monthlyreview.org/2009/05/01/why-socialism/>.

EMMETT, R. B. Introduction. In: EMMETT, R. B. (Ed.). The Elgar Companion to the Chicago School of Economics. Cheltenham; Northampton: Edward Elgar, 2010.

ENGERMAN, S.; SOKOLOFF, K. Factor endowments, institutions, and differential paths of growth among New World economies: a view from economic historians of the United States. In: HABER, S. (Ed.). How Latin America fell behind: essays on the economic histories of Brazil and Mexico, 1800-1914. Stanford: Stanford University Press, 1997.

ENGERMAN, S.; SOKOLOFF, K. Factor endowments, inequality, and paths of development among New World economies. Cambridge, Massachusetts: National Bureau of Economic Research, 2002. (NBER Working Paper n. 9259).

ERIKSON, R.; GOLDTHORPE, J. The constant flux: a study of class mobility in industrial societies. Nova York: Oxford University Press, 1992.

EVANS, G. Testing the validity of the Goldthorpe class schema. European Sociological Review, v. 8, n. 3, p. 211-232, 1992.

EVANS, G.; MILLS, C. Identifying class structure: a latent class analysis of the criterion-related and construct validity of the Goldthorpe class schema. European Sociological Review, v. 14, n. 1, p. 87-106, 1998.

EVANS, G.; MILLS, C. In search of the wage-labour/service contract: new evidence on the validity of the Goldthorpe class schema. British Journal of Sociology, v. 51, n. 4, p. 641-661, 2000.

FAUSTO, B. Trabalho urbano e conflito social (1890-1920). São Paulo: Difusão Européia do Livro, 1977.

FAUSTO, B. Estado, classe trabalhadora e burguesia industrial (1920-1945): uma revisão. Novos Estudos, v. 20, p. 6-37, 1988.

FAUSTO, B. História do Brasil. São Paulo: EdUSP, 1995.

FEENBERG, D. R.; POTERBA, J. M. Income inequality and the income of very high-income taxpayers: evidence from tax returns. Tax Policy and the Economy, v. 7, p. 145-177, 1993. 
FELDSTEIN, M. Reducing poverty, not inequality. Public Interest, v. 137, p. 33-41, 1999.

FERREIRA, A. H. B. A distribuição interestadual da renda no Brasil, 1950-85. Revista Brasileira de Economia, v. 50, n. 4, p. 469-485, 1996.

FERREIRA, F. H. G. Os determinantes da desigualdade de renda no Brasil: luta de classes ou heterogeneidade educacional? In: HENRIQUES, R. (Ed.). Desigualdade e pobreza no Brasil. Rio de Janeiro: Instituto de Pesquisa Econômica Aplicada, 2000.

FERREIRA, F. H. G. et al. Ascensão e queda da desigualdade de renda no Brasil. Econômica, v. 8, n. 1, p. 147-169, 2006.

FERREIRA, F. H. G.; LITCHFIELD, J. Education or inflation? The micro and macroeconomics of the Brazilian income distribution during 1981-1995. Cuadernos de Economía, v. 38, n. 114, p. 209-238, 2001.

FERREIRA, M. C. Permeável, ma non troppo? a mobilidade social em setores de elite, Brasil - 1996. Revista Brasileira de Ciências Sociais, v. 16, n. 47, p. 141-160, 2001.

FIRPO, S.; REIS, M. C. O salário mínimo e a queda recente da desigualdade no Brasil. In: BARROS, R. P. de; FOGUEL, M. N.; ULYSSEA, G. (Ed.). Desigualdade de renda no Brasil: uma análise da queda recente. Brasília: Instituto d, 2007. v. 2.

FISCHER, B. Direitos por lei, ou leis por direito? Pobreza e ambiguidade legal no Estado Novo. In: LARA, S.; MENDONCA, J. (Ed.). Direitos e justiças no Brasil. São Paulo: Editora Unicamp, 2006.

FISCHER, C. et al. Inequality by design: cracking the Bell Curve myth. Princeton: Princeton University Press, 1996.

FISHER, I. Economists in public service: Annual address of the president. The American Economic Review, v. 9, n. 1, p. 5-21, 1919.

FISHLOW, A. Brazilian size distribution of income. The American Economic Review, v. 62, n. 1/2, p. 391-402, março 1972.

FISHLOW, A. Algumas reflexões sobre a política econômica brasileira após 1964. Estudos Cebrap, v. 7, p. 6-65, 1974.

FISHLOW, A. The Latin American state. Journal of Economic Perspectives, v. 4, n. 3, p. 61-74, 1990.

FOGUEL, M. N.; AZEVEDO, J. P. Uma decomposição da desigualdade de rendimentos do trabalho no Brasil: 1995-2005. In: Desigualdade de renda no Brasil: uma análise da queda recente. Brasília: Instituto de Pesquisa Econômica Aplicada, 2007.

FONSECA, P. C. D.; MONTEIRO, S. M. M. O Estado e suas razões: o II PND. Revista de Economia Política, v. 28, n. 1, p. 28-46, 2007.

FOUCAULT, M. Nascimento da biopolítica - curso dado no Collège de France (1978-1979). São Paulo: Martins Fontes, 2008.

FRANCO, G. H. B. Auge e declínio do inflacionismo no Brasil. In: GIAMBIAGI, F. et al. (Ed.). Economia brasileira contemporânea. Rio de Janeiro: Elsevier; Editora Campus, 2005 . 
FRANK, R.; COOK, P. The winner-take-all society: why a few at the top get so much more than the rest of us. Nova York: Penguin, 1995.

FRANKEMA, E. Has Latin America always been unequal? Leiden; Boston: Brill, 2009.

FREEMAN, R.; KATZ, L. Rising wage inequality: the United States vs. other advanced countries. In: FREEMAN, R. (Ed.). Working under different rules. Nova York: Russell Sage Foundation, 1994.

FRIEDMAN, M. Capitalism and freedom. Londres; Chicago: The University of Chicago Press, 2002.

FRIEDMAN, M.; FRIEDMAN, R. Free to choose: a personal statement. Nova York; Londres: Harcourt Brace Jovanovich, 1980.

FRITSCH, W. Apogeu e crise na Primeira República: 1900-1930. In: ABREU, M. de P. (Ed.). A ordem do progresso: cem anos de política econômica republicana, 1889-1989. Rio de Janeiro: Editora Campus, 1990.

FURTADO, C. O mito do desenvolvimento econômico. Rio de Janeiro: Paz e Terra, 1974.

FURTADO, C. Raízes do subdesenvolvimento. Rio de Janeiro: Editora Civilização Brasileira, 2003.

GABAIX, X. Power laws in economics and finance. Annual Review of Economics, v. 1, p. 255-293, 2009.

GABAIX, X. Power laws in economics: an introduction. Journal of Economic Perspectives, v. 30, n. 1, p. 185-206, 2016.

GABAIX, X.; LANDIER, A. Why has CEO pay increased so much? The Quarterly Journal of Economics, v. 123, n. 1, p. 49-100, 2008.

GALBRAITH, J. K. The New Industrial State: a review of a review. Public Interest, v. 9, p. 109-119, 1967.

GALBRAITH, J. K. The affluent society. Nova York: Houghton Mifflin Company, 1984.

GALBRAITH, J. K. American capitalism: the concept of countervailing power. Nova York: Transaction Publishers, 1993.

GEORGE, H. Progress and Poverty: an inquiry into the cause of industrial depressions and of increase of want with increase of wealth. Kingsport: Robert Schalkenbach Foundation, 1935. Disponível em: < https://web.archive.org/web/20150721071110/https: //mises.org/library/progress-and-poverty $>$.

GERMANI, G. Politica y sociedade en una época de transición: de la sociedad tradicional a la sociedad de masas. Buenos Aires: Editorial Paidos, 1965.

GIAMBIAGI, F. et al. (Ed.). Economia brasileira contemporânea. Rio de Janeiro: Elsevier; Editora Campus, 2005.

GIDDENS, A. A estrutura de classes das sociedades avançadas. Rio de Janeiro: Editora Jorge Zahar, 1975. 
GIDDENS, A. O guru improvável: relendo Marcuse. In: Política, sociologia e teoria social: encontros com o pensamento social clássico e contemporâneo. São Paulo: Editora Unesp, 1997.

GILDER, G. A supply-side economics of the left. Public Interest, v. 72, p. 29-43, 1983.

GILENS, M. Inequality and democratic responsiveness. Public Opinion Quarterly, edição especial, p. 778-796, 2005.

GOBETTI, S. W.; ORAIR, R. O. Progressividade tributária: a agenda negligenciada. Brasília: Instituto de Pesquisa Econômica Aplicada, 2016. (Texto para Discussão, n. 2190).

GOLDIN, C.; KATZ, L. The race between education and technology. Cambridge, Massachusetts; Londres: The Belknap Press, 2008.

GOLDSCHMIDT, W. Social class in America - a critical review. American Anthropologist, v. 52, n. 4, p. 483-498, 1950.

GOLDTHORPE, J. On sociology: numbers, narratives, and the integration of research and theory. Oxford; Nova York: Oxford University Press, 2000.

GOLDTHORPE, J. Rent, class conflict, and class structure: a commentary on Sorensen. American Journal of Sociology, v. 105, n. 6, p. 1572-1582, 2000.

GOLDTHORPE, J. H. et al. The affluent worker and thesis of embourgeoisement: some preliminary research findings. Sociology, v. 1, n. 1, p. 11-31, 1967.

GOMES, A. de C. A invenção do trabalhismo. $3^{a}$ edição. Rio de Janeiro: Editora FGV, 2005 .

GOOS, M.; MANNING, A. Lousy and lovely jobs: the rising polarization of work in Britain. The Review of Economics and Statistics, v. 89, n. 1, p. 118-133, 2007.

GORDON, M. M. Social class in American sociology. American Journal of Sociology, v. 55, n. 3, p. 262-268, 1949.

GOTTSCHALK, P.; SMEEDING, T. Empirical evidence on income inequality in industrialized countries. In: ATKINSON, A. B.; BOURGUIGNON, F. (Ed.). Handbook of income distribution. Amsterdã: Elsevier Science, 2000. v. 1.

GOULDNER, A. W. The coming crisis of Western sociology. Nova York; Londres: Basic Books, Inc, 1970.

GROSS, L. The use of class concepts in sociological research. American Journal of Sociology, v. 54, n. 5, p. 409-421, 1949.

GRUBER, J. Public finance and public policy. $4^{a}$ edição. Nova York: Worth Publishers, 2012 .

GRUSKY, D.; GALESCU, G. Foundations of a neo-Durkheimian class analysis. In: WRIGHT, E. O. (Ed.). Approaches to class analysis. Cambridge, Reino Unido: Cambridge University Press, 2005.

GRUSKY, D.; SORENSEN, J. Can class analysis be salvaged? American Journal of Sociology, v. 103, n. 5, p. 1187-1234, 1998. 
GRUSKY, D.; WEEDEN, K. Decomposition without death: a research agenda for a new class analysis. Acta Sociologica, v. 44, n. 3, p. 203-218, 2001.

GRUSKY, D.; WEEDEN, K. Is market failure behind the takeoff in inequality? In: GRUSKY, D. B.; SZELÉNYI (Ed.). The Inequality Reader: Contemporary and Foundational Readings in Race, Class, and Gender. Boulder, Colorado: Westview Press, 2011.

GRUSKY, D. B. The stories about inequality that we love to tell. In: GRUSKY, D. B.; SZELÉNYI, S. (Ed.). The Inequality Reader: Contemporary and Foundational Readings in Race, Class, and Gender. $2^{a}$ edição. Boulder: Westview Press, 2011. p. 2-14.

HACKER, J.; PIERSON, P. Winner-take-all politics: public policy, political organization, and the precipitous rise o top incomes in the United States. Politics 6 Society, v. 38, n. 152, p. 152-204, 2010.

HADDAD, C. L. da S. Crescimento do produto real brasileiro - 1900/1947. Rio de Janeiro: Fundação Getúlio Vargas - Instituto Brasileiro de Economia, 1974.

HALL, P. A.; SOSKICE, D. (Ed.). Varieties of capitalism: the institutional foundations of comparative advantage. Londres; Nova York: Oxford University Press, 2001.

HATT, P. K. Stratification in the mass society. American Sociological Review, v. 15, n. 2, p. 216-222, 1950.

HAYEK, F. von. The Road to Serfdom. Nova York; Londres: Routledge, 2006.

HERMANN, J. Auge e declínio do modelo de crescimento com endividamento: o II PND e a crise da dívida externa. In: GIAMBIAGI, F. et al. (Ed.). Economia brasileira contemporânea. Rio de Janeiro: Elsevier, Editora Campus, 2005.

HERMANN, J. Reformas, endividamento externo e o "milagre" econômico. In: GIAMBIAGI, F. et al. (Ed.). Economia brasileira contemporânea. Rio de Janeiro: Elsevier, Editora Campus, 2005.

HIRSCHMAN, A. O. Exit, voice, and loyalty: responses to decline in firms, organizations, and states. Cambridge, Massachusetts; Londres: Harvard University Press, 1970.

HIRSCHMAN, A. O. Rival interpretations of market society: civilizing, destructive, or feeble? Journal of Economic Literature, v. 20, n. 4, p. 1463-1484, 1982.

HODGE, R. W.; SIEGEL, P. M.; ROSSI, P. H. Occupational prestige in the United States, 1925-1963. American Journal of Sociology, v. 70, n. 3, p. 286-302, 1964.

HOFFMANN, R. Considerações sobre a evolução recente da distribuição de renda no Brasil. Revista de Administração de Empresas, v. 13, n. 4, p. 7-17, 1973.

HOFFMANN, R. Tendências da distribuição da renda no Brasil e suas relações com o desenvolvimento econômico. In: TOLIPAN, R.; TINELLI, A. C. (Ed.). A controvérsia sobre distribuição de renda e desenvolvimento. Rio de Janeiro: Zahar Editores, 1975.

HOFFMANN, R. A subdeclaração dos rendimentos. Revista São Paulo em Perspectiva, v. 2, n. 1, p. 50-54, 1988. 
HOFFMANN, R. Desigualdade e pobreza no Brasil no período 1979/97 e a influência da inflação e do salário mínimo. Economia e Sociedade, v. 11, p. 199-221, 1998.

HOFFMANN, R. A distribuição da renda no Brasil no período 1992-2001. Economia e Sociedade, v. 11, n. 2, p. 213-235, 2002.

HOFFMANN, R. Efeito potencial do imposto de renda na desigualdade. Pesquisa e Planejamento Econômico, v. 32, n. 1, p. 107-113, 2002.

HOFFMANN, R. Inequality in Brazil: the contribution of pensions. Revista Brasileira de Economia, v. 57, n. 4, p. 755-773, 2003.

HOFFMANN, R. Aposentadorias e pensões e a desigualdade da distribuição da renda no Brasil. Econômica, v. 5, n. 1, p. 135-144, 2004.

HOFFMANN, R. Distribuição da renda no Brasil: mudanças de 2002 para 2003 e a delimitação dos relativamente ricos. Econômica, v. 7, n. 1, p. 77-95, 2005.

HOFFMANN, R. Transferências de renda e redução da desigualdade no Brasil e em cinco regiões entre 1997 e 2005. In: BARROS, R. P. de; FOGUEL, M. N.; ULYSSEA, G. (Ed.). Desigualdade de renda no Brasil: uma análise da queda recente. Brasília: Instituto de Pesquisa Econômica Aplicada, 2006. v. 1.

HOFFMANN, R. Desigualdade da distribuição da renda no Brasil: a contribuição de aposentadorias e pensões e de outras parcelas do rendimento domiciliar per capita. Economia, v. 18, n. 1, p. 213-231, 2009.

HOFFMANN, R. Transferências de renda e desigualdade no Brasil (1995-2011). In: CAMPEllo, T.; NERI, M. (Ed.). Programa Bolsa Família: uma década de inclusão e cidadania. Brasília: Instituto de Pesquisa Econômica Aplicada, 2013.

HOFFMANN, R.; DUARTE, J. C. A distribuição da renda no Brasil. Revista de Administração de Empresas, v. 12, n. 2, p. 46-66, abril/junho 1972.

HOFFMANN, R.; NEY, M. G. A recente queda da desigualdade de renda no Brasil: análise de dados da PNAD, do Censo Demográfico e das Contas Nacionais. Econômica, v. 10, n. 1, p. 7-39, 2008.

HOFFMANN, R.; NEY, M. G. Estrutura fundiária e propriedade agrícola no Brasil: grandes regiões e unidades da federação (de 1970 a 2008). [S.l.]: Ministério do Desenvolvimento Agrário, 2010.

HOLLANDER, J. The abolition of poverty. Boston; Nova York; Chicago: Houghton Mifflin Company, 1914. Disponível em: <https://archive.org/details/abolitionpovert01hollgoog >

HOLMES, G. K. The concentration of wealth. Political Science Quarterly, v. 8, n. 4, p. 589-600, 1893.

HOUT, M.; DIPRETE, T. What we have learned: RC28's contributions to knowledge about social stratification. Research in Social Stratification and Mobility, v. 24, p. 1-20, 2006.

HOWERTH, I. The social question of today. American Journal of Sociology, v. 12, n. 2, p. 254-268, 1906. 
IANNI, O. Industrialização e desenvolvimento social no Brasil. Rio de Janeiro: Civilização Brasileira, 1963.

IBGE. Anuário Estatístico do Brasil. Rio de Janeiro: Instituto Brasileiro de Geografia e Estatística, 1916-. (Anual desde 1945).

IBGE. Censo Demográfico 1940 - População e Habitação. Rio de Janeiro: Instituto Brasileiro de Geografia e Estatística, 1950. (Série Nacional, Volume II).

IBGE. População urbana e população rural. Rio de Janeiro: Instituto Brasileiro de Geografia e Estatística, 1954. (Documentos Censitários, Série D - Número 5).

IBGE. Sistema de Contas Nacionais - Brasil. Rio de Janeiro: Instituto Brasileiro de Geografia e Estatística, 2000. v. 1 e 2. (Contas Nacionais, n. 4, v. 1 e 2).

IBGE (Ed.). Estatísticas do século XX. Rio de Janeiro: Instituto Brasileiro de Geografia e Estatística, 2006. Acesso em 14 abr. 2015. Disponível em: <http://seculoxx.ibge.gov.br/>.

IBGE. Sistema de Contas Nacionais - Brasil. Rio de Janeiro: Instituto Brasileiro de Geografia e Estatística, 2011. (Contas Nacionais, n. 34).

IBGE. Sistema de Contas Nacionais - Brasil. Rio de Janeiro: Instituto Brasileiro de Geografia e Estatística, 2015. (Contas Nacionais, n. 44).

INHABER, H.; CARROLL, S. How rich is too rich? Income and wealth in America. Nova York: Praeger Publishers, 1992.

IPEA. Sobre a recente queda da desigualdade de renda no Brasil. Brasília: Instituto de Pesquisa Econômica Aplicada, 2006. (Nota Técnica).

JALLADE, J.-P. Educação de primeiro grau e desigualdade de renda no Brasil: perspectivas a longo prazo. Pesquisa e Planejamento Econômico, v. 8, n. 3, p. 561-598, 1978.

JENCKS, C. Inequality: a reassessment of the effect of family and schooling in America. Nova York; São Francisco; Londres: Harper Colophon Books, 1972.

JENCKS, C. Does inequality matter? Daedalus, v. 131, n. 1, p. 49-65, 2002.

JOHNSON, H. G. Some micro-economic reflections on income and wealth inequalities. Annals of the American Academy of Political and Social Science, v. 409, p. 53-60, 1973.

JORGENSON, D. W. Did we lose the War on Poverty? Journal of Economic Perspectives, v. 12, n. 1, p. 79-96, 1998.

JUDT, T. Past imperfect: French intellectuals, 1944-1956. Berkeley; Los Angeles: University of California Press, 1992.

JUDT, T. Ill fares the land. Nova York: The Penguin Press, 2010.

KACHKA, B. On tour with rock-star economist Thomas Piketty. Nova York, 2014. NY Magazine. Acesso em 30 jul. 2015. Disponível em: <https://web. archive.org/web/20150730053740/http://nymag.com/daily/intelligencer/2014/04/ on-tour-with-rock-star-economist-thomas-piketty.html $>$. 
KAKWANI, N. Income inequality and poverty: methods of estimation and policy application. Oxford: World Bank, Oxford University Press, 1980.

KANBUR, R.; LUSTIG, N. Why is inequality back on the agenda? In: Proceedings of the Annual World Bank Conference in Development Economics. Washington, D.C.: World Bank, 2000.

KANG, T. Descentralização e financiamento da educação brasileira: uma análise comparativa, 1930-1964. Estudos Econômicos, v. 41, n. 3, p. 573-598, 2011.

KAPLAN, S.; RAUH, J. It's the market: the broad-based rise in the return to top talent. Journal of Economic Perspectives, v. 27, n. 3, p. 35-56, 2013.

KATZ, L.; MURPHY, K. Changes in relative wages, 1963-1987: supply and demand factors. The Quarterly Journal of Economics, v. 107, n. 1, p. 35-78, 1992.

KAVANAGH, D. The postwar consensus. Twentieth Century British History, v. 3, n. 2, p. 175-190, 1992.

KENNICKELL, A. B. Getting to the top: reaching wealthy respondents in the SCF. Proceedings of the Section on Survey Research Methods, American Statistical Association Joint Statistical Meetings, n/a, p. 2055-2069, 2009. Acesso 11 abr. 2016. Disponível em: <http://www.amstat.org/sections/srms/proceedings/y2009f.html>.

KENWORTHY, L. Inequality and sociology. American Behavioral Scientist, v. 50, n. 5, p. 584-602, 2007.

KERR, C. et al. Industrialism and industrial man: the problems of labor and management in economic growth. Nova York: Oxford University Press, 1964.

KEYNES, J. M. A Teoria Geral do Emprego, do Juro e da Moeda. São Paulo: Editora Nova Cultural, 1996. (Coleção Os Economistas).

KING, W. I. The wealth and income of the people of the United States. Londres: The MacMillan Company, 1922. Acesso em 20 fev. 2014. Disponível em: < https: //archive.org/details/wealthandincome00kinggoog $>$.

KINGSTON, J. A lei de distribuição das rendas. Revista Brasileira de Economia, v. 6, n. 1, p. 9-26, 1952.

KINGSTON, J.; KINGSTON, L. S. A distribuição da renda no Brasil, 1960-1970. Revista Brasileira de Economia, v. 26, n. 4, p. 241-256, 1972.

KNOBL, W. Theories that won't pass away: the never-ending story of modernization theory. In: DELANTY, G.; ISIN, E. (Ed.). Handbook of Historical Sociology. Londres: Sage Publications, 2003.

KOLASKY, W. Theodore Roosevelt and William Howard Taft: Marching toward armageddon. Antitrust, v. 25, n. 2, p. 97-104, 2011.

KRAVIS, I. B. International differences in the distribution of income. The Review of Economics and Statistics, v. 42, n. 4, p. 408-416, 1960. 
KRIPPNER, G. The political economy of financial exuberance. In: LOUNSBURY, M.; HIRSCH, P. (Ed.). Markets on trial: the economic sociology of the U.S. financial crisis. [S.1.]: Emerald, 2010, (Research in the sociology of organizations, v. 30).

KRISTOL, I. "When virtue loses all ther loveliness" - some reflection on capitalism and "the free society". Public, v. 21, p. 3-15, 1970.

KRISTOL, I. The best of intentions, the worst of results. The Atlantic Monthly, Agosto, p. n/a, 1971. Acesso 26 ago. 2015. Disponível em: <https://web.archive.org/web/ 20150830014614/http://www.theatlantic.com/past/docs/unbound/flashbks/welfare/ kristolf.htm>.

KRISTOL, I. About equality. Commentary, v. 54, p. 41-47, 1972.

KRISTOL, I. Taxes, poverty, and equality. Public Interest, v. 37, p. 3-28, 1974.

KRISTOL, I. Some personal reflections on economic well-being and income distribution. In: FELDSTEIN, M. (Ed.). The American economy in transition. Chicago; Londres: The University of Chicago Press, 1980.

KRUEGER, A. B. Inequality, too much of a good thing. In: GRUSKY, D. B. (Ed.). Social stratification: class, race and gender in sociological perspective. $3^{a}$ edição. Boulder: Westview Press, 2008.

KUZNETS, S. Shares of Upper Income Groups in Income and Savings. Nova York: National Bureau of Economic Research, 1953.

KUZNETS, S. Economic growth and income inequality. The American Economic Review, v. 45, n. 1, p. 1-28, 1955.

LAGO, L. A. C. do. A retomada do crescimento e as distorções do "milagre": 1967-1973. In: ABREU, M. de P. (Ed.). A ordem do progresso: cem anos de política econômica republicana, 1889-1989. Rio de Janeiro: Editora Campus, 1990.

LAIDLER, D. Chicago monetary traditions. In: EMMETT, R. B. (Ed.). The Elgar Companion to the Chicago School of Economics. Cheltenham; Northampton: Edward Elgar, 2010.

LAM, D.; LEVISON, D. Idade, experiência, escolaridade e diferenciais de renda: Estados Unidos e Brasil. Pesquisa e Planejamento Econômico, v. 20, n. 2, p. 219-256, 1990.

LAM, D.; LEVISON, D. Declining inequality in schooling in Brazil and its effects on inequality in earnings. Journal of Development Economics, v. 37, p. 199-225, 1992.

LAMPMAN, R. J. Recent changes in income inequality reconsidered. The American Economic Review, v. 44, n. 3, p. 251-268, 1954.

LAMPMAN, R. J. Changes in the share of wealth held by top wealth-holders, 1922-1956. The Review of Economics and Statistics, v. 41, n. 4, p. 379-392, 1959.

LANE, D. The end of inequality? Stratification under state socialism. Hammondsworth: Penguin Books, 1971.

LANGONI, C. G. Distribuição de renda e desenvolvimento econômico do Brasil. Rio de Janeiro: Editora Expressão e Cultura, 1973. 
LANGONI, C. G. Distribuição da renda: uma versão para a minoria. Pesquisa e Planejamento Econômico, v. 4, n. 1, p. 167-180, 1974.

LAZZARINI, S. Capitalismo de laços: os donos do Brasil e suas conexões. Rio de Janeiro: Elsevier; Editora Campus, 2011.

LEBERGOTT, S. Wealth and want. Princeton: Princeton University Press, 1975.

LEIGH, A.; VAN DER ENG, P. Inequality in Indonesia: what can we learn from top incomes? Journal of Public Economics, v. 93, p. 209-212, 2009.

LEMIEUX, T. The changing nature of wage inequality. Journal of Population Economics, v. 21, n. 1 , p. $21-48,2008$.

LEMIEUX, T.; MACLEOD, W. B.; PARENT, D. Performance pay and wage inequality. The Quarterly Journal of Economics, v. 124, n. 1, p. 1-49, 2009.

LERNER, A. P. The economics and politics of consumer sovereignty. The American Economic Review, v. 62, n. 1/2, p. 258-266, 1972.

LEUCHTENBURG, W. E. When Franklin Roosevelt clashed with the Supreme Court - and lost. Smithsonian Magazine, v. 36, n. 2, p. 106-113, Maio 2005. Acesso 16 jul. 2015. Disponível em: <http://www.smithsonianmag.com/history/ when-franklin-roosevelt-clashed-with-the-supreme-court-and-lost-78497994/>.

LEVINE, A. A future for Marxism? In: GAUS, G.; KUKATHAS, C. (Ed.). Handbook of Political Theory. Londres; Nova York: Sage, 2004.

LEVY, F.; MURNANE, R. U.S. earnings levels and earnings inequality: a review of recent trends and proposed explanations. Journal of Economic Literature, v. 30, n. 3, p. 1333-1381, 1992.

LEVY, F.; TEMLIN, P. Inequality and institutions in $20^{\text {th }}$ century America. Cambridge, Massachusetts: MIT Industrial Performance Center, 2007. (Working Paper Series MIT-IPC-07-002).

LILLA, M. Why the "income distribution" is so misleading. Public Interest, v. 77, p. 62-76, 1984.

LIN, K.-H.; TOMASKOVIC-DEVEY, D. Financialization and U.S. income inequality, 1970-2008. American Journal of Sociology, v. 118, n. 5, p. 1284-1329, 2013.

LINDERT, P. H. Who owned Victorian England? The debate over landed wealth and inequality. Agricultural History, v. 61, n. 4, p. 25-51, 1987.

LIPSET, S. M. Some social requisites of democracy: economic development and political legitimacy. The American Political Science Review, v. 53, n. 1, p. 69-105, 1959.

LIPSET, S. M. The changing class structure and contemporary European politics. Daedalus, v. 93, n. 1, p. 271-303, 1964.

LIPSET, S. M.; BENDIX, R. Social status and social structure: a re-examination of data and interpretations, i. The British Journal of Sociology, v. 2, n. 2, p. 150-168, 1951. 
LIPSET, S. M.; BENDIX, R. Social status and social structure: a re-examination of data and interpretations, ii. The British Journal of Sociology, v. 2, n. 3, p. 230-254, 1951.

LIPSET, S. M.; SCHNEIDER, W. The decline of confidence in American institutions. Political Science Quarterly, v. 98, n. 3, p. 379-402, 1983.

LLUCH, C. Pobreza e concentração de renda no Brasil. Pesquisa e Planejamento Econômico, v. 11, n. 3, p. 757-782, 1981.

LOPES, J. S. L. O debate da distribuição da renda: leitura crítuca de um artigo de Fishlow. Revista de Administração de Empresas, v. 13, n. 3, p. 47-61, 1973.

LOPEZ-CALVA, L. F.; LUSTIG, N. Explaining the decline in inequality in Latin America: technological change, educational upgrading, and democracy. In: LOPEZ-CALVA, L. F.; LUSTIG, N. (Ed.). Declining inequality in Latin America: a decade of progress? Washington, D.C.; Nova York: United Nations Development Programme, Brookings Institution Press, 2010.

LOWY, M. The Romantic and the Marxist critique of modern civilization. Theory and Society, v. 16, p. 891-904, 1987.

LUCAS, R. The industrial revolution: past and future, 2003 Annual Report Essay. The Region, Maio, p. n/a, 2004. Acesso 20 out. 2015. Disponível em: <https://web.archive.org/web/20151031203631/https://www.minneapolisfed.org/ publications/the-region/the-industrial-revolution-past-and-future $>$.

MACLEAN, A. M. The plight of the rich man in a democracy. American Journal of Sociology, v. 21, n. 3, p. 339-344, 1915.

MALAN, P. Ainda sobre a distribuição da renda. Revista de Administração de Empresas, v. 14, n. 2, p. 116-123, 1974.

MALAN, P.; WELLS, J. Resenha bibliográfica: Distribuição da renda e desenvolvimento econômico. Pesquisa e Planejamento Econômico, v. 3, n. 4, p. 1103-1124, 1973.

MALLOCK, W. H. The distribution of incomes. The North American Review, v. 203, n. 727, p. 841-851, 1916.

MALOUTAS, T. Socio-economic classification models and contextual difference: the "European Socio-economic Classes" (ESeC) from a South European angle. South European Society and Politics, v. 12, n. 4, p. 443-460, 2007.

MANKIW, N. G. Defending the one percent. Journal of Economic Perspectives, v. 27, n. 3, p. 21-34, 2013.

MARANHÃO, R. O Estado e a Política "Populista" no Brasil (1954-1964). In: FAUSTO, B. (Ed.). O Brasil Republicano - Sociedade e Política (1930-1964). São Paulo: Difel, 1981, (História Geral da Civilização Brasileira, Tomo III, $3^{\circ}$ Volume).

MARQUES, E. Condições habitacionais e urbanas no Brasil. In: ARRETCHE, M. (Ed.). Trajetórias das desigualdades: como o Brasil mudou nos últimos cinquenta anos. São Paulo: Editora Unesp; CEM, 2016.

MARQUES, M. S. B. O Plano Cruzado: teoria e prática. Revista de Economia Política, v. 8, n. 3, p. 101-130, 1988. 
MARSHALL, G. et al. Social class in modern Britain. Londres: Routledge, 2005.

MARSHALL, T. H. Changes in social stratification in the twentieth century. In: Class, citizenship, and social development. Westport: Greenwood Press, 1964.

MARSHALL, T. H. Citizenship and social class. In: Class, citizenship, and social development. Westport, Connecticut: Greenwood Press, 1964.

MARTIN, J. Socialism and the class war. The Quarterly Journal of Economics, v. 23, n. 3 , p. 512-527, 1909.

MARX, K. Critique of the Gotha Programme - marginal notes on the programme of the German Workers' Party. In: CARVER, T. (Ed.). Marx - Later political writings. Cambridge, Reino Unido: Cambridge University Press, 1996, (Cambridge Texts in the History of Political Thought).

MEDEIROS, M. O que faz os ricos ricos: o outro lado da desigualdade brasileira. São Paulo: Editora Hucitec, Anpocs, 2005.

MEDEIROS, M. The rich and the poor: the construction of an affluence line from the poverty line. Social Indicators Research, v. 78, n. 1, p. 1-18, 2006.

MEDEIROS, M. Meio século de desigualdades no Brasil. Revista Brasileira de Ciências Sociais, v. 31, n. 90, p. 175-177, 2016.

MEDEIROS, M.; SOUZA, P. H. G. F. Estado e desigualdade de renda no Brasil: fluxos de rendimentos e estratificação social. Revista Brasileira de Ciências Sociais, v. 28, n. 83, p. 141-150, 2013.

MEDEIROS, M.; SOUZA, P. H. G. F. Previdências dos trabalhadores dos setores público e privado e desigualdade no Brasil. Economia Aplicada, v. 18, n. 4, p. 603-623, 2014.

MEDEIROS, M.; SOUZA, P. H. G. F. State transfers, taxes and income inequality in Brazil. Brazilian Political Science Review, v. 9, n. 2, p. 3-29, 2015.

MEDEIROS, M.; SOUZA, P. H. G. F.; CASTRO, F. A. de. O topo da distribuição de renda no Brasil: primeiras estimativas com dados tributários e comparação com pesquisas domiciliares (2006-2012). Dados - Revista de Ciências Sociais, v. 58, n. 1, p. 7-36, 2015.

MEDEIROS, M.; SOUZA, P. H. G. F.; CASTRO, F. A. de. The stability of income inequality in Brazil, 2006-2012: an estimate using income tax data and household surveys. Ciência \&s Saúde Coletiva, v. 20, n. 4, p. 971-986, 2015.

MÉDICI, A. Notas interpretativas sobre a variável "renda" nos Censos Demográficos brasileiros. Revista Brasileira de Estatística, v. 47, n. 187, p. 305-348, 1986.

MÉDICI, A. A mensuração da subjetividade: notas sobre a variável renda nas PNADs. In: SAWYER, D. (Ed.). PNADs em foco: anos 80. Belo Horizonte: Abep, 1988.

MENDES, M. Inequality, democracy, and growth in Brazil: a country at the crossroads of economic development. Amsterdã; Boston; Londres: Elsevier; Academic Press, 2015.

MENEZES-FILHO, N.; FERNANDES, R.; PICHETTI, P. Educação e queda recente da desigualdade no Brasil. In: BARROS, R. P. de; FOGUEL, M. N.; ULYSSEA, G. (Ed.). Desigualdade de renda no Brasil: uma análise da queda recente. Brasília: Instituto de Pesquisa Econômica Aplicada, 2007. v. 2. 
MENEZES-FILHO, N.; KIRSCHBAUM, C. Educação e desigualdade no Brasil. In: ARRETCHE, M. (Ed.). Trajetórias das desigualdades: como o Brasil mudou nos últimos cinquenta anos. São Paulo: Editora Unesp; CEM, 2016.

MERTON, R. K. The position of sociological theory - discussion. American Sociological Review, v. 13, n. 2, p. 164-168, 1948.

MICHEL, J.-B. et al. Quantitative analysis of culture using millions of digitized books. Science, v. 331, p. 176-182, 2011.

MICHELS, R. Political parties: a sociological study of the oligarchical tendencies of modern democracy. Glencoe: The Free Press, 1949.

MILÁ, M. M. Income concentration in a context of late development: an investigation of top incomes in Brazil using tax records, 1933-2013. Dissertação (Mestrado em Public Policy and Development) - Paris School of Economics, Paris, 2015.

MILANOVIC, B. The median-voter hypothesis, income inequality, and income redistribution: an empirical test with the required data. European Journal of Political Economy, v. 16, p. 367-410, 2000.

MILANOVIC, B. Why we all care about inequality (but are loath to admit it). Challenge, v. 50, n. 6, p. 109-120, 2007.

MILANOVIC, B. The return of "patrimonial capitalism": a review of Thomas Piketty's Capital in the Twenty-First Century. Journal of Economic Literature, v. 52, n. 2, p. 519-534, 2014.

MILANOVIC, B. Global inequality of opportunity: how much of our income is determined by where we live? Review of Economics and Statistics, v. 97, n. 2, p. 452-460, 2015.

MILLS, C. W. The power elite. Nova York: Oxford University Press, 1959.

MINCER, J. Schooling, experience, and earnings. Nova York: National Bureau of Economic Research, 1974.

MINNESOTA POPULATION CENTER. Integrated Public Use Microdata Series, International: version 6.4. Minneapolis, 2015. Acesso em 2 mai. 2016. Disponível em: $<$ https://international.ipums.org/international/index.shtml>.

MISHEL, L. et al. The State of Working America. $12^{a}$ edição. Ithaca: Economic Policy Institute, Cornell University Press, 2012.

MISHEL, L.; SHIERHOLZ, H.; SCHMITT, J. Don't blame the robots: assessing the job polarization explanation of growing wage inequality. Washington, D.C.: Economic Policy Institute, 2013. (EPI Working Paper).

MITZENMACHER, M. A brief history of generative models of power law and lognormal distributions. Internet Mathematics, v. 1, n. 2, p. 226-251, 2004.

MODIANO, E. A ópera dos três Cruzados: 1985-1989. In: ABREU, M. de P. (Ed.). A ordem do progresso: cem anos de política econômica republicana, 1889-1989. Rio de Janeiro: Editora Campus, 1990. 
MONASTERIO, L.; EHRL, P. Colônias de povoamento versus colônias de exploração: de Heeren a Acemoglu. Brasília: Instituto de Pesquisa Econômica Aplicada, 2015. (Texto para Discussão, n. 2119).

MOORE, G. Secular changes in the distribution of income. The American Economic Review, v. 42, n. 2, p. 527-544, 1952.

MOORE, W. But some are more equal than others. American Sociological Review, v. 28, n. 1, p. 13-18, 1963.

MORGAN, K.; PRASAD, M. The origins of tax systems: a French-American comparison. American Journal of Sociology, v. 114, n. 5, p. 1350-1394, 2009.

MORIGUCHI, C.; SAEZ, E. The evolution of income concentration in Japan, 1886-2005: evidence from income tax statistics. The Review of Economics and Statistics, v. 90, n. 4, p. $713-734,2008$.

MORRIS, M.; WESTERN, B. Inequality in earnings at the close of the twentieth-century. Annual Review of Sociology, v. 25, p. 623-657, 1999.

MORTARA, G. Dados e observações sôbre a distribuição das rendas das pessoas físicas contribuintes do impôsto de renda no Brasil. Revista Brasileira de Estatística, v. 10, n. 38, p. 197-222, 1949.

MORTARA, G. Representação analítica das distribuições dos contribuintes e das respectivas rendas líquidas determinadas para a aplicação do impôsto de renda, em função do valor da renda líquida. Revista Brasileira de Economia, v. 3, n. 2, p. 7-34, 1949.

MOSCA, G. The Ruling Class. Nova York; Londres: McGraw-Hill Book Company, 1939. Acesso 17 jul. 2015. Disponível em: < https://archive.org/details/rulingclass031748mbp>.

MUNSTERBERG, E. The problem of poverty. American Journal of Sociology, v. 10, n. 3, p. 335-353, 1904.

MURRAY, C. Coming apart: the state of white America, 1960-2010. Nova York: Crown Forum, 2012.

MYLES, J. Where have all the sociologists gone? Explaining economic inequality. The Canadian Journal of Sociology, v. 28, n. 4, p. 551-559, 2003.

NEARING, S. The why of income. American Journal of Sociology, v. 20, n. 6, p. 745-763, 1915 .

NERI, M. Sobre a mensuração dos salários reais em alta inflação. Pesquisa e Planejamento Econômico, v. 25, n. 3, p. 497-526, 1995.

NERI, M. Miséria em queda: mensuração, monitoramento e metas. Rio de Janeiro: Centro de Políticas Sociais, Fundação Getúlio Vargas, 2005. Acesso 28 out. 2015. Disponível em: <https://web.archive.org/web/20151028185927/http://www.cps.fgv.br/ibrecps/queda da_miseria/CPSdaFGV_IBRE_Mis\%C3\%A9riaEmQuedaFim2.pdf $>$.

NERI, M. Miséria, desigualdade e políticas de rendas: o Real do Lula. Rio de Janeiro: Centro de Políticas Sociais, Fundação Getúlio Vargas, 2007. 
NERI, M. A nova classe média. Rio de Janeiro: Centro de Políticas Sociais, Fundação Getúlio Vargas, 2008.

NEUMANN, G.; PEDERSEN, P. J.; WESTERGARD-NIELSEN, N. Long-run international trends in aggregate unionization. European Journal of Political Economy, v. 7, p. 249-274, 1991.

NICOLAU, J. Eleições no Brasil: do Império aos dias atuais. Rio de Janeiro: Zahar, 2012.

NISBET, R. The decline and fall of social class. The Pacific Sociological Review, v. 2, p. $11-17,1959$.

NISBET, R. The twilight of authority. Public Interest, v. 15, p. 3-9, 1969.

NISBET, R. The pursuit of equality. Public Interest, v. 35, p. 103-102, 1974.

NISKANEN, W. Why our democracy doesn’t work. Public Interest, v. 116, p. 88-95, 1994.

NÓBREGA, C. B. da. História do Imposto de renda no Brasil, um enfoque da pessoa física (1922-2013). Brasília: Receita Federal, 2014.

O CÊRCO sem violência: até onde vai a mão invisível do Fisco? Revista Veja, v. 76, p. 31-40, 18 de Fevereiro 1970.

O SALDO do ministro Delfim. Revista Veja, v. 70, p. 42-51, 7 de Janeiro 1970.

OCAMPO, J. A. Latin America's growth and equity frustrations during structural reforms. Journal of Economic Perspectives, v. 18, n. 2, p. 67-88, 2004.

OKUN, A. Equality and efficiency: the big tradeoff. Washington, D.C.: Brookings Institution Press, 2015.

OLIVEIRA, C. P. R. Política salarial e negociação coletiva. Indicador, v. 4, n. 17, p. 231-238, 1986.

ORENSTEIN, L.; SOCHACZEWSKI, A. C. Democracia com desenvolvimento: 1956-1961. In: ABREU, M. de P. (Ed.). A ordem do progresso: cem anos de política econômica republicana, 1889-1989. Rio de Janeiro: Editora Campus, 1990.

OSBORNE, T.; ROSE, N. Do the social sciences create phenomena? The example of public opinion research. British Journal of Sociology, v. 50, n. 3, p. 367-396, 1999.

OSORIO, R. G.; SOARES, S. S. D.; SOUZA, P. H. G. F. Desenvolvimento, modernização e condições de vida. In: CASTRO, J. A. ao de et al. (Ed.). Perspectivas da política social no Brasil. Brasília: Instituto de Pesquisa Econômica Aplicada, 2010.

OSTRY, J.; BERG, A.; TSANGARIDES, C. Redistribution, inequality, and growth. Washington, D.C.: International Monetary Fund, 2014. (IMF Staff Discussion Note).

PAKULSKI, J. Foundations of a post-class analysis. In: WRIGHT, E. O. (Ed.). Approaches to class analysis. Cambridge, Reino Unido: Cambridge University Press, 2005.

PALMA, J. G. Homogeneous middles vs. heterogeneous tails, and the end of the 'inverted-u': it's all about the share of the rich. Development and Change, v. 42, n. 1, p. 87-153, 2011. 
PAOLI, M. C. Trabalhadores e cidadania: experiência do mundo público na história do Brasil moderno. Estudos Avançados, v. 3, n. 7, p. 40-66, 1989.

PARCQ, H. du (Ed.). Life of David Lloyd George. Londres: Caxton Publishing Company, 1912. Acesso 18 jun. 2015. Disponível em: <http://archive.org/details/ lifeofdavidlloyd04dupauoft $>$.

PARETO, V. The rise and fall of elites: an application of theoretical sociology. Londres: Transaction Publishers, 2000.

PARKIN, F. Marxism and class theory: a bourgeois critique. Nova York: Columbia University Press, 1979.

PARSONS, T. Sociological elements in economic thought. The Quarterly Journal of Economics, v. 49, n. 3, p. 414-453, 1935.

PARSONS, T. Sociological elements in economic thought II: the analytical factor view. The Quarterly Journal of Economics, v. 49, n. 4, p. 646-667, 1935.

PARSONS, T. An analytical approach to the theory of social stratification. American Journal of Sociology, v. 45, n. 6, p. 841-862, 1940.

PARSONS, T. The motivation of economic activities. The Canadian Journal of Economics and Political Science, v. 6, n. 2, p. 187-202, 1940.

PARSONS, T. The position of sociological theory. American Sociological Review, v. 13, n. 2, p. 156-164, 1948.

PARSONS, T. The rise and fall of economic man. The Journal of General Education, v. 4, n. 1, p. 47-53, 1949.

PARSONS, T. Social classes and class conflict in the light of recent sociological theory. The American Economic Review, v. 39, n. 3, p. 16-26, 1949.

PARSONS, T. The structure of social action: a study in social theory with special reference to a group of recent European writers. Glencoe: The Free Press, 1949. Acesso 14 jul. 2015. Disponível em: <https://archive.org/details/structureofsocia00pars>.

PARSONS, T. A revised analytical approach to the theory of social stratification. In: Essays in sociological theory. Glencoe, Illinois: The Free Press, 1954.

PARSONS, T. Review: The distribution of power in American society. World Politics, v. 10, n. 1, p. 123-143, 1957.

PARSONS, T. Societies: evolutionary and comparative perspectives. Englewood Cliffs: Prentice-Hall, Inc, 1966.

PARSONS, T. Equality and inequality in modern society, or social stratification revisited. Sociological Inquiry, v. 40, n. 2, p. 13-72, 1970.

PARSONS, T. The system of modern societies. Englewood Cliffs: Prentice-Hall, Inc, 1971.

PARSONS, T. The social system. Londres: Routledge, 1991.

PECHMAN, J.; MAZURE, M. The rich, the poor, and the taxes they pay: an update. Public Interest, v. 77, p. 28-36, 1984. 
PEICHL, A.; SCHAEFER, T.; SCHEICHER, C. Measuring richness and poverty: a micro data application to Europe and Germany. Review of Income and Wealth, v. 56, n. 3, p. 597-619, 2010.

PERSKY, J. Retrospectives: Pareto's Law. Journal of Economic Perspectives, v. 6, n. 2, p. 181-192, 1992.

PIETERSE, J. N. Jan Nederveen Pieterse. Londres, Los Angeles: Sage Publications, 2010.

PIKETTY, T. Les hauts revenus en France au XX $X^{e}$ siècle. Paris: Bernard Grasset, 2001.

PIKETTY, T. Income inequality in France, 1901-1998. Journal of Political Economy, v. 111, n. 5, p. 1004-1042, 2003.

PIKETTY, T. L'économie des inégalités. Paris: La Decouverte, 2004.

PIKETTY, T. Capital in the Twenty-First Century. Cambridge, Massachusetts: Harvard University Press, 2014.

PIKETTY, T. Capital in the Twenty-First Century: a multidimensional approach to the history of capital and social classes. British Journal of Sociology, v. 65, n. 4, p. 736-747, 2014.

PIKETTY, T. Putting distribution back at the center of economics: reflections on Capital in the Twenty-First Century. Journal of Economic Perspectives, v. 29, n. 1, p. 67-88, 2015.

PIKETTY, T.; SAEZ, E. Income inequality in the United States, 1913-1998. The Quarterly Journal of Economics, v. 118, n. 1, p. 1-39, 2003.

PIKETTY, T.; SAEZ, E. The evolution of top incomes: A historical and international perspective. The American Economic Review, v. 96, n. 2, p. 200-205, 2006.

PIKETTY, T.; SAEZ, E. Optimal labor income taxation. In: AUERBACH, A. J. et al. (Ed.). Handbook in Public Economics. Nova York: Elsevier, 2013. v. 5, p. 392-474.

PIKETY, T.; SAEZ, E.; STANTCHEVA, S. Optimal taxation of top labor incomes: a tale of three elasticities. American Economic Journal: Economic Policy, v. 6, n. 1, p. 1-44, 2014.

PINHO NETO, D. M. de. O interregno Café Filho: 1954-1955. In: ABREU, M. de P. (Ed.). A ordem do progresso: cem anos de política econômica republicana, 1889-1989. Rio de Janeiro: Editora Campus, 1990.

PINTO, L. de A. C. Sociologia e desenvolvimento: temas e problemas de nosso tempo. $2^{a}$ edição. Rio de Janeiro: Editora Civilização Brasileira, 1965.

PLATT, C. Class consciousness. American Journal of Sociology, v. 30, n. 5, p. 558-568, 1925.

POLANYI, K. Our obsolete market mentality. Commentary, v. 3, p. 109-117, 1947.

PRADOS DE LA ESCOSURA, L. Inequality and poverty in Latin America: a long-run exploration. In: HUTTON, T. J.; O'ROUKE, K. H.; TAYLOR, A. (Ed.). The New Comparative Economic History: Essays in Honor of Jeffrey G. Wiliamson. Cambridge, Massachusetts: MIT Press, 2007. 
PREBISCH, R. O desenvolvimento econômico da América Latina e seus principais problemas. Revista Brasileira de Economia, v. 3, n. 3, p. 47-111, 1949.

PROCOPOVITCH, S. N. The distribution of national income. The Economic Journal, v. 36, n. 141, p. 69-82, 1926.

RANGEL, L. A. Aspectos distributivos do Regime de Previdência dos Servidores Públicos. Brasília: Instituto de Pesquisa Econômica Aplicada, 2011. (Texto para Discussão n. 1617).

RAWLS, J. A theory of justice, revised edition. Cambridge, Massachusetts: The Belknap Press, 1999.

REIS, J. G. A.; BARROS, R. P. de. Desigualdade salarial e distribuição de educação: a evolução das diferenças regionais no Brasil. Pesquisa e Planejamento Econômico, v. 20, n. 3, p. 415-478, 1990.

RESENDE, A. L. A política brasileira de estabilização: 1963-1968. Pesquisa e Planejamento Econômico, v. 12, n. 3, p. 757-806, 1982.

RIBEIRO, M. B. Uma análise da Carga Tributária Bruta e das transferências de assistência e previdência no Brasil no período 1995-2009: evolução, composição e suas relações com a regressividade e a distribuição de renda. In: CASTRO, J. A. de; SANTOS, C. H. M. dos; RIBEIRO, J. A. C. (Ed.). Tributação e equidade no Brasil: um registro da reflexão do Ipea no biênio 2008-2009. Brasília: Instituto de Pesquisa Econômica Aplicada, 2010.

ROBBINS, L. An essay on the nature and significance of economic science. Londres: MacMillan and Company, 1932.

ROCHA, S. A investigação da renda nas pesquisas domiciliares. Economia e Sociedade, v. 12, n. 2, p. 205-224, 2003.

RODRIGUES, F. Políticos do Brasil. São Paulo: PubliFolha, 2006.

RODRIGUES, J. A. Sindicato e desenvolvimento no Brasil. São Paulo: Difusão Européia do Livro, 1968.

RODRIGUES, L. M. Sindicalismo e classe operária (1930-1964). In: FAUSTO, B. (Ed.). O Brasil Republicano - Sociedade e Política (1930-1964). São Paulo: Difel, 1981, (História Geral da Civilização Brasileira, Tomo III, $3^{\circ}$ Volume).

ROGNLIE, M. Deciphering the fall and rise in the net capital share. In: INSTITUTION, T. B. (Ed.). Brookings Papers on Economic Activity Conference. Washington, D.C.: [s.n.], 2015.

ROINE, J.; VLACHOS, J.; WALDENSTROM, D. The long-run determinants of inequality: what can we learn from top income data? Journal of Public Economics, v. 93, p. $974-988,2009$.

ROMER, C.; ROMER, D. Monetary policy and the well-being of the poor. Economic Review, n. Q1, p. 21-49, 1999.

ROSE, D.; HARRISON, E. The European Socio-economic Classification: a new social class schema for comparative European research. European Societies, v. 9, n. 3, p. 459-490, 2007 . 
ROSEN, S. The economics of superstars. The American Economic Review, v. 71, n. 5, p. 845-858, 1981.

ROSEN, S. Authority, control, and the distribution of earnings. The Bell Journal of Economics, v. 13, n. 2, p. 311-323, 1982.

ROSENFELD, E. Social stratification in a "classless" society. American Sociological Review, v. 16, n. 6, p. 766-774, 1951.

ROSSI, P. H. The iron law of evaluation and other metallic rules. Research in Social Problems and Public Policy, v. 4, p. 3-20, 1987.

ROSTOW, W. W. The take-off into self-sustained growth. The Economic Journal, v. 66, n. 261 , p. 25-48, 1956.

RUNCIMAN, W. G. Relative deprivation and social justice: a study of attitudes to social inequality in twentieth-century England. Middlesex: Pelican Books, 1972.

RYAN, J. A. Distributive justice: the right and wrong of our present distribution of wealth. Nova York: The MacMillan Company, 1919.

RYTGAARD, M. Estimation in the Pareto distribution. Astin Bulletin, v. 20, p. 201-216, 1990.

SABINE, B. E. V. A History of Income Tax: the development of income tax from its beginning in 1799 to the present day related to the social, economic and political history of the period. $2^{a}$ edição. Londres: Routledge, 2006.

SAEZ, E.; VEALL, M. The evolution of high incomes in Northern America: lessons from Canadian evidence. The American Economic Review, v. 95, n. 3, p. 831-849, 2005.

SALM, C. Sobre a recente queda da desigualdade de renda no Brasil: uma leitura crítica. In: BARROS, R. P. de; FOGUEL, M. N.; ULYSSEA, G. (Ed.). Desigualdade de renda no Brasil: uma análise da queda recente. Brasília: Instituto de Pesquisa Econômica Aplicada, 2006.

SANTANA, M. A. O "novo" e o "velho" sindicalismo: análise de um debate. Revista de Sociologia e Política, v. 10-11, p. 19-35, 1998.

SANTOS, C. H. Políticas federais de habitação no Brasil: 1964/1998. Brasília: Instituto de Pesquisa Econômica Aplicada, 1999.

SANTOS, J. A. F. Classe social e deslocamentos de renda no Brasil. Dados - Revista de Ciências Sociais, v. 58, n. 1, p. 79-110, 2015.

SANTOS, J. A. F. Mudanças de renda no Brasil: fatores espaciais, setoriais, educacionais e de status social. Revista Sociedade e Estado, v. 30, n. 3, p. 749-772, 2015.

SANTOS, T. dos. O movimento operário no Brasil. Revista Brasiliense, v. 39, p. 100-118, 1962.

SANTOS, W. G. dos. Cidadania e justiça - A política social na ordem brasileira. Rio de Janeiro: Editora Campus, 1979. 
SAVAGE, M. Class and stratification: current problems and revival prospects. In: CALHOUN, C.; ROJEK, C.; TURNER, B. (Ed.). The SAGE Handbook of Sociology. Londres; Thousand Oaks: SAGE Publications, 2005.

SAVAGE, M. Against epochalism: an analysis of conceptions of change in British Sociology. Cultural Sociology, v. 3, n. 2, p. 217-238, 2009.

SAVAGE, M.; BURROWS, R. The coming crisis of empirical sociology. Sociology, v. 41, n. 5, p. 885-899, 2007.

SCHLIESSER, E. Friedman, positive economics, and the Chicago Boys. In: EMMETT, R. B. (Ed.). The Elgar Companion to the Chicago School of Economics. Cheltenham; Northampton: Edward Elgar, 2010.

SCHMITT, R. Partidos políticos no Brasil (1945-2000). Rio de Janeiro: Jorge Zahar Editor, 2000.

SCHMOLLER, G. F. Class conflicts in general. American Journal of Sociology, v. 20, n. 4, p. 504-531, 1915.

SCHUMPETER, J. Social classes in an ethnically homogeneous environment. In: Imperialism and social classes. Cleveland; Nova York: Meridian Books, 1966.

SCHWARTZ, R. Functional alternatives to inequality. American Sociological Review, v. 20, n. 4, p. 424-430, 1955.

SEIDMAN, G. Is South Africa different? Sociological comparisons and theoretical contributions from the land of Apartheid. Annual Review of Sociology, v. 25, p. 419-440, 1999.

SELTZER, I. Thatcher's vision. Public Interest, v. 111, p. 116-121, 1993.

SEN, A. Inequality Reexamined. Nova York: Oxford University Press, 1992.

SHIRRAS, G. F. The Pareto Law and the distribution of income. The Economic Journal, v. 45, n. 180, p. 663-681, 1935.

SHLEIFER, A. The Age of Milton Friedman. Journal of Economic Literature, v. 47, n. 1, p. 123-135, 2009.

SILVA, J. P. M. da. Os efeitos da fiscalização tributária no desempenho do Imposto de Renda da Pessoa Física, 1996-2002. Dissertação (Mestrado em Economia do Setor Público) — Universidade de Brasília, Brasília, 2003.

SILVA, N. do V.; BARBOSA, M. L. de O. População e estatísticas vitais. In: IBGE (Ed.). Estatísticas do século $X X$. Rio de Janeiro: Instituto Brasileiro de Geografia e Estatística, 2006. Acesso em 14 abr. 2015. Disponível em: <http://seculoxx.ibge.gov.br/>.

SILVEIRA, F. G. Tributação, Previdência e Assistência Sociais: impactos distributivos. Tese (Doutorado em Economia) - Instituto de Economia, Universidade de Campinas, Campinas, 2008.

SIMÃO, A. Sindicato e Estado. São Paulo: Editora Ática, 1981.

SIMONSEN, M. H. Brasil 2002. Rio de Janeiro: Apec; Edições Bloch, 1972. 
SIMPSON, G. Class analysis: what class is not. American Sociological Review, v. 4, n. 6 , p. 827-835, 1939.

SIMPSON, R. A modification of the functional theory of social stratification. Social Forces, v. 35, n. 2, p. 132-137, 1956.

SINGER, A. Os sentidos do Lulismo: reforma gradual e pacto conservador. São Paulo: Companhia das Letras, 2012.

SMELKER, M. W. Shifts in the concentration of income. The Review of Economics and Statistics, v. 30, n. 3, p. 215-222, 1948.

SMITH, R. E. Política salarial, mercados de trabalho e salários industriais no Brasil, 1960-1976: uma análise por propriedade e tamanho da empresa. Revista de Economia Política, v. 8, n. 1, p. 50-70, 1988.

SOARES, F. V. et al. Programas de transferência de renda no Brasil: impactos sobre a desigualdade. In: BARROS, R. P. de; FOGUEL, M. N.; ULYSSEA, G. (Ed.). Desigualdade de renda no Brasil: uma análise da queda recente. Brasília: Instituto de Pesquisa Econômica Aplicada, 2007. v. 2.

SOARES, S. S. D. Distribuição de renda no Brasil de 1976 a 2004 com ênfase no período entre 2001 e 2004. Brasília: Instituto de Pesquisa Econômica Aplicada, 2006.

SOARES, S. S. D. O ritmo de queda na desigualdade no Brasil é adequado? Evidências do contexto histórico e internacional. Brasília: Instituto de Pesquisa Econômica Aplicada, 2008. (Texto para Discussão n. 1339).

SOARES, S. S. D. O conhecimento paga bem? Habilidade cognitivas e rendimentos do trabalho no Brasil (e no Chile). Tese (Doutorado em Economia) - Universidade de Brasilia, Brasilia, 2011.

SOARES, S. S. D. et al. Conditional cash transfers in Brasil, Chile and Mexico: impacts upon inequality. Estudios Económicos, número extraordinario, p. 207-224, 2009.

SOARES, S. S. D. et al. O potencial distributivo do Imposto de Renda - Pessoa Física (IRPF). In: CASTRO, J. A. de; SANTOS, C. H. M. dos; RIBEIRO, J. A. C. (Ed.). Tributação e equidade no Brasil: um registro da reflexão do Ipea no biênio 2008-2009. Brasília: Instituto de Pesquisa Econômica Aplicada, 2010.

SOARES, S. S. D. et al. Os impactos do benefício do Programa Bolsa Família sobre a desigualdade e a pobreza. In: CASTRO, J. A. de; MODESTO, L. (Ed.). Bolsa Família 2003-2010: avanços e desafios. Brasília: Instituto de Pesquisa Econômica Aplicada, 2010. v. 2.

SOCHACZEWSKI, A. C. Finanças públicas brasileiras no século XX. In: IBGE (Ed.). Estatísticas do século XX. Rio de Janeiro: Instituto Brasileiro de Geografia e Estatística, 2006. Acesso em 14 abr. 2015. Disponível em: <http://seculoxx.ibge.gov.br/> .

SOKOLOFF, K.; ENGERMAN, S. Institutions, factor endowments, and paths of development in the New World. Journal of Economic Perspectives, v. 14, n. 3, p. 217-232, 2000 . 
SOLOW, R. A contribution to the theory of economic growth. The Quarterly Journal of Economics, v. 70, n. 1, p. 65-94, 1956.

SOLOW, R. Technical change and the aggregate production function. The Review of Economics and Statistics, v. 39, n. 3, p. 3, 1957.

SOLOW, R. The New Industrial State: son of affluence. Public Interest, v. 9, p. 100-108, 1967.

SORENSEN, A. B. The structural basis of inequality. American Journal of Sociology, v. 101, n. 5, p. 1333-1365, 1996.

SORENSEN, A. B. Toward a sounder basis for class analysis. American Journal of Sociology, v. 105, n. 6, p. 1523-1558, 2000.

SOROKIN, P. American millionaires and multi-millionaires: a comparative statistical study. Journal of Social Forces, v. 3, n. 4, p. 627-640, 1925.

SOROKIN, P. Impoverishment and the expansion of governmental control. American Journal of Sociology, v. 32, n. 2, p. 206-216, 1926.

SOROKIN, P. War and Post-War changes in social stratification of the Euro-American population. American Sociological Review, v. 10, n. 2, p. 294-303, 1945.

SOUZA, P. H. G. F. Poverty, inequality and social policies in Brazil, 1995-2009. Brasília: International Policy Centre for Inclusive Growth (IPC-IG), 2012. (Working Paper n. 87).

SOUZA, P. H. G. F. Top incomes in Brazil, 1933-2012: a research note. Social Science Research Network, 2014. SSRN Working Paper. (SSRN Working Paper). Acesso em 30 set. 2015. Disponível em: <http://papers.ssrn.com/sol3/papers.cfm?abstract_id=2537026>.

SOUZA, P. H. G. F. A distribuição de renda nas pesquisas domiciliares brasileiras: harmonização e comparação entre Censos, PNADs e POFs. Revista Brasileira de Estudos de População, v. 32, n. 1, p. 165-188, 2015.

SOUZA, P. H. G. F.; CARVALHAES, F. A. de O. Estrutura de classes, educação e queda da desigualdade de renda (2002-2011). Dados - Revista de Ciências Sociais, v. 57, n. 1, p. 101-128, 2014.

SOUZA, P. H. G. F.; MEDEIROS, M. The decline in inequality in Brazil, 2003-2009: role of the State. Berkeley: Institute for Research on Labor and Employment, 2013. (IRLE Working Paper n. 154). Acesso 28 out. 2015. Disponível em: $<$ http://www.irle.berkeley.edu/workingpapers/154-13.pdf>.

SOUZA, P. H. G. F.; MEDEIROS, M. Diferencial salarial público-privado e desigualdade de renda per capita no Brasil. Estudos Econômicos, v. 43, n. 1, p. 5-28, 2013.

SOUZA, P. H. G. F.; MEDEIROS, M. Top income shares and inequality in Brazil, 1928-2012. Sociologies in Dialogue, v. 1, n. 1, p. 119-132, 2015.

SOUZA, P. H. G. F.; OSORIO, R. G. A redução das disparidades regionais e a queda da desigualdade nacional de renda, 1981-2009. Planejamento e Políticas Públicas, v. 43, p. 273-297, 2014. 
SOUZA, P. H. G. F.; OSORIO, R. G.; SOARES, S. S. D. Uma metodologia para simular o Programa Bolsa Família. Brasília: Instituto de Pesquisa Econômica Aplicada, 2011. (Texto para Discussão n. 1654).

SOUZA REIS, F. T. de. O systema legal do imposto de renda. Rio de Janeiro: [s.n.], 1927.

SOUZA REIS, F. T. de. O imposto de renda em seis annos de adaptação no Brasil, 1924-1929. Rio de Janeiro: [s.n.], 1930.

SPEIER, H. Social stratification in the urban community. American Sociological Review, v. 1, n. 2, p. 193-202, 1936.

SPENCER, H. The man versus the State. Indianapolis: Liberty Classics, 1981.

SPENGLER, J. J. Changes in income distribution and social stratification: a note. American Journal of Sociology, v. 59, n. 3, p. 247-259, 1953.

STAMP, J. British incomes and property: the application of official statistics to economic problems. Londres: P. S. King \& Son, 1916. Acesso 24 jul. 2015. Disponível em: $<$ https://archive.org/details/britishincomespr00stamuoft $>$.

STAVENHAGEN, R. Estratificação social e estrutura de classes (um ensaio de interpretação). In: VELHO, O.; BERTELLI, A.; PALMEIRA, M. S. (Ed.). Estrutura de classes e estratificação social. Rio de Janeiro: Editora Jorge Zahar, 1974.

STIGLER, G. Director's law of public income redistribution. Journal of Law and Economics, v. 13, n. 1, p. 1-10, 1970.

STIGLER, G.; BECKER, G. De gustibus non est disputandum. The American Economic Review, v. 67, n. 2, p. 76-90, 1977.

SUMMERS, L. Foreword. In: OKUN, A. (Ed.). Equality and efficiency: the big tradeoff. Washington, D.C.: Brookings Institution Press, 2015.

SUMNER, W. G. What social classes owe each other. Caldwell: The Caxton Printers, 1974. Acesso 30 jun. 2015. Disponível em: < https://web.archive.org/web/20150721071442/https: //mises.org/library/what-social-classes-owe-each-other-0 $>$.

SWEEZY, M. Y. Distribution of wealth and income under the Nazis. The Review of Economics and Statistics, v. 21, n. 4, p. 178-184, 1939.

SZÉKELY, M.; HILGERT, M. What's behind the inequality we measure: an investigation using Latin American data. Washington, D.C.: Inter-American Development Bank, 1999. (Research Department Working Paper n. 409).

SZÉKELY, M.; HILGERT, M. What's behind the inequality we measure? An investigation using Latin American data. Oxford Development Studies, v. 35, n. 2, p. 197-217, 2007.

TAVARES, M. da C.; SERRA, J. Além da estagnação: uma discussão sobre o estilo de desenvolvimento recente do Brasil. In: BIELSCHOWSKY, R. (Ed.). Cinquenta anos de pensamento na CEPAL. Rio de Janeiro, São Paulo: Editora Record, 2000. v. 2.

TAWNEY, R. H. Equality. $4^{a}$ edição. Londres, Nova York: Barnes \& Noble, Unwin Books, 1964. 
TEMIN, P. The Golden Age of European growth reconsidered. European Review of Economic History, v. 6, p. 3-22, 2002.

THE MADDISON PROJECT. The Maddison Project Database. 2013. Acesso em $1^{o}$ jul. 2015. Disponível em: <http://www.ggdc.net/maddison/maddison-project/home.htm>.

THE TAX FOUNDATION. U.S. Federal Individual Income Tax

Rates History, 1862-2013 (nominal and inflation-adjusted brac-

kets). Washington, D.C., 2013. Acesso 9 nov. 2015. Disponível em:

<https://web.archive.org/web/20160410204700/http://taxfoundation.org/article/

us-federal-individual-income-tax-rates-history-1913-2013-nominal-and-inflation-adjusted-brackets $>$.

THOMPSON, E. P. The making of the English working class. Nova York: Vintage Books, 1966.

THOMPSON, L. A history of South Africa. New Haven; Londres: Yale University Press, 2001.

THORBECKE, E.; CHURAMILIND, C. Economic inequality and its socioeconomic impact. World Development, v. 30, n. 9, p. 1477-1495, 2002.

TOBIN, J. On limiting the domain of inequality. Journal of Law and Economics, v. 13, n. 2 , p. $263-277,1970$.

TOLIPAN, R.; TINELLI, A. C. (Ed.). A controvérsia sobre distribuição de renda e desenvolvimento. Rio de Janeiro: Zahar Editores, 1975.

TORRES, A. de M. Modelos de tributação ótima da renda: o cálculo de alíquotas marginais assintóticas para o Brasil no ano de 2000. Dissertação (Mestrado em Economia do Setor Público) — Universidade de Brasília, Brasília, 2003.

TOURAINE, A. Industrialization et conscience ouvrière a São Paulo. Sociologie du Travail, v. 3, 1961.

TRACY, M. Piketty's 'Capital': a hit that was, wasn't, then was again. Washington, D.C., 2014. The New Republic. Acesso em 30 set. 2015. Disponível em: < https: //web.archive.org/web/20150730055553/http://www.newrepublic.com/article/117498/ pikettys-capital-sold-out-harvard-press-scrambling $>$.

TREIMAN, D. Industrialization and social stratification. Sociological Inquiry, v. 40, n. 2, p. 207-234, 1970.

TREIMAN, D. Occupational prestige in comparative perspective. São Francisco; Nova York: Academic Press, 1977.

TUCKER, R. S. The distribution of income among income taxpayers in the United States, 1863-1935. The Quarterly Journal of Economics, v. 52, n. 4, p. 547-587, 1938.

TULLOCK, G. Inheritance justified. Journal of Law and Economics, v. 14, n. 2, p. 465-474, 1971.

TULLOCK, G. Public choice. In: The New Palgrave: A Dictionary of Economics. Londres; Nova York; Tóquio: Palgrave Macmillan, 1987. Disponível em: <https: //web.archive.org/web/20160429040032/http://www.dictionaryofeconomics.com/article? $\mathrm{id}=$ pde1987_X001792>. 
TUMIN, M. Some principles of stratification: a critical analysis. American Sociological Review, v. 18, n. 4, p. 387-394, 1953.

ULYSSEA, G. Segmentação no mercado de trabalho e desigualdade de rendimentos no Brasil: uma análise empírica. In: BARROS, R. P. de; FOGUEL, M. N.; ULYSSEA, G. (Ed.). Desigualdade de renda no Brasil: uma análise da queda recente. Brasília: Instituto de Pesquisa Econômica Aplicada, 2007. v. 2.

UNIVERSO em expansão: a boa renda para aumentar a receita. Revista Veja, v. 132, p. 36-44, 17 de março 1971.

U.S. COMMISSION ON INDUSTRIAL RELATIONS. Final Report of the U.S. Commission on Industrial Relations. Washington, D.C.: Barnard \& Miller Print, 1915. Acesso 17 jun. 2015. Disponível em: <https://archive.org/details/ finalreportofcom00unitiala $>$.

USHER, A. P. Justice and poverty. American Journal of Sociology, v. 26, n. 6, p. 689-704, 1921.

VAN HORN, R.; MIROWSKI, P. Neoliberalism and Chicago. In: EMMETT, R. B. (Ed.). The Elgar Companion to the Chicago School of Economics. Cheltenham; Northampton: Edward Elgar, 2010.

VANDENBERGHE, F. Une histoire critique de la sociologie allemande: alienátion et réification - Horkheimer, Adorno, Marcuse, Habermas. Paris: La Découverte, 1998. v. 2.

VANDERMEY, A. How America fell in love with a 685-page economics treatise.

Nova York: [s.n.], 2014. Fortune Magazine. Acesso em 30 set. 2015. Disponível em: <https://web.archive.org/web/20150730055757/http://fortune.com/2014/08/22/ contagion-how-america-fell-in-love-with-capital-piketty/> .

VEBLEN, T. The Theory of the Leisure Class. Nova York: Oxford University Press, 2007.

VÉLEZ, J. L. Income and wealth at the top in Colombia: an exploration of tax records, 1993-2010. Dissertação (Mestrado em "Public Policy and Development") - Paris School of Economics, Paris, 2012.

VELlOSO, J. Educação e desigualdade da renda urbana no Brasil. Pesquisa e Planejamento Econômico, v. 9, n. 5, p. 661-718, 1979.

VELOSO, F. A evolução recente e propostas para a melhoria da educação no Brasil. In: BACHA, E.; SCHWARTZMAN, S. (Ed.). Brasil: a nova agenda social. Rio de Janeiro: LTC, 2011.

VIANNA, F. J. de O. Direito do trabalho e democracia social: o problema da incorporação do trabalhador no Estado. Rio de Janeiro: José Olympio, 1951.

VIANNA, L. W. Liberalismo e sindicato no Brasil. Belo Horizonte: Editora UFMG, 1999.

VIANNA, S. B. Duas tentativas de estabilização: 1951-1954. In: ABREU, M. de P. (Ed.). A ordem do progresso: cem anos de política econômica republicana, 1889-1989. Rio de Janeiro: Editora Campus, 1990. 
VIANNA, S. B. Política econômica externa e industrialização: 1946-1951. In: ABREU, M. de P. (Ed.). A ordem do progresso: cem anos de política econômica republicana, 1889-1989. Rio de Janeiro: Editora Campus, 1990.

VIANNA, S. B.; VILLELA, A. O pós-Guerra (1945-1955). In: GIAMBIAGI, F. et al. (Ed.). Economia brasileira contemporânea. Rio de Janeiro: Elsevier; Editora Campus, 2005 .

VILLELA, A. Dos "anos dourados" de JK à crise não resolvida. In: GIAMBIAGI, F. et al. (Ed.). Economia brasileira contemporânea. Rio de Janeiro: Elsevier; Editora Campus, 2005.

VOLSCHO, T.; KELLY, N. The rise of the super-rich: power resources, taxes, financial markets, and the dynamics of the top 1 percent, 1949 to 2008. American Sociological Review, v. 77, n. 5, p. 679-699, 2012.

WAGNER, P. A crise da modernidade: a sociologia política no contexto histórico. Revista Brasileira de Ciências Sociais, v. 11, n. 31, p. n/a, 1996. Acesso 29 ago. 2015. Disponível em: <https://web.archive.org/web/20150830031101/http: //www.anpocs.org.br/portal/publicacoes/rbcs_00_31/rbcs31_02.htm>.

WANNISKI, J. Taxes, revenues, and the "Laffer curve". Public Interest, v. 50, p. 3-16, 1978.

WARD, L. F. Social classes in the light of modern sociological theory. American Journal of Sociology, v. 13, n. 5, p. 617-627, 1908.

WATKINS, G. P. The growth of large fortunes: a study of economic causes affecting the acquisition and distribution of property. Nova York: American Economic Association, MacMillan, 1907. Acesso 8 fev. 2012. Disponível em: $<$ https://archive.org/details/growthoflargefor01watk>.

WEBB, S.; WEBB, B. The Decay of Capitalist Civilisation. Londres: The Fabian Society, George Allen and Unwin, 1923. Acesso $1^{o}$ jul. 2015. Disponível em: $<$ https://archive.org/details/decayofcapitalis00webbuoft>.

WEBER, M. Economy and Society. Berkeley; Los Angeles: University of California Press, 1978.

WEDGWOOD, J. The influence of inheritance on the distribution of wealth. The Economic Journal, v. 38, n. 149, p. 38-55, 1928.

WEEDEN, K. Why do some occupations pay more than others? Social closure and earnings inequality in the United States. American Journal of Sociology, v. 108, n. 1, p. 55-101, 2002.

WEEDEN, K.; GRUSKY, D. Inequality and market failure. American Behavioral Scientist, v. 58, n. 3, p. 473-491, 2014.

WEEKS, A. D. A conservative's view of poverty. American Journal of Sociology, v. 22, n. 6 , p. $779-800,1917$.

WEFFORT, F. O populismo na política brasileira. Rio de Janeiro: Paz e Terra, 1978. 
WEINBERG, D. H. et al. Fifty years of U.S. income data from the Current Population Survey: alternatives, trends, and quality. The American Economic Review, v. 89, n. 2, p. 18-22, 1999.

WELLS, J. Distribuição de rendimentos, crescimento e a estrutura de demanda no Brasil na década de 60. Revista de Administração de Empresas, v. 14, n. 2, p. 21-44, 1974.

WELLS, J.; DROBNY, A. A distribuição da renda e o salário mínimo no Brasil: uma revisão crítica da literatura existente. Pesquisa e Planejamento Econômico, v. 12, n. 3, p. 893-914, 1982.

WHEATON, L. Underreporting of means-tested transfer programs in the CPS and SIPP. Proceedings of the American Statistical Associatoin, p. 3622-3629, 2007.

WILLIAMSON, J. G. Regional inequality and the process of national development: a description of the patterns. Economic Development and Cultural Change, v. 13, n. 4, p. 1-84, 1965.

WILLIAMSON, J. G. Five centuries of Latin American income inequality. Revista de Historia Económica / Journal of Iberian and Latin American Economic History, v. 28, n. edição especial 2, p. 227-252, 2010.

WILLIAMSON, J. G. Latin American inequality: colonial origins, commodity booms or a missed twentieth-century leveling? Journal of Human Development and Capabilities, v. 16, n. 3, p. 324-341, 2015.

WILSON, J. Q. The rise of the bureaucratic state. Public Interest, v. 41, p. 77-103, 1975.

WOLFF, E. N. Top heavy: a study of the increasing inequality of wealth in the United States. Nova York: Twentieth Century Fund, 1995.

WOLFF, E. N. Recent trends in the size distribution of household wealth. Journal of Economic Perspectives, v. 12, n. 3, p. 131-150, 1998.

WRIGHT, E. O. Class structure and income determination. Nova York; Londres: Academic Press, 1979.

WRIGHT, E. O. Varieties of Marxist conceptions of class structure. Politics $\&$ Society, v. 9, n. 3, p. 231-261, 1980.

WRIGHT, E. O. A general framework for the analysis of class structure. Politics $\&$ Society, v. 13, n. 4, p. 383-423, 1984.

WRIGHT, E. O. Rethinking, once again, the concept of class structure. In: WRIGHT, E. O. (Ed.). The debate on classes. Londres; Nova York: Verso, 1989.

WRIGHT, E. O. Class, exploitation, and econommic rents: reflections on Sorensen's "sounder basis". American J, v. 105, n. 6, p. 1559-1571, 2000.

WRIGHT, E. O. Class counts. Cambridge, Reino Unido: Cambridge University Press, 2004.

WRIGHT, E. O. Foundations of a neo-Marxist class analysis. In: WRIGHT, E. O. (Ed.). Approaches to class analysis. Cambridge, Reino Unido: Cambridge University Press, 2005. 
WRONG, D. The functional theory of stratification: some neglected considerations. American Sociological Review, v. 24, n. 6, p. 772-782, 1959.

WRONG, D. The oversocialized conception of man in modern sociology. American Sociological Review, v. 26, n. 2, p. 183-193, 1961.

WRONG, D. Social inequality without social stratification. Canadian Review of Sociology, v. 1 , n. 1 , p. 5-16, 1964.

YARROS, V. The labor question and the social problem. American Journal of Sociology, v. 9, n. 6, p. 768-780, 1904.

YARROS, V. Income and the principle of service. American Journal of Sociology, v. 21, n. 3, p. 317-333, 1915.

YITZHAKI, S. Do we need a separate poverty measurement? European Journal of Political Economy, v. 18, p. 61-85, 2002.

YOUNG, A. A. Do the statistics of the concentration of wealth in the United States mean what they are commonly assumed to mean? Publications of the American Statistical Association, v. 15, n. 117, p. 471-484, 1917.

YOUNG, M. The rise of the meritocracy, 1870-2033. Londres: Penguin Books, 1961. 